Danmarks geologiske Undersøgelse.

II. Række. Nr. 45.

\title{
Studier
}

over

\section{Daniet i Jylland og paa Fyn}

Af

Hilmar Ødum.

Med 7 Tavler og

English Summary.

I Kommission hos

C. A. Reitzels Forlag

København

1926. 
Danmarks geologiske Undersøgelse.

II. Række. Nr. 45.

\title{
Studier
}

over

\section{Daniet i Jylland og paa Fyn}

\author{
Af
}

Hilmar $\varnothing \mathrm{dum}$.

Med 7 Tavler og

English Summary.

I Kommission hos

C. A. Reitzels Forlag

Kobenhavn

1926. 


\section{Indholdsfortegnelse.}

Forord $\ldots \ldots \ldots \ldots \ldots \ldots \ldots \ldots \ldots \ldots \ldots \ldots \ldots \ldots \ldots \ldots \ldots$

Kap. I. Historie ................... 7

\$ II. Daniumbjergarternes Terminologi.......... 22

\ III. Beskrivelse af Daniumlokaliteter . . . . . . . . . 25

» IV. Beskrivelse af Senoniumlokaliteter . . . . . . . . . 140

" V. Palæontologi ... . . . . . . . . . . . . 146

" VI. Stratigrafi... . . . . . . . . . . . . . . . . . . . . 193

» VII. Palæogeografi. . . . . . . . . . . . . . . . . 218

" VIII. Tektonik . . . . . . . . . . . . . . . . . 226

Litteraturfortegnelse . . . . . . . . . . . 237

Lokalitetsregister. . . . . . . . . . . . . . . . 244

Summary of the Contents. . . . . . . . . 247

Bilag ...................... 273 


\section{Rettelser og Tilføjelser.}

S. 18. L. 4 f, o.: De to Kommaer udgaar.

, 26. L. 3 f. o.: ifølge Forsteningerne - læs: ifølge Lejringsforholdene.

, 51. Under Svendstrup: 104 (D. 5. 17) — læs: 104 (D. 5. 7).

"55. " Assens; tilføj: 123 (S. 36).

, 58. , Ove IV; , : 123 (S. 36).

„69. L. 7 f. n.: Ordet "men« udgaar.

"131. L. 10 f. $0 .: 48$ (S. 6) - læs: 48 (S. 9).

„149. L. 11 f. n.: E. Danium. - læs: Y. Danium.

„162. L. 9 f. n.: Lateralfasciolen — læs: Marginalfasciolen.

„163. Litteraturlisten under Cyclaster Brünnichi ændres saaledes:

1917. Brissopneustes sp.; Brünnich Nielsen (84).

1923. ," danicus Schlüter; Jessen og Øрum (47 S. 23, T. I).

1924. " , , ; Rosenkrantz (110), part.

„164. Hyalapamatus — læs: Hyalapomatus.

"164. Apamatus — læs Apomatus.

"179. L. 18 f. n.: skalformede - læs: skælformede.

"180. L. 10-11 f. n.: uadbuet; — læs: udadbuet:

"195. nederst og 196 øverst: M. H. t. den her omtalte Pecten oplyser Museumsinspektør Ravn, at der har fundet en Forbytning af Stykkerne Sted; det paagældende Stykke er derfor Pecten spathulatus.

„ 199. L. 5 f. o. (efter Tabellen): Lag C - læs: Lag G

„221. L. 22 f. o.: S. 104 - læs: S. 108

„230. L. 6 f. o.: S. - læs: SØ.

„235. L. 8 f. о.: Nordvest. — læs: Nordøst. 


\section{Forord.}

Der er i Tidens Løb blevet tilvejebragt et ret fyldigt Kendskab til det sjællandske Daniums Geologi, medens Kendskabet til de tilsvarende Aflejringer i Jylland og paa Fyn har ladet meget tilbage at ønske. Nærværende Arbejde har derfor stort set haft til Formaal at fremskaffe forøgede Oplysninger om disse Aflejringer. Dette er resulteret dels i en ren Beskrivelse af Forekomsterne, idet saa vidt muligt alt Kendskab til de enkelte Lokaliteter er samlet, dels i et forøget Kendskab til disse Lokaliteters Forsteningsindhold. Paa dette Grundlag har Forfatteren søgt at udrede de stratigrafiske Forhold vedrørende selve Daniet, uden at gaa ind paa Spørgsmaalet om, hvorvidt dette skal knyttes til Kridtet eller Tertiæret. I Tilslutning til de stratigrafiske Resultater er der fremsat en Del Overvejelser angaaende det danskskaanske Daniums Palæogeografi, og sluttelig de Betragtninger over den tektoniske Bygning af de her behandlede Omraader, som Undersøgelsen har givet Anledning til.

Forfatteren er paa det rene med, at nærværende Afhandling kun i store Træk har naaet sit Maal. Arbejdet har i høj Grad fremhævet det ønskelige i yderligere, specielle Undersøgelser baade af regional og stratigrafisk Art, før vort Kendskab til det jysk-fynske Danium kan siges at være fuldstændigt. Alligevel er det mit Haab, at Arbejdet i nogen Udstrækning har fremskaffet et brugeligt Grundlag for videre Arbejde.

Materialet til den foreliggende Afhandling tilhører for Størstedelen Danmarks geologiske Undersøgelse, hovedsagelig indsamlet af Forfatteren i Aarene 1923-25. For Østjyllands Vedkommende er der benyttet en Del i tidligere Aar indsamlet Materiale, ligesom en Del Iagttagelser fra Mors og Struer-Egnen stammer fra en Rejse i 1921, hvor Forfatteren ledsagede d'Hrr. Direktør, Dr. phil. Victor Madsen, Statsgeolog AxeL Jessen og Museumsinspektør J. P. J. Ravn. En Del Materiale fra Hjerm er elskværdigst blevet mig overladt af Hr. Stabslæge, Dr. phil. K. BRÜNnich Nielsen, ligesom Hr. stud. med. 
Kay Ahrentecht dels har hjulpet mig med Arbejde i Marken, dels selv har indsamlet en Del Materiale. Desuden er der gjort Brug af de i Danmarks geologiske Undersøgelse's Borearkiv beroende Prøver og Oplysninger.

Endvidere er de Universitetets Mineralogiske og Geologiske Museum tilhørende Samlinger inddraget i Undersøgelsen.

Ved Bearbejdelsen af Stoffet, specielt Bestemmelsen af Forsteningerne, har jeg modtaget værdifuld Hjælp af d'Hrr. Museumsinspektør J. P. J. Ravn, Stabslæge, Dr. phil. K. Brünnich Nielsen og Ingeniør, cand. polyt. Alfred Rosenkrantz. De kemiske Analyser er udført paa Danmarks geologiske Undersøgelse's Laboratorium af d'Hrr. Ingeniør, cand. polyt. Johs. Andersen og Ingeniør, cand. polyt. J. LUNDBERG.

Jeg beder alle de ovennævnte Herrer modtage min bedste Tak.

Hilmar Ødum. 


\section{Kapitel I}

\section{Historie.}

$\mathrm{F}$

or 25 Aar siden kunde GRönwaLL erklære, at »Kännedomen om kritsystemet i Jylland är synnerligen bristfällig«, Ord, der endnu, omend naturligvis ikke i samme Udstrækning som i 1899, har Gyldighed. Og dog, ser man paa den Udvikling, vort Kendskab til Daniumformationen paa Sjælland har gennemgaaet i de forløbne 25 Aar, saa maa det siges, at vort Kendskab til Forholdene i Jylland næsten er relativt mindre, end det var dengang. Dette Forhold skyldes - i hvor vel man fra gammel Tid har haft Kendskab til mange jyske Lokaliteter — den meget nærliggende Omstændighed, at Daniet paa Sjælland dels har ligget saa meget nærmere ved København og altsaa været lettere tilgængeligt, dels har budt paa en Række gode og oplysende Profiler (Faxe, Stevns Klint, Herfølge, Udgravninger i København, Saltholm o. s. v.). Jylland har stadig, til Trods for Daniets vide Udbredelse i denne Landsdel, været Stedbarn.

Ser man bort fra forudgaaende, geologiske Iagttagelser, der er meddelt i de topografiske Værker, maa BREDSDORFF vel siges at være en af de første, der paa mere geologisk Basis anstiller Undersøgelser over Kalkarternes Forekomst i Jylland. Fra sine Rejser i denne Landsdel angiver han en Række Forekomster, dog uden at skelne nøjere mellem Skrivekridtet og Daniets Kalksten. I 1824 (3) giver han - paa Grundlag af sine Iagttagelser den foregaaende Sommer — en ret omstændelig Beskrivelse af Kalken i Bulbjerg og sammenligner saavel denne som Kalken ved Torup Kløv (»Torup «) med Bryozokalken i Stevns Klint. Ligeledes besøger han Davbjerg og Mønsted og opregner - foruden Skrivekridtlokaliteter - Forekomsten af Kalk ved Ove, Klim, Gøttrup, i Thy og paa Mors, S. f. Løgstør »mellem Malle og Vindblæs« (Løgsted?), Holstebro-Egnen og Mariager, samt Klinterne i Djursland.

Med Forchнammers Virksomhed tager Undersøgelsen af Daniet Fart, og samtidig foretages en skarpere Adskillelse mellem Skrivekridtet 
og de andre Kalkbjergarter. Allerede i 1825 (15) er Forchinamer delvis inde herpaa, men i dette Arbejde nævner han kun flygtigt Forholdene i Jylland, som han endnu knap kender af Selvsyn.

Det første Forsøg paa en nøjere Inddeling af Danmarks (og dermed Jyllands) Kridtdannelser gjordes af Forchнамmer i 1835 i hans bekendte Afhandling om »Danmarks geognostiske Forhold« (16). Den Inddeling, han heri opstiller, ser saaledes ud:

»1) Grønsand og Graakridt paa Bornholm og i Skaane.

2) Saltholms-Kalk, paa Saltholm, ved Limeham og Torp i Sverrig, og Sangstrup Klint ved Greenaae; som løse Brudstykker i overordentlig stor Mængde ved Terkelskov i Sjelland og Katholm i Jylland.

3) Skrivekridt.

4) Faxøekalk, Blegekridt og Liimsteen.«

Til dette Resultat var han kommet, dels ved Iagttagelse af Profiler, hvor Daniets Bjergarter overlejrer Skrivekridtet, dels ved Studier over Bjergarternes Forekomst i »Bælter« og »Kjeder« i forskellig Rækkefølge; denne sidste Betragtning gav ham Anledning til at antage, at Saltholmskalken, hvortil han m. H. t. Dannelsestid regner Kalken i Karlby og Sangstrup Klinter, var ældre end Skrivekridtet.

Dog var han selv klar over, at denne sidste Vej var usikker, idet han fraviger den i sine Betragtninger over det »regelrette« og det wuregelrette« Kridt. Til det første henfører han det uforstyrrede Kridt i Stevns Klint og i det nordøstlige Jylland. Det »uregelrette Kridt« er de forstyrrede Skrivekridtforekomster i Møens Klint m. v. og paa Lokaliteter beliggende indenfor Danium-Omraaderne paa Mors og i Thy.

Daniet inddeles i flere petrografiske Grupper:

1) "Karlebyekalk" fra Karlby og Sangstrup Klinter; den stilles ret nær ved Saltholmskalk. Ogsaa den løse Glatvedkalk henregnes hertil, skønt Forсhнамmer finder, at den ligner "Saltholmskalken« overmaade meget.

2) »Saltholmskalk $\left.\ll^{1}\right)$.

3) »Faxøekalk«, hvortil ogsaa regnes »Cerithiumkalken«.

4) „Blegekridt», hvortil henregnes Forekomsterne paa Mors og flere Steder i Thy, samt Hjerm, Vejrum, Davbjerg og Mønsted.

5) "Limsten«, hvortil (foruden Stevns) henføres Forekomster i Thy og Hanherrederne: Hanstholm, Bulbjerg, Torupstrand, Vigsø og Hov, samt Egnen ved Løgstør (ogsaa N. f. Fjorden).

Foruden de saaledes bestemte Lokaliteter er paa det med Afhandlingen følgende Kort følgende Steder opført som »Liimsteen og Blege-

1) Det maa erindres, at $1-2$ ogsaa skulde betegne en Dannelse, der opfattedes som tilhørende en anden Tid end $3-5$. 
kridt«: Klavsholm, Jomfrubakken og Thyholm (Helligkilde), samt to tvivlsomme Lokaliteter, Haraldslund v. Aarhus (der sikkert, efter Omtalen og Analysen at dømme, ikke er Danium) og et Sted ved Lemvig.

Over Skrivekridtet noteres fra Eerslev Grube paa Mors et Lerlag og herover en "Koralkalksten«, der paralleliseres med "Faxøelaget» i Stevns og Faxekalken. Forholdet mellem Limsten og Blegekridt giver Forchhammer Anledning til en Del Tvivl, idet han paa den ene Side ser Skrivekridt og Cerithiumkalk i Eerslev Grube (og Thy) direkte overlejret af Blegekridt, hvorover atter Limstenen skal vise sig, mens paa den anden Side Limstenens geografiske Udbredelse nærmest tyder paa, at den er ældre end Blegekridtet. Forchhammer er tilbøjelig til at anse de to Bjergarter for at være samtidige, af lokale Forhold afhængige Dannelser, men vil alligevel nærmest anse Limstenen for at være den yngste af de to (S. 82).

Samme Aar, som Forchinamer udgav sit ovenfor omtalte Arbejde, blev der i The Geological Society of London oplæst en Afhandling af H. H. Beck, betitlet »Notes on the Geology of Denmark«; et Referat heraf blev trykt i Selskabets Forhandlinger og udkom i 1917 i dansk Oversættelse (1).

I denne Form er Afhandlingen af langt ringere Omfang end ForcHIA mMers Arbejde, ligesom Behandlingen er langt mindre udførlig, men dette Arbejde er dog af stor Interesse.

BECK deler Kridtaflejringerne saaledes:

1) $\mathrm{Kridt}_{\text {«. }}$

2) "Faxelagene«, hvortil foruden Faxe henregnes Cerithiumkalken i Stevns og paa Øen Mors samt Klinterne ved Grenaa.

3) » $\emptyset_{v r e}$ Kalksten«, hvortil foruden Kalken paa Saltholm alle de øvrige jyske Daniumlokaliteter henregnes.

BECK samler saaledes alle Daniumaflejringerne som værende yngre end Skrivekridtet (modsat Forchinamer), et Resultat, han kommer til, idet han »slutter efter de fundne Fossiler«.

Forchнammer var dog ikke tilbøjelig til at slutte sig til denne Opfattelse, hvad man ser af, at han endnu i 1843 (18) regner Saltholmskalken for at være ældre end Skrivekridtet.

I 1837 og 39 angiver Steenstrup Forekomsten af formodet Skrivekridt ved Legind, en Lokalitet, der senere har vist sig at være Danium, hvorfra han beskriver nogle Cirripedrester (118 S. 365 og 119 S. 409).

I 1840 giver Forchinammen for første Gang Oplysning om Daniumundergrunden paa Fyn, idet han nævner Forekomsten ved Refsvindinge »og flere Steder« (17 S. 4).

I 1847 har Forсннамmer sluttet sig til den Anskuelse, at ogsaa Saltholmskalken er yngre end Skrivekridtet (19), idet han støtter sig til Iagttagelser paa Sjælland. Han opstiller to samtidige Aflejringsræk- 
ker for de herhen hørende Dannelser, idet han sammenfatter dem under Navnet »Det nyere Kridt « for at faa en dansk Betegnelse for DEsor's Navn »terrain danien«.

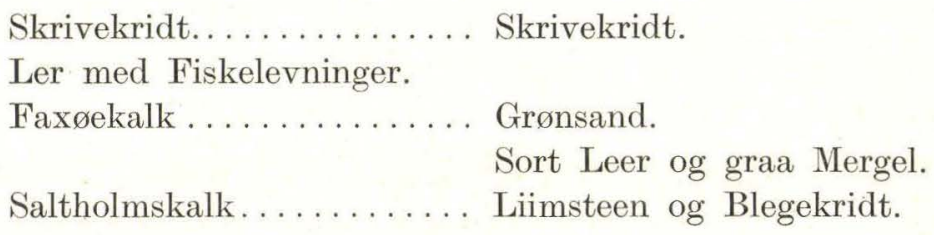

Ogsaa det bornholmske Grönsand henregnes til det nyere Kridt; de forskellige Bjergarter skal være dannet under forskellige Naturforhold.

Cerithiumkalken i Eerslev-Grube henregnes til »Faxøelaget«, men iøvrigt fordeles det jyske Danium i to Grupper: Limsten (Karlby, Mariagerfjord, Nibe, Løgstør, Klim) og Blegekridt (Thy, Hjerm, Davbjerg, Mønsted).

I 1858 meddeler ForсннаммеR en lille, populær Oversigt over Geologien omkring den vestlige Limfjord (20), idet han gør opmærksom paa Sammenhængen mellem disse Egnes forstyrrede Lagstillinger og de hyppigt indtrædende Jordskælv. Oversigten har særlig Interesse ved det ledsagende Kort. Skrivekridtet indtager større Omraader N. f. Thisted og S. f. Svinkløv samt findes ved Eerslev (desuden er Legind ligesom i 1835 (16 S. 66) opført som Skrivekridt). Daniet indtager Egnen omkring Thisted og Bakkeøerne $\mathrm{N}-\mathrm{N} \varnothing$. herfor og et Omraade paa Mors samt Egnen omkring Løgstør (bortset fra en smal Stribe Skrivekridt NØ. for Byen).

En Afhandling fra samme Aar, i hvilken Forchнамmer (21) lejlighedsvis fremsætter nogle Bemærkninger om Daniet i Jylland, har bl. a. Interesse ved, at han udtrykkelig skelner mellem Bjergarterne i »Bræstrup Klint« og »Karleby Klint», idet de nu regnes henholdsvis til "Saltholmskalk» og »Liimsteen«.

I en Oversigt fra 1860 (22), der væsentlig drejer sig om det sjællandske Grønsand, anfører Forсннаммев i sin Inddeling af »det nyere Kridt«, at saavel Limstenen som Saltholmskalken optræder i Grenaa-Egnen, uden dog at komme nærmere ind paa Fordelingen; han sigter sikkert til de i den foregaaende Afhandling nævnte Klinter. Iøvrigt bringer Afhandlingen ikke noget nyt om Daniet i Jylland.

I den i 1869 trykte, efterladte Afhandling af Forchinammer (24) om Jordskælvet 1841 giver han i Indledningen en Oversigt over det nordligste Jyllands Geologi. Foruden at nævne en Række af de tidligere omtalte Forekomster meddeler han, at Kridtet i Hanstholm og Hjardemaal Bakkeøer (»Østholmen«) overlejres af Limsten, som tillige angives fra »Bjørnsholm» (Lundgaard?). 
I en lille Afhandling fra 1875 (48) giver JoHnstrup en Oversigt over Jyllands Geologi. Under Omtalen af det nyere Kridt nævner han bl. a. Forekomsterne ved Skader og Lime, men ellers har kun det ledsagende Kort nogen Interesse; bl. a. findes her Forekomsten ved Legind afsat som Danium, medens Forсннамmer endnu i 1869 angiver den som Skrivekridt (24 S. 211).

Saavel denne Oversigt over Jyllands Danium som Kortet er omtrent uforandret i JoHnstruP's »Oversigt over de geognostiske Forhold i Danmark« fra $1882(50)$.

I dette Arbejde understreger Johnstrup, at Daniets Bjergarter (bortset fra Koralkalken) Saltholmskalk, Limsten og Blegekridt sikkert skal opfattes som mere eller mindre samtidige Dannelser, som han i Modsætning til Koralkalken sammenfatter under Benævnelsen Bryozokalk. Forskellighederne tilskrives dels Dannelse under Vand af vekslende Rolighed, dels senere Hærdning af forskellig Grad.

Ved Johnstrup's Arbejder i disse Aar ${ }^{1}$ ), hvoraf det sidstnævnte fremtræder som en resumerende Oversigt, var man efterhaanden naaet til følgende Inddeling af Danmarks Kridtaflejringer:

\section{Lellinge Grønsand. \\ Koralkal og Bryozokalk (med Saltholmskalk og Blegekridt). Faxelaget (Cerithiumkalk) Fiskeler.}

Skrivekridt.

Arnagerkalk og Grønsand paa Bornholm.
Nyere Kridt

eller

Danien.

Yngre Senon.

Aldre Senon.

Lellinge Grønsandet regnes altsaa med til Daniet, der overfor de øvrige Kridtaflejringer karakteriseres ved Mangelen af Belemnitella, Ammoniter og Inoceramus; kun i »Faxelaget« i Stevns Klint skal findes Baculites og Scaphites, saa JoHnstrup er nærmest tilbøjelig til at skille dette ud fra den egentlige Faxekalk og henføre det til Overgangen mellem Skrivekridtet og Daniet (49 S. 22).

Den palæontologiske Forskel mellem Skrivekridtet og det bornholmske Kridt markeres bl. a. ved, at det første som Ledefossil indeholder Belemnitella mucronata, det sidste B. (Actinocamax) westfalicus.

1) Særlig har Johnstrup's Afhandling fra 1876 (49): „Om Grönsandet i Sjælland været af Betydning, men skal ikke behandles nærmere paa dette Sted, da den udelukkende beskæftiger sig med sjællandske og bornholmske Forhold. 
Paa dette Tidspunkt var man altsaa naaet ret vidt $m$. H. t. at anbringe vore Kridt- og Daniumaflejringer i deres indbyrdes Rækkefølge. Men, som det fremgaar af det foran meddelte, var man væsentlig naaet til dette Resultat ved rent petrografiske Sammenligninger og ved Studium af Lejringsforholdene. Kun i ringere Grad hvilede Systemet paa palæontologiske Bestemmelser og Jævnføringer, hvilket for saa vidt var en Mangel. Ganske vist havde BEck været inde paa denne Vej (se S. 9) og bl. a. fattet en storstilet Plan om Beskrivelse af de danske Forsteninger "Gaea danica«, men skønt Forchinamer og Japetus SteensTRUP optog Tanken efter ham, blev den aldrig ført ud i Livet. Senere syslede O. Mörch med palæontologisk Arbejde (49 S. 24), men saavel hans som især den ældre Litteraturs palæontologiske Bidrag var af altfor spredt og overfladisk Art.

Paa den nævnte Tid, omkring 1880, var man imidlertid ad den omtalte Vej kommet omtrent saa langt med det geologiske Studium paa disse Felter, som det var gørligt. Det videre Arbejde paa disse Aflejringers Stratigrafi maatte nødvendigvis baseres paa palæontologiske Undersøgelser, en Vej, man i Udlandet forlængst var slaaet ind paa. Vi ser derfor, at man i de kommende Aartier beskæftiger sig med Bearbejdningen af de herhen hørende Fossiler, idet det rent stratigrafiske Arbejde kun med Mellemrum gør saadanne Fremskridt, som den palæontologiske Underbygning berettiger.

Begyndelsen til en systematisk, palæontologisk Undersøgelse af denne Art gjordes af Posselt, som i 1894 publicerede sin Oversigt over Brachiopoderne (91); af egentlig Stratigrafi indeholder den ikke meget. Posselt skelner (antagelig under Paavirkning af JoHnstrup) ikke mellem Limsten og Blegekridt, idet selv typiske Blegekridt-Lokaliteter er opført som "Limsten $\left.\aleph^{1}\right)$; til Saltholmskalk henføres af jyske Forekomster kun Sangstrup Klint. Skillingbro bestemmes som Skrivekridt (m. Terebratula carnea (91 S. 39)).

Iøvrigt meddeler han Bestemmelse af Brachiopoder fra følgende jyske Lokaliteter (»Limsten«): Bulbjerg, Vixø, Klimbjærg, Helligkilde Mark, Bredstrup, Thisted, Løgstør, Borup, Skaader, Hov og Daugbjerg.

Et vigtigt, overvejende petrografisk Arbejde af RøRDAn udkom i 1897 (112), hvori dog næsten udelukkende behandles sjællandske Forhold. RøRDAM inddeler Kalkbjergarterne efter deres Dannelse i

1) Koralkalk,

2) Bryozokalk,

3) Foraminiferkalk,

4) Kokkolithkalk,

5) Spongiekalk,

1) Blegekridt nævnes kun en enkelt Gang som "Blegekridt i det nordlige Jylland 
og meddeler omhyggelige Beskrivelser og Analyser, idet han tillige kommer ind paa Dannelsesvilkaarene for de forskellige Kalksorter og Flinten. Han tænker sig, at alle de nævnte Bjergarter er dannet samtidig under forskellige Faciesforhold. Af jyske Bjergarter henføres Forekomster i Thy og paa Mors saavel som Kalken i Karlby Klint til Bryozokalken (112 S. 70), medens Blegekridtet ved Davbjerg og Mønsted betegnes som stypisk Kokkolithkalk« (112 S. 79).

Som foran omtalt henregnede JoHnstrup ogsaa det sjællandske Grønsand til Daniet (S. 11). I en mindre Afhandling fra 1898 (26) vender Grönwalu sig (ligesom tidligere v. Koenen) mod denne Opfattelse, idet han udskiller Grønsandet som hørende til Eocæn, hvorimod Daniet henføres til Kridtet; Tanken om ogsaa at henregne Daniet til Tertiæret afviser han udtrykkelig. Som yngste Led af Daniet beskriver GrönWALL den faunistisk karakteriserede "Craniakalk». Iøvrigt kommer Forholdene i Jylland ikke til Behandling i denne Afhandling.

Paa denne Tid blev ogsaa Spørgsmaalet om Daniets Basis taget op til Diskussion, nærmest fra svensk Side (39, 27, 40, 93), men Diskussionen herom førtes udelukkende med Stevns-Profilet som Objekt; i en Fodnote af Grönwall (27 S. 373) oplyses det, at Lokaliteten i Jylland, Eerslev paa Mors, paa det paagældende Tidspunkt var utilgængelig.

Medens de fleste af disse Arbejder næsten udelukkende behandler sjællandske Forhold, giver GrönwaLL i en lille Afhandling fra 1899 (28) en Del Iagttagelser over Kridt og Danium i Løgstøregnen. Han beskæftiger sig særlig med Daniumaflejringerne, idet han giver en omhyggelig Opmaaling af et Profil i en Vandværksbrønd paa Bakken S. f. Byen, hvor Bjergarten havde vekslet mellem »Blegekridt« og Limsten; ligeledes har han i Kanalen mellem Byen og Lendrupstrand fundet begge de nævnte Bjergarter. N. f. Aggersund beskriver han ren Bryozokalk fra Brud paa Ostskraaningen af Bakken ved Aggersborg (Aggersborg I-III) $)^{1}$, hvorimod Kalken i en mindre Grav 800 m V. f. Aggersborg: Gaard i højere Grad bestod dels af Koralbrudstykker (Moltkia Isis), dels af en mere løs og usammenhængende Bryozokalk, der nærmede sig til at have kridtagtig Konsistens. Grönwalt meddeler en Del Forsteninger, særlig fra denne sidstnævnte Lokalitet, men giver sig desuden af med en Drøftelse af Forholdet mellem »Blegekridt« og Limsten, idet han kommer til det Resultat, at disse to Bjergarter ikke kan adskilles i stratigrafisk Henseende (28 S. 70).

Koralkalken fra Aggersborg Gaard sammenligner han nærmest med "Faxelaget«(Cerithiumkalken), skønt han dog ser, at Bjergarten som saadan ikke stemmer overens med "Faxelaget« ved Stevns og Eerslev (28 S.72).

En ret fyldig Omtale af Daniet giver Ussing 1899 i første Udgave

1) GRönwall gør opmærksom paa, at Faunaen paa disse Lokaliteter savner Terebratula lens, hvorimod den præges af visse andre Former (S. 68). 
af »Danmarks Geologi« (122), hvor ogsaa Forholdene i Jylland kommer under Behandling. Ussing behandler hver af de herhen hørende Bjergarter for sig. Fiskeleret og Cerithiumkalken regnes med til Daniet, men det fremhæres, at den sidstnævnte ikke maa opfattes som Akvivalent til Faxekalken.

De øvrige Danium-Bjergarter falder i de 3 Grupper:

Limsten, hvortil i Jylland henregnes Forekomster mellem LøgstørBulbjerg og i Hanherrederne; desuden Egnen ved Mariager, baade N. og S. f. Fjorden.

Saltholmskalk, hvortil Ussing henfører alle Klinterne ved Grenaa (Bredstrup, Sangstrup, Karlby) samt de haarde Bjergarter ved Løgstør Kanal.

Blegekridt, som angives fra følgende jyske Lokaliteter: Helligkilde, Hjerm, Sevel, Davbjerg-Mønsted, samt Legind, Thisted-Egnen og paa Mors; endvidere baade N. og S. for Randers (Asfærg, Clausholm, Skader, Lime) og i en Boring i Fredericia i 550 Fods Dybde, dækket af Tertiær, samt ligeledes ved Skive i 364 Fods Dybde. Ogsaa Forekomsterne i Salling henføres til Blegekridtet.

Ussing giver i dette Arbejde gode Beskrivelser af mange af de nævnte Lokaliteter, idet han desuden flere Steder henleder Opmærksomheden paa de hyppigt forekommende Overgange mellem de forskellige Bjergarter.

I et palæontologisk Arbejde over mSläktet Dimyodon i Danmarks krita fra 1900 meddeler GRönwalu Bestemmelser fra Sangstrup, Bredstrup (»Grenaa《) og Skader (30).

I sit Arbejde »Mineralproduktionen i Danmark« (123) fra 1902 giver Ussing en Række Oplysninger om Anvendelsen af danske Kalksorter til Brænding, Bygningsbrug (»Kridtsten«) og Gødningskalk. Han giver i Sammenhæng hermed Beskrivelser af Bjergarterne, hvorved han, ligesom i sit foran nævnte Arbejde (122), hæfter sig ved de jævne Overgange mellem de forskellige Bjergarter.

Af jyske Kalkbrud nævner han Mønsted, Davbjerg, Sevel, Hjerm og Bredstrup Klint som de betydeligere; desuden Aggersborg, Klim, Torup (= Torup Kløv), Thisted (= Th. IV og V), Legind, Helligkilde, Eerslev, Ø. Jølby, Frøslevvang, Vandsted (= Løgsted), Munksjørup, Voxlev, Tinbæk og Skillingbro; ogsaa Forekomsterne i Salling nævnes i denne Forbindelse, og paa det Afhandlingen ledsagende Kort findes afmærket »Brud i haard Kalksten til Brænding《 ved Hansted. Ogsaa Forekomsterne af løse Kalksten S. f. Grenaa nævnes.

Et særdeles vigtigt Arbejde er J. P. J. Ravn's i Aarene 1902-03 udkomne »Molluskerne i Danmarks Kridtaflejringer« (95). Som Titlen siger, er det først og fremmest et palæontologisk Arbejde (I og II Del), men dertil knytter RAvN et værdifuldt Afsnit (III Del) »Stratigrafiske 
Undersøgelser«. Heri giver han først en meget fyldig historisk Oversigt over disse Spørgsmaals Udvikling, for derefter at give en omfattende Redegørelse for sine egne Undersøgelser og sit Syn derpaa. Han beskæftiger sig særlig med Spørgsmaalet om Begrænsningen af Daniet, og som sit Bidrag til Afgørelsen opstiller han en Inddeling af vore senoniske og daniske Aflejringer, hvori Forholdet mellem Senonium og Danium opgøres saaledes:

\begin{tabular}{|c|c|c|}
\hline & Craniakalk. & Crania tuberculata NiLss. \\
\hline \multirow[t]{2}{*}{ Danien. } & $\begin{array}{l}\text { Saltholmskalk, Blegekridt, } \\
\text { Bryozokalk, Koralkalk. }\end{array}$ & $\begin{array}{l}\text { Ananchytes sulcata GoLdF. } \\
\text { Dromiopsis rugosa v. Schlotir. sp. }\end{array}$ \\
\hline & Lakune. & \\
\hline $\begin{array}{l}\text { Yngre } \\
\text { Senon. }\end{array}$ & $\begin{array}{l}\text { Cerithiumkalk. } \\
\text { Fiskeler. } \\
\text { Skrivekridt. }\end{array}$ & $\begin{array}{l}\text { Ananchytes ovata LESKE. } \\
\text { Scaphites constrictus Sow. sp. } \\
\text { Belemnitella mucronata v. ScHLoth. sp. }\end{array}$ \\
\hline
\end{tabular}

Grænsen mellem Senonium og Danium trækker RAvN, som naturligt er, væsentligt paa Grundlag af Undersøgelser af Forholdene i Stevns Klint, men han faar dog Lejlighed til flere Gange at komme ind paa de lignende Forhold paa Overgangslokaliteten Eerslev paa Mors (95 S. $401,405,411)$.

Ravn kommer ligeledes ind paa Forholdene ved Aggersborg Gaard, hvis koralholdige Kalk GrönwaLL (28 S. 72) havde været tilbøjelig til at sammenligne med »Faxelaget« (Cerithiumkalken) i Stevns og ved Eerslev. I Modsætning til denne Opfattelse vil RAVN snarere antage, at det paa denne Lokalitet (hvorfra han meddeler en ret udførlig Faunaliste) drejer sig om en mere koralførende, lokal Udvikling af Bryozokalken; Faunaen viser nær Tilknytning til Faxe, medens det dog er paafaldende, at de i Faxe stærkt bjergartdannende Koraller Lobopsammia faxensis og Dendrophyllia candelabrum ganske mangler ved Aggersborg Gaard (95 S. 406 og 423-24).

Hvad Daniet iøvrigt angaar, bruger RAvN følgende Inddeling af Bjergarterne, idet han dog bemærker, at Forskellen mellem Blegekridt og Saltholmskalk hovedsagelig ligger i Hærdningen, og at Craniakalk er en kronologisk Betegnelse for Daniets yngste, petrografisk varierende Aflejringer (95 S. 413):

1) Koralkalk.

2) Bryozokalk.

3) Saltholmskalk.

4) Blegekridt.

5) Craniakalk. 
Hrad iøvrigt angaar Senonium og Danium, beskæftiger RavN sig ret indgaaende med geografiske Forhold, Hævninger og Sænkninger o. lign., idet han bl. a. fremhæver, at Overgangen mellem Senonium og Danium karakteriseres ved en Hævning, det derpaa følgende Danium ved en Sænkning, som saa atter under Afsætningen af det "yngre Danien" (Craniakalken) afløses af en ny Hævning. RAvN formoder, at Dele af Danmark har ligget over Havet i Daniumtiden, nemlig det nordøstligste Jylland og de sydligste Øer. Bl. a. ser han en Bekræftelse herpaa i det Forhold, at de ikke Danium-dækkede Skrivekridtomraader i Reglen grænser op til Daniets Bryozokalk-Strækninger, idet han anser Bryozokalken for at være dannet paa lavere Vand end Blegekridtet og Saltholmskalken.

I sine Faunalister noterer RAVN følgende jyske Daniumlokaliteter: Bryozokalk: Skillingbro, Tinbæk Mølle, Voxlev, Lendrup Strand,

Løgstør, Aggersborg, Aggersborggaard, Klim Bjerge, Bulbjerg, Vigsø.

Saltholmskalk: Bredstrup Klint, Sangstrup Klint, Lønnerup (?), Hovsør

Havn, Hjardemaal, Østerodde (= Thisted III).

Blegekridt: Skader, Clausholm, Tinbæk Mølle ${ }^{1}$ ), Skillingbro, Albæk (ved

Skørping), Bjerge, Rær, Legind, Eerslev, Frøslev og Frøslevvang,

Helligkilde, Hjerm, Davbjerg og Mønsted.

I Aarene 1902-03 giver V. MADSEN en Del Oplysninger om Forholdene paa Fyn, hvis Daniumaflejringer hidtil kun havde været løseligt nævnt af Forсннаммек. Bryozokalken omkring Rejstrup gøres til Genstand for ret udførlig Omtale i en mindre Afhandling 1903 (62), og saavel i denne som i Kortbladsbeskrivelsen 1902 (61) gives Oplysning om en Række Boringer: Dalum, Odense, Seden, Munkebo, Ulriksholm, Marslev, Juelsberg, Nyborg (I), Vindinge, Torup, Blankborg, samt et Par Daglokaliteter: Refsvindinge og Rosille.

I 2. Udgave (1904) af „Danmarks Geologi« (124) slutter Ussing sig til RAVN's Opfattelse af Alderen for Cerithiumkalk og Fiskeler, men iøvrigt tilføjer han intet væsentligt ud over 1. Udgave ${ }^{2}$ ).

En Del Oplysninger om Daniets Optræden i Nibeegnen gives af A. Jessen i 1905 (41), idet han bl. a. nævner Forekomsterne af Limsten ved Voxlev, Bislev og Veggerbro (I) og samtidig fremsætter Bemærkninger om Forholdet mellem Danium og Senonium i disse Egne. JEssen

1) Det beror formodentlig paa en Fejltagelse, naar Ravn anfører Blegekridt fra Tinbæk Mølle i sin Faunaliste; han angiver ingen Fossiler derfra, ligesom jeg heller ikke paa Musæet har kunnet finde Oplysninger derom i denne Retning. Som det senere vil blive omtalt, findes begge Bjergarter i det meget nærliggende Brud ved Skillingbro.

2) 3. Udgave ved P. Harder 1913 (127) er, hvad dette Afsnit angaar, saa at sige uforandret fra 2 . Udg. 
hævder den utvivlsomt rigtige Opfattelse, at Limstenen ligger i uregelmæssigt begrænsede og delvis usammenhængende Dækker over Skrivekridtet (S. 32).

I Grönwall og Harder's Afhandling fra 1907 om Paleocænet ved Rugaard giver sidstnævnte i Indledningen en Del Oplysninger om Kalkens Forekomst i Djursland (31 S. 8-9). Foruden de tidligere kendte Klinter i Egnen N. f. Grenaa omtales faststaaende Kalk i Grave ved Enslev samt Forekomster ved Kirial og Nybro. Hertil føjes Oplysninger om en Række Boringer, ved hvilke den faststaaende Kalk er blevet truffet. Foruden 3 Boringer i Grenaa, i hvilke Kalkoverfladen laa i ret ringe Dybde, har man ved Vedø konstateret Kalkens Overflade paa en Kotehøjde af $\div 38 \mathrm{~m}$, ved Løvenholm paa $\div 27 \mathrm{~m} \mathrm{og}$ endelig ved Allingaabro Station paa $\div 31 \mathrm{~m}$. Om selve Kalkens Art gives desværre ingen Oplysninger.

I 1909 udkom et meget vigtigt Bidrag til Daniets Geologi, idet K. Brünnich Nielsen udsendte sit Arbejde "Brachiopoderne i Danmarks Kridtaflejringer ( $(\% 6)$. Afhandlingen fremtræder paa selvstændig Basis som en Afløsning af Posselt's allerede da noget forældede Arbejde over samme Emne.

Det i stratigrafisk Henseende vigtigste Punkt i denne Afhandling er BRÜNnich Nielsen's Paavisning af, at de foregaaende Forfatteres "Nedre Danien« (siden GrönwaLL udskilte Craniakalken som yngste Led af Daniet (26)), kunde adskilles i en ældre og en yngre Afdeling. Dette Resultat var naaet paa Grundlag af palæontologiske Studier, særlig over Brachiopoderne, et Felt, som GrönwaLL allerede i 1899 havde været periferisk inde paa, idet han bemærkede en Forskel i Optræden af de to Arter, Terebratula fallax og Terebratula lens (28 S. 68).

Brünnich Nielsen's Inddeling ser saaledes ud:

Danien $\left\{\begin{array}{l}\text { Yngre D. }\left\{\begin{array}{l}\text { Craniakalk m. Terebratula lens og Crania tuber- } \\ \text { culata. } \\ \text { Yngre Bryozokalk m. Ter. lens. } \\ \text { Saltholmskalk, Coccolithkalk m. Ter. Tens. } \\ \left.\text { Eldre Bryozokalk m. Ter. fallax var. faxensis }{ }^{1}\right) .\end{array}\right.\end{array}\right.$

Af andre faunistiske Forskelligheder mellem A. og Y. Danium nævner Brünnich Nielsen følgende. I A. Danium optræder Brissopneustes danicus, mens den i Y. Danium afløses af B. suecicus. I A. Danium er Piggene af Tylocidaris vexillifera kuglerunde og kornede, idet Kornene undertiden ordner sig i Rækker imod Spidsen, mens Eksemplarerne fra Y. Danium er forsynet med Kamme og Vinger.

1) Navnet er senere af Br. NiELSEN ændret til Terebratula fallax. var. tenuis (89 S. 14).

Danmarks geologiske Undersøgelse. II. R. Nr. 45 . 
Denne Inddeling var i det væsentlige opstillet paa Grundlag af Undersøgelse af sjællandske Lokaliteter. I Jylland faldt Blegekridtet ind under yngre Danium og al kendt Bryozokalk under ældre Danium, idet Yngre Bryozokalk, lige saa lidt som Craniakalken, var paavist i Jylland (76 S. 143).

BRÜNNICH NiELsen meddeler Bestemmelse af Brachiopoder fra følgende jyske Lokaliteter:

Aldre Danium: Valbjerg Sande, Valsted, Aggersund, Aggersborggaard,

Bulbjerg, Klim, Vigsø, Vr. Bjergetgaard, Voxlev, Løgstør, Tinbæk Mølle, Skillingbro, Kjølby, Brøndum.

Yngre Danium: Lønnerup, Hovsør, Rær, Skillingbro, Skader, Østerodde,

Kaase, Hjerm, Hørning, Bredstrup, Sangstrup.

Samme Aar udkom RøRDAm's »Danmarks Geologi« (113), hvori der bliver Daniet en ret fyldig Omtale til Del. Hovedtankerne heri er de samme som i samme Forfatters tidligere Arbejde (112) og bygger særlig paa sjællandske Forhold, men Forholdene i Jylland kommer dog gentagne Gange til Behandling. Han meddeler Oplysninger og Analyser fra flere jyske Lokaliteter, som han klassificerer saaledes:

Kokkolitkalk: Lok. paa Randersegnen, Davbjerg, Mønsted, Sevel,

Hjerm, Vejrum og Brædstrup Klint samt Lok. i Thy og paa Mors. Bryozokalk: Karlby Klint, Mariager, Løgstør, Bulbjerg, Roshage (=

Hansted I) og Voxler samt Lok. paa Mors.

I en Afhandling fra 1912 om Spongieslægten Aphrocallistes i danske Aflejringer anfører RAvN denne Form fra Aggersborggaard, Bredstrup Klint og Østerodde v. Thisted (97 S. 60).

I Aaret 1913 giver Brünnich Nielsen i sine Monografier over Octocorallerne (81) og Crinoiderne (80) i vore Kridtaflejringer et Par faunistiske Bidrag til det jysk-fynske Danium. Han tilføjer Forekomsten af et Par Octocoraller fra Aggersborg Gaard, Eerslev (»Older Danian«), Bredstrup Klint og Rejstrup, og Bestemmelser af Crinoider fra følgende Lokaliteter:

Aldre Danium: Viksø og Løgstør.

Yngre Danium: Bredstrup og "Grenaa«, Sangstrup, Korsø (Kaase), Skader, Thisted, Helligkilde, Hjerm, Aggersborggaard, Skillingbro og Rejstrup.

Desuden kan det noteres, at han har bestemt en Pentacrinus fra Salling (Batum) til P. Bronni og angiver Horisonten som Skrivekridt.

I en Mergelberetning fra 1913 (73) giver MrLthers og Claudi Westh en Række Oplysninger, der udvider Kendskabet til Lokaliteterne i Egnen Ø. og V. f. Viborg. Oplysningerne i Teksten er desværre ret sparsomme, men i Forbindelse med Kortet gives der her Oplysning om 
Forekomster af Blegekridt paa følgende Steder: Omkring Bjerregrav St. (I-V), Kovsted (I-II), omkring Purhus (I-II og IV-V) og Ejstrup (I-III). Endvidere Davbjerg, Stavnsbjerg og Mønsted (I og III). Desuden oplyser de, at faststaaende Kalk ved Langaa er truffet ved Boring $45 \mathrm{~m}$ under Havfladen.

Allerede Aaret efter udsendte Mintmens en lignende Oversigt over Mergel og Kalk i det nordvestlige Jylland (68). Ogsaa her gælder det desværre, at Teksten er meget sparsom i Forhold til Kortet, men sammenholdt med Kortet yder dette Arbejde dog et meget værdifuldt Bidrag til Oplysningen om Kalkbjergarternes Forekomst i disse Egne. Der noteres saaledes Blegekridt eller Limsten fra følgende Lokaliteter:

Thisted (III, IV, V og VIII) Faartoft (II), Skaarup, Torup v. Vang, Vang, (Ørhage), Vegebjerg (I), Bolsande, Klokrøgel (I), Nystrup, Vorupør, Legind, Stenbjerg v. Vorupør, Sennels (I-II), Hovsør, Dalgaard, Hansted (III), Rær, Bjerge (I-II ?), Hjardemaal (I-II), Kaase (I), Hjardemaal Fattiggaard, Tved, Torup Kløv, Torupstrand, Klim, Klim Bjerge, Bulbjerg, Ø. Jølby, Eerslev (I-III), Frøslevvang (I-II), Øxendal, Lødderup, Tødse og Helligkilde.

1914 meddeler J. P. J. RAvN lejlighedsvis Forekomsten af Blegekridt i den vestlige Del af Mariager Fjord ved Frederikseje (98 S. 263).

I 1916 oplyser Milthers endvidere, at der i en Bakke $400 \mathrm{~m}$ Ø. f. Nøvling Kirke findes Kalk, vistnok Blegekridt, men Lokaliteten var paa det paagældende Tidspunkt utilgængelig. Muligvis er Kalken heller ikke faststaaende paa Stedet (69 S. 5).

Endelig giver MrLthers i 1917 (71) en Oversigt over Kalkaflejringerne paa Holstebro Egnen, hvorunder han meddeler en Række Oplysninger om Forekomsterne ved Hjerm og Vejrum, samt mere i Forbigaaende nævner Sevel, Thyholm (Helligkilde) og Nøvling.

BRÜNnICH Nielsen giver i 1917 enkelte faunistiske Bidrag til Daniet i Jylland (85).

V. Madsen gav i 1918 en Redegørelse for Tertiæret ved Mariagerfjord $(65 a)$, i hvis Slutningskapitel han behandler hele Egnens Tektonik. I den Oversigt over de forskellige Dannelser, der ligger til Grund herfor, giver han ogsaa en Række Oplysninger om Daniets Udbredelse. Madsen nævner (og til Dels beskriver) saaledes Forekomsterne ved Ovegaards Vandmølle (Ove I og IV), Stinesminde (I-II), Jomfrubakken, NØ. f. Mariager (I-III) samt endelig Gravene ved Frederikseje (»Voldstedlund () .

I et Arbejde fra samme Aar (4) gav O. B. BøGGILD en Oversigt over en Række dybere Boringer, der naar ned i de ældre tertiære Dannelser. Herunder offentliggør han ogsaa nærmere Oplysninger om de allerede tidligere nævnte Boringer ved Skive, Langaa, Fredericia, Strib og Wedellsborg samt Skrøbelev, der ikke blot naar ned i Tertiæret, men 
gennemborer dette og bringer mere eller mindre fuldstændige Oplysninger om det underliggende Danium. I Skive-, Wedellsborg- og Skrøbelevboringerne bestaar det gennemborede Danium af Bryozokalk, mens i de andre Tilfælde den øverste Del af Daniets Kalksten synes at være repræsenteret af Coccolitkalk eller en lignende Bjergart (4 S. 86-87 og $93-97)$.

Endvidere maa det nævnes, at A. Jessen i 1918 oplyser om Forekomsten af Blegekridt i Grave ved Ø. Tørslev og Tørring (43 S. 14).

Endnu en Mergelberetning fra V. Milthens' Haand i 1919 (72) bringer en Del Oplysninger fra Djursland. Foruden at nævne de gammelkendte Klinter og de af HaRder omtalte Boringer, giver Milthers Meddelelse om Kalkens Optræden paa følgende Steder: Aastrup Mark, Hammelev Gaard, Havdal, Veggerslev, Laen og Revn.

Brünnich Nielsen gav samme Aar yderligere Bidrag til Aggersborg Gaard-Kalkens Faunistik, idet han offentliggjorde en Bestemmelse af Hydroider (87 S. 24).

I 1919 begyndte Udgivelsen af et Værk, der ved sine afgrænsede, geologiske Beskrivelser gav Anledning til Omtale af en Række Daniumlokaliteter, nemlig Daniel BRUun's "Danmark». I den geologiske Indledning omtaler V. Madsen $(65 b)$ det jyske Danium i Sammenhæng med det øvrige Lands, men han nævner kun enkelte af de almindelig kendte Lokaliteter. I »Amtsbeskrivelserne« nævnes en hel Række Lokaliteter, af hvilke følgende er nye eller nærmere fastslaaede: (Volsted (BøGGILD, 6)); Assens, Dalbynedre, Kastbjerg, Hald, Albæk v. Randers (BøGGILD 9).

I en Afhandling fra 1920 (88) omtaler BRÜNnich Nielsen den sandsynlige Forekomst af Overgang mellem ældre og yngre Danium ved Skillingbro, idet der herfra foreligger baade Bryozokalk og Blegekridt paa Min. Museum. Iøvrigt er der ikke Grund til her at komme nærmere ind paa Afhandlingen, der beskæftiger sig med Inddelingen af Daniet, men uden at bringe noget nyt om jyske Forhold.

Under Behandlingen af Craniakalken fra København udtaler Rosenkrantz sig i 1920 om Kalken i Bredstrup Klint, idet han bestemmer denne "Saltholmskalk« som Akvivalent for "Nedre Craniakalk", d. v. s. for den allerøverste Del af Daniets Kalkbjergarter. Paa Sjælland overlejres denne Nedre Craniakalk af Paleocænets Grønsand (eller Grønsandskalk), stedvis med et Bundkonglomerat af "Øvre Craniakalk«; som karakteristiske Forsteninger, der foreligger fra Bredstrup Klint, anfører Rospnkrantz Graphularia Grönwalli, Ditrupa Schlotheimi og Scalpellum Steenstrupi (106 S. 61).

Medens denne øverste Horisont af Daniet paa Sjælland overlejres af Grønsandet, blev denne Lagfølge først nu fundet i Jylland af $\mathrm{V}$. Minthens. I Litteraturen foreligger desværre kun et kort Referat af en 
Ekskursion (13), hvori Lagserien ved Hvalløse beskrives. Profilet her bestaar nederst af Blegekridt, hvorover ses $0,75 \mathrm{~m}$ grønliggraat Sand, indeholdende ret rigelige Rester af en paleocæn Fauna, der slutter sig nær til den ved Vestre Gasværk i København fundne. Den nederste Del af Grønsandet er opfyldt af stærkt rullede, glaukonitiserede Knolde og slidte Forsteninger, Rester af en omlejret Lavvandsdannelse, der i meget ligner Rosenkrantz's "øvre Craniakalk« ved København. Grønsandet dækkes atter af andre tertiære Dannelser.

I 1922 fortsætter BRÜNniCH NiELSEN sine palæontologiske Arbejder med en Afhandling om Zoantharierne (90), hvori gives faunistiske Bidrag til Aggersborggaard, Vixø, Bulbjerg og Rejstrup $\left.{ }^{1}\right)$.

Som det vil ses, havde de sidste Aar udvidet Kendskabet til Daniets Udbredelse i Jylland paa mange Punkter, men først i 1922 sammenarbejdede J. P. J. RAvn disse til en Oversigt i sit Kort over Undergrunden i Danmark (104). Teksten til Kortet indskrænker sig til at oplyse om Lokaliteternes Beliggenhed og Art, Kalkens Art, eventuelt dens Højde o. lign., hvorimod Kortet selv giver en udmærket Oversigt over vort Kendskab til Daniets Forekomst og Udbredelse, ført op til det paagældende Tidspunkt.

RAVN medtager herved næsten alt, hvad der forelaa i Litteraturen, men desuden meddeler han yderligere en Række nye Forekomster af Daniet, som ikke hidtil havde været offentliggjort; i Jylland Aalsø Mejeri, Aarslev, St. Ajstrup Skole, Bjørnsholm Mejeri, Dalbyovre, Faldgaarde, Hvamstrup Gaard, Pindsminde, Mejlby Vandværk, Svendstrup, Svejstrup (Blegekridt med overlejret Paleocæn-Mergel), Tustrup, Ørsted Vandværk, Glatved Vandværk; paa Fyn og Langeland Nyborg (II-III), Lohals, Bøstrup, Lejbølle, Korsebølle og Tranekær.

Et nyt Bidrag til Kendskabet til Daniets Basis, som hidtil kun kendtes fra Stevns Klint og fra Mors, gaves i 1923 af A. Jessen og H. ØDum i en Afhandling om Forholdene ved Voxlev (4\%). Heri resumeres forst Kendskabet til Kridt- og Daniumaflejringernes Udbredelse paa Nibeegnen (herunder et Par nye Forekomster ved Grydsted Skole, Øster Hornum og Abildgaarde (S. 11)), hvorpaa der gives en udførlig Beskrivelse af Overgangen mellem Skrivekridtet og Daniets Bryozokalk ved Voxlev Kalkværk.

Interesse i samme Forbindelse har Rosenkrantz's Undersøgelser i 1924 (109 S. $37 \mathrm{og}$ 110) af Stevns Klint. Arbejdet vedrører ikke direkte Jylland, men Rosenkrantz bringer Klarhed over forskellige Forhold vedrørende Overgangen i Stevns Klint og parelleliserer »det døde Lag«

1) I Faunalisten (90 S. 212) anfører Brünnich Nielsen Ceralotrochus Milthersi fra "Younger Danian«, Randers; dette er imidlertid ukorrekt, idet Forsteningerne, som det ogsaa anføres S. 218, er hjemmehørende i det ovenfor nævnte Grønsand ved Hvalløse. 
fra Voxlev med den over Fiskeleret liggende Cerithiumkalk (»Brissopneusteslaget«); Rosenkrantz omtaler samtidig (109) en af Ebeltoftboringerne (II).

Endelig behandler RavN i 1925 (105) Daniets geologiske Stilling i Almindelighed, hvorved han lejlighedsvis berører jyske Forhold.

Hovedindtrykket af denne historiske Oversigt bliver følgende. I Tidens Løb er der tilvejebragt ret fyldige Oplysninger om Udbredelse og Forekomst af Daniumlagene i Jylland. Paa en Række Undtagelser nær er vort Kendskab herudover imidlertid temmelig ringe. En fornyet Undersøgelse med det Formaal systematisk at oplyse Lokaliteternes nøjagtige Beliggenhed, Kalkens Art, Forsteningsindhold og andre geologiske Omstændigheder, Forhold, hvorom Litteraturens Meddelelser ofte er ringe eller modstridende, er derfor meget paakrævet. Saa meget mere gælder dette, naar der ses hen til Udviklingen af Kendskabet til det sjællandske Danium, idet man bør undersøge, om den for dette opstillede Inddeling har Gyldighed i Jylland, og eventuelt søge at fremskaffe supplerende Oplysninger.

Kapitel II

\section{Daniumbjergarternes Terminologi.}

Lige siden det Tidspunkt, da man her i Landet fik delt »Kridtformationen« i de to Grupper, Skrivekridt og Nyere Kridt eller Terrain danien, er de til denne sidste Gruppe hørende Aflejringer blevet beskrevet under en lang Række forskellige Navne. I Naturen er det, selv ved en overfladisk Betragtning, ret let at skelne mellem Skrivekridtet og Daniumbjergarterne, men medens det førstnævnte overalt er ret ensartet, varierer de sidstnævnte i temmelig høj Grad i petrografisk Henseende, baade med Hensyn til Bjergartens oprindelige Komposition og med Hensyn til senere Forandringer, især Hærdning. De enkelte Bjergarter indenfor Daniet varierer meget stærkt, og de enkelte Grupper danner alle Overgange med hinanden. Dels som Følge heraf, dels som Følge af de forskellige Forfatteres Anskuelser eller Kendskab til Fænomenerne, indeholder Litteraturen en hel Række Bjergartsnavne, der enten ikke er skarpt definerede eller i større eller mindre Udstrækning er synonyme. 
Det følgende skal imidlertid ikke være nogen omhyggelig historisk Udredning af disse Forhold (i den Henseende vil jeg i det store og hele indskrænke mig til, hvad der er sagt i Kap. I), og heller ikke er dette Pladsen til at foretage en gennemgribende, kritisk Revision af de anvendte Termini $^{1}$ ). Imidlertid er man, naar man beskæftiger sig med et Emne som det foreliggende, tvunget til at træffe sit Valg af, hvilke Benævnelser man vil bruge, og der skal derfor gives en kortfattet Begrundelse af dette Valg.

Forchinmmer anvendte 1835 følgende Navne (16): 1) Karlebykalk, 2) Saltholmskalk, 3) Faxekalk, 4) Blegekridt, 5) Limsten. Af disse Navne gik det første meget snart over i Historien, idet Kalken i Karlby og Sangstrup Klinter (som Forchнамmen forøvrigt i samme Arbejde benævner Saltholmskalk) viste sig identisk med hans »Limstenk. (21).

De øvrige Navne lider under flere Mangler, og allerede 1882 forsøgte Johnstrup en ny Gruppering (50): 1) Koralkalk og 2) Bryozokalk. Under Gruppe 2) indbefattede han alle åndre Daniumbjergarter end Koralkalken, idet han ansaa Variationerne i Finhed for at være mindre væsentlige.

At denne sidste Betragtning ikke er holdbar, paavistes senere af RøRDAM 1897 (112), der leverede den første velbegrundede og efter bestemte Principer gennemførte Inddeling af Daniumbjergarterne: 1) Koralkalk, 2) Bryozokalk, 3) Foraminiferkalk, 4) Kokkolithkalk, 5) Spongiekalk. Den her gennemførte Inddeling har i alle Tilfælde den Fordel at være rent petrografisk beskrivende og neutral overfor Spørgsmaalet om Aflejringernes indbyrdes Alder.

Ussing 1899 og $\left.1902(122,123)^{2}\right)$ vender tilbage til de gamle ForchHAMMER'ske Benævnelser, idet han (foruden »Fiskeler« og »Cerithiumkalk«) bruger Navnene: 1) Limsten, 2) Saltholmskalk og 3) Blegekridt, og hermed er man atter inde i Forvirringen. "Limsten« er omtrent ensbetydende med Bryozokalk; "Saltholmskalk« anvendes derimod om haarde Kalkstene (fortrinsvis bryozofrie), men herunder indrangerer Ussing baade Bryozokalken i Karlby-Sangstrup Klinter og hærdnet Coccolitkalk; "Blegekridt « omfatter det meste Coccolitkalk, men nogle Forekomster heraf udskydes saa som »Saltholmskalk«.

Ravn 1902-03 (95) befinder sig paa et Mellemstadium mellem de to Navnegrupper, idet han bruger Navnene 1) Koralkalk, 2) Bryozokalk, 3) Saltholmskalk, 4) Blegekridt og 5) Craniakalk. RAvs forklarer

1) I og for sig er en saadan Revision i høj Grad tiltrængt, men denne bør tages op paa en bredere Basis, end jeg har været i Stand til.

$\left.{ }^{2}\right)$ Her ses indtil videre bort fra Grönwall's "Craniakalk , da dette Navn er (og som Regel kun er anvendt som) en ren Zonebetegnelse. 
nærmere dette Skema, idet han med "Saltholmskalk" mener stærkt hærdnet Coccolitkalk, med „Blegekridt « blødere Coccolitkalk ${ }^{1}$ ); "(raniakalk« er en kronologisk Betegnelse, som kan omfatte flere petrografiske Grupper og altsaa ikke burde bruges sideordnet sammen med disse $\left.^{2}\right)$.

Brünnich Nielsen bruger en lignende Gruppe Navne i 1909 (76), men i 1920 (88) opstiller han en Række Betegnelser for det yngre Daniums Bjergarter, idet han argumenterer for deres samtidige Dannelse: 1) Cocolithkalk, 2) Foraminiferkalk, 3) Koralkalk, 4) Spongiekalk, 5) Bryozokalk, 6) Craniakalk, 7) Grønsand og Grønsandskalk.

At den sidste Gruppe opfattes som en Dannelse (Glaukonitfacies) synkron med Daniets Kalkbjergarter, bliver en Sag for sig. Den eneste Forskel fra RøRDAM's Serie bliver dernæst, at han vil fæstne Begrebet "Craniakalk« paa lige Fod med de andre, rent petrografisk beskrivende Navne. Han skriver : „- men alligevel er der noget særegent ved Craniakalkens Fauna _ _ - , saaledes at man, selv om man ikke kan opretholde Craniakalken som Tidsafsnit ${ }^{3}$ ), godt kan bruge Betegnelsen om en bestemt Facies. Vi maa nemlig antage, at samtidig med den øvre Craniakalks Dannelse paa en bestemt Havdybde aflejredes Lagene, som vi finder ved Frederiksholm og paa Saltholm, paa en anden Havdybde." Rent bortset fra det problematiske i den sidste Paastand er det klart, at Anvendelsen af Navnet Craniakalk paa denne Maade er baade forvirrende og ulogisk; det sidste, fordi hans „Craniakalk« (øvre og nedre) petrografisk falder ind under de af ham selv anvendte Navne Coccolithkalk, Foraminiferkalk, Spongiekalk, Kalksand og Kalksandsten, finkornet Kalksten o. s. v.

Efter denne kortfattede Oversigt over Terminologiens Udvikling, behøves der ikke mange Ord til yderligere Forklaring. Det vil være klart, at det under alle Forhold maa være absolut ønskeligt at kunne benævne en foreliggende Bjergart ved et rent neutralt, petrografisk Navn; saa maa den yderligere Inddeling eller Sammenfatning i Grupper af palæontologisk eller kronologisk Art blive en Sag for sig, hvorom nærmere i Kap. VI. Under Beskrivelse af Daniumforekomsterne og de her op-

1) Det sidste (for hvilket Skylden nærmest maa lægges paa ForcHнАммеR) forekommer umiddelbart uheldigt, da "Blegerne» netop er de hærdnede Partier af "Coccolitkalken«.

$\left.{ }^{2}\right)$ En hertil svarende Inddeling bruges af Ussing i 1910 (126):

a) Bryozoenfacies (»Limsten«),

b) Korallenfacies ("Faxekalk«),

c) Kokkolithenfacies ("Blegekridt«),

d) Saltholmskalk (hærdet Coccolitkalk),

e) Litoralfacies (Craniakalk).

$\left.{ }^{3}\right)$ Dette kan for Resten slet ikke betragtes som fastslaaet. 
trædende Bjergarter vil jeg derfor foretrække at anvende Navne af den Rørday'ske Type:

Bryozokalk,

Coccolitkalk ${ }^{1}$,

Koralkalk,

o. s. v.

Disse kan altid suppleres med rent petrografiske Navne efter samme Princip og med Tilføjelse af beskrivende Adjektiver.

\section{Kapitel III}

\section{Beskrivelse af Daniumlokaliteter.}

Ved hver Lokalitet anføres — saa vidt muligt - de Steder i Litteraturen, hvor den tidligere har været omtalt. At dette kun til en vis Grad har været gørligt, er indlysende, bl. a. gælder det, at man ofte (desværre ogsaa naar det drejer sig om palæontologiske Data) har anvendt mere omfattende Fællesnavne som f. Eks. »Løgstør«, „ved Mønsted« o. s. v. for ikke at tale om »Thy«, »Mors«, "det nordlige Jylland«.

Ved de fleste Lokaliteter er Kotehøjden angivet efter Generalstabens Kort; Kotetallet angiver Terrænhøjden. Kalkens Dybde under Jordoverfladen er ofte angivet, men i det store Antal Tilfælde (de fleste aabne Grave), hvor intet desangaaende er bemærket, betyder det, at de over Kalken liggende Lag har saa ringe Mægtighed, at det opgivne Tal uden videre kan overføres som gældende for Kalkens Overflade ${ }^{2}$. Angaaende de brugte Etage- og Zoneangivelser kan refereres til Slutningsskemaet i Kap. VI.

Skrøbelev I. 4 (S. 97). 10 (S. 8). 104 (F. 10. 5)³).

Boring ved Skrøbelev Mejeri. Bryozokalk i 113 m Dybde, overlejret, af paleocænt Ler og plastisk Ler. Kalken bestaar af ret fine, velbevarede

1) Da Bjergarten ikke præges saa absolut af Coccoliterne som f. Eks. Koralkalk af Koraller og Bryozokalk af Bryozoer, vilde det egentlig være bedre at anvende Udtrykket Slamkalk. Alligevel foretrækker jeg at beholde Navnet Coccolitkalk, dels for at undgaa Anvendelsen af nye Navne, dels fordi Coccoliter indgaar i de herhen hørende Bjergarter i et saadant Forhold, at Navnet Coccolitkalk kan forsvares.

$\left.{ }^{2}\right)$ Disse Bemærkninger gælder ogsaa for Kap. IV.

3) Paa Kortet er Numrene F. 10. 4 og F. 10. 5 byttet om, ligesom F. 10. 6 er urigtigt anbragt. 
Bryozoer og er aabenbart meget løst sammenhængende. Flinten (kun lidt) er graa.

Y. Danium, ifølge Forsteningerne.

Tranekær. 104 (F. 10. 1).

2 Boringer ved Mejeriet. Kote $19 \mathrm{~m}$. Bryozokalk fra 51,8 m Dybde.

Y. Danium?

Korsebølle. 104 (F. 9. 11).

Boring. Kalk i 59,6 m Dybde.

Lejbølle I. 104 (F. 9. 10).

Boring ved Lejbølle ny Mejeri. Prøverne fra $28 \mathrm{~m}$ Dybde bestaar af Kalk, de øverste dog noget urene. En Prøve fra 40,8-43,9 m bestaar af ren Bryozokalk; denne er løst sammenhængende, Bryozoerne ret grove, indlejret i den løse, hvide Grundmasse.

Bøstrup I. 10 (S. 8). 104 (F. 9. 9).

Boring ved Bøstrup Andelsmejeri. Kalk 37,7 m u. Overfladen.

Lohals I. 104 (F. 9. 5).

Boring ved Mejeriet. Kote $11 \mathrm{~m}$. Kalk i 45,2 m Dybde.

Svendborg I.

Boring ved Svendborg Gasværk 1921. Ifølge Oplysninger i D. G. U.s Borearkiv er der her truffet Bryozokalk i 60-62,4 Dybde, overlejret af tertiært (eller kvartært?) Ler. Prøverne viser en meget fin, stedvis dog ret grov Bryozokalk, meget løst sammenkittet, med velbevarede Bryozoer. Flinten graa.

Y. Danium (Zone D), ifølge Forsteningerne.

Taarup. 61 (S. 10). 10 (S. 8). 104 (F. 9. 4).

Brøndgravning. »Kalk« i 16 m Dybde.

Refsvindinge I. 17 (S. 4). 19 (S. 536). 20 (S. 29). 61 (S. 8).

Grav N. f. Refsvindinge.

Madsen gengiver (61) Forchiammer's Beskrivelse af Graven, ifølge hvilken "Limstenen er temmelig blød —. Flint findes deri i store, sorte Nyrer, der - ikke var samlet i regelmæssige Lag.»

Holckenhavn. 19 (S. 536, »Liimsteen - ikke langt fra Holkenhavn«). 20 (S. 29). 10 (S. 8).

Nærmere herom vides ikke. 
Blankborg. 61 (S. 10). 104 (F. 9. 3).

Brønd. Kote ca. $15 \mathrm{~m}$. "Kalken« findes i en Dybde af $16 \mathrm{~m}$.

Rosille I. 61 (S. 9). 62. 10. (S. 8). 104 (F. 9. 1).

Brønd $400 \mathrm{~m} \mathrm{SV}$. f. Vindinge Kirke. Kote ca. $7 \mathrm{~m}$.

Coccolitkalken fandtes i $3 \mathrm{~m}$ Dybde. »Prøverne viste sig at være temmelig grovkornet Blegekridt, der er saa urent, at det beholder Formen ved Behandling med fortyndet Saltsyre. Under Mikroskopet ses en Mængde Kokkoliter samt mange Foraminiferer, hvoraf en Del med Glaukonitudfyldning. Ret hyppig ses ogsaa Spongienaale ligeledes i Glaukonit — (61). Kalken nærmer sig stærkt til "Kalksandskalk«.

Y. Danium, ifølge Forsteningerne.

Rosille II. 61 (S. 9).

Brønd $500 \mathrm{~m}$ SSV. f. Vindinge Kirke. Kote ca. $9 \mathrm{~m}$. Kalk i $5 \mathrm{~m}$ Dybde. Formodentlig Y. Danium.

Vindinge I. 61 (S. 10 og 145). 62.10 (S. 8). 104 (F. 9. 1).

Boring ved Andelsmejeriet. Kote $6 \mathrm{~m}$. Kalk og lidt Flint 12,2$25,7 \mathrm{~m}$ u. Overfladen.

Nyborg I. $61($ S. 10) 1 ).

Boring ved den gamle Stationsbygning. Kote ca. $2 \mathrm{~m}$. Kalk i en Dybde af 17,6 m. Formodentlig Y. Danium.

Nyborg II. 104 (F. 9. 2).

Boring ved Cichorietørreriet. Kalk fra 24,3 m Dybde; det er en ret haard Bryozokalk, hvis fine, velbevarede Bryozoer ligger indlejret i en meget finkornet Grundmasse. Formodentlig Y. Danium.

Nyborg III. 104 (F. 9. 2).

Boring ved "Carlsminde Bryggeri«. Kote ca. 5 m. "Limsten« i ca. $17 \mathrm{~m}$ Dybde. Prøverne bestaar af finere og grovere Bryozoer af en aabenbart løst sammenhængende Kalk.

Y. Danium, ifølge Forsteningerne.

Nyborg IV. 104 (F. 9. 2).

Boring ved Gormsens Bryggeri. »Kalk« i 12,6 m Dybde. Formodentlig Y. Danium.

Juelsberg I. 61 (S. 10 og 145). 62.10 (S. 8). 104 (F. 8: 6).

Boring. Kote ca. $25 \mathrm{~m}$. »Limsten« i 33,6 m Dybde.

1) Madsen anfører (efter Forchinamer) et Par ældre Boringer. 
Rejstrup I. 62. 81. 80. 85. 65 (»Omegnen af Nyborg«). 10 (S. 8). 104 (F. 8.5).

2 Grave $200 \mathrm{~m}$ NNV. f. Rejstrup. Kote $21 \mathrm{~m}$.

Kalken er Bryozokalk med finere og grovere Bryozoer i en fin, afsmittende, rigelig Grundmasse; kun løst sammenkittet. Flinten graa. Kalken er muligvis ikke faststaaende.

Y. Danium, ifølge Forsteningerne.

Rejstrup II. 62 (S. 35).

Brønd i Rejstrup By. Kote 19 m. Kalk i 8,7 m Dybde. Formodentlig Y. Danium.

Marslev I. 61 (S. 10 og 144). 4 (S. 120).

Boring ved Mejeriet. Kote $14 \mathrm{~m}$.

Kalk i $60 \_82,2$ m Dybde, overlejret af paleocænt Ler. Prøverne bestaar af temmelig fine Bryozoer og løst Slampulver.

Y. Danium (Zone D), ifølge Forsteningerne.

Ulriksholm. 61 (S. 10 og 131). 4 (S. 120). 10 (S. 8).

Boring. Kote ca. $13 \mathrm{~m}$. Kalk i 87,6 -94,1 m Dybde, overlejret af paleocæn Mergel.

Munkebo I. 61 (S. 10 og 130). 64.

Boring ved Mejeriet. Kote ca. 6 m. »Kalk og Flint« i 121,2-133,4 m Dybde.

Seden I. 61 (S. 10 og 130).

Boring ved Lærerboligen. Kote $3 \mathrm{~m}$. »Kalksten« i $55,8-69,6 \mathrm{~m}$ Dybde, overlejret af paleocænt Ler.

Odense I. 61 (S. 10 og 140). 64.4 (S. 120). 10 (S. 8).

Boring i Vestergade (Brandts Fabrik). Kote ca. $13 \mathrm{~m}$.

Kalk i 76,6-113,1 m Dybde, overlejret af paleocænt Ler. De foreliggende Prøver fordeler sig saaledes:

77,5 -78,4 m (247-50'): Coccolitkalk m. lidt Bryozoer.

$78,4-79,0 \mathrm{~m}\left(250-52^{\prime}\right)$ : Coccolitslam m. faa Bryozoer; under Mikroskopet viser Slammet sig — foruden grovere Bestanddele - at være meget rigt paa Coccoliter.

Flinten graasort med tyk, hvid

85,0 ? m (272' ?): Bryozokalk; mange Bryozoer, ret fine Skorpe. samt en Del grovere.

87,8-97,3 m (280-310'): Ren Coccolitkalk, ingen Bryozoer; Kalken ret fin, afsmittende. Hvid Flint. Y. Danium. 
Dalum I. 61 (S. 143). 4 (S. 120-21).

Boring. Kote $10 \mathrm{~m}$. Bryozokalk i 75,3-77,5 m Dybde, overlejret af paleocænt Ler. Y. Danium.

Dalum II. 61 (S. 10 og 143). 4 (S. 120-21).

Boring ved Dalum Papirfabrik. Kote ca. $9 \mathrm{~m}$.

Bryozokalk i 74,3-97,1 m Dybde, overlejret af paleocænt Ler; den bestaar af finere og lidt grovere Bryozoer og er ret løst bygget.

Østrup Gaard.

Boring 1876. Ifølge Oplysninger i D. G. U.s Borearkiv gennemboredes her wren Kalk« i 102_112,3 m Dybde, overlejret af Kvartær.

Wedellsborg. 122 (S. 121). 63 (S. 96, 192). 4 (S. 95). 10 (S. 8 ). 104 (D. 8. 32).

Kote ca. $8 \mathrm{~m}$. Ved Boringen her gennemboredes Bryozokalk i Dybden 149-165 m; Bryozoerne fine. Kalken overlejres af paleocænt og eocænt Ler.

Strib I. 122 (S. 121). 63 (S. 96). 4 (S. 95). 10 (S. 8). 104 (D. 8.17 ).

Kote ca. 4 m. Boring ved Strib Station. "Kridt《i en Dybde af $152 \mathrm{~m}$, overlejret af paleocænt og eocænt Ler.

Fredericia. 122 (S. 103). 63 (S. 96). 76 (S. 172). 4 (S. 93). 11 (S. 132). 104 (D. 8. 14).

2 Boringer ved Jernbanestationen, foretagne i Aarene 1873 og 75 . Kalken blev truffet i 173 m Dybde, overlejret af paleocænt Ler og plastisk Ler med Tuf.

Om Daniet og dets Overgrænse bemærker BoGGILD følgende:

»Paa Grænsen mellem Paleocæn og Kridt findes Grønsandsdannelser, idet der ved $173 \mathrm{~m}$ (fra 1873) findes en Prøve af næsten usammenhængende, ret grovt Grønsand med 12,8 p. Ct. Kalk. Det indeholder meget Glaukonit, Krarts og Svovlkis.

Kridtet begynder temmelig sikkert ved $173 \mathrm{~m}$, idet der her fra 1873 findes graa Flint og fra 1875 uren Kalksten med 56,6 p. Ct. Kalk. Fra den sidstnævnte Boring findes en Del Prøver herfra ned til $185 \mathrm{~m}$, der bestaar af alle mulige Overgange fra Flint til forholdsvis ren Kalk; den tilsyneladende kalkrigeste Prøve (fra $177 \mathrm{~m}$ ) indeholdt dog kun 85;3 p.Ct. Kalk, og det er vel rimeligt, at mulige kalkrigere Bjergarter har været for bløde til at kunne komme op i hel Stand. Kalkstenen ligner i det Ydre nærmest Blegekridt, men det er ikke muligt ved Sønderdeling af den at se Foraminiferer eller Kokkoliter, hvilket muligvis staar i Forbindelse med den ret rigelige Imprægnation med Kiselsyre. Flinten 
indeholder en usædvanlig Mængde Svampenaale, men ogsaa mange Foraminiferer.«

Bryozoer findes ikke.

Kalken tilhører Y. Danium (Zone D.).

Møllerup I.

Boring ved Møllerup, $1 \mathrm{~km}$ SØ. f. Bjødstrup.

Ifølge Oplysning i D. G. U.'s Borearkiv er der her truffet »Kalk og Flint« i en Dybde af $59 \mathrm{~m}$ u. Overfladen. Kalkens Art ubekendt.

Abelt oft I.

Boring ved "Abeltoft Andels-Svineslagteri«.

Efter de paa D. G. U. opbevarede Prøver ser Profilet saaledes ud: $0-41,5 \mathrm{~m}$ Kvartær.

$41,5-42,7$ - Graa Flint.

43,5-43,6 - Løst Kalkpulver.

$43,6-43,9$ - Graa Flint.

43,9-44,3 - Graa Kalk som ovennævnte, haard, tildels forflintet.

44,3—44,9 - Blød, smuldrende, sandet, graa Kalk.

44,9-45,8 - Hvid Flint.

45,8-46,1 - Haard, delvis forflintet Kalk.

$46,1-78,5$ - Løst Kalkpulver.

78,5-79,1 - Haard Kalk.

Kalken viser sig under Mikroskop at bestaa af finere og grovere, klastiske Bestanddele, hvortil kommer et stort Kontingent af Mikrofossiler, især Foraminiferer; Coccoliter er ikke iagttaget, hvilket dog kan skyldes Bevaringstilstanden. Det hele er sammenkittet af Calcit. Kvarts og Glaukonit findes næppe.

Ebeltoft II. 104 (F. 6. 5). 109 (S. 36).

Boring ved »Abeltoft Lædervarefabrik«, udført i 1918. Ifølge Oplysning og Prøver paa Mineral. Museum ser Profilet saaledes ud:

$0-1,5 \mathrm{~m}$

$1,5-2,75$ - Diluvialsand.

$2,75-36,0$ - Moræneler og -sand.

$36,0-39,0-$ Kertemindeler $\left.^{1}\right)$.

39,0 -40,75 - Grønsandsmergel m. korroderede Aragonitskaller og rullede Calcitskaller.

40,75-42,0 m Grov Grønsandsmergel m. uopløste Aragonitskaller og rullede Calcitskaller.

$42,0-42,75 \mathrm{~m}$ Graa Flint.

1) Saavel denne Prøve som Prøverne fra de dybere liggende Lag er tit forurenet af Kvartærmateriale. 
42,75-47,0 m Danium. Prøven bestaar væsentlig af smaa Brudstykker af graa Flint, blandet med en ringere Mængde Smaastumper af en graa, finkornet, lidt grynet, haard Cocolitkalk af samme Art som Kalken i Abeltoft I.

47,0-57,5 m Danium. Prøven, som er fint knust, er meget uren og viser kun, at den gennemborede Strækning bestaar af Coccolitkalk.

A. Rosenkrantz har bestemt de (ret sparsomt) foreliggende Forsteninger, væsentligst Foraminiferer og Bryozoer; bortset fra disse to Grupper er Forsteningerne opført i Bilag H. De fleste - eller maaske alle - Daniumformer i Prøven 40,75-42,0 ligger sikkert paa sekundært Leje.

Lagfølgen kommer til at se saaledes ud:

$$
\begin{aligned}
& \text { 1,5-36,0 m Kvartær. } \\
& 36,0-42,0-\text { Selandium. } \\
& 42,0-\quad \text { Y. Danium (Zone D). }
\end{aligned}
$$

Glatved I. 104 (F. 6. 1).

Boring ved Vandværket. "Limsten« $38,9 \mathrm{~m}$ u. Overfladen.

Rugaard.

Boring foretaget i 1917 .

Ifølge Oplysninger i D. G. U.'s Borearkiv har man her gennemboret 19,8 m Kvartær og er derefter stødt paa faststaaende Kalk.

Den foreliggende Kalkprøve bestaar af Brokker af en gul og graa, haard, krystallinsk Kalksten noget kornet, der dog nærmest maa være en stærkt hærdnet Coccolitkalk.

Aalsø I. 104 (F. 5. 10).

Boring ved Mejeriet. Kote $22 \mathrm{~m}$. Kalk 17,6 m u. Overfladen.

Revn. 72 (S. 21). 704 (F. 5. 9).

Kalken er truffet tæt under Overfladen ved Boring flere Steder i Egnen tæt V. f. Revn. Kote ca. 15 m. Ved Besøg paa Egnen i 1919 fandtes ingen aabne Grave.

Mrtmhers angiver kun »Kalk«og »Kalk m. Flint«. Kalkprocenten varierer fra $44,6-62,6$.

Enslev. 31 (S. 8).

Ifølge HARDER findes faststaaende Kalk tilgængelig i flere Grave omkring Enslev, men af hrad Art Kalken er, oplyses ikke. At dømme efter et paa Mineral. Museum opbevaret Ekspl. af Echinocorys sulcatus er Bjergarten Coccolitkalk.

(Y. Danium?). 
Kirial. 31 (S. 8).

Ifølge HARDER findes faststaaende Kalk iagttaget under senglacialt Smeltevandsgrus i Bunden af Dalen ved Kirial. Kote ca. 3 m. Nærmere Oplysning om Kalkens Natur foreligger ikke.

Nybro. 31 (S. 8).

Herom gælder, hvad der er sagt om Kirial. Kote ca. $6 \mathrm{~m}$.

Grenaa. 31 (S. 8). 104 (F. 5. 8).

2 Boringer ved Gasværket. Kote ca. 2 m. Kalken 3,8-4,1 m u. Overfladen (desuden er Kalken truffet lidt dybere i en Boring ved Amtssygehuset).

Prøverne af Kalken, som opbevares paa Mineral. Museum, er dels meget stærkt pulveriseret, dels bestaaende af smaa Brokker af Flint og haard, finkornet, homogen Coccolitkalk. De haarde Lag optræder øverst i Boringerne, medens Kalken dybest nede ikke synes at indeholde saa stærkt hærdnede Lag. Den dybeste af Boringerne er ført ned til 28 $\mathrm{m}$, men nogen væsentlig Variation i Bjergartens Sammensætning kan ikke spores.

Kalken tilhører formodentlig Y. Danium.

Bredstrup Klint. 21 (S. 35, "Bræstrupklint-Saltholmskalk«). 22 (S. 3, "Saltholmskalk - i Nærheden af Grenaa «) $)^{1}$. 48 (Kortet lader »Nyere Kridt« omfatte alle Klinterne ved Grenaa). 50 (S. 52, "Saltholmskalk«). 91 (»Limsten«). 122 (S. 97, »Saltholmskalk«). 30 (»Grenaa«). 95 (»Saltholmskalk«). 123 (S. 33, "Saltholmskalk« og »Kridtsten«). 31 (S. 8). 113 (S. 54, »Kokkolitkalk«). \%6. 97 (S. 60, »Saltholmskalk«). 80.81 (S. 7, "Grenaa《; S. 8, »Bredstrup«). 99 (S. 386, »Grenaa«). 85.72 (S. 4-5). 88. 9 (S. 542, "Saltholmskalk«). 106 (S. 61). 104 (F. 5. 7, "Blegekridt og Saltholmskalk «).

Kote $14 \mathrm{~m}$.

Ussing beskriver Klinten saaledes: „Naar man fra Grenaa Havn følger Stranden mod Nord, træffer man først den henimod en halv Fjerdingvej lange Bredstrup Klint, der hæver sig omtrent 40 Fod over Havet. Den bestaar af Saltholmskalk, dækket af $7-9$ Fod sten- og grusblandet Ler. Næsten hele Klinten er et stort Kalkbrud (der dog for Tiden ikke benyttes), saa at man har fortrinlig Lejlighed til at se Kalklagene. De øvre af dem bestaar overvejende af en graalig, haard Saltholmskalk, de nedre Lag er løsere og af Beskaffenhed næsten som groft Blegekridt. Vandrette Flintlag findes rigelig baade i de øvre og i de nedre Partier."

1) Hermed mener Forсhнамmer formodentlig baade Bredstrup Klint og Kalken ved Glatved. 
I 1919 og 1923 viste Klinten sig kun lidet ren, helt tilskredet forneden. Den synlige Del af Profilet viser overvejende en overordentlig flintrig Masse, en tæet Ophobning af tykke Lag af graa Flintknolde. Den mellemliggende Kalk er enten (og overvejende) stærkt hærdnet i Knoldeform, klingende, eller ogsaa (mellem Flint- og Kalkknoldene) løst Kalkpulver. Stedvis ses dog tykkere Lag af mindre haard Kalksten, godt spaltende. De gamle Kalkbunker nedenfor Klinten bestaar af denne sidste Slags, Flager af ret sammenhængende, men ikke klingende haard Kalk. Ved Forvitringen falder de fra hinanden i tynde Flager og Brokker, men falder vanskeligere helt hen til Pulver.

Denne Kalk er paa friske Brudflader lysegraa, oftest med et gulligt Skær; den er lidet afsmittende, sandet at føle paa. Under Mikroskop viser Kalken sig at være bygget af finere og grovere krystallinske Partikler, dels af tydelig klastisk Natur, dels sikkert af sekundær Udskillelse. I Forhold til mange daniske Kalktyper — for ikke at tale om Skrivekridt — spiller de groveste Elementer kvantitativt en stor Rolle. Foraminiferer og Fragmenter af saadanne indgaar i stor Stil; Coccoliter og Brudstykker heraf er almindelige. Ved Opløsning i Saltsyre faas en Rest, der overvejende bestaar af Kvartskorn, hvortil kommer en Del Glaukonit.

En Analyse af Kalken viste et Indhold af 94,0\% $\mathrm{CaCO}_{3}$. En Prøve som Rordam (113 S. 55) analyserede, viste følgende Sammensætning: $\mathrm{CaCO}_{3} 88,64 \%, \mathrm{MgCO}_{3} 1,66 \%, \mathrm{Fe}_{2} \mathrm{O}_{3}+\mathrm{Al}_{2} \mathrm{O}_{3}+\mathrm{Ca}_{3}\left(\mathrm{PO}_{5}\right)_{2} 0,80 \%$. Uopløst 8,04\%.

Lagstillingen i Klinten er omtrent horisontal, med kun en svag Hældning $\bmod \mathrm{N}$.

Faunaen er ret artsrig og henfører Kalken til Y. Danium (Zone D).

Aastrup I. 72 (S. 21). 104 (F. 5. 6).

Ca. $1400 \mathrm{~m}$ ØNØ. f. Aastrup By. Kote $15 \mathrm{~m}$. Boring med »Kalk» $\left(82,0 \% \mathrm{CaCO}_{3}\right) \quad 0,7-1 \mathrm{~m} \mathrm{u}$. Overfladen.

Robstrup $\mathrm{T}$.

Brønd $600 \mathrm{~m}$ NØ. f. Tyvhøj. Kote $31 \mathrm{~m}$. Her saas i 1919 en opgravet Bunke af Coccolitkalk, indeholdende Flint samt Echinocorys og Brudstykker af en Serpula.

Kalken tilhører sikkert Y. Danium.

Stensmark I.

I 1923 saas her en meget lille Grav umiddelbart ved NØ-Spidsen af Parken. Der var kun meget lave og daarlige Profiler at se. Kote $16 \mathrm{~m}$.

Der fandtes en meget løs og let smuldrende, hvid Bryozokalk; denne indeholder kun lidt Flint, tynde eller indtil $10 \mathrm{~cm}$ tykke, hvide Nyrer og Flager med graa Kerne.

Danmarks geologiske Undersøgelse. II. R. Nr. 45 . 
Lagstillingen horisontal.

Forsteningerne henfører Kalken til A. Danium (Zone B).

Hammelev Gaard. 72 (S. 21). 104 (F. 5. 4).

Kote $12 \mathrm{~m}$. Graven ligger umiddelbart N. f. Gaarden. Den er ikke stor, og i 1923 var Profilet ret daarligt.

Kalken er Bryozokalk, meget ren. Milthens angiver 97,0\% $\mathrm{CaCO}_{3}$ med kun lidt Flint; Kalken er tildels sammenhængende $\mathrm{i}$ store, faste Blokke, der ikke er særlig spaltende for Slag. Bryozoerne er vel bevarede, sammenkittede med en kornet Mellemmasse, men Bjergarten er ret porøs.

Lagstillingen horisontal.

Faunaen er ret righoldig; Tylocidaris vexillifera-Piggene nærmer sig meget stærkt til $f . \beta$, og Lokaliteten maa efter al Sandsynlighed henregnes til $\mathrm{Y}$. Danium (Zone $\mathrm{C}$ ).

Karlby Klint. 3 (S. 269). 16 (S. 49, »Karlebyekalk«). 19 (S. 536, »Liimsteen«). 21 (S. 35, »en fast Varietet af Liimstenen«). 22 (S. 2-3, »Liimsten - nordlig for Grenaa«). 112 (S. 70, „Bryozokalk«)1). 122 (S. 97, "Saltholmskalk«). 31 (S. 8, "regelmæssige, vandrette Lag«). 113 (S. 60, »Bryozokalk«). 72 (S. 4). 9 (S. 542, »Saltholmskalk«). 104 (F. 5. 2, »Limsten og Saltholmskalk«). 34 (S. 67).

Kote $10 \mathrm{~m}$. Forсhнамmer benævner den her forekommende Kalk "Karlebyekalk", som han i Dannelsestid stiller meget nær ved »Saltholmskalk«. Han beskriver Forholdene saaledes:

"Den Kalksteen, som forekommer i Karlebye og Sangstrup Klint norden for Grenaa, har de følgende Characterer:

Den bestaair af 3 Led, nemlig: 1) løs Kalksteen, 2) fast Kalksteen, 3) Flint.

1) Den løse Kalksteen er guulgraae, meget blød, den øvre Del udskilt i meget tynde Lag, den dybere har tykkere Lag, som dog ikke overstige 1 Alen i Mægtighed. I den nordøstligste Deel er denne Kalksteen haardere, har færre underordnede Lag af haard Kalksteen og Flint, men her er det hvor der viser sig Leer, som underordnede Lag, og indvævede Masser. Denne Kalksteen har igjennem hele Klinten noget meget ejendommeligt derved, at den indeholder Brudstykker af en rød Koral, der har vedligeholdt sin Farve, eller maaske rigtigere, der er gjennemtrængt af Jernilte.

2) Den underordnede haarde Kalksteen er hvid muslet og splintret i Brudet; indeholder mange Koraller ${ }^{2}$ ).

1) Rørdam opstiller Stevns og Karlby Klinter som Lokaliteter med typisk Bryozokalk.

${ }^{2}$ ) Med Koraller mener Forchimmer her Bryozoer. 
3) Flinten er snart almindelig sort Flint, og dette især i den sydvestligste Deel af Klinten, snart graae hornsteenagtig Flint, hvilket især er Tilfældet i den nordøstlige (sandsynligviis ældre) Deel; den hvide muslede Flint ligner den hvide muslede Kalksteen saa meget, at man ikkun ved Haardheden kan adskille dem, og begge gaa over i hinanden.«

I 1847 henregner Forchinamer Kalken i Karlby Klint til Limstenen.

Ovenstaaende Beskrivelse kan suppleres med følgende Iagttagelser. Kalken er i hele Klintens Længde Bryozokalk. Denne er af varierende Beskaffenhed, snart ret ensartet, kompakt i store Blokke og metertykke Bænke, snart stærkere sprækket og stærkt spaltende. Den er paa sine Steder mere eller mindre lerholdig, idet lange, men altid ret tynde Striber kan være temmelig lerede og herved stærkt og tydeligt lagdelte, næsten indtil Skifrighed. Disse Striber er hyppigst skarpt begrænset opad. En Analyse af 2 Prøver, en af almindelig, fast Bryozokalk og en af en Lerstribe, taget umiddelbart over hinanden, viste henholdsvis 98,5 og $83,5 \% \mathrm{CaCO}_{3}$.

Flinten er overvejende hvid, undertiden graa, oftest i Form af tynde Nyrer, ordnet i Rækker eller optrædende spredt uden Orden; undertiden træffes mere sammenhængende Lag paa $1-2 \mathrm{dm}$ Tykkelse.

Lagstillingen er bølget, noget lignende Stevns og Bulbjerg, idet Flintlagene stadig hæver og sænker sig jævnt, ligesom Kalklagene skifter Tykkelse og kan tynde helt ud. Dog viser Lagene aldrig saa stærk Diskordans som i Stevns Klint. I det store og hele ligger Lagene sikkert vandret; det er ikke muligt at paavise nogen Aldersforskel.

Faunaen henviser Kalken til E. Danium (Zone B).

Sangstrup Klint. 16 (S. 49, »Karlebyekalk«). 22 (S. 2-3, »Liimsteen - nordlig for Grenaa《). 91 (»Saltholmskalk«). 122 (S. 97, "Saltholmskalk«). 30. 95 (»Saltholmskalk«). 31 (S. 8). 76 $6^{1}$ ). 80 (»Yngre Danien«). 72 (S. 4). 9 (S. 542, „Saltholmskalk«). 104 (F. 5. 3, »Limsten og Saltholmskalk () .

Kote $18 \mathrm{~m}$. De geologiske Forhold i denne Klint er i et og alt Mage til Karlby Klint, hvorfor en speciel Omtale vil være overflødig.

Laen. 72 (S. 5).

Milthers oplyser, at der her findes Kalk i en Dybde af $6 \mathrm{~m} \mathrm{u}$. Havets Overflade. Nærmere Oplysninger om Kalkens Art gives ikke.

1) Brünnigh Nielsen anfører Sangstrup Klint under Gruppen »Coccolithkalk. Yngre Bryozokalk (Saltholmskalk, Blegekridt)*. 
Veggerslev. 72 (S. 20). 104 (F. 5. 1).

Kalken har tidligere været gravet i nu helt tilgroede Grave ca. $600 \mathrm{~m} \varnothing$. f. Byen. Kote $9 \mathrm{~m}$. Kalken har været meget løs og smuldrende, men af hrad Art oplyses ikke. Milthens angiver 55,2 og 85,0\% $\mathrm{CaCO}_{3}$.

Havdal. 72 (S. 20). 104 (F. 5. 5, »Hovdal $).$

Kote $9 \mathrm{~m}$. »Kalk og Flint« er truffet ved Boring i $5 \mathrm{~m}$ Dybde; Kalkprocent 83,0 .

Vedø. 31 (S. 8). 72 (S. 5). 104 (F. 5. 11).

Boring. Terrænkote ea. $3 \mathrm{~m}$. Kalk i $41 \mathrm{~m}$ Dybde.

Løvenholm. 31 (S. 9). 72 (S. 5). 104 (E. 5. 12).

Boring. Terrænkote ca. $16 \mathrm{~m}$. "Kridt og Flint« i $43 \mathrm{~m}$ Dybde.

Ørsted I. 104 (E. 5. 10).

Boring ved Vandværket. »Blød Kalk med Flintlag«i 48,1 m Dybde.

Stenalt I.

Kote ca. $5 \mathrm{~m}$. Ifølge Oplysning i D. G. U.s Borearkiv er der ved en Boring (1919) truffet Kalk i en Dybde af 17-23 m.

Allingaabro I. 31 (S. 9). 72 (S. 5). 9 (S. 542). 104 (E. 5.11 ).

Boring ved Stationen. Kote $3 \mathrm{~m}$. »Kalksten m. Flint« i $34 \mathrm{~m}$ Dybde.

Fløjstrup I.

$500 \mathrm{~m} \mathrm{V.f.} \mathrm{Ny} \mathrm{Rævebro.} \mathrm{Kote} 36 \mathrm{~m}$.

Ret stor, $10 \mathrm{~m}$ dyb Grav; Profilerne, som i 1924 var meget urene, viser $1-2 \mathrm{~m}$ Diluvialsand over Kalken. Denne er en ret løs, delvis noget mere sammenhængende Coccolitkalk, stærkt smuldrende ved Forvitring; den er graalig, afsmittende, spaltende. Flinten er graa; den optræder dels (øverst i det større Profil) i tætliggende, tynde, porøse Lag dels (i det nedenfor omtalte, mindre Profil) i større Blokke af hvid Flint med skarpt begrænset, sort Kerne.

I største Delen af Graven, hvor Kalklagene kun er synlige foroven, er Lagstillingen horisontal, paa det aller nærmeste i hvert Fald. Men i en lille Gravning en Snes m længere mod Ø., i Indkørslen til den større Grav, hælder Lagene ca. $30^{0} \bmod$ SV. Hvorledes Overgangen er til de horisontale Lag, kunde ikke iagttages; i 1919 saas et Spring i Kalken, men dette kan ikke lokaliseres i Gravens nuværende Tilstand.

Kalken, som er ret forsteningsfattig, tilhører sikkert Y. Danium.

Hørning I. \%6. 104 (E. 5. 13).

$800 \mathrm{~m} \mathrm{S.t.} \mathrm{V.f.} \mathrm{Krogsager.} \mathrm{Kote} 15 \mathrm{~m}$. 
Ret stor Grav paa ca. 10 m Dybde med gode Profiler; øverst findes 0,5-1,0 m Morænegrus og Lokalmoræne. Kalken er en hvid, undertiden svagt gullig eller graalig Coccolitkalk, fin, som Regel ikke sandet at føle paa. Flinten er mørk, optræder i usammenhængende Lag og i store, uregelmæssige Konkretioner eller i runde og elliptiske Boller med hvidt, kalkrigt Midterparti; desuden hvid Flint som kiselimprægneret Kalk.

Lagstillingen horisontal.

Faunaen henviser Kalken til Y. Danium (Zone D).

$\mathrm{H} \oplus \operatorname{rning}$ II.

$400 \mathrm{~m}$ NNØ. f. Kirken. Kote $28 \mathrm{~m}$.

Graven er kun lille; Profilet i Kalken er 3-4 m højt, hvorover kommer $1 \mathrm{~m}$ Diluvialsand. Kalken er Coccolitkalk, graa, ret blød, godt spaltende, stærkt smuldrende ved Forvitring. Flinten er graa, meget uregelmæssigt svampet og hullet.

Kalken tilhører Y. Danium.

Hørning III.

$800 \mathrm{~m}$ S. f. Kirken. Kote $28 \mathrm{~m}$.

Lille Grav med ca. $4 \mathrm{~m}$ højt Profil, hvori Kalken naar omtrent til Overfladen. Kalken er Coceolitkalk af samme Type som i H. I-II, men den er meget løs, kun i ringe Udstrækning hærdnet, ellers smuldrende og opbladende. Flinten er sortegraa - hvid, meget uregelmæssigt formet, spredt i Kalken som fortrukne Klumper, der kun i yderst ringe Grad er sammenhængende i Rækker eller Lag.

Lagstillingen horisontal.

Kalken tilhører sikkert Y. Danium.

Pindsminde. 104 (E. 5. 14).

Grav tæt udenfor Gaarden; Kote $42 \mathrm{~m}$. Har i de senere Aar været fuldstændig tilgroet. Kalken er Coccolitkalk.

Tilhører sikkert Y. Danium.

Tustrup I. 104 (E. 5. 16).

$400 \mathrm{~m}$ V. f. Gaarden. Kote $31 \mathrm{~m}$.

Grav med ca. 5-6 m høje Vægge, som delvis frembyder gode Profiler. Kalken er Cocolitkalk af den sædvanlige Type, gennemgaaende godt sammenhængende og fast (men ikke klanghærdret). Flinten er graa (lysere eller mørkere) og hvid; den optræder i ret store Klumper og Ellipsoider med porøs og svampet Overflade, øverst i Profilet dannende et Par tætliggende Lag, i den nedre, større Del af Profilet derimod kun færre, uden Orden spredte Knolde. 
Lagstillingen horisontal.

Faunaen, som er ret righoldig, henviser Kalken til Y. Danium (Zone D).

Aarslev I. 104 (E. 5. 15).

Lige Ø.f. Aarslev Mølle. Kote $16 \mathrm{~m}$.

Ret stor Grav med gode Profiler. Kalken er Coccolitkalk, hvid med et let gulligt Skær; den er som Regel noget afsmittende, finkornet, stedvis lidt grynet og lidt porøs.

Flinten danner ret tykke Bænke eller Rækker af Knolde.

Lagstillingen horisontal.

Faunaen henfører Kalken til Y. Danium (Zone D).

Lime I. 48 (S. 6, »Lihme«). 122 (S. 103). 9 (S. 542). 104 (E. 5. 20, "S. V. f. Lime«).

1300 m SV. f. Lime Kirke. Kote 25 m.

Stor Grav med 6-7 m høje Vægge, der frembyder gode Profiler. Kalken er Coccolitkalk, hvid, undertiden lidt gullig; den er finkornet, blød og afsmittende, svagt sandet at føle paa. Flinten optræder som graa Knolde i Rækker eller omtrent sammenhængende Lag.

Lagstillingen horisontal.

Hvad Forsteningerne angaar, er den store Hyppighed af Pentacrinstilke et iøjnefaldende Træk; de staar i oprejst Stilling og kan følges paa lange Stykker igennem Kalk- og Flintlagene.

Faunaen henviser Kalken til Y. Danium (Zone D).

Mygind I.

Ved Mygind Vandmølle. Kote $18 \mathrm{~m}$.

Grav med ca. $5 \mathrm{~m}$ højt Profil. Kalken er Coccolitkalk af den paa Egnen sædvanlige Type; de nedre Lag er noget mere gullige i Farven. Flinten danner tyndere eller tykkere, delvis ret sammenhængende Lag.

Lagstillingen horisontal.

Faunaen henfører Kalken til Y. Danium (Zone D).

Mygind II.

$500 \mathrm{~m} \mathrm{NV}$. f. Byen. Kote $25 \mathrm{~m}$.

Graven, som er ganske lille, 2-3 m dyb, var i 1924 helt tilskredet. Et Par Smaabunker af det opgravede Materiale viste, at Graven fører en flintholdig Coccolitkalk.

Sikkert Y. Danium.

Mygind III.

Paa Vestsiden af Rosenholm Aa, $500 \mathrm{~m} \mathrm{~V}$. f. Byen. Kote $18 \mathrm{~m}$. 
Graven er ganske lille og var i 1924 fuldstændig tilskredet; dog kunde det ses, at der havde været gravet Coccolitkalk.

Sandsynligvis Y. Danium.

Skader I. 48 (S. 6). 91 (»Limsten - Skaader ). 122 (S. 103). 30.95. $76^{1}$ ). 80 (»Yngre Danien«). 9 (S. 542). 104 (E. 5. 22, »N. f. Skader«).

$300 \mathrm{~m}$ NNV. f. Byen. Kote $35 \mathrm{~m}$.

Stor Grav med gode Profiler paa 6-7 m Højde. Kalken er en finkornet Coccolitkalk, svagt sandet at føle paa, dels blødere, dels stærkere hærdet. Ophiomorpher forekommer. Flinten danner uregelmæssige Knolde eller tyndere Nyrer, ordnet delvis sammenhængende i Rækker, ikke tykkere Lag. Den er som Regel lysere eller mørkere graa.

Lagstillingen horisontal.

Kalken hører til Y. Danium (Zone D).

Skader II.

I den sydlige Udkant af Byen. Kote $40 \mathrm{~m}$.

Lille Grav med 5-6 m højt Profil. Kalken er Coccolitkalk som i Skader I.

Y. Danium.

Rigtrup I.

$500 \mathrm{~m} \mathrm{NV}$. f. Byen. Kote $31 \mathrm{~m}$.

Mellemstor Grav; de øverste Lag er ikke længere tilgængelige, idet den øverste Del af Graven er tilgroet, men i den nedre Del af Graven findes gode ca. 6-7 m høje Profiler. Kalken er Coccolitkalk af den paa Egnen sædvanlige Type. Flinten, som er graa af Farve, viser sig ikke som udprægede, gennemgaaende Flintlag, men findes som enkelte Knolde spredt overalt i Kalken, kun nu og da ordnende sig til en kort Række.

Lagstillingen horisontal.

Kun Pentacrinstilke, som er meget hyppige, er fundet. Kalken hører sikkert til Y. Danium.

Voldum I.

$1 \mathrm{~km}$ NØ.f. Kirken. Kote $32 \mathrm{~m}$.

Meget stor Grav, hvorfra Gødningskalk udkøres med Tipvogne til hele Oplandet.

Kalken er en gullig-graa Coccolitkalk som i de omliggende Grave, svagt sandet at føle paa; den er ret fast sammenhængende, selv hvor

1) S. 139 anfører BrüNnich Nielsen Lokaliteten under Gruppen »Coccolithkalk. Yngre Bryozokalk (Saltholmskalk, Blegekridt)", hvorimod han S. 160 henregner den til "Eldre Bryozokalk». 
den ikke er forkislet. Flinten er tilstede i særdeles stor Mængde; den er hvid - graasort, dannende tykke, massive Bænke eller flade Konkretioner eller store Blokke, spredte i Kalken imellem de iøvrigt ret tætliggende Lag.

Lagstillingen horisontal.

Faunaen henviser Kalken til Y. Danium.

Klavsholm I. 16 (Kortet). 122 (S. 103). 95. 113 (S. 54). 9 (S. 542). 104 (E. 5. 19).

Umiddelbart S. f. Avlsgaarden. Kote $31 \mathrm{~m}$.

Temmelig stor Grav, som imidlertid er delvis tilskredet, saa kun enkelte Profiler paa 5-6 m Højde er tilgængelige. Kalken er Coccolitkalk, overvejende af den paa Egnen sædvanlige, finkornede, lidt grynede, ofte noget graa-gullige Type. Desuden findes paa Mineral. Museum en Prøve af en noget grovere Type, gullig-hvid, daarligt sammenkittet, sandet at føle paa, som kan benævnes Kalksandskalk. Flinten danner ret tætliggende, graa Lag.

Lagstillingen horisontal.

Faunaen henfører Kalken til Y. Danium (Zone D).

Hvalløse I. 13.90 (»Randers《). 104 (C. 5. 17, »Hvalløse Mark«). 105 (S. 27).

$500 \mathrm{~m}$ NØ. f. Hvalløse. Kote $27 \mathrm{~m}$.

Lille Grav, som i de sidste Par Aar har frembudt et godt Profil (Fig. 1). Paa Grundlag af Undersøgelser, foretaget sammen med Statsgeolog V. Mштнers, kan følgende Beskrivelse af Profilet gives.

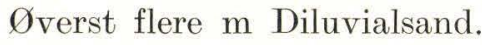

Iøvrigt regnet fra neden:

D) $3 \mathrm{~m}$ Coccolitkalk, ganske lignende den paa Egnen sædvanlige Type; den er graalig-hvid af Farve, ikke hærdnet, afsmittende, ret blød, svagt sandet at føle paa, fint grynet. Under Mikroskop viser Kalken sig at bestaa af større og mindre (indtil ganske fine) Partikler, dels tydeligt klastiske af Natur, dels - for en Del af de størres Vedkommende - aabenbart sammenkittede Korn; smaa Foraminiferer indgaar, og Coccoliter er meget almindelige; Glaukonit findes ikke.

Kalken indeholder en Del Flint, lysere eller mørkere graa af Farve, omgivet af tykke Lag af hvid Flint; den danner tykke, uregelmæssigt knoldede, delvis ret sammenhængende Lag.

C) $0,75 \mathrm{~m}$ Grønsandsler. Hovedbestanddelen af denne Bjergart er fedt Ler, graat med et svagt gulligt Skær. Kvartskorn forekommer kun i meget ringe Grad. Den grønne Farve hidrører fra en meget stærk Indblanding af Glaukonit i Form af afrun- 


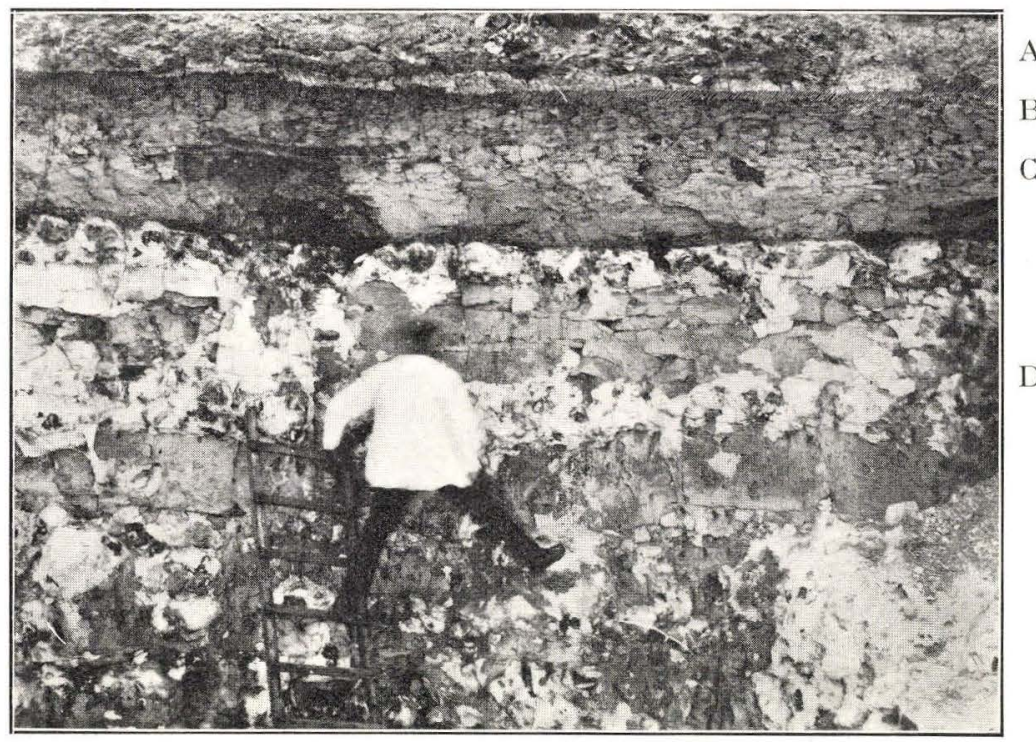

Fig. 1. Hvalløse I. A-C Paleocænt Ler og Grønsandsler med Bundkonglomerat. D Coccolitkalk.

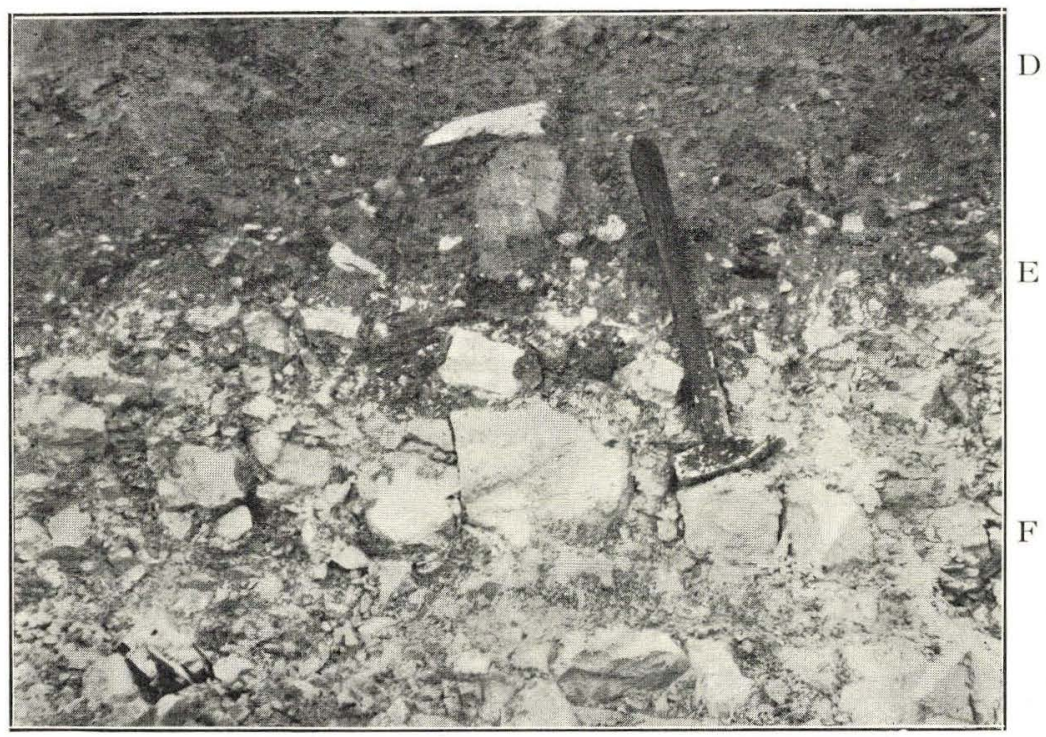

Fig. 2. Bøgelund. D Coccolitkalk. E Ler, Bundkonglomerat. F Skrivekridt. 
dede Korn. Leret er ikke særlig stærkt lagdelt og kun spaltende i større Stykker.

I sit nederste Parti, $10-20 \mathrm{~cm}$, er Grønsandsleret udviklet som Konglomerat, idet det indeholder et overordentlig stort Antal stærkt rullede og slidte Sten og Forsteningsfragmenter. Stenene bestaar af en grønlig eller graalig-brun, stærkt glaukonitiseret Kalksten, dels formet som simple Rullesten af indtil et Hønseægs Størrelse, dels som Stenkærner af Echinocorys, Terebratula m. m. Alle er de stærkt angrebne af borende Organismer.

Grænsen mod den underliggende Coccolitkalk er skarp, udviklet som en Abrasionsflade; den nærmeste Del af Coccolitkalklaget er et svært Flintlag, som tilsyneladende har standset Abrasionen. Overfladen af Kalken er stærkt angrebet og fuld af Borehuller, der er udfyldt med løst Grønsandsmateriale. Hullerne er i Almindelighed skarpt begrænsede, cylindriske, tydelige Borehuller $0,5-0,75 \mathrm{~cm}$ i Diameter, men desuden forekommer mere uregelmæssige »Ophiomorpha«-agtige Udfyldninger, sandsynligvis efter Spongier. Hullerne synes først at være boret efter Flintlagets Dannelse.

B) 0,25 m fedt brunligt Ler; synes nærmest at være et øverste, forvitret Parti af $\mathrm{C}$.

A) $2 \mathrm{~m}$ fedt, graat Ler, i tør Tilstand meget lyst og med muslet Brud.

De kemiske Analyser har givet følgende Resultater:

$$
\begin{aligned}
& \text { Lag A ......6. } 67,5 \% \mathrm{CaCO}_{3} \\
& \text { - C ......... 59,0 - - } \\
& \text { Rullesten........ 32,0 - - } \\
& \text { Lag D . . . . . }
\end{aligned}
$$

Lagstillingen horisontal.

Coccolitkalken er ikke særlig forsteningsrig. Grønsandsleret er meget forsteningsførende, idet det foruden den paa sekundært Leje liggende Fauna indeholder en rig, primært liggende Fauna. Ogsaa det øverste, lysegraa Ler (A) er forsteningsførende.

Daniets Overgrænse maa sættes over D, og den overliggende Serie henføres til Selandiet (se nærmere Kap. VI) ; Kalken tilhører Y. Danium (Zone D).

Hvalløse II. 104 (E. 5. 18).

Boring i Vandværkets Brønd. Terrænhøjde 48,5 m. Der er her truffet Coccolitkalk i en Dybde af $35,0 \mathrm{~m}$, overlejret af tertiært Ler (ifl. Oplysning fra Statsgeolog V. Milthers). 
Jernit.

Boring ved Jernit Hovedgaard.

Boringen udførtes i 1921-22, for den sidste Dels Vedkommende som Diamantboring, og Prøverne indsendtes af Ing. Albert Larsen til D. G. U.'s Borearkiv, hvorfra nedenstaaende Oplysninger hidrører.

$0-25 \mathrm{~m}$ ingen Prøver.

25-105 - Mellem og Øvre Oligocæn?

105 - 225 - Plastisk Ler (Eocæn).

225 - Lag med vulkansk Aske.

230 - Kalkfrit Ler m. enkelte Stykker vulkansk Aske.

235 - 240 - Kalkfrit Ler m. meget vulkansk Aske.

245 - Kalkfrit Ler uden vulkansk Aske (Paleocæn).

250 - Kalkfrit, paleocænt Ler med enkelte Stykker kalkholdigt Ler.

$255 \mathrm{~m}$ - Overvejende kalkholdigt Ler.

263 - Overvejende kalkholdigt Ler med meget Flint, Glaukonit m. m.

264,2 m Kalkholdigt Ler.

270 - Blød Grønsandsmergel.

273,17 m Blandet Prøve af sandet Paleocæn og (flintholdigt) Danium.

273,17-326,14 m Coccolitkalk (Danium).

Hele den gennemborede Daniumserie, godt $53 \mathrm{~m}$, bestaar af en temmelig ensartet Coccolitkalk, ret finkornet grynet, kun lidet sandet at føle paa; den er, hvor den ikke er forflintet, ret blød, men ikke særlig afsmittende; meget af den mellem Flintlagene liggende, bløde Kalk er aabenbart skyllet bort under Boringen.

Flint er tilstede i stor Udstrækning som tykke, massive Lag, ensartet af graa - hvidgraa Farve.

Kalken indeholder en hel Del Forsteninger, overvejende Foraminiferer, færre Bryozoer, samt Echinodermer. Forekomsten af Ditrupa Schlotheimi helt ned til en Dybde af 318,65 m viser, at hele Kalkserien maa henregnes til Y. Danium (Zone D).

Langaa I. 73 (S. 34). 4 (S. 87). 7 (S. 182). 104 (D. 5. 38).

Boring i Langaa, foretaget i 1896.

I 1918 giver BøGGILD en kritisk Gennemgang af de foreliggende Oplysninger og Boreprøver og opstiller følgende Profil:

$0-5 \mathrm{~m}$ Kvartær.

5 -54 - Eocæn og Paleocæn.

$54-59$ - Nyere Kridt. 
Daniet er her i $54 \mathrm{~m}$ Dybde direkte overlejret af Selandium. Prøverne fra Daniet er meget daarlige; BøGGLD nævner »Stykker af en glaukonit- og flintholdig Kalksten, der væsentlig bestaar af smaa Rester af Foraminiferer og andre Kalkorganismer.»

I en Prøve fra $59 \mathrm{~m}$ er der fundet en lille Brachiopod, der af BøGGILD (efter J. P. J. RAvN) kaldes Argiope scabricula v. Koen. Efter Dr. Brünnich Nielsen's senere Revision maa Stykket henføres til $A$. Koeneni.

Randers I.

Boring ved Blækhuse (S. f. Mariesminde). Kote 30 m. Ifølge Statsgeolog V. Minthers er Profilet her følgende:

$$
\begin{aligned}
& 0-26 \text { m Kvartær. } \\
& 26-52 \text { - Tertiær (?) } \\
& 52-\quad \text { - Kalk og Flint. }
\end{aligned}
$$

Den øverste Del af Tertiæret (?) bestod af mørkt, meget fedt »Blaaler«; nærmest Daniet derimod fint, glimmerholdigt, blaaligt, klæget Sand.

Randers II.

Boring paa Fabriken »Scandia«. Kote ca. $6 \mathrm{~m}$.

Ifølge Oplysning fra Statsgeolog V. Milthers var det gennemborede Profil saaledes:

0—47,0 m Dels Kvartær, dels »Skiferlag« og »Blaaler« (Tertiær). $47,0-56,5$ - Kalk og Flint.

Randers III.

Boring ved Bryggeriet »Thor«. Kote $24 \mathrm{~m}$.

Ifølge Oplysning fra Statsgeolog V. MiLtwens er Profilet saaledes: $0-12,8 \mathrm{~m}$ Kvartær.

$12,8-18,2$ - »Sort Skiferler« (tertiært).

$0-73,0$ - »Blaaler« (tertiært).

73,0-85,0 - »Haard Kalk og Flint

Nærmere Oplysning om Kalken foreligger ikke.

Randers IV.

Boring i Gasværkets Eng, Kote ca. 2 m, udført af Randers Vandværk 1912. Ifl. Statsgeolog V. MrLthers er Kalken her truffet i en Dybde af $39,5 \mathrm{~m}$.

Over Hornbæk I.

En Boring her paa Terrænhøjde $42 \mathrm{~m}$ gav, ifølge Oplysning fra Statsgeolog V. MiLthers, følgende Resultat: 
0-62 m Kvartær.

$62-72$ - Tertiær.

72 - Kalk.

Orst Mølle.

6 Boringer, foretaget af Randers Vandværk i 1905—06, liggende paa en Terrænhøjde af ca. $10 \mathrm{~m}$.

Kalken er her truffet i en Dybde af 17-19,5 m (ifl. Oplysning fra Statsgeolog V. MiLthers).

Svejstrup I. 104 (D. 5. 22).

$2,4 \mathrm{~km}$ SØ. f. Bjerregrav St. Kote $42 \mathrm{~m}$.

Graven her frembød for et Par Aar siden ret gode Profiler: Efterfølgende Beskrivelse støtter sig til Iagttagelser af Statsgeolog V. MiLthers, eand. polyt. A. Rosenkrantz og Forf.

Forholdene er meget lig Hvalløse I. Dybest i et Hjørne af Graven var Coccolitkalken synlig; denne er af sædvanligt Udseende, hvid med graaligt Skær, ret blød, lidt sandet at føle paa.

Overgrænsen af Kalken er en skarpt fremtrædende Abrasionsflade, som er fuld af Borehuller. Paa Kalken hviler en fed, graa Mergel, meget mindende om Lag C i Hvalløse I, men federe og lysere, idet Glaukonitindholdet er meget ringere; den er ogsaa langt stærkere spaltende. Ved Basis indeholder dette Lerlag et Konglomerat af stærkt slidte Rullesten, Mage til dem fra Hvalløse og ligeledes meget angrebne ved Boring. Foruden Rullestenene findes indtil ganske forsvindende smaa Stumper af Glaukonit og grøntfarvede Fossilfragmenter. Dette Bundkonglomerat, er dog baade fattigere paa Rullesten og ringere af Mægtighed end det tilsvarende Lag i Hvalløse, selv om enkelte Sten kan findes endnu $25 \mathrm{~cm}$ over Basis.

Opadtil gaar denne graa Mergel over i lysere, tertiære Mergelarter, tildels med brune Omdannelsesprodukter.

Lagstillingen horisontal.

Fra Coccolitkalken foreligger kun faa Forsteninger. Det overliggende Lag indeholder — foruden de sekundært liggende Fossiler — en ret rig Fauna, særlig i Lagets nedre Del. Nærmere Omtale heraf findes i Kap. VI. Coccolitkalken maa henregnes til Y. Danium (Zone D), den overliggende Mergel til Selandium.

Borup I. 91 (S. 33, »Limsten«). 9 (S. 542).

Kalkgraven, som ifølge Oplysninger paa Stedet, er beliggende umiddelbart ved Præstegaarden, var i 1923 tilgroet og bebygget. Kote $35 \mathrm{~m}$.

En i 1903 indsamlet Bjergartsprøve bestaar af gullig, afsmittende, 
finkornet Coccolitkalk. Den indeholder et Stilkstykke af Pentacrinus paucicirrhus-Typen, Pigge af Phymosoma, Gryphaea vesicularis; Posselt angiver desuden Terebratulina striata.

Kalken tilhører formodentlig Y. Danium.

Raasted I. 73 (S. 34). 9 (S. 542). 104 (D. 5. 18).

Umiddelbart S. f. Raasted Bro. Kote 25 m. I 1916 var der her en lille Grav aaben ved Vejens Østside, ud imod Aaen; i 1923 fandtes V. f. Vejen en Grav med delvis gode Profiler af $3-4 \mathrm{~m}$ Højde.

Kalken er Bryozokalk (dækket af Diluvialsand), ret fast sammenhængende i Blokke, men smuldrende ved Forvitring. Bryozoerne er ret godt bevarede, ikke overmaade dominerende i Kalken, idet de ligger indlejret i en fin, hvid Grundmasse.

Kalken indeholder $96,5 \% \mathrm{CaCO}_{3}$. Desuden findes der meget Flint i meget uregelmæssige, ofte flade Knolde, hvide med graa Kerne. Flinten træffes, foruden i Form af disse spredte Knolde, som mere eller mindre sammenhængende Lag.

Lagstillingen horisontal.

Fossilindholdet henviser Kalken til A. Danium (Zone B).

Bjerregrav I. 73 (S. 34 og Kort). 104 (D. 5. 19) $)^{1}$ ).

Ca. $100 \mathrm{~m} \mathrm{~N}$. t. V. for Hedegaard, SØ. f. Stationen. Kote $25 \mathrm{~m}$.

Coccolitkalken graves her i en stor Grav med indtil $4 \mathrm{~m}$ høje Profiler. Kalken er gennemgaaende ret sammenhængende, ikke haard, men ret let smuldrende og ret stærkt afsmittende. Farven er hvid med et meget svagt gulligt Skær. Kalken indeholder $94,5 \% \mathrm{CaCO}_{3}$. Mellem Flinten løst Pulver. Flinten er rigelig tilstede, danner dels større Klumper, dels fladere Knolde og Nyrer af uregelmæssig Form, tildels ordnet i Lag.

Lagstillingen horisontal.

Faunaen henfører Kalken til Y. Danium (Zone D).

Bjerregrav II. 73 (S. 34 og Kort).

Tæt SØ.f. Skovvad Bro. Kote $25 \mathrm{~m}$.

Aaben Grav med gode Profiler paa 3-4 m Højde. Samme Horisont som Bjerregrav III (se denne), kendelig paa et tykt Flintlag liggende umiddelbart over en mere graagullig farvet Kalkbænk; Ophiomorpher ses ret hyppigt i Kalken.

Y. Danium (Zone C).

Bjerregrav III. 73 (S. 34 og Kort). 104 (D. 5. 17)²).

Tæt NV. f. Skovvad Bro. Kote $25 \mathrm{~m}$.

1) Herunder indbefatter Ravn sandsynligvis ogsaa Bjg. IV.

2) Herunder indbefatter RAvN sandsynligvis ogsaa Bjg. II og V. 
Aaben Grav med godt $3 \mathrm{~m}$ høj Væg med rent Profil i Coccolitkalk. Kalken er overvejende en lidt graalig, fast, sammenhængende, men ikke egentlig hærdnet, godt spaltende Kalk; den indeholder mange grovere Korn og Kalkpartikler og er grynet at føle paa. Under Mikroskop viser den sig at bestaa af en løst sammenhængende Masse af finere og grovere krystallinske Partikler; Foraminiferer er ret hyppige, Coccoliter er derimod mindre hyppige, ligesom kun en mindre Del af Kalkpartiklerne er smaa nok til at kunne hidrøre fra disse. Hist og her ses lidt — aabenbart primært liggende - Glaukonit. En Zone paa godt $1 \mathrm{~m}$ Tykkelse midt i Væggen er af en lettere, hvidere Kalksort, uregelmæssig sprækket, men ikke godt spaltende; den er skarp at føle paa, idet den indeholder fint fordelt Kisel, der desuden i Form af uregelmæssige, porøse Knolde opfylder hele Massen uden nogen Orden. I den øvrige Del af Profilet danner Flinten gennemgaaende og sammenhængende, tildels porøse Lag af 10 -20 cm Tykkelse, eller den har Form af flade Nyrer ordnet i Rækker; Farven er graa og hvid.

Lagstillingen horisontal.

Faunaen henfører Kalken til Y. Danium (Zone C).

Bjerregrav IV. 73 (S. 34 og Kort).

Ca. $400 \mathrm{~m}$ NØ. f. Stationen. Kote $31 \mathrm{~m}$. »Blegekridt». Sikkert Y. Danium.

Bjerregrav V. 73 (S. 34 og Kort).

Ca. $500 \mathrm{~m} \mathrm{~N}$. f. Stampegaard. Kote ca. $35 \mathrm{~m}$. »Blegekridt«. Sikkert Y. Danium.

Bjerregrav VI.

Ved Jernbanelinien N. f. Kovsted Aa. Kote 18 m.

I Jernbanegennemskæringen her gaar Coccolitkalken frem i Dagen.

Bjerregrav VII.

Boring ved Bjerregrav Mejeri. Kote ca. $55 \mathrm{~m}$.

Ifølge Oplysning fra Statsgeolog V. Mrlthers er Profilet saaledes:

$0-39,0$ m Kvartær.

$39,0-42,6$ - Mørkt, kalkfrit Ler med Svovlkis.

$42,6-56,5$ - Graat, kalkholdigt Ler.

56,5 - - "haardt Lag« (Flint?).

Daniets Overgrænse ligger sandsynligvis ved en Dybde af $56,5 \mathrm{~m}$.

Kovsted I. 73 (S. 34 og Kort). 104 (D. 5. 16).

I Kovsted By. "Blegekridtet« er her truffet ved Brøndgravning. Formodentlig Y. Danium. 
Kovsted II. 73 (S. 34 og Kort). 104 (D. 5. 15).

$1,5 \mathrm{~km}$ NNØ. f. Kovsted By. Kote ca. $35 \mathrm{~m}$. Ogsaa her er der truffet »Blegekridt« ved Brøndgravning. Formodentlig Y. Danium.

Purhus I. 73 (S. 34 og Kort). 104 (D. 5. 11) $)^{1}$ ).

Ved Landevejen $260 \mathrm{~m}$ V. f. Purhus Kro. Kote $30 \mathrm{~m}$.

Kalkgravningen har her fundet Sted i flere Etager, saa Profilet er ialt 7-8 m højt. Kalken er Coccolitkalk, graahvid af Farve, ret sammenhængende uden at være haard; at føle paa er den skarp, sandet, og den indeholder en Mængde smaa, ormformede Legemer (Ormeekskrementer?) og større Ophiomorpher af samme Materiale som Kalken; de kommer især tilsyne ved Forvitring. Kalken indeholder saa godt som ikke Flint, med Undtagelse af et øverst i Profilet liggende Lag af uregelmæssige Knolde af hvid Flint. Den ringe Flintmængde skyldes sikkert, at Kalkens Kiselindhold ikke er blevet koncentreret i Flintkonkretioner, men findes jævnt fordelt $\mathrm{i}$ hele Kalkmassen og giver denne dens ejendommelige, skarpe Præg. Ifølge Analyse er Kalkindholdet 56,0\%. Dette skyldes næppe, som Minthers antager, Indblanding af fremmede Stoffer, men den jævnt fordelte Kisel.

Lagstillingen er horisontal.

Faunaen, som iøvrigt ikke er særlig righoldig, henviser Kalken til Y. Danium (Zone C?).

Purhus II. 73 (Kort).

$300 \mathrm{~m}$ N. f. Ørrild. Kote ca. $22 \mathrm{~m}$.

Milthers og Claudi Westh angiver Forekomst af Blegekridt paa dette Sted, men Kalken er ikke tilgængelig i nogen Grav.

Formodentlig Y. Danium.

Purhus III.

$400 \mathrm{~m} \mathrm{S.} \mathrm{f.} \mathrm{Nygaard.} \mathrm{Kote} 35 \mathrm{~m}$.

Lille Grav. I 1923 fandtes et godt $2 \mathrm{~m}$ højt Profil, hvori Kalken gik omtrent helt op til Overfladen. Kalken er Bryozokalk, hvid, med et temmelig stort Indhold af Bryozoer, løst sảmmenhængende, stærkt spaltende og forvitrende. Flinten graa med hvid Skorpe, i Form af større og mindre Knolde, ordnet i delvis sammenhængende Rækker. Flinten er ikke dominerende i Forhold til Kalken.

Lagene hælder vistnok svagt $\bmod \varnothing$.-SØ., men Maaling var umulig paa Grund af Profilets daarlige Tilstand.

Faunaen henfører Kalken til A. Danium (Zone B).

Purhus IV. 73 (Kort). 104 (D. 5. 14).

NØ.f. Petersminde. Kote $28 \mathrm{~m}$.

1) Herunder indbefatter RavN formodentlig ogsaa Purhus II. 
Lille Grav af ringe Dybde; den er fuldstændig tilgroet, men de løstliggende, graa Flintknolde viser - i Overensstemmelse med MrLthers' og Claudi Westh's Angivelse - Forekomsten af Coccolitkalk paa dette Sted.

Sikkert Y. Danium.

Purhus V. 73 (Kort).

Ved Nordøstenden af Mølledammen. Kote $22 \mathrm{~m}$.

Graven her er meget lille, Profilet 1,5 m højt, men stærkt tilskredet. Kalken er Coccolitkalk, meget fin, ikke skarp at føle paa, nogenlunde blød, hvid af Farve.

Flinten forekommer i Knolde af graahvid Farve.

Lagene hælder, saa vidt de daarlige Forhold tillader at se, ca. $10^{\circ}$ i sydvestlig Retning.

Kalken tilhører sikkert Y. Danium.

Purhus VI.

$500 \mathrm{~m}$ SV. f. Purhus Kro. Kote $30 \mathrm{~m}$.

Mindre Gravninger paa begge Sider af Vejen med Profiler af ialt ca. 5-6 m Højde. Kalken er en naturligt sammenhængende, men ret blød, graalig Cocolitkalk, skarp og sandet at føle paa, ganske af samme Type som Kalken i Purhus I.

Lagstillingen horisontal.

Kalken tilhører Y. Danium (Zone C?).

Ejstrup I. 73 (Kort). 104 (D. 5. 13)1).

$200 \mathrm{~m}$ V.f. Vandmøllen. Kote $35 \mathrm{~m}$.

Kalken graves her i 2 større Grave, en paa hver Side af Vejen, Profilerne er ca. $7 \mathrm{~m}$ høje. Kalken, Coccolitkalk, er stærkt sprækket og brokket, men iøvrigt ret godt sammenhængende i Brokkerne uden dog at være stærkt hærdnet. Kalken er meget finkornet, svagt afsmittende, ikke skarp at føle paa. Midt i Profilet (det østligste) findes en ca. $5 \mathrm{~cm}$ tyk Zone af blødt, fedt, graat, kalkholdigt Ler, fint lagdelt, smuldrende og opbladende efter Lagdelingen ved Forvitring. Nedad er det skarpt begrænset mod den underliggende, haardere Kalk, opad gaar det jævnt over i Kalken.

Flinten er lysegraa - graasort, med uregelmæssig, tyk, hvid Skorpe; den optræder i tætliggende, sammenhængende Bænke og Lag af 10-15 cm Tykkelse.

Lagene hælder ca. $10^{0} \bmod$ Vest.

Efter Faunaen maa Kalken henføres til Y. Danium (sandsynligvis Zone C).

1) Herunder indbefatter RAvn formodentlig ogsaa Ejstr. III. 
Ejstrup II. 73 (Kort). 104 (D. 5. 12).

Ca. 400 m S. f. Vandmøllen. Kote ca. 40 m. »Blegekridt«; Graven, som kun er lille, er nu tilgroet. Sikkert Y. Danium.

Ejstrup III. 73 (Kort).

$500 \mathrm{~m}$ SSV. f. Østergaard. Kote ca. $30 \mathrm{~m}$. Coccolitkalken her er ikke Genstand for nogen Gravning. Sikkert Y. Danium.

Asfærg. 122 (S. 103). 9 (S. 542).

Ussing angiver Forekomsten og Brydningen af "Blegekridt"ved Asfærg, hvormed han dog sandsynligvis mener Forekomsterne omkring Purhus og Ejstrup. Nærmere ved Asfærg By finder ingen Kalkgravning Sted.

Svendstrup. 104 (D. 5. 17).

Boring. Kote ca. $35 \mathrm{~m}$. Bryozokalken er her truffet ved en Dybde af $22 \mathrm{~m} \mathrm{u}$. Overfladen.

Mejlby I. 104 (E. 5. 9).

Boring ved Vandværket. I 43,6 m Dybde er der her truffet »haardt Kridt«.

Hald. 9 (S. 542). 104 (E. 5. 8).

Ifølge RAvn er der her ved 2 Boringer i Byen truffet Limsten eller Blegekridt i en Dybde af henholdsvis 56,2 og 65,3 m u. Overfladen. Et Par Prøver fra 56,2 m (179') Dybde bestaar kun af fin, lysegraa, bryozofri Flint; desuden en Prøve af hvid Coccolitkalk, afsmittende, meget finkornet.

Forsteninger foreligger ikke, men efter Bjergarten at dømme drejer det sig formodentlig om Y. Danium.

Albæk (v. Randers). 9 (S. 542).

BøgGILD nævner Forekomsten af Danium ved Albæk, men uden nærmere Omtale. Nogen Gravning af Kalk finder ikke Sted ved Albæk.

Tørring I. 43 (S. 14).

Jægerland Grave SØ. f. Tørring. Kote $3 \mathrm{~m}$. Jessen angiver, at der her »findes en lille, sammenskreden Grav i Blegekridt«. Formodentlig Y. Danium.

Ø. Tørslev I. 43 (S. 14). 9 (S. 542). 104 (E. 5. 7).

Flere tætliggende Grave lige ved Aaen NØ. f. Byen. Kote 16 m.

I 1923 fandtes et stort, ca. $6 \mathrm{~m}$ højt Profil. Kalken er typisk Coccolitkalk, uden Bryozoer, hvid, finkornet, ikke særlig afsmittende. En Del af Kalken er lidt mere skarp at fole paa. Kalken indeholder meget 
Flint i Form af graa, uregelmæssige Knolde, dels ret spredt fordelt i Kalkmassen, dels ordnet i mere eller mindre sammenhængende Rækker.

Lagstillingen horisontal.

Faunaen henviser Kalken til Y. Danium (Zone D).

Dalbyovre I. 104 (E. 5. 6).

Ca. $400 \mathrm{~m} \mathrm{~S}$. f. Stationen. Kote $47 \mathrm{~m}$.

I 1923 fandtes her en ret stor Grav med ca. $7 \mathrm{~m}$ høje Vægge med rene Profiler, hvoraf den øverste Del bestaar af Lokalmoræne.

Kalken er Coccolitkalk, meget lys, ofte lidt skarp at føle paa, men stærkt afsmittende, meget finkornet, rent hvid. Overfladisk set kan den minde lidt om Skrivekridt. Analysen viser et Indhold af $65,0 \% \mathrm{CaCO}_{3}$. Kalken er yderst flintfattig. Der findes kun faa, smaa, som Regel flade Knolde af sort Farve, meget lignende Skrivekridtflint, men med lidt tykkere hvid Skorpe, end det sædvanligvis findes i Skrivekridt. De er dels jævnt spredt i Kalken, dels ordnet i ret utydelige Rækker (langt imellem Knoldene).

Lagstillingen horisontal.

Kalken er meget forsteningsfattig, men Forekomsten af Ditrupa Schlotheimi henviser Lokaliteten til Y. Danium.

Dalbyovre II.

Boring ved Mejeriet. Kote ca. $50 \mathrm{~m}$.

I ringe Dybde under Overfladen stødte man her paa en gullighvid Coccolitkalk af almindelig Type.

Dalbynedre I. 9 (S. 542). 104 (E. 5. 5).

Ca. $600 \mathrm{~m}$ ØSØ. f. Kirken. Kote $31 \mathrm{~m}$.

Graven er ret stor, men var i 1923 næsten fuldstændig tilskredet og tilgroet. Kun et enkelt Sted saas et meget lille Profil i Kalken, der nærmest maa kaldes Bryozokalk. Den er hvid, bestaaende af en fin Grundmasse, hvori er indlejret en stor Mængde Bryozoer, der gør Kalken, som ikke er særlig afsmittende, skarp at føle paa.

Lagstillingen vistnok horisontal.

Forsteninger foreligger ikke, saa Lokalitetens Stilling er uvis; sandsynligvis Æ. Danium.

Kastbjerg I. 9 (S. 542). 104 (E. 5. 2).

$300 \mathrm{~m}$ Ø. f. Kirken. Kote $30 \mathrm{~m}$.

Graven er ret stor, 5-7 m dyb. Øverst i Profilerne, som i 1923 kun var delvis rene, ses $1-1,5 \mathrm{~m}$ Diluvialsand. Kalken er Bryozokalk, temmelig blød, stærkt spaltende. Bryozoerne, som ikke er særlig godt be- 
varede, ligger indlejret i en blød, fin Grundmasse. I Nordvæggen saas i Væggens halve Højde en Zone paa et Par dm af mere leret og mindre bryozorig Kalk, graa, stærkt lagdelt, spaltende, men den er ellers ikke saa stærkt smuldrende ved Forvitring som den over- og underliggende Bryozokalk, hvortil den er knyttet ved jævne Overgange. Der saas 3 Flintlag. Flinten er graasort med hvide Partier.

I Sydvæggen, som er lidt højere, men hvis nederste Del er dækket af Skred, ses ligeledes Bryozokalk. Saavel her som i den øvrige Del af Graven er Lagstillingen vandret, men at Bevægelser har fundet Sted, ses af en Foldning af Kalk- og Flintlagene. Dens Strygning kunde ikke iagttages. En højereliggende, mindre Grav tæt S. herfor var komplet tilgroet.

Faunaen, som er temmelig artsrig, henfører Lokaliteten til $\mathbb{A}$. Danium (Zone B).

Bøgelund.

»Bøgelund Kalkværk« 900 m SV. f. Skarodde. Skrivekridtets Overflade paa Kote ca. $10 \mathrm{~m}$.

I den stærkt tilskredne Grav konstaterede Hr. K. Ahrentecht i 1925 Tilstedeværelsen af saavel Skrivekridt som Bryozokalk, hvorpaa der ved foretagen Rengravning blottedes følgende Profil (Fig. 2, S. 41, og T. III) :

F) $5 \mathrm{~m}$. Skrivekridt, rent hvidt med Smaaflammer af graalig Farve; disse er dels uregelmæssigt formede Flammer, dels har de Form af Ophiomorpher. Kridtet er iøvrigt almindeligt, typisk Skrivekridt, ikke særlig forsteningsrigt (bortset fra lokale, Terebellaagtige Ophobninger). $25 \mathrm{~cm}$ under Lagets Overgrænse findes en Række af $10-15 \mathrm{~cm}$ tykke Nyrer af typisk, sort Skrivekridtflint med tynd, hvid Skorpe.

E) 0,30 m. Lerlag, udviklet som Konglomerat. Leret er i fugtig Tilstand blødt, plastisk, ikke skifret, meget fint; tørt er det haardt, af lysegraa Farve med et meget svagt gulligt Anstrøg.

Laget er af udpræget transgressiv Karakter; det er nok skarpt afgrænset mod det underliggende Kridt, men dettes Overflade er meget ujævn, smuldrende og fuld af Sprækker, hvori Leret er trængt ned. Leret er endvidere opfyldt af Rullesten af Skrivekridt, oftest kun svagt rullede, kantede; alle Størrelser findes blandet, fra ganske smaa til ret store (den største af de udgravede maaler $17 \mathrm{~cm}$ i Længden). Blandt Stenene findes baade Sten af typisk, hvidt Skrivekridt, utvivlsomt stammende fra det underliggende Kridt, og desuden Sten af graat Kridt, noget flammet af lysere Pletter, af Konsistens som det øvrige Kridt paa Stedet; disse sidste kan heller ikke være trans- 
porteret nogen længere Strækning, saa de stammer formodentlig fra nedbrudte, mere lerede eller lerflammede Partier af Kridtet.

Opadtil aftager Rullestenene i Antal, Leret bliver lysere og haardere og gaar jævnt over i

D) $0.65 \mathrm{~m}$ Coccolitkalk. Laget begrænses opad af et ret sammenhængende, $0,10 \mathrm{~m}$ tykt Lag af Flint, sort med hvid Skorpe, lidt urenere end Skrivekridtflint.

C) $0,25 \mathrm{~m}$ Coccolitkalk. Denne er langt mindre hærdnet og sammenhængende, end det ellers er Tilfældet med Coccolitkalk, dannende en løs, sandet Masse; hist og her indeholder denne uskarpt begrænsede, haardere Partier. Farven er hvid og graaligt skjoldet.

Laget gaar uden nogen Begrænsning jævnt over i

B) 0,60 $\mathrm{m}$ hærdnet Coccolitkalk. Denne er meget haard, uden nogen Spaltningsretning for Slag, dannende større og mindre Knolde, skilt af bugtede Spalter med løst Kalkpulver; smaa Glideflader viser, at Massen har været underkastet »Sætning《 efter Hærdningen. Kalken er en meget finkornet Coccolitkalk, uden Indhold af Bryozoer, men med en Del Foraminiferer; den indeholder desuden Pletter af spongiøs Struktur og Hulrum efter Kiselnaale, ligesom ogsaa større Fossiler har efterladt sig Aftryk i den haarde Kalk.

De øverste $30 \mathrm{~cm}$ af dette Lag er gennemsat af et forgrenet og omfattende System af uregelmæssigt rørformede Hulrum, fyldt med nedsunket Materiale fra den overliggende Bryozokalk, mere eller mindre lost lejret; ofte kan disse Partier af Bryozokalk dog ogsaa være lidt hærdnet, saa det kan være vanskeligt at fastsæette Grænsen mellem de to Slags Kalk. Hulrummene ses oftest at være af tydelig spongiøs Oprindelse.

Den øverste, horisontale Overflade af Coccolitkalken er, hvor den er haard, ujævnt afglattet ved en næppe langvarig Abrasion. Saavel denne Overflade, som Overfladen af den øvre Del af mange af de Bryozokalk-udfyldte Hulrum, er beklædt med et tyndt Overtræk af gulligt og grønligt Ler, der undertiden kan danne et helt, tyndt Lag; den samme lerede, grønfarvede Overflade ses paa de sparsomt forekommende, smaa Rullesten af Coccolitkalk, der kan træffes i den nederste Del af Bryozokalken.

I Nedsynkningerne af Bryozokalk kan ogsaa større Fossiler (Echinocorys, Cyclaster) findes, og stratigrafisk maa Kalken i disse Hulrum naturligvis henregnes til det overliggende Lag.

A) 1,40 m Bryozokalk, ren, spaltende, let smuldrende. Bryozoerne 
er meget fine, talrige, indlejrede $\mathrm{i}$ en fin Grundmasse. Ved Lagets Basis er denne Coccolitkalk-Grundmasse endnu dominerende, indeholdende et stort Kontingent af Foraminiferer, men Bryozoerne indgaar hurtigt i større Mængde, og ca. $5 \mathrm{~cm}$ over Basis har Laget Karakter af ren Bryozokalk.

Grænsen mod den underliggende Coccolitkalk er, som ovenfor omtalt, skarp, beklædt med et glaukonitisk Lerlag. Tæt over sin Basis indeholder Bryozokalken hyppigt smaa, glaukonitiserede Pletter og indtil centimeterstore Knolde af en grønlig-brun, leret Substans, indeholdende mikroskopiske, organiske Rester. Et Kvartskorn paa adskillige mm Størrelse er ogsaa iagttaget.

Ved Analyse fandtes følgende Indhold af $\mathrm{CaCO}_{3}$ :

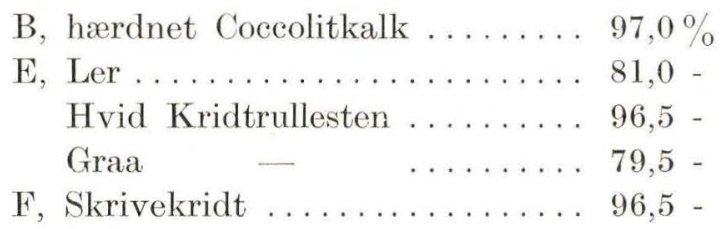

Lagstillingen er, saavidt det kunde observeres i det korte Profil, horisontal; Lagene maa dog sikkert have et, omend ringe, Fald indad i Fjorden.

Lagseriens stratigrafiske Forhold vil blive nærmere behandlet i Kap. VI; Forsteningerne er anført i Bilag F. Lagene A-E maa henregnes til Daniet, Skrivekridtet F til Senoniet.

Assens. ? 16 (Kortet). ? 19 (S. 536, »Liimsten - Mariagerfjord«). ? 122 (S. 85, 86, "Limsten - nær Mariager By«). ? 113 (S. 60, »Bryozokalk ved Mariager«). 9 (S. 542). 104 (D. 4. 22, "Limsten«).

I Egnen V. f. Assens findes en stor Mængde gamle Kalkgrave. BogGILD skriver, at »Bryozokalken findes umiddelbart Vest for de omtalte, store Kridtgrave; her har der i tidligere Tid været betydelig Brydning; paa Kr. d. 4des Tid brændtes der Kalk i stor Maalestok for at føres vidt omkring, men da Skovene led altfor stærkt derved, maatte Virksomheden ophøre igen«. I de senere Aar har der ikke været aabne Grave her.

Paa Mineral. Museum findes fra 1896 en Prøve fra en Brønd 3/4 km V.f. Assens. Den bestaar af Bryozokalk, hvid haard; Bryozoerne, som ikke er særlig dominerende, ligger indlejret i en finkornet Grundmasse af Coccolitkalk. En tilsvarende Flintprøve er hvid, bryozoholdig, med graa Pletter.

Forsteninger fra Bryozokalken paa denne Egn foreligger desværre ikke, men det drejer sig sikkert om Æ. Danium. 
Jomfrubakken. 16 (Kort). 65 a (S. 32). 9 (S. 542). 104 (D. 4. 19).

Madsen skriver følgende om Forholdene paa dette Sted: „Paa Mariager Fjords Sydkyst træffer man paa Blegekridtet paa Gaarden Jomfrubakkens Jorder. AxEL JESSEN har i 1910 foretaget en Undersøgelse af dette, hvoraf det fremgaar, at der i den Nordvest for Gaarden liggende, $24 \mathrm{~m}$ høje Banke, som staar med stejl Skrænt ud mod Fjorden, findes Blegekridt, der paa en Strækning af $630 \mathrm{~m}$ langs med Skrænten $\mathrm{og}$ indtil $220 \mathrm{~m}$ ind i Landet kun er drkket 0,3--2,0 $\mathrm{m}$ Jord. Blegekridtet naar saaledes her op til en Højde af ca. $22 \mathrm{~m}$ over Havet. Blegekridtet er dog ingenlunde indskrænket til det omtalte Omraade; det strækker sig mod Nordøst tværs over den Lavning, gennem hvilken Vejen op til Gaarden er anlagt, og videre i den høje Mark Nordøst derfor. Ogsaa Sydvest for det omtalte Omraade findes der Blegekridt. For Tiden brydes Blegekridtet i et Brud i Skrænten ved Kysten Nordvest for Gaarden, $2400 \mathrm{~m}$ Nordøst for Mariager. Bruddets Bund ligger 2,3 m over Havfladen, og Blegekridtet naar helt ned til Bunden; dets Underlag kommer ikke til Syne i Bruddet. Blegekridtet danner 0,2-1,5 m tykke, omtrent vandret liggende Bænke. Mellem disse findes der hist og her gabende Mellemrum paa indtil $4 \mathrm{~cm}$. Ved Brydningen var nogle Steder »Loftene« i Mellemrummene bleven tilgængelige, saa man kunde undersøge dem; de var knudrede, saa at de gabende Mellemrum ikke kan være fremkomne ved Forskydning af Bænkene mod hverandre; det ser nærmest ud, som om de er et Udvaskningsfænomen.

Blegekridtet er flintfattigt; der findes Knolde af sort Flint, dels spredt og dels samlede i enkelte Lag.»

Bjergarten er Coccolitkalk af den sædvanlige Type, finkornet, hvid, i Almindelighed noget afsmittende, blød.

Faunaen henfører Lokaliteten til Y. Danium (Zone C?).

Mariager I. 65 a (S. 33, »Blegekridt - 1400 m Nordøst for Mariager $($ ).

$1 \mathrm{~km}$ NØ. f. Knudshoved. Coccolitkalken gaar her op til en Højde af ca. $16 \mathrm{~m}$. Sandsynligvis Y. Danium.

Mariager II. 65 a (S. 33).

$400 \mathrm{~m}$ NØ. f. Knudshoved. Coccolitkalkens Højde er her 3,3 m.

Mariager III. 65 a (S. 33, "Knudshoved«).

Paa Nordsiden af Knudshoved.

Madsen skriver: „Ved det nordvestlige Hjørne af Knudshoved, $600 \mathrm{~m}$ Nord for Mariager, kommer der Blegekridt frem under Strandgruset c. $0,7 \mathrm{~m}$ over Havfladen.«

Paa Mineral. Museum findes fra 1871 en Prøve af Kalk taget »østenfor Havnen i Mariager«. Den bestaar af almindelig Coccolitkalk, fin- 
kornet, svagt grynet, noget afsmittende, hvid; den indeholder en glaukonitiseret Plet, skarpt begrænset.

Forekomsten tilhører sikkert Y. Danium.

Frederikseje I. 98 (S. 263). 65 a (S. 33). 9 (S. 542 ). 104 (D. 5. 6).

$200 \mathrm{~m}$ V. f. Anløbsbroen (ved Gaarden Frederikseje).

Om denne og den følgende Lokalitet (Frederikseje II) skriver MaDSEN : „Vest for Mariager træffer man ikke paa Blegekridtet før i Nærheden af Anløbsbroen Voldstedlund. Her findes der i Saltvandsalluviet ved Kysten $200 \mathrm{~m}$ Vest for Anløbsbroen og $500 \mathrm{~m}$ Øst for Anløbsbroen to smaa Grave med Blegekridt. Gravene var i 1917 sammenskredne og fyldte med Sten og Affald, men det kunde dog konstateres, at der i dem findes Blegekridt med Flint, der snarere er sort end graa. I den østlige Grav ligger Blegekridtets Overflade c. $0,8 \mathrm{~m}$ og i den vestlige Grav c. I,6 m over Havfladen. $120 \mathrm{~m}$ Øst for Anløbsbroen saas opgravet Blegekridt ved nogle Hegnstolper.«

I 1923 var Graven i samme Tilstand, og Profil fandtes ikke. Der laa opgravede Bunker af den lidt graalige, bryozofri Coccolitkalk, stærkt smuldrende, samt større Knolde af graa og hvid Flint.

Faunaen henviser Kalken til Y. Danium (Zone D).

Frederikseje II. 98 (S. 263). 65 a (S. 33). 104 (D. 5. 6).

$500 \mathrm{~m} \varnothing$. f. Anløbsbroen.

RAVN skriver (1914): „Under mit Besøg i denne Egn fandt jeg nemlig i Engen østfor Gaarden Frederikseje (Dampbaadenes Anløbsplads »Voldstedlund«) en lille Grav i Blegekridt.« En af RAvN indsamlet Prøve bestaar af graagul Coccolitkalk, ret blød og afsmittende; den er finkornet, noget grynet af Struktur, sandet at føle paa.

Se iøvrigt MaDsen's Omtale under Frederikseje I.

Forsteninger foreligger ikke, men Kalken er sikkert identisk med den i Frederikseje I.

Ove I. 65 a (S. 32)1). 104 (D. 4. 18).

Kystskrænten ca. $700 \mathrm{~m} \mathrm{SV}$. f. Ovegaards Vandmølle. Kote $15 \mathrm{~m}$.

Ved et Besøg i 1923 fandtes her en Prøvegravning, foretaget et Par Aar i Forvejen. Herved var der i en Højde af ca. $8 \mathrm{~m} \mathrm{o}$. Havet frembragt et rent Profil af $4 \mathrm{~m}$ Højde og $1,5 \mathrm{~m}$ Bredde.

Kalken er ren Coccolitkalk, absolut uden Bryozoer. Kalken sprækker ud i haandstore Knolde, der er ret faste, spaltende; den er hvidgraa af Farve, ikke afsmittende, meget finkornet. Analysen viser kun et

1) Ifølge Madsen skal der noget længere mod Vest findes en tilskredet Gravning i Blegekridt. Ravn's Angivelse henviser antagelig baade til disse Lokaliteter og til Ove IV, da han angiver "Blegekridt, Limsten? «. 
Indhold af $83,5 \% \mathrm{CaCO}_{3}$, hvilket for Størstedelen skyldes et Indhold af Ler. Egentlige Flintlag findes ikke, men Flinten er jævnt udskilt som Imprægnation af Kalken som hvid eller som blaalig Flint, saa der sjældent er skarp Grænse mellem Flint og Kalk.

I noget udgravet Materiale fandtes enkelte, sparsomt forekommende Forsteninger. Disse henviser Kalken til Y. Danium (Zone C?).

Ove II.

Den vestlige Aaskrænt $1 \mathrm{~km} \mathrm{N.} \mathrm{og} \varnothing$. for Ove By. Kote $22 \mathrm{~m}$.

Skrænten er her paa en længere Strækning fuld af Gruber og Fordybninger som Vidne om tidligere Tiders Kalkgravning, men alt er forlængst tilgroet (Fig. 3, S. 61).

Det er lykkedes at finde en Del løse Stykker af Bryozokalk med et ikke overvældende stort Indhold af Bryozoer liggende indlejret i en finkornet Grundmasse; den er hvid af Farve, lidt afsmittende. Kalken indeholder $96,8 \% \mathrm{CaCO}_{3}$. Flinten er hvid.

Der er fundet en Del Forsteninger, hvilke henviser Kalken til $\mathbb{E}$. Danium (Zone B).

Ove III.

$200 \mathrm{~m} \mathrm{~N}$. f. Fimmersdal Gaard. Kote ca. $16 \mathrm{~m}$.

I 1923 var her en gammel, delvis tilskredet Grav.

Under et Dække af $3 \mathrm{~m}$ Diluvialgrus saas et Profil gennem $4 \mathrm{~m}$ Bryozokalk. Kalken er sprækket i ret store Brokker, forvitret, men aabenbart ikke særlig stærkt henfaldende. Bryozoindholdet er ikke særlig stort, og Bryozoerne domineres ved en overfladisk Iagttagelse af den hvide, noget grynede Grundmasse; føler man paa den kun svagt afsmittende Kalk, mærker man imidlertid straks Bryozoindholdet. Flinten forekommer som uregelmæssige, graasorte Knolde, omtrent sammenhængende i 4 Baand af $10 \mathrm{~cm}$ Tykkelse.

Lagstillingen horisontal.

Faunaen henviser Kalken til A. Danium (Zone B).

Ove IV. (3 (S. 247)). ? $\left.122(\text { S. 86) })^{1}\right) .65 a$ (S. 31). 6 (S. 11). 104 (D. 4.18$\left.)^{2}\right)$.

Omkring Ovegaards Vandmølle har der fra meget gammel Tid fundet Kalkbrydning Sted, dels i aabne Grave, dels i underjordiske Brud eller i dybe Brønde; nu er Brydningen paa disse Steder dog ophørt, og man ser kun de tilstyrtede og tilgroede Huller, særlig i Skoven SV. f. Vandmøllen.

Ved Foden af Skrænten tæt NØ. f. Gaarden findes en tilgroet Grav. Kote 3-4 m. Her blev paa min Opfordring i 1924 af Hr. K. Ahrenтеснт foretaget en mindre Gravning, der blottede Kalken og et Flint-

1) Ussing omtaler her Limsten paa Nordsiden af Mariager Fjord.

2) Se Fodnote til Ove I. 
lag i Skrænten. De tilsendte Kalkprøver er Bryozokalk, ret fast, godt spaltende, kun lidt afsmittende. Bjergarten bestaar af en finkornet, lidt grynet Grundmasse, hvori Bryozoerne, der egentlig ikke er dominerende, ligger indlejret.

Flinten danner et godt $10 \mathrm{~cm}$ tykt Lag, er hvidgraa af Farve med mørkt, omtrent sort Midtparti.

Lagstillingen horisontal.

Efter de faa foreliggende Forsteninger at dømme, maa Lokaliteten sikkert henføres til A. Danium (Zone B).

Stinesminde I. 65 a (S. 32).

$600 \mathrm{~m} \mathrm{~V}$. f. Stinesminde. Kote $6 \mathrm{~m}$.

Væggen i Graven er godt $10 \mathrm{~m}$ lang og ca. $2 \mathrm{~m} \mathrm{høj,} \mathrm{men} \mathrm{er} \mathrm{til-}$ skredet. Ifølge fremskaffede Oplysninger er Kalken faststaaende og indeholder øverst i Væggen et Flintlag.

Efter nogle i 1924 indsendte Prøver er Bjergarten Coccolitkalk af en ret fin Beskaffenhed, hvid, afsmittende, ret godt sammenhængende. Bryozoer indgaar ikke. Flinten er graasort med en tyk Skorpe af hvid Flint.

Faunaen henviser Kalken til Y. Danium (Zone D).

Stinesminde II. 65 a (S. 32).

Strandbrinken $700 \mathrm{~m} \mathrm{SV}$.f. Stinesminde. Kote ca. $5 \mathrm{~m}$.

Her findes en nu tilgroet Grav, hvori intet er at se, men et kort Stykke længere mod Vest er Vejen i 1923 gravet et Stykke ind i Skrænten, hvorved man er stødt paa Kalken. Profilet her var i 1924 tilskredet, saa den faststaaende Kalk ikke kunde iagttages.

En indsendt Prøve af det løse Kalksand bestod af Coccolitkalk, meget lignende Kalken fra Stinesminde I, men maaske en Smule mere grynet af Struktur.

Faunaen henviser Kalken til Y. Danium (Zone D).

Løvdal.

SV. f. Stinesminde. Kote $14 \mathrm{~m}$.

Ifølge modtagne Oplysninger er man her ved Brøndgravning stødt paa Kalken i ringe Dybde under Overfladen. Prøver af Kalken foreligger ikke, men det drejer sig formodentlig om Coccolitkalk som paa de tilstødende Lokaliteter.

Laaenhus I.

$400 \mathrm{~m}$ NØ. f. Laaenhus, Ø. f. Kjeldstrup Sø.

I 1923 fandtes her i en Grav i Skrænten et $4-5 \mathrm{~m}$ højt, rent Profil 
i Kalk, overlejret dels af Tapesgrus og Skaller, dels af 6 -8 m Diluvialgrus. Kalkens Overflade ligger ca. $8 \mathrm{~m} \mathrm{o.} \mathrm{Havet.}$

Kalken er Coccolitkalk, graahvid, stærkt sprækket; den er fin, noget afsmittende, uden Indhold af Bryozoer. Analysen viser et Indhold af $86,8 \% \mathrm{CaCO}_{3}$. Flinten er graa med hvid Skorpe, mest i Form af smaa Knolde med meget uregelmæssigt grubet Overflade. Øverst i Kalken fandtes et $19 \mathrm{~cm}$ tykt Lag mere sammenhængende Flint, men bortset herfra danner Flintknoldene ikke Lag, men forekommer spredt, jævnt fordelt, i Kalken.

Lagstillingen er, saa vidt det kunde ses, horisontal.

Faunaen henfører Kalken til Y. Danium (Zone D).

Arden I. 48 (S. 6). 6 (S. 11). 104 (D. 4. 17).

Boring ved Stationen. Kote $72 \mathrm{~m}$.

Ifølge Ravn er der i en Dybde af $10 \mathrm{~m} \mathrm{u}$. Overfladen truffet »Kalk og Flint«.

En Prøve paa Mineral. Museum, mærket »Blegekridt fra Brøndgravningen ved Arden Station« (1873), bestaar af hvid, finkornet, typisk Coccolitkalk, delvis afsmittende, delvis imprægneret med Kisel.

Formodentlig Y. Danium.

Roldtved I.

2 Grave, paa hver sin Side af Hovedlandevejen ved Roldtved, $3,7 \mathrm{~km}$ N. f. Rold Kro. Kote $66 \mathrm{~m}$. Gravene er dybe, med stejle Vægge, hvori øverst ses 2-3 m Diluvialsand og Morænesand og derunder 6-8 m Kalk; Kalken graves ud og hejses op.

Kalken er Coccolitkalk, typisk, fin, afsmittende, ret blød; stedvis mere sammenhængende, spaltende. Bryozoer optræder kun enkeltvis. Kalken falder stærkt hen ved Forvitring. Pletvis ses i de opgravede Bunker noget Kalk af den under Ersted II (S. 69) omitalte, kiselrige Type. Analysen viser et Indhold af $66,5 \% \mathrm{CaCO}_{3}$. Flinten mørkegraa, i store, uregelmæssige Knolde paa indtil flere dm i Tværsnit; tildels er de ordnet i Rækker, men stedvis, hvor Flintknoldene er mindre talrige, ligger de i spredt Orden.

Lagstillingen horisontal.

Den temmelig rige Fauna henviser Forekomsten til Y. Danium (Zone D).

$100 \mathrm{~m}$ mod Nord ses endnu en lille Gravning i Kalk Ø. f. Vejen.

Ræbild I. 104 (D. 4. 15).

Boring i Ræbild By. Kote ca. 78 m. "Haardt Kridt« 34,5 m u. Overfladen. 


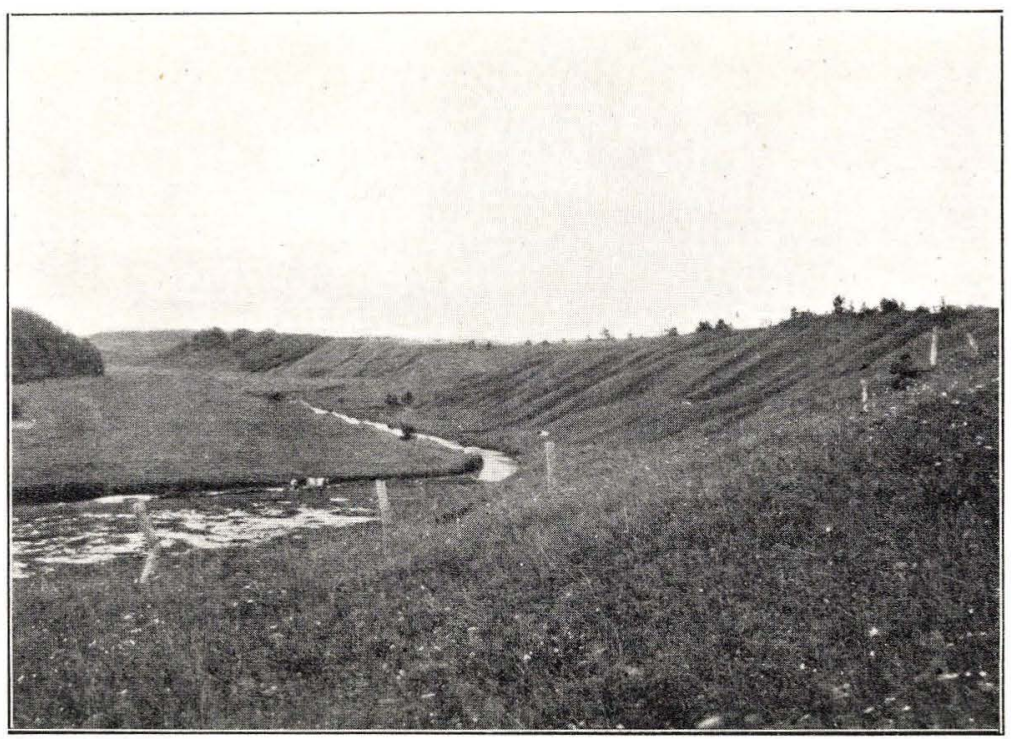

Fig. 3. Ove II. Gamle Kalkgrave.

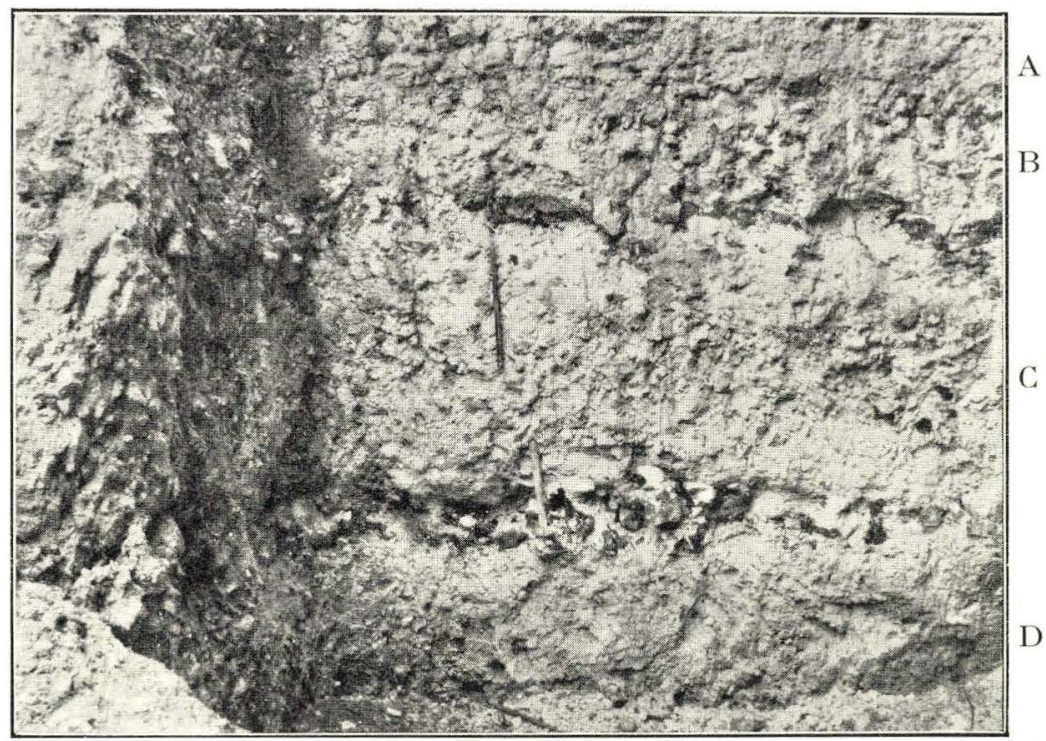

Fig. 4. Gravlev I. A Bryozokalk. B-D Coccolitkalk. 
Gravlev I.

$350 \mathrm{~m} \mathrm{~N}$. f. Nybro. Kote $20 \mathrm{~m}$.

Umiddelbart Ø. f. Vejen fandtes der her i 1923 og 25 en lille, firkantet Gravning, kun 4,5 × 2,5 m. Væggene var stejle (bortset fra en skraa Gennemgravning op til Landevejen) og frembød gode Profiler, idet det tilgængelige Profil dog maatte suppleres nedadtil ved Gravning. Lagfølgen var saaledes fra neden (Fig. 4 og T. III):

G) Skrivekridt. Det er fast, hvidt, i sin øverste Del indeholdende smaa, graa, skarpt begrænsede Flammer af lerholdigt Kridt; disse er i hvert Fald delvis opstaaet som Sprækker i Kridtets Overflade, udfyldt med Lermateriale fra oven.

F) 0,10 m Ler, udviklet som Konglomerat. Leret selv er i fugtig Tilstand blødt, meget fedt, ikke skifret, uden Indblanding af Sandskorn eller grovere Materiale, og det lader sig slæmme fuldstændigt op. Det indeholder smaa Okkerprikker. Farven er graa med et gulligt eller svagt brunligt Anstrøg, lidt vekslende.

Leret indeholder et meget stort Antál Kridtrullesten, tilsyneladende alle af det samme hvide, typiske Skrivekridt, som udgør Underlaget. Størrelsen kan variere fra det rent minimale til et Hønseægs Størrelse. De er kun lidt slidte, mere eller mindre kantede, og er utvivlsomt losbrudt fra det underliggende Kridt uden at have været udsat for nogen længere Transport. Af Forsteninger indeholder Leret kun lidt, sikkert Skrivekridtforsteninger paa sekundært Leje.

Et Stykke af Leret, udtaget saa rent som muligt, viste ved Analyse et Indhold af 71,5\% $\mathrm{CaCO}_{3}$, men da det ikke var fuldstændig frit for smaa Indblandinger af rent Kridt, ligger Lerets Kalkprocent i Virkeligheden endnu en lille Smule lavere.

Opad gaar dette Ler jævnt over i

E) $0,30 \mathrm{~m}$ hvid Cocolitkalk, ganske lig Lag D.

4) 0,10 m Flint, sort med tyk, hvid Skorpe, dannende et kompakt Lag.

D) 0,80 m Coccolitkalk, fed, let sammenhængende, smaabrokket, meget forsteningsfattig. Opadtil bliver den mere fed og mindre haard, dog kan de øverste Dele undertiden indeholde enkelte haarde Knolde i Lighed med den nedre Del af Lag C. Ind mellem Knoldene af det overliggende Flintlag er Kalken stedvis helt pulverformig.

Under Mikroskop viser Kalken sig at bestaa af et fint Pulver af krystallinske Bestanddele, der, til Trods for at Coccolitkalken her ellers gør et meget skrivekridtagtigt Indtryk, indeholder langt flere grove Elementer, end det er Tilfældet 
med Skrivekridt. Coceoliter er langt sjældnere end i Skrivekridt.

3) 0,20 m tykt Flintlag, bestaaende af store, uregelmæssige, men ret sammenhængende Knolde. Flinten er omtrent sort, i sin øverste Halvdel mere graalig, med tykkere eller tyndere hvid Skorpe.

C) 0,85 m Coccolitkalk. Kalken er ret stærkt hærdnet, men sprækket og brokket, saa den falder ud i større eller mindre Klumper og Knolde, enten med en uregelmæssig, grubet Overflade eller begrænset af Brudflader; de er meget haarde, uden nogen Spaltningsretning for Slag. Mellem Knoldene er Kalken ganske løs og uhærdnet.

Det er særlig den midterste Zone af Lag C, der er saaledes hærdnet; opadtil og nedadtil bliver Knoldene færre og Kalken mere homogen, men ikke saa løs som Pulveret mellem de stærkt hærdnede Partier. Laget kan i sin øverste Del indeholde nogle faa Bryozoer.

Under Mikroskop viser de mindst sammenkittede Dele af dette Kalklag sig omtrent identiske med den underliggende Coccolitkalk D. Hist og her i Laget ses en enkelt hvid — graa Flintkonkretion.

2) Flintlag, indtil 0,20 m tykt; graa, uregelmæssige Knolde, ikke saa kompakt som Lag 3 ; den hvide Skorpe er tykkere end hos Lag 3.

B) $0,20 \mathrm{~m}$. Coccolitkalk, meget lignende Lag C's øverste, mindre hærdnede og knoldede Del; indeholder flere Bryozoer, men disse er ikke dominerende, idet de ikke er tilstede i større Antal og ikke formaar at berøve Kalken sin Karakter af Coccolitkalk med en meget fint grynet Grundmasse. Bryozoerne mærkes især ved Berøring af Kalken.

1) En usammenhængende Række af mindre Flintknolde.

A) 0,80 m. Bryozokalk, godt spaltende, sprækkende ud i firkantede Brokker. Bryozoerne dominerende, indlejrede i velbevaret Tilstand i en finkornet Grundmasse.

Analysen viser følgende Indhold af $\mathrm{CaCO}_{3}$ :

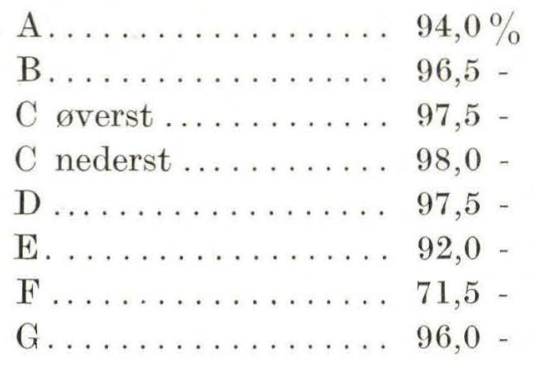


Over Bryozokalken fandtes $0,5 \mathrm{~m}$ Lokalmoræne, og herover Diluvialsand.

Lagstillingen horisontal.

Af Forsteninger foreligger en hel Del. En fuldstændig Liste over de bestemte Former findes i Bilag D, og en mere speciel Behandling af de palæontologiske Forhold gives i Kap. VI. Den hærdnede Del af Lag C indeholder bl. a. mange Aftryk af aragonitskallede Former, hvorimod den underliggende Coccolitkalk D og E er meget forsteningsfattig. Lagene A - F tilhører Daniet, det underliggende Skrivekridt G Senoniet.

Skillingbro. 91 (S. 39, »Skrivekridt《). 95.123 (S. 35). 76. 80 (»Yngre Danien«). 88 (S. 14). 6 (S. 11). 104 (D. 4. 14).

900 m S.t.V. f. Nybro. Kote ca. $28 \mathrm{~m}$.

Lokaliteten nævnes første Gang af PosselT, som dog fejlagtig opfører den som Skrivekridt, idet han kun har Bestemmelsen af en Terebratula at støtte sig til. Senere opfører RavN denne Lokalitet (ligesom Tinbæk Mølle) baade under Bryozokalk og Blegekridt, men angiver udelukkende Forsteninger fra Blegekridt, ingen fra Bryozokalk. Først 1909 angiver Brünnich Nielsen bestemte Brachiopoder fra begge disse Bjergarter, og i 1920 understreger han atter Forekomsten af begge Bjergarter i dette Brud.

I 1920 opmaaltes følgende Profil (Fig. 5 og T. III):

G) I Gravens Bund; ren Bryozokalk. Herover følger $7 \mathrm{~m}$ vekslende Lag af Bryozokalk og Flint indtil

F) $0,9 \mathrm{~m}$ Bryozokalk. Kalken har en Grundmasse af finkornet Coecolitkalk, hvori er indlejret en stor Mængde Bryozoer (der særlig gør sig bemærket ved Berøring); Bryozoerne er lidt finere end i Kalken ved Bunden, og alle Mellemrum udfyldes af Grundmassen.

6) 0,10 m Flint, hvid med graa Kerne, ret sammenhængende.

E) 0,20 m. Kalken bestaar af den samme Grundmasse som F, hvori indgaar en Del Bryozoer (samt Foraminiferer), men i betydelig ringere Mængde, saa Bjergarten nærmest er en Mellemting mellem Bryozokalk og Coccolitkalk, ru at føle-paa, afsmittende; desuden ses enkelte Glaukonitkorn. Farven er gulliggraa.

5) 0,10 m Flint; lig Nr. 6 .

D) 0,7 m Coccolitkalk. Grundmassen er den samme som i E, men noget mere homogen i Struktur, uren i Bruddet og ujævn at føle paa, idet der i Massen indgaar en Del Foraminiferer, mens der af Bryozoer kun er iagttaget enkelte hist og her.

25-30 cm under Overkanten indeholder denne Kalkbænk en mere leret Zone, let skifret, spaltende, ofte lidt haardere, graa af Farve; den indeholder enkelte Glaukonitkorn og glaukonitiserede organiske Rester. 
4) 0,10 m Flint; graa, dannende et sammenhængende Lag.

C) $0,20 \mathrm{~m}$ Coccolitkalk.

3) 0,25 m Flint; usammenhængende Knolde.

B) 0,70 m Coccolitkalk. Den er noget renere og endnu mere homogen end D. Den er ensartet, ret fast (uden at være særlig hærdnet), noget afsmittende, finkornet, svagt grynet og porøs af Struktur, sandet at føle paa. Bryozoer forekommer ikke, og heller ikke Foraminiferer eller større Kalkkorn indgaar i Massen.

2) 0,10 m Flint; ret sammenhængende Lag, mørkt med hvide Partier med mørkere Kerne.

A) 0,40 m Coccolitkalk, lig Lag B.

1) $0,20 \mathrm{~m}$ Flint, lig Lag 2 .

Herover følger $2 \mathrm{~m}$ Lokalmoræne.

Lagstillingen er horisontal.

Den fuldstændige Fortegnelse over de fra disse Lag bestemte Forsteninger findes i Bilag $G$, en nærmere Behandling af de palæontologiske Forhold i Kap. VI. Herefter maa Lagene A-D henregnes til Y. Danium (Zone C), Lagene E-G til A. Danium (Zone B).

Tinbæk Mølle. 95. 123 (S. 35, »Tindbæk Mølle«). 76. 104 (D. 4. 14). Kote $20 \mathrm{~m}$.

Ravn opfører Tinbæk Mølle som Lokalitet for et Par Fossiler. Dog maa det bero paa en Fejltagelse, naar han i Faunalisten S. $414 \mathrm{ff}$. opstiller Lokaliteten som førende baade Bryozokalk og Blegekridt, da der kun forekommer Bryozokalk; RAVN angiver da heller ingen Forsteninger fra Blegekridt.

Graven, som ligger i Bakkeskrænten lige bag Vandmøllen, er ret stor; der ses $8 \mathrm{~m}$ rent Profil i Bryozokalken, overlejret af over $3 \mathrm{~m} \mathrm{Mo-}$ ræneler. Kalken er fast sammenhængende og hugges ud i store Blokke. Bryozoindholdet er ret stort, men den fine Grundmasse af Coccolitkalk er alligevel ret fremtrædende. Flinten er graa med hvid Skorpe; den danner Lag af $10 \mathrm{~cm}$ Tykkelse eller flade Knolde, ordnet i Rækker.

Lagene ligger i Buer, diskordant, paa samme Maade som i Stevns, Bulbjerg, Karlby m. v. Der ses ingen Tegn paa egentlige Forstyrrelser af Lagene.

Faunaen henviser Lokaliteten til Æ. Danium (Zone B).

\section{Oplev I.}

$1,5 \mathrm{~km} \mathrm{NV}$. f. Oplev By. Kote $70 \mathrm{~m}$.

Gammel Grav; i 1923 var den omtrent helt tilgroet. Et Par Steder havde der dog i senere Tid været gravet Kalk i et Par brøndagtige Gravninger paa godt $4 \mathrm{~m}$ Dybde, hvorfra Kalken var blevet hejset op. I disse Profiler saas Coccolitkalk, dels løsere, let forvitrende, dels fastere, mere 


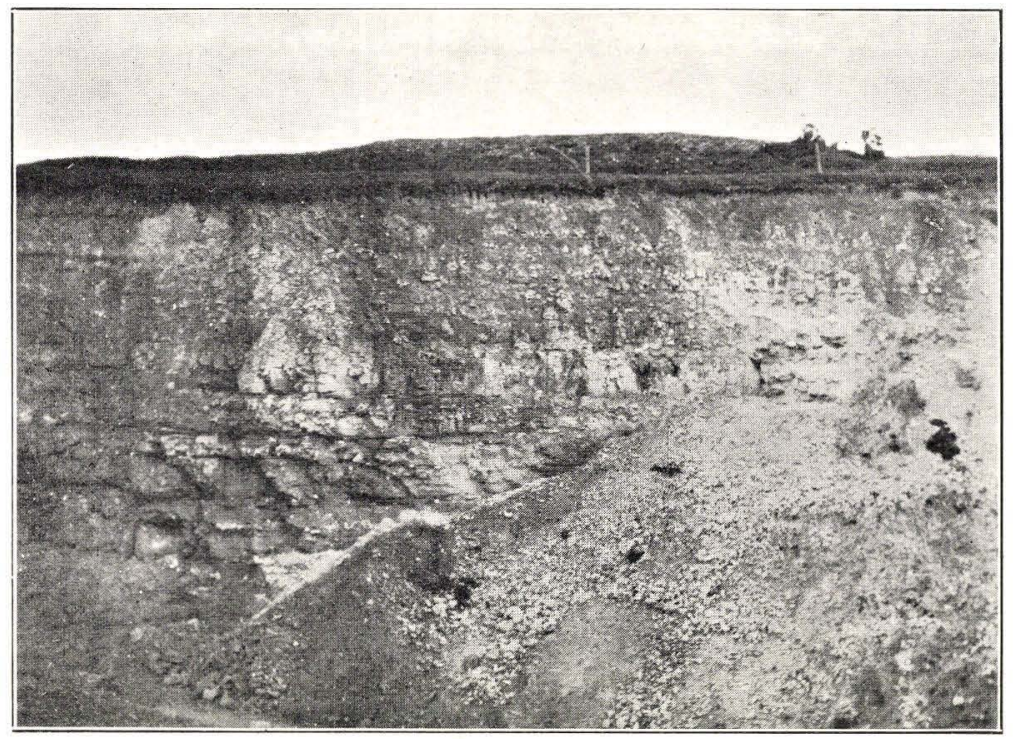

Fig. 5. Skillingbro. Nederst Bryozokalk (Zone B), øverst Coccolitkalk (Zone C).

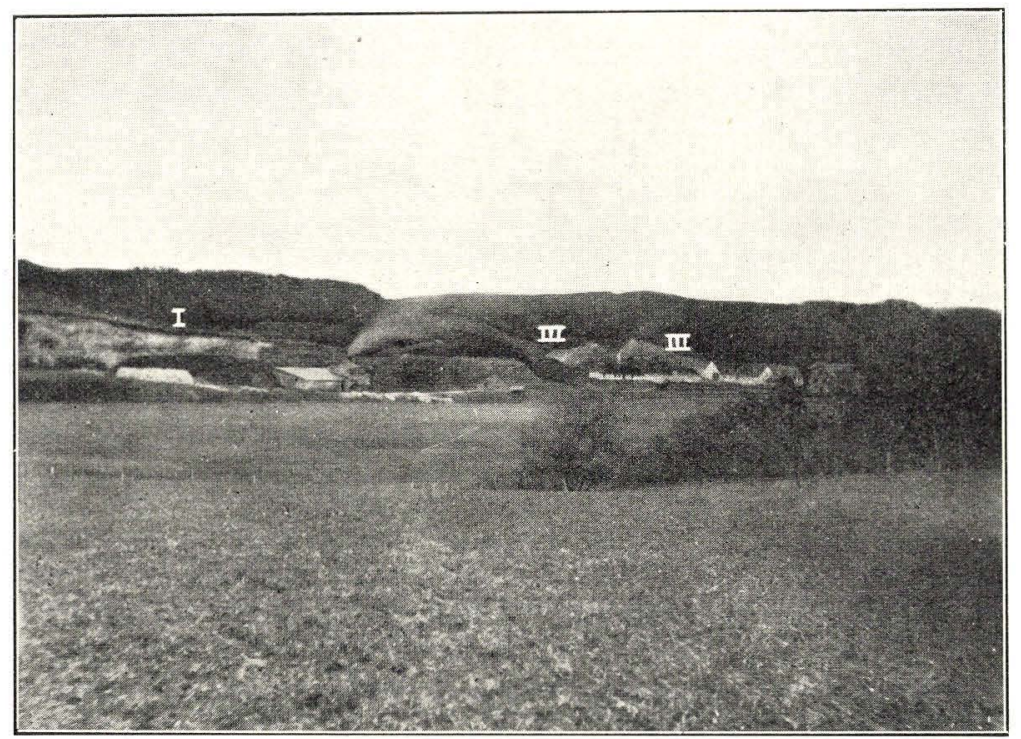

Fig. 6. Veggerbro I (Bryozokalk) og Veggerbro III (Skrivekridt). Set $\bmod N \varnothing$. 
hærdnet. Den er graa, finkornet, indeholder ikke Bryozoer; kun lidt afsmittende. Kalkindholdet er 96,5\%.

Flinten forekommer i store, runde eller lidt ovale Klumper med stærkt »korroderet« Overflade. Farven er sortegraa — undertiden med et gulligt Anstrøg — og Knoldene er overtrukket med en tyk, hvid Skorpe; desuden er Knoldene ofte hvide i Midten.

Lagstillingen er, saa vidt det kunde ses i de smaa Profiler, paa det nærmeste vandret.

Faunaen henviser Kalken til Y. Danium (Zone D).

Oplev II.

Ca. $400 \mathrm{~m}$ Ø. f. Oplev By. Kote $59 \mathrm{~m}$.

Lille Grav med indtil $2 \mathrm{~m}$ høj Væg, næsten helt tilskredet; kun et enkelt Sted saas i 1923 rent Profil. Kalken er sprækket og knust til en vis Grad, men iøvrigt faststaaende.

Kalken er Coccolitkalk, lignende Kalken i Oplev I, meget fin, delvis ret stærkt hærdnet, kun svagt afsmittende, ikke sandet at føle paa. Under Mikroskop ses - foruden en Mængde uorganiske Kalkpartikler og Fragmenter - en stor Del Coccoliter og smaa Foraminiferer. Flinten forekommer i tætliggende, tykke Lag af graa og hvid Farve.

Lagstillingen horisontal.

Efter Faunaen hører Kalken til Y. Danium.

Ersted I.

Ca. $600 \mathrm{~m} \mathrm{~N}$. f. Ersted By. Kote $62 \mathrm{~m}$.

Lokaliteten ligner meget Oplev I; stejl Gravning af ca. 5 m Dybde. Profilet var i 1923 meget urent. Øverst saas $2 \mathrm{~m}$ Diluvialsand, hvorunder $3 \mathrm{~m}$ Coccolitkalk. Kalken var stærkt brokket. Flinten optræder som store, graa Knolde og er næsten dominerende i Forhold til Kalken.

Lagstillingen horisontal.

Kalken tilhører Y. Danium (Zone C?).

Ersted II.

Ca. $800 \mathrm{~m} \mathrm{~N}$. f. Ersted By. Kote $70 \mathrm{~m}$.

Stejl, dyb Grav (Kalken hejses op, som det er Tilfældet i mange Grave heromkring). Under et Par $\mathrm{m}$ Diluvialsand saas $6-7 \mathrm{~m}$ Kalk. Kalken er Coccolitkalk, men løst sammenhængende, skør, daarligt spaltende, meget finkornet, "melet«; Analysen viser et Indhold af $62,0 \%$ $\mathrm{CaCO}_{3}$, og dette lave Tal (ligesom ogsaa at Kalken er mere "skarp« at føle paa) skyldes et stort Indhold af fint fordelt Kisel. Farven er rent hvid, men med en Mængde smaa Okkerprikker. Enkelte, spredte Bryozoer ses.

Under Mikroskop viser Bjergarten sig at være forholdsvis finkornet, 
bestaaende af finere, krystallinske Fragmenter samt en noget ringere Mængde af grovere Partikler. Coccoliterne er almindelige. Efter Behandling med Syre faas en Rest, der væsentlig bestaar af fnuggede Sammenhobninger af amorf Kiselsyre; i det indre af saadanne Klumper ses ofte begyndende Krystaldannelser. I Profilerne ses desuden mørkegraa Flint i Form af smaa uregelmæssige Knolde, spredt uden Orden og Orientering i Kalken. Flintmængden er temmelig ringe i Forhold til Kalken.

Lagstillingen horisontal.

Kalken tilhører Y. Danium (Zone C?).

Albæk. 95 (»Blegekridt«). 6 (S. 11). 104 (D. 4. 13).

For Tiden er der ingen Grave tilgængelige omkring Gaarden Albæk. En Del Prøver paa Mineral. Museum bestaar af Coccolitkalk.

Y. Danium (Zone D).

\section{Sørup I.}

Knap $2 \mathrm{~km} \mathrm{V.f.} \mathrm{Sørup} \mathrm{By.} \mathrm{Kote} 62 \mathrm{~m}$.

Der findes her flere mindre Grave, delvis med gode Profiler. I disse ses 3-4 m Coccolitkalk, graa, ret blød og stærkt afsmittende, stærkt smuldrende ved Forvitring; kun nu og da træffes klingende hærdnede Partier, eller Kalken er imprægneret med Flint. Flinten er dels hvid, dels graasort; den er ret sparsom og forekommer spredt i Kalkmassen, dog mest samlet i Form af tynde, udflydende, porøse Lag, som oftest sammenhængende, men uden skarp Begrænsning mod Kalken og uden at danne egentlige Knolde.

Lagstillingen horisontal.

Faunaen henfører Kalken til Y. Danium (Zone D).

Volsted. 6 (S. 11).

BøgGiLD angiver "Nyere Kridt" ved Volsted. Det er dog ikke lykkedes Forf. at finde Daniumbjergarter i Dagen omkring Volsted, og alle de i Egnen tæt NV. herfor liggende Grave indeholder Skrivekridt.

Veggerbro I. 41 (S. 32). 6 (S. 11, „Veggerby«). 104 (D. 4. 12).

Paa Nordsiden af Aaen, $800 \mathrm{~m}$ Ø. f. Veggerbro. Kote $7 \mathrm{~m}$ (Fig. 6).

Kalken brydes her til Brænding. I 1921 fandtes et rent, 3-4 m højt Profil i haard, stærkt sammenhængende Bryozokalk; Kalken falder ud i store Blokke, adskilt af Sprækker med livlig Travertindannelse; ved Forvitring skaller den ret stærkt af. Kalken, som er meget lidt afsmittende, bestaar i overvejende Grad af velbevarede Bryozoer; kun sjældent tager den meget finkornede Grundmasse Overhaand. Hvid Flint, ofte med graa Kerne, er hyppigst. En Del store Flintknolde findes spredt, men Dele af Profilet er meget fattige herpaa.

Lagstillingen horisontal. 
Et halvt Hundrede m V. f. Bruddet gaar Bryozokalken frem i Aalejet paa en Kotehøjde af ca. 1,5 m.

Kalken tilhører ifølge Faunaen E. Danium (Zone B).

Veggerbro II.

$450 \mathrm{~m}$ NØ.f. Veggerbro, V. f. Vejen. Kote $10 \mathrm{~m}$.

Ret stor Grav, men delvis tilskredet. I 1916 og 1921 iagttoges i et Profil ca. 6 m Coccolitkalk. Kalken er rent hvid og ret let i tør Tilstand, let smuldrende til Støv og Brokker, meget afsmittende; den er meget finkornet, næsten skrivekridtagtig. Flinten er mørkegraa, undertiden næsten sort, men med udflydende hvid Skorpe.

De øverste $3 \mathrm{~m}$ af Kalken er meget rige paa Flint, der optræder i buede, delvis sammenløbende Lag af tynde Knuder, jævnlig afbrudt af større Knolde paa 20-40 cm i Diameter. De nederste $3 \mathrm{~m}$ af Kalken i Profilet er derimod næsten flintfri, idet der kun ses meget faa, smaa Knolde.

Lagstillingen vistnok vandret.

Kalken er meget forsteningsfattig, men maa formodentlig henregnes til Y. Danium.

Abildgaarde I. 47 (S. 11).

$1,5 \mathrm{~km}$ SSV. f. Ø. Hornum Kirke (tæt ved Gaarden). Kote $48 \mathrm{~m}$.

I 1921 var Graven omtrent helt tilskredet og tilgroet; kun et enkelt lille, $3 \mathrm{~m}$ højt Profil var tilgængeligt. Kalken er Coccolitkalk, hvidgraa, ofte med et gulligt Skær, meget finkornet, afsmittende ved Berøring; den er ikke skarp at føle paa, men gør et ret "massivt « Indtryk. I Kalken saas kun et enkelt, tyndt Flintlag, ellers kun spredte Knolde.

Kalkmassen var stærkt knust, men ikke bragt ud af horisontal Stilling.

Faunaen henviser Kalken til Y. Danium.

Ø. Hornum I. 47 (S. 11).

Ved Vejens Østside, tæt S. f. Byen. Kote $50 \mathrm{~m}$.

Graven her er lille, kun ca. $10 \mathrm{~m}$ i Diameter. Profilet var i 1921 stærkt tilskredet, kun delvis rent i 2 m Dybde. Kalken er Bryozokalk, ensartet, mellemhaard, stærkt vandret kløftet og let forvitrende. Bryozoerne dominerer Bjergarten overfor den finkornede Grundmasse, som udfylder alle Mellemrum, saa Kalken kun er lidet porøs. Der fandtes spredt en Del uregelmæssige, urene Flintknolde.

Lagstillingen horisontal.

Faunaen henviser Kalken til ÆE. Danium (Zone B). 
Voxlev. 95 (S. 401 m. m.) ${ }^{1}$ ). 123 (S. 35). 41 (S. 32). 113 (S. 60). \%6 (» Eldre Bryozokalk«). 6 (S. 11). 104 (D. 4. 4, »Voxlev Kalkværk (Hulemølle)«). 47. 109 (S. 37). 110. 105 (S. 9).

Ca. $1 \mathrm{~km}$ VSV. f. Voxlev Kirke. Foden af Skrænten ligger i en Kotehøjde af ca. $10 \mathrm{~m}$.

I det her beliggende Voxlev (Hulemølle) Kalkværk brydes udelukkende Bryozokalk. Af Jessens Beskrivelse af Forholdene hidsættes følgende:

"Kalken brydes i den høje Skrænt paa Vestsiden af Binderup Aas Dal (Fig. 3-4, Side 2); det er typisk Bryozokalk, rig paa Fossiler og med graa, pladeformet Flint i gennemgaaende Lag. I den høje fra SV. til NØ. gaaende Væg i Kalkbruddet (Fig. 1, S. 7) ses Flintlagene at være svagt bølgede og at have en ringe Stigning mod NØ. I den øverste Halvdel af Væggen er Kalken kornet og porøs. I den nederste Halvdel af Væggen er Kalken tættere og indeholder mere løst Kalkslam mellem Bryozofragmenterne.«

Da der i Skrænten kort N. f. Kalkværket forekommer Skrivekridt, foretoges af JESSEN og ØDUM (47) 3 Gravninger (I-III) paa den mellemliggende Strækning af Skrænten, hvilket gav følgende Resultat (sml. T. III) :

Fra Aaens Bund og (i Profil II) til en Højde over denne af ca. $6 \mathrm{~m}$ findes Skrivekridt. Dette er af sædvanlig Type, indeholder temmelig lidt Flint og er fuldkommen ensartet helt igennem. Kun i sin allerøverste Del indeholder det uregelmæssige Striber af graaligt, rimeligvis lerblandet Kridt.

Oven paa dette Skrivekridt findes et Lerlag, hvis Tykkelse veksler fra 2 til $8 \mathrm{~cm}$, og som trods sit store Indhold af kulsur Kalk $\left(73 \% \mathrm{CaCO}_{3}\right)$ har en graa, svagt brunlig Farve. Opad gaar Lerlaget jævnt over i Coccolitkalk. Det ca. $2 \mathrm{~m}$ mægtige Kalklag, der overlejrer Lerlaget, betegnedes under Udgravningen som »det døde Lag« som Følge af sine særlige Egenskaber. Farven er ikke saa ren hvid som Skrivekridtets; dog blev Formodningen om, at det indeholdt mere Ler, kun delvis bekræftet ved Analyserne. Det er skarpere at føle paa end Skrivekridt, men langt mere dødt, naar man slaar paa det med en Hammer. I sin øverste Del indeholder det en Del Bryozofragmenter, men iøvrigt er Dyrelevninger i "det døde Lag« overordentlig sjældne i Forhold til, hvad der findes i under- og overliggende Lag.

Grænsen mellem »det døde Lag« og den herpaa følgende Bryozokalk er lagt ved et Flintlag, men er dog langtfra skarp; den nederste Del af Bryozokalken (L) ér endnu en blød, tæt, bryozofattig Kalksten, og først $30-40 \mathrm{~cm}$ over Flintlaget ses typisk Bryozokalk (Limsten).

1) Naar Forсhнамmer i et Par af sine Arbejder nævner Limstenens Forekomst ved Nibe, sigter han maaske til denne Lokalitet. 
Hældningen angives til $3-4^{0}$ i vestlig Retning.

Ved Indsamlingen deltes »det døde Lag« i flere Horisonter (A-D) og Skrivekridtet ligesaa. Paa Grundlag af det tidligere fremkomne gives i Kap. VI en nøjere Redegørelse for de faunistiske Forhold i Voxlev-Serien.

Skrivekridtet i Gravningerne er senonisk, medens Lagene fra Lerlaget og opefter maa henregnes til Daniet.

Grydsted I. 4\% (S. 11).

Boring ved Skolen. Kote $22 \mathrm{~m}$. Bryozokalk $10 \mathrm{~m} \mathrm{u}$. Overfladen. Æ. Danium?

Bislev. 41 (S. 32). 104 (D. 4. 3).

I de senere Aar har der ikke været aabne Grave her omkring. Ifølge A. Jessen er Bjergarten Bryozokalk. Sandsynligvis Æ. Danium.

Hvanstrup Gaard. 104 (C. 4. 19).

Boring. Kote ca: $12 \mathrm{~m}$. Kalk og Flint« i 8,5 m Dybde.

Farsø I.

Boring paa Mejeriet »Fælleslykke«, 1914.

Ifølge Oplysninger i D. G. U.'s Borearkiv er der her gennemboret $36,5 \mathrm{~m}$ Kvartær og herunder graalighvid, ret blød Coccolitkalk med graa Flint til en Dybde af 42,0 m.

Sikkert Y. Danium.

Lundgaard I. ? 24 (S. 214, "ved Bjørnsholm« $\left.)^{1}\right)$.

$1100 \mathrm{~m}$ VNV. f. Lundgaard. Kote $6 \mathrm{~m}$.

Stor Grav, ca. 5 m dyb; i 1923 var Profilerne omtrent helt tilskredne. Kalken er Bryozokalk, løst sammenhængende, nærmest brokket; Bryozoerne ligger indlejrede i en finkornet Grundmasse, der udgør en ikke ubetydelig Del af den noget afsmittende, bløde Bjergart. Flinten er sortegraa, undertiden gullig; saa vidt det kunde ses, er den ret jæivnt fordelt i Kalken i Form af uregelmæssige Nyrer.

Lagstillingen horisontal.

Faunaen bestemmer Kalken som hørende til A. Danium (Zone B).

Bjørnsholm I. 104 (C. 4. 16).

Boring ved Mejeriet. Kote ea. $4 \mathrm{~m}$. Bryozokalk 7,5 m u. Overfladen. Prøver findes ikke. A. Danium?

1) Om Forchнамmer har kendt og sigter til denne Lokalitet er dog tvivlsomt, da han i 1858 (21, Kortet) ikke lader Daniet strække sig S. f. Bjørnsholm Aa. 
Faldgaarde. 104 (C. 4. 18).

Boring. Kote ca. $15 \mathrm{~m}$. Bryozokalk $34,5 \mathrm{~m} \mathrm{u}$. Overfladen.

Munksjørup I. 123 (S. 35). 104 (C. 4. 14).

$800 \mathrm{~m}$ NNV. f. Blødhøj. Kote $12 \mathrm{~m}$.

Ret stor Grav med 4-5 m høje Vægge; Profilet var i 1923 rent i det meste af Væggens Længde (Fig. 8, S. 81). Kalken er en hvid, afsmittende, blød og smuldrende Bryozokalk, bestaaende af en fin Grundmasse, hvori er indlejret en Mængde Bryozoer og Fragmenter af Bryozoer. Kalken er stærkt sprækket. Flinten er sort med hvid Skorpe. Den optræder i tynde Lag, der ofte er ganske ubrudte paa lange Strækninger. I en noget dybere liggende, mindre Gravning er Flinten gullig og Laget tykkere.

Lagene hælder i den nordlige Del af Profilet lidt mod SØ., stryger ca. NØ.-SV.; ellers er Lagstillingen horisontal.

Forsteningerne henviser Kalken til $\mathbb{E}$. Danium (Zone B).

Barmer I.

$200 \mathrm{~m}$ Ø. f. Nr. Skovgaard. Kote $9 \mathrm{~m}$.

Større Grav, delvis tilskredet i 1923, men med mindre Gravninger med rene Profiler, ialt $3-4 \mathrm{~m}$ dybt.

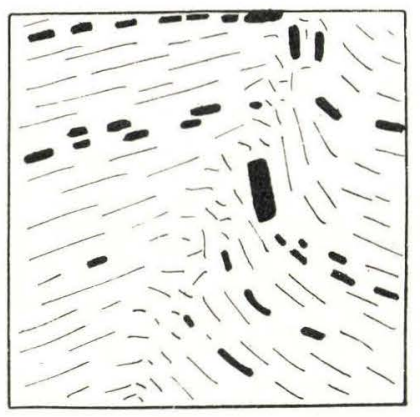

Fig. 7. Barmer I. Skitse af Flexuren i Østvæggen. $3 \times 3 \mathrm{~m}$.

Kalken er fast, men ret let smuldrende, lidet afsmittende Bryozokalk, bestaaende af velbevarede Bryozoer, indlejrede $\mathrm{i}$ en fin Grundmasse, som saaledes udgør en stor Del af Bjergarten. Farven er hvid. Flinten er graasort med et gulligt Anstrøg; den findes i Form af mindre, flade Knolde, sjældnere i større Klumper, og ligger ordnet i Rækker.

Lagene ligger i det store og hele vandret, men i Øst- og Vestvæggene ses en Flexur med skarpt Knæk af Lagene (Fig. 7); dens Retning er ca. Ø. $20^{\circ} \mathrm{S}$.

Forsteningerne henfører Kalken til $A$. Danium (Zone B).

Barmer II.

$300 \mathrm{~m} \mathrm{~N}$. f. Danshøj. Kote $6 \mathrm{~m}$.

Ved Foden af Skrænten er i en Gravning iagttaget Lokalmoræne af Bryozokalk.

Kalken, formodentlig A. Danium, maa sikkert være faststaaende i ringe Dybde.

Valsted I. 76. 47 (S. 11). 104 (C. 4. 8).

$700 \mathrm{~m} \mathrm{~N}$. f. Valsted Gaard. Kote $3 \mathrm{~m}$. 
Lille Grav Ø. f. Vejen langs Skrænten. I en ca. $8 \mathrm{~m}$ lang Væg saas i 1923 et $1 \mathrm{~m}$ højt Profil i Bryozokalk, dækket af 0,5 m Sand.

Kalken er ret fast, ikke særlig sprækket; den spalter ret godt og synes at smuldre nogenlunde hurtigt; den bestaar af en Grundmasse af Coccolitkalk med et større Indhold af Bryozoer. Flinten danner 10-15 em tykke, solide Flager med uregelmæssige Udvækster paa Fladerne; den er hvid, undertiden med graa Pletter indvendig.

Lagene hælder ca. $30^{\circ} \bmod$ Vest.

Faunaen henviser Kalken til A. Danium (Zone B).

St. Ajstrup I. 104 (C. 4. 9).

Boring ved Skolen. Kote $22 \mathrm{~m}$. Bryozokalk 8,5 m u. Overfladen.

Farstrup I.

$400 \mathrm{~m}$ NNØ. f. Kirken. Kote ca. $7 \mathrm{~m}$.

I 1923 fandtes her en Grav, men i de $2 \mathrm{~m}$ høje Vægge, der var stærkt tilskredne, saas kun Diluvialsand. I Graven laa en ret stor Bunke af Kalksmuld og Brokker, gravet op paa Stedet, blandet med Flint og skandinaviske Blokke. Det hele gjorde nærmest Indtryk af at være Lokalmoræne, men i hvert Fald maa der være faststaaende Bryozokalk tæt under Overfladen.

Forsteningerne henviser Kalken til A. Danium (Zone B).

Kjølby I. $\left.76^{1}\right) .104$ (C. 4. 7).

I Kjølby By. Kote $6 \mathrm{~m}$.

Graven er meget stor, men var i 1923 næsten fuldstændig nedlagt og tilgroet; kun et Par enkelte Steder saas smaa, uanselige Profiler indtil et Par $\mathrm{m}$ u. Jordoverfladen.

Kalken er Bryozokalk, hvid, temmelig let smuldrende og stærkt kløftet. Efter Sigende findes der herunder fast sammenhængende Kalk (3-4 m u. Overfladen), der har været benyttet til Bygningssten. Kalken er saa godt som ikke afsmittende og bestaar overvejende af Bryozoer, indlejrede $\mathrm{i}$ en fint kornet Grundmasse. Kalken er næsten absolut fri for Flint; der saas kun nogle faa, løstliggende Knolde af hvid Flint.

Lagstillingen horisontal.

Faunaen henfører Kalken til A. Danium (Zone B).

Kjølby IT.

$800 \mathrm{~m}$ Ø. f. Kjølby. Kote $18 \mathrm{~m}$.

Grav m. 15-20 m lange Vægge. I Profilerne heri ses øverst 0,5 m Muld og Diluvialsand, 1,0 m stærkt brokket, udtværet og omlejret (del-

1) Brünnich Nielsen angiver «Kjølby v. Nibe«; dette refererer formentlig til Kjølby I, muligvis ogsaa til Kjølby II. 
vis vandsorteret) Bryozokalk, iblandet løse Flintesten, og herunder 1,0 m stærkt knust Bryozokalk in situ, stærkt smuldrende. Kalken indeholder ret tæt liggende Rækker af flade, graasorte Flintnyrer, tæt sammensluttede i Rækkerne.

Lagstillingen horisontal.

Faunaen henfører Kalken til A. Danium (Zone B).

Hemdrup I.

Lige N. f. Byen. Kote $5 \mathrm{~m}$.

Tilgroet Grav. I en mindre Gravning saas i 1923 i indtil 1,5 m Dybde u. Overfladen Lokalmoræne (delvis vandsorteret) af Bryozokalk. Kalken maa sikkert være faststaaende i ringe Dybde.

(A. Danium ?).

Brøndum I. \%6. 104 (C. 4. 6).

$200 \mathrm{~m}$ VSV. f. Brøndum Gaard (ved Vejens Nordside). Kote $7 \mathrm{~m}$.

Gammel, omtrent tilgroet, 3-4 m dyb Grav. I 1923 fandtes i Gravens Bund en mindre Gravning med et lille Profil paa $1 \mathrm{~m}$ Højde i Bryozokalk. Kalken er stærkt spaltende Bryozokalk, iøvrigt ret haard, lidet afsmittende. Bryozoerne ligger indlejret i en fin Grundmasse af graalig Farve. Kalken er fattig paa Flint; denne optræder som spredte, hvide Knolde.

Lagstillingen horisontal.

Faunaen henviser Lokaliteten til A. Danium (Zone B).

Vindblæs I.

1,8 km NV. f. Vindblæs St. (paa Nordsiden af Banelinien). Kote $15 \mathrm{~m}$.

I 1923 fandtes her gravet et mindre, godt $1 \mathrm{~m}$ dybt Hul, i hvis Bund der lige skimtedes noget Kalk, hvorimod de øvre Jordlag bestod af Diluvialsand. En opgravet Bunke bestod af Diluvialsand blandet med Lokalmoræne af Bryozokalk, som sikkert er faststaaende i ringe Dybde. Forsteningerne henviser Kalken til E. Danium (Zone B).

Braarup I.

$600 \mathrm{~m}$ NNV. f. Byen. Kote $10 \mathrm{~m}$.

Graven her er lille, men frembød i 1925 et godt Profil i Coccolitkalk; denne er af sædvanlig Art, meget finkornet, graa med et gulligt Anstrøg. Flinten er graa, stærkt svampet, men ellers dannende et Par sammenhængende Lag af $10-20 \mathrm{~cm}$ Tykkelse.

Lagstillingen er horisontal.

Kalken tilhører ifølge Faunaen Y. Danium.

Løgsted I. ? 3 (S. 264, »mellem Malle og Vindblæs«). ? 123 (S. 35, "ved Vandsted(). 
$1,5 \mathrm{~km}$ SØ. f. Løgsted By. Kote $22 \mathrm{~m}$.

Ret stor Grav, ca. $15 \times 20 \mathrm{~m} \mathrm{og} 6-7 \mathrm{~m}$ dyb; denne Grav udgør kun den sydlige Del af en gammel, 3 Gange saa stor, men omtrent helt tilgroet Grav.

Kalken er Bryozokalk, der dels udgør fastere Lag, der kan danne større Blokke, dels mere smuldrende Lag. Kalken bruges baade til Brænding og til Gødning. Bryozoerne er dominerende i den hvide Kalk; gennemgaaende er de stærkt fragmentariske og giver hele Bjergarten en grusagtig Karakter; de er dog næppe stærkt rullede. Flinten er overvejende hvid, sjældnere med graasort Kerne. Den er yderst sparsomt tilstede, dannende korte Rækker eller Samlinger af flade, skøre Knolde med uregelmæssige Udvækster.

I Gravens Vestvæg ses en svag Hældning af Lagene, der nordligst i Profilet sænker sig mod Nord, sydligst mod Syd. I de øvrige Profiler, ogsaa i et Par smaa Profiler i den gamle, større Grav, er Lagstillingen horisontal.

Faunaen henfører Kalken til Æ. Danium (Zone B).

\section{Løgstør I.}

Jernbanegennemskæringen Ø. f. Byen. Kote ca. 7 m.

Skæringen her er for en stor Del ført igennem Kalk. I 1923 fandtes intet rent Profil, men i en Udvidelse af Skæringen tæt S. f. Landevejen fandtes en Del afgravet Kalk i Bunker.

Kalken er Bryozokalk, ret fast, ikke særlig afsmittende; Hovedmassen af Bjergarten dannes af de ret vel bevarede Bryozoer, der bindes sammen af en finkornet Grundmasse.

Lagstillingen ubekendt.

Faunaen henviser Kalken til A. Danium (Zone B).

Løgstør II. 28 (S. 67). ? 6 (S. 11, "Saltholmskalk«).

Løgstør Kanal, tæt inde ved Byen. Kote ca. 0.

Rent Profil findes ikke nu, men tæt ved Gasværket saas i 1924 gamle, opgravede, store Kalkbunker. Kalken heri er en graa Coccolitkalk, og heri fandtes en Del Flint, omtrent sort, undertiden lysere graalig, med tyk, hvid Skorpe.

Kalken er meget forsteningsfattig, men maa formodentlig henregnes til Y. Danium.

Løgstør III. 28 (S. 65). ? 95 (»Bryozokalk - Løgstør«) ? 76 (»ÆEldre Bryozokalk - Løgstør ()$\left.^{1}\right)$.

1) BrünNich Nielsen angiver kun Terebratulina striata »Løgstør«; PosSELT angiver ligeledes denne Art fra "Løgstør", og Grönwall den samme fra L. III, saa det er umuligt at afgøre, til hvilken Lokalitet Br. N. hentyder. 
Bakken S. f. Løgstør. Kote $22 \mathrm{~m}$.

I 1898 var der her et større Profil gennem Daniet tilgængeligt, idet der blev gravet en Brønd til Byens Vandforsyning. Grörwall havde Lejlighed til at foretage en indgaaende Undersøgelse, hvis Resultat han meddeler i den citerede Afhandling.

Brønden var 25,10 m dyb, hvoraf de $22 \mathrm{~m}$ stod i Kalk. Fra Brøndens Bund var der ført en Boring videre ned til en Dybde af 37,66 m under Overfladen; ifølge Boremesterens Mening, som GRönwalL ikke anser for usandsynlig, skulde Grænsen mellem Danium og Skrivekridt være naaet paa en Dybde af $30,75 \mathrm{~m}$.

Profilet i selve Brønden viste en Skiften af Bjergartens Beskaffenhed, idet Bryozoindholdet var stærkt vekslende. Desværre foreligger der ikke Prøver af de under Brønden gennemborede Kalklag.

Lagene i Brønden hældede $4^{0} \bmod \mathrm{NV}$.

Den stratigrafiske Stilling af Kalklagene i Brønden her er uvis, da Forsteningerne ikke giver nogen Oplysning; men efter Bjergarterne at dømme maa hele den i Brønden synlige, vekslende Serie af bryozorig og bryozofattig Coccolitkalk henføres til Y. Danium. I saa Fald kan det dog umuligt tænkes, at Skrivekridtet skulde være naaet i en Dybde af kun 5,65 m under Brøndens Bund. Langt rimeligere er det, at Bjergarten i denne Dybde er gaaet over til en mere ren Coccolitkalk, lignende den ved L. II opgravede. Det maa derfor anses for sandsynligt, at hele den paa dette Sted gennemgravede og gennemborede Lagserie tilhører Y. Danium.

Lendrup Strand. ? 16 (S. 63, „Liimsteenen forekommer ved Liimfjordens Bredder indtil Løgstør «). ? 19 (S. 536, »ved Løgstør — Limsten«). ? 91 (»Limsten - Løgstør«). ? 122 (S. 85, "Limsten - i Omegnen af Løgstør $)^{1}$ ). 122 (S. 98, »Saltholmskalk«). 28 (S. 67). 95 (»Bryozokalk Lendrup Strand«). ? 76 (»Løgstør - Aldre Bryozokalk«) . ? 113 (»Bryozokalk v. Løgstør«). ? 6 ("Saltholmskalk«).

Sydenden af Løgstør Kanal. Kote ca. 0.

GRöNWALL beskriver Stedet saaledes: „Hela Lögstörkanalen är gräfd genom kalksten tilhörande »det nyere kridt«. Huru vida denna är att beteckna som limsten eller »blegekridt« är mig obekant, då der icke fanns någon goda observationspunkter. I strandbrinken utanför (NV. om) kanalen, »Lendrupstrand « fann jag i mängd lösa stycken af båda bärgarterna. Någon olikhet mellan bärgarterne i norra delen af denna strandbrink och i den södra finns troligen; - - I norra delen af stranden är flintan bildad som stora rundade klumpar, hvilka innerst omsluta en kärna af lös kalksten, hvilket gör, att de lätt sönderfalla; Anan-

$\left.{ }^{1}\right)$ Ussing sigter dog hermed muligvis til Løgsted. 
chytesformen här är aflång och stor; i den södra delen är flintan slaggliknande och hård samt Ananchytesformen liten och rundad. Båda Ananchytesformerna är tydligt sneda och öfverensstämma fullständigt med exemplar från andra förekomster i den yngre kritan. Ehuru på grund af de observationer, man nu kan göra $V$. om Lögstör, någon visshet icke kann åstadkommas, anser jag dock det vara troligt, att äfven här limsten och »blegekridt« förekomma i nära samband med hvarandra och troligen vexellagra«.

Ved Forf.'s Besøg paa Stedet i 1924 fandtes ved Kanalens sydlige Udløb, paa det af GröNwall omtalte Sted, større Mængder af det opgravede Materiale tilgængeligt. Dette bestod ganske overvejende af hvid Bryozokalk, og kun enkelte Stykker af en graalighvid, fin, ret blød og noget bryozoholdig Coccolitkalk fandtes. Profiler i faststaaende Bjergart forekom ikke.

Faunaen er ret righoldig, og efter denne maa Kalken henregnes til Y. Danium (Zone C).

Aggersborg Gaard. 28 (S. 71). 95 (S. 406, 413, 423, »Bryozokalki). ? 41 (S. 32, 》Agersund《). 76 ("Aldre Bryozokalk«). 97 ("Bryozokalk«). 80 (»Yngre Danien«). 81 (»Yngre Danien«). 85.87 (S. 24). 44 (S. 17, "Aggersund (). 88 (S. 16, »Koralkalk«). 90 (S. 210 og 212, )Younger Danian Coral Chalk «) $)^{1}$. 104 (C. 4. 1, »Limsten«).

$800 \mathrm{~m}$ V. f. Aggersborg Gaard. Kote $1 \mathrm{~m}$.

GRönwaLL skriver: "Ca. $800 \mathrm{~m}$ V. om Aggersborg Gård ligger nära Limfjorden utanför 5-fots-kurvan en liten kalkgraf, som vid mitt besök var fylld med vatten, så att mina insamlingar gjordes i det uppgräfda materialet. Bärgarterna voro dels en limsten, som mera liknade den, som fanns i brunnen vid Lögstör, an den i kalkbrotten vid Aggersborg, d. v. s. mellanrummen mellan bryozofragmenterne utfyllas mer eller mindre fullständigt af fina jordartade kalkpartiklar liknande »blegekridtet«, dels en helt hvit kalksten, lös og jordartad, som påminte både om »blegekridt« och skrifkrita. Desutom funnos hårdare kalkstensstycken, nästen uteslutande bildade af koraller: Moltkia Isis Steenstr., m. m.《

Ved Forf.'s Besøg var Lokaliteten ogsaa ret daarlig, idet Bryozokalken og dens Flintlag kun paa en kort Strækning var synlige i faststaaende Stilling, ca. 0,5 m i Mægtighed. Lagstillingen er, saa vidt det kan ses, omtrent horisontal.

GRönWALL er nærmest tilbøjelig til at henføre Bjergarten til »Faxelaget« (Cerithiumkalken), selv om han ikke finder nærmere Overensstemmelse i Bjergarterne, men heri har han næppe Ret. Fossilindholdet peger tydeligt i Retning af Y. Danium, og RAvN har utvivlsomt Ret, naar han

1) S. 210 »Aggersborggaard«, S. 212 »Aggersborg.» 
sammenligner denne Bryozokalks Fauna med Faunaen ved Faxe. Derimod gaar BRÜNNICH Nielsen sikkert for vidt, naar han (1922) hævder, at Kalken fra Aggersborg Gaard, "which contains a fauna with countless typical Faxe fossils $«$ er en Koralkalk, dannet paa samme Maade som Koralkalken ved Faxe.

Det synes mig rimeligst at antage, at den koralrige Bryozokalk ved Aggersborg Gaard er en lokal Udvikling af det Y. Daniums Coccolitkalk; dette støttes af RAvN's Iagttagelse af "Saltholmskalk« i en nærliggende Grav. Ogsaa fra andre yngre daniske Lokaliteter (f. Eks. Helligkilde I) kendes det, at der i den ellers bryozofattige Coccolitkalk kan træffes en meget bryozorig Zone, og denne tiltagende Bryozorigdom følges oftest af et stigende Indhold af Octocoraller (hvilke ogsaa ved Aggersborg Gaard er langt hyppigere end Hexacorallerne); de to Dyregrupper stiller aabenbart omtrent de samme økologiske Krav til Milieuet.

Kalken tilhører altsaa Y. Danium (Zone C).

Aggersborg I. 16 (Kortet) $^{1}$ ). 24 (S. 213, »Aggersborg《). 28 (S. 68). 122 (S. 85, "Agersborg«). 95 (»Aggersborg«). 123 (S. 35). ? 41 (S. 32, »Aggersund(). 76 ("Aggersund«). 44 (S. 17, "Aggersund«). 104 (C. 3. 16).

$400 \mathrm{~m}$ NØ. f. Kirken. Kote $12 \mathrm{~m}$.

Stor Grav, over $20 \mathrm{~m}$ lang; Syd-og Østvæggene er ca. $8 \mathrm{~m}$ høje, lodrette, og frembød i 1923 gode Profiler.

Kalken er Bryozokalk, for det meste fast sammenhængende, hugges ud i solide Klumper til Brænding. I den allernederste Del af Bruddet bliver Kalken endnu mere fast og overordentlig solid. I den øvre Halvdel af Profilet er Kalken derimod mindre kompakt, den smuldrer og spalter lettere, og der indskyder sig lettere forvitrende Lag og Flintlag. Kalken bestaar af (delvis meget fragmentariske) Bryozoer, indlejrede i en Grundmasse, der dog domineres af Bryozoerne; paa sine Steder er Mellemrummene ikke udfyldt, saa Kalken er ret porøs. Flinten er yderst sparsomt tilstede, kun som Lag i de øvre Partier af Kalken, mens den er næsten absolut fraværende $\mathrm{i}$ de andre Kalklag. Flinten er hvid, ofte med graa Kérne.

Lagstillingen er paa det nærmeste horisontal; GRÖNWALL angiver, at "Bärgarten stupar oregelbundet mot N. och NO.»

Faunaen henviser med Sikkerhed Kalken til AE. Danium (Zone B).

Aggersborg II. (angaaende Litteratur se under Aggersborg I).

Ca. $700 \mathrm{~m} \mathrm{N \varnothing .f.} \mathrm{Kirken.} \mathrm{Kote} \mathrm{ca.} 11 \mathrm{~m}$.

Graven, som er ret stor og ca. $7 \mathrm{~m}$ dyb, var i 1923 fuldstændig tilskredet.

1) Forchhammer sigter her, saavel som ved en senere Angivelse af Limsten ved Aggersborg (24 S. 213), sandsynligvis ogsaa til A. II og III, ifald disse Grave har eksisteret paa hans Tid (det gælder maaske ogsaa senere Forf.). 


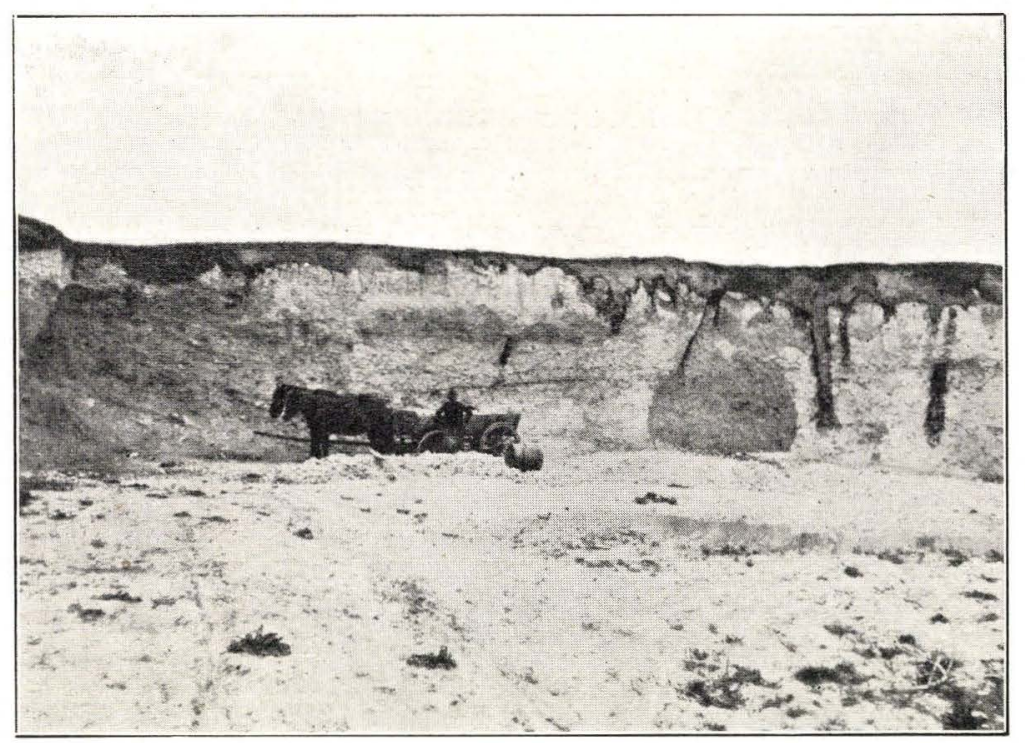

Fig. 8. Munksjørup I. Set mod Ø.

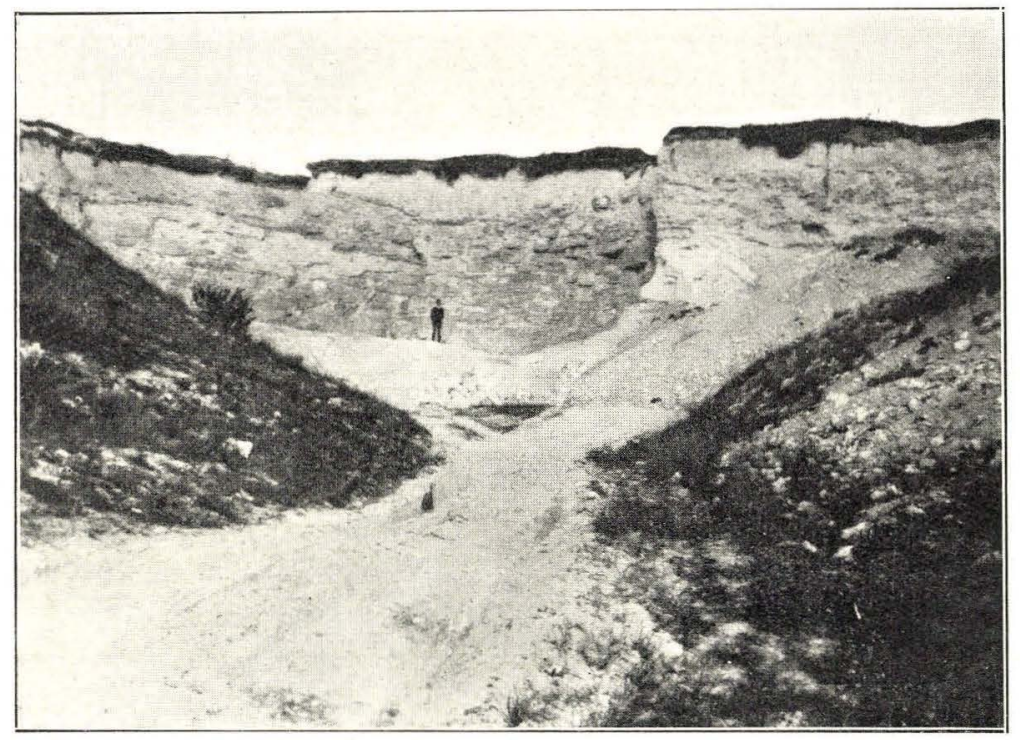

Fig. 9. Klim Bjerg. Set mod Ø. 
Det kunde ses, at Kalken er en Bryozokalk af samme Art som i Aggersborg I.

Faunaen henviser Lokaliteten til A. Danium (Zone B).

Aggersborg III. (angaaende Litteratur se under Aggersborg I).

$800 \mathrm{~m}$ NNØ. f. Kirken. Kote ca. $12 \mathrm{~m}$.

Nogenlunde stor, ca. $10 \mathrm{~m}$ dyb Grav. I 1923 var Brydningen opgivet og Profilerne delvis tilskredne.

Kalken er som i Aggersborg I Bryozokalk, løsere foroven, men i de andre Partier fast og kompakt; den har været savet ud til Bygningssten. Flint er kun sparsomt tilstede.

Lagstillingen horisontal.

Faunaen henviser ogsaa denne Lokalitet til $\mathbb{A}$. Danium (Zone B).

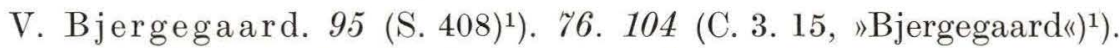

Umiddelbart N. f. V. Bjergegaard. Kote $3 \mathrm{~m}$.

Graven er nu tilgroet, men, som de opbevarede Prøver og Forsteninger viser, forekommer her Bryozokalk, som maa henføres til A. Danium.

N. Bjergegaard. 3 (S. 262)르. 95 (S. 408 ). 104 (C. 3.15 ).

Umiddelbart $\varnothing$. f. Gaarden i den gamle Klint. Kote $8 \mathrm{~m}$.

Der findes her en lille Gravning i Skrænten. Profilet var i 1923 urent og delvis tilskredet, $4 \mathrm{~m}$ højt.

Der ses en hvid Bryozokalk, ret fast, noget smuldrende i den øverste Del af Profilet. Bjergarten udgøres overvejende af de tætpakkede Bryozoer, mens den sammenbindende Grundmasse udfylder alle Mellemrum. Flint ses ikke i Profilet, men der fandtes opgravet en lille Bunke hvid Flint i nyreformede Knolde.

Faunaen henviser Kalken.til A. Danium (Zone B).

Gøttrup Strand. 68 (S. 24).

Milthers oplyser, at der ved Gøttrup Strand muligvis forekommer Bryozokalk (»Limsten«?), med et Indhold af 89,0\% $\mathrm{CaCO}_{3}$. Nærmere Bekræftelse herpaa foreligger ikke, lige saa lidt som det i 1923 var muligt at faa Oplysning om Kalkgravning ved Gøttrup Strand.

Det maa betragtes som tvivlsomt, om der paa dette Sted findes Danium.

Klim Bjerg. 3 (S. 269, »i Klim«). 19 (S. 536) ${ }^{3}$ ). 23 (S. 9, »Kliim«). ? 24 (S. 213). 91. 95. 123 (S. 21 og 35, "Klim«). 41 (S. 32). ? "76 ("Klim«). 68 (T. I). 5 (S. 190). 45 (S. 38). 104 (C. 3. 3).

1) Hermed sigter Ravn saavel til denne som til den følgende Lokalitet.

$\left.{ }^{2}\right)$ BredsdorfF nævner her Forekomsten af "kridtagtig Kalksteen«i en Holm S. f. Gjøttrup, med hvilken han utvivlsomt mener denne Lokalitet.

$\left.{ }^{3}\right)$ Forchunmer omtaler her, at Limstenen i Klim Sogn »danner en Mængde enkelte Partier, der hæve sig frem af Flyvesandet.« Hermed sigter han sikkert til Klim Bjerg. 
$2,5 \mathrm{~km} \mathrm{~N}$. f. Klim Station. Kote $25 \mathrm{~m}$.

Her ligger en Række store, tildels sammenhængende Grave med høje Profiler (Fig. 9). Kalken er ensartet i dem alle, en hvid Bryozokalk, ofte løsere sammenhængende i de øvre Partier, nedadtil fast og kompakt i store Blokke. Den haarde, ikke afsmittende Kalk bestaar af en graagullig — hvid, meget fin Grundmasse, gennemvævet med Bryozoer; den er i Almindelighed godt spaltende. Kalken er meget brugt til Bygningssten og Brænding. Der er meget lidt Flint. Kun i den vestligste af Gravene ses et indtil $20 \mathrm{~cm}$ tykt, sammenhængende Lag af noget porøs, graasort Flint med mange Hulrum og forsynet med tyk, hvid Skorpe.

Lagstillingen er meget svagt bølgende, snart mod N., snart mod S.; snart - og i det store og hele altid - horisontal.

Faunaen henviser Lokaliteten til A. Danium (Zone B).

Klim I. ? $\left.76^{1}\right) .68$ (T. I). 104 (C. 3. 5).

$1 \mathrm{~km}$ VNV. f. Klim St. Kote $10 \mathrm{~m}$.

Temmelig stor, ialt ca. $6 \mathrm{~m}$ dyb Grav, men Profilerne var i 1923 ikke særlig rene. Kalken er en hvid Bryozokalk; i de øvre Partier er den mere løst sammenhængende, øverst stærkt knust, medens den i de dybere Dele er solid og sammenhængende og uden mange Sprækker. Den brydes ud i større Flager til Kalkbrænding. Bryozoerne, som danner Hovedmassen af den kun lidet afsmittende Kalk, holdes sammen af en fin, hvid Grundmasse. En mikroskopisk Undersøgelse viser, at Grundmassen af Kalken er ganske identisk med en stor Del af Daniets bryozofri Coccolitkalk. Kalken er meget ren for Flint; der ses kun et enkelt større Flintlag strækkende sig igennem Kalken.

Lagstillingen horisontal.

Kalken tilhører efter Fossilindholdet A. Danium (Zone B).

Torup Kløv. $\mathrm{I}^{2}$ ). 3 (S. 262, "ved Torup — en blød, kridtagtig Kalksteen, liig den i Stevns Klint med mange Brudstykker af Koraller $\ll) .123$ (S. 35, »Torup«). 68 (T. I). 45 (S. 38, « Kløv«). 104 (C. 3. 2, „Kløv《).

$2 \mathrm{~km} \mathrm{~N}$. f. Torup Station. Kote $15 \mathrm{~m}$.

Her findes paa en Strækning af $300 \mathrm{~m}$ en Række Kalkstensbrud i en gammel Klint. I 1923 var den nordligste, næsten 7 m dybe Grav om-

1) Saavel af BrüNNICH NiELSEN som i den ældre Litteratur anvendes Navnet "Klim«, hvor man ofte maa formode, at det drejer sig om Klim Bjerg; det gælder muligvis ogsaa i dette Tilfælde.

2) Stedet ligger i Nærheden af Stationsbyen Torup, hvorfor dette Navn er brugt et Par Gange i den ældre Litteratur (dog ikke den palæontologiske); Jessen og Ravn bruger Navnet Kløv. For at undgaa Forveksling med Torup ved Thisted og alligevel ikke ignorere dette ældre Navn — "Kløv« (= Klint) er heller ikke særlig karakteristisk og kan tilmed forveksles med Kløv ved Hunstrup — har jeg foretrukket Navnet „Torup Kløv«. 
trent helt tilskredet, saa intet Profil i fast Kalk var synligt. De 3 sydligere Brud havde derimod rene, stejle Vægge paa 8-10 m Højde.

Kalken er en ret fast, men regelmæssigt kløvende Bryozokalk, der saves ud til Bygningssten. Væggene er med flere dm Mellemrum gennemsat af vandrette Sprækker. Kalken bestaar af velbevarede Bryozoer, indlejret i en rigelig, fin Grundmasse af en hvid - gullighvid Farve. Stenen er ofte noget porøs, da Kalkpulveret ikke udfylder alle Mellemrum. Kalken er omtrent fri for Flint. Kun et Par Steder ses nogle uregelmæssige, flade Flintnyrer, dels spredt uden Orden, dels ordnet med nogen indbyrdes Afstand i en kort Række. Flinten er enten gulliggraa eller hvid, eventuelt med sortegraa Kerne.

Lagene hælder tilsyneladende svagt mod Syd. Den øverste Del af Kalken, der adskiller sig ved at være løsere sammenhængende end den nedre, tiltager svagt i Mægtighed, naar man gaar fra de nordligere Brud til de sydligere.

Forsteningerne henviser Kalken til \&. Danium (Zone B).

\section{Torup Kløv II.}

$1400 \mathrm{~m} \mathrm{~N}$. f. Torup Station. Kote $13 \mathrm{~m}$.

Vejgennemskæring øverst i den gamle Klint.

I Siderne af Vejen ses fremstikkende Lokalmoræne af Bryozokalk. Kalken ligner den i Torup Kløv I.

A. Danium (?).

Torup Strand $\mathrm{I}^{1}$ ). 16 (S. 81, »Torupstrand«). 23 (S. 9, "Thaarupstrand«). 68 (T. I). 45 (S. 38, »Stenbjerg«). 104 (C. 3. 1, »Stenbjerg«).

$3 \mathrm{~km} \mathrm{N.} \mathrm{f.} \mathrm{Torup} \mathrm{Station.} \mathrm{Kote} 15 \mathrm{~m}$.

Ret stor og ret dyb, gammel Grav. I 1923 var Væggene omtrent helt tilskredne, saa man kun paa et enkelt Sted saa den faststaaende Kalk i en Mægtighed af. 3 m, dækket af Lokalmoræene. De lavere Dele af Graven var fulde af nedskredne Kalkblokke af samme Type som den, der saas i Profilet. Det er en hvid Bryozokalk, spaltende ud i ret faste Flager, eller ogsaa stærkt smuldrende under Forvitringen. Bryozoerne, som oftest er temmelig fragmentariske, danner Hovedmassen af Bjergarten. Flinten er overvejende hvid, delvis med graa - mørkegraa, undertiden gullig Kerne. Den har Form af tynde Flager og Nyrer (under $10 \mathrm{~cm}$ ). I Profilet ses saa godt som ingen Flint, og i de løse Bunker er den heller ikke tilstede i nogen stor Mængde.

Lagstillingen er, saa vidt det kunde ses, horisontal.

Forsteningerne henfører Kalken til A. Danium (Zone B).

1) Navnet Torup Strand foretrækkes her fremfor "Stenbjerg», for at undgaa Forveksling med Kirkebyen Stenbjerg. 
Valbjerg Huse I. 76 (»Valbjerg Sande«). 104 (B. 3. 2).

I Strandklinten NØ.f. Valbjerg Huse. Kote $17 \mathrm{~m}$.

Gammelt Brud. Profilet er $4 \mathrm{~m}$ højt og omtrent $5 \mathrm{~m}$ langt. Kalken er Bryozokalk som i Bulbjerg. Den er forholdsvis let smuldrende, hvid, lidet afsmittende; kun i Basis af Profilet findes en 0,4 m tyk Bænk, der er saa ren og saa fast, at den har kunnet saves ud til Sten; $1 \mathrm{~m}$ højere findes ligeledes et Par mere faste, men tynde Lag. Bryozoerne ligger tæt indlejret i Grundmassen; pletvis er Kalken dog lidt porøs, idet Mellemrummene mellem Bryozoerne ikke er udfyldt af Kalkslammet. Flinten danner sortegraa Nyrer med tyk, hvid Skorpe, ordnet i omtrent ubrudte Rækker; desuden findes Knolde af hvid Flint i usammenhængende, tættere liggende Rækker. Flintens Mængde er underordnet i Forhold til Kalkens.

Lagstillingen horisontal.

Efter Faunaen hører Lokaliteten til A. Danium (Zone B).

Bulbjerg. 3 (S. 262). 16 (S. 81). 1 (S. 8). 21 (S. 37). 24 (S. 213). 48 (S. 6). 50 (S. 53). 91.122 (S. 86). 95.113 (S. 60). 76. 68 (T. I). $65 b$ (S. 51 ). 5 (S. 190). 88 (S. 14). 45 (S. 38). 90.104 (B. 3. 1).

Den ca. $40 \mathrm{~m}$ høje Klint er saa velkendt, at en nærmere Beskrivelse er overflødig. I geologisk Henseende ligner Kalken ganske Bryozokalken i Stevns Klint. Selve Kalken varierer en hel Del; Grundmassen kan være af forskellig Finhed, og Bryozoindholdet kan svinge baade i Mængde og i Bryozofragmenternes Størrelse.

Flintlagene, som ofte er meget massive, ligger stedvis ret tæt, stedvis langt fjernet fra hinanden, saa Kalken danner tykke, flintfri Lag. Flintlagene ligger, ganske som paa Stevns, i store Buer, dannende Systemer af diskordant sammenstødende Banker, saa Kalklagene veksler i Tykkelse og kiler sig ud. Flinten er lysere eller mørkere graa — brunlig.

Forsteningsindholdet henviser Kalken til Æ. Danium (Zone B).

Sandnæshage. 45 (S. 41).

Ved Lildstrand. Ved Boringer (med Henblik paa Havneanlæg) fandtes faststaaende Bryozokalk i en Dybde af $4 \mathrm{~m}$ u. Havets Overfl. Sikkert 玉. Danium.

Bragerne. 45 (S. 41).

Grund i Skagerrak, 2,8 km NV. f. Sandnæshage, $5,6 \mathrm{~km} \mathrm{V.} \mathrm{t.} \mathrm{N.} \mathrm{f.}$ Bulbjerg. Kote $\div 3 \mathrm{~m}$.

Paa Mineral. Museum findes opbevaret en Prøve (1894. 227), øjensynlig løsbrudt fra Grunden. Den bestaar af meget kalkholdig, hvid Flint eller maaske rettere kiselimprægneret Kalk; denne er en finkornet, 
graa Coccolitkalk, som indeholder spredt forekommende Bryozoer, men ingen andre Forsteninger ses.

(A. Danium?).

Hansted I. ? 16 (S. 81). ? 24 (S. 212)1 ). ? 123 (Kortet)2). 113 (S. 60, "Roshage $\ll)$.

$400 \mathrm{~m}$ S. f. Roshage. Kote $18 \mathrm{~m}$.

Hvor Vejen gaar ned over den gamle Klint, findes der en lille, aabenbart ældre Grav i Bryozokalk; Graven er delt i 2 »Etager«, en øvre og en nedre.

I den øvre Del af Graven ses øverst $1 \mathrm{~m}$ Flyvesand og Lokalmoræne og herunder $1,5 \mathrm{~m}$ brokket Bryozokalk, faststaaende, men grundig knust. Kalken er hvid, ikke ret afsmittende, og Bryozoindholdet i den finkornede Grundmasse er forholdsvis ringe, men dog stort nok til at karakterisere Bjergarten som Bryozokalk. Herunder kommer en Zone paa $0,5 \mathrm{~m}$ af mere leret Kalk; hvor Regnen har vasket den noget ud, faar Slammet en graagrøn Farve. Hovedbestanddelen er den graalige, finkornede, lidt grynede, svagt afsmittende Grundmasse, men Bryozoindholdet heri er meget ringe, saa Bjergarten ikke kan kaldes Bryozokalk, men snarere Coccolitkalk. Et Lag hvid Flint gaar igennem dette lerede Lag.

Den nedre Gravs Overkant ligger omtrent i Højde med Bunden af den øvre, og den er ca. $2 \mathrm{~m}$ dyb; den er tilskredet og Bryozokalken stærkt forvitret, saa denne Del af Graven væsentlig er opfyldt med flade Knolde og Stumper af hvid og graa Flint. Kalken ligner Bryozokalken i den øvre Grav, men Bryozoindholdet synes at være lidt ringere. Analysen viser følgende Kalkindhold:

Bryozokalken over den lerede Zone ... 93,8\%

Den lerede Zone............... 87,0\%

Lagstillingen horisontal.

Efter Faunaen maa Lokaliteten henregnes til Y. Danium (Zone C).

Hansted II.

$1400 \mathrm{~m}$ NØ. f. Kirken (ca. $400 \mathrm{~m} \mathrm{S.} \mathrm{f.} \mathrm{Hansted} \mathrm{I).} \mathrm{Kote} \mathrm{ca.} 35 \mathrm{~m}$.

I 1922 blev her gravet en Brønd, ifølge Oplysning paa Stedet af 60 Alens Dybde. Det meste af den opgravede Kalk var kørt bort som Vejmateriale, men en meget stor Bunke Flintknolde samt meget Kalk laa tilbage paa Stedet den næste Sommer. Alt det tilgængelige Materiale bestod af Bryozokalk, hvid, afsmittende, ret blød; Bryozoerne ud-

1) Se Fodnote under Bjerge II S. 91.

2) Ussing angiver paa Kortet "Brud i haard Kalksten til Brænding" omtrent paa dette Sted, men Teksten yder ingen Oplysning desangaaende. 
gør gennemgaaende kun en mindre Del af Bjergarten i Forhold til den finkornede Grundmasse, men er dog tilstrækkelige til at præge Bjergarten som Bryozokalk. Flinten var graa af Farve og fandtes i store Knolde.

Terrænhøjden er ca. $35 \mathrm{~m}$, men skønt Brønden altsaa var ført ca. $38 \mathrm{~m}$ ned, fandtes der ikke i det opgravede noget Tegn til, at man var naaet ned i andre Bjergarter.

Efter Faunaen maa Lokaliteten - ligesom Hansted I - henregnes til Y. Danium (Zone C).

Hansted III. 68 (T. I). 104 (B. 3. 3, "Baadsgaard«).

$600 \mathrm{~m}$ SSØ. f. Kirken.

I ca. $20 \mathrm{~m}$ Højde findes her langs Vejen ned over den gamle Klint et meget urent, tilskredet Profil i Kalken, idet denne er delvis blottet paa en Strækning af $8-10 \mathrm{~m}$ i Højden.

Kalken er en ret blød Coccolitkalk, død at slaa paa, og ikke villig til at spalte. Hist og her indeholder den nogle Bryozoer, men Bryozoindholdet varierer ikke kontinuerligt. Grundmassen er meget finkornet, ensartet. Analysen viser et Indhold af $94,0 \% \mathrm{CaCO}_{3}$. Flinten er hvid og fast, undertiden med graa Kerne. Den danner flade Nyrer eller tykkere, gennemgaaende, haarde Bænke, meget tætliggende, saa Flinten dominerer i Profilet.

Lagstillingen horisontal.

Y. Danium (Zone C?).

Hansted IV. 45 (S. 45, "Helshage«). 52. 53.

Ved Undersøgelser i Anledning af Havneanlæg har det vist sig, at Havbunden udfor Helnæshage bestaar af en lignende Kalksten som ved H. III. Et Par Prøver, der af Hr. mag. scient. P. Kramp er overladt til Danmarks geologiske Undersøgelse, viser sig at være af haard, klingende Coccolitkalk, finkornet, uden Bryozoer. Den gaar i hvert Fald ud til en Dybde af $\div 10 \mathrm{~m}$.

Lagstillingen er paa det nærmeste horisontal.

Sikkert Y. Danium.

Rær I. 95. 76.68 (T. I). 104 (B. 3. 5).

$850 \mathrm{~m}$ V.t. N. f. Kirken. Kote ca. $35 \mathrm{~m}$.

Gammel Kalkgrav beliggende i den øverste Del af den gamle Klint. Graven er absolut tilgroet. RAvN angiver Bjergarten som Blegekridt; mens BRÜNNICH NiELSEN paa S. 139 opfører "Rær« under Gruppen »Coccolitkalk. Yngre Bryozokalk», henfører han den derimod S. 160 til »Aldre Bryozokalk«. Hr. Museumsinspektør J. P. J. Ravn har venligst meddelt mig følgende Notater fra sit Besøg paa Stedet i 1899: ». . . findes 
helt oppe i Klintens Overkant et Brud i Blegekridt paa ca. 6 Alen grov Kalksten med ikke saa lidt brun Flint i Bænke . . . Lagdelingen bølgeformig, dog maaske gennemgaaende med lidt Hældning i Nord, lidt til Øst. Klintens Overkant ligger her i en Højde af ca. $110^{\prime}$.«

En Prøve af Bjergarten, indsamlet af RAvN 1899 bestaar i overvejende Grad af en hvid, meget finkornet, blød og afsmittendeGrundmasse, hvori er indlejret et ikke ringe Antal Bryozoer. Bryozoindholdet er dog næppe stort nok til at kunne karakterisere Kalken som Bryozokalk.

Lagstillingen maaske hældende $\bmod \mathrm{N}$. lidt til $\varnothing$.

Forsteningsmaterialet er for Tiden desværre for ringe til at afgøre Lokalitetens Stilling.

Rær II.

Hulvejen $400 \mathrm{~m}$ V.f. Trælshøje.

Hvor denne Hulvej fører op gennem den gamle Klint, ses i en Højde af ca. $22 \mathrm{~m}$ et enkelt Sted fremstikkende Bryozokalk, men uden at der er blottet noget egentligt Profil.

Formodentlig A. Danium.

Rær III.

Jordemoderboligen tæt S. f. Rær Mølle. Kote ca. 22 m.

I 1899 gravedes her en Brønd. J. P. J. RAvN har ved denne Lejlighed indsamlet et Par Prøver, som opbevares paa Mineral. Museum og som viser, at Brønden gaar gennem Daniet ned i Skrivekridt.

Skrivekridtet er typisk, hvidt Kridt. Forsteninger er ikke fundet deri.

Daniumkalken er omtrent af samme Type som Kalken fra Rær I, idet den bestaar af en fin, hvid, afsmittende Coccolitkalk med et Indhold af Bryozoer, men saa ringe, at Kalken maa kaldes Coccolitkalk. Prøver af eventuelle andre Lag eller Angivelse af Dybder fandtes ikke.

Febbersted I.

I den østlige Udkant af Febbersted By, godt $100 \mathrm{~m} \mathrm{N.} \mathrm{f.} \mathrm{Vejen.}$ Kote ca. $30 \mathrm{~m}$.

Graven, som er ca. 2 m dyb, var i 1923 meget tilskredet, saa Profilet var ikke særlig rent; $1 \mathrm{~m}$ under Overfladen saas et Par ret sammenhængende Lag af graa Flint, og herimellem en hvidgraa Kalksten. Bjergarten er Coccolitkalk med en finkornet, let hærdnet, lidet afsmittende Grundmasse, hvori indgaar en mindre Mængde Bryozoer og Foraminiferer; Kalken kan dog ikke kaldes Bryozokalk. Ofte er Bryozoerne koncentreret paa mindre Pletter i Kalken. Over det øverste Flintlag saas kun Lokalmoræne, og den nedre Del af Væggen var dækket af Skred. Der fandtes megen løs, hvid Flint. 
Lagstillingen horisontal.

De foreliggende Forsteninger er ikke tilstrækkelige til at afgøre Lokalitetens stratigrafiske Stilling.

Vigsø I. 16 (S. 65 og 83, »Vixøe«, »Vixiø»). 91 (»Vixø»). 95. \%6. 80 (»Viksø»). 90 (»Vixø«).

$250 \mathrm{~m}$ NØ. f. Kirken. Kote ca. $14 \mathrm{~m}$.

Lille Grav; i 1923 var den omtrent tilskredet, og kun en mindre Gravning viste et friskt Profil.

$$
\begin{aligned}
& \text { 0,3 m Flyvesand. } \\
& 0,8 \text { - Lokalmoræne. } \\
& 0,5 \text { - Bryozokalk. }
\end{aligned}
$$

Kalken er ikke særlig blød, godt spaltende, brækkende i mindre Stykker paa tværs af Lagdelingen, Grundmassen af Bjergarten er den sædvanlige, med et ret stort Indhold af Bryozoer. Flinten er hvid og graa med hvid Skorpe.

Lagstillingen kunde ikke iagttages.

Forsteningerne henviser Kalken til A. Danium (Zone B).

Vigsø II.

$800 \mathrm{~m}$ ØSØ. f. Kirken.

Ca. $15 \mathrm{~m}$ over Havet er Kalkgrunden blottet i den gamle Klint ved Gravning paa en Strækning af $6 \mathrm{~m}$ Længde og $2 \mathrm{~m}$ Højde. Profilet var her i 1923 friskt og viste en fast sammenhængende Bryozokalk, kløftet ud i ret store Blokke, spaltende nogenlunde godt for Slag; Kalken er ellers ikke særlig hærdnet og er noget afsmittende. Bjergarten domineres af den hvide, fine Grundmasse, idet Bryozoindholdet ikke er overvældende stort. Flinten er overvejende hvid med Pletter af sortegraa Farve. Den danner flade Knolde af flere dm Tykkelse, sammenhængende i Lag, der i Reglen skilles fra hinanden af noget tykkere, flintfri Kalkbænke.

Lagstillingen horisontal.

Lokalitetens stratigrafiske Stilling er ikke afgjort.

Bjerge $\mathbf{I}^{1}$ ). 68 (T. 1$)$.

$400 \mathrm{~m}$ SØ. f. Tovsgaard. Kote $12 \mathrm{~m}$.

Lille Grav ved Foden af den gamle Klint. Profil kun 1,5 m højt, i 1923 delvis tilskredet. Kalken er en hvid Bryozokalk, ikke særlig blød, men godt spaltende for Slag og smuldrende ved Forvitring. Hovedmassen af Kalken udgøres af en fin, lidt afsmittende Grundmasse, hvori de ikke særlig fremtrædende Bryozoer ligger indlejret; dog mærkes de straks ved Berøring. Flinten er hrid og graa, i Form af flade Knolde.

1) Se Fodnote under Bjerge II. 
Lagstillingen tilsyneladende vandret.

Faunaen henviser Lokaliteten til A. Danium (Zone B).

Bjerge II. ? 16 (S. 81). ? 24 (S. 212)1). 68 (T. I).

$100 \mathrm{~m} \mathrm{SV}$. f. Bjerge I. Kote $22 \mathrm{~m}$.

Graven, som ligger højere oppe i den gamle Klint, var i 1923 helt tilgroet. Bjergarten er Bryozokalk.

Faunaen henfører Kalken til A. Danium (Zone B).

En Echinocorys sulcatus, opbevaret paa Mineral. Museum, og etiketteret »Klinten Ø. f. Bjerge«, synes at være hjemmehørende i Coccolitkalk. Det er saaledes muligt, at ogsaa Coccolitkalk forekommer i dette Omraade af Hanstholmene.

Bjerge III. 95 (S. 415 flg.). 68 (T. I). 104 (B. 3. 7).

I Bjerge By.

Foruden de her anforte Bjerge I og II anfører RAvn 1902-03 en Lokalitet "Bjerge" med »Blegekridt", efter Kortet (i I Del, Lamellibranchiater) beliggende umiddelbart ved Bjerge By. RAvN angiver imidlertid ingen Fossiler herfra, og ved Forf.'s Besøg paa Stedet fandtes kun Grave i Skrivekridt. Ravn's Lokalitet 1922 er vel den samme, som anføres i 1902—03, og paa dette Sted angiver ogsaa Mrtmers 1914 en Daniumforekomst paa sit Kort.

Kaase I. 76 ("Blegekridt«). 80 ("Korsø i Thy — Yngre Danien«). 68 (T. I). 104 (B. 3. 11, »Limsten«).

$250 \mathrm{~m}$ S. f. Brunbakke. Kote $18 \mathrm{~m}$.

Graven er ret stor, beliggende i den gamle Klint, men er nu tilgroet.

Prøver paa Mineral. Museum viser en Bjergart bestaaende af en hvid, finkornet Grundmasse af Coccolitkalk, hvori er indlejret en hel Del velbevarede Bryozoer; Kalken har dog næppe Karakter af Bryozokalk.

(Y. Danium?).

Kaase II.

$450 \mathrm{~m} \mathrm{S.} \mathrm{f.} \mathrm{Brunbakke.} \mathrm{Kote} \mathrm{ca.} 7 \mathrm{~m}$.

En lille, frisk Gravning paa NØ.-Siden af Vejen, lidt under Halvdelen af Klintens Højde. Profilet er rent, ca. 2 m langt og 1 m højt. Kalken er en hvid Coccolitkalk, fast sammenhængende i store Blokke, hærdnet, kun lidet afsmittende. Hovedmassen af Bjergarten udgøres af en

1) I de nævnte Afhandlinger omtaler Forchinammer Forekomsten af Limsten paa Hanstholm og Hjardemaal (Østholmen) Bakkeøer, uden at der dog siges, fra hvilke Lokaliteter han kender den. 
meget fin Grundmasse, men denne indeholder en Del Bryozoer samt en ret stor Mængde Foraminiferer; overfladisk set præger disse ikke Kalken, men gør sig straks gældende ved Berøring eller ved, at man knuser Kalken mellem Fingrene. Flinten er hvid; fast sammenhængende i Lag af $10-15 \mathrm{~cm}$ Tykkelse og med en indbyrdes Afstand af $20-30 \mathrm{~cm}$.

Lagstillingen horisontal.

Faunaen henfører Kalken til Y. Danium (Zone C?).

Tred I. 68 (T. I). 104 (B. 3. 12).

$800 \mathrm{~m}$ NNV. f. Hjardemaal Kirke. Kote ca. $25 \mathrm{~m}$.

Profilet, en lille Gravning i Vejsiden, var i 1924 et Par m højt, men meget daarligt; den øvre Del af den synlige Kalk er stærkt knust.

Kalken er Cocolitkalk, men med et ret stort Indhold af Bryozoer; dette gælder især de øvre og de nedre Dele af den blottede Kalk, mens en Zone i Midten af Profilet er meget bryozofattig. Flinten er overvejende hvid, uden skarp Grænse mod Kalken, men den mørkere graa Kerne af de tykke Flintknolde bliver tit dominerende.

Lagstillingen kunde ikke afgøres med Sikkerhed.

Efter Faunaen maa Lokaliteten sikkert henføres til Y. Danium (Zone $\mathrm{C}$ ).

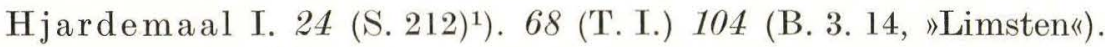

$250 \mathrm{~m} \varnothing \mathrm{N} \varnothing$. f. Kirken. Kote $9 \mathrm{~m}$.

Lille Grav med en Væg paa en halv Snes m Længde og et Profil paa et Par m Højde, som dog ikke er særlig rent. Kalken er Bryozokalk, (dækket af $1 \mathrm{~m}$ Lokalmoræne og lidt Flyvesand); den er let smuldrende og usammenhængende, men kun lidet afsmittende, og iøvrigt ret hærdnet; Farven er hvid. Hovedmassen af Bjergarten udgøres af en kridtagtig Grundmasse, hvori de forholdsvis faa Bryozoer, der dog alligevel præger Bjergarten, ligger indlejret. Flinten er hvid eller graa og danner sammenhængende Lag paa $10-20 \mathrm{~cm}$ Tykkelse; den er meget rigeligt tilstede.

Lagstillingen er horisontal.

Lokalitetens stratigrafiske Stilling er ikke absolut afgjort, men efter Faunaen er der størst Sandsynlighed for, at den maa henregnes til Y. Danium (Zone C).

Hjardemaal II. 95 (»Saltholmskalk«). 68. (S. 20 og T. I, »Blegekridt(i).

$450 \mathrm{~m}$ SØ. f. Kirken. Kote $12 \mathrm{~m}$.

Ret stor Grav med stærkt tilskredne Vægge. I Bunden af Graven

1) Se Fodnoten under Bjerge II, S. 91. 


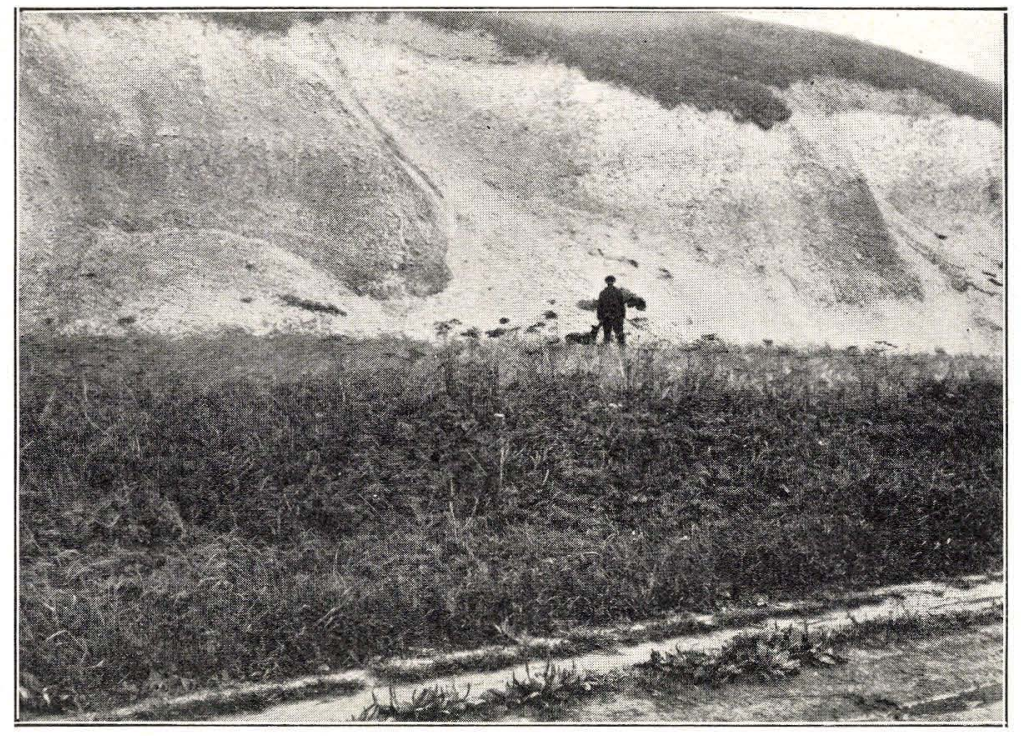

Fig. 10. Kjølby Gaard I. Grænsen mellem Skrivekridt og Danium ligger øverst i Profilet.

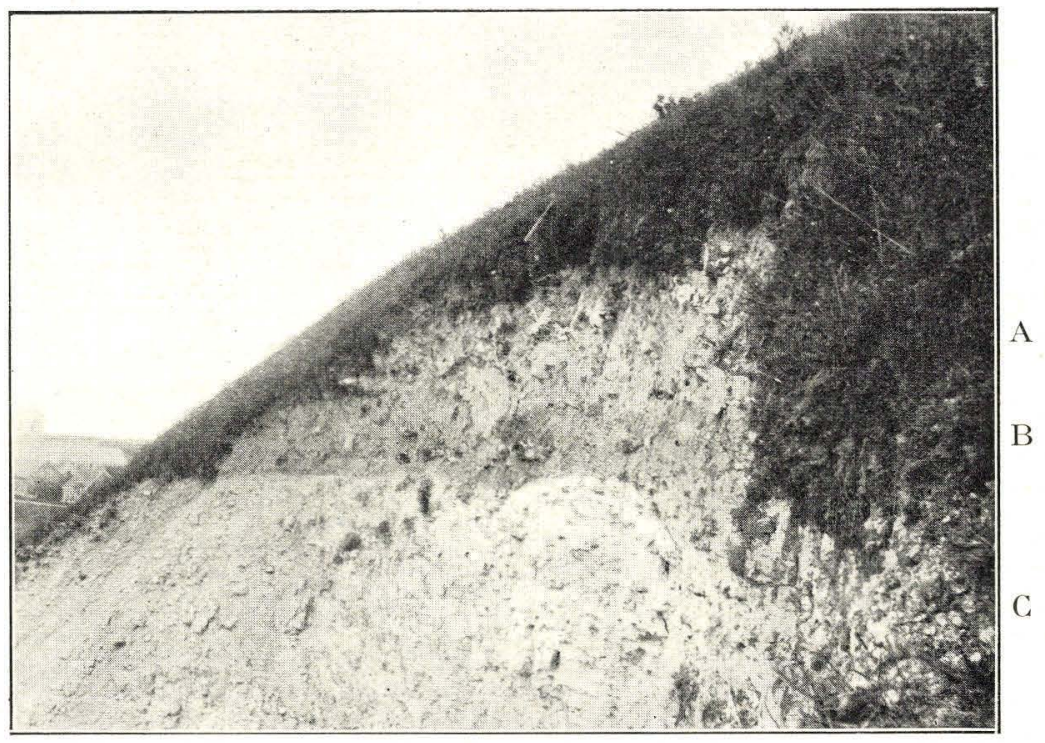

Fig. 11. Kjølby Gaard I. A Coccolitkalk. B Ler. C Skrivekridt. 
var gravet et mindre Hul paa et Par m i Diameter og $2 \mathrm{~m}$ dybt. Heri saas en hvid Coccolitkalk, meget finkornet, lidet afsmittende. Hyppig indeholder denne Grundmasse (som delvis er eneherskende) et ret stort Antal Bryozoer, der dog aldrig bliver saa stort, at man kan kalde Bjergarten for Bryozokalk. Flinten er hvid eller graasort med hvid Skorpe; den danner ret sammenhængende Lag af flade, godt $10 \mathrm{~cm}$ tykke Nyrer. Kalklagene mellem Flintlagene er dobbelt saa tykke.

Lagstillingen horisontal.

Kalken hører formodentlig til Y. Danium.

Hjardemaal Fattiggaard. 68 (T. I). 104 (B. 3. 13, "Limsten«).

Ravn angiver Forekomsten her som Limsten. Der finder ingen Udnyttelse af Kalken Sted. Paa Mineral. Museum opbevares en Bjergartsprøve, etiketteret "Blegekridt? «, men denne ligner i højeste Grad Skrivekridt. Indtil videre maa Lokaliteten betragtes med Tvivl.

Kjølby Gaard I. 68 (T. I, »Skrivekridt«). 104 (B. 3. 26, »Skrivekridt«) 300 m SV. f. Hunstrup Kirke. Profilets Fod paa Kote 3 m, Skrivekridtets Overkant paa $12 \mathrm{~m}$.

Graven ligger i den gamle Klint og er ret stor, og Profilet var i 1924 rent og klart (Fig. 10-11). Paa Grund af den overhængende Tilstand af Gravens Overkant, var den øverste Del af Lagserien kun tilgængelig paa et enkelt Sted, og endda under vanskelige Forhold. Lagfølgen er gengivet paa T. III.

C) Ca. $9 \mathrm{~m}$ Skrivekridt, typisk, i Almindelighed ikke særlig fossilrigt; dog fandtes en Del løse Stykker af en mere fossilrig Bjergart, mere ujævn og nubret i Bruddet end den sædvanlige, men disses Plads i Serien er ikke bestemt.

Den øverste Del af Skrivekridtet, nærmest dettes Overgrænse, er ikke særlig fossilrig; her iagttoges kun Ophiomorphaagtige Dannelser, men til hvilken Dybde dette gælder, bestemtes ikke nærmere. Den øverste Del af Skrivekridtet afviger ellers ikke iøjnefaldende fra den nedre Del.

Af Flint indeholder Kridtet yderst lidt. Et Par $m$ under Overkanten ses en Række smaa, tynde Flintknolde af den sædvanlige, sorte Type, og endnu 2-3 m dybere en Række til.

B) $9 \mathrm{~cm}$ Ler. Grænsen mod det underliggende Skrivekridt er skarp, men ujævn, dels bølgende og bulet, dels lidt sprækket og opspaltet, saa Leret, der udfylder alle Ujævnhederne, sender Smaagrene ned i Kridtet.

Leret er meget kalkrigt, lysegraat af Farve i tør Tilstand, med Mellemrum indeholdende fine, smaa Rustpletter. Det er meget fint, overordentlig fedt og synes ikke at indeholde Kvartssand. Derimod er det opfyldt af Rullesten af Skrivekridt. Disse 
varierer i alle Størrelser fra forsvindende smaa indtil et Hønseægs Størrelse; den største af de fundne Rullesten er omtrent 7 cm lang. Overfladen af dem er mere eller mindre ujævn, de er ofte facetterede, tildels ret skarpkantede, og de synes ikke at være blevet rullede i nogen høj Grad. Undertiden er de okkerfarvede paa Overfladen. Foruden Rullesten af Skrivekridt indeholder Lerlaget en Del Skrivekridtforsteninger, liggende paa sekundært Leje.

A) 1,25 m Coccolitkalk. Lermængden i Lag B aftager opadtil, og omtrent samtidig (dog lidt senere) forsvinder Skrivekridt-Stenene. Bjergarten gaar over i en homogen Coccolitkalk og bliver mere fast og haard, dog ikke egentlig klingende hærdnet; den er lidt afsmittende, meget finkornet, ikke skarp at føle paa, hvid (undertiden svagt graalig) af Farve. Kalken spalter overordentlig daarligt for Slag, men er in situ spaltet ud i tykkere eller tyndere Bænke. Den er yderst forsteningsfattig og minder meget om »det døde Lag《 fra Voxlev. Af Hulrum ses - foruden de nævnte Sprækker - enkelte okkerfarvede, smalle Huller, aabenbart stammende fra Spongier; fine Huller efter Spongienaale er almindelige.

I dette Lag findes tre Flintlag, alle ensartede. Flinten er omtrent kulsort, med faa lysere Pletter, og med en hvid Skorpe, der oftest er lige saa tynd, som det i Almindelighed er Tilfældet med Skrivekridtflint; derimod er Flintknoldene mere hullede og indeholder flere tykskorpede Hulrum end Skrivekridtflint. De 3 Lag er dannet af flade Knolde, gennemgaaende $10 \mathrm{~cm}$ tykke, der er vokset saa tæt sammen, at de danner omtrent ubrudte Lag.

Lagstillingen er tilsyneladende horisontal.

Den nærmere Behandling af denne Lagseries palæontologiske Forhold findes i Kap. VI. Skrivekridtet er senonisk, mens Lagene A-B maa henregnes til Daniet. Forsteningerne opføres i Bilag B.

Nye Kløv.

I Grave og Smaahuller i den gamle Klint kommer der flere forskellige Kalkaflejringer i Dagen. Til Orientering hidsættes en Skitse af Klinten, set ude fra det foranliggende, flade Land (Fig. 12).

Skrivekridt (Fig. 12,1). I Sommeren 1925 byggedes en ny Skole, og under dette Arbejde afgravedes Gaardspladsen tæt op til Klinten og i Klintefoden; ved dette Gravearbejde blottedes Skrivekridtet i en Kotehøjde af 4,5 m; Kridtets Overgrænse maa antagelig ligge paa ca. $5 \mathrm{~m}$. Kridtet er rent, hvidt, meget forsteningsrigt, bl. a. indeholdende mange Bryozoer. 
Coccolitkalk (Fig. 12,2). Denne kommer frem i to Grave, en umiddelbart N. f. Skolen og en N. f. Landevejen fra Thisted. I den sydligste af de to Grave (ved Skolen) er Kalken blottet i Højden $6,5-9,5 \mathrm{~m}$ o. H., og i den nordligste fortsæettes den fra det sidstnævnte Niveau op til en Højde af $12,5 \mathrm{~m}$, altsaa ialt med en Mægtighed af mindst $6 \mathrm{~m}$.

Kalken er en graalighvid, ret fin Coccolitkalk, ikke skarp at føle paa, fast uden at være egentlig hærdnet, temmelig godt spaltende for Slag. Af Flint ses et $10 \mathrm{~cm}$ tykt, sammenhængende, porøst Lag af sort Farve, forsynet med tyk, hvid Skorpe.

$100 \mathrm{~m}$ S. f. Skolen ses Coccolitkalken desuden i et lille, gravet Hul i Klinten ovenfor den derliggende Gaard, gaaende i Dagen i en Kotehøjde af ea. $10 \mathrm{~m}$.

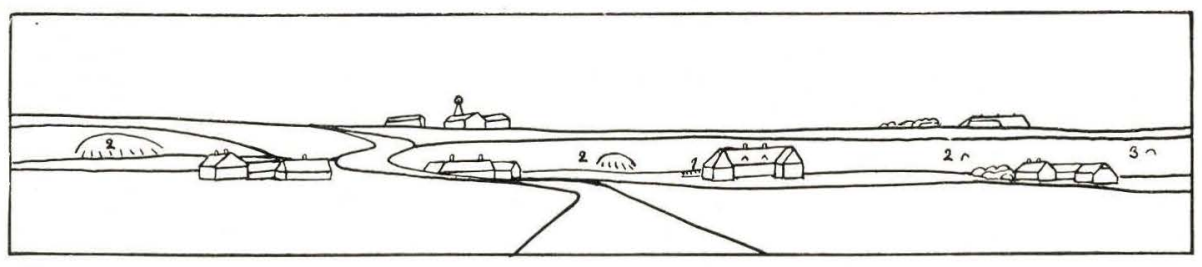

N. Fig. 12. Skitse af Klinten ved Nye Kløv. 1 Skrivekridt. 2 Coccolit- s. kalk (Zone A). 3 Bryozokalk (Zone B).

Bryozokalk (Fig. 12,3). 75 m S. f. denne sidstnævnte Forekomst kommer endelig Bryozokalk tilsyne i et lignende, lille Hul; Kotehøjde ca. $13 \mathrm{~m}$. Kalken er fast, godt sammenhængende, men ikke hærdnet konkretionært; Bryozoerne er fine, men meget talrige og dominerende. Kalken indeholder gulgraa Flint i tykke Nyrer.

Bryozokalk forekommer endelig som Brokker i Lokalmorænen over Coccolitkalken i den nordligste Grav.

Set i Profilerne ligger Kalklagene tilsyneladende horisontalt; de maa dog have et svagt Fald i sydlig Retning.

I Profilerne her findes altsaa Skrivekridtets øverste og Daniets nederste Lag repræsenteret, idet Coccolitkalken maa henføres til Daniet (Zone A) og den overliggende Bryozokalk ligesaa (Zone B); nærmere herom i Kap. VI. Forsteningerne fra de forskellige Dannelser er anført i Bilag C.

Lønnerup I. 76 ("Aldre Bryozokalk - Lynnerup « $\left.)^{1}\right)$.

$1150 \mathrm{~m}$ NV. f. Hovsør Havn. Kote $8 \mathrm{~m}$ (Klintens Overkant).

1) Foruden denne Angivelse S. 167 opfører Brünnich Nielsen S. 139 "Lønnerup» under Gruppen "Coccolithkalk. Yngre Bryozokalk«, men uden Angivelse af Fossiler. 
Lille Grav i Klinten under Gaarden. Der har her været gravet Kalk til en Dybde af $4 \mathrm{~m}$ under Overkanten af Klinten, men Graven var i 1923 omtrent tilskredet, saa det eneste, der kunde ses i Profilet, var Lokalmoræne.

Kalken er typisk, ren Bryozokalk. Flinten er graa.

Faunaen henviser Lokaliteten til A. Danium (Zone B).

Lønnerup II. $95($ S. 121) 1 ).

I sin Dagbog fra 1869 skriver K. J. V. Stennstrup: "Kalken i den vesterste Kalkgrav i Lønnerup falder $5^{0} \bmod$ NO. og Flintlagene er 6 - $10^{\prime \prime}$ tykke og ligge i en Afstand af $6^{\prime \prime}$ til $8^{\prime \prime}$. Noget af Flinten er saa kulsort som Skrivekridtets, andet er gul hornstenagtig. I Bunden af det mellemste Brud ved Lynnerup træder et tyndt Lerlag 6" frem, jeg fandt i Blegerne en Nucula og Caratomus hemisphaericus? Heldningen som i det vestligste.《

Stykket med Aftrykket af den omtalte Nucula findes paa Mineral. Museum. Bjergarten er en meget haard, hvid, finkornet Coccolitkalk, indeholdende enkelte Bryozoer og Foraminiferer. STEenstrup's Beskrivelse kunde tyde paa, at det her drejer sig om en Overgang mellem Senonium og Danium, og Stykket med Nucula hidrører sandsynligvis fra en hærdnet Zone af Daniets Kalksten, som vel nærmest maa svare til Lag A ved Kjølby Gaard I.

Hverken Gravene selv eller nærmere Oplysninger om deres Beliggenhed har kunnet findes.

Dalgaard. 68 (T. I). 104 (B. 3. 30).

Dalgaard N. f. Hovsør. Kote ca. $3 \mathrm{~m}$.

Ifølge RAvN er der her truffet Limsten ved Brøndgravning i 1899. En af ham indsamlet Bjergartsprøve bestaar af en hvid, blød, afsmittende, fin Coccolitkalk som Grundmasse, men med saa stort et Indhold af indlejrede Bryozoer, at man er stærkt tilbøjelig til at kalde den Bryozokalk. Især ved Berøring gør Bryozoerne sig gældende, selv om deres Masse er underordnet i Forhold til Grundmassen.

Forsteninger foreligger ikke, men det maa formodes, at Kalken tilhører A. Danium.

Hovsør. 16 (S. 65, „Liimsteen - Høxer«). 95 (»Hovsør Havn — Saltholmskalk«). $76^{2}$ ). 68 (S. 4 og T. I). 104 (B. 4. 13, "Saltholmskalk«).

1) RAvN benævner her Bjergarten "Blegekridt«; desuden har RAvN set Skrivekridt ved "Lønnerup«.

$\left.{ }^{2}\right)$ S. 139 opfører BRÜNnich Nielsen Hovsør under Gruppen »Coccolithkalk. Yngre Bryozokalk«, mens han S. 160 opfører den som »Ældre Bryozokalk". 
Gravene, der tidligere har leveret »Blege« til Brænding, har ligget i den gamle Klint NV. f. Havnen, men de er nu komplet tilgroede.

Et Par Echinocorys sulcatus, indsamlet af RAvN 1899, er etiketteret ఐ. f. Hovsør Havn«; de ses at stamme fra Coccolitkalk. Koten her ca. 0.

Kalken tilhører Y. Danium.

Hov I. 16 (S. 65, »Hovbjerget - Blegekridt og Liimsteen«). ? 91 (S. 40, »Hou — Limsten«). ? 76 (S. 167, »Hou — Aldre Bryozokalk«).

Nordskrænten af Hov Aas, $300 \mathrm{~m} \mathrm{NV}$. f. Toppen.

Forсннаммев meddeler, at i Hovbjerget er Skrivekridtet dækket af Blegekridt og Limsten. Posselt opfører Terebratula lens fra Limsten ved Hou, men Brünnich Nielsen oplyser 1909 (76 S. 165), at han forgæves har eftersøgt Posseuts Eksemplar.

Paa Mineral. Museum findes en Kalkprøve, indsamlet af K. J. V. Steenstrup (1870. 2470) og etiketteret »Hou, Thy«; hans Dagbog yder ingen yderligere Oplysning. Det er en ret haard, lidet afsmittende Bryozokalk, hvid (bortset fra en rustfarvet Stribe); Grundmassen er finkornet, svagt grynet, og heri ligger de ret talrige Bryozoer indlejret.

Ved Forf.'s Besøg paa Stedet i 1923 og 1924 saas øverst i den gamle Klint nogle gamle, tilgroede Grave i en Højde af $20-30 \mathrm{~m}$; i og nedenfor disse fandtes en Del løstliggende, stærkt forvitret Afrømning fra Kalkgravene.

Kalkprøverne var af to Slags: 1) En ret haard Coccolitkalk, hvid, uden Bryozoer, men med mange fine Huller efter Spongienaale; den ligner ganske Kalken A fra Kjølby Gaard I. 2) En Kalkart med en Grundmasse af samme Art, men indeholdende en stor Mængde fine Bryozoer; den maa nærmest kaldes Bryozokalk.

Flinten var ligeledes af to Slags: 1) En sort Flint, enten fra Skrivekridt eller fra et Lag Coccolitkalk af ovennævnte Type. 2) En graagul Daniumflint.

Fra Bryozokalken foreligger fra gammel Tid et Eksemplar af Terebratula fallax $f$. tenuis ${ }^{1}$ ) paa Mineral. Museum, mens der paa Stedet bl. a. fandtes Echinocorys sulcatus.

Det maa saaledes anses for fastslaaet, at der paa dette Sted i hvert Fald forekommer Danium, og da Skrivekridtet er udbredt i Egnen, tæt V. herfor, er der al mulig Grund til at antage, at Forсннаммев har Ret, og at der her findes en Overgang fra Senonium til Danium. De fundne Bjergarter synes at antyde, at denne er Mage til Overgangen ved Kjølby Gaard.

Sennels I. 68 (S. 5 og T. I). 104 (B. 4. 12).

Ø. f. Byen.

$\left.{ }^{1}\right)$ Det er sandsynligvis dette Ekspl., Posselt har bestemt til T. lens. 
Milthens angiver, at der her er truffet Blegekridt, og Ravn tilføjer den Oplysning, at det forekommer i Grav.

I 1923 var det umuligt at opspørge nogen Grav i Nærheden af det angivne Sted.

Sennels II. 68 (S. 5 og T. I). 104 (B. 4. 11).

N. f. Byen.

Om denne Lokalitet gælder det samme, som er sagt om Sennels I.

Faartoft I.

Den gamle Klint Ø.f. Byen. Kote ca. $8 \mathrm{~m}$.

Klinten er stærkt tilgroet, men i et Par Huller i Klinten iagttoges Lokalmoræne af Coccolitkalk, stærkt blandet med hvid Flint.

(Y. Danium?).

Faartoft II. 68 (S. 22 og T. I). 104 (B. 4. 9) $)^{1}$.

I Byen.

Ifølge Minthens er der her truffet Coccolitkalk (»Blegekridt«) ved Brøndgravning; nogen Dybde for Kalken meddeles ikke. MrLthers opgiver Kalken til 91,0\% $\mathrm{CaCO}_{3}$.

Formodentlig Y. Danium.

Thisted I.

I den sydøstlige Udkant af Byen, tæt ved Svineslagteriet. Kote ca. $10 \mathrm{~m}$.

Graven er meget stor (Fig. 13, S. 103), men Væggene er for en stor Del tilskredne og Profilerne kun delvis gode.

Kalken varierer lidt i Beskaffenhed. I den øvre Del af Graven ved A - er det Coccolitkalk, bestaaende af en finkornet, graalighvid Grundmasse, der undertiden kun indeslutter en ringe Mængde Bryozoer, mens Bryozoindholdet til andre Tider (og som oftest) er saa stort, at Bjergarten maa kaldes Bryozokalk. Den er uregelmæssigt hærdnet og danner delvis jævn Overgang til hvid Flint, medens andre Partier er mere bløde, og i Hulrum i de tilstødende Flintlag findes løst Kalkpulver.

Denne Kalkbænk er 0,5 m tyk og begrænses opad af et $10-25 \mathrm{~cm}$ tykt, ikke helt sammenhængende Lag af hvid Flint med sort Kerne, nedad af et fastere, mindre porøst Lag af graa Flint, ligeledes med sort Kerne (undertiden med hvide Pletter af løs Kalk). Over det øvre Flint-

1) Det beror sikkert paa en Fejltagelse, naar RAvN opfører Lokaliteten som "Grav", thi han opgiver MrLthers som Kilde, og denne omtaler Lokaliteten som en Brønd. 
lag findes indtil $3 \mathrm{~m}$ Lokalmoræne ${ }^{1}$ ), medens alt under det nedre er dækket af Skred.

Denne bryozorige Kalk fortsætter sig et langt Stykke i Væggen mod Syd, ligesom den ses i et gravet Hul foran Væggen.

Ved B er Kalken en hvidgraa eller hvid Coccolitkalk uden Bryozoer, delvis og uregelmæssigt hærdnet. En Kalkbænk imellem 2 Flintlag er mere graalig og stærkt lerflammet — lagdelt. Kalken er finkornet og noget afsmittende.

Flinten optræder her dels som større, sorte Boller med hvid Skorpe og hvid Kerne dels som Lag af meget porøs, sort Flint med hvid Skorpe eller som kompakte, $20 \mathrm{~cm}$ tykke Lag af graa, homogen Flint.

Længst mod Syd findes en lavere liggende Del af Graven - C med 4-5 $\mathrm{m}$ høje Vægge (herover er der atter $6-7 \mathrm{~m}$ over $\mathrm{B}$ op til Overfladen). Kalken her er en hvid Coccolitkalk, gennemgaaende yderst fattig paa Bryozoer; kun i et enkelt Lag tæt ved Bunden findes Striber af bryozorige Partier i Kalken. Denne indeholder mange graa „Ophio-. morpher ; den er meget finkornet, stærkt afsmittende, ofte lidt »skarp« at føle paa. Flinten er i den øvre Halvdel graa og hvid, ret sammenhængende; i den nedre Del er den mere porøs, sort med hvid Skorpe. Flintlagene er gennemgaaende ret tætliggende, kun ca. $10 \mathrm{~cm}$ tykke.

De tektoniske Forhold i Graven er ret komplicerede.

Ved A hælder Lagene nogle faa Grader mod S., men i den lange Væg fra A henimod B nærmer de sig stærkt til at blive horisontale.

Ved B findes en skarp Sadel, hvor Lagene er knækket under en Vinkel paa $120^{\circ} \mathrm{og}$ falder baade mod N. og S.; Strygningsretningen kunde ikke konstateres. Lagenes Fortsættelse mod S. var dækket af Skred og kunde ikke følges, men mod N. gaar Lagene et Par m fra Sadlens Toppunkt over til horisontal Stilling, som beholdes paa en Strækning af ca. $8 \mathrm{~m} \bmod \mathrm{N}$. (i Retning af A). Saa afbrydes de horisontale Lag pludselig af en Forkastning, og paa en Strækning af $2,75 \mathrm{~m}$ afløses de af stejlt stillede Lag, strygende omtrent $\varnothing .-\mathrm{V}$. og hældende ca. $75^{\circ}$ mod N. Denne Serie afsluttes atter mod N. af en Forkastning (begge Forkastningerne er orienteret som de stejlt stillede Lag), hvorpaa der atter optræder horisontale Lag. Men medens Kalklagene S. f. denne Serie er identiske med den bryozofattige Coccolitkalk ved B, er Kalken $\mathrm{N}$. herfor af samme meget bryozorige Type som ved $\mathrm{A}^{2}$ ). Den stejlt stillede Lagserie bestaar af bryozofri Kalk, delvis stærkt hærdnet og meget rig paa Flint, dels sort, porøs Flint, dels mere fast, graahvid

1) Skønt Lokalmorænen ellers udelukkende bestod af Kalk, saas tæt over Flinten en Eruptivblok.

2) Den bryozorige Kalk umiddelbart N. f. Forkastningszonen kan ikke følges direkte til A paa Grund af Tilskridning, men der er næppe Grund til at betvivle dens Identitet med Kalken ved $\mathrm{A}$. 
Flint; Seriens eventuelle Identitet med andre tilgængelige Kalk- og Flintlag i Graven kunde ikke fastslaas.

Ved den nordlige Forkastning tydede Slæbet i de horisontale Lag paa, at den stejlt stillede Serie maatte være hævet i Forhold til disse. I selve Forkastningslinien fandtes imidlertid en Flintblok tilsyneladende i Fortsættelse af et horisontalt Flintlag, men knækket nedad paa en saadan Maade, at det antydede den modsatte Bevægelse af Lagene. Slæb paa Sydsiden af Serien kunde ikke ses.

Ved C hælder Lagene svagt mod Syd, men Forbindelsen med Lagene ved B kunde ikke iagttages.

Analysen viser følgende Indhold af $\mathrm{CaCO}_{3}$ :

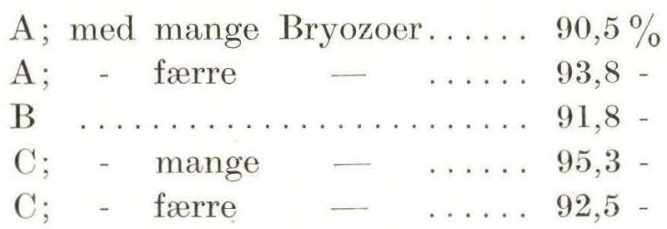

Forsteningsindholdet (væsentligst fra A) henviser Kalken til Y. Danium (Zone C).

\section{Thisted II.}

Johnsens Allé, $300 \mathrm{~m} \varnothing$. f. Slagteriet. Kote $7 \mathrm{~m}$.

Paa den nyanlagte Vej fra Slagteriet mod Ø. var der i 1923 foretaget Gravning til Nedlæggelse af Ledninger. Herved var der midt i Vejen gravet en Masse Kalk og Flint op. Kalken er en Coccolitkalk, ikke rig paa Bryozoer, men paa Flintstykker og enkelte Spalteflader i Kalken fandtes hist og her ret rigelige Bryozoer. Grundmassen er hvid med et graaligt Skær, finkornet, svagt grynet, som Regel blød og afsmittende.

Flinten er overvejende graa, sjældnere sort, men desuden fandtes mange store Blokke af hvid Flint.

Lejringsforholdene kunde ikke iagttages.

Faunaen henviser Kalken til Y. Danium (Zone C?).

Thisted III. 19 (S. 536) $\left.{ }^{1}\right) .95$ (»Østerodde《). $\% 6$ (»Østerodde ved Thisted«). 97 (S. 60, »Østerodde (Strøje) ved Thisted«). 68 (T. I). 104 (B. 4. 8, "Storodde () .

Klinten $1 \mathrm{~km}$ Ø. f. Svineslagteriet. Kote ca. $6 \mathrm{~m}$.

I de senere Aar er Klinten stærkt tilskredet og viser intet godt Profil. Et enkelt Sted længst mod $\varnothing$. fandtes et gravet Hul, hvor Kalken paa en $1 \mathrm{~m}$ lang Strækning kunde iagttages i faststaaende Stilling.

1) ForсннамuеR angiver Forekomsten af Krebselevninger i Blegekridt si Nærheden af Thisted«, hvilket tyder paa, at han sigter til denne Lokalitet. 


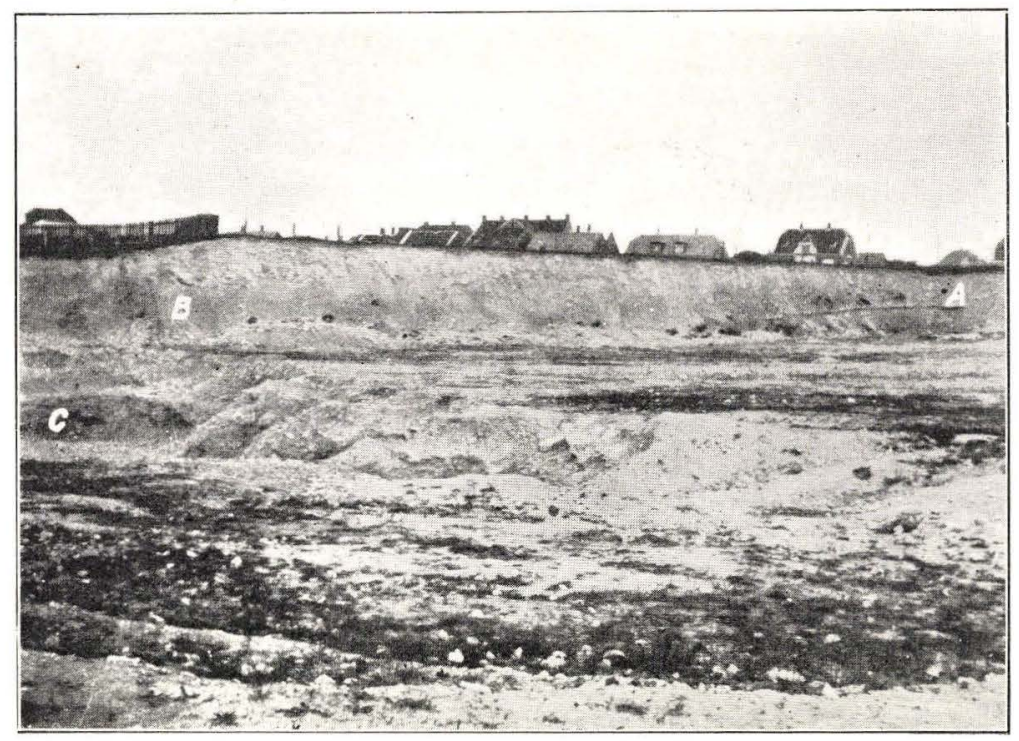

Fig. 13. Thisted I. Set mod NNV.

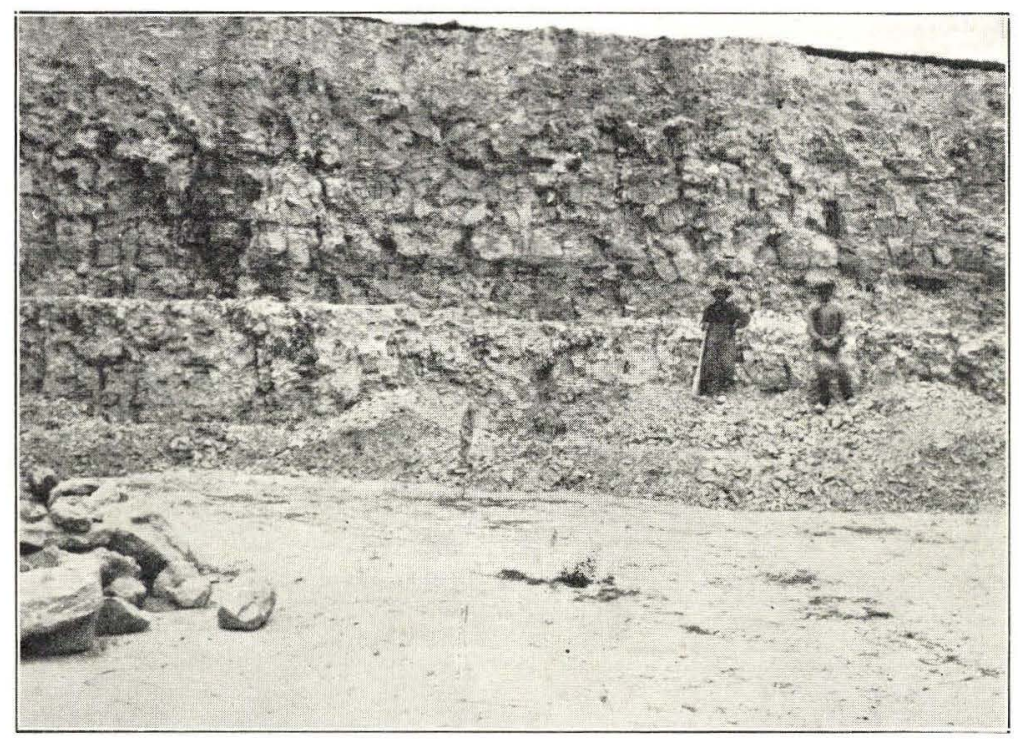

Fig. 14. Thisted V. Den lerede Horisont ses lige over Mændenes Hoved. 
Kalken er Coccolitkalk, finkornet, lidt grynet, ikke særlig godt spaltende. Den er hvid, lidt afsmittende, men ellers ikke blød, ret skarp at føle paa, da den indeholder en Masse Kiselnaale (samt Hulrum efter disse). Kalken er ret flintfattig.

Lagstillingen horisontal.

Lokaliteten er kendt ved at indeholde rigelige Rester af et større Krebsdyr; Faunaen iøvrigt henviser Kalken til Y. Danium (Zone C).

Thisted IV. 123 (S. 35, "Vest for Byen«). 68 (S. 20 og T. I). ? 5 (S. 192, "Omegnen af Thisted«). 104 (B. 4. 6).

"De jydske Kalkværker«s store Grav i den vestlige Udkant af Byen. Graven frembyder et udmærket Profil i sin lange Nordvæg. Kote ca. $21 \mathrm{~m}$.

Kalken er en finkornet, ret blød, meget afsmittende Coccolitkalk, næsten fri for Bryozoer, af hvilke man saa at sige aldrig ser nogle i langt den største Del af Bruddet. I den nederste Del af Graven længst mod Vest samt i Væggens halve Højde i Gravens Østende observeres dog Partier af Kalken, der stedvis indeholder endog meget rigeligt af Bryozoer. Farven er rent hvid. Flinten er især tilstede som sorte, porøse Lag af $10-20 \mathrm{~cm}$ Tykkelse, gennemgaaende over meget lange Strækninger. Desuden optræder Flinten som store, massive Knolde af graa Farve og med Udvækster af varierende Form, samt som $30 \mathrm{~cm}$ tykke, faste Lag af hvidgraa Flint.

Lagstillingen er gennemgaaende horisontal. Dog findes midt i Væggen en Flexur som en stor, flad Skaal, og fra dennesVestkant sænker Lagene sig svagt mod Vest.

Faunaen henviser Kalken til Y. Danium (Zone D).

Thisted V. 68 (S. 20, 22, T. I, »Tilsted《). 104 (B. 4. 5, "N. f. Tilsted《).

N. og S. f. Landevejen, knap $3 \mathrm{~km} \mathrm{~V}$. f. Thisted. Kote $35 \mathrm{~m}$. Der findes her et Komplex af Grave, der dog paa store Strækninger er tilskredne.

I den nordvestlige Del af Komplexet (N. f. Landevejen) saas i 1923 et mindre Profil i en meget bryozofattig Coccolitkalk. Flinten er omtrent sort, dels i Rækker af mere eller mindre sammenhængende, flade Nyrer, dels i en usammenhængende Række af mere eller mindre kugleformede Knolde paa et Par dm Diameter.

En ganske lignende Coccolitkalk ses i Graven lige S. f. Banelinien.

Større Interesse knytter der sig til det større og renere $6,4 \mathrm{~m}$ høje Profil i Graven længst mod NØ., N. f. Landevejen (Fig. 14). Kalken er en for det meste ret blød, stedvis dog mere hærdnet Coccolitkalk. Hovedparten af den er meget bryozofattig; dog findes der et Par Lag af mere bryozorig Beskaffenhed, hvilket f. Eks. er Tilfældet tæt over Gravens Bund, hvor der er en faa cm tyk Stribe af bryozorig Kalk, 
over- og underlejret af Coccolitkalk uden Bryozoer. Bryozoindholdet er forholdsvis stort, og de ligger indlejret i en til den bryozofri Coccolitkalk nøje svarende Grundmasse, hvid (med et svagt graaligt Skær), ret haard, lidet afsmittende. Coccolitkalken er ret godt vandret spaltende. Den mikroskopiske Undersøgelse viser, at den bestaar baade af meget fine og af lidt grovere, krystallinske, klastiske Bestanddele, foruden senere udskilt Calcit; Coccoliter og smaa Foraminiferer er tilstede i stort Antal. Ved Behandling med Syre faas en Rest, der bl. a. indeholder Kvarts, organiske Kiselelementer og Glaukonit, overvejende som imprægnerende Farvestof.

Midt i Væggen findes et 0,25 cm tykt Lag af mere leret Beskaffenhed; tillige indeholder det en Del Glaukonit. Det er godt spaltende for Slag og meget kraftig lagdelt. Hovedmassen af Kalken i dette Lag bestaar af en Grundmasse, der meget ligner den over- og underliggende Coccolitkalk, finkornet i samme Grad, blot mere eller mindre stærkt graafarvet. Laget præges af at være langt rigere paa Forsteninger end Coccolitkalken i Almindelighed er, og den ringere $\mathrm{CaCO}_{3}-\%$ (se nedenfor) har desuden virket konserverende paa de tilstedeværende Aragonitrester. Laget har et temmelig broget, varierende Udseende. Intensiteten af den graa Lerfarve er noget vekslende paa en flammet Vis. Bjergartens Farve kan desuden veksle i gule Toner, som Regel i begrænsede Pletter, og stedvis bliver den tillige mere grovkornet, ofte i Forbindelse med større Ophobning af Glaukonitkorn, Svampenaale, Foraminiferer og andre Mikrofossiler. De hyppige, adsplittede eller tydeligt samlede Rester af Kiselspongier meddeler Bjergarten en hvid Farve. Calcitrester er ofte farvet stærkt brunliggraa.

Iøvrigt er det nærmest, foruden Lerindholdet, Glaukoniten, der præger Laget. Ikke fordi den optræder med nogen stor Procent, men den grønne Farve giver alligevel Laget en Særstilling paa Baggrund af de sædvanligvis glaukonitfattige Kalkbjergarter i Daniet. Glaukoniten optræder ikke som imprægnerende Stof i selve Bjergarten, men viser sig i to Former, dels som skarpt afgrænsede, runde eller uregelmæssigt formede Korn, dels som imprægnerende Farvestof i organiske Rester, Knoglerester og Aragonitskaller, i hvilke Tilfælde Skallen "er stærkt destrueret og henfalden, saa der egentlig kun er et grønt Pulver tilbage; ogsaa i Svamperester og andre Ting optræder den. Glaukonitkornene ligger ofte koncentreret paa mindre Omraader i Kalken.

Baade opad og nedad gaar Laget jævnt over i den tilgrænsende Kalk, idet Yderpartierne af det lerede Lag efterhaanden opløser sig i vandrette Lerflammer.

Den over Lerlaget liggende Kalk er Coccolitkalk, Mage til den nederste. Ogsaa her forekommer stærkt bryozorige Striber.

Flinten danner Rækker, sjældnere mere sammenhængende Lag af 
tynde Nyrer, men desuden findes spredte, større og mindre Knolde med en Diameter paa indtil flere dm; Farven er graa. Alt i alt er Flintens Masse dog stærkt underordnet i Forhold til Kalken.

Analysen af Kalklagene viste følgende Indhold af $\mathrm{CaCO}_{3}$ :

Godt $1 \mathrm{~m}$ over det lerede Lag . . . . . . 96,0\%

$0,25-\ldots \ldots \ldots .95,8-$

Det lerede $\operatorname{Lag} \ldots \ldots \ldots \ldots \ldots \ldots \ldots \ldots . \quad 89,0$ -

$0,5 \mathrm{~m}$ under det lerede $\operatorname{Lag} \ldots \ldots \ldots \ldots .94,5$ -

$1,15-\quad-\quad-\ldots \ldots \ldots \ldots 95,0-$

$2,35-\quad-\quad-\ldots \ldots \ldots 99,5-$

Lagstillingen horisontal.

Faunaen henviser hele Lagserien til Y. Danium (Zone D).

Thisted VI.

$300 \mathrm{~m}$ NNØ. f. Thisted V. Kote $36 \mathrm{~m}$.

Mindre Grav med et ca. 5 m højt, rent Profil i Vestvæggen. Kalken er Coccolitkalk, dels ret bryozofattig, dels mere rig paa Bryozoer - i de nedre Lag — uden dog at tabe Karakteren af Coccolitkalk. Flinten er lysere eller mørkere graa, Lagene gennemgaaende, temmelig sammenhængende, indtil $10 \mathrm{~cm}$ tykke. Desuden findes større, spredte Knolde, samt hvid Flint. Flinten er rigelig, stærkt fremtrædende.

Lagene stryger ca. V. $10^{\circ} \mathrm{N}$.

hælder $\quad 15^{\circ} \bmod$ S. $10^{\circ} \mathrm{V}$.

Faunaen henviser Kalken til Y. Danium (Zone D ?).

Thisted VII.

$400 \mathrm{~m}$ V. f. Nørremølle. Kote $15 \mathrm{~m}$.

Graven var i 1923 helt tilgroet; der saas kun Bunker af den sædvanlige hvide og graa Flint. Kalken er Coccolitkalk.

Kalken tilhører sikkert Y. Danium.

Thisted VIII. 68 (T. I).

NØ.f. Vejen til Ø. Vandet, $800 \mathrm{~m}$ NV. for Thisted Kirke. Kote $21 \mathrm{~m}$.

Ret lang, smal Grav i Retningen NØ.-SV. Væggene er ca. $7 \mathrm{~m}$ høje, men var i 1923 omtrent helt tilskredne. Kalken er Coccolitkalk, dels og overvejende - temmelig fri for Bryozoer, dels med større Bryozoindhold; Grundmassen er hvid, finkornet. Flinten er overvejende hvid, i mindre Mængde graa, og har Form af større og mindre Knolde. Den er meget rigelig.

Lagstillingen horisontal.

Kalken tilhører sikkert Y. Danium.

Thisted IX.

N. f. Vilsundvejen, 1,4 km fra Thisted. Kote ca. $4 \mathrm{~m}$. 
I Vesthjørnet af den her beliggende, store Grusgrav, gaar Kalken i Dagen. Kalken er Coccolitkalk, men i 1923-24 var Profilet saa tilskredet, at kun forvitret Lokalmoræne saas.

(Y. Danium?).

Thisted X. 104 (B. 4. 7). Kote ca. 6 m.

Boring paa Torvet. Boringen er kun ført $3 \mathrm{~m}$ ned, men næsten udelukkende gennem »Blegekridt» med omtrent horisontale Flintlag. Prøver findes ikke.

(Y. Danium?).

Thorsted $\mathrm{I}^{\mathbf{1}}$ ).

$1700 \mathrm{~m} \mathrm{S.} \mathrm{f.} \mathrm{Thorsted} \mathrm{Kirke} \mathrm{(paa} \mathrm{Nordsiden} \mathrm{af} \mathrm{Landevejen,} 150 \mathrm{~m}$ Ø. f. $5 \mathrm{~km}$ Stenen). Kote $13 \mathrm{~m}$.

Meget stor, gammel Grav, men nu helt tilgroet undtagen en lille, friskere Gravning længst mod Vest. Profilet her er ca. $8 \mathrm{~m}$ langt og viser 3-4 m Kalk, overlejret af $1 \mathrm{~m}$ Morænesand. Adskillige Skorstene findes.

Kalken er en meget bryozorig Coccolitkalk, ret blød, let forvitrende; stedvis er den mere hærdnet, men ikke i nogen højere Grad. Den er tæt gennemsat af Sprækker og Spalter, men disse er meget fine. Flinten danner store, uregelmæssige Klumper af adskillige dm Tværsnit. Disse har yderst en noget fastere Skal, men indvendig er hele Massen stærkt porøs og fuld af Sprækker og Hulrum. Flinten er sort med hvid, stærkt "korroderet« Overflade og hvide Hulrum. Flintbollerne er spredt uden Orden i Kalken.

Lagstillingen kunde ikke bestemmes.

Forsteningerne er ikke tilstrækkelige til at afgøre Lokalitetens Stilling (Y. Danium?).

\section{Thorsted II.}

$250 \mathrm{~m}$ SV.f. St. Sjørringhøj. Kote ea. $30 \mathrm{~m}$.

Gammel, tilgroet Grav; længst $\bmod \mathrm{N}$. fandtes et nyere, lille Profil. Her saas $2 \mathrm{~m}$ Kalk, overlejret af $1-2 \mathrm{~m}$ Morænegrus, som forneden er iblandet Opløsningsrester af Kalken.

Kalken er en hvidgraa Coccolitkalk, fin, blød, stærkt afsmittende, fint spaltende efter Lagdelingen og brokkende op. Kalken indeholder nogle Bryozoer, men ikke i større Mængde; de ses ikke paa Brudflader af Kalken, men kommer først frem ved Udvaskning. Analysen viser et Indhold af $98,8 \% \mathrm{CaCO}_{3}$.

Flinten findes dels som et Par Baand, $10 \mathrm{~cm}$ tykke, stærkt porøse, af sortegraa Farve, dels som store porøse eller ganske kompakte Boller

$\left.{ }^{1}\right)$ Foruden denne og de følgende Grave findes i den nærmeste Omegn en Række smaa, men fuldstændig tilgroede Kalkgrave. 
af graa Farve, delvis med gult Anstrøg. De kan opnaa flere dm Tværsnit og optræder spredt, uden Forbindelse med Flintlagene.

Lagstillingen horisontal.

Faunaen henviser Lokaliteten til Y. Danium (Zone D).

Thorsted III.

$600 \mathrm{~m} \mathrm{NV}$. f. St. Sjørringhøj. Kote ca. $30 \mathrm{~m}$.

Graven var i 1923 omtrent fuldstændig tilgroet, men i den østlige Ende fandtes gravet et ubetydeligt, $2 \mathrm{~m}$ dybt Hul. Kalken heri naar næsten helt op til Overfladen.

Kalken er en hvid, blød Coccolitkalk, som er stærkt brokket; i den dybeste Del af Hullet er Kalken dog hærdnet til faste, sammenhængende Blokke. Bjergarten er meget finkornet, næsten bryozofri. Flinten findes dels som store, graa Blokke, dels som mindre Knolde af sort, porøs, hvidskorpet Flint.

Lagstillingen kunde ikke iagttages.

Formodentlig Y. Danium.

\section{Thorsted IV.}

$1200 \mathrm{~m}$ Ø. f. Thorsted Kirke (400 m SV. f. Bakkegaard). Kote $44 \mathrm{~m}$.

Lille, frisk Grav med et 2,5 m højt Profil, hvori Kalken naar helt op til Mulden. Det er overvejende en blød, afsmittende, i store Stykker homogen, kridtagtig Coccolitkalk. Andre Partier er mere eller mindre hærdnet og kan blive helt klingende. I den fine Grundmasse findes indlejret en Del spredte Bryozoer, men ikke tilstrækkeligt til at sætte noget Præg paa Bjergarten. Flinten danner store, faste, hvide (sjældnere graa) Knolde med helt sort Kerne. Flinten er ikke dominerende ved sin Mængde.

Lagstillingen kunde ikke iagttages, da Kalken i hele Profilets Højde er knust.

Faunaen henviser Kalken til Y. Danium.

Skaarup I. 68 (T. I). 104 (B. 4. 1).

$850 \mathrm{~m}$ Ø. f. Skaarup Skole. Kote ca. $35 \mathrm{~m}$.

Graven, som kun er lille, var i 1923 tilgroet og delvis tilkastet. Øverst under Overfladen, hvortil Kalken omtrent naar op, ses noget Lokalmoræne, stærkt udludet, saa næsten kun Flinten er tilbage. Dog skimtes lige noget stærkt smuldrende Kalk. Grundmassen af Bjergarten er en finkornet, lidt grynet Coccolitkalk, men med saa stort Indhold af Bryozoer (daarligt bevarede), at den nærmest maa kaldes Bryozokalk. Iøvrigt er Graven optaget af tilsiderømmet Affald fra Kalkgravningen, særlig af gulgraa Flint, uregelmæssige Knolde med Skorper og indre Partier af hvid Flint. Desuden findes større Flager af haardere Kalk, 
meget rig paa Bryozoer, saa den næsten nærmer sig til at kunne kaldes Bryozokalk.

Faunaen henviser Kalken til Y. Danium (Zone C?).

Dollerup I.

$1250 \mathrm{~m} \mathrm{~V}$. f. Dollerup Mølle (S. f. Vejen). Kote $32 \mathrm{~m}$.

Graven er kvadratisk, $12 \times 12 \mathrm{~m}$, Væggene $2-3 \mathrm{~m}$ høje, orienteret N.-S. og Ø.-V. En mindre Gravning umiddelbart Ø. f. den større Grav er i geologisk Henseende lig denne.

Kalken er en ret blød og smuldrende, afsmittende Bryozokalk, for det meste spaltende op efter Lagdelingen, som er tydelig. Stedvis forekommer noget mere hærdnet Kalk. Hovedmassen af Bjergarten udgøres af en fin, hvid Grundmasse, hvori Bryozoerne (der er vel bevarede) ligger indlejret. Analysen viser et Indhold af 99,0\% $\mathrm{CaCO}_{3}$. Flinten er

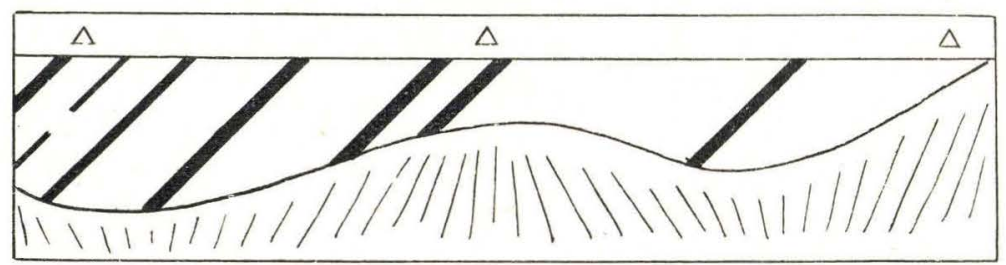

Fig. 15. Dollerup I. Skema af Vestvæggen med de hældende Lag af Kalk og Flint. Øverst Moræneler.

meget porøs, graa med hvid Skorpe, dannende sammenhængende Lag af 10-30 cm Mægtighed; desuden forekommer Nyrer af hvid - graa Flint. Den er ikke dominerende i Forhold til Kalken.

Lagene hælder ca. $40^{\circ} \bmod \mathrm{S}$. lidt til V. (se Skitse af Vestvæggen Fig. 15).

Faunaen henviser Kalken til Y. Danium (Zone C).

\section{Dollerup II.}

$300 \mathrm{~m} \mathrm{~V}$. f. Dollerup I. Kote $28 \mathrm{~m}$.

Stor Grav, Nordvæggen er ca. $20 \mathrm{~m}$ lang og $6 \mathrm{~m}$ høj, Vestvæggen lidt mindre. Øverst i Væggen ses $1-1,5 \mathrm{~m}$ Diluvialsand, Resten er rent Profil gennem Kalken (Fig. 16).

Kalken er Bryozokalk, blød og afsmittende, smuldrende og opspaltende, meget lignende den i Dollerup I, men Bryozoerne synes i Almindelighed at være af grovere, og derfor mere fremtrædende Former; den indeholder $99,0 \% \mathrm{CaCO}_{3}$. Flinten er næsten udelukkende tilstede i Form af meget store Nyrer og Linser samt Blokke af mindre regelmæssig Form, flere dm tykke og meterstore i Udstrækning. Al Flinten er ens, graa med hvide Pletter og hvid Skorpe. Den er dels 


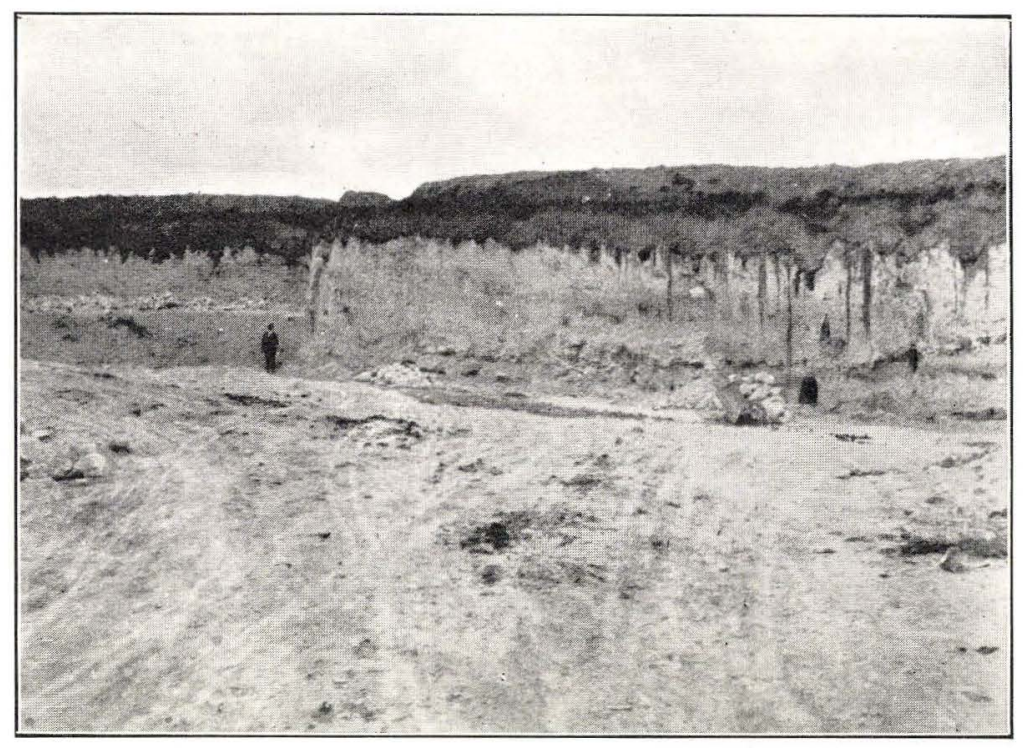

Fig. 16. Dollerup II. Set mod NV.

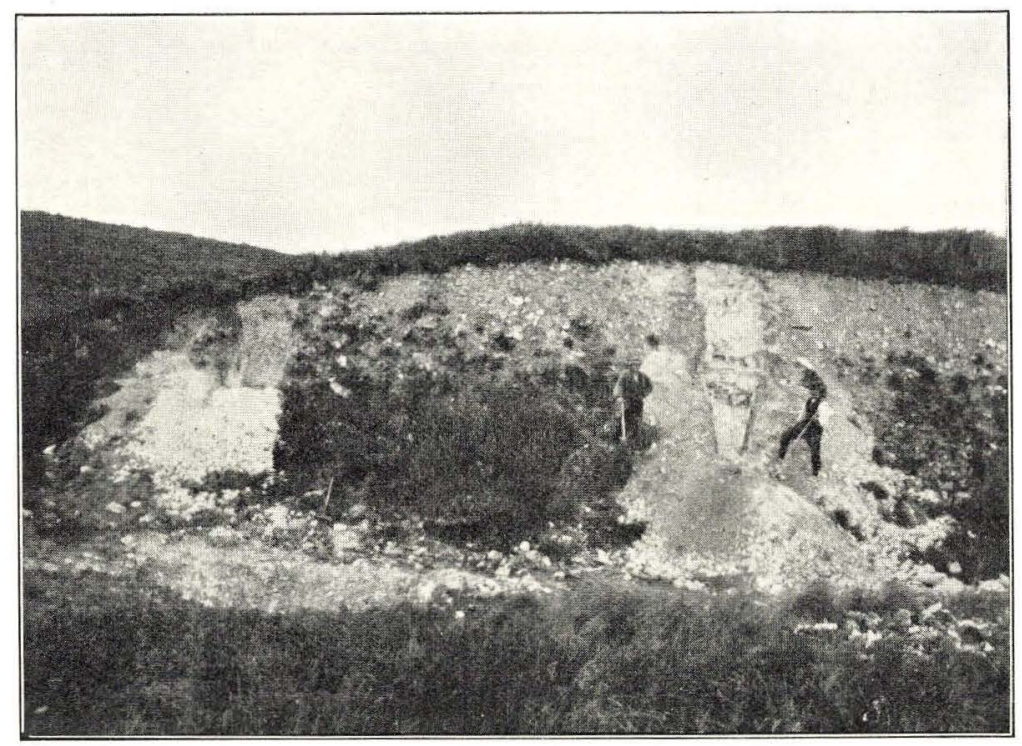

Fig. 17. Nystrup I. 
orienteret i Rækker, dels frit svævende i Kalken. Et sammenhængende Lag er dannet af mindre, sammenvoksede Knolde af uregelmæssig Form.

Lagene ligger i Form af et stort, fladt Trug med Strygning VNV.ØSØ. Paa begge Sider falder Lagene ca. $30^{\circ}$ indad. I Vestvæggen gaar Lagene 8-10 $\mathrm{m}$ fra Trugets Midtlinie over til horisontal Stilling.

Faunaen henviser Kalken til Y. Danium (Zone C).

Vang I. 68 (T. I). 104 (A. 4. 1).

$700 \mathrm{~m} \mathrm{~N}$. f. Kirken. Kote ca. $30 \mathrm{~m}$.

Kun lille Grav, hvis Vægge i 1923 var delvis tilskredne, og Profilet af ca. $2 \mathrm{~m}$ Højde ikke særlig godt.

Bjergarten er Bryozokalk ${ }^{1}$ ), ret blød og smuldrende i temmelig høj Grad, noget afsmittende; stedvis indeholder den haardere Partier. Bryozoerne udgør en meget stor Del af Bjergarten, indlejrede i en finkornet Grundmasse. Flinten er kun tilstede i ringe Mængde (mest løstliggende; Profilet er omtrent flintfrit) i Form af uregelmæssige, porøse Knolde af hvid og graa Farve.

Faunaen henviser Kalken til Y. Danium.

Torup I. 68 (S. 20, 22, T. I). 104 (A. 4. 2).

$1300 \mathrm{~m}$ S. f. Vang Kirke. Kote ca. $30 \mathrm{~m}$.

Graven her er stor, men var i 1923 for største Delen tilgroet. I Østvæggen fandtes dog en frisk Gravning, hvorved der var fremkommet et $10 \mathrm{~m}$ langt og $3 \mathrm{~m}$ højt Profil i Kalken, dækket af 0,5-1,0 m Diluvium.

Kalken er en blød, stedvis noget haardere, afsmittende Coccolitkalk, dog med et ret stort Indhold af Bryozoer, hvilket særlig ses paa lidt forvitrede Stykker. Bjergarten bestaar overvejende af en hvid, meget fin Grundmasse af Coccolitkalk, men Bryozoindholdet er i Almindelighed saa stort og sætter saa stærkt Præg paa Kalken, at denne maa siges at danne en Overgang til Bryozokalk. Bryozoindholdet kan imidlertid undertiden være saa ringe, at den fine Bjergart kommer til at minde om Skrivekridt. Milthers angiver 98,5\% $\mathrm{CaCO}_{3}$. Flinten forekommer i større og mindre, meget uregelmæssige Knolde; de er ret faste, men deres Overflade er stærkt »korroderet«, hullet og grubet. I Hulrummene findes løst Kalkpulver. Flinten er kun utydeligt ordnet i Rækker; Størsteparten er jævnt fordelt gennem Kalken i Profilet.

Lagstillingen er vanskelig at iagttage, men det synes, som om Lagene falder svagt mod Nord; dog kan man af de nævnte Grunde (hvortil

1) RAvn angiver Blegekridt, antagelig refererende til MiLthers' summariske Oplysninger om Kalken paa denne Egn.

Danmarks geologiske Undersøgelse. II. R. Nr. 45 . 
kommer, at Kalken er knust til ret stor Dybde) næppe tillægge dette større Værdi.

Faunaen henviser Kalken til Y. Danium (Zone C?).

Nystrup I. 68 (T. I). 104 (A. 3. 5).

$600 \mathrm{~m}$ V. f. Gaarden Nystrup. Kote $24 \mathrm{~m}$.

Lille Grav, for største Parten tilskredet og tilgroet, naar undtages en frisk Gravning i Gravens Bund, hvor der var blottet godt 1 m Skrivekridt. I den højere liggende, tilskredne Væg førtes i 1923 et Par Gravninger ind med en indbyrdes Afstand af $7 \mathrm{~m}$, hvorved der fremskaffedes gode Profiler gennem Lagene (Fig. 17-19).

G) I den omtalte Gravning i Bunden af Graven fandtes et rent Profil i Skrivekridt; dette var af almindelig Type, rent hvidt, uden noget større Indhold af Forsteninger. Heller ikke Bryozomængden viste sig at være større end i almindeligt Skrivekridt.

F) Blottet paa en vertikal Strækning af 1,2 m. Skrivekridt, hvoraf Hovedmassen er fint, ret blødt, hvidt, men fuldt af graa Ophiomorpha-agtige Dannelser. Disse er vandret liggende; de er i Reglen lige saa bløde som det omgivende Kridt, men undertiden er de dog forflintede i Midten og viser da ofte tydelige Rester af Spongiestrukturen. Ellers er Kridtet meget forsteningsfattigt og viser ikke den Tiltagen af Bryozoer og andre Forsteninger, som paa flere Lokaliteter iagttages lige under Senoniets Overgrænse.

$0,8 \mathrm{~m}$ under Lagets Overkant findes en Række af $5-10 \mathrm{~cm}$ tykke, sorte, typiske Skrivekridt-Flintnyrer, med ret tynd, hvid Skorpe. Under dette Flintlag skifter Kridtet Karakter, idet de graa Ophiomorpher forsvinder, og Kridtet viser sig som typisk Skrivekridt, aabenbart en direkte Fortsættelse af Kridtet i Gravningen G. Afstanden fra Flintlaget til Overkanten af G er $1,2 \mathrm{~m}$.

E) $0,65-0,75 \mathrm{~m}$ Coccolitkalk. Laget indeholder mindre, spredte Knolde af hvid - graa Flint, særlig i Lagets Over- og Underkant. Lagets Grænse nedad dannes ved en Række Flintknolde; i den ene af Gravningerne kommer dette dog ikke saa tydeligt frem i Underkanten paa Grænsen mod F. Kalken er haard og stærkt knoldet, fuld af uregelmæssige Hulrum, Spalter og Sprækker omkring de mere hærdnede Knolde. Bjergarten er meget finkornet, men dog noget grovere end Tilfældet er med Lag F og G; den er overalt gennemsat af Porer og Hulrum, dels paa Grund af ufuldstændig Sammenkitning, dels efter Opløsning af forskelligt organisk Indhold, især Svampenaale, der har opfyldt hele Kalkmassen. De øverste faa cm af 


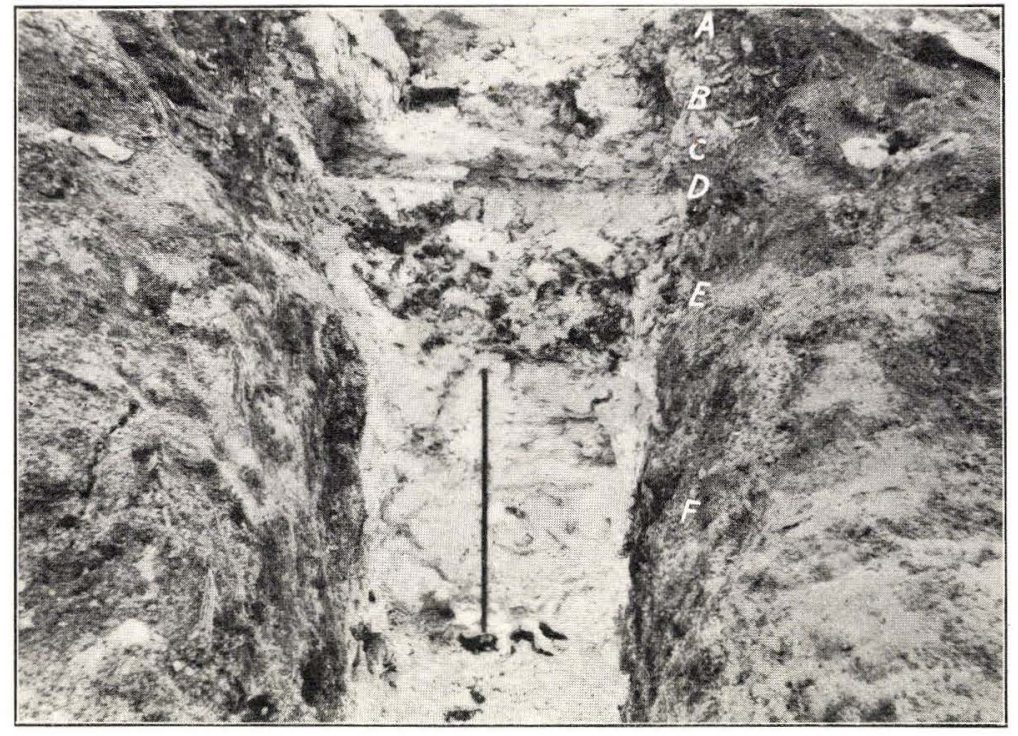

Fig. 18. Nystrup I. A Bryozokalk. B Flint. C Bryozorig Coccolitkalk. D Ler. E Coccolitkalk. F Skrivekridt.

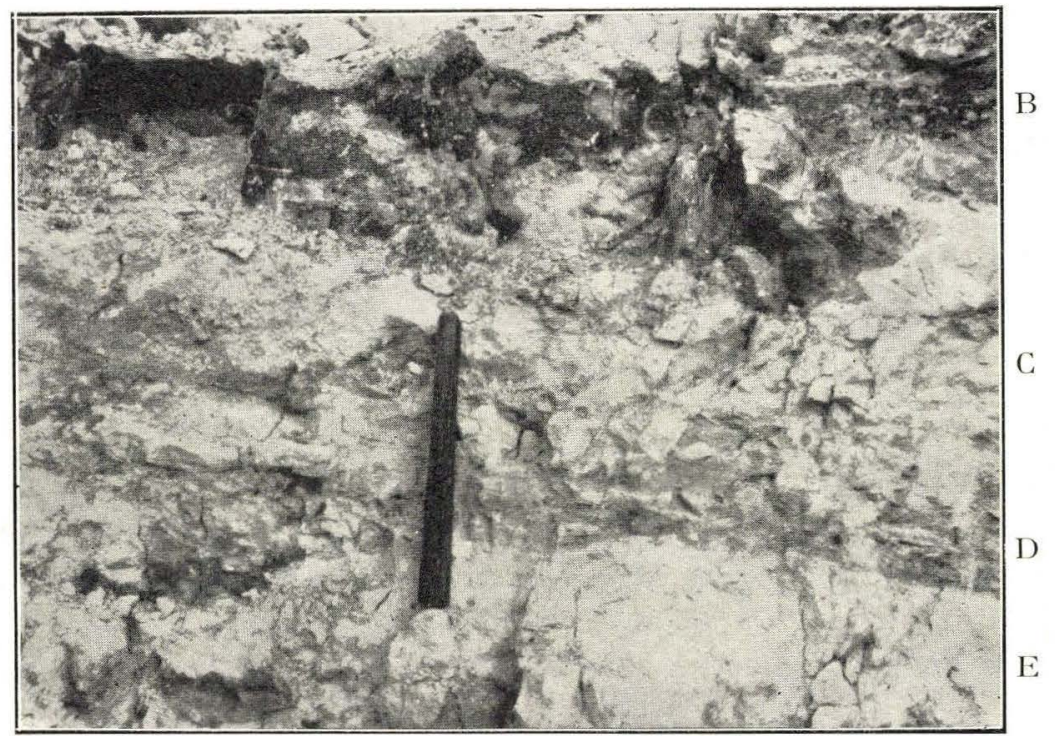

Fig. 19. Nystrup I. 
Laget er ikke knoldede, men mere homogene og blødere; Mægtigheden af denne øverste, ikke hærdnede Zone kan stige indtil $10 \mathrm{~cm}$, mens den paa andre Steder kan være ganske forsvindende. Overgangen mellem det haarde, knoldede Lag og denne øverste Zone er dog stadig ganske jævn og uskarp.

Hele Laget E antager ofte en gullig Farve, hvilket undertiden ogsaa gælder Flinten. Men medens dette i mindst Grad gælder den haarde Kalk, er det løse Kalkpulver i Sprækkerne mellem Knoldene oftest stærkt gult eller bestaar ligefrem af det rene Okkerpulver.

D) $6-8 \mathrm{~cm}$. Stærkt lerholdigt Kalklag, tydeligt lagdelt og stærkt spaltende; det er ikke brokket eller knust. Kalken er meget finkornet, ofte lidt grynet, og de enkelte Korn er ikke stærkt kittede til hinanden, ligesom Bjergarten er meget blød og afsmittende. Laget kan indeholde en Del Bryozoer, men disse er meget daarligt bevarede. Overgangen fra E opad til dette Lerlag er pludselig, men Grænsen er ikke absolut skarp; den er skarpere i den ene Gravning end i den anden. Opadtil er Lerlaget ikke skarpt begrænset, men gaar jævnt over i det følgende Lag.

C) $10-16 \mathrm{~cm}$. Coccolitkalk med et ret stort Indhold af Bryozoer, men disse er dog langtfra saa talrige som i det overliggende Lag A. Grundmassen er graalig hvid, finkornet, ret blød og afsmittende.

B) $20 \mathrm{~cm}$. Kompakt, sammenhængende Flintlag. Flinten er for en stor Del hvid, men med dominerende Partier af gulliggraa Farve.

A) Indtil 1,2 m. Bryozokalk, dels fastere og haardere, dels stærkere lagdelt og spaltet, gennemgaaende godt spaltende for Slag. De haardere Partier kan stedvis være ret klingende, men ellers er Kalken blød. Den bestaar af en finkornet, hvid Grundmasse med et stort Indhold af ikke særlig godt bevarede, smaa og fine Bryozoer. Bryozoindholdet er ens i de øvre og i de nedre Dele af Laget. Med $40 \mathrm{~cm}$ Mellemrum indeholder Lag A 3 Flintlag, eller rettere Rækker af delvis sammenhængende, tynde Nyrer af graa Farve.

Lagenes Kalkindhold fremgaar af følgende Analyser:

Lag A; øverste $40 \mathrm{~cm} \ldots \ldots \ldots \ldots . . .94,0 \%$

- A; mellemste $40 \mathrm{~cm} \ldots \ldots \ldots \ldots .96,8$.

- A; nederste $40 \mathrm{~cm} \ldots \ldots \ldots \ldots . .293,5$.

- C ................. 95,3 .

- D ............... 87,0

- E; haard Knold $10 \mathrm{~cm}$ under D. . 97,5 -

- F .................................. 98,0 -

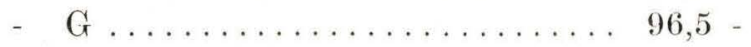


Lagstillingen horisontal.

Lagseriens palæontologiske Forhold vil blive nærmere omtalt i Kap. VI. Forsteningerne anføres i Bilag E. Lagene F og G er senonisk Skrivekridt; Lagene A-E maa henregnes til Daniet.

Bolsande I. 68 (S. 20, T. I). 104 (A. 3. 3).

$1950 \mathrm{~m} \mathrm{S \varnothing .} \mathrm{f.} \mathrm{Plantørboligen.} \mathrm{Kote} \mathrm{ea.} 28 \mathrm{~m}$.

Lille Grav, i 1923 fuldstændig tilgroet. Det var lige muligt at se, at Bjergarten er en hvid, bryozoholdig Kalk med et stort Indhold af hvid Flint.

Kalken tilhører muligvis Æ. Danium.

Klokrøgel I. 68 (S. 20, T. I). 104 (A. 3.4).

$1 \mathrm{~km} \mathrm{NV.f.} \mathrm{Vodbakke.} \mathrm{Kote} 15 \mathrm{~m}$.

Mage til og i samme Tilstand som Bolsande.

Klokrøgel II.

$400 \mathrm{~m}$ V.f. Vodbakke (Ø. f. Vejen). Kote $28 \mathrm{~m}$.

Lille Gravning, gammel og tilgroet. De opgravede Bunker bestaar af hensmuldret, noget bryozoholdig Kalk samt Blokke af hvid, stærkt forvitret Flint.

Faunaen henviser til A. Danium (Zone B).

Vegebjerg I. 68 (S. 20, T. I). 104 (A. 3. 1, 》Veggebjerg《).

$500 \mathrm{~m}$ NNV. f. Plantørboligen. Kote $15 \mathrm{~m}$.

Mindre Grav, Væggen ca. $10 \mathrm{~m}$ lang og indtil $4 \mathrm{~m} \mathrm{høj.} \mathrm{Profilet} \mathrm{be-}$ staa i sin øverste Halvdel af Lokalmoræne, delvis vandsorteret (lige til Overfladen); den nederste Del bestaar af uomlejret Kalk, men denne er saa stærkt knust, at Lagdelingen er omtrent udvisket.

Kalken $^{1}$ ) er en ret blød, temmelig bryozofattig Coccolitkalk, der stedvis er mere hærdnet, saa den ikke er afsmittende. Bjergarten er finkornet, svagt grynet, hvid af Farve. Flinten danner ret store Flager eller Knolde af ca. $10 \mathrm{~cm}$ Tykkelse af hvid Farve med Partier af sort og graa, hvidplettet Flint indvendig.

Lokaliteten maa sikkert henregnes til Y. Danium (Zone C?).

Vegebjerg II.

$1100 \mathrm{~m}$ SØ. f. Plantørboligen. Kote $19 \mathrm{~m}$.

Graven er lille, med en $3 \mathrm{~m}$ høj Væg, som i 1923 dog var helt tilgroet.

1) Kalken fra denne, saavel som alle de nærliggende Grave anvendes til Vejforbedring i Plantagen. 
Kalken, hvoraf en Mængde løst Materiale forefandtes, er en delvis stærkt hærdnet, ikke afsmittende Bryozokalk. Grundmassen er hvid, finkornet, opfyldt af Foraminiferer; den er stedvis noget porøs. Flinten er gulgraa af Farve.

Lagstillingen kunde ikke iagttages.

Lokalitetens stratigrafiske Stilling er usikker (Æ. Danium?).

Vorupør I. 68 (S. 4). 45 (S. 50).

Ved Læmolen. Ved Boring har man her truffet flintholdig Coccolitkalk paa en Kote af $\div 2,5 \mathrm{~m}$.

Stenbjerg. 68 (S. 4). 45 (S. 49).

Undergrunden bestaar her af Coccolitkalk (»Blegekridt(), men i hvilken Dybde den er faststaaende, er ikke fastslaaet.

Legind I. 16 (S. 66, "Kridt" (Skrivekridt)). 118 (S. 365). 119 (S. $\left.407^{1}\right)$ ). 24 (S. 211, "Kridt - Lægind«). 48 (Kortet, »Nyere Kridt«). 122 (S. 103, "Blegekridt《). 95 (S. 418). 123 (S. 35). 68 (S. 4, T. I, "Ovesø ). 5 (S. 192). 45 (S. 50). 104 (A. 4. 4).

Ved Nordenden af Ove Sø. Kote $15 \mathrm{~m}$.

Ret stor Grav, hvis 7-8 $\mathrm{m}$ hrje Vægge frembyder gode Profiler.

Kalken er absolut bryozofri Coccolitkalk, hvid med et gulligt eller graaligt Anstrøg; den er meget godt sammenhængende og brydes ud i store Blokke til Brænding. Kalken er afsmittende, blød at føle paa og meget mindre skarp end sædvanligt, men iøvrigt er Bjergarten, hvad Kornstørrelse m. v. angaar, typisk danisk Coccolitkalk, omend den mikroskopiske Undersøgelse viser, at de fineste Bestanddele - hvorimellem Coccoliter og Fragmenter heraf - spiller en temmelig stor Rolle. Flinten ligger i gennemgaaende, sammenhængende Lag, som Regel dannet af $10-20 \mathrm{~cm}$ tykke Knolde, graa med gulligt Anstrog og med tyk, hvid Skorpe. Desuden findes spredte, større Knolde af hvidgraa Flint. Omtrent i Væggens halve Højde findes et ejendommeligt Flintlag; det er $15 \mathrm{~cm}$ tykt og er et ensartet, uafbrudt Lag uden egentlig Knoldestruktur. Det er parallelt lagdelt, idet det gule Flintbaand indeholder Striber af hvid Flint; ved Brud spaltes det vandret i tynde Fliser.

Lagene stryger N. $45^{\circ} \varnothing$., hælder svagt $\bmod \mathrm{S} \varnothing$.

Kalken tilhører ifølge Faunaen Y. Danium (Zone C).

Ø. Jølby I. 123 (S. 35). 68 (S. 4). 104 (B. 4. 35).

$150 \mathrm{~m} \mathrm{~S}$. f. Skolen. Kote $12 \mathrm{~m}$.

1) J. SteEnstrup betragter i 1837 Bjergarten »som Skrivekridt, uagtet det hist og her er temmelig haardt«; i 1839 kalder han den "Bleger». 
Lille Grav, som i 1921 frembød Profil gennem 6 m Kalk, dækket af $0,5 \mathrm{~m}$ Opløsningsrester, væsentlig Flint blandet med Ler, stammende fra det nedsivende Vands Indvirkning paa Kalken, samt yderligere $0,5 \mathrm{~m}$ Overjord.

Kalken er en graa - undertiden lidt gullig - Coccolitkalk, finkornet, svagt sandet at føle paa, noget afsmittende, lidt porøs. Flinten er af sortgraa Farve og optræder i tykke, knoldede Lag.

Ifølge Maaling foretaget af Hr. Dr. Victor Madsen hælder Lagene $10-15^{0} \bmod \mathrm{N} .70^{\circ} \mathrm{V}$.

Sandsynligvis Y. Danium.

Ø. Jølby II. 123 (S. 35). 68 (S. 4). 104 (B. 4. 35).

$500 \mathrm{~m} \mathrm{S.} \mathrm{f.} \mathrm{Skolen.} \mathrm{Kote} 12 \mathrm{~m}$.

Graven var i 1921 tilskredet. Kalken er Coccolitkalk Mage til Kalken i $\varnothing$. J. I.

Eerslev I). 16 (S. 61, 63, 76, 79, „Eerslef-Grube«). 1 (S. 7, 》Mors Faxelaget«). 19 (S. 530, 535, „Erslevgruben«). 24 (S. 213). 50 (S. 51 ). 91. 95 (S. 401, 405, 411 m. v.). 76 (»Skrivekridt — Eerslev«). 81 (S. 18, »Erslev - Eldre Danien«). 68 (S. 5, T. I). ? 85 (»Older Danian«). 5 (S. 192, "Omegnen af Erslev«)2). 47 (S. 56). 104 (B. 4. 37).

$1200 \mathrm{~m}$ Ø. f. Kirken. Kote $19 \mathrm{~m}$.

Forсннаммев meddeler i 1835 Iagttagelsen af følgende Profil:

1) Skrivekridt.

2) et tyndt Leerlag.

3) haardere Kalksteen med Caryophyllea.

4) Blegekridt, som træder her i Stedet for Liimstenen.«

I sine korte Bemærkninger 1847 og 1869 synes Forchinamer dog snarere tilbøjelig til at lade Limsten følge efter »Faxelaget», og ikke Blegekridt.

K. J. V. Stennstrup har iagttaget den samme Lagserie, dog uden at finde Spor af det omtalte Lerlag (RAvn, 95, S. 405). Det samme gælder Ravs, der giver en udførlig Beskrivelse af Profilet:

»3. Blegekridt.

2. Cerithiumkalk.

1. Skrivekridt.

_ - Iøjnefaldende er det da, at man her ligesom i Stevns Klint har en ganske jævn Overgang mellem Skrivekridt og Cerithiumkalken,

1) Adskillige Forfattere nævner Daniumbjergarternes Forekomst "paa Mors", men de citeres kun for saa vidt, som deres Angivelser kan lokaliseres nærmere.

2) Gælder sikkert lige saa meget Eerslev II-IV. 
medens der findes en skarp Grænse mellem dette sidste Lag og det overlejrende Danien.«

Profilet, som dette præsenterer sig i de senere Aar, er gengivet paa T. III (og Fig. 20, S. 123).

C) $6 \mathrm{~m}$. Skrivekridtet i Graven er af den sædvanlige Type, ret blødt, stærkt afsmittende, meget fint. Forsteningsindholdet er ikke særlig stort, og nogen Rigdom paa Bryozoer i de øvre Lag iagttages ikke. Der findes tynde Lag af sort Flint.

B) $0,25 \mathrm{~m}$. "Cerithiumkalken« er en haard, klingende Kalksten, hvid af Farve, men gennemsat af okkerfarvede Sprækker og Spalter, der dels er plane, tydelige Brudflader, dels forløber ganske uregelmæssigt som Hulrum mellem de haarde Kalkknolde. Dette Kalklag indeholder en Mængde rørformede, grenede Hulrum, undertiden delvis fyldt med en stærkt poret Kalkmasse; de er fremkommet ved Opløsning af Kiselsvampe, hvis Naale iøvrigt har efterladt sig fine Hulrum overalt i Kalken. Bjergarten er meget finkornet, fuldstændig svarende til det underliggende Skrivekridt i denne Henseende; den er meget homogen, idet man — foruden de nævnte Svampeporer — kun nu og da ser en Foraminifer indgaa i Kalken.

Analysen viser et Indhold af 98,0\% $\mathrm{CaCO}_{3}$.

Lag B repræsenterer utvivlsomt en hærdnet Zone af det underliggende Skrivekridt, med hvilket det er forbundet ved jævn Overgang.

A) 0,20 m. Coccolitkalken er en Bjergart, der i sin nuværende Tilstand minder meget om Lag A ved Kjølby Gaard I og Coccolitkalken fra Hov I. Dens Grundmasse er ikke saa fin og homogen, som Tilfældet er med Lag B og C, men indeholder flere grovere Bestanddele. Kalken er næsten klingende haard, ubetydeligt afsmittende; i den faste Grundmasse ses en Mængde fine Huller efter Spongienaale. Kalken er i Profilets nuværende Tilstand stærkt knust, men iøvrigt er den fast og godt sammenhængende. Bryozoindholdet (Bryozoerne er fine og tynde) er meget ringe; ved Lagets Basis er det ganske forsvindende, $20 \mathrm{~cm}$ over Basis (største Mægtighed i 1924) noget større. Iøvrigt er Coccolitkalken meget forsteningsfattig. Den indeholder Flintknolde af gulgraa Farve og med ret tyk, hvid Skorpe. Analysen af Kalken viser et Indhold af $98 \% \mathrm{CaCO}_{3}$.

Ifølge Maaling udført af Hr. Dr. Viotor MAdser er Skrivekridtets Lagstilling saaledes: Strygning ca. N. $80^{\circ}$ V., Hældning $8^{\circ} \bmod$ N. Lagseriens stratigrafiske Stilling maa opfattes saaledes (se Kap. VI): Skrivekridtet og dettes øverste, hærdnede Lag (B) tilhører Senoniet, mens den overliggende Coccolitkalk er danisk. 
Eerslev II. 123 (S. 35, »Blegekridt«). 68 (S. 5, T. I). 104 (B. 4. 38).

$800 \mathrm{~m}$ N. f. Kirken. Kote $19 \mathrm{~m}$.

Graven er kun lille, faa $\mathrm{m}$ dyb, og den er omtrent tilskredet og tilgroet, saa den faststaaende Kalk kun ses paa en enkelt lille Plet.

Kalken er Coccolitkalk, ret blød og afsmittende, meget finkornet, gullighvid, med et ringere Indhold af velbevarede Bryozoer. Flinten er graasort, tykskorpet.

Lagstillingen kunde ikke konstateres.

Kalken tilhører sikkert Y. Danium.

Eerslev III. 123 (S. 35, »Blegekridt《). 68 (S. 5, T. I). 104 (B. 4. 38). $700 \mathrm{~m}$ Ø. f. Kirken. Kote $22 \mathrm{~m}$.

Graven er ret stor, ca. $5 \mathrm{~m}$ dyb, men har i de senere Aar kun frembudt daarlige Profiler. Kalken er Coccolitkalk, ret fin, hvid. Flinten er meget mørk og optræder i tynde Lag.

Lagstilling horisontal.

Faunaen henviser Kalken til Y. Danium (Zone C).

Eerslev IV. ? 123 (S. 35, »Blegekridt«).

$400 \mathrm{~m}$ NV. f. Kirken. Kote $15 \mathrm{~m}$.

Ret stor Grav, men gode Profiler, 5-6 m høje ialt, findes kun i ringere Udstrækning.

Kalken er Coccolitkalk, temmelig fast, men godt og stærkt spaltende, noget afsmittende og kun i ringere Grad stærkere hærdnet. Grundmassen af Kalken er meget fin, hvid. I den øverste Del af Profilet er Kalken meget bryozofattig, men i det nederste Par $\mathrm{m}$ indeholder Kalken en Del Bryozoer; Overgangen er fuldstændig jævn. Flinten er dels graa og hvid, dels mere mørk, omtrent sort; den danner Rækker af sammenhængende, flade Knolde.

Lagstillingen er paa det nærmeste horisontal.

Faunaen er ikke afgørende for Lokalitetens Klassificering, men den maa formodentlig henregnes til Y. Danium ${ }^{1}$ ).

Tødse. 16 (S. 64, »Tødse-Grube«). 20 (Kortet, »Todsø«). 68 (S. 5).

Lokalitetens Beliggenhed kendes ikke.

Forсннаммев angiver Forekomsten af "Blegekridt", og dettes Hældning til at være nordlig.

1) Et Eksemplar af Isis vertebralis, opbevaret paa Mineral. Museum, er etiketteret »Eerslev«; der er en vis Sandsynlighed for, at dette kan hidrøre fra den bryozorige Horisont i Eerslev IV, som i saa Fald maa sættes som sikkert Y. Danium. 


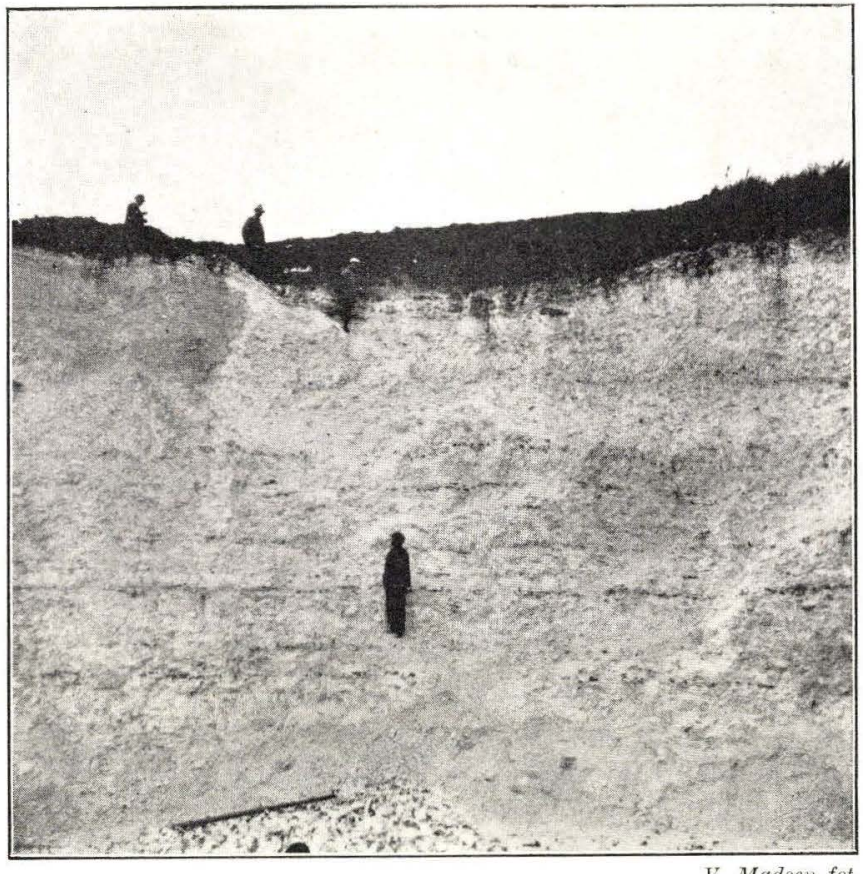

Fig. 20. Eerslev I. Grænsen mellem Skrivekridt og Danium ligger tæt under Profilets Overkant.

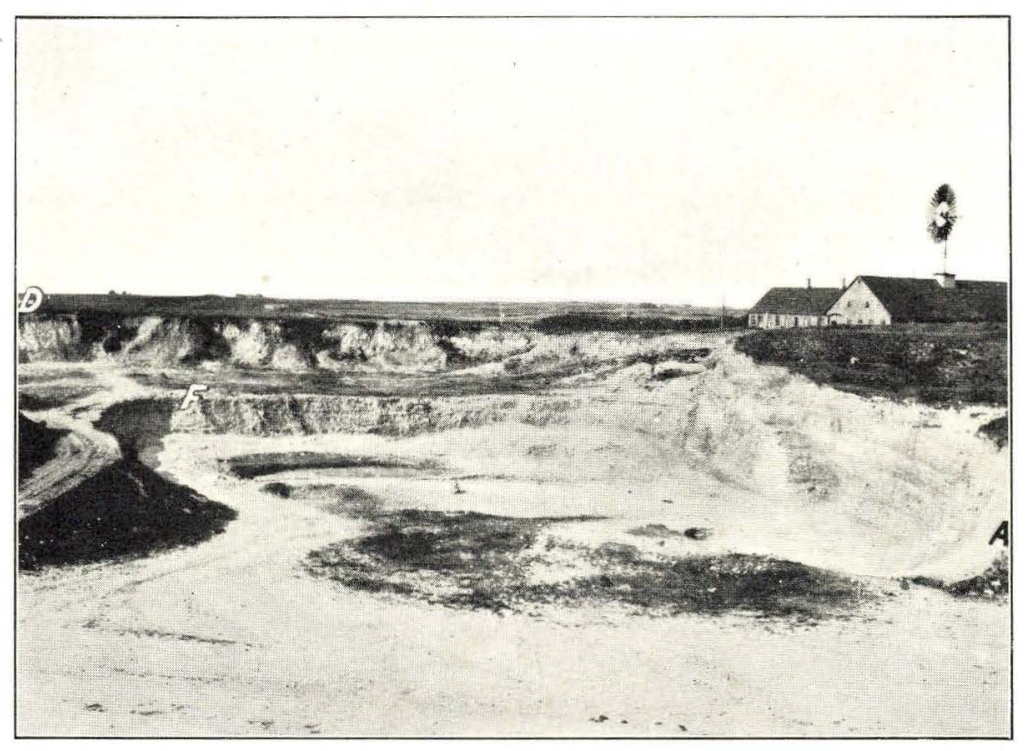

Fig. 21. Helligkilde I. Set mod NV. 
Frøslev Gaard. ? 95 (»Frøslev«)1). 104 (B. 4. 39).

I 1923 fandtes ingen aaben Grav ved Frøslev Gaard. De paa Mineral. Museum opbevarede Prøver viser en mere eller mindre hærdnet, finkornet, ved Berøring svagt sandet Coccolitkalk.

Frøslevvang I. 95 (»Frøslev Vang«)2). 123 (S. 35). 76 (»Skrivekridt Frøslevvang(). 68 (S. 5, T. I). 104 (B. 4. 40).

$300 \mathrm{~m}$ NØ. f. Glintborg. Kote ca. $31 \mathrm{~m}$.

Stor Grav, som i 1923 var omtrent helt tilgroet; kun i et Hjørne længst mod NV. saas lidt Kalk, men Profilet her var ogsaa stærkt tilskredet.

Kalken er Coccolitkalk, næsten helt fri for Bryozoer; stedvis er den ret blød, afsmittende, men der findes dog ogsaa meget hærdnet Kalk i gamle Bunker. Bjergarten er finkornet, svagt sandet at føle paa, gulliggraa af Farve. Kalken er meget rig paa Ophiomorpher, og især paa forvitrede Flader ser man dem i store Mængder. Flinten er graa.

Lagstillingen kunde ikke observeres med Sikkerhed.

Faunaen henviser Kalken til Y. Danium (Zone D?).

Frøslevvang II. ? 16 (S. 64, »Frøslef-Grube«). 953). 123 (S. 35). 68 (S. 5, T. I). 104 (B. 4. 40).

$400 \mathrm{~m} \mathrm{S.} \mathrm{f.} \mathrm{Glintborg.} \mathrm{Kote} \mathrm{ca.} 31 \mathrm{~m}$.

Meget store Grave paa begge Sider af Vejen, der frembyder gode, $8-9 \mathrm{~m}$ høje Profiler.

Kalken er en finkornet Coccolitkalk med kun enkeltvis forekommende Bryozoer; den er blød, afsmittende, meget smuldrende, oftest kun meget løst sammenhængende. Bjergarten spalter ikke særlig udpræget; Farven er hvidgraa. Flinten er omtrent sort, forekommer i meget store Blokke, ofte med hvide, kalkrige, smuldrende Partier indvendig. Flintblokkene optræder som Regel spredt og uden Orden, kun sjældnere ordnet i Rækker. Desuden findes hvid Flint som Imprægnation i Kalken.

Forchinamer opgiver "Schichternes Fald« til $10^{\circ} \mathrm{S}$. Hr. Direktør, Dr. phil. Victor MaDSEN har i 1921 maalt Lagenes Hældning til ca. $15^{\circ} \bmod$ S., Strygningen N. $80^{\circ}$ V., men Lagstillingen gør ikke Indtryk af at være helt konstant.

Faunaen henfører Kalken til Y. Danium (Zone D).

1) Ravn sætter udtrykkelig »Frøslev« i Modsætning til "Frøslev Vang".

${ }^{2}$ ) Gælder formodentlig baade Frøslevvang I og II; den sidste Grav er den største.

$\left.{ }^{3}\right)$ Se Fodnote til Frøslevvang I. 
Øxendal. 16 (S. 64, 80, „Øxendal - Blegekridt - Skrivekridt《). 95 (S. 349, Faunaliste III, 》 Øxendal - (Blegekridt) - Skrivekridt«). 80 (»Øxendal - Senon«). 68 (S. 5, T. I, »Blegekridt«). 104 (B. 4. 41, »Frøslevvang - Blegekridt ().

$600 \mathrm{~m} \mathrm{SSV}$. f. Thorshøj. Kote $25 \mathrm{~m}$.

Gravene her er fuldstændig tilgroede. De var allerede i Forfald og Brydningen ophørt ved K. J. V. Stennstrup's Besøg 1869. Ifølge Litteraturen skal der her forekomme Skrivekridt overlejret af »Blegekridt« under lignende Omstændigheder som ved Eerslev I.

Forchнамmer opgiver Lagenes Hældning til $10^{\circ} \mathrm{SS} \varnothing$.

Se iøvrigt Kap. VI.

Lødderup I. 16 (S. 64, »Lodderup «). 68 (S. 5, T. I). 104 (B. 4. 42, »N. f. Løderup «).

Grav lidt N. f. Lødderup. Graven er tilgroet.

Paa Mineral. Museum findes en Prøve, bestaaende af hvid Coccolitkalk, ret hærdnet; den er finkornet, men indeholder spredte, rullede Bryozostumper og smaa Kalkkorn. Hertil kommer et Par Prøver af hvid og graa Flint.

Forchнамmer opgiver, at Lagene hælder $10^{\circ} \bmod$ SSØ.

Navtrup. 68 (S. 5, 16).

Ifølge MiLtнers skal der forekomme Blegekridt i Egnen S.-SØ. f. Glyngøre. En indsendt Kalkprøve fra Navtrup havde vist et Indhold af $89,5 \% \mathrm{CaCO}_{3}$.

I 1923 fandtes der ikke omkring Navtrup nogen Kalkgrav, idet Egnen her blev forsynet med Kalk fra Batum. Som omtalt andetsteds (Kap. IV) bestaar Kalkforekomsterne ved Batum og Torum af Skrivekridt, saa det vilde have været af stor Interesse at faa nærmere Oplysninger ogsaa om Kalken i denne Egn. Da Omraadet omkring Navtrup aabenbart danner et Parti for sig, er der, indtil nærmere Undersøgelse en Gang kan foreligge, næppe Grund til at betvivle, at Undergrunden her kan udgøres af Danium.

Helligkilde $\mathrm{I}^{1}$ ). 16 (Kortet). 1 (S. 8, „Saltholmskalk — det sydlige Thyholm《). 24 (S. 211, »Thyholm - Liimsteen«). 91 (»Limsten - Helligkildeby Mark«). 122 (S. 103, »Blegekridt - paa Thyholm (ved Hvidbjerg(i)). 30 (S. 36, »Thyholm«). 95 (»Helligkildeby — Blegekridt«). 123 (S. 35, »Thyholm«). $\% 6$ (»Yngre Bryozokalk — Helligkilde Mark«). 80

1) Da de fleste Forfattere kun opgiver "Thyholm«, "Helligkilde« eller lignende, maa den citerede Litteratur sikkert ogsaa ofte omfatte Helligkilde II og III, uden at dette kan udredes. 
(»Helligkilde, Thyholm - Yngre Danien«). 68 (S. 4, T. I). 71 (S. 5). 5 (S. 192, »Hvidbjærg«). 104 (A. 5. 3).

$1600 \mathrm{~m}$ N. f. Uglev Station, $800 \mathrm{~m} \mathrm{~V}$. f. Lynghøj. Kote $38 \mathrm{~m}$.

Hovedgraven lige S. f. Gaarden er meget stor, ca. $100 \times 60$ m (Fig. 21-24) og frembyder delvis meget gode Profiler. Kalken varierer lidt i Sammensætning; for det meste er det en meget bryozofattig Coccolitkalk, hvid, finkornet, lidt afsmittende. Stedvis er Kalken rigere paa Bryozoer, og i Zonen omkring Linien A-B (særlig smukt fremtrædende i Profilet ved C) er det en ren Bryozokalk (Ussing omtaler denne Varietet af Kalken i 1899), som er meget rig paa Koraller m. m. Grundmassen af Bjergarten er identisk med den øvrige Coccolitkalk i Graven, men er opfyldt af de tætlejrede Bryozoer; Bryozokalken er

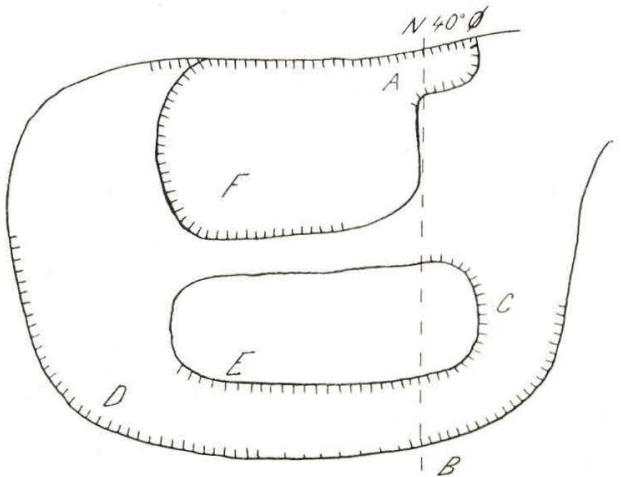

Fig. 22. Helligkilde I. Skematisk Plan over den store Grav. iøvrigt ikke særlig haard. Ø. f. (d. v. s. ovenover) denne Horisont af Bryozokalk gaar Kalken atter med jæevn Overgang - over til den normale, bryozofattige Type af Coceolitkalk. Flinten danner Lag, som Regel tynde og meget porøse og ofte meget tætliggende; den er graa — omtrent sort, undertiden brunlig. Af og til ses enkelte, større Blokke paa indtil $1 \mathrm{~m}$ i Diameter.

Igennem Graven (A-B) gaar med en Retning af ca. N. $40^{\circ} \varnothing$. en Forkastning, eller rettere sagt en Brudzone; langs denne er Lagene paa Østsiden sænket og hælder $20-30^{\circ} \bmod \varnothing$. I Nordvæggen (ved A, Fig. 23) viser dette sig som et tydeligt Spring, i Sydvæggen (ved B) er det nærmest en Flexur, hvor Lagene bøjer fra vandret Stilling V. f. Linien til hældende Stilling Ø. f. denne. Foruden de oprindelige Flintlag er der i de ved Forstyrrelserne opstaaede Sprækker ofte dannet Pladeflint (med forskellig Orientering.).

I den sydvestlige Del af Graven (ved D) hælder Lagene mod Ø. med omtrent nordlig Strygning, maaske som ved den store Forkastning A-B, Hældningen er ca. $30^{\circ}$; Strækningen mellem B og D er skjult af Skred. Lagene har her været udsat for et stærkt Tryk, og Sprækker gaber overalt. Der findes flere Spring med en Hældning af ca. $45^{\circ} \bmod V$., men Springhøjden er dog stadig ringe. Paa Fig. 24 ses, hvorledes det store Flintlag midt i Væggen har været Genstand for flere Forskydninger, hvorved det paa flere Steder er blevet tværet ud til en Breccie. Til højre paa samme Billede ses en 1,25 m bred Spalte, hvis nærmere For- 
løb dog ikke kunde konstateres; den er udfyldt med Diluvialsand. Paa Jord- og Kalklagene over Spalten kunde det ses, at Isens Bevægelse har været fra Ø. eller $\mathrm{N} \varnothing$.

I Væggen E samt i hele den lavere liggende Del af Graven, F (indtil den store Forkastning ved A), ligger Lagene horisontalt, men Overgangen til de hældende Lag ved D kunde ikke ses.

Faunaen henviser Kalken til Y. Danium (Zone C?).

Helligkilde $\left.\mathrm{II}^{1}\right)$.

$400 \mathrm{~m}$ Ø. f. Helligkilde I. Kote $28 \mathrm{~m}$.

Lille, forholdsvis dyb Grav med kun delvis gode Profiler. Al Kalk i Profilerne er af samme Type som den- bryozofri Coccolitkalk i Helligkilde I, og ogsaa Flinten er den samme.

Lagene hælder ca. $10^{\circ} \bmod \varnothing$.

Faunaen henviser Kalken til Y. Danium (Zone C?).

Helligkilde III. 68 (S. 4, T. I). 104 (A. 5. 2) $)^{1}$ ).

$200 \mathrm{~m} \mathrm{~V}$. f. Helligkilde I. Kote $30 \mathrm{~m}$.

Graven er ret stor og dyb, men Væggene frembyder kun delvis gode Profiler.

Kalken er af den samme bryozofri Type Coccolitkalk, som danner Hovedmassen i Helligkilde I.

Lagene ligger omtrent horisontalt, dog med en meget svag Hældning $\bmod \varnothing$.

Kalken tilhører utvivlsomt ogsaa Y. Danium.

Skive I. 122 (S. 102). 125 (S. 192). 63 (S. 96). 127 (S. 129). 4 (S. 86). 7 (S. 182). 104 (B. 5. 9).

Boring ved Skive Station, udført i Aarene 1895-96. Kote ca. 3 m. BøGGILD har revideret det foreliggende og meddeler (4) følgende Profil :

0-4 m Kvartær,

$4-45$ - Septarieler,

45-58 - Mørkebrunt, kalkfrit, plastisk Ler,

58-66 - Rødt, kalkholdigt, plastisk Ler,

66-74 - Vulkansk Tuf,

74-79 - Vulkansk Tuf med kalkfrit, plastisk Ler,

79-91 - Graat, kalkfrit Ler,

91-114 - Graat, kalkholdigt Ler,

114-118 - Nyere Kridt.

1) Se Litteraturlisten under Helligkilde I. 


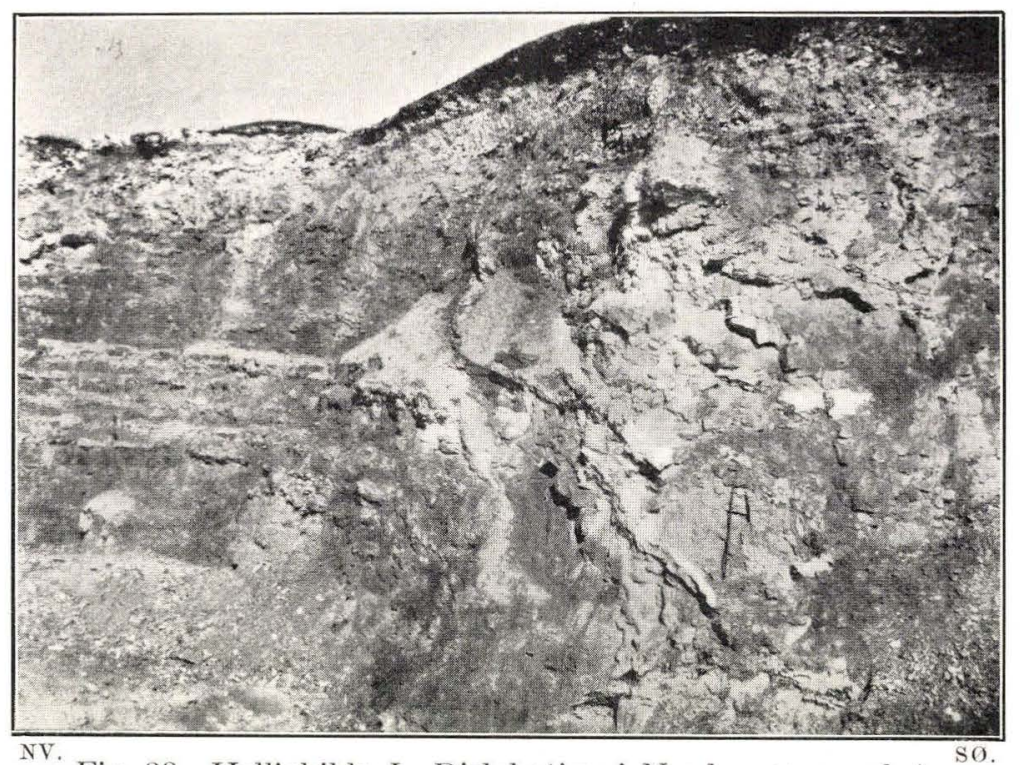

Fig. 23. Helligkilde I. Dislokation i Nordvæggen ved A.

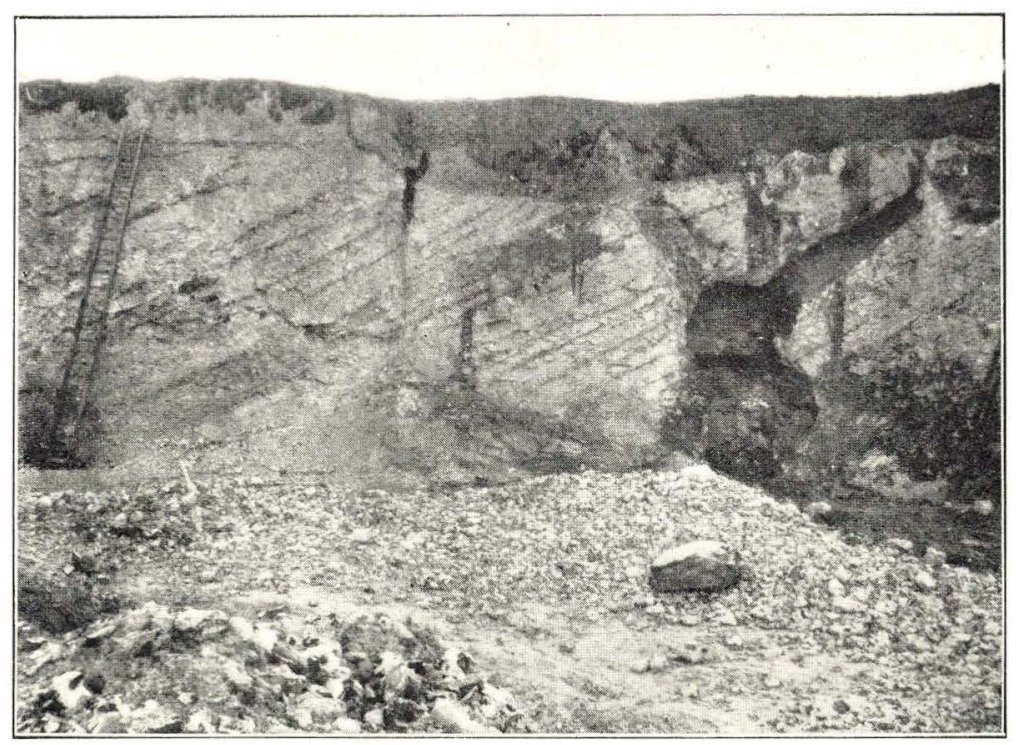

Fig. 24. Helligkilde I. Sydvestvæggen ved D. Hældende Lag med Forkastninger og Sprækker. 
Blandt de paa Mineral. Museum opbevarede Prøver findes ogsaa en af Daniet fra $114-118 \mathrm{~m}\left(364^{\prime}-3751 / 2^{\prime}\right)$. Den bestaar overvejende af fint knust Flint af graa, undertiden gullig Farve, men desuden i næsten lige saa høj Grad af Bryozofragmenter og smaa Brokker af meget finkornet Coccolitkalk. Bjergarten er sandsynligvis Bryozokalk, bygget af smaa, tynde Bryozoer og en finere Grundmasse.

Udover Bryozoerne er i Prøven kun set enkelte Foraminiferer og et ubestemmeligt Fragment af en Cidarispig.

Davbjerg I. 3 (S. 265, »Dagbjerg«). 16 (S. 63, 80, »Daugbjerg«). 1 (S. 8). 19 (S. 536). 48 (S. 6). 50 (S. 52). 91 (»Limsten«). 112 (S. 79). 122 (S. 101). 95.123 (S. 33). 76 (S. 165). 113 (S. 54). 73 (S. 34). 656 (S. 51). 7 (S. 182). 104 (C. 5. 3).

Den brede Dalsænkning, der $\varnothing$. f. Kirken strækker sig op gennem Byen, er ganske oversaaet med gamle Grave, runde Huller Side om Side, mindende om Granatkratere. Nutildags er alle Grave imidlertid fuldstændig tilgroede. Kote ca. $30 \mathrm{~m}$.

Posselts Angivelse af Terebratula lens (som Brünnich Nielsen betvivler) er rigtig nok, idet Stykket findes paa Mineral. Museum.

Faunaen henviser Kalken her til Y. Danium.

Davbjerg II.

$1200 \mathrm{~m}$ NNØ. f. Davbjerg Kirke. Kote ca. $45 \mathrm{~m}$.

Den her beliggende lille Dal er fuldstændig opfyldt med gamle "forhistoriske« Grave, enten gravet som aabne Brud ind i Dalsiderne eller som tragtformige Huller, der ofte er af en anselig Dybde. Desuden er der for et Par Aar siden opdaget underjordiske Brud af ukendt Alder, i Form af vidtstrakte, forgrenede Systemer af lave, smalle Stoller.

I den nedre Del af Dalen er Kalken synlig i Dagen i nogle friske Gravninger, som dog ikke er særlig gode; Kalken er synlig i indtil $2 \mathrm{~m}$ høje Profiler, naaende omtrent helt op til Jordoverfladen. Det er Coccolitkalk, graa, skarp, lidt sandet, ret blød og afsmittende; den er stærkt spaltende. Flinten danner store, hvide - lysegraa Knolde, uregelmæssigt fordelt i Kalken.

Lagene synes at hælde svagt mod SØ., men Profilets daarlige Tilstand umuliggør en sikker Bestemmelse heraf.

Kalken er yderst forsteningsfattig, men maa formodes at tilhøre Y. Danium.

Davbjerg III.

$800 \mathrm{~m}$ NØ. f. Davbjerg Kirke. Kote ca. $40 \mathrm{~m}$.

Her findes et Par smaa, ikke særlig dybe Grave; af løstliggende Materiale ses det, at der her forekommer Coccolitkalk, men Gravene er iøvrigt fuldstændig tilgroede. 
Stavnsbjerg I. 73 (T. I, "Blegekridt»). 104 (C. 5. 4, "Blegekridt«).

Umiddelbart ved Gaarden. Kote ca. $30 \mathrm{~m}$. Graven er nu tilgroet.

Mønsted I'1). 3 (S. 265). 16 (S. 63, 80). 1 (S. 8). 19 (S. 536). 48 (S. 6). 50 (S. 52, 53). 112 (S. 79). 122 (S. 99, 101). 95.123 (S. 33). 113 (S. 54, 55). 73 (S. 34, T. I). 656 (S. 51). 7 (S. 182). 104 (C. 5. 5).

»De jydske Kalkværker«s store Brud 1400 m NV.f. Kirken. Kote 47 m.

Graven er meget stor, med 12-14 m høje Profiler i Kalken, overlejret af endnu nogle $m$ Diluvialsand. Foruden i det store, aabne Brud er Kalken tillige tilgængelig i de udstrakte Kover, der aabner sig i Bunden af Bruddet. Brydningen af Kalken - baade til Brænding og Gødning - er i de senere Aar væsentlig foregaaet i Koverne, saa de store Profiler i Dagen er i Forfald og delvis dækket af nedstyrtet og nedskyllet Sand, hvorfor de ikke frembyder saa gode Betingelser for Studiet af Kalklagene.

Kalken er Coccolitkalk og er af en ret ejendommelig, nok nogenlunde sammenhængende, men ikke hærdnet Beskaffenhed, stedvis dog ogsaa temmelig løs og blød, i Almindelighed godt spaltende. Den er afsmittende, sandet at føle paa, lysere eller mørkere graalighvid, undertiden med et rødligt Skær. Flinten er graa og optræder dels som svævende Blokke i Kalken, dels i Lag og tykkere Bænke, indesluttende hvide, flade Kalkpartier.

Lagstillingen er meget indviklet, idet Lagene falder i forskellig Retning, og der hyppigt optræder Foldninger og Spring. Diskordanser mellem Flintlagene ses ligeledes, men synes ikke altid at kunne henføres til senere Forstyrrelser af Lagene. Paa Grund af Profilernes ovenfor omtalte, daarlige Tilstand er det imidlertid umuligt at foretage en nærmere Udredning af Forholdene.

Kalken er meget forsteningsfattig, men de fundne Former henviser den til Y. Danium (Zone D).

Mønsted II. 104 (C. 5. 6, »Bryrup Mølle«).

$1 \mathrm{~km}$ N. f. Kirken. Kote ca. $30 \mathrm{~m}$.

Skrænten paa Vestsiden af Dalen er her ganske opfyldt af gamle Grave, runde Huller, der ofte er meget dybe. De er imidlertid alle fuldstændig tilgroede, og kun ved senere Gravning eller Skred er Materialet synligt i nogle Afrømningsbunker.

Kalken er en graa Coccolitkalk af samme Art som i de andre Grave paa Egnen, men kun smaa Brokker fandtes. Flinten er delvis graa, men tildels ogsaa meget mørk.

1) Naar Literaturen kun nævner »Mønsted«, »ved Mønsted « eller lignende, omfatter dette maaske, foruden Mønsted I, undertiden tillige de i Nærheden liggende Lokaliteter, uden at dette kan bestemmes nærmere. 


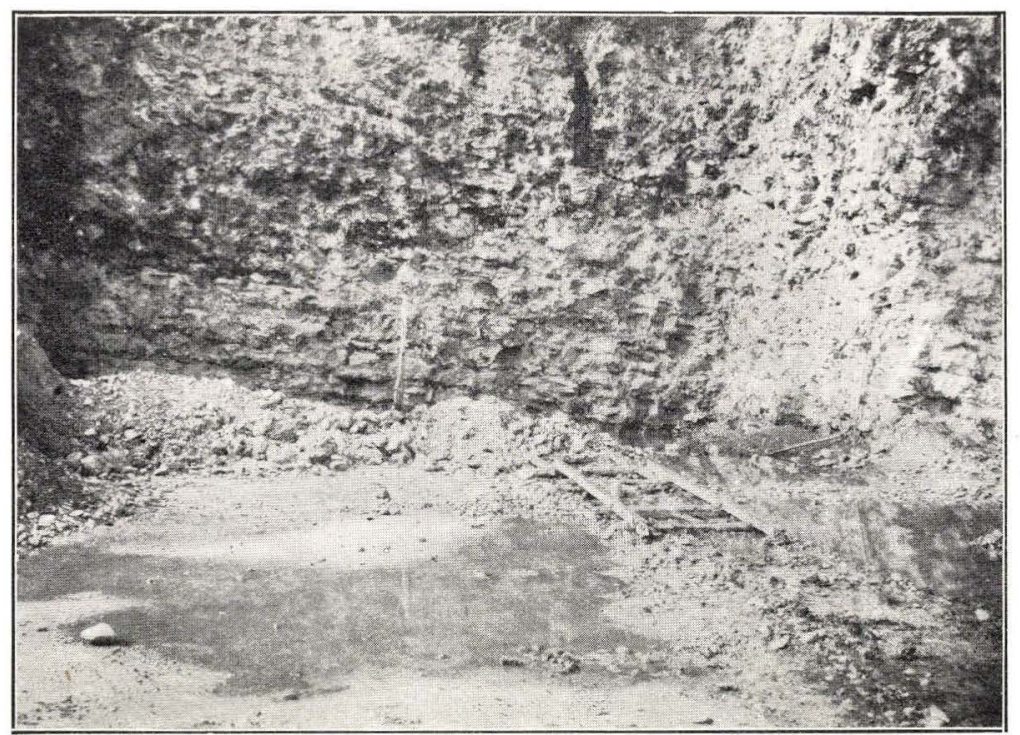

Fig. 25. Sevel I.

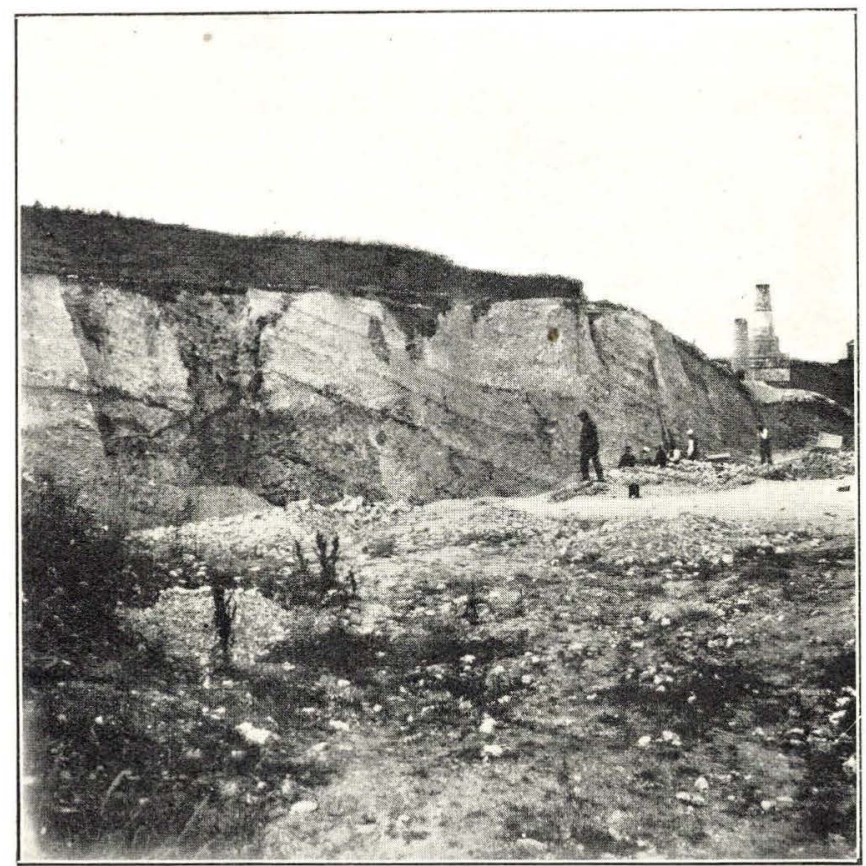

Fig. 26. Vejrum I. Set mod NV. 
Lagstillingen kunde ikke iagttages.

Faunaen henviser Kalken til Y. Danium.

Mønsted III. 112 (S. 79, »Rings Brud«). 73 (S. 34, T. I). 104 (C. 5. 7). »Mønsted Kalkværk«s Brud $1 \mathrm{~km}$ SV. f. Kirken. Kote $40 \mathrm{~m}$.

Ret stor, ca. $10 \mathrm{~m}$ dyb Grav, hvori Kalken dog ikke naar helt op til Overfladen, men dækkes af nogle m Diluvialsand. Kalken er en ret fast, men ikke haard, graa, lidt sandet Coccolitkalk. Den ligger i ret rene Bænke, adskilte ved Rækker af sammenhængende Flintknolde. Flinten synes ikke at danne massive Bænke som i Mønsted I; den er hvid og graa af Farve, og Knoldene er ofte stærkt svampede og porøse.

Da Brydningen er ophørt, er Profilet meget ødelagt og tilskredet, saa Kalken kun ses faststaaende et enkelt Sted og i ringe Udstrækning. Det er derfor vanskeligt at bedømme Lejringsforholdene, men Lagene synes at hælde svagt mod NØ.

Faunaen henfører Kalken til Y. Danium (Zone C?).

Sevel I. 122 (S. 102). 123 (S. 33). 123 a (S. 148). 113 (S. 54). 64 (»Stubbergaard Sø«). 71 (S. 5). 8 (S. 381, »Søndermølle«). 104 (B. 5. 16).

Sevel Kalkværk, $1200 \mathrm{~m}$ SSØ. f. Søndermølle ved Sydenden af Stubbergaard Sø. Kote $26 \mathrm{~m}$. Kalkværkets Grav er stor og frembyder gode Profiler (Fig. 25), hvori ses godt $5 \mathrm{~m}$ Kalk, overlejret af $1-2 \mathrm{~m}$ senglacialt Smeltevandssand. $500-800 \mathrm{~m} \mathrm{~V}$. herfor ses en Del ganske tilgroede Grave uden Profiler.

Kalken er Coccolitkalk, som kun indeholder spredte, enkeltvis forekommende Bryozoer. Kalken er let smuldrende, svagt grynet, graalig af Farve, noget afsmittende, sandet at føle paa. Under Mikroskopet viser Kalken sig overvejende at bestaa af meget fine Kalkpartikler samt en ringere Mængde større; de er delvis stærkt sammenkittede, og tydelige Calcitkrystaller findes. Foraminiferer og Coccoliter spiller en stor Rolle. Kalken indeholder 97,5\% $\mathrm{CaCO}_{3}$. Flinten er graa; den danner sammenhængende Lag, tildels massive, oftere dog mere eller mindre porøse, indtil $10 \mathrm{~cm}$ tykke. Flintlagene ligger tæt, gennemgaaende kun adskilt af $10-30 \mathrm{~cm}$ Kalk.

Lagene stryger $\varnothing .-\mathrm{V}$., hælder $15^{\circ} \bmod \mathrm{N}$.

Efter Faunaen maa Lokaliteten henføres til Y. Danium (Zone D).

Vejrum I. 16 (S. 81 ). 48 (S. 6). 50 (S. 52 ). 113 (S. 54 ). 71 (S. 5 ). 8 (S. 381). 104 (B. 5. 11).

$800 \mathrm{~m}$ SSV. f. Vejrum Kirke. Kote $31 \mathrm{~m}$.

Milthers giver følgende Beskrivelse af Stedet: "Der er her gamle Brud paa begge Sider af den Dal, som gaar mod Nord forbi Vejrum 
Kirke; for Tiden brydes der Vest for Dalen. Her findes i den nordlige Del af Bruddet Blegekridt med temmelig megen Flint og hældende mod Nord. I den sydlige Del af Bruddet findes derimod brokket Skrivekridt med Flintlag, hældende mod Nord. Hældningen er ca. $20^{\circ}$.«

Graven er en ret stor Grav, hvori Kalken brydes baade til Brænding og til Gødning. Den nordligste Del af Graven er i de sidste Par Aar tilgroet, men det ses dog, at Kalken her er ganske som i den nordlige Del af det nedenfor omtalte Profil.

Den sydlige Del af Graven (Fig. 26) frembyder i Vestvæggen et ca. $8 \mathrm{~m}$ højt Profil i Kalk, dækket af et Par m Diluvium.

Længst mod Syd i Profilet (Lagene hælder mod Nord) er Coceolitkalken meget fin, omtrent skrivekridtagtig, men ikke saa rent hvid paa friske Flader, som det er Tilfældet med Skrivekridt. Den er ret sammenhængende uden at være haard, ved Berøring afsmittende, blød, næsten fed at føle paa. Kalken her er i hele Væggens Højde stærkt forkløftet, uden at de enkelte Brokker er bragt ud af deres indbyrdes Stilling, samt meget stærkt okkerfarvet. I denne sydlige Del af Profilet ligger Flintlagene med større indbyrdes Afstand, indtil $1 \mathrm{~m}$.

I den nordlige Del af Profilet, hvortil Overgangen er ganske jævn, bliver Coccolitkalken en Smule mindre fin, omend Forskellen er meget ringe. Dog er Kalken straks lidt mere skarp at føle paa, men finere end Coccolitkalken i Almindelighed er; den er fast, men kun sjældent stærkere hærdnet. Flintlagene ligger her en Del tættere end i den sydlige Del af Profilet. Ophiomorpher er ikke sjældne.

Flinten er ens i hele Profilet, lysere eller mørkere graa eller stærkt gul. Den optræder som flade Konkretioner, skarpt begrænsede, $10-20 \mathrm{~cm}$ tykke Lag eller tyndere, næsten pladeformede Lag. De flade Knolde danner ogsaa Rækker, og alle Rækker og Lag er ensartet gennemgaaende.

Ifølge Maaling foretaget af Hr. Direktør, Dr. phil. Victor Madsen hælder Lagene i den sydlige Del af Profilet $20-22^{\circ} \bmod$ N. med Strygning Ø.-V. Længst mod N. i Graven er Hældningen kun ca. $10^{\circ}$, samme Strygning.

I den sydlige Del af Profilet fandtes ingen Forsteninger, men alle de indsamlede Forsteninger stammer fra den nordlige Del, dels tagne in situ, dels i herfra hidrørende Bunker.

Faunaen henfører Kalken til Y. Danium (Zone D).

Hjerm I ${ }^{1}$ ). 3 (S. 269, »Egnen om Holstedbroe«). 16 (S. 63, 65, 81). 1 (S. 8 ). 19 (S. 536 ). 48 (S. 6). 50 (S. 52). 122 (S. 102). 95.123 (S. 33 ). 113 (S. 54). 76.80 .64 .71 (S. 4). 8 (S. 380). 104 (B. 5. 12).

1) En Del af den anførte Litteratur berører maaske ikke blot nærværende Grav, men muligvis tillige Hjerm II eller de nedlagte Grave i Nærheden. 


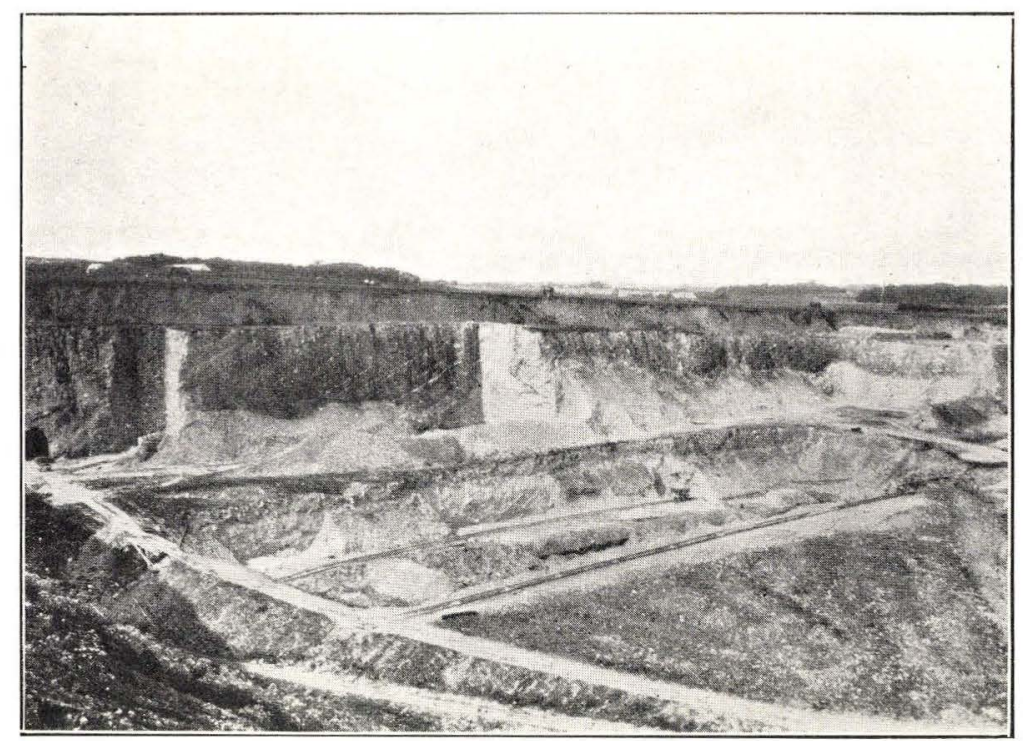

Fig. 27. Hjerm I. Set $\bmod$ NV.

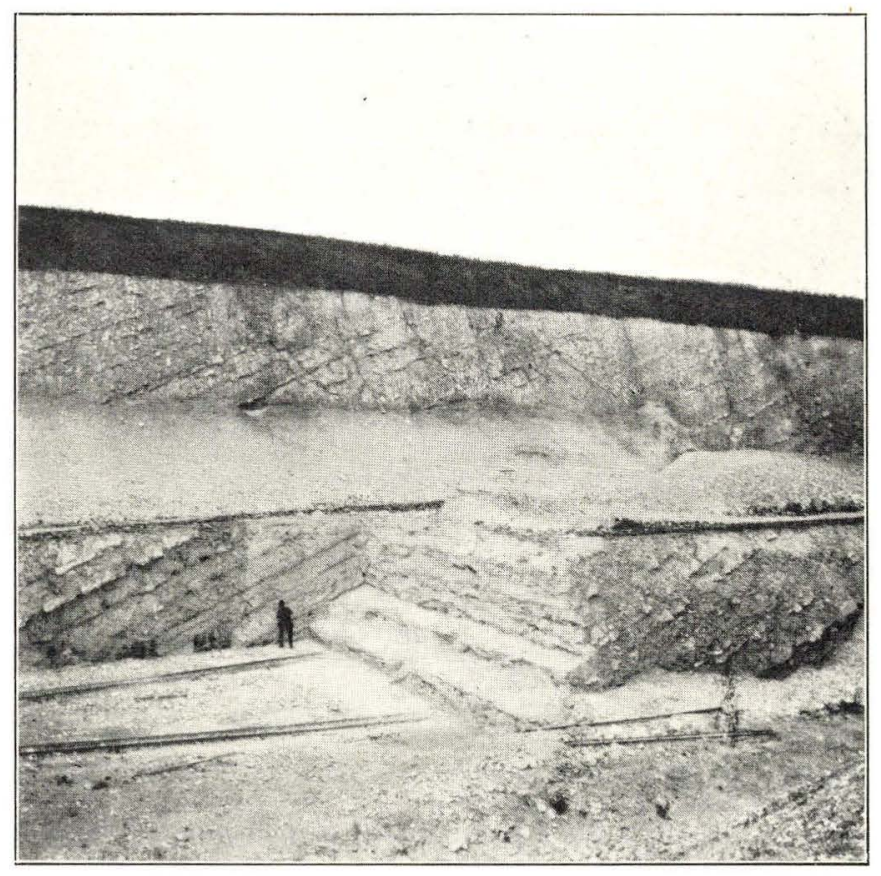

Fig. 28. Hjerm I. Den nordlige Del af Vestvæggen med de tre Forkastninger. 
800 m S. f. Stationen, »De jydske Kalkværker«s Grav V. f. Banelinien og Graven lige Ø. herfor. Kote $44 \mathrm{~m}$. Den følgende Beskrivelse gælder udelukkende den store Grav V. f. Banen, da Graven Ø. f. Banen i de sidste Par Aar har været daarligere, og Forholdene her iøvrigt svarer til den førstnævnte (Fig. 27-28). Især Vestvæggen i Graven frembyder et godt Profil.

Bjergarterne i det store Brud varierer en Del. S. f. den sydligste af de nedenfor omtalte 3 Forkastninger er Lagene uforstyrrede, bortset fra den hældende Stilling, de er bragt i, og i hele denne Del af Profilet danner Lagene en fortsat Serie.

I den nedre Del af denne Serie (paa Fig. 27 midt i Billedet) er Bjergarten en overordentlig fin Coccolitkalk, der i sin Karakter staar meget nær ved det typiske, senoniske Skrivekridt; den er rent hvid, blød, stærkt afsmittende, fed at føle paa. Under Mikroskop viser den sig at bestaa af meget fine Kalkpartikler og at indeholde Coccoliter i stort Antal. Den mikroskopiske Undersøgelse viser, at denne Bjergarts Grundmasse alligevel indeholder lidt større Partikler i langt højere Grad, end det f. Eks. er Tilfældet med en Prøve typisk Skrivekridt fra Eerslev (I, C). Flinten i denne Bjergart er meget mørk, omtrent fuldstændig sort, med tynd, hvid Skorpe; den danner sammenhængende, ret massive Lag.

I den øvre Del af Serien (paa Fig. 27 øverst til venstre) er Bjergarten ikke skrivekridtagtig. Den er her en mere almindelig Coccolitkalk, graalig af Farve, ret fast, omend ikke saa sammenhængende som den ovenfor 'omtalte Bjergart, mindre stærkt afsmittende, men ellers ikke særlig hærdnet; den er mere sandet at føle paa. Under Mikroskop viser den sig at være nogenlunde fin af Grundmasse, men den er alligevel langt grovere og indeholder en Mængde Korn og større Partikler, hvorved den adskiller sig stærkt fra den forrige; Coccoliter er meget almindelige. Flinten her er lysere eller mørkere graa af Farve og med tykkere, hvid Skorpe; den er i Almindelighed stærkt svampet og porøs, og Lagene er mindre massive — som Regel ogsaa tyndere — end i den fine Bjergart.

Overgangen mellem de to Bjergarter er fuldkommen jævn. Tydeligst ses den ved Flintlagene, idet disse ret pludseligt skifter Karakter. De ligger som Regel tættest i den grovere, med større Afstand i den fine Kalk. I den øvrige Del af Bruddet genfindes de samme to Bjergarter, selv om den grove maaske er mest udpræget længst mod S.

Lejringsforholdene fremgaar af Fotografierne. Ifølge Maaling af $\mathrm{Hr}$. Direktør, Dr. phil. V. MaDsen stryger Lagene N. $65^{\circ} \varnothing$., hælder $22^{\circ}$ $\bmod$ S. $25^{\circ} \varnothing$. Profilet gennemsættes af 3 Spring (Fig. 28); det sydligste af disse stod særlig rent i 1924, ved hvilken Lejlighed Springhøjden maaltes til 1,2 m. Springhøjden har ikke kunnet konstateres 
for de to nordlige Forkastninger, da den er saa stor, at den unddrager sig Iagttagelse. I alle Tilfælde er Lagserien N. f. Springene sænket.

Forsteningsindholdet er meget fattigt i den finere, rigere i den grovere Kalk. I faunistisk Henseende er de iøvrigt ens, og hele Lagserien maa henregnes til Y. Danium (Zone D).

Hjerm II. 71 (S. 5, "Avsum«). 8 (S. 381, Fig. S. 377). 104 (B. 5. 13, "Ost f. Avsum Gaard «).

$1 \mathrm{~km} \mathrm{V.f.} \mathrm{Kirken.} \mathrm{Kote} 40 \mathrm{~m}$.

Forholdene i denne Grav svarer nøje til Hjerm I. Maaling af den indbyrdes Afstand mellem Flintlagene viser, at Lagserien her er identisk med en Del af Lagene i Hjerm I.

Nøvling I. 69 (S. 5). 64. 70 (S. 5). 8 (S. 381).

Børshøj. 2 km N. t. Ø. f. Skibbild Station ${ }^{1}$ ). Kote $47 \mathrm{~m}$.

Paa dette Sted, i en lille, isoleret liggende Bakke, har der tidligere fundet Kalkgravning Sted, men Graven er nu fuldstændig tilgroet. Gravningen er, ifølge Oplysning af Ejeren, standset for over 40 Aar siden. Boringer har vist, at Kalken naar tæt op til Overfladen, og den dybeste af Boringerne naaede ca. $6 \mathrm{~m}$ ned i Kalken uden at gaa igennem denne. Om Kalken paa denne Lokalitet er faststaaende, maa stadig betragtes som uafgjort, men det er ingenlunde usandsynligt.

Statsgeolog MrLthers har i 1914 indsamlet en Del løstliggende Bjergartsprøver. Kalken er en fast, graa Coccolitkalk, gennemsat af Glideflader og breccieagtig af Struktur. Dette ses endnu tydeligere paa Flinten; denne er meget mørkt graa, omtrent sort, knust til Breccie og regenereret med en lysere graa Flintmasse. Smaa skarpkantede Flintstykker findes spredt i Kalken, som ligeledes er fuldstændig regenereret uden om dem. Den stærke Regeneration viser, at Knusningen er af gammel Dato.

Kapitel IV

\section{Beskrivelse af Senoniumlokaliteter.}

Et Led i Undersøgelsen af Daniet i Jylland er — foruden Opklaringen af de »indre« Spørgsmaal - Fastlæggelsen af Grænserne for dets Udbredelse.

1) Milthers' Angivelse, $400 \mathrm{~m}$ Ø. f. Kirken, refererer til den gamle, nu nedrevne Kirke. 
Ved Undersøgelserne i Marken har der været Lejlighed til at iagttage en Del Skrivekridtlokaliteter, og som Bidrag til en nøjere Konstatering af Grænserne mellem de forskellige Etager, skal jeg tillægsvis meddele nogle Iagttagelser i denne Retning. Jeg skal indskrænke mig til at nævne saadanne observerede Skrivekridtforekomster, som ikke er medtaget paa RAVN's Kort af 1922 (104), medmindre de af anden Grund har Krav pȧa særlig Interesse.

Nye Selandiumforekomster er ikke iagttaget.

Ørhage. 68 (S. 4). 45 (S. 48).

Milthers nævner Forekomsten af flintrig Daniumkalksten ved Ørhage, men Jessen, som kommer nærmere ind paa Forholdene, mener, at Undergrunden her maa bestaa af Skrivekridt fra en Kote af $\div 4 \mathrm{~m}$.

Ø. Vandet I.

$1200 \mathrm{~m} \mathrm{~V}$. f. Kirken. Kote $15 \mathrm{~m}$.

Ret stor Grav med almindeligt, typisk Skrivekridt. Flinten sort. Lagstillingen horisontal.

Nystrup I.

(se under Danium, S. 114).

Hov I.

(se under Danium, S. 99).

Hov II.

$600 \mathrm{~m}$ NNØ. f. Brusgaard. Kote ca. $9 \mathrm{~m}$.

Skrivekridt.

Hov III.

$400 \mathrm{~m}$ ØNØ. f. Svingel. Kote ca. $4 \mathrm{~m}$.

Nederst i Gravens $3 \mathrm{~m}$ høje Profil er Kridtet fast og uforstyrret til en Højde af $1 \mathrm{~m}$, og her over er det brokket. Kridtet er af den yngste, forsteningsrige (Bryozo-) Type. Flinten optræder som sorte, flade Nyrer. En Analyse af Kridtet, udført af D. G. U. i 1920, viste et Indhold af $97,0 \% \mathrm{CaCO}_{3}$.

Lagstillingen horisontal.

Cidaris sp., Bryozoer.

Hov IV. 68 (T. I). 104 (B. 4.10 ).

$400 \mathrm{~m}$ ØSØ. f. Brusgaard. Kote $28 \mathrm{~m}$.

Grav med $3 \mathrm{~m}$ højt Profil i Skrivekridt; dette er af almindelig Type, forsteningsfattigt; det er knust helt ned til Profilets Bund, men ikke egentlig udtværet. Flinten er sort, meget sparsomt optrædende, idet der kun ses en enkelt, afbrudt Række af Nyrer. 
Lagstillingen horisontal.

Et Fragment af en Skal tilhører sikkert Inoceramus tegulatus; Scaphites constrictus.

Skorsted I. 68 (T. I). 104 (B. 3. 28).

$150 \mathrm{~m}$ Ø. f. Skovstedlund Høj. Kote $3 \mathrm{~m}$.

Nederst i Klinten ses i en Gravning $2 \mathrm{~m}$ faststaaende Skrivekridt; det er godt spaltende, af den yngste, bryozorige Type. Der saas kun enkelte, løstliggende, sorte Flintknolde.

Terebratulina semiglobularis, Bryozoer.

Skovsted II.

$300 \mathrm{~m} \mathrm{SV}$. f. Skovstedlund Høj. Kote $18 \mathrm{~m}$.

Graven var i 1923 tilgroet; i det nedskredne Materiale saas kun mindre Skrivekridtbrokker, samt sorte Flintnyrer.

Skovsted III.

$400 \mathrm{~m} \mathrm{~V}$. f. Søndergaard. Kote $12 \mathrm{~m}$.

Skrivekridt.

Kjølby Gaard I. (se under Danium, S. 95).

Nye Kløv. (se under Danium, S. 96).

Tolstrup I. (ved Løgstør).

$1 \mathrm{~km}$ SV. f. Tolstrup By. Kote $15 \mathrm{~m}$.

Skrivekridt i lille Grav. Vandret Lagstilling.

Kornum I.

I den nordlige Udkant af Byen. Kote $21 \mathrm{~m}$.

Der findes her en lille Grav med stærkt brokket Skrivekridt, overlejret af Lokalmoræne. I Lokalmoræenen ses indskudte Striber af Diluvialsand i en Dybde af $3 \mathrm{~m}$ under Overfladen. Desuden saas meget smalle, dybe Skorstene.

Veggerbro III. 41 (S. 32). 104 (D. 4.11).

$1 \mathrm{~km}$ Ø. t. S. f. Veggerbro. Kote (Kridtets Overkant) $12 \mathrm{~m}$.

Der findes her to Grave umiddelbart ved Siden af hinanden, frembydende gode Profiler af indtil $7 \mathrm{~m}$ Højde i Skrivekridt. Kridtet hvidt, meget rent, delvis godt spaltende. Flinten, som kun findes i meget ringe Mængde, er typisk Skrivekridtflint, sort, med tynd hvid Skorpe; i Form af spredte, smaa Knolde.

Lagstillingen er, som ogsaa A. JESSEN gør opmærksom paa, stærkt 
forstyrret. I hele den synlige Mægtighed er Kridtet knust og fremtræder som en grov Breccie, hvor Lagdelingen er fuldstændig udvisket. Dette skyldes utvivlsomt Undergrundsforstyrrelser (se Kap. VIII).

Kridtet er ikke forsteningsrigt; bl. a. fandtes Aptychus (I), Pecten Puggaardi.

Nibe I. 47 (S. 6).

$900 \mathrm{~m}$ N. f. Nibe Mølle. Kote $28 \mathrm{~m}$.

Mindre Grav i typisk Skrivekridt, stærkt knust. Flint i smaa, spredte Knolde.

Af Forsteninger fandtes bl. a.: Cidaris sp., Tylocidaris baltica, Terebratulina gracilis, Terebratella Humboldti, Avicula pectinoides, Scaphites sp., Baculites sp.

\section{Vive I.}

$650 \mathrm{~m} \mathrm{~N}$. f. Kirken. Kote $22 \mathrm{~m}$.

Ret stor Kridtgrav med godt $5 \mathrm{~m}$ høje Vægge med rene Profiler. Heri ses under et ubetydeligt Muldlag et Par m Lokalmoræne af Skrivekridt, som nedad gaar over i faststaaende, men knust Kridt. Kridtet er af den almindelige, ikke forsteningsrige Type. Flinten er sort, yderst sparsomt forekommende i smaa, spredte Konkretioner.

Lagstillingen er, saa vidt det kan ses, horisontal.

Terebratulina gracilis.

Vive II. 65 a (S. 31, 》Kridtbakkerne«).

$800 \mathrm{~m}$ SØ. f. Kirken. Kote ca. $6 \mathrm{~m}$.

I »Kridtbakkerne« her findes en Del tilskredne Grave. Kun en meget lille Gravning viser et frisk Profil i Skrivekridt af den sædvanlige Type.

Tostrup I. (N. f. Ove).

$300 \mathrm{~m}$ V.f. Kirkehøj. Kote $12 \mathrm{~m}$.

Stor Grav, delvis tilskredet. Der saas et Profil paa et Par m Højde gennem stærkt knust Lokalmoræne af Skrivekridt, overlejret af Diluvialsand. Der saas ingen Flint.

Inoceramus tegulatus.

Tostrup II.

Ca. $400 \mathrm{~m}$ VSV. f. Kirkehøj. Kote ca. $8 \mathrm{~m}$.

Der ligger her to mindre Grave tæet ved hinanden. De er begge tilskredne, men man ser i det nedskredne Materiale, at Bjergarten bestaar af Skrivekridt. 
Brøndbjerg I.

$500 \mathrm{~m} \mathrm{SSV}$. f. Byen. Kote ca. $20 \mathrm{~m}$.

Ret stor Grav med 3-4 m Skrivekridt, overlejret af Diluvialsand. Kridtet er af den sædvanlige Type. Flinten er sort, meget sparsomt optrædende, i Form af tynde, flade Knolde, som er ordnet i ikke særlig tydelige Rækker.

Lagstillingen horisontal.

Pecten sp. (glat), Pecten inflexus, Terebratula carnea.

Rostrup I.

$500 \mathrm{~m}$ NNØ. f. Kirken. Kote $28 \mathrm{~m}$.

Ret stor Grav med gode Profiler. Heri ses $3 \mathrm{~m}$ Skrivekridt, overlejret af Diluvialsand. Kridtet er af den sædvanlige Type. Flinten, der kun er sparsomt tilstede, danner sorte, flade Linser, der som Regel er spredt uden Orden; kun et enkelt Sted er Flintknoldene med læengere Mellemrum ordnet i en Række.

Lagstillingen horisontal.

Cidaris Bolli, Pecten pulchellus.

Bøgelund. (se under Danium, S. 53).

Spentrup I. 104 (D. 4. 21).

$1500 \mathrm{~m}$ N. t. Ø. f. Kirken. Kote $55 \mathrm{~m}$.

Graven her er meget stor, og Kridtet graves dels i Gravens Vægge, dels i brøndagtige Gravninger, hvorfra det hejses op; herved er fremkommet Profiler paa ca. $14 \mathrm{~m}$ i Højden igennem Kridtet. Dette er normalt Skrivekridt, hvidt eller stedvis meget svagt graaligt. Flinten er sort, typisk, kun sparsomt tilstede i Form af flade Nyrer, ordnet i Rækker med flere $m$ Afstand.

Lagstillingen er horisontal; et enkelt Sted iagttoges et ret skarpt bueformet Forløb af en Flintrække, men det kunde ikke fastslaas, om dette skyldtes Forstyrrelser.

Kridtet er meget forsteningsfattigt; Avicula pectinoides, Vola striato-costata.

Lerkenfeld. 104 (C. 4. 24) ${ }^{1}$ ).

Kote ca. $8 \mathrm{~m}$.

Ifølge Oplysninger fra D. G. U.s Borearkiv er der her gennemboret 18,8 m Kvartær og herunder Skrivekridt til en Dybde af 20,7 m.

Elkjær Gaarde I.

$600 \mathrm{~m} \mathrm{~S}$. f. Gaardene. Kote ca. $5 \mathrm{~m}$.

Graven er lille og fuldstændig tilgroet. Se under Elkjær Gaarde II.

1) Lokaliteten er angivet paa Ravn's Kort, men er ved en Fejltagelse faldet ud i Teksten. 
Elkjær Gaarde II. 68 (S. 5, T. I, »Blegekridt《). 7 (S. 182, »ved Selde«). 104 (B. 4. 46, »Blegekridt«).

Imellem Gaardene. Kote $3 \mathrm{~m}$.

Graven er fornylig tilkastet; efter Oplysninger af Ejeren strækker Kalken sig i nogen Omkreds omkring Gaardene og træffes ved Gravninger i Engene N. herfor. Kalken skal være af ganske samme Art som ved Batum, altsaa formodentlig Skrivekridt.

Torum I. 68 (S. 5, T. I, »Blegekridt«). 104 (B. 4. 48, »Blegekridt《). $900 \mathrm{~m} \mathrm{SV}$. f. Møjbæk Bro. Kote $22 \mathrm{~m}$.

Ret stor Grav; i de stejle Vægge, der delvis frembød gode Profiler, saas i 1923 øverst et Par m Kvartær, dels Moræneler, dels Diluvialgrus $^{1}$ ). Herunder fandtes $3-4 \mathrm{~m}$ Lokalmoræne af brokket Skrivekridt. Kridtet er delvis ret haardt, meget fint; det er tildels ret stærkt flammet af tynde, graagule Lerflager, men ligner iøvrigt det almindelige Skrivekridt.

Spongia, Cardiaster sp., Ditrupa sp., Inoceramus tegulatus.

Torum II. 104 (B. 4. 49, »Blegekridt«).

$1100 \mathrm{~m}$ NØ. f. Torum Kirke. Kote $19 \mathrm{~m}$.

Graven er nu tilgroet; Bjergarten er formodentlig den samme som i T. I.

Batum. 122 (S. 103, »Blegekridt - Omegnen af Selde«). 123 (S. 35, "Blegekridt - Selde $\ll)^{2}$ ). 80 (S. 80, "Skrivekridt - Salling«). 68 (S. 5, T. I, »Blegekridt《). 7 (S. 182). 104 (B. 4. 47, »Blegekridt«).

I Terrænet mellem Batum og Kællingvad Bro, paa Kotehøjder indtil $15 \mathrm{~m}$, findes en hel Række af tætliggende Grave i Retningen Ø.-V. Nogle af Gravene er tilgroede, men flere af dem frembyder gode Snit paa indtil et Par m Højde gennem uforstyrret Kridt, overlejret af indtil 2-3 m Lokalmoræne; andre Steder er alt Kridtet saa knust, at det hele maa kaldes Lokalmoræne.

Bjergarten er ens i alle Gravene. Den er hvid (hist og her lidt graalig), hyppig noget flammet, sejg, daarligt spaltende. I fugtig Tilstand »sprøjter« den ved Slag som typisk Skrivekridt (i Modsætning til f. Eks. Blegekridt). Flint fandtes overhovedet ikke.

1) I Graven fandtes en løs Blok Faxekalk samt mange tertiære Lerjernstenskonkretioner.

$\left.{ }^{2}\right)$ Under Hensyntagen til de paa Mineral. Museum liggende Bjergartsprøver og Tidspunktet for disses Indsamling, maa det sikkert formodes, at Ussing her sigter til Batum.

Danmarks geologiske Undersøgelse. II. R. Nr. 45 . 
Lagstillingen horisontal.

Pentacrinus Bronni (Br. N. det. 1913), Inoceramus tegulatus, Aptychus sp. (》A. II《 RavN 1902-03 95 S. 259).

Kapitel V

\section{Palæontologi.}

Dette Kapitels Hensigt er at gøre Rede for de i det fynsk-jyske Danium fundne Forsteninger. Egentlig Beskrivelse af de foreliggende Former er kun givet i det meget begrænsede Antal Tilfælde, hvor det enten drejer sig om ikke tidligere beskrevne Former, eller hvor en nærmere, supplerende Omtale af en eller anden Grund har været ønskelig.

Af denne Aarsag er det imidlertid tilstræbt at give saa fyldige Litteraturhenvisninger som muligt, baade m. H. t. Artens Beskrivelse i Almindelighed og ganske særligt m. H. t. dens Optræden. Forf. har derfor tilstræbt for alle de daniske Formers Vedkommende at angive alle de Steder, hvor de tidligere har været omtalt i dansk eller til danske Forhold knyttet Litteratur. For senoniske Arters Vedkommende er der kun henvist til nærliggende Litteratur, der kan yde nærmere Oplysning.

Efter hver Art følger en kortfattet Angivelse af dens Optræden. Herom gælder følgende. For de i Fyn og Jylland fundne Arter er der til Etageangivelsen føjet en nærmere Bestemmelse (f. Eks. "Alm.«, "Hyppig《 eller Lokalitetsnavn); mangler denne, saa der kun er angivet f. Eks. »Y. Danium«, betyder det, at Arten forekommer i den paagældende Horisont, men ikke er fundet deri paa Fyn eller i Jylland. De senoniske Arter er dog kun forsynet med Lokalitetsbetegnelse, hvis denne refererer til en af Overgangslokaliteterne, eller Stedet ikke tidligere har været nævnt i Litteraturen.

De mere almindeligt forekommende Arter er ikke forsynet med Lokalitetsangivelse i Teksten, men er opført tabellarisk i Bilag A ${ }^{1}$ ). Vil man gaa den modsatte Vej og udlede hele den paa en Lokalitet fundne Fauna, maa man altsaa, foruden at benytte sig af Bilagene A-J, gennemgaa Lokalitetsangivelserne i nærværende Kapitel.

1) Af Pladshensyn omfatter Bilag A kun de mere almindeligt forekommende Arter, mens Bilag B-J er af mere speciel Art. 


\section{Foraminifera.}

En Del Foraminiferer, fordelende sig paa en Række forskellige Slægter, foreligger fra de allerfleste Lokaliteter. En nærmere Bestemmelse er dog ikke forsøgt.

\section{Spongiae.}

Plinthosella squamosa Zitt.

1851. Achilleum resonans ("Ranglesten«), PuggaARd (92 S. 41, 61, Fig. 5 -6). 1899. Plinthosella squamosa Zilt. ("Ranglesten«); Ravn (94 S. 24, T. I Fig. Y. Danium. Alm.

A.

Senonium.

\section{Aphrocallistes sp.}

1912. Aphrocallistes sp.; Ravn (97).

Y. Danium. Alm.

A. 》 》.

Senonium.

Ubestemte Silicispongiae

foreligger fra en lang Række Lokaliteter.

Porosphaera universa Br. N. ${ }^{1}$ )

Y. Danium. Alm.

A. 》 》.

Y. Danium.

Porosphaera foliata $\mathrm{Br}$. N.

Æ. " . Bryozokalk: Bulbjerg.

Porosphaera umbonata Br. N.

Y. Danium.

Æ. " Bryozokalk: Ove III-IV, Munksjørup I, Torup Kløv I, Gravlev I A.

Coccolitkalk: Nye Kløv.

Porosphaera adhaerens Br. N.

Y. Danium. Alm.

A. " " .

1) Bestemmelsen af samtlige Porosphaera-Arter skyldes Hr. Stabslæge, Dr. phil. K. Brünnich Nielsen. 
Porosphaera ramosa $\mathrm{Br}$. N.

Y. Danium. Bryozokalk: Aggersborg Gaard, Hjardemaal I.

E. " " : Kastbjerg I, Torup Strand I.

Y. Danium.

Porosphaera echinata Br. N.

A. " . Bryozokalk: Sangstrup Klint.

Porosphaera aplanata $\mathrm{Br}$. N.

Y. Danium. Bryozokalk: Hansted I.

Æ. 》 》 : Bulbjerg.

Porosphaera canaliculata $\mathrm{Br}$. N.

Y. Danium. Bryozokalk: Aggersborg Gaard.

A. 》 » : Bulbjerg, Torup Kløv I.

Porosphaera globularis Phill.

1851. Achilleum globosum Hag.; Puggand (92 S. 62).

1908. Porosphaera globularis Phill.; Ravn (96 S. 68).

1913. " " " " (2).

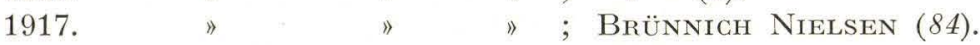

Senonium. Nye Kløv Skrivekridt, Nystrup I G (desuden paa sek. Leje i Lerlaget Kjølby Gaard I B).

\section{Hydrozoa.}

Pliobothrus dispergens $\mathrm{Br}$. N.

1919. Pliobothrus dispergens, Brünnich Nielsen ( 87 S. 18, 24, T. I Fig. 7-10).

Y. Danium. Bryozokalk: Aggersborg Gaard.

Congregopora nasiformis $\mathrm{Br} . \mathrm{N}$.

1919. Congregopora nasiformis, BrüNNich Nielsen (87 S. 21, 24, T. II Fig. $24-27)$.

Y. Danium. Bryozokalk: Aggersborg Gaard.

Astylus crassus $\mathrm{Br}$. N.

1919. Astylus crassus, Brünnich Nielsen (87 S. 22, 24, T. II Fig. 28-32). Y. Danium. Bryozokalk: Aggersborg Gaard.

Conopora arborescens $\mathrm{Br}$. N.

1919. Conopora arborescens, Brünnich Nielsen (87 S. 23, 24, T. II Fig. $33-40)$.

Y. Danium. Bryozokalk: Aggersborg Gaard. 


\section{Anthozoa.}

Dendrophyllia candelabrum Hennig.

1899. Dendrophyllia candelabrum, Hennig (38 S. 8, T. I Fig. 6 -12).

1908. " " " RAvN (96 S. 68).

1922. " " " BRünnich Nielsen (90 S. 214, T. I Fig. 8-22).

Y. Danium. Bryozokalk: Aggersborg Gaard.

Ceratotrochus saltholmensis $\mathrm{Br}$. N.

1922. Ceratotrochus saltholmensis, Brünnich Nielsen (90 S. 217, T. I Fig. $26-31)$.

Y. Danium. Coccolitkalk: Bredstrup Klint, Voldum I, Aarslev I, Thisted V, Hjerm I.

Bryozokalk: Lendrup Strand.

Ceratotrochus Milthersi Br. N.

1922. Ceratotrochus Milthersi, Brünnich Nielsen (90 S. 217, Fig. 1-4).

Findes paa sekundært Leje i Grønsandet Hvalløse I, aabenbart stammende fra Yngre Danium.

Y. Danium.

Epitrochus vermiformis $\mathrm{Br} . \mathrm{N}$.

1922. Epitrochus vermiformis, Brünnich Nielsen (90 S. 218, T. II Fig. $1-4)$.

$1923 . "$ " " " J JESSEN Og ØDUM (47 S. 18).

A. Danium. Bryozokalk: Voxlev L, Kjølby II, Bulbjerg, Klim Bjerg ?, Vigsø I.

Epitrochus pusillus Forchh. og Stp.

1866. Monomyces pusillus Forchh. og Stp.; Fischer-Benzon (14 S. 17).

1922. Epitrochus " " ; Brünnich Nielsen (90 S. 219, T. II Fig. 5-13, T. III Fig. 7).

A. Danium. Bryozokalk: Aggersborg Gaard.

Coelosmilia excavata Hag.

1851. Turbinolia excavata Hag.; PuggaArd (92 S. 66, Fig. 9).

1908. Parasmilia " " ; Ravn (96 S.68).

1917. " " " BRÜNNICH Nielsen (84).

1922. Coelosmilia " " " " $\quad$ (90 S. 222, T. II Fig. 21-28, T. III Fig. 8, $8 \mathrm{a}-\mathrm{b})$.

Y. Danium. Coccolitkalk: Hjerm I, Legind I.

Æ. ". Bryozokalk: Bjerge I.

Senonium. 
Coelosmilia brevis Forchh. og Stp.

1922. Coelosmilia brevis Forchh. og Stp.; Brünnich Nielsen (90 S. 223, T. III Fig. $2-3$, T. IV Fig. 3-4).

Arten er hidtil kun kendt fra Y. Danium (Faxe), men et Eksemplar fra det hærdnede Skrivekridt i Eerslev I maa sikkert henføres til denne.

Danium.

Senonium. Eerslev I B.

Parasmilia biseriata $\mathrm{Br}$. N.

1922. Parasmilia biseriata M. U. H., Brünnich Nielsen (90 S. 224, T. IV Fig. 5-9).

Æ. Danium. Coccolitkalk: Gravlev I C, Bøgelund B, Hov I.

Parasmilia cincta $\mathrm{Br}$. N.

1922. Parasmilia cincta, Brünnich Nielsen (90 S. 225, T. IV Fig. 10-12).

Y. Danium. Coccolitkalk: Frøslevvang II.

Æ. 》 》 : Gravlev I C.

Parasmilia parva $\mathrm{Br}$. N.

1922. Parasmilia parva, Brünnich Nielsen (90 S. 225, T. IV Fig. 13-16).

Y. Danium. Bryozokalk: Rejstrup I.

A.

\section{Parasmilia n. sp.}

Et Par Eksemplarer af en Parasmilia, der ikke er identisk med nogen af de hidtil kendte, er fundet i Skrivekridtet Nystrup I F og G.

Smilotrochus faxensis Forchh. og Stp.

1922. Smilotrochus faxöensis Forchh. og Stp.; Brünnich Nielsen (90 S. 227, T. III Fig. $1-1 \mathrm{a}, \mathrm{T}$. IV Fig. 19-24).

Y. Danium. Bryozokalk: Aggersborg Gaard.

Ubestemte Hexacorallia.

Voxlev Kalkværk, Thisted V, Hov I.

Graphularia Grönwalli Br. N.

\begin{tabular}{|c|c|c|c|c|c|c|c|}
\hline 1898. & Graphularia. & & & ; & GRÖNWALL & $(26$ S. 2$)$ & \\
\hline ?1907. & $"$ & $s p$ & & ; & GRÖNWALL & og HARD & DER (31 S. 22). \\
\hline 1913. & " & Grönwalli & & , & BRÜNNICH & Nielsen & $\begin{array}{l}(81 \text { S. } 8, \text { T. III } \\
\text { Fig. } 1-3)\end{array}$ \\
\hline 1913. & $"$ & sulcata & & & " & 1) & $\begin{array}{l}(81 \text { S. } 8, \text { T. III } \\
\text { Fig. } 4-6) \text {. }\end{array}$ \\
\hline 1917. & 1) & Grönwalli & $B r$. & N.; & $"$ & ") & (85 S. 3, Fig.1). \\
\hline 1917. & ") & sulcata & " & " ; & " & $»$ & (85 S. 4, Fig.2). \\
\hline 1920. & " & Grönwalli & " & i); & $\begin{array}{l}\text { RosenkraI } \\
6 \text {, T. II Fi }\end{array}$ & $\begin{array}{l}\text { NTz (106 S } \\
\text { ig. 1). }\end{array}$ & S. 17, S. 61, Fig. \\
\hline
\end{tabular}


Selandium?

Y. Danium. Coccolitkalk: Bredstrup Klint, Hørning I, Mygind I, Hvalløse I, Bjerregrav I, Roldtved I, Thorsted II, Frøslevvang II.

Ubest. Pennatulide?

Nogle Fragmenter af en Kalkstok, ensartet tyk, svagt kantet cylindrisk, af lagdelt straalet Bygning, hidrører sandsynligvis fra en ikke nærmere bestemt Pennatulide.

Y. Danium. Coccolitkalk: Hjerm I.

\section{Primnoa costata Br. N.}

1913. Primnoa costata, Brünnich Nielsen (81 S. 9, T. III Fig. 13-26).

1917. " " " " (85 S. 4, Fig. 4).

1918. " " " " $\quad$ " 86 S. 462, T. 8 Fig. 1).

Y. Danium. Bryozokalk: Thisted I A, Rejstrup I.

Gorgonella torta $\mathrm{Br}$. N.

1913. Gorgonella tenuis, Brünnich Nielsen (81 S. 9, T. III Fig. 27).

1913. " " $"$ (81 S. 10, T. III Fig. 28-31).

1917. "

1917. " " torta, " (85 S. 5, Fig. 6).

1918. " torta, " (86 S. 462, T. 8 Fig. 2).

1920. " " $"$ "

Brünnich Nielsen opstillede i 1913 to Arter Gorgonella, G. tenuis og G. torta. Den første skulde være tyndere og bygget af ligeløbende Kalkstrenge, den sidste tykkere og bygget af slyngede Strenge. Imidlertid viser det indsamlede Materiale, at disse Karakterer optræder i vilkaarlig Kombination, idet saavel tynde som tykke Stykker kan være dannet af parallele Fibre, og ligeledes kan saavel tynde som tykke Individer være stærkt slynget byggede, og endelig kan begge Strukturer optræde i samme Kalkstok. BRÜNNICH Nielsen bemærker selv om $G$. torta, at "navnlig de ydre, yngre Fibre slynge sig om de ældre«.

Heller ikke m. H. t. deres Optræden kan de to Former holdes ude fra hinanden. Arten forekommer i hele Daniet, især i bryozorig Facies.

Gorgonella radicifera $\mathrm{Br}$. N.

1913. Gorgonella radicifera, Brünnich Nielsen ( 81 S. 10, T. III Fig. $32-33)$.

1917.4 " " "

Et Rodstykke, svarende til Beskrivelsen af denne Art.

Y. Danium.

A. 》 . Bryozokalk: Nystrup I A. 
Isis Steenstrupi $\mathrm{Br} . \mathbf{N}$.

1913. Isis Steenstrupi, Brünnich Nielsen (81 S. 10, T. III Fig. 34-43).

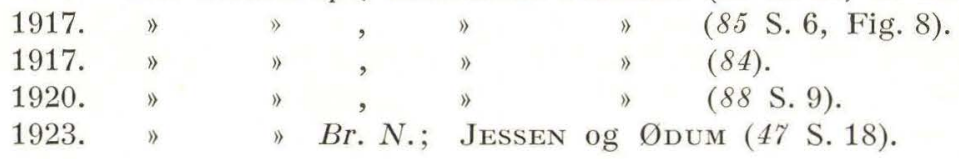

Forekommer baade i E. og Y. Danium, men næsten altid knyttet til bryozorige Lag, hvorfor den ikke er almindelig i Y. Danium.

Desuden er der fundet et Par Eksemplarer i Nystrup I G (Skrivekridt), der ikke i noget væsentligt synes at afvige fra denne Art.

Danium. Alm.

Senonium. Nystrup I G.

Isis vertebralis Hennig.

1899. Isis vertebralis, Hennig (38 S. 5, T. I Fig. 1-3).

1902-03. " " ; RAvN (95 S. 423).

1913. " " " ; BrüNNich Nielsen (81 S. 11, T. II Fig. 17

-21, T. IV Fig. 1-12).

1917. " " $"$ " " " $\quad$ (85 S. 7, Fig. 9).

1918. " " " " "

Paa Mineralogisk Museum findes et Eksemplar henlagt sammen med andre Forsteninger etiketteret »Hov«, men da Omstændighederne kan tyde paa, at der har fundet Forbytning Sted, vil det sikkert være klogest at se bort herfra.

Y. Danium. Coccolitkalk: Thisted V.

Bryozokalk: Lendrup Strand, Aggersborg Gaard.

\section{Moltkia Isis Stp.}

1846. Moltkia Isis, Steenstrup (120 S. 149).

\begin{tabular}{|c|c|c|c|c|}
\hline 1899. & ") & $\gg$ & $»$ & ; Hennig (38 S. 7, T. I Fig. 4-5). \\
\hline 1899. & " & ) & ” & ; GröNWALL (28 S. 72). \\
\hline $1902-03$. & " & 》) & 》 & ; RavN (95 S. 423). \\
\hline 1913. & " & $\gg$ & $"$ & $\begin{array}{l}\text {; Brünnici Nielsen ( } 81 \text { S. } 12 \text {, T. I, T. II } \\
\text { Fig. } 1-16 \text {, T. IV Fig. } 13-30) \text {. }\end{array}$ \\
\hline 1917. & $\Rightarrow$ & $》$ & " & ; Brünnich Nielsen (85 S. 8, Fig. 10-13) \\
\hline 918. & 》) & 》) & $"$ & ; $\quad " \quad \| \quad(86$ S.464, T.8 Fig. 6$)$. \\
\hline
\end{tabular}

Y. Danium. Hyppig.

A. "

Moltkia Lyelli Br. N.

1913. Moltkia Lyelli, Brünnich Nielsen (81 S. 18, T. IV Fig. 31-45).

1917. " " " " (85 S. 10, Fig. 14-15).

1918. " " " " (86 S. 465, T. 8 Fig. 7).

Er i Jylland kun fundet i var. scanica ved Aggersborg Gaard; nogle Stykker fra Helligkilde I er kun med Tvivl henført til denne Art.

Y. Danium. Bryozokalk: Aggersborg Gaard, Hellekilde I? 


\section{Grinoidea.}

Rhizocrinus maximus $\mathrm{Br}$. N.

1915. Rhizocrinus maximus, Brünnich Nielsen (83 S. 392, Fig. 1).

1920. " " " "

Y. Danium. Coccolitkalk: Bredstrup Klint, Tustrup I, Svejstrup I, Jernit, Hjerm I.

Bryozokalk: Dollerup I.

A. " .

\section{Bourgueticrinus Hagenowi Goldf.}

1913. Bourgueticrinus Hagenowi Goldf.; Brünnich Nielsen (80 S. 48, T. I).

Senonium. Bøgelund Skr.; (desuden paa sek. Leje i Gravlev I F).

Bourgueticrinus danicus $\mathrm{Br}$. $\mathrm{N}$.

1913. Bourgueticrinus danicus, Brünnich Nielsen (80 S. 53, Fig. 13-16, T. 2 Fig. $45-51$, T. 3 Fig. 1-58).

1915. " " " " " $\quad$ (83 S. 394, Fig. 2).

$1917 . \quad$ " " " "

Særlig Interesse frembyder et Eksemplar fra Bredstrup Klint, idet Bægret (Proximale + Basalia + Radialia) er fundet i Sammenhæng med de tilhørende Primibrachialia samt en Del af Stikleddene; disse sidste er af rhizocrin Type.

Y. Danium. Alm.

A. 》 》 .

Bourgueticrinus Brünnichi Nielseni Ødum.

1923. Bourgueticrinus Brünnichi Nielseni, Jessen og Ødum (47 S. 18, Fig. 8).

A. Danium. Coccolitkalk: Bøgelund C, Voxlev B, Kjølby Gaard I A (samt do. B, paa sek. Leje).

Bourgueticrinus verrucosus $\mathrm{Br}$. $\mathrm{N}$.

1913. Bourgueticrinus verrucosus, Brünnich Nielsen (80 S. 51, Fig. 32, T. 2 Fig. 4-11).

1923.

; JESSEN og ØDum (47

Senonium. Voxlev Skr.

S. 18).

Foruden de mere eller mindre bestemmelige Bægre af Bourgueticrinider er der fundet en stor Mængde løse Stilkled, der næppe kan henføres til bestemte Arter. Næsten alt, hvad der findes i Daniet, er Led af rhizocrin Type; Led af bourgueticrin Type er kun fundet enkeltvis i sjældne Tilfælde. Bourgueticrinus danicus har haft rhizocrine Led, 
og Rhizocrinus maximus formodentlig ligesaa. Flaskeformede Led foreligger fra et Par Lokaliteter. Sammenhængende Stykker af forgrenede Rodcirrhi er fundet i Kjølby Gaard I B.

\section{Pentacrinus Bronni Hag.}

1851. Pentacrinus Bronni Hag.; Puggand (92 S. 68).

$1908 . \quad " \quad "$ " RAvN (96 S. 68).

1913. " " ; Brünnich Nielsen (80 S. 79, Fig. 8, T. 6

Senonium. Batum, Øxendal.

Fig. $35-38)$.

\section{Pentacrinus paucicirrhus $\mathrm{Br}$. N.}

1913. Pentacrinus paucicirthus, BrüNnich Nielsen (80 S. 81, Fig. 24, T. 6 Fig. $39-52$, T. 7 Fig. $1-26)$.

1923. 》) " ?; Jessen og Ødum (47 S. 19, Fig. 9).

Bestemmelige Led er fundet baade i E. og Y. Danium.

Stilkstykker hørende til Pentacriner af paucicirrhus-Typen hører til de almindeligste Forsteninger i Daniet, men kan ikke bestemmes til Art. I mange Tilfælde er Tegningen paa Ledfladerne ikke typisk pentacrinoid, men nærmer sig stærkt til den balanocrine Type.

\section{Pentacrinus crassus $\mathrm{Br}$. N.}

1913. Pentacrinus crassus, Brünnich Nielsen (80 S. 84, T. 7 Fig. 27-53, T. 8 Fig. $1-6)$.

En Del Led har med større eller mindre Sikkerhed kunnet henføres til denne Art.

Y. Danium. Coccolitkalk: Tustrup I, Klavsholm I, Frøslevvang II. Bryozokalk: Thisted I A.

E. 》 》 : Sangstrup Klint?

Pentacrinus longus Br. N.

1913. Pentacrinus longus, Brünnich Nielsen (80 S. 86, Fig. 2-6, 11, 25,

1917.

$1920 . \quad " \quad$ " $"$ Rosenkrantz (106 S. 22).

Et Primibrachiale tilhører sandsynligvis denne Art.

Y. Danium. Bryozokalk: Rejstrup I.

Æ. 》 » : Karlby Klint.

Stilkstykker af Pentacriner af longus-Typen træffes hyppigt i hele Daniet, men heller ikke disse er nærmere bestemmelige. 
Pentacrinus fionicus Br. N.

1913. Pentacrinus fionicus, Brünnich Nielsen (80 S. 90, T. 8 Fig. 41 - 66, T. 9 Fig. $1-7)$.

Y. Danium. Bryozokalk: Rejstrup I, Svendborg I.

Pentacrinus divergens $\mathrm{Br}$. N.

1913. Pentacrinus divergens, Brünnich Nielsen ( 80 S. 92, Fig. 27, T. 9 Fig. 8-31).

1920. " " " " Rosenkrantz (106 S. 21).

Y. Danium. Coccolitkalk: Klavsholm I, Bjerregrav II, Ove I, Sørup I, Eerslev II, Mønsted III.

Bryozokalk: Dollerup I, Rejstrup I, Svendborg I.

A. " \ : Bulbjerg, Ove III ?

Pentacrinus Rejstrupianus $\mathrm{Br}$. N.

1913. Pentacrinus Rejstrupianus, Brünnich Nielsen (80 S. 94, Fig. 21, T. 9 Fig. $32-36$ ).

Y. Danium. Bryozokalk: Thisted I A ?, Rejstrup I.

E. " " : Munksjørup I.

Pentacrinus miliaris Br. N.

1913. Pentacrinus miliaris, Brünnich Nielsen (80 S. 97, T. 9 Fig. 47-51). Y. Danium.

A. 》 . Bryozokalk: Ove III, Gravlev I A.

\section{Pentacrinus n. sp.?}

Et internodalt Stilkstykke er sammensat af ensartede, ret høje Led; hvert Led bærer paa Midten en kraftig, ringformet Opsvulmning, indtagende ca. ${ }^{1 / 3}$ af Leddets Højde, opadtil og nedadtil begrænset ved et Par rundbundede Furer.

E. Danium. Bryozokalk: Bjerge II.

Antedon danica $\mathrm{Br}$. N.

1913. Antedon danica, Brünnich Nielsen (80 S. 100, T. 10 Fig. 39-43, T. II Fig. 1-44).

Y. Danium. Bryozokalk: Rejstrup I.

A. 》.

Antedon cava Br. N.

1913. Antedon cava, Brünnich Nielsen (80 S. 104, T. 11 Fig. 45-59, T. 12 Fig. 1-35).

Y. Danium. Bryozokalk: Rejstrup I. 
Antedon plana Br. N.

1913. Antedon plana, Brünnich Nielsen (80 106, T. 12 Fig. 54-56).

Y. Danium. Bryozokalk: Rejstrup I.

\section{Ophiuroidea.}

Fra forskellige Lokaliteter foreligger der en Del Ophiur-Plader, tildels i Sammenhæng. En nærmere Behandling er dog ikke forsøgt.

\section{Asteroidea.}

Metopaster mammilatus Gabb.

1913. Metopaster mammilatus Gabb; Spencer (11\% S. 114, T. 10 Fig. 9, 16, T. 15 Fig. $8-11)$.

1917. 》; Brünnich Nielsen (84).

1920

》 Spc. var. radiatus Spencer; Rosenkrantz (106 S. 22).

1923. 1925 . Gabb; Jessen og Ødum (47 S. 20). "; Rosenkrantz (111 S. 9).

Arten optræder i to Former.

M. mammilatus typicus har korte Arme, endende i store, usymmetrisk udviklede Supero-Marginalia.

Y. Danium. Coccolitkalk: Thisted III.

Bryozokalk: Lendrup Strand.

A. » : Alm.

Senonium (Maastrichtien).

M. mammilatus var. radiatus har lange Arme, sammensatte af mindre Plader, hvorfor man ikke finder store, terminale Supero-Marginalia.

Y. Danium. Coccolitkalk: Tustrup I?, Thisted V, Helligkilde I, Mønsted III, Hjerm I?.

Bryozokalk: Aggersborg Gaard, Dollerup I--II.

\section{Mitraster Hunteri Forbes.}

1913. Mitraster Hunteri Forbes; Spencer (117 S. 117, T. 10 Fig. 21-23. T. 11 Fig. $1-2)$.

Y. Danium. Ret hyppig.

A. 》 》 》 .

Senonium og Turonium.

Teichaster favosus Spencer.

1913. Teichaster favosus, Spencer (117 S. 122, T. 12 Fig. 14-19, T. 16 Fig. 14-16). 
1917. Teichaster favosus, Spencer; Brünnich Nielsen (84).

$1920 . \quad " \quad "$ " var. retiformis Spencer; Rosenkrantz (106 S. 22).

1923. " " "JESSEN og ØDUm (47 S. 20).

Arten er en Del Variation underkastet. Spencer opstillede en var. retiformis, udmærket ved større Højde og delvis anden Form af Supero-Marginalia, samt en finere Net-Skulptur; den skulde være særegen for Y. Danium.

Hvad det jyske Materiale angaar, varierer det delvis i Overensstemmelse med SPEncer's Former, men der kan ikke spores nogen Konsekvens i Formernes Optræden. De Plader, der nærmest stemmer overens med Spencen's var. retiformis, stammer fra en Del BryozokalkLokaliteter i A. Danium.

Y. Danium. Alm.

A. 》 》 .

Senonium.

Pycinaster crassus Spencer.

1913. Pycinaster crassus, Spencer (117 S. 125, T. 11 Fig. 16-17, T. 16 Fig. $1-6)$.

1920. " " ; Rosenkrantz (106 S. 22).

Y. Danium. Ret hyppig.

Æ. " " 》.

Senonium.

Chomataster acules Spencer.

1913. Chomataster acules, Spencer (117 S. 128-129, T. 12 Fig. 28, 31, T. 16 Fig. $8-13)$.

1917. " " " \# BrüNnich Nielsen (84).

1920. " " "; Rosenkrantz (106 S. 22).

$1923 . "$ " " Jessen og ØDUM (47 S. 20).

Y. Danium. Ret hyppig.

E. " " "

Senonium.

\section{Ophryaster magnus Spencer.}

1913. Ophryaster magnus, Spencer (117 S. 130, T. 16, Fig. 20-27).

Y. Danium. Bryozokalk: Rejstrup I.

(E. 》 .)

Senonium.

Stauranderaster gibbosus var. pyramidalis Spencer.

1913. Stauranderaster gibbosus var. pyramidalis, Spencer (117 S. 135, T. 13 Fig. 12-13, T. 16 Fig. 30). 
Y. Danium. Bryozokalk: Rejstrup I.

A. » . Coccolitkalk (Lerlag): Nystrup I D.

Senonium.

\section{Stauranderaster senonensis Val.}

1913. Stauranderaster senonensis Val.; Spencer (117 S. 134, T. 13 Fig. 14-15).

Y. Danium. Coccolitkalk: Hjerm I.

Bryozokalk: Rejstrup I, Dollerup I, Helligkilde I.

A. 》

Senonium.

\section{Tholaster argus Spencer.}

1913. Tholaster argus, Spencer (117 S. 137-138, T. 13 Fig. 22-23).

Y. Danium.

A. » Alm.

Senonium.

Tholaster ocellatus Spencer.

1913. Tholaster ocellatus, Spencer (117 S. 137-138, T. 13 Fig. 24).

Y. Danium. Alm.

A. 》 " .

Senonium.

\section{Lophidiaster pygmaeus Hag.}

1913. Lophidiaster pygmaeus Hag.; SPENCER (117 S. 139, T. 11 Fig. 20-21, Y. Danium. Alm.

A. " " .

Senonium.

\section{Echinoidea.}

Temnocidaris danica Desor.

1892. Temnocidaris danica Desor; Schlüter (115 S. 125, T. 17 Fig. 1-2).

$1899 . "$ " " GröNwALL (28 S. 71).

1902-03. " " " RAVN (95 S. 423).

1908. " " " RAVN (96 S. 68).

?1923. " " ; JESSEN og ØDum (47 S. 21).

1924. " " ; Mortensen (74 S. 173, Fig. 79).

Bestemmelige Plader er fundet paa flere Lokaliteter.

Y. Danium. Bryozokalk: Aggersborg Gaard.

Æ. " " Kjølby II, Aggersborg I, Valbjerg Huse, Bulbjerg, Lønnerup I. 
Cidaris subvesiculosa D'0rb.

1923. Dorocidaris subvesiculosa D'Orb.; Jessen og Ødum (47 S. 21).

Arten anføres fra Voxlev, og en Del Pigge fra Gravlev har ligeledes kunnet henføres hertil; det er dog ikke udelukket, at Arten har en større Udbredelse, ogsaa i Daniet.

A. Danium. Coccolitkalk: Gravlev I C, Voxlev A-D.

Senonium. Voxlev Skr.

Cidaris Bolli Lambert.

1892. Cidaris spinosa Boll; Schlüter (115 S. 15).

1923. " "; Jessen og ØDum (47 S. 22).

1923. " Bolli, Lambert (55).

Piggene af denne Form er oprindelig beskrevet under Navnet $C$. spinosa af BoLL. LAMBERT gør imidlertid opmærksom paa, at dette Navn er optaget for en anden Art, hvorfor han ændrer Navnet til C. Bolli.

Foruden de tidligere omtalte Pigge fra Voxlev foreligger der fra en Række jyske Daniumlokaliteter en Del Pigge af denne Type; de henregnes her til $C$. Bolli, omend det er muligt, at der foreligger flere Arter.

Æ. Danium. Bryozokalk: Sangstrup Klint, Purhus III, Tinbæk Mølle, Lundgaard I, Munksjørup I, Barmer I, Klokrøgel II.

Coccolitkalk: Voxlev D.

Senonium. Voxlev Skr., Rostrup I.

Cidaris sp.

Cidarislevninger - Plader, isolerede Pigge m. m. - foreligger fra et overordentlig stort Antal Lokaliteter. Da de danske, fossile Echinider imidlertid ikke er blevet underkastet nogen samlet Bearbejdelse, vil et Forsøg paa en midlertidig Bestemmelse, der ikke formes som en rationel Bearbejdning, være temmelig værdiløs. Der er derfor ikke gjort noget Forsøg i denne Retning.

\section{Tylocidaris vexillifera Schlüter.}

(T. I).

1892. Tylocidaris vexilifera, Schlüter (11.5 S. 54, T. 17 Fig. 3-4).

1900 .

$1902-03$

1917.

1920.

1923.

1924.

1925 .
Grönwall (29).

; Ravn (95 S. 423).

; Brünnich Nielsen (84).

(88 S. 8).

; Jessen og ØDUM (47 S. 22, T. II

Fig. 3).

; Mortensen (74 S. 173).

; Rosenkrantz (111 S. 9). 
Denne Art optræder i Daniet hovedsagelig i to Former, mellem hvilke der dog er fuldstændig jævn Overgang.

T. vexillifera $f . \alpha$ (BRÜnNich Nielsen's »ældre Type«, T. I Fig. 1), har i sin typiske Udvikling Pigge af omtrent kuglerund Facon, hvis Overflade har uregelmæssigt stillede Korn; undertiden er disse dog henimod Spidsen ordnede i Rækker.

T. vexillifera f. $\beta$ (BRÜnnich Nielsen's "yngre Type«, T. I Fig. 2) har typisk større Pigge, hvis Facon er mindre regelmæssigt kugleformet; Hovedet af Piggen vider sig mere pludseligt ud fra Stilken og er mere tilspidset opefter samt forsynet med vingeformede Udvækster. Kornene er oftest stillede i Række og er mere tilspidsede, især henimod Toppen. Formen er mere variabel end $f$. $\alpha$.

$T$. vexillifera $f$. a træffes udelukkende i $\mathbb{E}$. Danium.

T. vexillifera $f$. $\beta$ træffes i Y. Danium, dels i typisk Form, dels som en Række Varianter til begge Sider fra denne; til den ene Side Pigge uden Tendens til Vinger, blot med tilspidsede, rækkestillede Korn (ligesom Piggen selv er tilspidset), til den anden Side Pigge, der er trukket fuldstændig ud til flade, vingeformede Forlængelser, mens Hovedet selv kan være næsten ganske reduceret (T. I Fig. 2 h-i).

Foruden disse to Former findes, omend sjældnere, i ældre Danium en Type af $T$. vexillifera-Pigge, der synes at skille sig ud fra den af Formerne $\alpha-\beta$ repræsenterede Udviklingsrække, men som alligevel er nær knyttet til $f$. $\alpha$, maaske som en særlig, differentierende Form (T. I Fig. 3). Den benævnes i det følgende $\left.f \cdot \gamma^{1}\right)$. Piggene er betydelig større end hos $f$. $\alpha$, udpræget kølleformede, idet den svære Stilk mod Spidsen udvider sig jævnt til en tykkere Opsvulmning; Toppen af Piggen er enten jævnt afrundet eller svagt affladet (47 T. II Fig. 3). Piggene kan enten være jævnt kornede over det hele eller ganske glatte med Undtagelse af den øverste Del; i begge Tilfælde bærer denne øverste Del tætstillede, mere eller mindre skarpt markerede Rækker af Torne.

T. vexillifera $f . \gamma$ forekommer saaledes:

A. Danium. Bryozokalk: Voxlev Kalkværk, Gravlev I A, Karlby Klint, Veggerbro I, Barmer I, Klim I?. Coccolitkalk: Gravlev I B-C.

\section{Tylocidaris baltica Schlüter.}

1904.

1913.

Ussing (124 Fig. 24).

") (127 Fig. 24).

1923. Tylocidaris baltica Schlüt.; JESSEN og ØDUM (47 S. 22, T. II Fig. 2). 1924. " " ; Mortensen ( 74 S. 173, Fig. 80).

1) Om det fylogenetiske Forhold mellem Formerne $\alpha$ og $\gamma$ kan næppe noget afgørende siges; de optræder begge i Daniets basale Dannelser Side om Side. Med Henblik paa f. $\gamma$ 's Morfologi kan den Mulighed tænkes, at den danner Overgang fra $T$. baltica til $f$. $\alpha$. 
(A. Danium. Paa sek. Leje i Kjølby Gaard I B).

Senonium. Voxlev Skr., Nibe I, Kjølby Gaard I C, Nystrup I G, Eerslev I C, Bøgelund Skrivekridt.

\section{Salenia sp.}

Ubestemte Salenier er fundet paa en lang Række Lokaliteter, men en nærmere Behandling af Materialet, der sandsynligvis falder i flere Arter, er ikke foretaget.

Phymosoma taeniatum Hag.

1908. Cyphosoma taeniatum Hag.; Ravn (96 S. 68).

1923. " " ; JESSEN og ØDUM (47 S. 23).

Senonium. Voxlev Skr.

\section{Phymosoma corollare Klein.}

1923. Cyphosoma corollare Klein; Jessen og Øрum (47 S. 23).

A. Danium. Coccolitkalk: Voxlev C.

Senonium.

\section{Phymosoma sp.}

Om denne Slægt, der er overordentlig almindelig i Daniet, gælder det samme, som ovenfor er sagt om Cidaris.

\section{Pseudopyrina subovalis Ravn.}

Arten vil blive beskrevet af Museumsinspektør J. P. J. Ravn.

Y. Danium. Bryozokalk: Lendrup Strand, Aggersborg Gaard.

Echinocorys ovatus Leske.

1851. Ananchytes ovata Lamk.; PugGaARd (92 S. 72, Fig. 14 (og 15?)).

1902-03. " " Leske; RavN (95 S. 375).

1904. " " Ussing (124 Fig. 25).

1913. \# $\Rightarrow$ (127 Fig. 25).

1917. Echinocorys ovatus Leske; BrüNNich Nielsen (84).

1923. " " ; JESSEN og ØDUM (47 S. 27).

1924. " " " Mortensen (\%4 S. 194, Fig. 94),

1924. " " \# Rosenkrantz (110).

AE. Danium. Coccolitkalk: Bøgelund C?, Voxlev D, Kjølby Gaard I A?, Nye Kløv.

Senonium. Voxlev Skr., Nye Kløv Skrivekridt.

\section{Echinocorys sulcatus Goldf.}

1886. Ananchytes sulcatus Goldf.; Lundgren (59 S. 282).

1902-03. " sulcata " Ravn (95 S. 375).

1903. " sulcatus "; LAmbert (54 S. 88, T. VI Fig. 11-14). 
1917. Echinocorys sulcatus Goldf.; Brünnich Nielsen (84).

$1920 . \quad " \quad$ " $\quad$ Rosenkrantz (106 S. 24).

$1923 . \quad " \quad "$; JESSEN og ØDum (47 S. 25).

1924. " sulcata " ; MorTensen (74 S. 194).

Arten er overordentlig variabel, baade i Form og Størrelse. Yderpunkterne repræsenteres dels af store Former, hvis Højde er meget betydelig i Forhold til Længde og Bredde, dels af en lille, forholdsvis lav Form. Ligeledes er Skævheden, Pladernes Konvexitet, Vortebesætningen $\mathrm{m}$. v. Variation underkastet, men fra det ene Yderpunkt til det andet findes Variationerne kombineret forskelligt og med saa mange jævne Overgange, at det næppe er muligt at udskille faste Former.

Arten er udbredt i hele Daniet, hvor den kan siges at være omtrent den almindeligste Forstening. I Almindelighed er den i det \&. Danium repræsenteret ved en middelhøj Form, der kun sjældent overskrider $6 \mathrm{~cm}$ i Længde, mens den i det Y. Danium er underkastet større Variation til begge Sider. Den ganske lille, lave, skæve Form synes at være indskrænket til det alleryngste Danium, hvor den ofte optræder i Mængde.

Med Hensyn til Artens Afgrænsning er fulgt den af Forf. (47) brugte Metode. Eksemplarer fra Nystrup I D-E tillader ikke Maaling af de paagældende Plader, men Skaltykkelsen, Pladernes Konvexitet, samt den hele Habitus gør det utvivlsomt, at disse Stykker hører herhen.

(Selandium. Paa sek. Leje).

Y. Danium. Alm.

E. " " .

Holaster faxensis Hennig.

1898. Holaster faxensis, Hennig (36 S. 6, Fig. 1-5).

1908. " 》 (M.U.H.) Lundgr.; Ravn (96 S. 68).

Y. Danium. Coccolitkalk: Legind I.

Bryozokalk: Hammelev Gaard.

\section{Cardiaster sp.}

Et desværre meget fragmentarisk Stykke, som kun har Underdelen af Skallen i Behold, viser sig tydeligt ved Forløbet af Lateralfasciolen under Periproctet at høre til denne Slægt. Det foreliggende Stykke minder meget om $C$. ananchytis Leske, men afviger ved en slankere og mere kantet Form, større Indtrykning af Partiet omkring Periproctet og ved et færre Antal (og større) Vorter paa Plastron.

Senonium. Torum I.

Micraster Desori n. sp.

(T. II Fig. 1).

1910. Micraster sp.; BrüNNich Nielsen (77 S. 466). 
Nedenstaaende Beskrivelse er tildels baseret paa Eksemplarer fra København, opbevarede paa Mineral. Museum.

Formen er afrundet hjerteformet, smallest bagtil, bredest lidt foran Topfeltet, hvilket synes at ligge en Smule bag Midten af Skallen. Oversiden er jævnt hvælvet, svagt affladet omkring de forreste parrede Ambulacralfurer, højest ved Topfeltet, hvorfra en svag Køl gaar bagud.

Den forreste, uparrede Ambulacralfure er meget dyb, dybest hvor den som en halveylindrisk Udskæring gaar ned over Forranden, og denne Fure fortsættes ind til Munden. Denne ligger langt fremme, bagest i den indsænkede Fure, og dette i Forbindelse med den fremspringende Baglæbe, der omtrent ligger i Plan med den næsten flade Underside, gør, at Mundaabningen kommer til at vende fremad. Munden er halvcirkelformet.

De forreste parrede Ambulacralfelter er kun svagt indsænkede, omtrent lige brede i hele deres Forløb, kun ubetydeligt indsnævrede mod Spidsen; de indeholder 25-30 Par porebærende Plader. De bageste parrede Ambulacralfelter er næsten slet ikke indsænkede, er ovale i Form og meget korte, idet de kun fører 6-8 Par porebærende Plader.

Periproctet sidder højt oppe paa den stejlt opstigende Bagflade.

Maal paa et Par Individer (tilnærmede):

$$
\begin{array}{r}
\text { Længde: } 37 \mathrm{~mm} \text { Bredde: } 34 \mathrm{~mm} . \\
\text { ca. } 34 \text { » }
\end{array}
$$

Y. Danium. Coccolitkalk: Purhus I.

Cyclaster Brünnichi Ravn.

1917. Brissopneustes danicus Schlüter (part.); BrüNnich Nielsen (84).

1923. " " " " JESSEN og ØDUM (47 S. 23 , T. I).

1924. " " " $"$ "

Arten vil blive beskrevet af Museumsinspektør J. P. J. RAvn i et kommende Arbejde. Den staar meget nær Brissopneustes, og bl. a. hører de af Forf. i 1923 beskrevne og afbildede Eksemplarer fra Voxlev herhen.

A. Danium. Bryozokalk: Bjerge I?, Bøgelund A, Gravlev I A, Voxlev L, Nye Kløv Brzk.

Coccolitkalk: Bøgelund B-C-D, Gravlev I C-D, Voxler A-B - C-D, Kjølby Gaard I A, Nye Kløv Cek.

Brissopneustes danicus Schlüter.

1908. Brissopneustes danicus Schlüter; RavN (96 S.68).

1920. " " " Brünnich Nielsen (88 S. 9).

(1923. " " " JESSEN og ØDUM (47 S. 23)).

1924. " " "Mortensen (74 S. 197).

1924. " " (part.); Rosenkrantz (110). 
Det har været formodet, at denne Art allerede skulde optræde i den yngste Del af Skrivekridtet paa Stevns (4\%), men efter RosenKRANTz's Undersøgelser (110) maa det betragtes som fastslaaet, at $B$. danicus er en rent danisk Art.

E. Danium. Bryozokalk: Hyppig.

\section{Brissopneustes suecicus Schlüter.}

1908. Brissopneustes suecicus Schlüter; Ravn (96 S. 68).

1920. " " " B Bünnich Nielsen (88 S. 9).

(1923. " " " JESSEN og ØDUM (47 S. 23).)

1924. " " " Mortensen (74 S. 197, Fig. 95).

Paa Grundlag af Materialet fra Voxlev har Forf. tidligere villet forene denne Art med den foregaaende; efter RAvn's (endnu ikke publicerede) Undersøgelser er det imidlertid atter sandsynligt, at de to Former kan opretholdes som selvstændige Arter.

Y. Danium. Hyppig.

\section{Bryozoa.}

Bestemmelige Bryozoer foreligger fra saa at sige alle jyske DaniumLokaliteter. Til Trods for, at dette meget store Materiale muligvis vil kunne give interessante Oplysninger i stratigrafisk Henseende, er en Bestemmelse dog ikke foretaget. En saadan maatte nemlig nødvendigvis forme sig som en Bearbejdning af de danske Danium-Bryozoer, et Arbejde, der i denne Forbindelse maa anses for at være uoverkommeligt.

\section{Vermes.}

Serpula (Hyalapamatus) gordialis Schloth.

1851. Serpula implicata Hag.; Puggand (92 S. 93).

1908. " " " RAvN (96 S. 69).

1917. " " ; BrüNNich Nielsen (84).

1921. " gordialis Schloth.; RavN (103 S. 16).

$1923 . "$ " " J JESSEN og ØDUM (47 S. 28).

Y. Danium. Alm.

A. " " .

Senonium.

\section{Serpula (Apamatus) laevicollis $\mathrm{Br} . \mathbf{N}$.}

Arten vil blive beskrevet af Dr. BRÜNNICH NIELSEN i en kommende Publikation $\left.{ }^{1}\right)$.

Y. Danium. Alm.

E. 》 " .

1) Det samme gælder alle Arter, der i det følgende betegnes med Autornavnet Br. N. 
Serpula (Hydroides) contorta Br. N.

Y. Danium. Ret hyppig.

A. " . Hyppig.

Serpula (Hydroides) aplanata Br. N.

Optræder fortrinsvis i Bryozokalk.

Y. Danium. Ret hyppig.

A. " . Hyppig.

Serpula (Spirorbis) ascendens $\mathrm{Br} . \mathbf{N}$.

Y. Danium. Hyppig.

A.

Serpula (Spirorbis) conica Hag.

1851. Serpula conica Hag.; PuggaArd (92 S. 93).

$1908 . "$ " " $\operatorname{RAvN}(68$ S. 69).

1917. " " ; BrüNnich Nielsen (84).

Senonium. Nye Kløv Skrivekridt.

Serpula (Spirorbis) Hisingeri Lundgr.

1920. Serpula Hisingeri Lundgr.; Rosenkrantz (106 S. 24).

Y. Danium. Coccolitkalk: Bredstrup Klint, Stinesminde I, Laaenhus I, Mønsted I.

Serpula (Spirorbis) consolida n. sp.

(T. II Fig. 3).

Røret er regelmæssigt oprullet i Kegleform med en Topvinkel paa omtrent $90^{\circ}$; Keglen med aaben Navle. Rørets Gennemsnit er omtrent circulært, noget affladet paa Oversiden; dette Parti er svagt længdestribet; Kanten ind mod Navlen er afrundet, Yderkanten skarpt kølet. Udenfor denne Kant ses endnu et affladet Parti, atter begrænset af en endnu svagere Køl. Partiet mellem denne og den uregelmæssigt udflydende Sutur er svagt længdestribet. Tilvækstlinier over hele Skallen, Varices med Mellemrum.

Højde: $6 \mathrm{~mm}$. Største Diameter: $9 \mathrm{~mm}$.

Y. Danium. Coccolitkalk: Kaase II, Frøslevvang II.

Æ. " . Bryozokalk: Nye Kløv.

Serpula (Spirorbis) sulcata $\mathrm{Br}$. N.

Y. Danium. Coccolitkalk: Bjerregrav I, Thisted VIII.

Bryozokalk: Hansted I-II, Tved I, Hjardemaal I, Skaarup I.

AE. \ " : Vigsø I. 
Serpula (Spirorbis) cingulata Br. N.

Y. Danium. Bryozokalk: Aggersborg Gaard.

A. 》 .

Y. Danium.

Serpula (Spirorbis) striata $\mathrm{Br}$. N.

A. " Bryozokalk: Lundgaard I, Munksjørup I, Klim Bjerg, Klim I, Torup Kløv I, Bulbjerg.

Serpula (Spirorbis) multilineata $\mathrm{Br}$. N.

Fortrinsvis i Bryozokalk.

Y. Danium. Ret hyppig.

Æ. " Hyppig.

Serpula (Spirorbis) distincta Br. N.

Denne Art er den almindeligst forekommende Spirorbis i det $\mathrm{E}$. Daniums Bryozokalk i Jylland, hvor den synes at være begrænset i sin Optræden til denne Afdeling af Daniet. Paa Sjælland forekommer den derimod tillige i visse Dele af $\mathrm{Y}$. Danium (Faxe).

Y. Danium.

Æ. » . Bryozokalk.

Serpula incrassata Br. N.

Y. Danium. Coccolitkalk: Bjerregrav I.

Bryozokalk: Dollerup II.

Serpula terundulata $\mathrm{Br}$. N.

Y. Danium. Bryozokalk: Svendborg I, Hansted II, Hjardemaal I.

Serpula quinquedentata $\mathrm{Br}$. N.

Y. Danium. Coccolitkalk: Thisted VIII.

Bryozokalk: Aggersborg Gaard.

Æ. " " : Stensmark, Klim I, Torup Kløv I.

Serpula proboscis n. sp.

(T. II Fig. 2).

Det foreliggende Fragment er et Stykke af Røret, maalende $30 \mathrm{~mm}$ i Længde, $4 \mathrm{~mm}$ i ydre Diameter; Rørets Lysning er $2 \mathrm{~mm}$; de to sidste Maal gælder den yngste Part af Rørstykket, men Tykkelsen er kun ubetydeligt ringere paa den ældste Del.

Røret har sikkert ikke været fastvokset i hele sin Længde, men har formodentlig været nedliggende paa Havbunden paa den ene Side. Tværsnittet er afrundet kvadratisk. Kanterne udgøres af afrundede Længdefolder, de to - øverste - bredere og fladere afrundede, de to - 
nederste - smallere og skarpere. Paa de tre frie Sider findes en ikke særlig dyb Længdefure. Den fjerde, nederste Side er flad eller konkav, i Midtlinien forsynet med en ret skarp Længdekøl.

Røret er paa hele Overfladen forsynet med fine, tætliggende, uregelmæssige Tværrynker.

Y. Danium. Bryozokalk: Dollerup I.

\section{Serpula (Pomatocerus) dentata $\mathrm{Br}$. N.}

1920. Serpula sp. I; Rosenkrantz (106 S. 25).

Y. Danium. Coccolitkalk: Alm.

Bryozokalk: Aggersborg Gaard, Hansted I.

Serpula (Pomatocerus) undulifera $\mathrm{Br}$. N.

Y. Danium. Coccolitkalk: Thisted IV og VI, Frøslevvang II.

Bryozokalk: Tved I.

Serpula (Pomatocerus) erecta $\mathrm{Br} . \mathrm{N}$.

Fortrinsvis i Bryozokalk.

Y. Danium. Hyppig.

E. "

Ditrupa canteriata Hag.

1851. Serpula canteriata Hag.; PugaAard (92 S. 93, Fig. 39).

1908. " " " RavN (96 S. 69).

Y. Danium. Coccolitkalk: Thisted I (paa sek. Leje?).

Senonium.

Ditrupa Schlotheimi Rosenkr.

1902-03. Dentalium (?); RAvN (95 S. 212).

1910. Serpula laevis Schloth.; Brünnich Nielsen (77 S. 467).

1920. Ditrupa Schlotheimi, Rosenkrantz (106 S. 25, T. II Fig. 8-9).

1922. " " HARder (34 S. 28, 31).

Y. Danium. Coccolitkalk: Alm.

Ditrupa tubaeformis $\mathrm{Br}$. N.

Y. Danium. Cocolitkalk: Jernit, Helligkilde II.

\section{Ditrupa interjuncta Ødum.}

1923. Ditrupa interjuncta, Jessen og ØDum (47 S. 28, Fig. 11, T. II Fig. 8).

Y. Danium. Coccolitkalk: Hjerm I.

Bryozokalk: Hjardemaal I.

A. 》 " Kastbjerg I, Ove IV, Voxlev L, Gravlev I A. 
Coccolitkalk: Gravlev I C, Voxlev A-B, Nye Kløv, Bøgelund C.

\section{Terebella sp.}

?1915. „Terebella« lewesiensis Mant.; Ravn (99 S. 385).

1920. " sp. ; Rosenkrantz (106 S. 27).

1923.

; Jessen og ØDUM (47 S. 46).

En Del Sammenhobninger bestaaende af forskelligt Materiale, enten Fiskeskæl og Fiskeknogler, eller andre Ting saasom Foraminiferer, Crinoidrester, Serpulastumper o. s. v., kan med større eller mindre Sandsynlighed henføres til rørbyggende Orme.

Foreligger fra adskillige Lokaliteter.

Mineringer i Molluskskaller, især Ostreider, er sandsynligvis udført af Orme, muligvis Spionider.

\section{Brachiopoda.}

\section{Crania ignabergensis Retzius.}

1851. Crania costata Sowb.; Puggaard (92 S. 85 Fig. 33-34).

1895. 》" 》 $\gg$ Posselt (91 S. 15, T. I Fig. 1-4).

1894. " ignabergensis Retz.; Posselt (91 S. 14).

1909. " " " BRÜNNich NiELSEN (76 S. 147).

1911. " " " " " \# (78 S. 605).

Arten forekommer i Daniet som forholdsvis smaa Eksemplarer, der dog kan variere en Del, særlig med Hensyn til Antallet af Costae. Fælles for dem alle er det, at de afviger fra den typiske $C$. ignabergensis ved, at Limbus-Indskuddet foran de bageste Divaricatorindtryk er yderst svagt udtalt eller mangler helt. De burde maaske holdes ude fra Artens Hovedtype som en særlig Varietet.

Y. Danium. Hyppig.

A. " ".

Senonium.

\section{Crania tuberculata Nilsson.}

1866. Crania spinulosa, Fischer-Benzon (14 S. 18).

1885. " tuberculata Nilss.; Lundgren (5\% S. 27, T. I Fig. 19-20).

1885. " transversa, Lundgren (57 S. 25, T. I Fig. 5-6).

1894. " tuberculata Nilss.; Posselt (91 S. 19).

1898. " " " GRöNWALL (26).

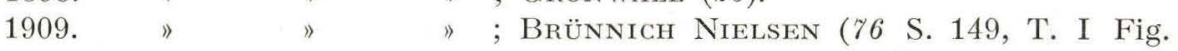

1-9).

1911. " " $" \Rightarrow \quad$ (78 $\quad$ S. $605, \quad$ T. 12 Fig. 1). 
1911. Crania tuberculata var. transversa Lundgr.; BrüNNich Nielsen (78

S. 605 , T. 12 Fig. 2).

1917.

1920.

1920.

$$
\begin{aligned}
& \text { Nilss.; Rosenkrantz (106 S. 31, T. II Fig. 2-3). } \\
& \text { var. transversa Lundgr.; Rosenkrantz (106 } \\
& \text { S. 31, T. II Fig. 4). }
\end{aligned}
$$

Crania tuberculata optræder i de to Former, mellem hvilke der findes Overgange.

C. tuberculata typica.

Y. Danium. Coccolitkalk: Bredstrup Klint.

C. tuberculata var. transversa.

Y. Danium. Bryozokalk: Rejstrup I, Marslev I?

A. $»$ Alm.

Crania faxensis $\mathrm{Br} . \mathrm{N}$.

1911. Crania faxensis, Brünnich Nielsen (78 S. 606, T. 12 Fig. 3 -7).

1914. " " 》 (82 S. 288).

Y. Danium. Coccolitkalk: Bjerregrav III.

Bryozokalk: Hammelev Gaard.

Æ. » $\gg$ Klim I.

Crania comosa Bosq.

1885. Crania comosa Bosq.; Lundgren (57 S. 29, T. I Fig. 12-13).

1909. " " " BRÜNnich Nielsen (76 6 S. 153, T. I Fig. 1911. 10 - 11).

1911. " " " " $\quad(78$ S. 606, T. 12 Fig. $8-9)$.

Denne Art er hjemmehørende baade i Senonium og Danium, men er her til Lands kun fundet i Daniet.

Y. Danium. Coccolitkalk: Hjerm I.

Bryozokalk: Rejstrup I, Marslev I, Hansted I.

A. 》 》 : Sangstrup Klint, Vigsø I.

Senonium.

\section{Crania pallida n. sp.}

(T. II Fig. 4).

Kun en Overskal kendes.

Formen er afrundet trapezoedrisk, smallere bagtil end fortil, Bagranden svagt indtrykt. Skallen er kun svagt hvælvet.

Ydersiden er glat; kun svage Tilvækstlinier spores. Den ret fremtrædende Umbo deler Skallens Længdeakse i omtrent 1 : 3.

Indersiden er forsynet med en smal, glat Limbus, afbrudt af en Sænkning midt paa Bagranden; længst tilbage ses dog meget svage Tilløb til Korn paa Limbus. Fordybningen foran Bagranden er kun svag. 
Muskelindtrykkene er svage, kun lidet iøjnefaldende. Divaricatorindtrykkene er kort ovale, mere affladet begrænsede mod Yderkanten end indad; de ligger ret stærkt fjernet fra hinanden. Occlusorindtrykkene ligger lidt tættere ved hinanden, omtrent i Skallens Midte; de er ovale, lidt divergerende bagtil; skraat fortil imellem dem ligger et svagt forhøjet, hjerteformet Parti, hvorfra der udgaar lave Volde, der danner Begrænsningen af Occlusorindtrykkene. Paa Ydersiderne af Occlusorindtrykkene ligger en svag Fordybning, der i en Bue strækker sig indenfor Limbus ned foran til de skraa Ydersider af den hjerteformede Ophøjning.

Længde omtrent $=$ største Bredde, lidt over $2 \mathrm{~mm}$.

Æ. Danium. Bryozokalk: Løgsted I.

Thecidium Grönwalli $\mathrm{Br}$. N.

1909. Thecidium Grönwalli, Brünnich Nielsen (76 S. 177, T. I Fig. 67).

1914. " " " " (82 S. 292).

Y. Danium. Bryozokalk: Aggersborg Gaard.

Thecidium danicum $\mathrm{Br}$. $\mathrm{N}$.

1911. Thecidium danicum, Brünnich Nielsen (78 S. 613, T. 12 Fig. $31-34)$.

1914. " " " " (82 S. 293).

Y. Danium. Bryozokalk: Rejstrup I, Helligkilde I.

Rhynchonella retracta Roem.

1923. Rhynchonella retracta Roem.; Jessen og ØDum (47 S. 30).

Senonium. Voxlev Skr., Bøgelund F.

Rhynchonella plicatilis Sow.

1909. Rhynchonella plicatilis Sow.; Brünnich Nielsen (76 S. 156, T. I Fig. $18-20)$.

Senonium. Eerslev I C.

Rhynchonella incurva Schloth.

1813. Terebratulites incurva, v. Schlotнeim (114).

1894. Rhynchonella faxensis, Posselt (91 S. 30, T. II Fig. 4 -9).

1909. " incurva Schloth.; Brünnich Nielsen (76 S. 157, T. I Fig. $21-23 \operatorname{og} 27)$.

1911. " " $"$ " "

1911. 》 var. faxensis Poss.; Brünnich Nielsen (78 S.

1914. " "f. typica og var. faxensis; BrünNich Nielsen

1917. " " var. faxensis Poss.; Brünnich Nielsen (84).

1923. " " " " " JESSEN og ØDUM (47 S. 30). 
Denne Art falder i to Former, angaaende hvilke især kan henvises til Brünnich Nielsex 1914, med jævn Overgang mellem Yderpunkterne, saa en afgørende Bestemmelse ofte er vanskelig.

Til de foreliggende Beskrivelser kan bemærkes, at var. faxensis paa mange jyske Lokaliteter afviger mere fra Hovedformen ved sin ringere Størrelse og tyndere Skal, end ved nogen særlig stærk Udvikling af Folder i Sinus.

$R$. incurva f. typica: Y. Danium. Hyppig.

$R$. incurva $f$. faxensis: Y. Danium. Bryozokalk: Aggersborg Gaard. Æ. " Alm.

\section{Rhynchonella flustracea Schloth.}

1866. Terebratula flustracea Schloth.; Fischer-Benzon (14 S. 17).

1894. Rhynchonella " " ; Posselt (91 S. 31, T. II Fig. 1-3).

1909. " " " BRÜNnich Nielsen (76 S. 158).

1911. " " " " " " $\quad\left(\begin{array}{llll}78 & \text { S. } 608, & \text { T. } 12\end{array}\right.$

Y. Danium. Bryozokalk: Aggersborg Gaard. Fig. 12-15).

\section{Argiope Davidsoni Bosq. ${ }^{1}$ )}

1909. Argiope Davidsoni Bosq.; Brünnich Nielsen (76 S. 174, T. I Fig. $50-53)$.

Y. Danium. Bryozokalk: Rejstrup I, Marslev I, Dollerup II.

\section{Argiope Bronni Hag.}

1894. Argiope Bronni Hag.; Posselt (91 S. 49).

1909. " " ; Brünnich Nielsen (76 S, 171, T. I Fig.

Senonium. Nystrup F. $36-38)$.

\section{Argiope Buchi Hag.}

1909. Argiope Buchi Hag.; Brünnich Nielsen (76 S. 171, T. I Fig. $40-42)$.

1923. " " ; Jessen og ØDUM (47 S. 32).

(Y. Danium. Coccolitkalk: Hjerm I?)

Senonium. Voxlev Skr.

Argiope Pindborgi Br. N.

1909. Argiope Pindborgi, Brünnich Nielsen (\%6 S. 178).

1911. " " " " (78 S.612, T. 12 Fig. 23 - 26).

1914. " " " "

Y. Danium. Coccolitkalk: Hjerm I.

Bryozokalk: Dollerup II.

$\left.{ }^{1}\right)$ Bestemmelsen af samtlige Argiope-Arter er konfereret med en endnu ikke udkommet monografisk Revision ved Dr. K. BrünNich Nielsen. 
Argiope Koeneni Br. N.

1911. Argiope scabricula Koen; Brünnich Nielsen (78 S. 611, T. 12 Fig. 20-22).

1918. 1);BøgGild (4 S. 88).

Arten vil iøvrigt blive beskrevet af Dr. Brünnich Nielsen.

Y. Danium. Hyppig.

A. 》

Argiope Ravni Br. N.

1909. Argiope Ravni, Brünnich Nielsen (76 S. 173, T. I Fig. 39).

1911. " " " " (78 S. 611).

1914. " " " "

Y. Danium. Coccolitkalk: Bjerregrav I.

Bryozokalk: Marslev I, Rejstrup I, Hansted I-II.

E. " " : Karlby Klint, Raasted I, Valsted I?, Valbjerg Huse.

Argiope Posselti Br. N.

1909. Argiope Posselti, Brünnich Nielsen ( 76 S. 174, T. I Fig. 46-48).

1911. " " " " (78 S. 610).

1914. " " " "

$1917 . \quad$ " "

Arten, som er almindelig i hele Daniet, synes at staa meget nær $A$. Bronni.

Argiope dorsata $\mathrm{Br}$. N.

Arten vil blive beskrevet af Dr. Brünnich Nielsen.

Y. Danium. Alm.

E.

Argiope faxensis Posselt.

1894. Argiope faxensis, Posselt (91 S. 52, T. I Fig. 16-17).

1909. " " ; BrüNnich Nielsen (76 S. 173)

1911. " " " " " " (78 S. 610).

1917. " " " " "

1923. " " ; Jessen og ØDUM (47 S. 32, T. II Fig. 4).

Y. Danium. Alm.

A. 》 》.

\section{Argiope scabricula Koen. $\left.{ }^{1}\right)$}

1885. Argiope scabricula, v. Koenen (51 S. 105, T. V Fig. 8).

1894. " acuta, Posselt (91 S. 50, T. I Fig. 14-15).

1) Sammen med de to følgende Arter danner denne en Gruppe for sig indenfor Daniets Argioper. I Forekomst er de alle begrænset til Daniets øverste Lag, hvor de synes at optræde vikarierende for hinanden. 
1909. Argiope acuta Posselt; BrüNnich Nielsen (76 S. 172, T. I Fig.

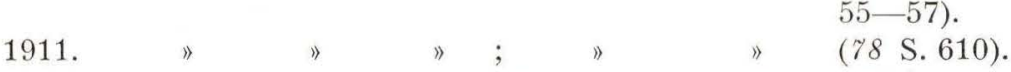

1920. 》 scabricula Koen.; Rosenkrantz (106 S. 32).

1924. " " ; " " (109).

$1925 . " \gg$; RAvN (105 S. 35).

Selandium.

Y. Danium. Coccolitkalk: Fredericia.

Bryozokalk: Marslev I.

\section{Argiope Johnstrupi Posselt.}

1894. Argiope Johnstrupi, Posselt (91 S. 51, T. I Fig. 12-13).

1909. " " " ; Bünnich Nielsen (76 S. 172, T. I Fig. 49 og 54).

Y. Danium. Coccolitkalk: Bredstrup Klint, Frederikseje I, Roldtved I, Oplev I.

\section{Argiope Cimbrorum Br. N.}

Arten vil blive beskrevet af Dr. BRÜNnich Nielsen.

Y. Danium. Coccolitkalk: Tustrup I, Bjerregrav I, Vejrum I, Hjerm I.

Bryozokalk: Svendborg I.

Terebratula carnea Sow.

1909. Terebrutala carnea Sow.; Brünnich Nielsen (76 S. 163, T. II Fig. $68-77)$.

Senonium. Brøndbjerg I.

Terebratula cfr. lens Nils.

1885. Terebrutala lens Nilss.; Lundgren (57 S. 55, T. II Fig. 29).

1894. " " " POSSELT (91 S. 39).

1909. " " ; Brünnich Nielsen (76 S. 164, T. II Fig. $78-88)$.

1911. " " " B BünNich Nielsen (78 S. 608).

1919. \" "

1919. \ carnea var. incisa Buch; Hadding (32 S. 8, T. I Fig. $6-10)$.

1919. " subrotunda Sow.; Hadding (32 S. 9, T. III Fig. 1-6).

1920. " lens Nilss.; Rosenkrantz (106 S. 31).

1920. " " " Brünnich Nielsen (88 S. 19).

1921. " " " " "

1922. $" \| \quad$; HARDER (34 S. 29).

1923. $\|$ \# HADDING (33).

1923. " carnea var. incisa v. Buch; HAdDIng (33).

1923. " subrotunda Sow.; HADDING (33). 
Opfattelsen af denne eller de herhen hørende Former har i de senere Aar været stærkt omstridt; BRÜNNICH NIELSEN vil sammenfatte alle de i vort yngre Danium forekommende Terebratler med lille Foramen til een Art, T. lens, mens Hadding vil dele de herhen hørende Former i 4 Grupper: T. lens Nitss., T. carnea Sow., T. carnea var. incisa Buch og T. subrotunda Sow.

Da de herhen hørende danske Former er underkastet stærk Variation, maa Hadding's Forsøg paa at udskille flere afgrænsede Former modtages med Velvilje. Ved en Gennemgang af det foreliggende Materiale kan man forholdsvis let udtage Typer, der svarer til de af HADDING omtalte Former (undtagen den typiske T. carnea Sow.), men mellem disse Typer findes imidlertid saa mange jævne Overgange og en saa vilkaarlig Kombination af de fremhævede Karakterer, at det i et overordentlig stort Antal Tilfælde er umuligt at afgøre, hvor et givet Individ skal anbringes, noget som BRÜNNICH NIELSEN ogsaa gør opmærksom paa.

Imidlertid er det til Raadighed staaende, jyske Materiale ret ringe, baade hvad Mængde og Bevaringstilstand angaar, saa det vil sikkert være forhastet paa Grundlag heraf at dømme om det berettigede i HADDrNG's eller BRÜnnich Nielsen's Opfattelse; hertil vil Gennemarbejdelsen af et langt større Materiale være nødvendig. Jeg har derfor foretrukket i denne Forbindelse at betragte denne yngre-daniske Gruppe under eet, idet det dog udtrykkelig skal understreges, at dette sker af rent praktiske Hensyn; dette er formodentlig saa meget mere berettiget, som Gruppen kun optræder i yngre Danium, ikke i ældre Danium, og saaledes her i Landet ikke optræder i direkte Kontinuitet af de senoniske Former.

Med Hensyn til Beskrivelsen af de forskellige Former henvises til Brünnich Nielsen og Hadding. Det skal kun bemærkes, at de til denne Gruppe hørende, jyske Eksemplarer alle udmærker sig ved en stor Muskeltilhæftningsknude paa Dorsalskallen.

Selandium. Hvalløse I C, Svejstrup I graa Mergel.

Y. Danium. Alm.

\section{Terebratula fallax Lundgr.}

1885. Terebratula fallax, Lundgren (57 S. 53, T. III Fig. 1 og 3).

1894. " " \# Posselt (91 S. 41).

1894. \ faxensis, Posselt (91 S. 43).

1909. " fallax Lundgr.; Brünnich Nielsen ( 76 S. 166, T. II

1911. Fig. 89-95).

1919. " obesa Sow. var. fallax Lundgr.; HadDing (32 S. 17, 'T.

VII Fig. 1-5).

1917. $"$ fallax Lundgr.; Brünnich Nielsen (84).

1920 . " " $"$ " 
1921. Terebratula fallax Lundgr.; Brünnich Nielsen (89 S. 11, Fig. 1--4). 1921. 1923. var. tenuis, Brünnich Nielsen (89). JESSEN Og ØDUM (47 S. 31).

1925 . Rosenkrantz (111 S. 9).

Denne almindelige Terebratula er, som bekendt, underkastet nogen Variation, og i Almindelighed kan man følge Brünnich Nielsen i at betragte den mindre og mere tyndskallede Form tenuis som en Form for sig; dog kan Grænsen mellem denne og den typiske fallax næppe betragtes som skarp.

T. fallax f. typica: Y. Danium. Alm.

T. fallax $f$. tenuis: Y. Danium. Sjældnere.

E. " . Alm.

Terebratulina striata Whlb.

1851. Terebratula striatula Mant.; PUGGaAnd (92 S. 85).

1866. " " ; Fischer-Benzon (14 S. 17).

1894. Terebralulina slriala Whlb.; Posselt (91 S. 32).

1909. " " \# Brünnich Niflenen (76 S. 159, T. I Fig.

1913. " " " " "

1916. " " " " " (100 S. 21).

1917. 》" " B BüNnich Nielsen (84).

1918. " " " $\quad$ RAvN (102 S. 23).

1921. " " $\quad$ " $\quad(103 \mathrm{~S} .18)$.

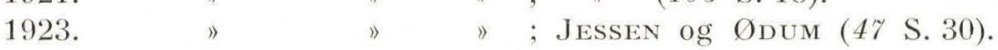

Y. Danium. Alm.

A. " " .

Senonium-Necomium?

Terebratulina locellus Roem.

1923. Terebratulina locellus Roem.; Jessen og ØDum (47 S. 30).

Senonium. Voxler Skr.

Terebratulina Gisi Hag.

1923. Terebratulina Gisi Hag.; JESSEN og ODum (47 S. 31).

Senonium. Voxlev Skr.

Terebratulina gracilis Schloth.

1923. Terebratulina gracilis Schloth.; Jessen og Øрum (47 S. 31).

Senonium. Voxlev Skr., Vive I, Nibe I.

Terebratulina semiglobularis Posselt.

1894. Terebratulina semiglobularis, Posselt (91 S. 35, T. III Fig. 10-13).

1909. 》 》 ; BRÜNnich NiElsen (76 S. 161,

1923. " " " " $"$ I I Fig. 35). 
A. Danium. Coccolitkalk: Voxlev D; desuden i Lerlaget Bøgelund $\mathrm{E}$ paa muligvis sekundært Leje.

Senonium. Voxlev Skr., Skovsted I, Bøgelund Skrivekridt.

Terebratella Humboldti Hag.

1923. Terebratella Humboldti Hag.; Jessen og Ødum (47 S. 32).

Senonium. Voxlev Skr., Nibe I.

\section{Lamellibranchiata.}

\section{Avicula danica Ravn.}

1902-03. Avicula danica, Ravn (95 S. 79, T. I Fig. 1-2).

1908.

(96 S. 71).

Senonium. Bøgelund Skr., Eerslev I C.

Avicula pectinoides Reuss.

1851. Avicula pectinoides Reuss; Puggand (92 S. 82).

1902-03. " " ; RAVN (95 S. 80, T. I Fig. 3).

Senonium. Spentrup I, Nibe I.

Avicula sp.

Paa Mineral. Museum opbevares et Aftryk af en mindre Avicula fra Jomfrubakken.

\section{Pinna sp.}

Fra et Par Lokaliteter foreligger der nogle ret velbevarede Eksemplarer af en ikke nærmere bestemt Pinna; desuden er der paa flere Steder fundet en Del prismatisk byggede Fragmenter, der sandsynligvis ogsaa hører til denne Slægt.

\section{Inoceramus tegulatus Hag.}

1922. Inoceramus tegulatus Hag.; Øрuм (130).

Senonium. Voxlev Skr., Tostrup I, Torum I, Hov IV, Batum, Eerslev I C, Øxendal?.

Lima (Limatula) decussata Münst.

1923. Lima decussata Münst.; Jessen og Ødum (4\% S. 33).

Senonium. Voxlev Skr.

Lima (Limatula) semisulcata Nilss.

1923. Lima semisulcata Nils.; JESSEN og ØDum (47 S. 33).

Senonium. Voxler Skr. 
Lima (Limatula) bisulcata Ravn.

1902-03. Lima bisulcata, RAvN (95 S. 97, T. II Fig. 13).

1920. " " ; Rosenkrantz (106 S. 33).

Y. Danium. Coccolitkalk: Jernit, Frøslevvang II.

\section{Lima (Limatula) densestriata Hennig.}

1899. Lima densestriata, Hennig (37 S. 8, T. I Fig. 3-4).

1902-03. " " ; RAvN (95 S. 98).

Y. Danium. Bryozokalk: Hjardemaal I.

Lima (Limea) testis Grw.

1907. Lima testis, Grönwall og Harder (31 S. 24, T. I Fig. 2-5).

1910. " " " " " \# BRÜNNICH NIELSEN (y S. 468).

1920. " " "

1924. " " " " "

1925. " " " RAVN (105 S. 35, 36).

Arten er karakteristisk for Daniets yngste Aflejringer, hvorfra den gaar op i det herover liggende Paleocæn.

Selandium.

Y. Danium. Coccolitkalk: Svejstrup I, Sevel I, Vejrum I, Hjerm I.

Lima (Limea) Geinitzi Hag.

1923. Lima Geinitzi Hag.; Jessen og Ødum (47 S. 33).

1925. 》" " $\operatorname{RavN}(105 \mathrm{~S} .36)$.

Arten er af ØDUM fejlagtig henført til Underslægten Limatula; et af Eksemplarerne fra Voxlev viser tydelige Laastænder.

Senonium. Voxlev Skr.

\section{Lima (Plagiostoma) Hoperi Mant.}

1923. Lima Hoperi Mant.; Jessen og Ødum (47 S. 33).

Senonium. Voxlev Skr.

\section{Lima Holzapfeli Hennig.}

1899. Lima Holzapfeli, Hennig (37 S. 10, T. I Fig. 1-2).

1902-03. " " ; RAVN (95 S. 100, T. II Fig. 15).

Y. Danium. Coccolitkalk: Bredstrup Klint.

Æ. " Bryozokalk : Torup Kløv I.

Lima granulata Nils.

1923. Lima granulata Nils.; Jessen og ØDUM (47 S. 34).

Senonium. Voxlev Skr.

Ove II, Hjerm I.

\section{Lima sp.}


Pecten (Synclonema) spathulatus Roem.

1923. Pecten spathulatus Roem.; Jessen og Øрum (47 S. 34).

Senonium. Voxlev Skr., Bøgelund Skr.

Pecten (Synclonema) cretaceus Nyst.

1923. Pecten cretaceus Nyst.; Jessen og ØDum (47 S. 34).

Senonium. Voxlev Skr.

Pecten (Synclonema) Nilssoni Goldf.

?1923. Pecten Nilssoni Goldf.; Jessen og Ødum (47 S. 34).

Senonium. Bøgelund F, Nye Kløv Skr., Voxlev Skr., Nystrup I F, Eerslev I B.

Pecten (Camptonectes) monotiformis Hennig.

(T. II Fig. 6).

1899. Pecten monotiformis, Hennig (37 S. 11, T. I Fig. 7-8).

1902-03. " " ; RAVN (95 S. 87).

$1923 . \quad " \quad$ " J JESSEN og ØDUM (47 S. 35).

$1925 . " \| \quad " \quad$ " $\quad$ RAVN (105 S. 35).

Hennig's vigtigste Karakterer for denne Art angives her efter RAvN :

Cirkelrunde, usymmetriske, $5-7 \mathrm{~mm}$ høje, næsten plane Skaller. Det bageste Øre er paa begge Skaller triangulært og ikke skarpt adskilt fra selve Skallen. - Højreskallens Yderside er glat med svagt antydede koncentriske Furer. Det forreste Øre er retvinklet og har et dybt Byssusudsnit samt en triangulær Indbugtning af det Parti, der ligger nærmest selve Skalranden. - Paa Venstreskallens Yderside ses skarpe koncentriske Tilvækststriber samt fine Radialribber; disse sidste ses dog kun tydeligt i Nærheden af Hvirvlen ${ }^{1}$ ); endvidere iagttages en meget fin Stribning omtrent som hos $P$. pulchellus Nilss.; det forreste Øres Yderhjørne er næsten retvinklet; det er større end det bageste, som er stumpvinklet. Skallens Skulptur fortsættes ud paa Ørene.

Hertil føjer RAvN, at Højreskallens forreste Øre bærer fine, kornede Radialribber, samt at dets Hjørner er mindre skarpe, end HenNig's Figur viser.

Fra en hel Række jyske Lokaliteter foreligger nu en Del smaa Pectines, der utvivlsomt alle hører til denne Art. Fælles for dem alle, baade Højre- og Venstreskaller, er Skallens runde Omkreds og det lille, stumpvinklede, fra Skallen uskarpt begrænsede, bageste Øre.

Højreskallerne svarer alle til ovenstaaende Beskrivelse, med den

1) Hennig tilføjer her: "utât mot periferien äro de endast antydda, derigenom att de koncentriska tillväxtlamellerna vid platsen för deras läge bilda hvalf- eller tandliknande små upphöjningar.« 
Tilføjelse, at de alle i stærkere eller svagere Grad er i Besiddelse af den samme meget fine "Transversalstribning" som Venstreskallerne. - Venstreskallerne svarer delvis nøje til den givne Beskrivelse, idet de bærer fine Tilvækststriber, der er forsynet med smaa, tornformede eller skalformede Fremspring, ordnet i radierende Rækker; denne Skulptur er især tydelig paa Skallens ældre Partier og Orene. Men foruden disse typiske Eksemplarer findes en Del, der kun har den omtalte Skulptur med Smaatornene meget svagt udtalt eller denne kan mangle fuldstændigt, saa Skallen kun er prydet med en fin "Transversalstribning". Mellem de skulpterede og de glatte Former findes Overgange, eller det samme Eksemplar kan paa et Parti af Skallen være svagt skulpteret, mens det paa et andet Parti er gariske glat (f. Eks. et Ekspl. fra Nystrup A).

Et lidt tvivlsomt Eksemplar fra Hansted III er paa Skallens ældre Del prydet med en fin, grubet Skulptur, der meget ligner den hos $P$. sericeus Grw.; det samme gælder en Skal fra Bulbjerg.

Y. Danium. Alm.

E. " " .

Pecten (Camptonectes?) cimbricus n. sp.

(T. II Fig. 7).

Højreskallen omtrent kredsrund med en tydelig, noget forlænget Udstrækning fortil; ret stærkt hvælvet; Laasranden indbøjet. Skallens Skulptur bestaar af meget svage, lidet udprægede Radialribber; hvor disse skærer de endnu svagere, koncentriske Tilvækstribber, opstaar smaa skalformede Knuder; denne Skulptur er svagest, paa det ene Eksemplar omtrent forsvindende, paa Skallens Midtparti. Desuden er hele Skallens Overflade (Ørene inclusive) dækket af en fin "Transversalstribning《.

Det forreste Ore er foroven stumpvinklet, forneden jævnt afrundet og har et dybt Byssusudsnit, der fortsættes i en smal Fure mellem Øret og Skallen selv. Det er prydet med 4-5 stærke Radialribber, der krydses af en tydelig koncentrisk Stribning, stærkest foroven. Det bageste Øre er kun ubetydeligt kortere end det forreste (regnet fra Umbo); det er stumpvinklet $\left(\mathrm{ca} \cdot 100^{\circ}\right)$, nedløbende og uafgrænset fra Skallen, prydet med Skallens Skulptur, men stærkt svækket.

Skulpturen minder noget om Venstreskallens Skulptur hos $P$. monotiformis, men denne Art har glat Højreskal; desuden adskilles de to Arter let ved den udtrukne Forrand hos P. cimbricus.

Foruden de to hele Højreskaller foreligger der et Fragment af Bugpartiet af en Skal, hvilket, efter Formen at dømme, muligvis kan hidrøre fra en Venstreskal. Det er prydet med en lignende Skulptur som Højreskallerne, men tættere og stærkere. 
Dimensioner: Højde: 4,0 mm. Længde: 4,3 $\mathrm{mm}$.

" 3,6 " " 3,6 "

Y. Danium. Coccolitkalk: Thisted V.

Pecten (Amussium) inversus Nils.?

1923. Pecten inversus Nils.?; Jessen og ØDum (47 S. 37).

? Y. Danium.

A. " Coccolitkalk: Voxlev B og D.

Pecten (Chlamys) inflexus Hag.

1923. Pecten inflexus Hag.; Jessen og Ødum (47 S. 35, T. II Fig. 5).

Æ. Danium. Coccolitkalk: Voxlev C.

Senonium. Voxlev Skr., Brøndbjerg I, Nye Kløv Skr.

Pecten (Chlamys) cretosus Defr.

1923. Pecten cretosus Defr.; Jessen og ØDum (47 S. 36).

Senonium. Voxlev Skr.

Pecten (Chlamys) variabilis Hag.

1923. Pecten variabilis Hag.; Jessen og Ødum (4'7 S. 36, T. II Fig. 1).

Senonium. Voxlev Skr.

\section{Pecten (Chlamys) tesselatus Hennig.}

(T. II Fig. 5).

1899. Pecten tesselatus, Hennig (37 S. 10, T. I Fig. 5-6).

1902-03. " " " RAvN (95 S. 87).

$1920 . \quad " \quad$ " $\quad$ Rosenkrantz (106 S. 34).

De foreliggende Venstreskaller svarer alle til Hennig's Beskrivelse. - Højreskallen er forsynet med den samme rudede Skulptur som Venstreskallen; Costae forøges ved Indskydning. Det bageste Øre er omtrent retvinklet, ret stort, prydet med radierende Rækker af smaa Skæl. Det forreste Øres øverste Hjørne er svagt stumpvinklet (kun lidt over $90^{\circ}$ ), det nederste Hjørne afrundet retvinklet, Forranden let uadbuet; Byssusudskæringen ligger i en indsænket Fure paa Grænsen mellem Øret og selve Skallen; Skulpturen bestaar af fine koncentriske Ribber og radiære Furer. Laasranden er lidt indbøjet baade paa forreste og bageste Øre.

En Venstreskal (fra Bredstrup Klint), som sandsynligvis hører herhen, afviger ved, at de koncentriske Lister paa Skallens yngre Partier ligger meget tæt, saa de smaa Rektangler er meget lave; det samme gælder et Eksemplar fra Aggersborg Gaard.

Y. Danium. Alm.

A. " " . 
Pecten (Chlamys) Puggaardi Ravn.

1923. Pecten Puggaardi Ravn; Jessen og Ødum (47 S. 35).

Senonium. Voxlev Skr., Bøgelund Skr., Nye Kløv Skr., Veggerbro III.

Pecten (Aequipecten) pulchellus Nils.

1923. Pecten pulchellus Nils.; Jessen og Ødum (47 S. 37).

Senonium. Voxler Skr., Bøgelund Skr.

Vola (Neithea) striato-costata Goldf.

1923. Vola striato-costata Goldf.; Jessen og Ødum (47 S. 38).

Senonium. Voxlev Skr., Spentrup I.

\section{Plicatula Ravni Rskr.}

1902-03. Plicatula sp.; Ravn (95 S. 104, T. II Fig. 16-17).

$1910 . \quad " \quad$ " B BüNNich Nielsen ( $7 \%$ S. 469).

1920. "Ravni, Rosenkrantz (106 S. 34, T. II Fig. 10-13).

Paa Sjælland er denne Art almindelig i og karakteristisk for det yngste Danium. I Jylland er der kun fundet 3 Eksemplarer, der alle er ualmindelig smaa og daarligt udviklede.

Y. Danium. Coccolitkalk: Tustrup I, Bjerregrav I.

\section{Dimyodon Nilssoni Hag.}

1900. Dimyodon Nilssoni Hag.; Grönwall (30 S. 75, T. 2 Fig. 1 -3).

1902-03. " " ; RavN (95 S. 109).

Y. Danium. Alm.

A. " " .

Dimyodon costatus Grw.

1900. Dimyodon costatus, Grönwall (30 S. 77, T. 2 Fig. 4-7).

1902-03. " " ; RAvN (95 S. 110).

Y. Danium. Alm.

A. 》 》.

Spondylus latus Sow.

1923. Spondylus latus Sow.; JEssen og ØDum (47 S. 38).

Senonium. Voxlev Skr.

\section{Spondylus faxensis Lundgr.}

1885. Spondylus faxensis M. U. H., Lundgren (58 S.10, T. II Fig. 19-20). 1899. " " Lundgr.; Hennig (37 S. 6).

1902-03. Spondylus faxensis Lundgr.; Ravn (95 S. 107, T. III Fig. 1-3). 1917. " " " Brünnich Nielsen (84). 
Denne Art og den følgende er vanskelige at holde ude fra hinanden, hvorfor Bestemmelsen meget ofte bliver usikker.

Y. Danium. Alm.

E. 》 》 .

Spondylus danicus Ravn.

1902-03. Spondylus danicus (M. U. H.), Ravn (95 S. 108, T. II Fig. 23-24).

Almindeligere end foregaaende.

Y. Danium. Alm.

E. " ".

Spondylus nipensis Ødum.

1923. Spondylus nipensis, Jessen og ØDum (47 S. 38, T. II Fig. 6).

Senonium. Voxlev Skr.

Anomia (?) asperella n. sp.

(T. II Fig. 8).

Omkredsen afrundet oval, skæv, noget forlænget skraat bagtil. Laasranden meget kort. Højreskallen omtrent flad, Venstreskallen stærkere hvælvet. Skallen tynd, bladet. Noget Foramen er ikke iagttaget.

Begge Skaller bærer uregelmæssige Tilvækstringe og fine Tilvækstlameller; disse sidste krydses af en fin Radialskulptur, saa der paa Tilvækstlamellerne opstaar radierende Rækker af nedliggende, halvt rørformede Skæl, omtrent af samme Bredde som de plane Mellemrum.

Den største af Højreskallerne maaler $4 \times 4 \mathrm{~mm}$.

Y. Danium. Coccolitkalk: Tustrup I, Mønsted I, Torup I.

Bryozokalk : Hansted I.

Placunopsis undulata J. Müll.

1923. Placunopsis undulata J. Müll.; Jessen og Ødum (47 S. 39).

Senonium. Voxlev Skr.

Ostrea semiplana Sow.

1923. Ostrea semiplana Sow.; Jessen og Ødum (47 S. 39).

Senonium. Voxlev Skr., Bøgelund Skr.

Ostrea reflexa Ravn.

1866. Ostrea reflexa M. U. H.; Fischer-Benzon (14 S. 17).

1902-03. " ; RAvN (95 S. 115, T. III Fig. 12-14).

Y. Danium. Bryozokalk: Aggersborg Gaard.

Ostrea sp.

Y. Danium. Coccolitkalk: Bredstrup Klint, Voldum I. 


\section{Gryphaea vesicularis Lam.}

1851. Ostrea (Gryphaea) vesicularis Lam.; Puggand (92 S. 74, Fig. 16).

1902-03. " hippopodium Nilss.; RAvN (95 S. 114).

1902-03. Gryphaea vesicularis Lam.; " (95 S. 116).

1916. Ostrea hippopodium Nilss.; Ravn (100 S. 28).

1917. " vesicularis Lam.; BrüNnich Nielsen (84).

1918. " hippopodium Nilss.; Ravn (102 S. 30).

1920. 》" "

1920. Gryphaea vesicularis Lam.; " (106 S. 36).

1921. Ostrea hippopodium Nilss.; Ravn (103 S. 25).

1921. Gryphaea vesicularis Lam.; " (103 S. 25).

1922. " " " HARDER (34 S. 29).

1923. " " " ; JESSEN og ØDUM (47 S. 40, T. II Fig. 7).

1924. Ostrea " " Rosenkrantz (109 S. 30).

Forekommer overalt i Daniet. Form og Størrelse er ret varierende; i ældre Danium er den ret lille og tyndskallet, i yngre Danium gennemgaaende stor, svær og tykskallet, men dette synes paa den anden Side at være underkastet Indflydelse af Facies, idet den lille, tyndskallede Form overvejende findes i Bryozokalk, den store Form næsten udelukkende i Coccolitkalk.

Selandium.

Y. Danium. Alm.

A. " "

Senonium og ældre Kridt.

\section{Exogyra canaliculata Sow.}

1902-03. Exogyra lateralis Nilss.; RAvn (95 S. 118).

1916. " canaliculata Sow.; Ravn (100 S. 29).

1917. " lateralis Nilss.; BrüNnich Nielsen (84).

1918. " canaliculata Sow.; Ravn (102 S. 30).

$1920 . \quad " \quad$ "

1920.

1922.

1923.

") ; (107 S. 6)

") ; Harder (34 S. 29).

»; JesSEN og ØDUM (47 S. 40).

Selandium.

Y. Danium. Alm.

A. " "

Senonium - Neocomium.

\section{Modiola Cottae Roem.}

1902-03. Modiola Cottae Roem.; Ravn (95 S. 118, T. III Fig. 6).

1917.

$1920 . \quad " \quad$ " $\quad$ Rosenkrantz (106 S. 37).

$1923 . \quad " \quad$ " JESSEN og ØDUM (47 S. 43).

Y. Danium.

A. " . Bryozokalk: Voxlev L. 
Crenella sphaericula Koen.

1885. Crenella sphaericula, v. Koenen (51 S. 85, T. IV Fig. 4).

1920. " " " ROsenkrantz (107 S. 7).

1924. " " ; " $\quad$ (109 S. 30).

En Skal fra Roldtved I viser stor Overensstemmelse med denne Art; den afviger fra Selandium-Eksemplarerne ved sin betydeligere Størrelse, Højde: $6 \mathrm{~mm}$, Længde: $5 \mathrm{~mm}$.

Selandium.

Y. Danium. Coccolitkalk: Jernit, Roldtved I.

Nucula $\mathrm{sp}$.

Haard Kalksten (»Cerithiumkalk«) Lønnerup II (RAvN 95, S. 120), Voxlev Kalkværk (ÆE. Danium).

Arca (Barbatia) Forchhammeri Lundgr.

1899. Barbatia Forchhammeri Lundgr.; Hennig (37 S. 15, T. I Fig. 12-14). 1902-03. Arca (Barbatia) Forchammeri Lundgr.; Ravn (95 S. 121, T. III 1923. Fig. 10).

1923.

JESSEN og ØDUM (47 S. 43).

Y. Danium.

Æ. " . Bryozokalk: Voxlev L. Coccolitkalk: Gravlev I C.

Arca sp.

Aggersborg Gaard (RAvN 95 S. 424), Frederikseje I.

\section{Cucullaea crenulata Lundgr.}

1867. Arca crenulata, Lundgren (56 S. 26, T. I Fig. 6).

1899. Cucullaea " " ; Hennig (37 S. 18, T. II Fig. 20-22).

1902-03. " " " RAvN (95 S. 123).

Y. Danium. Coccolitkalk: Thisted V.

A.

Limopsis Höninghausi J. Müll.

1899. Limopsis Höninghausi. Müll.; Hennig (37 S. 21, T. II Fig. 27-28). 1902-03. " ») RavN (95 S. 125).

Y. Danium.

A. " . Coccolitkalk: Gravlev I C, Hov I.

Senonium.

\section{Gyropleura Münsteri Hag.}

1902-03. Gyropleura Münsteri Hag.; RavN (95 S. 126, T. IV Fig. 10-11). Senonium. Bøgelund Skr. 


\section{Cardium Vogeli Hennig.}

1899. Nemocardium Vogeli, Hennig (37 S. 23, T. II Fig. 31-34).

1902-03. Cardium " " Ravn (95 S. 130, 424, T. IV Fig. $25-26)$.

Y. Danium. Bryozokalk: Aggersborg Gaard.

A. 》. .

Senonium?

\section{Isocardia faxensis Lundgr.}

1867. Isocardia faxensis, Lundgren (56 S. 30, T. I Fig. 11).

1899. 》 》 " $\quad$ \#ENNIG (37 S. 27, T. II Fig. 35-36).

1902-03. " " " $\quad$ " Ravn (95 S. 131, 424, T. IV Fig. 22).

1917. 》" 》 ; Brünnich Nielsen (84).

Y. Danium. Bryozokalk: Aggersborg Gaard.

A. ” .

\section{Isocardia sp.}

Meget mindende om I. faxensis, men med større og stærkere indrullet Umbo.

A. Danium. Coccolitkalk: Nystrup I E, Bøgelund B.

Senonium. Eerslev I B.

\section{Pholadomya sp.}

Fra Bredstrup Klint foreligger en enkelt Skal (Aftryk med delvis paasiddende Skalsubstans) af en Pholadomya. Den minder en Del om P. clausa Hennig (37 S. 27, T. II Fig. 42), baade i Omrids og ved næsten ganske at mangle Radialskulptur, men da Skallen er deformeret ved Fladtrykning, er en sikker Sammenligning udelukket.

Et bedre bevaret, tveskallet, men ubestemt Eksemplar hidrører fra Roldtved.

\section{Pholadidea sp.}

?1902-03. Pholadidea sp.?; Ravn (95 S. 134, T. IV Fig. 27-29).

En Del Stenkærner, delvis med tilhørende Aftryk, er næppe den samme Art, som RAvN anfører.

Æ. Danium. Coccolitkalk: Gravlev I C.

\section{Teredo sp.}

Rør af Teredo er fundet ved Oplev I (i Træ), Barmer I, Vegebjerg II og Voxlev (Bryozokalk).

\section{Scaphopoda.}

\section{Dentalium sp.}

Der foreligger en Del Aftryk af Dentalier, dels i Bjergarten, dels paa Ostreider. 
Y. Danium. Coccolitkalk: Bredstrup Klint, Sevel I.

E. 》 » : Gravlev I C.

Bryozokalk: Voxlev L.

\section{Gastropoda.}

Pleurotomaria niloticiformis Schloth.

1820. Trochites niloticiformis, v. Schlotheim (114 S. 156).

1866. Trochus "

; Fischer-Benzon (14 S. 15).

1902-03. Pleurotomaria 》 " ; RAvN (95 S. 214, 424, T. I

1917.

Fig. $3-4$.

; BrünNich Nielsen (84).

Y. Danium. Coccolitkalk: Hørning I, Thisted V, Bredstrup Klint, Skillingbro?, Tustrup.

Bryozokalk: Aggersborg Gaard.

? A. \# . Coccolitkalk: ? Lønnerup.

\section{Turritella sp.}

To Aftryk paa Gryphaea af den samme Art hidrører fra Nye Kløv Cocolitkalk.

Siliquaria ornata Lundgr.

1866. Siliquaria ornata M. U. H.; Fischer-Benzon (14 S. 16).

1867. " " " Lundaren (56 S. 17, T. I Fig. 4).

1902-03. " " " ) RAvN (95 S. 219, 424, T. I Fig. 11-12).

1917. " " " ; BrüNnich Nielsen (84).

Y. Danium. Bryozokalk: Aggersborg Gaard?

\section{Cerithium balticum Forchh.}

1860. Cerithium balticum, Forchinamer (22 S. 1).

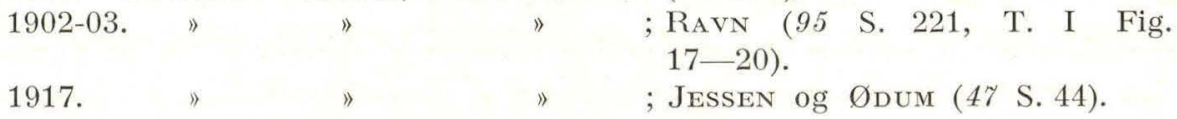

A. Danium. Bryozokalk: Voxlev L.

Coccolitkalk: Gravlev I C.

Cerithium selandicum Lundgr.

1866. Cerithium selandicum M. U. H.; Fischer-Benzon (14 S. 16).

1867. " " " Lundgren (56 S. 17, T. I Fig. 2).

1902-03. " " (") ; RAvN (95 S. 220, 424, T. I Fig. 15-16).

Y. Danium. Bryozokalk: Aggersborg Gaard? 


\section{Cerithium horningense $\mathrm{n}$. $\mathrm{sp}$.}

(T. II Fig. 9).

Der foreligger Brudstykker af 2 Eksemplarer af en Cerithium, det ene med tilsyneladende bevaret Skal, det andet som Aftryk paa en Gryphaea.

Skallen er høj, taarnformet. Vindingerne er omtrent flade, og den nederste Del af Vindingen springer kun lidt frem over den svagt indsænkede Sutur. Skulpturen bestaar af fine, skarpe Spiralfurer, efterladende mellem sig flade eller svagt hvælvede Spiralribber. Furernes Antal synes at forøges ved Indskydning. Afstanden mellem Furerne er noget varierende og ikke ganske regelmæssig; gennemgaaende ligger de tættest paa Vindingens øvre og midterste Parti (paa en $4,3 \mathrm{~mm}$ høj Vinding taltes 18 Furer). Nedad mod den nedre Sutur bliver Afstanden større, hvorved der dannes et Par bredere, flade Ribber paa Kanten imod Undersiden af Vindingen, eller denne Kant danner i sig selv en hvælvet, glat Køl; Kantens Vinkel er noget over $100^{\circ}$, og Undersiden af Vindingen er meget svagt hvælvet, dækket af den samme Spiralskulptur, tættere og tættere ned mod Kanalen. Paa Skallens yngre Vindinger ses paa nogle af Spiralribberne svage, tvær- eller skraastillede Indtryk, hvorved Ribben kommer til at ligne et snoet Tov. Ud over dette iagttages ingen anden Tværskulptur end de yderst fine Tilvækststriber, der i en bagudrettet Bue forløber over Vindingerne, uden Indflydelse paa den ovenfor omtalte Skulptur.

Y. Danium. Coccolitkalk: Hørning I, Hjerm I.

\section{Cerithium sp.}

Bredstrup Klint?, Bjerregrav III, Gravlev I C, Voxlev L.

\section{Cypraea bullaria Schloth.}

1820. Cypraeacites bullarius, v. Schlotherm (114 S. 117).

1866. Cypraea bullaria Schloth.; Fischer-Benzon (14 S. 15).

1902-03. " " ; Ravn (95 S. 226, 424, T. II Fig. 4-5).

Y. Danium. Bryozokalk: Aggersborg Gaard.

\section{Cypraea spirata Sehloth.}

1820. Cypraeacites spiralus, v. Sснцотнеiм (114 S. 118).

1866. Cypraea spirata Schloth.; Fischer-Benzon (14 S. 15).

1902-03. " " RAvN (95 S. 225, 424, T. II Fig. 1-3).

Y. Danium. Bryozckalk: Aggersborg Gaard.

A. 》 .

\section{Tritonium sp.?}

Bredstrup Klint (RAVN 95 S. 229). 


\section{Trophon sp.}

Dele af Skallen er bevaret, spændende over 3 Vindinger, tilsammen af ca. $23 \mathrm{~mm}$ Højde; den nederste af de 3 Vindinger er $9 \mathrm{~mm}$ høj. Skallen er dækket af tætstaaende, skarpe, tynde Mundrande, svagt bagudbøjede; paa Midten af den nederste af Vindingerne er deres Afstand gennemsnitlig $1 \mathrm{~mm}$. Skallen er endvidere dækket med en Spiralskulptur af lave, rundryggede Ribber med flade Mellemrum; mellem de ældre Spiralribber ses yngre, alle løbende ud paa Mundranden; deres Antal paa nederste Vinding er ca. 25. Endvidere findes paa tværs af Vindingerne en yderst fin Stribning.

Y. Danium. Coccolitkalk: Thisted V.

\section{Fusus sp.}

Aftryk af 2 Arter fra Voxlev Bryozokalk L (47 S. 44--45). Et Aftryk af en tredie Art stammer fra Bøgelund B.

\section{Fasciolaria glabra Ravn.?}

1902-03. Fasciolaria glabra, Ravn (95 S. 231, T. II Fig. 19-20).

1917.

Det nedre Parti af en Skal hører muligvis til denne Art, omend Bestemmelsen ikke er helt sikker.

Y. Danium. Coccolitkalk: Hjerm I.

A

? Senonium.

\section{Voluta faxensis Ravn.}

1902-03. Voluta (Aurinia) faxensis, Ravn (95 S. 233, T. III Fig. 1-3).

Y. Danium. Coccolitkalk: Bredstrup Klint.

\section{Voluta sp.}

Bredstrup Klint (RAvN 95 S. 234).

Pleurotoma cfr. Steenstrupi Ravn.

1902-03. Pleurotoma Steenstrupi, Ravn (95 S. 237, T. II Fig. 23-24).

Et Aftryk viser en Pleurotoma, der synes at staa meget nær denne Art; Furerne under Suturen er knap saa fremtrædende, som paa RAvN's Eksemplar.

Æ. Danium. Coccolitkalk: Gravlev I C.

? Senonium.

\section{Pleurotoma faxensis Ravn.}

1866. Pleurotoma angulosa M. U. H.; Fischer-Benzon (14 S. 15).

1902-03. " faxensis, RavN (95 S. 235, T. III Fig. 8 og 10).

Y. Danium. Coccolitkalk: Bredstrup Klint. 


\section{Cinulia danica Ravn?}

1902-03. Cinulia (Avellana) danica, Ravn (95 S. 238, T. III Fig. 7).

$1917 . "$ " " Brünnich Nielsen (84).

Der foreligger to ret daarlige Eksemplarer; det bedste af dem synes at have haft 2 stærke + en svagere Fold paa Columella samt paa Ydersiden en fint punkteret Spiralskulptur; formodentlig er de identiske med denne Art.

A. Danium. Coccolitkalk: Gravlev I C.

? Senonium.

\section{Tornatina sp.}

Gravlev I C.

Ubestemte Gastropodrester foreligger endvidere fra Bredstrup Klint, Gravlev I C, Aggersborg Gaard, Kjølby II, Frøslevvang II, Thisted III.

\section{Cephalopoda.}

\section{Nautilus fricator Beck.}

1835. Nautilus fricator, Beck (1 S. 7).

1899. " " " RAvN (93 S. 266).

1902-03. 》 " ; 》 (95 S. 246, T. V Fig. $1-2$ og 4).

Y. Danium. Coccolitkalk: Thisted V.

Nautilus sp.

Y. Danium. Coccolitkalk: Albæk (v. Skjørping).

Scaphites constrictus Sow.

1902-03. Scaphites constrictus Sow.; Ravn 95 S. 254, T. III Fig. 9).

$1913 . \quad 》 \quad$; $》(2)$.

1923. " " " JESSEN og ØDUM (47 S. 45).

Saavel Skalaftryk som Aptycher forekommer ret hyppigt.

Senonium. Voxlev Skr., Nystrup I G, Eerslev I C, Øxendal, Nibe I?, Veggerbro III, Bøgelund F.

\section{Baculites sp.}

Senonium. Gravlev I G, Voxlev Skr., Nye Kløv Skr., Nystrup I G, Nibe I.

En Aptychus (RAvN's A. I (95 S. 259)), som formodentlig hører til Slægten Baculites, er fundet i Batum; ligeledes i Eerslev I C. 


\section{Crustacea.}

\section{Calantica (Scillaelepas) dorsata Stp.}

1839. Pollicipes dorsatus Beck; Steenstrup (119 S. 411, T. IV Fig. 27).

1839. " validus (part.), " (119 S. 412, T. IV Fig. 30).

1912. " dorsatus Stp. (part.); BrüNnich Nielsen (79 S. 30, T. I, Fig. 1-17).

1914. Calantica (Scillælepas) dorsata Stp.; Withers (128 S. 192, T. VIII Fig. 12-23).

1925. " " " ; RAvN (105 S. 34).

Y. Danium. Coccolitkalk: Hjerm I.

(A. ( 》) .

Senonium.

Scalpellum maximum var. sulcatum Sow.

1835. Pollicipes maximus Sow.; Forchinamer (16 S. 75 ).

1839. " " " Steenstrup (119 S. 406, T. 4 Fig. 12).

1851. " " " PUggatard (92 S. 94).

1923. Scalpellum maximum var. sulcatum Sow.; Jessen og Ødum (47 S. 46, T. II Fig. 10).

Senonium. Voxlev Skr. (Carina), Nystrup I G (Tergum).

Scalpellum Steenstrupi Br. N.

1837. Pollicipes elongatus, Steenstrup (118 S. 363).

1839. " laevis Sow.; " (119 S. 409, T. IV Fig. 9-11).

1839. " spathulatus Beck; " (119 S. 411, T. IV Fig. 7-8).

1912. Scalpellum Steenstrupi, Brünnich Nielsen (79 5 S. 36, T. II Fig. 19-39).

1920. " " Br. N.; Rosenkrantz (106 S. 41, T. II Fig.

$15-27)$.

$1923 . \quad " \quad " \quad$ " " " $\quad$ (108 S. 7 Fig. 2).

$1924 . \quad " \quad " \quad ; \quad$ "

Selandium.

Y. Danium. Coccolitkalk: Bredstrup Klint, Tustrup I, Aarslev I, Roldtved I, Thisted V, Legind I, Helligkilde II.

Bryozokalk : Aggersborg Gaard.

Scalpellum sp.

Et Fragment af et lille, tyndt Tergum stammer fra Svejstrup I, Coccolitkalken.

\section{Galathea munidoides Segerb.}

1900. Galathea munidoides, Segerberg (116 S. 353, T. 7 Fig. 5).

1901. " " ; WoODWARD (129 S. 489, T. XII Fig. 8-9). 
Y. Danium.

A. " Bryozokalk: Nystrup I A.

\section{Dromiopsis rugosa Schloth.}

1820. Brachyurites rugosus, Schlotheim (114 S. 31, T. I Fig. 2).

1866. Dromia rugosa Schlotheim; Fischer-Benzon (14 S. 24, T. III Fig. $1-3)$.

1899. " " " "Ussing (122 Fig. 29).

1900. Dromiopsis rugosa " ; Segerberg (116 S. 358, T. 7 Fig. 8-12, 13 ?).

1901. " " " WoODWARD (129 S. 493, T. XII Fig. $3-4)$.

1902-03. " " " $\quad$ RAVN (95 S. 424).

Et Eksemplar fra Nystrup stemmer nǽrmest overens med $f$. nodosa Segerberg (116 T. 7 Fig. 12).

Y. Danium. Coccolitkalk: Hjerm I.

Bryozokalk : Aggersborg Gaard.

A. " " : Nystrup I A.

Ubestemte Crustaceer.

Af ikke nærmere bestemte Crustacé-Rester foreligger en Del Fragmenter af et større Krebsdyr, tilsyneladende tilhørende samme Art, fra Hørning I, Bjerregrav III, Kaase I, Vigsø I?, Thisted III, Legind I, Nye Kløv Coccolitkalk, Skillingbro Cocoolitkalk.

Andre Rester stammer fra Bredstrup Klint og Nystrup I A.

\section{Pisces.}

Notidanus microdon Ag. $\left.{ }^{1}\right)$

1890. Notidanus microdon Ag.; Davis (12 S. 380, T. XXXVIII Fig. 4-7). $1920 . "$ " " Rosenkrantz (106 S. 45).

Y. Danium. Coccolitkalk: Hjerm I?? (desuden paa sek. Leje i Hvalløse I C).

A. ”. Bryozokalk : Nystrup I A ?

Scapanorhynchus tenuis Davis.

1890. Scapanorhynchus tenuis, Davis (12 S. 385, T. XXXVIII Fig. 10-13). $1920 . \quad 》 \quad$ " $\quad$ Rosenkrantz (106 S. 45).

Y. Danium. Coccolitkalk: Bredstrup Klint?, Thorsted II?. Bryozokalk : Aggersborg Gaard.

E

Senonium.

1) Samtlige Fisketænder er blevet bestemte af Hr. cand. polyt. A. RosenKRANTZ. 
Odontaspis incurva Davis.

1890. Lamna incurva, Davis (12 S. 400, T. XL Fig. 18-24).

$1920 . " \quad "$; Rosenkrantz (106 S. 45).

1923. Odontaspis incurva "; Jessen og Ødum (47 S. 46).

Y. Danium. Coccolitkalk: Bredstrup Klint, Hjerm I.

A. " " : Voxlev A.

Senonium.

\section{Odontaspis acuta Davis.}

1890. Odontaspis acuta, DAvis (12 S. 387, T. XXXVIII Fig. 21-24).

Y. Danium. Coccolitkalk: Bredstrup Klint, Hørning I.

A.

Senonium.

Odontaspis sp.

1890. Lamna elegans Ag.; Davis (12 S. 398, T. XL Fig. 11-17).

Y. Danium. Coccolitkalk: Helligkilde I.

\section{Lamna appendiculata Ag.}

1890. Otodus appendiculatus Ag.; Davis (12 S. 402, T. XLI Fig. 1-11).

1920. Lamna appendiculata "; Rosenkrantz (106 S. 46).

1923. " "; Jessen og ØDum (47 S. 46, T. II Fig. 10).

Y. Danium. Coccolitkalk: Skillingbro, Helligkilde I, (desuden paa sek. Leje i Hvalløse I C).

Bryozokalk: Dollerup II.

A. 》 " : Voxlev L, Nystrup I A.

„0xyrhina” Lundgreni Davis.

1890. Oxyrhina Lundgreni, Davis (12 S. 393, T. XXXIX Fig. 8-13).

Y. Danium. Coccolitkalk: Thisted IV.

A. 》

Senonium.

Synechodus sp.

Æ. Danium. Bryozokalk: Hov I.

Coccolitkalk: Bøgelund C.

Cestracion danicus Rosenkr.

1920. Cestracion danicus, Rosenkrantz (106 S. 46, T. II Fig. 29-36).

1920 . " 》

Selandium?.

Y. Danium. Coccolitkalk: Thisted V, Mønsted II?, (desuden paa sek. Leje i Hvalløse I C).

E. » . Bryozokalk: Aggersborg I, Nystrup I A. 
Myliobatis $\mathrm{sp}$.

?1917. Myliobatis; RavN (101).

1920. \sp.; Rosenkrantz (106 S. 47).

(Selandium. Paa sekundært Leje i Hvalløse I C.)

Y. Danium.

? Senonium.

Trichiurides sp.

Y. Danium. Coccolitkalk: Hjerm I.

Løse Fiskeskæl og Fiskeknogler er fundet paa mange Lokaliteter.

Kapitel VI

Stratigrafi.

Alle Enkeltresultater af denne Undersøgelse af Danium-Aflejringerne i Jylland og paa Fyn er fremstillet ovenfor i Kap. III, og i Kap. $V$ samt i de medfølgende Faunalister (Bilag A-I) er der givet en Oversigt over samtlige bestemte Forsteninger fra de paagældende Lokaliteter. Tilbage staar da dels at foretage en nærmere Klassificering af Daniets forskellige Elementer i Jylland og paa Fyn, dels at uddrage de mere almindelige Resultater af denne Undersøgelse.

I det følgende skal Forf. derfor forsøge at give: 1) En Inddeling af Daniet i Jylland-Fyn, 2) En Oversigt paa dette Grundlag over Inddelingen i Danmark-Skaane.

\section{1) Inddelingen af Daniet i Jylland og paa Fyn.}

Til at skaffe os et Overblik over Aldersfølgen indenfor den brogede Mængde af Daniumaflejringer i Jylland og paa Fyn - og indtil videre behandles disse Egne forsøgsvis uden Hensyntagen til andre Omraader - har vi to Midler: For det første den umiddelbare Iảgttagelse af vekslende Lagfølge paa Lokaliteter, hvor Grænsen mellem to eller flere Aflejringer er blottet; for det andet Slutning ved palæontologisk Sammenligning herfra til Lokaliteter, hvis Lejring ikke er direkte iagttagelig. Af Iagttagelser over Daniets Basis er kun et Par Tilfælde oplyst i Litteraturen, nemlig Voxlev og Eerslev (I). Af disse er Voxlev det bedst 
undersøgte ved Jessen og ØDUM's Arbejde (4'), paa hvilket den følgende Fremstilling derfor bygger.

Lagfølgen ved Voxlev gengives (efter Jessen's Fig. 5) paa T. III:

L) Bryozokalk.

A) Coccolitkalk.

B) "

C) "

D) "

Lerlag.

Skr.) Skrivekridt.

Tæt over den i Gravningen synlige Bryozokalk følger Bryozokalken i Voxlev Kalkværk (se udførligere Kap. III, S. 72). Fossilindholdet af denne Lagserie fremgaar af $4 \%$ S. 48. Uddrages heraf de Arter, der kan have Betydning i stratigrafisk Øjemed, faas for Coccolitkalkens ("Det døde Lags«) Vedkommende følgende Liste ${ }^{1}$ ):

\begin{tabular}{|c|c|c|c|c|c|}
\hline Voxlev. & $\mathrm{D}$ & $\mathrm{C}$ & $\mathrm{B}$ & A & \\
\hline 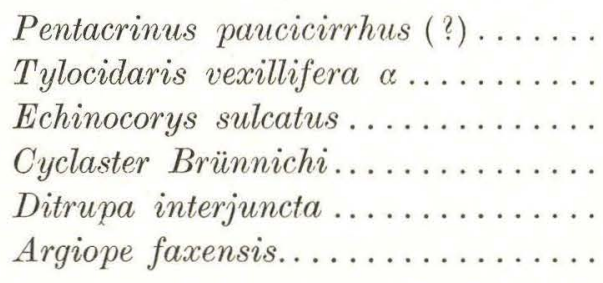 & $\begin{array}{l}\cdots \\
\cdots \\
\cdots \\
\times \\
\cdots \\
\cdots\end{array}$ & $\begin{array}{l}\cdots \\
\cdots \\
\cdots \\
\times \\
\cdots \\
\cdots\end{array}$ & $\begin{array}{l}\cdots \\
\cdots \\
\cdots \\
\times \\
\times \\
\cdots\end{array}$ & $\begin{array}{l}\times \\
\times \\
\times \\
\times \\
\times \\
\times\end{array}$ & $\begin{array}{l}\text { Daniske } \\
\text { Former }\end{array}$ \\
\hline 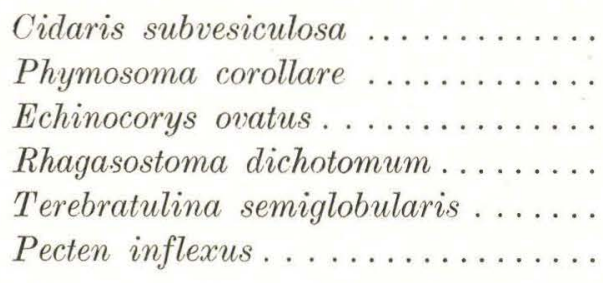 & $\begin{array}{l}\times \\
\cdots \\
\times \\
\times \\
\times \\
\cdots\end{array}$ & $\begin{array}{l}\times \\
\times \\
\cdots \\
\cdots \\
\cdots \\
\times \\
\times\end{array}$ & $\begin{array}{l} \\
\ldots \\
\cdots \\
\cdots \\
\cdots \\
\cdots \\
\cdots\end{array}$ & $\begin{array}{l}\cdots \\
\cdots \\
\cdots\end{array}$ & $\begin{array}{c}\text { Senoniske } \\
\text { Former }\end{array}$ \\
\hline
\end{tabular}

Coccolitkalken indeholder altsaa 6 daniske Arter, af hvilke 1 gaar hele Laget igennem, 1 anden viser sig i $\mathrm{B}$ og yderligere 4 i A. - 3 senoniske Arter er fundet i D, yderligere 2 i C, og hertil kommer 1, der gaar hele

1) ØDuм udskyder Bourgueticrinus Brünnichi Nielseni og Ditrupa interjuncta, idet disses Udbredelse ikke var kendt paa det daværende Tidspunkt. Den første findes paa muligt sekundært Leje i Daniet ved Kjølby Gaard og kan maaske saaledes forekomme i Senoniet, mens den sidste, efter hvad vi kender, er speciel danisk; dette gælder ogsaa Cyclaster Brünnichi. Cidaris Bolli (spinosa) er tvivlsom og maa udelades. 
Laget igennem (muligt er det dog, at den vil vise sig ogsaa at være re. præsenteret i det øvrige Danium), altsaa ialt 6 (eller 5 ?). Det under D liggende Skrivekridt er rent Senonium, den over A liggende Bryozokalk rent Danium. Senoniumformerne overskrider kun Grænsen mellem Skr. og D for en kort Strækning, og Daniumformerne tager straks fat i D; det synes derfor Forf. rimeligt at betragte de senoniske Arter i C og D som Reliktformer og fastholde sin tidligere Opfattelse, at »det er de ved Grænsen mellem Skrivekridtet og »det døde Lag« afspejlede Naturbegivenheder, der betegner den stratigrafiske Grænse mellem Senon ogDanien.« Lagene fra Lerlaget og opefter i Voxlev-Serien maa saaledes betragtes som Daniets ældste Lag paa Stedet.

Eerslev I (Kap. III, S. 120) paa Mors har fra gammel Tid været kendt som Grænselokalitet mellem Skrivekridtet og Daniets Bjergarter, men de forskellige Fremstillinger af Forholdene er ikke ganske overensstemmende, idet Forchinamer omtaler et Lag af »Fiskeler", som de senere Iagttagere ikke har observeret. Forf.'s egne Iagttagelser stemmer ganske med den Fremstilling, RAvN har givet paa Grundlag af sine egne og K. J. V. Stennstrup's Optegnelser, og Profilet (gengivet paa T. III) er saaledes:

A) Coccolitkalk.

B) Skrivekridt, hærdnet.

C) " normalt.

Medens Skrivekridtet er nogenlunde forsteningsførende, er de øvre Lag, især Lag A meget fattige paa Forsteninger, og hertil kommer, at Forholdene i de senere Aar har gjort denne Del af Profilet meget vanskeligt tilgængelig.

Fra hele Lagserien foreligger hidtil følgende bestemte Former (delvis efter RAvN, 95):

A) Cidaris sp.

B) Silicispongiae.

Coelosmilia brevis.

Pecten cfr. Nilssoni.

Isocardia sp.

C) Cidaris sp.

Tylocidaris baltica.

Rhynchonella plicatilis.

Kingena lima.

Inoceramus tegulatus.

Avicula danica.

Pecten variabilis.

"Nilssoni. 
Gryphaea vesicularis.

Scaphites constrictus.

Aptychus sp. (I og II).

Faunaen i Lag C er absolut senonisk.

Af Arterne fra Lag B er Coelosmitia brevis hidtil kun fundet i Faxekalken; Pecten cfr. Nilssoni er vel sagtens den samme, som af RAvN nævnes som P. spathulatus?; efter Forf.'s Skøn maa den dog sikkert henføres til P. Nilssoni eller en af de denne Art nærstaaende, senoniske Former. Dette Lag, der altsaa heller ikke ved nogen skarp Grænse skiller sig fra C, maa utvivlsomt opfattes som hærdnet Skrivekridt, altsaa Senonium.

Fra Lag A foreligger desværre ingen bestemte Forsteninger, men efter Bjergartens hele Habitus og Lejringsforhold at dømme, kan der næppe være Grund til at tvivle paa dets Henførelse til Daniet. Ved Eerslev maa altsaa den skarpe Grænse mellem A og B opfattes som Grænse mellem Senonium og Danium, og Coccolitkalken A som Daniets rldste Led.

Fra denne Del af Mors foreligger desuden fra gammel Tid en Iagttagelse af Daniets Undergrænse, idet Fовсннаммев skriver, at en Lagserie, ganske svarende til den ved Eerslev, er truffet ved Øxendal (se Kap III S. 126). Lokaliteten er nu utilgængelig, men paa Mineral. Museum opbevares enkelte Forsteninger herfra.

I Coccolitkalk: Crustacé (lignende de i Daniet forekommende).

I hærdnet Kridt: Inoceramus tegulatus (?)

Scaphites constrictus.

I Skrivekridt: Baculites vertebralis. Pentacrinus Bronni.

Der er saaledes god Grund til at antage, at man her har en Overgang Mage til den i Eerslev I, og at Daniets basale Lag ogsaa her er udviklet som Coccolitkalk.

En lignende Lagserie træffe sved Kjølby Gaard (Kap. III S. 95, T. III) :

A) Coccolitkalk

B) Ler, Konglomerat med Kridtrullesten.

C) Skrivekridt.

Efter Faunaen - samtlige bestemte Former er opført i Bilag B bliver Skrivekridtet typisk Senonium. Lerlaget (B) danner Bundkonglomerat, men det er vanskeligt at afgøre, om hele den ret rige Crinoidfauna ligger paa sekundært Leje; det gælder dog sikkert en stor Del af den, ligesom det ogsaa gælder de fundne Stykker af Tylocidaris baltica 
og Porosphaera globularis. I Lag A træffes Bourgueticrinus Brünnichi Nielseni paa uomtvisteligt primært Leje og desuden Cyclaster Brünnichi; er den førstes Stilling lidt tvivlsom, idet dens muligt sekundære Optræden i B tyder paa, at den maaske vil kunne findes i Skrivekridtet, saa er den sidste i hvert Fald karakteristisk for Daniet.

I Analogi med det tidligere fremsatte vil det synes rimeligst at opfatte Grænsen mellem Lerlaget og Skrivekridtet som Undergrænse for Daniet, til hvilket vi altsaa maa henregne saavel Lerlaget som Coccolitkalken. Echinocorys ovatus forekommer muligvis i A og maa i saa Fald opfattes som Relikt.

Profilet ved Kjølby Gaard suppleres yderligere ved de Oplysninger, der ydes af Forholdene ved det nærliggende Nye Kløv (Kap. III S. 96): Overlejrende hinanden finder man

Bryozokalk.

Coccolitkalk.

Skrivekridt.

Grænsen mellem Lagene har ikke været blottet, men der er næppe Grund til at betvivle, at Overgangen mellem Skrivekridt og Cocolitkalk maa være meget lignende den ved Kjølby Gaard. Samtlige bestemte Forsteninger fra denne Lagserie er angivet i Bilag C; de stratigrafisk værdifulde Former fordeler sig saaledes:

Bryozokalk: Tylocidaris vexillifera $\alpha$. Cyclaster Brünnichi.

Serpula consotida.

Coccolitkalk: Øvre Lag:

Nedre Lag:

Echinocorys sulcatus.

Pentacrinus paucicirrhus-Typen.

Echinocorys sulcatus.

» ovatus.

Cyclaster Brünnichi.

Ditrupa interjuncta. Serpula multilineata. Argiope Koeneni.

Skrivekridt: Echinocorys ovatus.

Serpula conica.

Pecten Nilssoni.

" inflexus.

"Puggaardi.

Baculites sp.

Heraf fremgaar, at Skrivekridtet er rent Senonium, mens Coccolitkalken - til Trods for Tilstedeværelsen af $E$. ovatus — samt den overliggende Bryozokalk maa henregnes til Daniet.

En lignende Lagserie synes at findes ved Lønnerup II (se Kap. III S. 98) samt ved Hov I (Kap. III S. 99); sidstnævnte Sted 
overlejres Skrivekridtet af Coccolitkalk og Bryozokalk; af Forsteninger kendes fra

Bryozokalk: Terebratula fallax tenuis.

(? Gryphaea vesicularis).

Synechodus sp.

Coccolitkalk: Parasmitia biseriata.

Ubest. Hexacoral.

Limopsis Höninghausi.

Ubest. Crustacé.

En meget lignende Lagserie findes ved Gravlev (Kap. III S. 63, T. III) :

A) Bryozokalk.

B) Coccolitkalk.

C) " , hærdnet Zone.

D) "

E) 》

F) Ler, Konglomerat med Kridtrullesten.

G) Skrivekridt.

De øvre Lag af denne Serie er ret forsteningsrige, især indeholder Lag C et stort Antal aragonitskallede Former i Aftryk; derimod er de nedre Coccolitkalklag temmelig sterile. Den fuldstændige Faunaliste for Lokaliteten findes i Bilag D.

Hrad Aragonitfaunaen fra Lag C angaar, er en Del Arter kendt fra Faxe, er altsaa i hvert Fald fundne i Daniet, men hvad de Former angaar, der hidtil kun er kendt fra „Cerithiumkalken« paa Stevns, er man indtil videre nødt til at tage Forbehold, da Rosenkrantz ikke meddeler, hvilke Arter, der hører hjemme i det hærdnede Skrivekridt, og hvilke, der stammer fra »Brissopneusteslaget«; de maa altsaa lades ude af $\mathrm{Be}$ tragtning. Cidaris subvesiculosa kendes fra Skrivekridt og som mulig Reliktform fra »det døde Lag« ved Voxlev, men om dens eventuelle Optræden eller Fraværelse i Daniet er intet afgjort, saa den maa i al Fald betragtes med Skepsis. Med disse Indskrænkninger kommer de stratigrafisk vigtige Former fra denne Lagserie til at fordele sig saaledes:

\begin{tabular}{|c|c|c|c|c|c|c|c|c|}
\hline Gravlev I & G & $\mathrm{F}$ & $\mathrm{E}$ & D & C & B & A & \\
\hline $\begin{array}{cc}\text { Bourgueticrinus } & \text { Hagenowi... } \\
\# & \text { danicus ..... } \\
\text { Pentacrinus } & \text { paucicirrhus .... } \\
\Downarrow & \| \quad \text {-Typen }\end{array}$ & $\begin{array}{l}\cdots \\
\cdots \\
\cdots \\
\cdots\end{array}$ & $\begin{array}{l}* \\
\cdots \\
\cdots \\
\cdots\end{array}$ & $\begin{array}{l}\cdots \\
\cdots \\
\cdots \\
\cdots\end{array}$ & $\begin{array}{l}\cdots \\
\cdots \\
\cdots \\
\cdots\end{array}$ & $\begin{array}{l}\cdots \\
\cdots \\
\cdots \\
\cdots\end{array}$ & $\begin{array}{l}\cdots \\
\cdots \\
\cdots \\
x\end{array}$ & $\begin{array}{l}\cdots \\
x \\
x \\
x\end{array}$ & paa sek. Leje. \\
\hline
\end{tabular}




\begin{tabular}{|c|c|c|c|c|c|c|c|}
\hline & G & $\mathrm{F}$ & $\mathrm{E}$ & D & $\mathrm{C}$ & B & A \\
\hline Pentacrinus longus-Typen ... & $\ldots$ & $\ldots$ & $\ldots$ & $\ldots$ & $\ldots$ & $\ldots$ & $x$ \\
\hline$» \quad$ miliaris ........ & . & . & . & . & . & . & $x$ \\
\hline Metopaster mammilatus typ... & . & . & . & . & . & . & $x$ \\
\hline Tylocidaris vexillifera $\gamma \ldots \ldots$ & . & . & . & . & $x$ & $x$ & $x$ \\
\hline Echinocorys sulcatus........ & . & . & . & . & $\times$ & . & $x$ \\
\hline Cyclaster Brünnichi......... & . & . & . & $x$ & $x$ & . & $x$ \\
\hline Ditrupa interjuncta ......... & . & . & . & . & $x$ & . & $x$ \\
\hline Argiope Koeneni ......... & . & . & . & . & $x$ & . . & $x$ \\
\hline$» \quad$ dorsata ........... & $\cdots$ & $\cdots$ & . & . & $x$ & . & $x$ \\
\hline " faxensis............ & $\cdots$ & $\cdots$ & $\cdots$ & . & $x$ & . & . \\
\hline Pecten monotiformis......... & . & $\cdots$ & $\cdots$ & $\cdots$ & . & . & $x$ \\
\hline Baculites sp............ & $x$ & . & . & . & . & . & $\therefore$ \\
\hline
\end{tabular}

Heraf fremgaar det, at Lagene A-B - C er tydeligt daniske, og ogsaa Lag D maa henregnes til Daniet, idet C. Brünnichi ikke kendes fra Senonium; fra $\mathrm{E}$ haves ingen Forsteninger, og fra Lerlaget $\mathrm{F}$ kun $B$. Hagenowi paa sekundært Leje, stammende fra Kridtet; Forekomsten af Baculites i Lag C bestemmer dette som typisk senonisk Skrivekridt. I Betragtning af den meget vel udviklede Grænse mellem G og F vil det eneste rimelige være at henregne alle Lagene fra F'og opefter til Daniet.

Endvidere er en noget anderledes udviklet Overgangsserie iagttaget ved Nystrup (Kap. III S. 114); Lagserien er her saaledes (T. III):

A) Bryozokalk.

B)

Flint.

C) $\quad$, ringere Bryozoindhold.

D) Ler.

E) Coccolitkalk, hærdnet.

F) Skrivekridt.

G) 》

Forsteninger foreligger fra alle Lagene; desværre er den hærdnede Coccolitkalk meget forsteningsfattig. Den fuldstændige Faunaliste findes i Bilag E, men paa næste Side gives en kort Oversigt over de stratigrafisk vigtige Former (idet de for Senonium og Danium fælles Arter udelukkes).

Herefter ser Resultatet saaledes ud: Skrivekridtet (baade F og G) er senonisk; Coccolitkalken E maa i Henhold til karakteristiske Daniumformer henregnes til Daniet, og det samme gælder naturligvis hele den overliggende Serie. 


\begin{tabular}{|c|c|c|c|c|c|c|c|}
\hline Nystrup I. & G & $\mathrm{F}$ & $\mathrm{E}$ & $\mathrm{D}$ & C & $\mathrm{A}$ & \\
\hline 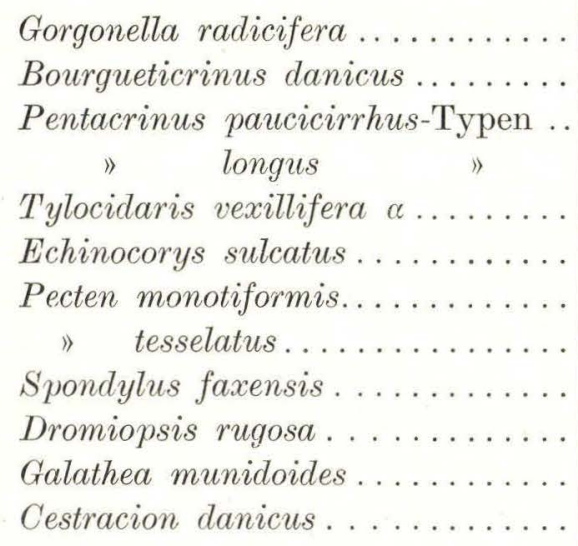 & $\begin{array}{l}\cdots \\
\cdots \\
\cdots \\
\cdots \\
\cdots \\
\cdots \\
\cdots \\
\cdots \\
\cdots \\
\cdots \\
\cdots \\
\cdots\end{array}$ & $\begin{array}{l}\cdots \\
\cdots \\
\cdots \\
\cdots \\
\cdots \\
\cdots \\
\cdots \\
\cdots \\
\cdots \\
\cdots \\
\cdots \\
\cdots\end{array}$ & $\begin{array}{l}\cdots \\
\times \\
\cdots \\
\cdots \\
\cdots \\
\times \\
\cdots \\
\cdots \\
\cdots \\
\cdots \\
\cdots \\
\cdots\end{array}$ & $\begin{array}{l}\cdots \\
\cdots \\
\times \\
\cdots \\
\cdots \\
\times \\
\cdots \\
\cdots \\
\cdots \\
\cdots \\
\cdots \\
\cdots\end{array}$ & $\begin{array}{l}\cdots \\
\cdots \\
\times \\
\cdots \\
\cdots \\
\times \\
\cdots \\
\cdots \\
\cdots \\
\cdots \\
\cdots \\
\cdots\end{array}$ & $\begin{array}{l}\times \\
\ldots \\
x \\
\times \\
x \\
\times \\
\times \\
\times \\
\times \\
x \\
x \\
x\end{array}$ & $\begin{array}{l}\text { Daniske } \\
\text { Former. }\end{array}$ \\
\hline 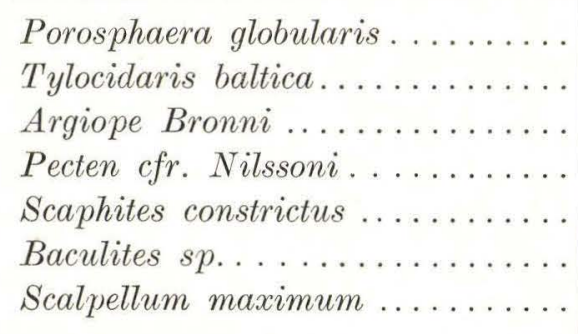 & $\begin{array}{l}\times \\
\times \\
\ldots \\
\cdots \\
\times \\
\times \\
\times\end{array}$ & $\begin{array}{l}\cdots \\
\ldots \\
\times \\
\times \\
\cdots \\
\cdots \\
\cdots\end{array}$ & $\begin{array}{l}\cdots \\
\ldots \\
\ldots \\
\ldots \\
\ldots \\
\cdots \\
\cdots\end{array}$ & $\begin{array}{l}\cdots \\
\cdots \\
\cdots \\
\cdots \\
\cdots \\
\cdots \\
\cdots\end{array}$ & $\begin{array}{l}\ldots \\
\ldots \\
\ldots \\
\ldots \\
\cdots \\
\ldots \\
\ldots\end{array}$ & $\begin{array}{l}\cdots \\
\ldots \\
\ldots \\
\ldots \\
\ldots \\
\ldots \\
\ldots\end{array}$ & $\begin{array}{c}\text { Senoniske } \\
\text { Former. }\end{array}$ \\
\hline
\end{tabular}

Mens Grænsen mellem Skrivekridt og den herover liggende Coccolitkalk paa alle de i det foregaaende omtalte Lokaliteter fremtræder skarpt markeret, er denne Grænse her ved Nystrup kun betegnet ved et ikke særlig vel udviklet Flintlag. I Modsætning til de foregaaende er Nystrup derimod karakteristisk ved at frembyde en ved et Lerlag skarpt markeret Grænse mellem den hærdnede Coccolitkalk og den overliggende Bryozokalk.

Endelig findes en meget fuldstændig Overgangsserie udviklet ved Bøgelund (Kap. III S. 53), hvor Lagfølgen ser saaledes ud (T. III):

A) Bryozokalk.

B) Coccolitkalk, hærdnet.

C) 》

D) "

E) Ler, Konglomerat med Kridtrullesten.

F) Skrivekridt.

Samtlige fra denne Lokalitet bestemte Forsteninger er opført i 
Bilag F. Uddrages heraf de stratigrafisk betydende Former faas følgende Liste:

\begin{tabular}{|c|c|c|c|c|c|c|c|}
\hline Bøgelund. & $\mathrm{F}$ & $\mathrm{E}$ & $\mathrm{D}$ & C & B & A & \\
\hline 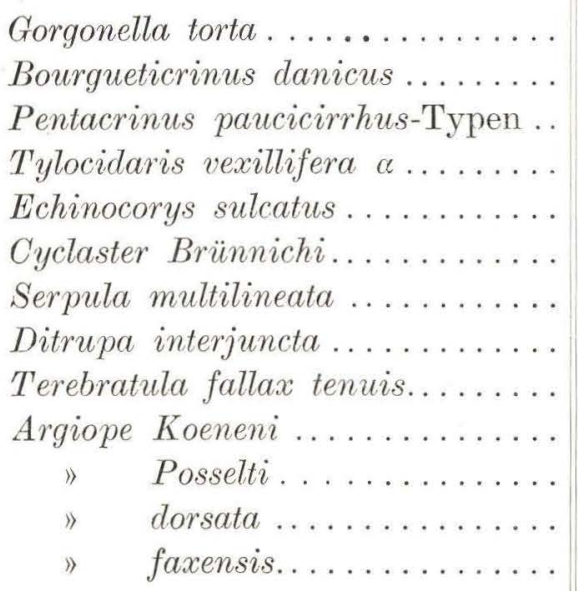 & $\begin{array}{l}\cdots \\
\cdots \\
\cdots \\
\cdots \\
\ldots \\
\cdots \\
\ldots \\
\ldots \\
\cdots \\
\ldots \\
\cdots \\
\cdots \\
\ldots\end{array}$ & $\begin{array}{l}\cdots \\
\cdots \\
\cdots \\
\cdots \\
\cdots \\
\cdots \\
\cdots \\
\ldots \\
\cdots \\
\ldots \\
\ldots \\
\ldots \\
\ldots\end{array}$ & $\begin{array}{l}\cdots \\
\cdots \\
\cdots \\
\cdots \\
\cdots \\
\times \\
\cdots \\
\cdots \\
\cdots \\
\cdots \\
\cdots \\
\cdots \\
\ldots\end{array}$ & $\begin{array}{c}\cdots \\
\times \\
\times \\
\times \\
\cdots \\
\times \\
\cdots \\
\times \\
\cdots \\
\times \\
\cdots \\
\times \\
\cdots\end{array}$ & $\begin{array}{l}\cdots \\
\ldots \\
\cdots \\
\ldots \\
\ldots \\
\times \\
\ldots \\
\ldots \\
\ldots \\
\ldots \\
\ldots \\
\ldots \\
\ldots\end{array}$ & $\begin{array}{l}\times \\
\cdots \\
\times \\
\times \\
\times \\
\times \\
\times \\
\cdots \\
\times \\
\cdots \\
\times \\
\times \\
\times\end{array}$ & $\begin{array}{l}\text { Dảniske } \\
\text { Former. }\end{array}$ \\
\hline $\begin{array}{l}\text { Echinocorys ovatus. . .......... } \\
\text { Rhynchonella retracta........... } \\
\text { Terebratulina semiglobularis..... } \\
\text { Pecten Nilssoni............. } \\
\text { Scaphites constrictus .......... }\end{array}$ & $\begin{array}{l}\cdots \\
\times \\
\cdots \\
x \\
\times\end{array}$ & $\begin{array}{l}\cdots \\
\cdots \\
\times \\
\cdots \\
\cdots\end{array}$ & $\begin{array}{l}\cdots \\
\cdots \\
\cdots \\
\cdots \\
\cdots\end{array}$ & $\begin{array}{l}? \\
\cdots \\
\cdots \\
\cdots \\
\cdots\end{array}$ & $\begin{array}{l}\cdots \\
\cdots \\
\cdots \\
\cdots \\
\cdots\end{array}$ & \begin{tabular}{l|}
$\cdots$ \\
$\cdots$ \\
$\cdots$ \\
$\cdots$ \\
$\cdots$
\end{tabular} & $\begin{array}{c}\text { Senoniske } \\
\text { Former. }\end{array}$ \\
\hline
\end{tabular}

Heraf fremgaar, at Skrivekridtet F - samt dettes Fortsættelse nedad, der indeholder endnu flere senoniske Arter — er rent Senonium. Terebratulina semiglobularis i Konglomeratlaget E ligger enten paa primært eller sekundært Leje, hvilket kan ikke ses, men den kendes i Forvejen fra primært Leje i Coccolitkalken ved Voxlev, og det samme gælder Echinocorys ovatus, der dog ikke er sikkert bestemt fra Bøgelund; ifald begge disse sidste forekommer paa primært Leje i Coccolitkalkhorisonten ved Bøgelund, maa de betragtes som Relikter, der ikke formaar at fratage Lagene B-E Karakteren af Danium, hvilken saa stærkt understreges af det store Antal daniske Arter.

Skønt Coccolitkalken B-E ogsaa er skarpt adskilt fra det overliggende Lag, A, maa Grænsen mellem Senonium og Danium altsaa lægges ved dens Undergrænse, saa baade Coccolitkalken og Bryozokalken tilhører Daniet.

Som fælles Resultat af Undersøgelsen af de i det foregaaende omtalte Lokaliteter fremgaar, at Skrivekridtet, hvor dettes Overgrænse er tilgængelig, adskilles fra det overliggende Danium ved en saavel petrografisk som faunistisk vel bestemt Grænse. I alle Tilfælde be- 
staar Daniets basale Aflejringer af en Coccolitkalk, hvis forskellige Fremtræden i hvert Fald delvis kan tilskrives senere undergaaede Forandringer. Hvor Lagserien er fuldstændigst bevaret, følges denne Coccolitkalk ret hurtigt af en Aflejring af Bryozokalk, hvortil Overgangen kan forme sig noget forskelligt.

Den Tanke er da umiddelbart nærliggende, at selv om de geografiske Forhold har bevirket Afvigelser i Udviklingen paa de forskellige Steder, saa er disse Cocolitkalk-Horisonter sikkert identiske, saa de uden videre kan sammenstilles; større Tidsforskel mellem deres Dannelse findes næppe. De palæontologiske Oplysninger er i flere Tilfælde ringe, men det, der er oplyst, modsiger ikke en saadan Parallelisering. Egentlige Ledefossiler lader sig ikke opstille, men faunistisk er Laget præget af Forekomsten af senoniske Reliktformer (især Echinocorys ovatus) Side om Side med daniske Former. Blandt disse sidste synes især Cyclaster Brünnichi at spille en Rolle, idet den er almindelig paa fem Lokaliteter (foruden Stevns); den er dog ikke indskrænket til Coccolitkalk-Horisonten alene, men optræder ogsaa i den derover følgende Bryozokalk.

I fire Profiler - Bøgelund, Gravlev, Voxlev og Nystrup - er der i umiddelbar Tilslutning til denne Coccolitkalk iagtttaget en fortsættende Bryozokalkdannelse, og hertil slutter sig (tæt over Coccolitkalken) Bryozokalken i Voxlev Kalkværk, ved Nye Kløv og ved Hov I. Bryozokalken paa disse Lokaliteter udgør saaledes Daniets ældste Led næst efter Coccolitkalken, og med Faunaen heri som Udgangspunkt er det ikke vanskeligt at genkende denne Bryozokalk paa andre Steder.

Vi faar saaledes udskilt en lang Række Bryozokalklokaliteter, hvis faunistiske Karakterer er følgende:

Ledefossiler: Epitrochus vermiformis.

Tylocidaris vexillifera $\alpha$ og $\gamma$.

Cyclaster Brünnichi.

Hertil slutter sig:

Metopaster mammilatus typicus.

Brissopneustes danicus.

Serpula distincta.

1) erecta.

Rhynchonella incurva faxensis.

Terebratula fallax tenuis.

Som typiske Forekomster af denne Gruppe, hvis Fauna er overordentlig ensartet og ikke særlig righoldig paa Arter, kan nævnes: Sangstrup og Karlby Klinter, Raasted, Tinbæk Mølle, Aggersborg I-III, Klim Bjerg, Torup Kløv I, Bulbjerg og Bjerge I-II. Iøvrigt fremgaar 
Rækken af Lokaliteter, der med Sikkerhed kan henføres til denne Gruppe, af Bilag $\mathrm{I}^{1}$ ).

Den saaledes karakteriserede Bryozokalk kan sammen med den underliggende Coccolitkalk udsondres som et ældre Afsnit af Daniet, og ved en umiddelbar Betragtning deles det naturligt i de to beskrevne Underafsnit, Coccolitkalken og Bryozokalken. Af største Interesse vilde det nu være, hvis de to Zoner ogsaa faunistisk kunde skelnes fra hinanden, bortset fra facielle Uligheder.

Et Par Arter hører til de mere fremtrædende Forsteninger i Coccolitkalken. Cyclaster Brünnichi er, som før nævnt, almindelig, men den er ikke indskrænket til Coccolitkalken alene, idet den ogsaa forekommer i Bryozokalkens basale Lag, og en lignende Udbredelse synes Tylocidaris vexillifera $f . \gamma$ at have.

Af Arter, der hidtil kun er fundet i Coccolitkalken, er der særlig Grund til at bemærke de som Relikter optrædende Senoniumformer, og blandt disse især Echinocorys ovatus, idet den foruden fra Voxlev og Nye Kløv (samt maaske Bøgelund og Kjølby Gaard) kendes fra tilsvarende Lag i Stevns Klint (se S. 210--11)2).

Paa den anden Side er der Grund til at hæfte sin Opmærksomhed ved Terebratula fallax tenuis, som hidtil i det ældre Danium kun er fundet i Bryozokalken, ikke i Coccolitkalken. At Faunaen i de to Kalkhorisonter kan afvige fra hinanden, kan ikke tillægges Betydning, medmindre det drejer sig om Arter, der vides at kunne leve under Naturforhold svarende baade til den ene og den anden af de to Bjergarter; men dette gælder imidlertid sikkert den nævnte Terebratula, der andre Steder kan findes baade i Coccolit- og Bryozokalk.

Som et Forsøg i den angivne Retning kan man derfor dele det $Æ$. Danium i to Horisonter, en ældre - Zone A - med Echinocorys ovatus, og en yngre - Zone B - med Terebratula fallax tenuis. Fælles for begge Zoner er Tylocidaris vexillifera $\alpha \operatorname{og} \gamma$ samt Cyclaster Brünnichi.

Foruden paa de foran omtalte Lokaliteter træffes det ældre Daniums Bryozokalk paa endnu et Sted, hvor det ses i Kontakt med andre Dannelser, nemlig i Skillingbro Kalkværk (Kap. III S. 65). Profilet her (T. III) udgøres i sin største Mægtighed af Bryozokalk, blottet paa 7-8 m ( F-G); herover følger 0,2 m bryozorig Coccolitkalk (E), der

1) Foruden disse sikre Lokaliteter kan en stor Mængde Forekomster med større eller mindre Sandsynlighed henføres hertil; de fremgaar dels af T. IV, dels af Kap. III.

$\left.{ }^{2}\right)$ Parasmilia biseriata, P. cincta, Cerithium balticum og Cinulia danica er ikke fundet i Bryozokalken, men dette kan ikke tillægges Betydning, da disse Former er aragonitskallede. Bourgueticrinus Brünnichi Nielseni er heller ikke taget i Bryozokalken, men den foreligger ialt kun fra tre Lokaliteter. 
atter dækkes af et Par m ren, bryozofri Coccolitkalk (A-D). Ser man bort fra de ret tæatliggende Flintlag, maa Overgangen mellem de to Bjergarter siges at være temmelig jævn.

Samtlige fra denne Lokalitet bestemte Forsteninger er opført i Bilag G. Heraf fremgaar, at Bryozokalken i Profilets nedre Del er den typiske, ældre daniske Bryozokalk, karakteriseret ved Tylocidaris vexillifera $\alpha$, ledsaget af Serpula distincta, S. erecta og Terebratula fallax tenuis. I Lag D træffes jævnsides med T. fallax tenuis Terebratula lens ${ }^{1}$ ), og i de følgende Coccolitkalklag er denne sidste eneraadende af de to Terebratler. Om Tylocidaris vexillifera gælder det, at mens Eksemplarer taget in situ i Lag G er typiske $f$. $\alpha$, saa foreligger der et Par løse Stykker, stammende fra de øverste Lag i Graven (et muligvis fra Coccolitkalken), der nærmer sig stærkt til $f$. $\beta$.

Af Lagfølgen ved Skillingbro fremgaar, at Daniets ældre Afdeling, Bryozokalken, i hvert Fald stedvis overlejres af Coccolitkalk, karakteriseret ved Terebratula lens og Ditrupa Schlotheimi. Ved Skillingbro maa Grænsen drages under Lag D.

Medens denne Coccolitkalk kun er iagttaget i Kontakt med ældre Dannelser paa denne ene Lokalitet, saa finder man paa en hel Række andre Lokaliteter Selandiets Grønsandsdannelser hvilende paa en Coccolitkalkdannelse, der utvivlsomt maa anses for at være en direkte Fortsættelse af den ved Skillingbro tilgængelige. Det gælder følgende Steder: Odense, Strib, Fredericia, Ebelt oft II, Hvalløse I-II, Langaa, Jernit og Svejstrup.

For en nærmere Beskrivelse af disse Lokaliteter henvises til Kap. III, men om dem alle gælder det, at man under Selandiets lerholdige Dannelser træffer Daniets Kalkbjergarter, alle Steder bestaaende af en finere eller grovere Coccolitkalk. Fra Kalkhorisonten paa disse Steder foreligger en - desværre ikke særlig rig - Fauna; den fuldstændige Liste herover fremgaar af Bilag A og H, men særlig Interesse knytter sig til de i Tabellen øverst paa næste Side anførte Arter ${ }^{2}$.

Af disse er der især Grund til at lægge Mærke til Terebratula lens og Ditrupa Schlotheimi, idet disse ogsaa findes ved Skillingbro. Der er derfor, i Forbindelse med Bjergartens petrografiske Beskaffenhed, Grund til at antage, at Forekomsterne ved Skillingbro og paa ovennævnte Steder udgør henholdsvis ældste og yngste Led af en Coccolitkalkdannelse, der altsaa maa sættes som Daniets yngre Afdeling, i Modsætning til den i det foregaaende omtalte, ældre Bryozokalk- og Coccolitkalkdannelse (Zone A-B). Gaar vi ud fra det, der er oplyst

1) Dette Navn bruges her stadig i den Betydning — $c f r$. lens — som er tillagt det under Omtalen af denne Art eller Artsgruppe i Kap. III.

${ }^{2}$ ) For Fuldstændigheds Skyld er Svendborg og Marslev medtaget i dette Skema, skønt det yngste Danium her udgøres af Bryozokalk. 


\begin{tabular}{|c|c|c|c|c|c|c|c|}
\hline & \multicolumn{5}{|c|}{ Coccolitkalk } & \multicolumn{2}{|c|}{ Bryozokalk } \\
\hline 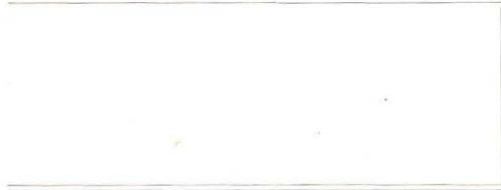 & 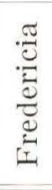 & 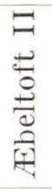 & 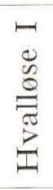 & 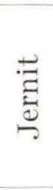 & 吾 & 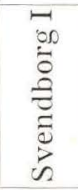 & 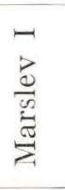 \\
\hline Graphularia Grönwalli...... & $\ldots$ & $\ldots$ & $x$ & $\ldots$ & . & $\ldots$ & $\ldots$ \\
\hline Serpula dentata.......... & . . & . & $x$ & . . & . & . & . \\
\hline Ditrupa Schlotheimi........ & . & $x$ & $x$ & $x$ & $x$ & . & . \\
\hline Argiope scabricula......... & x & . & . & . & . & . & $x$ \\
\hline " Cimbrorum......... & . & . . & . & . & . & $x$ & . \\
\hline Terebratula lens........... & . . & . & . . & $x$ & $x$ & . & . \\
\hline Lima testis ............ & . & $\cdots$ & . & . & $x$ & . & $\cdots$ \\
\hline " bisulcata............ & . & . & . & $x$ & . & . & . \\
\hline
\end{tabular}

ved Kontaktlokaliteterne, har vi ingen Vanskelighed ved at genkende denne Coccolitkalk, som viser sig at være overordentlig udbredt. Idet vi ud fra disse Forudsætninger inddrager Faunaen fra disse andre Lokaliteter under vor Betragtning, bliver det muligt at opstille følgende nogenlunde almindeligt forekommende Former som Ledefossiler for Y. Danium, idet disse forekommer sammen, men aldrig er fundet i den ældre daniske Bryozokalk:

Ceratotrochus saltholmensis.

Isis vertebratis.

Tylocidaris vexillifera $\beta$.

Brissopneustes suecicus.

Serpula dentata.

" undulifera.

Ditrupa Schlotheimi.

Rhynchonella incurva typica.

Terebratula lens.

Scalpellum Steenstrupi $\left.{ }^{1}\right)$.

Gennem disse Ledefossiler er altsaa den store Mængde af Coccolitkalkforekomster fastslaaet som tilhørende Y. Danium; men paa samme Grundlag nødes man til at opfatte en hel Række Bryozokalkforekomster som tilhørende Y. Danium. Paa en enkelt jysk og flere fynske Lokaliteter

1) S. Steenstrupi og T. lens er begge fundet paa primært Leje i Selandiet, den forste ved Lellinge (Rosenkrantz, 109), den anden ved Hvalløse og Svejstrup (Bilag H) og København (HArder, 34); i alle Tilfælde dog kun i Selandiets nederste Lag, hvor de sikkert maa opfattes som Relikter (jvf. Senoniumformer i Daniet), saa det er næppe uberettiget at anvende dem som "Ledefossiler" for Y. Danium. Noget lignende gælder Argiope scabricula (109). 
har man ved Boring truffet Bryozokalk overlejret af Selandiets Grønsands- eller Leraflejringer, nemlig Skive, Skrøbelev, Svendborg, Marslev, (Ulriksholm?), Dalum og Wedellsborg. Paa Grundlag af deres Indhold af de foran nævnte Ledefossiler for Y. Danium maa endvidere følgende Bryozokalklokaliteter henregnes til dette: Lejbølle (?), Nyborg III, Rejstrup I, Hammelev Gaard, Lendrup Strand, Aggersborg Gaard, Hansted I-II, Tred I, Hjardemaal I, Dollerup I-II, Skaarup I, Vang I. Underordnede Lag af Bryozokalk forekommer endvidere i Y. Danium i Thisted I og IV, Helligkilde I og Eerslev IV.

Imidlertid melder det Spørgsmaal sig, om det ikke er muligt yderligere at belyse Aldersfølgen indenfor det Y. Daniums Aflejringer, især at bringe visse af Bryozokalk-Aflejringerne i nærmere Relation til Coccolitkalk-Aflejringerne. Som Vejledning her kan man teoretisk bruge Fossiler af følgende Typer:

1) Arter, der i Y. Danium forekommer i dettes umiddelbart yngste (af Selandium overlejrede), men ikke i dets ældste Lag.

2) Arter, der forekommer sammen med de under 1, men ikke med de under 3 nævnte.

3) Arter, der i Y. Danium forekommer i dettes umiddelbart ældste (Æ. Danium overlejrende), men ikke i dets yngste Lag.

4) Arter der forekommer sammen med de under 3, men ikke med de under 1 nævnte.

Forsøges dette gennemført ${ }^{1}$ ), faas under Grupperne 1-4:

1) Graphularia Grönwalli (Hvalløse).

Argiope scabricula (Marslev, Fredericia).

1) Cimbrorum (Svendborg).

Lima testis (Svejstrup).

" bisulcata (Jernit).

2) Serpula Hisingeri.

Crania tuberculata typica.

Argiope Johnstrupi.

Terebratula fallax typica.

Plicatula Ravni.

3) Terebratula fallax tenuis (Skillingbro D).

4) Metopaster mammilatus typicus.

Brissopneustes danicus.

Serpula distincta ${ }^{2}$.

1) Der ses naturligvis bort fra Arter, hvis Forekomst er saa lidt kendt, at de bliver altfor usikre.

${ }^{2}$ ) Denne er i Jylland ikke fundet i Y. Danium, men nævnes alligevel for Fuldstændigheds Skyld paa dette Sted, idet den paa Sjælland vides at optræde i Y. Danium (Faxe; ifl. Dr. Brünnich Nielsen). 
Serpula erecta.

Rhynchonella incurva faxensis.

Det viser sig altsaa, at der indenfor Y. Danium kan skelnes mellem to vel definerede Horisonter: En ældre - Zone C - karakteriseret ved Tilstedeværelsen af visse fra det A. Danium kendte Former, der her optræder for sidste Gang, og en yngre - Zone D - karakteriseret ved Tilkomsten af en Række nye Former ${ }^{1}$. Fælles for begge Zoner, til Afgrænsning fra E. Danium, er de paa S. 205 nævnte Ledefossiler for Y. Danium.

I denne Forbindelse - Spørgsmaalet Ledefossiler - er der Grund til at henlede Opmærksomheden paa, at ovennævnte Arter ikke er de eneste, der adskiller Y. og A. Danium. Y. Daniums Fauna er langt rigere paa Arter end A. Daniums, og naar ikke flere af disse er blevet fremhævet som Ledefossiler, ligger det i, at mange af dem kun foreligger i saa faa Fund, at det vilde være uklogt at bygge paa deres Optræden efter vort øjeblikkelige Kendskab dertil; dette gælder i særlig Grad de aragonitskallede Grupper, idet disses Repræsentanter kun efterlader sig Spor under særlige Forhold. Alligevel skal der her meddeles en yderligere Oversigt over de i Jylland og paa Fyn fundne Arter, der hidtil kun er taget i Y. Danium, da det ved senere Undersøgelser vil være ønskeligt at have Opmærksomheden henvendt paa deres Forekomst:

Asteroidea: Metopaster mammilatus radiatus.

Echinoidea: Pyrina sp., Micraster Desori, Holaster faxensis.

Anthozoa: Dendrophyllia candelabrum, Ceratotrochus Milthersi, Epitrochus pusillus, Smilotrochus faxensis, Primnoa costata, Moltkia Lyelli.

Vermes: Serpula cingulata, S. terundulata, S. incrassata,. S. proboscis.

Brachiopoda: Thecidium Grönwalli, T. danicum, Rhynchonella flustracea, Argiope Davidsoni, A. Pindborgi.

Lamellibranchiata: Lima densestriata, Pecten cimbricus, Crenella sphaericula, Anomia asperella, Ostrea reflexa.

Gastropoda: Siliquaria ornata, Cerithium selandicum, C. horningense, Cypraea bullaria, Voluta faxensis, Pleurotoma faxensis.

Forf. har i Overensstemmelse med dette Inddelingsgrundlag forsøgt at ordne de jysk-fynske Daniumlokaliteter i den naturlige Aldersfølge. Resultatet heraf fremgaar af Bilag I, hvor alle de Forekomster er

1) Som yderligere Støtte kan undertiden anvendes den Udvikling, Piggene af Tylocidaris vexillifera a undergaar i Løbet af Y. Danium, men da $f$. $\alpha$ idet hele er meget variabel, er denne ikke paalidelig. 
opført, hvorfra der foreligger tilstrækkeligt Forsteningsmateriale til at tillade et mere eller mindre fast Skøn ${ }^{1}$ ). I og for sig behøver dette Skema ingen nærmere Kommentarer, da Begrundelsen er tilstrækkeligt fremsat i det foregaaende. Forf. skal derfor indskrænke sig til her at ledsage Skemaet med nogle kortfattede Bemærkninger, kommenterende Anbringelsen af de Forekomster, hvis Forsteningsmateriale kan give Anledning til Tvivl.

Zone D. Lejbølle I; er tvivlsom; skal muligvis henføres til Zone C.

Rosille I; ligesaa.

Nyborg III; ligesaa.

Rejstrup I; ligesaa.

Hørning II; er usikker; afgørende Forsteninger er ikke fundet, men Beliggenheden taler nærmest for D.

Thisted VI; henført hertil p. G. af sin Beliggenhed tæt ved T. V, selv om Lagstillingen kan antyde et ældre Niveau.

Zone C. Purhus I (og VI); Fraværelsen af Zone D's Fossiler. Beliggenheden i Forhold til Ejstrup I og Bjerregrav II-III taler ikke imod Anbringelsen.

Ejstrup I; Fraværelsen af Zone D's Fossiler. Lokaliteten ligger ikke langt tra E. Danium (Purhus III).

Dalbyovre I; Fraværelsen af Zone D's Fossiler.

Jomfrubakken; Fraværelsen af Zone D's Fossiler.

Ersted I-II; Fraværelsen af Zone D's Fossiler. Kalken er den samme kiselrige som i Purhus I og VI.

Abildgaarde I; tvivlsom; muligvis til Zone D.

Hansted III; Beliggenheden tæt ved H. I-II.

Kaase II; ikke helt sikker.

Thisted II; Beliggenhed mellem T. I og III.

Thorsted IV; tvivlsom; muligvis til Zone D.

Vang I; Fraværelsen af Zone D's Fossiler.

Vegebjerg I; tvivlsom.

Eerslev IV; ikke helt sikker; dog synes Zone D's Fossiler at mangle, og Stedet ligger mellem E. II-III og I (A. Danium og Skrivekridt).

Helligkilde I--II; Zone D's Fossiler er ikke fundet, trods ret god Undersøgelse. Tylocidaris-Piggene er af ret

1) Naar en hel Række Lokaliteter, som ikke er opført i Bilag I, i Kap. III alligevel med stærkere eller svagere udtalt Sikkerhed er henført til Æ. eller Y. Danium, saa hviler dette i Almindelighed paa Bjergarten, Lokalitetens Beliggenhed o. a. lign. 
ung Type, men tilsvarende er ogsaa fundet f. Eks. i Dollerup I-II.

Davbjerg I; Anbringelsen er tvivlsom, da Forsteningsmaterialet er meget ringe.

Mønsted II; ligesom Davbjerg I.

Zone B. Kastbjerg I; lidt usikker; ganske vist er ingen Ledefossiler for $\mathbb{E}$. Danium fundet, men heller ingen for Y. Danium.

Ove IV; Beliggenheden i Forhold til O. I-III og Skrivekridtet.

Vigsø II; lidt usikker; tilhører muligvis Zone C.

Vegebjerg II; tvivlsom.

Hov I; T. fallax tenuis herfra findes i typisk Bryozokalk, aabenbart stammende fra højere Niveau end Coccolitkalken; maaske er Stykket ikke taget lige i de under Hov I (Kap. III S. 99) omtalte, gamle Grave.

Zone A. Hov I; Coccolitkalken herfra maa henføres til Zone A.

\section{2) Oversigt over Inddelingen af Daniet i Danmark-Skaane.}

I det følgende skal Forf. søge at sammenligne den i det foregaaende skitserede Inddeling af det jysk-fynske Danium med de Resultater, der fra anden Side er fremkommet angaaende Daniets Inddeling.

Som nævnt i den historiske Indledning har dette Spørgsmaal allerede tidligere været stærkt under Debat, men selv om jyske og fynske Forhold flere Gange har været inddraget i det fremkomne, saa har de opstillede Skemaer dog som Regel hovedsagelig været baserede paa sjællandske Forhold, mod hvilke Interessen i denne Forbindelse altsaa særlig maa rettes $\left.{ }^{1}\right)$.

Saa længe det danske Danium overhovedet har været underkastet geologisk Forskning, har dets Elementer været klassificeret i forskellige Grupper, hvilket for den ældre Tids Vedkommende dog ikke skal tages op til nærmere Diskussion her, dels da der er gjort Rede derfor i Kap. I, dels da disse Grupper næsten udelukkende har været opstillet paa rent petrografisk Grundlag, og faunistiske Sammenligninger kun sjældnere har spillet nogen Rolle i ældre Tid. Større Værdi har det naturligvis haft, naar disse petrografiske Sammenligninger tillige har været knyttet til Iagttagelser over Lejringsforholdene.

1) Saa længe vort Daniums Forhold til dets mere eller mindre sikre Ekvivalenter i Udlandet - delvis endda andre Havomraader - er saa lidt kendt, er der næppe Grund til i denne Sammenhæng at beskæftige sig med. disse. Kun Syd-Sveriges Danium falder direkte i Traad med vort.

Danmarks geologiske Undersøgelse. II. R. Nr. 45. 
Paa denne Maade blev ret tidligt "Fiskeleret« og "Cerithiumkalken" (= „Faxekalken«), hv̉ortil Forchiammer (og JoHnstrup) kun henregnede den over Fiskeleret liggende, haarde Kalk, fastslaaet som de ældste Lag af »det nyere Kridt« — bortset fra, at man først senere blev enige om dettes Enhed. Men netop p. G. a. petrografiske Sammenligninger blev Cerithiumkalken slaaet sammen med Faxekalken (og »Klinterne ved Grenaa«; BЕск). Et af de første Resultater af faunistisk Sammenligning indenfor det danske Danium blev da netop at adskille disse Dannelser - selv om det rigtige i denne Adskillelse nærmest fremkom ved en Fejltagelse. Samtidig med, at Johnstrup fastslog Daniets Stilling til de over- og underliggende Dannelser, fremhævede han, at »Faxelaget« i Stevns Klint maatte holdes ude fra den egentlige Faxekalk, da det førstnævnte indeholdt Baculiter og Scaphiter (49); men JohnsTRUP har næppe været klar over, at disse stammede fra det mellem Fiskelersbækkenerne liggende, „Cerithiumkalk«-lignende, hærdnede Skrivekridt.

Omkring Aarhundredskiftet førtes, dels paa stratigrafisk-petrografisk, dels paa faunistisk Basis, en stærk Diskussion om Daniets Undergrænse i Stevns Klint, og Lagene her blev ret forskelligt opfattede af Hennig, Grönwall og Ravn. Imidlertid er der næppe Grund til at komme ind paa Enkelthederne i denne Strid, der nu væsentlig har historisk Interesse; at Spørgsmaalene angaaende Grænselagenes Stilling kunde give Anledning til en Del Famlen, skyldes sikkert, at man ved Indsamling af Forsteninger ikke havde skelnet mellem den egentlige, over Lerlaget liggende "Cerithiumkalk" og det herunder liggende, hærdnede Skrivekridt (som RAVN identificerer med „Cerithiumkalken«). De stratigrafiske Forhold i Stevns Klint maa siges at have faaet deres rimeligste Forklaring af Rosenkrantz (110), hvis Skema ser saaledes ud:

Bryozokalk.

"Brissopneusteslag« (= "Cerithiumkalk»).

Fiskeler.

Skrivekridt.

Fiskeleret, der er aflejret i flade Bækkener, er udviklet som Basalkonglomerat og gaar jævnt over i "Brissopneusteslaget«, der er en Coccolitkalkdannelse. Ved en til den øvre Lakune svarende Hærdningsproces er saavel »Brissopneusteslaget« som det imellem dettes Bækkener (»under Lerlaget«) liggende Skrivekridt blevet hærdnet og sprækket. Disse to Bjergarter ligner i det ydre hinanden, men er faunistisk meget forskellige; desværre meddeler Rosenkrantz ikke Faunalister fra disse Lag, men det fremgaar af hans Foredragsreferat, at alt under den nedre Lakune liggende er typisk Senonium, mens »Brissopneusteslaget« (og naturligvis 
Bryozokalken) er Danium med enkelte Senoniumrelikter, blandt hvilke der især er Grund til at lægge Mærke til Echinocorys ovatus.

Rosenkrantz henleder selv Opmærksomheden paa Overensstemmelsen mellem dette Profil og Profilet ved Voxlev (idet der maa ses bort fra Hærdningen af Lagene). Saa længe »Cerithiumkalkens« faunistiske Karakter ikke var fastslaaet, var denne Sammenstilling ikke mulig, men efter det oplyste, kan det næppe betvivles, at Rosenkrantz har Ret, naar han identificerer »Brissopneusteslaget« i Stevns Klint med Coccolitkalken (»det døde Lag«) ved Voxlev, begge nederst begyndende med et mod Skrivekridtet skarpt afgrænset Lerlag. "Brissopneusteslaget《 paa Stevns svarer saaledes til det jyske Daniums Zone A.

Hvad Delingen af Daniet i de to Hovedgrupper, A. og Y. Danium, angaar, fremsattes den første Antydning i denne Retning af GrönwalL 1899 (28 S. 68), idet han udtrykkelig bemærker, at Kalkbruddene ved Aggersborg (I-III) bl. a. indeholder Terebratula fallax og Rhynchonella (faxensis?), men derimod ikke Terebratula lens. Denne Iagttagelse førtes dog først ud i sine Konsekvenser af Brünnich Nielsen 1909 (\%6), idet han, væsentlig ud fra sjællandske Forhold, deler Daniet i Yngre Danium (»Saltholmskalk» + "Yngre Bryozokalk« + den i det følgende omtalte "Craniakalk«), karakteriseret ved Terebratula lens, og Aldre Danium ()Aldre Bryozokalk«), karakteriseret ved Terebratula fallax faxensis (= tenuis). Specielle for $\mathbb{E}$. Danium var endvidere den Form af Tylocidaris vexillifera, der her er kaldet $f$. $\alpha$, for Y. Danium $f$. $\beta^{1}$ ). Sjællands » Elldre Bryozokalk« (Stevns Klint, Kagstrup) svarer saaledes til det jyske A. Daniums Bryozokalk (ogsaa ifl. BrünniCH Nielsen), altsaa Zone B. Sjællands Y. Danium svarer til Fyns og Jyllands Y. Danium, Zonerne C-D.

Foruden de foran nævnte Forskelligheder gør Brünnich Nielsex i 1920 (88) opmærksom paa endnu en Del faunistiske Uligheder mellem A. og Y. Danium: Crania tuberculata transversa er almindelig i E. Danium, mens den i Y. Danium desuden optræder i Formen C. tuberculata typica. Rhynchonella incurva typica findes kun i Y. Danium, mens kun Formen var. faxensis findes i ÆE. Danium (den gaar dog ogsaa op i Y. Danium Zone C). Argiope scabricula Koen. findes kun i Y. Danium; desuden er der Forskel i Fordelingen af andre Argiope-Arter. Blandt Cidariderne findes visse Forskelligheder imellem A. og Y. Daniums Former; det samme gælder Slægten Cassidulus. Angivelsen af Gorgonella tenuis (= G. torta $)$ og Isis Steenstrupi som specifike for A. Danium er ikke holdbar (se Kap. V); Graphularierne er derimod indskrænket til Y. Danium. Ditrupa Schlotheimi skulde være karakteristisk for visse Dele af Y. Danium (efter Rosenkrantz); den findes dog i hele Y. Danium.

$\left.{ }^{1}\right)$ Desuden A. Danium: Brissopneustes danicus, Y. Danium: B. suecicus. 
Det første, virkelige Forsøg paa faunistisk at skelne mellem forskellige af Daniets Elementer gjordes 1898 af Grönwatu (26), idet han - samtidig med at udskille det overliggende Grønsand (modsat JoHnsTRUP) - fremhævede, at de yngste Daniumdannelser ved København, Herfølge og Aashøj, til Trods for deres forskellige Habitus, kunde sammenfattes for sig, idet de karakteriseredes ved Crania tuberculata; desuden fremhæver Grönwall bl. a. C. cfr. larva (=C. Posselti Rosenkr.), Graphularia og Dentalier eller Serpularør (Ditrupa Schlotheimi). Til denne "Zone med Crania tuberculata« henførte Grönwall dog ogsaa visse glaukonitiske Bjergarter, der nu maa henregnes til Selandiets basale Dannelser.

Denne yngste Zone, »Craniakalken«, accepteres uforandret af RAvN (95) og Brünnich Nielsen $\left.(\% 6)^{1}\right)$. En udførligere Behandling af „Craniakalken« gives af RosenkRantz 1920 (106), der udskiller den glaukonitiserede, konglomeratiske "Øvre Craniakalk» som Basaldannelse af den over Kalkbjergarten liggende Grønsandsdannelse (for hvilken han i 1924 indfører Navnet Sélandien (109)). Af Forsteninger, der synes at være særlig karakteristiske for Craniakalken ${ }^{2}$ ) nævner RosenkRAntz:

$\begin{array}{ll}\text { Graphularia Grönwalli. } & \text { Lima testis. } \\ \text { Ditrupa Schlotheimi. } & \text { Pecten sericeus. } \\ \text { Crania Posselti. } & \text { Plicatula Ravni. } \\ \text { " tuberculata typ. } & \text { Modiola Hauniensis. } \\ \text { Argiope scabricula. } & \text { Scalpellum Steenstrupi. } \\ \text { Lima bisulcata. } & \text { Cestracion danicus. }\end{array}$

Efter dette har vi ingen Vanskelighed ved at opfatte den $» \mathrm{Nedre}$ Craniakalk" som mere eller mindre fuldstændigt Akvivalent til det jysk-fynske Y. Daniums Zone $D^{3}$ ). Dog maa bemærkes, at Scalpellum Steenstrupi og Ditrupa Schlotheimi ifl. Forf.s Iagttagelser i Jylland findes i hele Y. Danium (Zone C-D) og Cestracion danicus i hele Daniet; Crania Posselti, Pecten sericeus og Modiola Hauniensis er ikke fundet i Fyns eller Jyllands Danium.

Efter den foreliggende Litteratur kan man uden Tvang sammenligne de sjællandske Daniumforekomster med de jysk-fynskes System, som det fremgaar af den i Bilag J givne Oversigt. Maaske vil en eventuel Revision af det sjællandske Materiale kunne tilvejebringe et noget ændret

1) Det maa her erindres, at vor nuværende Adskillelse i Æ. og Y. Danium ikke forelaa, da Ravn's Arbejde fremkom, saa hans "Yngre (el. Øvre) Danium« kun omfatter Craniakalken.

$\left.{ }^{2}\right)$ Det gælder i dette Tilfælde baade "Øvre» og "Nedre Craniakalk«, men de fleste af de nævnte Former ligger paa sekundært Leje i "Øvre Craniakalk" (se 109 og 105).

3) Ogsaa Rosenkrantz angiver Kalken i Bredstrup Klint som Ækkvivalent til nedre Craniakalk. 
Billede, men paa Grundlag af det foreliggende synes de sjællandske Daniumlokaliteter at fordele sig saledes:

Zone D: København ("Nedre Craniakalk«), Herfølge, Aashøj, Solhøjsgaard, Frederiksholm (mulig kun de øvre Lag), Thorslunde, Saltholm, Faxe Bryozokalk III og X (samt mulig andre Lag), Lille Skensved.

Zone C: Faxe (Størsteparten af Koral- og Bryozokalken).

Zone B: Stevns Klint (Bryozokalken), Kagstrup, Valby.

Zone A: Stevns Klint (»Brissopneusteslaget»).

Af de skaanske Lokaliteter maa Limhamn og Klagshamn sikkert henregnes til Zone D, Annetorp til Zone C.

Før vi opstiller en Oversigt over det endelige Resultat af denne Undersøgelse, kan det være praktisk at kaste et Blik paa de for Daniet hidtil opstillede faunistisk-stratigrafiske Inddelinger. Som før nævnt opstillede Grönwall "Zonen m. Crania tuberculata《, og i RavN's Arbejde 1902--03 deles Daniet i Overensstemmelse hermer saaledes (idet Fiskeler og »Cerithiumkalk« regnes til Senonium):

Yngre Danium: Craniakalk.

AEldre Danium: Blegekridt.

Saltholmskalk.

Bryozokalk.

Koralkalk.

De 4 sidstnævnte Bjergarter er hos RAvN rent petrografiske Bestemmelser.

I 1909 bruger BRÜNNich Nitessen følgende Inddeling, idet Betegnelsen "Craniakalk« er faunistisk, de andre Kalkarter petrografisk bestemte:

Yngre Danium: Craniakalk.

Yngre Bryozokalk.

Saltholmskalk, Coccolitkalk.

Aldre Danium: AEldre Bryozokalk.

Denne Sondring mellem E. og Y. Danium er den samme som den i denne Afhandling brugte.

I 1913 (81) gaar BrÜNnICH Ninisen et Skridt videre, idet han deler Daniet i 3 Grupper (Fiskeler og »Cerithiumkalk« henregnes stadig til Senonium):

1) Craniakalk.

2) Yngre Danien.

3) AEldre Danien.

Iøvrigt har disse Grupper det samme Indhold som i Inddelingen fra 
1909; Forskellen er kun den, at Craniakalken udskilles som en tredie Gruppe af samme Orden som de to andre.

I Aaret 1920 bringer 2 Forfattere en Oversigt over det Yngre Danium. Den ene, Rosenkrantz (106), holder sig i alt væsentligt til Brünnich Nielsen's Skema fra 1909, idet han til Y. Danium henregner de tre Bjergarter:

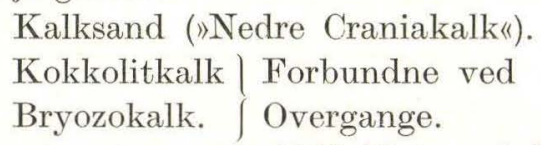

Det samme er ogsaa Tilfældet med den anden, Brünnich Nielsen (88), idet han ganske synes at have glemt sin egen Tredeling fra 1913. Derimod tillægger han Rosenkrantz Motiveringen af denne Tredeling, et Forhold, hvorom der imidlertid intet findes i Litteraturen ( 88 S. 6), og ud fra denne Opfattelse udsætter BRÜnnich Nielsen Tredelingen for Kritik: "Lige saa let det er at skelne mellem Elldre og Yngre Danien, lige saa svært er det at foretage yderligere Tidsinddelinger af disse to Afsnit. Rosenkrantz har forsøgt at udskille et "Mellemste Danien", som skulde indbefatte Saltholm, Frederiksholm og det jyske Blegekridt, men for hver Undersøgelse, der bliver gjort, viser det sig, at hans "nedre Craniakalk«, der skulde være en Bestanddel i hans "yngste Danien«, breder sig mere og mere og efterhaanden opsluger hele hans »mellemste Danien«.«BRÜNNICI NIELSEN paaviser videre, at Craniakalkens Fauna næppe er synderlig forskellig fra Faunaen i mange andre sjællandske, yngre daniske Aflejringer; "Craniakalken« bliver herved kun bestemt som en særlig Facies, "- saaledes at man, selv om man ikke kan opretholde Craniakalken som et Tidsafsnit, godt kan bruge Betegnelsen om en bestemt Facies. Vi maa nemlig antage, at samtidig med den øvre Craniakalks Dannelse paa en bestemt Havdybde aflejredes Lagene, som vi finder ved Frederiksholm og paa Saltholm, paa en anden Havdybde.«

I den sidste Henseende gaar BRÜNnich Nielsen utvivlsomt for vidt, naar han vil inddrage "Øvre Craniakalk« (Selandiets Basalkonglomerat) og Selandiets Grønsandsdannelser under Daniet (88 S. 13-16), aflejret mere eller mindre samtidigt med Y. Daniums Kalkbjergarter. Men hans Udviklinger indeholder den sikkert rigtige Kerne, at de forskellige Former af "Nedre Craniakalk», d. v. s. de regressionsprægede Lavvandsdannelser, i faunistisk Henseende stemmer næsten overens med andre af det $\mathrm{Y}$. Daniums Aflejringer, hvilket atter vil sige, at Tidsforskellen mellem deres Dannelse kun er ringe. Begge falder i geokronologisk Henseende indenfor den i det foregaaende karakteriserede Zone D, men med denne Udvidelse af Begrebet »Zonen med Crania tuberculata«, kan denne udmærket godt opretholdes som Tidsafsnit.

Medens Brünnich Ntelsen i den nævnte Afhandling henfører de paleocæne Grønsandsdannelser til Y. Danium uden nærmere indgaaende 
Begrundelse, saa søger HARDer i 1922 (34) at begrunde Synchroniseringen af »Sundkroglagene« (Grønsand og Ler) med det Y. Daniums Kalkbjergarter, idet denne Gruppe opstilles som »Mellem Danien«; de øvige Grønsandsdannelser og Kertemindeleret gøres til »Øvre-Danien«, mens hans "Nedre-Danien« beholder samme Omfang som hidtil. HaRDers Placering af Sundkroglagene i Daniet og dettes Udvidelse til at omfatte de paleocæne Ler- og Sandaflejringer er imidlertid tilstrækkeligt blevet tilbagevist af Rosenkrantz 1924 (109), til hvem Ravn slutter sig (105), og hermed er ogsaa hans Tredeling af Daniet bortfaldet.

Derimod er der endnu et Punkt i HaRder's Skema, der behøver nærmere Omtale. Han indfører for AE. Daniums Bryozokalk Navnet »Rødvigkalk «1 ${ }^{1}$ ) og for Y. Daniums ${ }^{2}$ ) Kalksten (med Undtagelse af Faxekalken) Navnet »Saltholmskalk«, hvortil henregnes »de af vor normale Lagrækkes Kalksten, der tilhører Mellem-(Y-)Danien.«

For det første maa Forf. indrømme, at denne Anvendelse af Ordet "Saltholmskalk» er ham uforstaaelig. Det kunde maaske til Tider skønt det sjældent savnes — være ønskeligt at have et Fællesnavn for det Aldre og et for det Yngre Daniums Bjergarter, men naar Harder's Begreb waltholmskalk ikke maa omfatte alle Y. Daniums Bjergarter, idet Koralkalken, Faxekalken, sættes udenfor, hvorfor skal da Coccolitkalk, Bryozokalk, Gruskalk o. s. v. sammenfattes under eet? En Bryozokalk-Horisont i Coccolitkalken er ikke mere »normal« end Koralkalken.

Men dertil kommer, at denne Anvendelse af Navnet Saltholmskalk kun kan give Anledning til Forvirring, idet Navnet hidtil har været brugt i flere Betydninger, der afviger fra HARDER's nye.

RøRDAM er vist den eneste, der tidligere har lagt en stratigrafisk Betydning i Navnet, idet han skriver saaledes (112 S. 18): „Under Betegnelsen »Saltholmskalk« indbefattes foreløbig alle de hvide, graahvide eller gulhvide Kalksten, der udgøre det vigtigste Lag af »Nyere Kridt«, uden Hensyn til om man ved nærmere Undersøgelse efter den æoldre Terminologi vilde kalde Kalkstenene "Saltholmskalk", "Limsten« eller "Blegekridt«u. Ogsaa Koralkalken indbefattes (Modsætningen er det "Yngre Grønsand«).

I al den øvrige Litteratur er Navnet »Saltholmskalk« brugt som en ren Bjergartsbetegnelse, nemlig den haarde, krystallinske Kalksten; siden man har skelnet mellem $\AA$. og Y. Danium, er det kun brugt om Bjergarter indenfor den sidste Gruppe, idet man dog ofte fejlagtigt har angivet Kalken i Karlby og Sangstrup Klinter som Eksempel, idet man ansaa den for at være yngre danisk. Dette gaar aabenbart tilbage til en Fejltydning af det Sted, hvor ForсHнамmer lancerer Navnet "Salt-

$\left.{ }^{1}\right)$ Navnet »Karlbykalk" havde været bedre, baade sprogligt og historisk set.

$\left.{ }^{2}\right)$ I det følgende erstattes Harder's »Mellem-Danien« med »Y. Danium». 
holmskalk«, en Fejllæsning, som ogsaa HaRder gør sig skyldig i, naar han vil tillægge Forсннаммев den samme, stratigrafiske Hensigt med Navnet, som han selv hævder.

Indenfor den Aflejringsgruppe, som Forchнамmer ansaa for at være ældre end Skrivekridtet, skelner han udtrykkelig (16 S. 49) mellem to Slags Kalksten, »Karlebyekalk« og »Saltholmskalk«, som altsaa kun er »hinanden meget nærstaaende med Hensyn til deres Dannelsestid«; det betones, at de viser mogen udvortes Forskellighed «1 $)$. Den samme Mening fremgaar af hans senere Afhandlinger: „Faxøekalken svarer til Grønsandet og Liimstenen til Saltholmskalken« (19 S. 538). "Samtidigt med Liimstenen forekommer paa andre Steder en haard og fast Kalksteen, tildeels med muslet Brud, som jeg har kaldt Saltholmskalk. -- I Stedet for denne optræder i det øvrige Jylland en langt blødere, kridtlignende Kalksteen - «(22 S. 3). Det samme gælder Johnstrup, som siger, at "Denne Varietet af Bryozokalk benævnes Saltholmskalk" (50 S. 52).

Det forekommer derfor absolut uheldigt, naar HARDEn vil tillægge denne rent petrografiske Bestemmelse en kronologisk Betydning, som ikke engang er den samme som RøRDAM's, men iøvrigt kommer man næppe ud over Forvirringen paa anden Maade end ved helt at stryge Ordet "Saltholmskalk«.

Det forekommer Forf., at man herved ikke vil føle noget større Savn, idet de foreliggende Termini synes tilstrækkelige til — i hvert Fald i Øjeblikket -- at klargøre Begreberne. Navnet Danium bruges om og betyder i første Række den samlede Lagserie (Étage danien). I anden Række har det tillige Tidsbetydning (Époque danien), paa Dansk: Daniumtid. Underafdelingerne A. og Y. Danium er ganske analoge hermed, og det samme gælder disses Underafdelinger, der i denne Oversigt for Nemheds Skyld er kaldt A, B, C, D. Disse Benævnelser angiver saaledes paa een Gang Tiden og den hertil svarende, samlede Lagserie; dennes enkelte Komponenter betegnes saa rent petrografisk som Coccolitkalk, Bryozokalk, Koralkalk o. s. v. (eller eventuelt med andre karakteriserende Navne, hvis disse ikke kan give Anledning til Misforstaaelser).

1) Ifald nogen skulde misforstaa denne Passus hos Forchinamer, saa fremgaar hans Mening endnu tydeligere S. 50, hvor han siger om Glatvedkalken, at den er moget afvigende fra de Varieteter, der findes i Karlebye og Sangstrup Klinter. Den er fastere end den løse Kalksteen i de de nævnte Klinter — - Den ligner Saltholms Kalksteen overmaade meget — - " Det skal dog indrømmes, at Forchinamer selv kan synes at insinuere en stratigrafisk Betydning i Navnet Saltholmskalk, naar han - maaske af Nemhedshensyn - herunder anbringer Sangstrup Klint og lader Navnet betegne den Gruppe, han ansaa for at være ældre end Skrivekridtet (16 S. 43; se Kap. I, S. 8); men hverken i Definition eller Indhold svarer denne Betydning af Ordet "Saltholmskalk« til Harder's. 
Herefter bliver altsaa Betegnelserne "Brissopneusteslaget«, Forchnammer's og Johnstrup's "Cerithiumkalk» og Zone A synonyme; ligeledes »Aldre Bryozokalk«, »Rødvigkalk« og Zone B (saalænge vi fra Zone B kun kender Bryozokalk). "Nedre Craniakalk« svarer paa det nærmeste til Zone D).

Indtil videre kan vi altsaa opstille følgende Oversigt over Daniet i Danmark-Skaane $\left.{ }^{1}\right)$ :

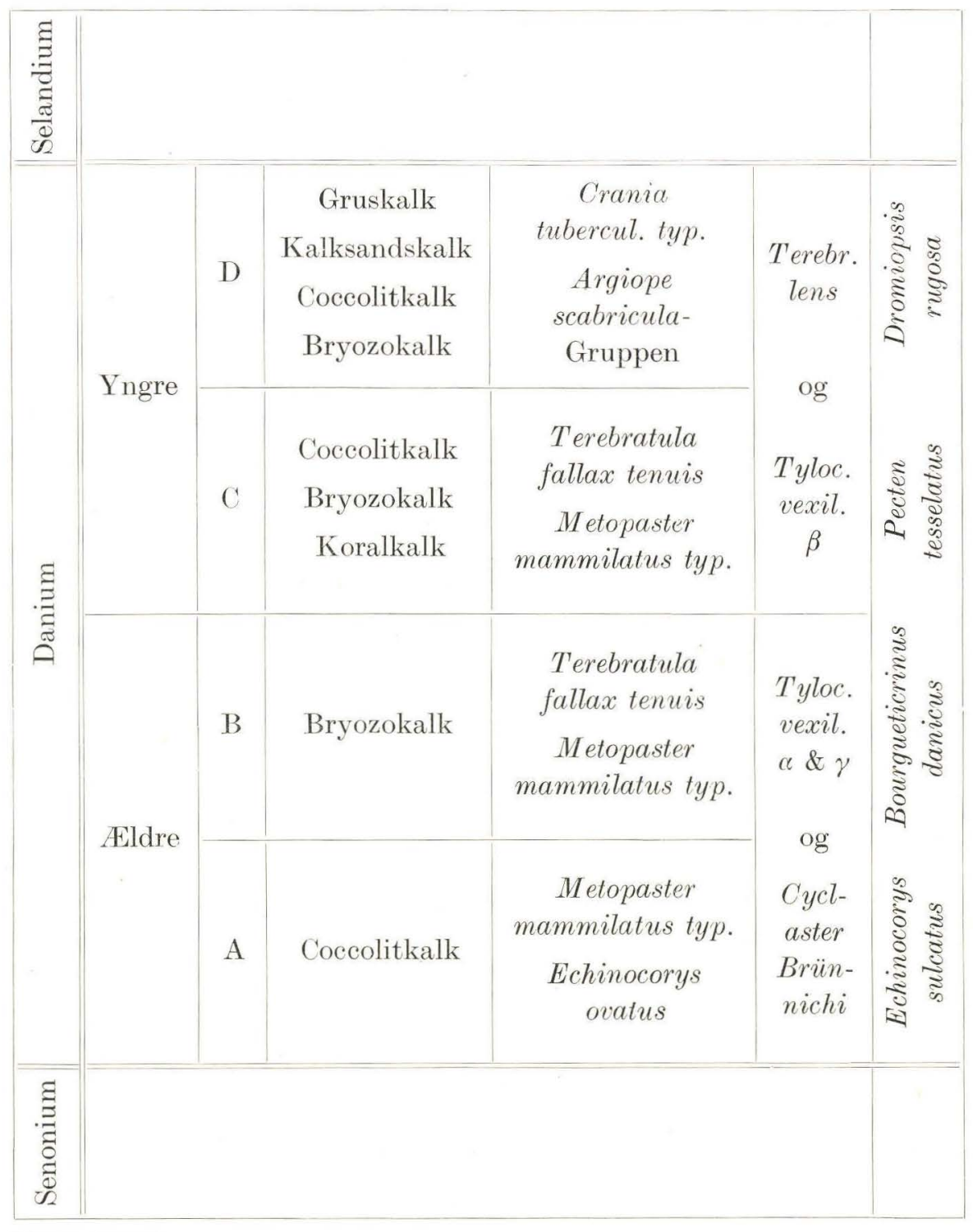

1) Med Hensyn til Bjergarterne maa det bemærkes, at tynde Lerlag optræder i alle fire Grupper af Daniet, men da de aldrig opnaar nogen væsentlig Tykkelse, er de ikke opført i Skemaet. 
Kapitel VII

\section{Palæogeografi.}

Maalet for en historisk-geologisk Undersøgelse maa være at udrede alle palæogeografiske Forhold (saavel af fysisk som biologisk Art), der ligger indenfor den givne Undersøgelses Ramme. Saaledes maa ogsaa Daniumforskningen her i Landet have til Maal at udrede Daniumtidens Geografi saa detailleret som muligt for de paagældende Omraader, og en palæogeografisk Undersøgelse vil derfor være en naturlig Fortsættelse af det hidtil fremsatte; den Undersøgelse, hvis Resultater her er fremlagt, og den systematiserende Oversigt, hvori Undersøgelsen konkluderer, er for saa vidt kun Udgangspunktet for det videre Arbejde, men danner samtidig et uundværligt Grundlag for dette.

Imidlertid er denne videre Undersøgelse en afgræenset Opgave for sig, og hertil kommer, at der til dens Løsning kræves mere omfattende Specialstudier, især af petrografisk og palæobiologisk Art, end det foreliggende Arbejde har nødvendiggjort. Endvidere vilde det være unaturligt at foretage dyberegaaende, palæogeografiske Undersøgelser og indskrænke disse til Jylland og ikke tage Hensyn til Forholdene i SjællandSkaane, men for disse Egnes Vedkommende findes ikke tilstrækkeligt Materiale tilgængeligt i Litteraturen; en foregribende, jysk-fynsk Undersøgelse vilde sandsynligvis være hjemfalden til en snarlig Revision.

Ud fra disse Betragtninger vilde det derfor maaske have været rimeligst at lade Arbejdet slutte med den opnaaede, orienterende Oversigt over det jyske Danium; de følgende, palæogeografiske Bemærkninger fremsættes derfor kun for Fuldstændigheds Skyld, men bliver af ovennævnte Grunde ganske kortfattede og vil kun mere løseligt behandle disse Forhold.

Hvad angaar Fordelingen af Hav og Land, maa det sikkert betragtes som fastslaaet, at Daniumhavet ikke dækkede hele Danmark, men har været mere begrænset i sin Udbredelse end Senoniumtidens SkrivekridtHav, et Forhold, der behandles ret udførligt af RAvN (95 S. 404 ff.). Hævningen er begyndt allerede mod Slutningen af Senoniumtiden, idet Skrivekridtets øverste Lag flere Steder er udviklet paa afvigende Maade, og især ved sin rige Bryozofauna viser sig at være afsat paa ret lavt Vand (Ravn 1. e., Multhers 67 S. 12-14, Jessen og Ødum 47 S. 55; endvidere Kap. III: Kjølby Gaard I, Nye Kløv og Kap. IV: Hov III og Skovsted I). Hvor stor Udstrækning denne Hævning har haft, er ikke let at fastslaa, men ved Overgangen mellem Senonium og Danium har utvivlsomt store Strækninger af de nu Danium-dækkede Omraader 
enten været hævet over Havets Overflade eller været hævet til eller i umiddelbar Nærhed af Littoralzonen. Derom vidner de Spor af Abrasion, som træffes paa flere af Overgangslokaliteterne, og i samme Retning peger de Hærdningshorisonter, der ligeledes optræder flere Steder, selv om Hærdningen næppe er at opfatte som en blot og bar Indtørring, men sikkert skyldes mere komplicerede Processer. At disse Fænomener kan være ret forskelligt udviklede paa hinanden nærliggende Lokaliteter, viser dels, at Havbunden maa have været ret ujævn ved Hævningens Indtræden, dels lader de formode, at Hævnings- og Sænkningsprocessen ikke har været ganske enkel.

Som stratigrafisk Udgangspunkt maa det anses som det eneste rimelige at parallelisere Coccolitkalken paa de forskellige Lokaliteter (Zone A), idet den — bortset fra Hærdnings- og Transgressionsfænomenerne som en ret ensartet Dannelse skyder sig ind mellem Skrivekridtet og Daniets Bryozokalk; men i saa Fald kan de forskellige Hærdnings- og Transgressionshorisonter ikke henføres til eet Hævningsmaximum, idet de hærdnede Lag og de mere eller mindre tydeligt transgressive Lerlag paa de forskellige Steder ikke ligger paa samme Sted i Lagserien. Hvad Forholdene paa Sjælland angaar, saa fremgaar det af RosenkRAntz' Undersøgelser (110), at man ikke kan forklare Stevnsprofilet med det transgressive Lerlag og den herover liggende Hærdningshorisont uden at antage to Hrvninger, og paa en enkelt jysk Lokalitet, Bøgelund, er der ogsaa udviklet to Lakuner (sikkert af kort Varighed) i samme Profil. Ved Coccolitkalkens Basis findes et Bundkonglomerat, og de højereliggende Dele af samme Lag er hærdnet og abraderet.

Paa de øvrige jyske Lokaliteter finder kun den ene af de to paa hinanden følgende Hævninger tydeligt Udtryk i Profilerne. Den ældre af dem har foraarsaget Hærdningen af det øverste Skrivekridt i Eerslev I og Øxendal, og ved dens Afslutning dannes Lerlagene (delvis konglomeratisk) ved Bøgelund, Gravlev, Voxlev og Kjølby Gaard. Den yngste af de to Hævninger foraarsager Hærdningen af Coccolitkalken ved Bøgelund, Gravlev og Nystrup, ligesom Lerlaget ved Nystrup dannes ved dens Afslutning.

At der ved Daniumtidens Begyndelse finder en almindelig, positiv Forskydning Sted, hvorved Havet atter breder sig over en Del af Skrivekridtomraadet, er ofte blevet fremhævet. Lige saa ofte er det blevet fastslaaet, at dette Hav ikke naaede Skrivekridthavet i Dybde. I det store $\mathrm{og}$ hele er dette sidste vel nok rigtigt, men alligevel er det af Interesse at sammenligne det Eldre Daniums Bryozokalk med det bryozorige, yngste Skrivekridt. I dette sidste findes oftere ret grove Typer, mens A. Daniums Bryozokalk gennemgaaende er opbygget af Stammer af finere Type; desuden spiller store Membranipora-Kolonier en langt større Rolle i Skrivekridtet end i Daniets Bryozokalk, hvilket antyder en kraf- 
tigere Algevegetation under Dannelsen af det nævnte Skrivekridt ${ }^{1}$ ). Denne yngste Skrivekridthorisont maa altsaa være dannet paa lavere Vand end Daniets Bryozokalk. Hexnig (39 S. 110-116) har foretaget en Sammenligning mellem Bryozofaunaen fra (det yngre) Danium og Bryozofaunaen i Kristianstad-Omraadets littorale Senoniumdannelser og kommer til den Slutning, at Daniets Bryozokalk er dannet under rolige Forhold paa en Havdybde af ca. 200-300 m. Bryozoernes fragmentariske Tilstand i Daniets Bryozokalk kan saaledes ikke skyldes Bølgeslaget, men maa hidrøre fra den benthoniske, bryozoofile Faunas Virksomhed; at Troensson finder, at dette ikke kan være Tilfældet ved Limhamn (121b S. 560), afkræfter ikke Hennig's Ræsonnement med Hensyn til andre af Daniets (og specielt det E. Daniums) Bryozokalkdannelser.

Ved denne Sænkning breder Daniumhavet sig altsaa over Skrivekridtomraadet i Nordjylland. Nordgrænsen for Daniumhavets daværende Udbredelse kender vi ikke, idet en Del af Aflejringerne senere maa tænkes fjernet ved Erosion. At Havet under ældre Daniumtid skulde have haft en meget større Udbredelse end A. Danium nu har, er der dog næppe Grund til at tro; Omraadet N. herfor har sikkert, som RAVN fremhæver (95), været Land.

Alle Forfattere, der har beskæftiget sig med herhen hørende Spørgsmaal, er enige om, at Daniumtiden afsluttes med en ny Hævning, under hvilken de forskellige Bjergarter i "Zonen med Crania tuberculata" (Ravs's "Yngre Danien«, 95) afsattes paa lavt Vand. Hvad derimod Y. Daniums Hovedbjergart, Coccolitkalken, angaar, synes man at opfatte den som afsat paa dybt Vand, repræsenterende Daniumsænkningens Maximum. Stærkest er dette hævdet af Rorday (112 S. 85), der anser Coccolitkalken for at være dannet paa meget store Dybder; nærmest herefter kommer Foraminiferkalken, Bryozokalken og endelig Koralkalken, der er dannet paa lavt Vand. RAvN (95 S. 418) henfører Coccolitkalken til en dybere Facies end Bryozokalken, mens Hennig anser begge Bjergarter for at være dannet paa ret dybt Vand, men ved begge disse sidstnævnte Forfatteres Ræsonnementer maa det erindres, at man ikke paa dette Tidspunkt skelnede mellem Bryozokalk fra A. og Y. Danium.

Det synes dog tvivlsomt, om denne Betragtning af Forholdet mellem Bryozokalken (specielt Æ. Daniums) og Coccolitkalken er rigtig; Forf. vil være mere tilbøjelig til at anse Daniets Coccolitkalk for at være afsat paa ringere Dybde end Bryozokalken. Daniumsænkningen har sikkert naaet sin største Dybde under Afsætningen af Zone B's Bryozokalk,

1) Ved Betragtning af Gastropodfaunaen kommer Hennig (39 S. 122) til det Resultat, at ved Faxe og Annetorp har Algevegetationen i det mindste været meget fattig (Koralkalken $\mathbf{i} \gg$ Ravns Næse« danner en Undtagelse, idet dens Sneglefauna afgjort tyder paa Algevegetation). 
og den Hævning, som kulminerer med Afslutningen af Daniet, indledes allerede ved Overgangen mellem A. og Y. Danium.

Allerede den geografiske Fordeling af Aflejringerne viser dette. Trækker man N.-NØ.-Grænsen op for de forskellige Zoners Udbredelse i Jylland, vil man se, at det ældre Danium overalt gaar lidt længere nord paa end Y. Danium. Paa Grund af senere Erosion maa man maaske ikke tillægge dette alt for stor Betydning, men hertil kommer, at vi endnu ikke noget Sted har iagttaget Y. Danium liggende transgressivt oven paa Skrivekridtet.

Hvad Sedimenterne angaar, synes der ikke at være nogen iøjnefaldende Forskel paa Størsteparten af det Y. Daniums Coccolitkalk og det Kalkslam, der udgør Grundmassen i A. og Y. Daniums Bryozokalk i Jylland. Aflejringen af dette Kalkslam er foregaaet gennem hele Daniumtiden, efter skiftende Tid og Sted med en varierende Indblanding af autochtont, benthogent Materiale af Bryozoer, Koraller o. a. Forskellen mellem Bjergarterne i A. og Y. Danium kan formodentlig i første Linie henføres til en Veksling i Sedimentationens Hastighed, som saa atter maa føres tilbage til den begyndende Hævning og dertil knyttede Foreteelser. Kalkslammets Oprindelse staar i direkte Sammenhæng hermed, idet man maa formode, at kun en ringere (men sikkert tilstedeværende) Del heraf er primært, planktogent Materiale (se Ussing, 124 S. 104); den største Del er sikkert af terrigen Oprindelse, hvad enten det hidrører fra senoniske (eller ældre kretaciske) eller — for de yngre Afsnit af Daniets Vedkommende - daniske Aflejringer ${ }^{1}$ ).

Fattigdommen paa Bryozoer i Y. Danium skyldes i første Række sandsynligvis, at den meget stærkt forøgede Slamtilførsel har vanskelig-

1) I den seneste Tid har man fra amerikansk Side hævdet den Opfattelse, at det fine Kalkslam, der udgør Hovedmassen af Skrivekridtet, skulde være fremkommet ved simpel kemisk, uorganisk Udskillelse i Havets øverste Vandlag, tildels maaske under Medvirkning af Bakterier (se f. Eks. TArr, 121 a). Der er meget, der taler til Gunst for denne Opfattelse, og de Betragtninger, der ligger til Grund herfor, kan sikkert overføres paa Daniets Aflejringer. Der er især to Faktorer der vil fremkalde en Udskillelse af mikroskopisk fine Kalkkrystaller af en mættet Opløsning, nemlig simpel Fordampning og Bortgang af $\mathrm{CO}_{2}$, og begge disse Processer fremskyndes med stigende Temperatur.

Udskillelsen af Kalken foregaar derfor i de øverste Vandlag i Havet, mens de dybere, koldere Lag er i Stand til at opløse større Kalkmængder. I Daniumhavet, som har været et tropisk eller subtropisk Indhav med en rigelig Tilførsel af opløste Salte fra de omgivende Landstrækninger, har denne Kalkudskillelse og Bundfældning altsaa fortrinsvis fundet Sted paa de Steder, hvor Vanddybden har været ringest. En negativ Niveauforskydning vil baade bevirke en større terrigen Tilførsel til et givet Sted og en forøget kemisk Kalkudfældelse, saa hvad enten en forøget Sedimentation af Kalkslam fortrinsvis skyldes den ene eller den anden af de to Processer, kan den tages som Udtryk for en Hævning. 
gjort deres Eksistens paa Havbunden, mens andre, direkte Følger af den ringere Dybde vel nok har spillet en mindre Rolle. I det hele er disse yngre daniske Aflejringer fattige paa Dyreformer, der lever fasthæftede til mere eller mindre haard Bund, naar de ikke benytter sig af Molluskskaller, Echinider o. lign. At Sedimentationen maa have været betydelig stærkere i Y. end i A. Danium fremgaar af forskellige Ting $\left.{ }^{1}\right)$. Paa flere Lokaliteter (bl. a. Lime, Rigtrup) kan man iagttage Pentacrinstilke af flere Decimeters Længde i lodret Stilling igennem Kalklagene, hvilket næppe vilde være muligt, hvis de ikke var blevet indlejret ved en hurtig Sedimentation ${ }^{2}$ ); Tilstedeværelsen af større Former af fasthæftede Mollusker og Brachiopoder i Y. Danium strider tilsyneladende herimod, men for det første har Sedimentationen sikkert været meget uregelmæssig, og for det andet kan man iagttage, at Gryphaea-Individer, der har hæftet sig med stor Tilhæftningsflade (hippopodium-Form) paa en større Genstand, som Regel kun opnaar en ringe Størrelse ${ }^{3}$ ), medens Individer med minimal Tilhæftningsflade (vesicularis-Form) opnaar betydelig Størrelse; disse sidste, som ikke hæmmes af et tungt Substrat, har sikkert været i Besiddelse af nogen Bevægelsesfrihed, medens de paa en større Genstand fastsiddende Individer er blevet begravede.

Coccolitkalken i Y. Danium maa altsaa formodes at være afsat paa lavere Vand end det A. Daniums Bryozokalk, en Antagelse, der støttes ved, at Faunaen i Y. Danium er betydelig rigere paa Arter end Faunaen i Æ. Danium; en nærmere Betragtning af Arterne vil sandsynligvis kunne fremskaffe flere Indicier i denne Retning (en Gruppe som Cirrhipedierne, der udelukkende er fundet i Y. Danium, hører i udpræget Grad hjemme paa ringere Dybde; noget lignende gælder mange Octocoraller, og saa fremdeles) $)^{4}$.

I den ældre Afdeling af $\mathrm{Y}$. Danium (Zone C) forekommer flere Steder Bryozokalk, formodentlig afsat i Kontinuitet af Zone B's Bryozokalkdannelse, og disse Lokaliteter repræsenterer da Steder, der ved Hævningens Indtræden har været beskyttet mod forøget Slamtilførsel ved større Afstand fra Land, større Dybde eller paa anden Maade; disse Omraader indskrænkes i Tidens Løb, og i yngre Afdeling af $\mathrm{Y}$. Danium (Zone D) findes Bryozokalk i Jylland kun som underordnede Lag (Thi-

1) At Y. Danium har betydelig større Mægtighed end Æ. Danium, kan naturligvis ikke tillægges afgørende Betydning, da vi ikke kender de paagældende Tidsrums Længde, men er dog værd at notere.

2) Rosenkrantz bemærker det samme m. H. t. Graphularier (106 S. 20).

${ }^{3}$ ) Man finder ofte Echinocorys-Eksemplarer, der er tæt besat med unge hippopodium-Individer af Gryphaea vesicularis, alle paa omtrent samme Alderstrin.

$\left.{ }^{4}\right)$ Underordnede Lerlag (ofte glaukonitiske), som optræder hyppigere i Y. end i Æ. Danium, tyder ogsaa paa en ringere Afstand til Land, resp. ringere Dybde. 
sted IV-V (og VI?), Skive); paa Fyn derimod er Zone D hyppigere udviklet som Bryozokalk ${ }^{1}$ ). I petrografisk Henseende er der fuldkommen jævn Overgang mellem den jyske Coccolitkalk og de sjællandske, uomtvistelige Lavvandsdannelser, de forskellige Varieteter af Kalksandskalk; ogsaa i Jylland ses mod Daniets Slutning stedvis lidt grovere Kalkvarieteter.

Vi maa altsaa formode, at Daniumsænkningens Maximum i Danmark falder i A. Danium (Zone B); ved Overgangen til Y. Danium (med Zone C) indtræder Hævning og Regression, hvilket fortsættes til Daniumtidens Slutning (Zone D); se Fig. 29.

Forholdene paa Grænsen mellem Daniet og Selandiet viser, at vi

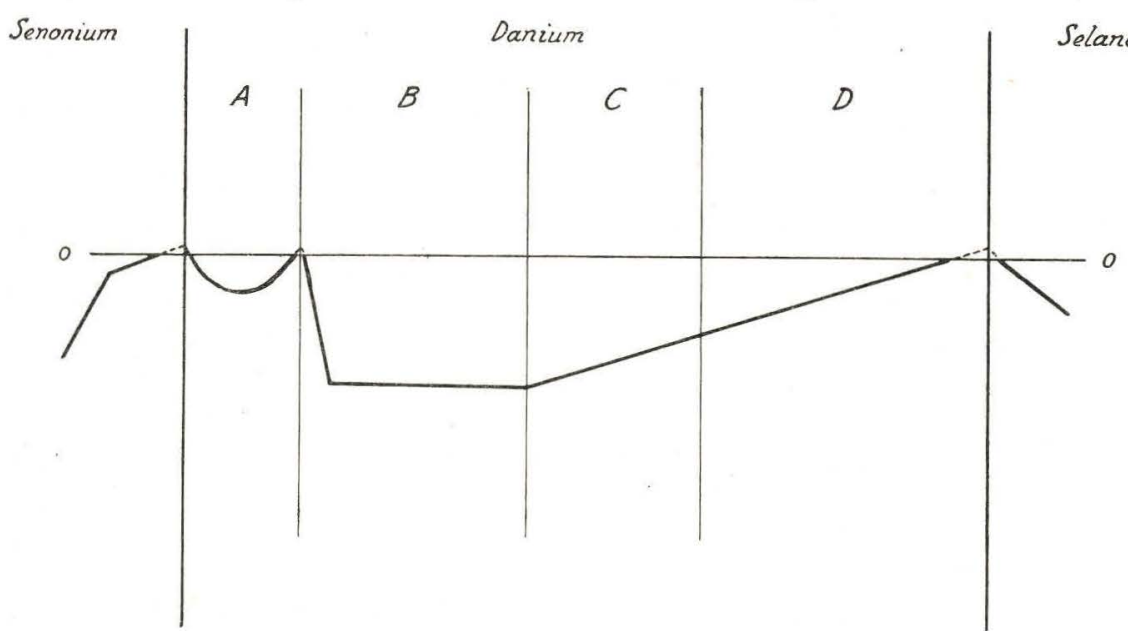

Fig. 29. Skematisk Fremstilling af Hævnings- og Sænkningsforløbet.

her har denne Hævnings Kulmination, hvorefter Selandiet indledes med en ny, omfattende Sænkning. Konglomeratet ved Basis af Selandiet ved Hvalløse og Svejstrup antyder dog, at der ogsaa ved denne Overgang har fundet mere komplicerede Begivenheder Sted, men disse Forhold er endnu ikke endeligt udredede.

Selandiet er præget af stærkt Tilførsel af terrigent Materiale, som i Modsætning til Daniets Bjergarter overvejende bestaar af Ler og Sand. Medens de kretaciske og daniske Aflejringer i dette Havomraade, repræsenterende meget lange Tidsrum, saa at sige ganske har savnet Tilførsel af disse sidste Elementer, tager disse ved Selandiumtidens Begyndelse atter Overhaand. Mens Daniets terrigene Kalkmateriale maa være hentet fra de kun lidt ældre Aflejringer indenfor selve det sydskandinaviske Geosynklinalomraade, saa maa Selandiets (og det øvrige Tertiærs) Lerog Sandmateriale hidrøre enten fra Skandinaviens Grundfjeld (maaske

1) Lokaliteter, hvor Daniets yngste Lag (under Selandiet) er udviklet som Bryozokalk, ligger fjernere fra Kysten (Skive, flere Steder paa Fyn). 
i ringere Omfang fra Tyskland) eller i hvert Fald fra Randzonen. Der er derfor al Grund til at hæfte sig ved denne Forandring, thi den maa utvivlsomt skyldes epokegørende Begivenheder indenfor Skandinavien eller Randzonen, hvis Begyndelse straks sætter sig Spor i Sedimentationen, og denne Grænse mellem de to Sedimenttyper, paa de forskellige Lokaliteter synchron i tilnærmelsesvis absolut Betydning, er derfor en stratigrafisk Grænse af høj Værdi ${ }^{1}$. At fastslaa, af hvad Art disse Begivenheder er, er vanskeligt, men det ligger nær at tænke paa orogenetiske Bevægelser og det er højst sandsynligt, at bl. a. Randzonens som tertiære bestemte, store Forkastninger i hvert Fald delvis skal henføres til dette Tidspunkt.

Den videre Udformning af Daniets Palæogeografi maa baseres foruden paa petrografiske Studier - paa Studier af zoogeografisk og -økologisk Natur. Forf. skal ikke her komme nærmere ind paa dette Emne, men da de herhen hørende Spørgsmaal ogsaa har Betydning med Hensyn til de forskellige Formers Værdi som Ledefossiler, skal der her gives en kortfattet Oversigt over, hvorledes de i denne Afhandling omtalte, daniske Ledefossiler i deres Forekomst forholder sig til Sediment, Bundform e. a.

Ceratotrochus saltholmensis (Y. Danium): Baade i Coccolit- og Bryozokalk.

Epitrochus vermiformis (A. Danium): Er kun truffet i Bryozokalk (Z. B).

Graphularia Grönwalli (Y. Danium Z. D): Med Undtagelse af, at den af BRünnich Nielsen anføres fra Koralkalken i »Ravns Næse« i Faxe, er denne Form udelukkende indskrænket til Coccolitkalken, i hvis Slambund den har været fastsiddende.

Isis vertebralis (Y. Danium): Synes fortrinsvis at forekomme, hvor der samtidig findes Bryozoer; vist baade paa lavere og dybere Vand.

Metopaster mammilatus typ. (AE. Danium, Y. Danium Z. C): Optræder baade i Coccolit- og Bryozokalk; baade paa lavere og dybere Vand.

Tylocidaris vexillifera: De forskellige Former synes at være uafhængige af Bundformen; dog har de næppe været levende paa meget lavt Vand og heller ikke paa tæt Koralbund. Muligvis er $f . \gamma$ 's indskrænkede Forekomst betinget af lavere Vand.

Cyclaster Brünnichi (E. Danium): Forekommer baade i Coccolit- og Bryozokalk, men opnaar sin største Udvikling i den første.

1) Dette afkræfter, som ogsaa Rosenkrantz fremhæver (109 S. 34), Harder's Tolkning af »Sundkrogslagene« (34 S. 57). 
Brissopneustes danicus (A. Danium, Y. Danium Z. C): Baade i Coccolit- og Bryozokalk.

Brissopneustes suecicus (Y. Danium): Som foregaaende.

Serpula Hisingeri (Y. Danium Z. D): Kun paa Slambund (og lavt Vand?).

Serpula distincta (A. Danium, Y. Danium Z. C): Kun paa Bryozobund.

Serpula dentata (Y. Danium): Baade i Coccolit- og Bryozokalk.

" undulifera (Y. Danium): Baade' i Coccolit- og Bryozokalk (vikarierende for den foregaaende).

Serpula erecta (A. Danium, Y. Danium Z. C): Kun paa Bryozobund.

Ditrupa Schlotheimi (Y. Danium Z. D): Kun paa Slambund (og lavere Vand?); dog næppe i Brændingszonen.

Crania tuberculata typ. (Y. Danium): Træffes baade paa Slam(Kalksands-) og Bryozobund; den opnaar sin kraftigste Udvikling paa lavt Vand ( $f$. transversa synes uafhængig af Dybden). Rhynchonella incurva f. faxensis (E. Danium, Y. Danium Z. C) : Findes kun i Koral- eller Bryozokalk.

Rhynchonella incurva typ. (Y. Danium): Findes baade i Coccolitog Bryozokalk.

Argiope Johnstrupi (Y. Danium Z. D): Er kun truffet i Coccolitkalk.

Argiope scabricula (Y. Danium Z. D): Baade i Coccolit- og Bryozokalk.

Argiope Cimbrorum (Y. Danium Z. D): Ligeledes.

Terebratula cfr. lens (Y. Danium (og Selandium)): Træffes baade i Coccolit- og Bryozokalk; derimod synes den at være afhængig af Vanddybden, idet den i Jylland kun optræder i Coccolitkalken, altsaa paa lavere Vand, og hvor den paa Øerne forekommer i Bryozokalk (eller Gruskalk), er det ogsaa i Dannelser, der oftest uomtvisteligt hører hjemme paa lavt Vand (f. Eks. Herfølge, Faxe Bryozokalk I, III, IV og X)1).

Terebratula fallax typ. (Y. Danium Z. D): Findes baade i Coccolit- og Bryozokalk, muligvis under samme Betingelser som T'. lens.

Terebratula fallax tenuis (A. Danium, Y. Danium Z. C): Træffes baade i Coccolit- og Bryozokalk; i Modsætning til T. lens er dens Forekomst betinget af dybere Vand. I Zone C optræder den derfor fortrinsvis paa Bryozobund, og kun meget sjældent finder man den i Selskab med T. lens.

1) Paa Fyn kendes Arten kun med Sikkerhed fra Rosille I (Coccolitkalk), mindre sikkert fra Svendborg I (Bryozokalk). 
Lima bisulcata (Y. Danium Z. D): Synes kun at optræde i Lavvandsdannelser.

Lima testis (Y. Danium Z. D, Selandium): Synes at kunne optræde under alle Forhold.

Plicutala Ravni (Y. Danium Z. D): Synes kun at optræde i Lavvandsdannelser (Slam-, Sand- og Grusbund).

Scalpellum Steenstrupi (Y. Danium (og Selandium)): Baade i Coccolit- og Bryozokalk, samt Kalksandskalk; næppe paa altfor dybt Vand.

\section{Kapitel VIII}

\section{T e k t o n i k.}

De i det foregaaende, særlig i Kap. III, anførte Iagttagelser over Daniumlokaliteternes Beliggenhed og Lejringsforhold lader sig, under Hensyntagen til vort Kendskab til andre Aflejringer, samle til et mere overskueligt Billede. Medens de forskellige Enkeltlokaliteter er indlagt paa T. IV, har Forf. paa T. V søgt at drage Grænserne mellem de Aflejringer, der danner Grunden under de kvartære Lag $\left.{ }^{1}\right)$. Det følgende skal søge at karakterisere de forskellige Omraader, hvor Daniet kommer frem i Dagen eller kendes paa anden Vis.

\section{Fyn.}

For Fyns Vedkommende har det ny tilkomne Materiale ikke ændret noget væsentligt i det Billede, Ravr's Kort giver (104). Kalkundergrunden synes at ligge ret ensartet i det østlige Fyn - Langeland, overlejret af Selandium, og Forstyrrelser er ikke paavist, hverken direkte eller indirekte.

At Selandiet sine Steder kun opnaar en ringere Mægtighed, fremgaar bl. a. af Forholdene omkring Odense Fjord, hvor Iagttagelserne

1) Paa T. IV er de ikke-daniske Lokaliteter i Hovedsagen indlagt efter Ravn's Kort af 1922 (104). Paa T. IV og V er der skelnet mellem Senonium, Danium og Selandium, mens alt Tertiær yngre end dette sidste er indlagt under eet; desuden er Lagstillinger og Forkastninger angivet (for Mønsteds Vedkommende har dette ikke kunnet lade sig gøre med Sikkerhed, saa Signaturen her maa kun opfattes som gældende stærke, uregelmæssige Forstyrrelser). 
viser, at Daniet et Par Steder overlejres direkte af Kvartær. Grunden hertil skal sikkert søges i Iserosionen fra NØ., der delvis har fjernet Selandiet.

\section{Jylland.}

I Djursland ligger de prækvartære Dannelser ogsaa for største Delen uforstyrret af tektoniske Bevægelser; Forkastninger og forstyrrede Lag er ikke iagttaget, og Kalkundergrunden ligger jævnt, højest i Egnen N. f. Grenaa, sænkende sig mod S. og V. Selandiet overlejrer det Y. Danium paa normal Vis i det sydlige Djursland; ogsaa i det nordlige Djursland synes det Y. Danium at ligge uforstyrret over det $\mathbb{E}$. Danium, idet dette sidste kun kendes med Sikkerhed fra Karlby og Sangstrup Klinter og Stensmark; nærmest dette kommer Y. Daniums Zone C (Hammelev Gaard).

S. f. Selandiets Nordgrænse er der kun iagttaget direkte Overlejring af Kvartær over Danium to Steder, Ebeltoft I og Møllerup (hvor Forholdene dog er mangelfuldt oplyste); begge Steder ligger i Inderlavninger bag den østjyske Israndslinie, hvor det tynde Lag Selandium er blevet fjernet ved Iserosionen.

I Klavsholm-Omraadet kommer Kalkens Overflade atter op paa større Højde, karakteriseret ved en Mængde tætliggende Daglokaliteter, mens den mellem Grenaa og denne Egn kun kendes fra Boringer, hvilket ogsaa gælder Rongsø Herred. Den vestlige Grænse for Kalkens Tilsynekomst i dette Omraade sættes af Selandiet, hvor dette normalt overlejrer Daniet; Forkastninger i denne Grænse er ikke iagttaget, og Kalken synes i det store og hele at ligge horisontalt og uforstyrret. Kun paa een Lokalitet, Fløjstrup I, den østligste af disse Daglokaliteter, er Forstyrrelser bemærket. Sandsynligvis udgøres Klavsholm-Omraadets Ø.-NØ.-Grænse af Forkastninger, hvorved det er hævet over det lavere Kalkplateau i Djursland; ogsaa mod N., mod Randers-Dalen, findes sikkert Forkastninger.

Randers-Dalen. Fra Randers og Egnen nærmest omkring Byen kendes Daniet og Selandiet kun fra Boringer, men de Oplysninger, Hr. Statsgeolog V. MiLthers har været saa venlig at overlade mig, giver et ret klart Billede af Forholdene. Det viser sig, at Kalkens Overflade, hvor den S.-SØ.f. Randers overlejres af Kvartær eller Selandium, ligger paa ret højt Niveau; omkring Byen sænker den sig til stor Dybde for atter at stige stærkt N.--NV. f. denne. Randers-Dalen fremtræder altsaa ogsaa, som Statsgeolog Milthers har paavist, som en Lavning i de prækvartære Aflejringer, og de tertiære Lerarter, der her ellers har deres NØ.-Grænse V.f. Randers, strækker sig i denne Dal Ø.f. Byen. Disse Tertiæraflejringers Tilstedeværelse dér kan forklares ved at an- 
tage, at Dalen er opstaaet som en Gravsænkning (og ikke ved Erosion), og de begrænsende Forkastninger maa da have et Forløb omtrent som vist paa T. V.

Spentrup-Omraadet begrænses mod S.--SØ. af Randers-Dalens Sænkning; mod V. overlejres Daniet af Selandium og yngre Tertiærdannelser; $\bmod \mathrm{N}$. danner Mariager Fjord Grænsen, og $\bmod$ NØ. kommer Skrivekridtet frem og danner Undergrunden.

Skrivekridtet N. f. Spentrup, der træder frem i Dagen $55 \mathrm{~m}$ over Havet, danner Centrum for dette Omraade, omgivet af yngre Dannelser. Gaar man ud fra Skrivekridtet i Spentrup mod SV.-V.-NV. træffer man først A. Danium (Raasted, Purhus III, Svendstrup (?)), dernæst Y. Danium Zone C (Bjerregrav II-III, Purhus I (?), Ejstrup I (?)), Y. Danium Zone D (Bjerregrav I), Selandium (Svejstrup, Bjerregrav VII) og endelig Oligocæn (Faarup, Sønderbæk). Mod N. træffer man atter Y. Danium ved Mariager Fjord, og det samme er Tilfældet mod Ø. (Hald, Mejlby, Dalbyovre, Ø. Tørslev).

Mens Begrænsningen mod S. dannes af Randers-Dalens Dislokationssystem, synes de Grænser, man passerer ved at gaa fra Spentrup mod SV. at være normale Overlejringsgrænser. Mere tvivlsomme er Forholdene mellem Spentrup og Faarup; Oligocænet er her i Dagen rykket meget tæet ind mod Daniet, endda paa lavere Niveau (Faarup Tglv. : ca. $18 \mathrm{~m}$, Purhus I og VI: $30 \mathrm{~m}$ ), saa her nødes man næsten til at antage Tilstedeværelsen af Dislokationer, selv om disses Forløb ikke kan fastslaas; desuden er hældende Lag iagttaget ved Purhus V og Ejstrup I.

Hvorledes Overgangen er fra Centrets Skrivekridt til Daniets N. og NØ.-Grænser, kan ikke i Øjeblikket fastslaas. Mod NØ. overlejrer Spentrup-Omraadets Danium Skrivekridtet paa normal Vis, idet man fra Skrivekridtet (Skarodde, Trudsholm, Binderup, Dalbynedre) bevæger sig mod SV. over ÆE. Danium (Bøgelund, Assens(?), Dalbynedre I(?), Kastbjerg) og Y. Danium (Jomfrubakken, Dalbyovre, Ø. Tørslev, Tørring(?)). I denne Egn maa Dislokationerne gaa i nordøstlig Retning; direkte Iagttagelse af foldede Lag foreligger fra Kastbjerg (hvor Foldningens Retning dog ikke er fastslaaet med Sikkerhed), og Forholdet mellem Daniet i Dalbynedre I og Skrivekridtet i Byens sydvestlige Udkant (Kridtet gaar op til mindst samme Højde som Bryozokalken) gør det nærliggende at antage en Forkastning med et lignende Forløb (eller et Fald med denne Strygning); disse Dislokationer forløber parallelt med den ydre Del af Randers Fjord, og denne synes saaledes i hele sit Forløb at være tektonisk betinget.

I den sydøstlige Del af Himmerland, nærmest Mariager Fjord, følger de forskellige Aflejringer ogsaa hverandre i regelmæssig Aldersfølge: Skrivekridt (Vive, Tostrup, Brøndbjerg, Rostrup), AE. Danium (Ove II-IV), Y. Danium Zone C (Ove I), Y. Danium Zone D (Stinesminde, 
Laaenhus) og endelig Tertiæraflejringerne i den indre Del af Fjorden (se Madsen, 65 a). Aflejringerne paa Fjordens N.- og S.-Side korresponderer paa det nøjeste, og der kan næppe være Tale om, at Fjorden i sit Anlæg skyldes lignende Gravsænkninger som Randers Fjord. De Dislokationer, der findes i denne Egn, gaar sikkert paa tværs af Fjorden, saaledes som det hævdes af Victor Madsen, der har paavist en saadan Dislokation i Tertiæret ved Skovbo (65 a S. 36).

I den nordlige Del af Himmerland optræder der atter Forstyrrelser af Undergrunden. Omkring Lindenborg Aa gaar de forskellige Zoner frem i Dagen paa saa tætliggende Steder, at der kan være Mulighed for Dislokationers Tilstedeværelse. Tallene er saaledes: Gravlev I $20 \mathrm{~m}$, Tinbæk Mølle $20 \mathrm{~m}$, Skillingbro ca. $28 \mathrm{~m}$, Oplev II $59 \mathrm{~m}$, Oplev I og Ersted II $70 \mathrm{~m}$, Ersted I $62 \mathrm{~m}$. Især den ringe Forskel, ca. $5 \mathrm{~m}$, mellem A. Daniums Undergrænse ved Gravlev og dets Overgrænse ved Skillingbro (Horisontalafstand $1200 \mathrm{~m}$ ) antyder Tilstedeværelsen af en Forkastning i Lindenborg Aas Dal, langs hvilken Lagene paa Nordsiden er hævet. Mellem det Æ. Danium i Gravlev (og Tinbæk Mølle) og Y. Danium (Zone C) i Oplev II er Differensen $40 \mathrm{~m}$, hvilket formodentlig angiver Æ. Daniums omtrentlige Mægtighed i denne Egn.

Ved Veggerbro gaar Danium (V. I) og Skrivekridt (V. III) i Dagen under saadanne Forhold, at man med Sikkerhed kan fastslaa Tilstedeværelsen af en Forkastning imellem de to Lokaliteter. Bryozokalken viser sig indenfor Kotehøjderne 1,5-5 m, mens Skrivekridtet kun $100 \mathrm{~m}$ Ost herfor ligger oppe i Kotehøjderne 5-12 m (Fig. 6 S. 67). Forkastningshøjden maa altsaa mindst være $10,5 \mathrm{~m}$, og den er sikkert betydeligt større. Saavel Bryozokalken som i Særdeleshed Skrivekridtet bærer Spor af stærke Forstyrrelser; den stærkt fremtrædende BreccieTilstand af Kridtet kan i hvert Fald ikke skyldes Istryk, idet dette sikkert ikke kan frembringe en saa gennemgribende Knusning til over $7 \mathrm{~m}$ Dybde. Forkastningens Retning kan ikke fastslaas, men maa formodentlig være nord-sydlig.

I den vestlige Del af Himmerland optræder flere Forstyrrelser. Hældende Lag ses ved Valsted, og i den nærliggende Grav ved Barmer I findes en Dislokation, hvor Lagene paa Sydsiden er sænket i Forhold til Lagene paa Nordsiden. Ogsaa ved Løgstør III er hældende Lag iagttaget af Grönwall. Foruden AE. Danium i den østlige Udkant af Løgstør (I) optræder i samme By Y. Danium og Skrivekridt i umiddelbar Nærhed af hinanden (for L. II's og den ene Skrivekridtborings Vedkommende paa omtrent samme Niveau), ligesom den store Differens i Kridtets Overflade i de to af RAvN omtalte Boringer virker iøjnefaldende. Noget nærmere om Forkastningers Optræden og Forløb kan dog ikke for Tiden fastslaas.

Gaar man fra Løgstør mod S., træffes Y. Danium ved Lendrup Strand 
i Havets Niveau, Æ. Danium ved Løgsted paa $22 \mathrm{~m}$, Skrivekridt ved Ranum paa $15 \mathrm{~m}$ (foruden paa større Dybde), \&. Danium ved Munksjørup paa $12 \mathrm{~m}$, Lundgaard paa $6 \mathrm{~m}$, Faldgaarde paa ca. $\div 19 \mathrm{~m}$, og atter Skrivekridt ved Overlade paa ca. $\div 11 \mathrm{~m}$. Endelig kommer Kridtet frem ved Borup og Skinderup Gaarde. Lagene nordligst i Graven ved Munksjørup hælder mod S., og da Skrivekridtet ved Ranum ligger paa højere Niveau end Daniet $\mathrm{S}$. herfor, saa kan man næppe se bort fra, at Niveauforskellen maa skyldes Forstyrrelser. Ogsaa Grænsen mellem Daniet og Tertiæret i Artebølle Hoved maa være betinget af Dislokationer, saa Bevægelser i Undergrunden maa i nogen Grad have præget denne Egn.

Hanherrederne-Thy. Paa Nordsiden af Limfjorden fortsættes Daniet i de to Holme ved Aggersund. Holmene omgives delvis af Skrivekridt og bestaar af ældre danisk Bryozokalk, tilsyneladende liggende normalt som Dækker over Kridtet, som det fremhæves af JESSEN (41 S. 32). Kun længst mod S. synes Forholdet mere tvivlsomt, idet Y. Danium (Zone C) ved Aggersborg Gaard ligger helt nede i kun 1 m Højde over Havet, mens A. Danium (Zone B) tæt Ø. herfor gaar op i 12 m Højde; Lagene ligger, saa vidt Iagttagelserne strækker, horisontalt, saa man maa indrømme Muligheden af Forkastningers Tilstedeværelse (28 S. 72).

I de tre Holme omkring Klim — Torup — Bulbjerg ligger Bryozokalken horisontalt, saa Holmene hviler sikkert som Dækker (maaske sammenhængende) over Skrivekridtet; Forstyrrelser af nogen Art spores ikke.

Set i store Træk ligger ogsaa Hanstholm og Hjardemaal Bakkeøers Danium som Dækker over Skrivekridtet, der kommer frem i det flade Land; men i Detailler er Forholdene næppe helt enkle. A. Jessen tyder (45 S. 44-45) Bakkeøerne som Horste, hvis Omgivelser er blevet sænket, idet han dels støtter sig til Forekomsten af Blegekridt under Havets Niveau ved Helshage (Hansted IV), dels til Øernes stejle, omtrent retlinede Skrænter.

Ser vi først paa Hanstholm, kan man ikke nægte, at der er stor Mulighed for Dislokationers Tilstedeværelse, selv om der ikke foreligger direkte Iagttagelse under nogen Form. I Bjerge I og II ligger det A. Danium paa Kote $12 \mathrm{og} 22 \mathrm{~m}$, mens Skrivekridtet $500-1200 \mathrm{~m}$ i vestlig Retning herfra gaar op til henholdsvis $15 \mathrm{og} 26 \mathrm{~m}$. Men netop dette Skrivekridt ligger paa den skraa Flade udenfor den stejle Skrænt, som JESSEN anser for at danne Horstens Rand; dette Kridt maa altsaa være hævet i Forhold til det indenfor liggende Danium eller Daniet maa være sænket, og det saaledes konstaterede Brud ligger indenfor Bakkeøen. $700 \mathrm{~m} \mathrm{~V}$. f. Rær Kirke gaar Skrivekridtet frem til ca. $18 \mathrm{~m}$ Højde over Havet, og ved Rær III maa dets Overflade ligge i en lignende Højde, overlejret af Danium. Da Fladen S. f. Hanstholm bestaar af Skrivekridt 
(hvis øverste Del endda maa formodes fjernet ved Erosion), kan en eventuelt eksisterende Forkastningsdifferens, ifald Fladen var sænket, ikke være særlig betydelig; var den det, maatte man vente at træffe Daniumbjergarter udenfor Bakkeøen, og dette er ikke Tilfældet paa Sydsiden. Ved Hansted IV gaar derimod Coccolitkalken ud under Havet (mindst til $\div 10 \mathrm{~m}$ ), og en Brøndgravning ved H. II ned til Havets Niveau gennemborer kun Danium. Hvorledes Forholdet er mellem Bryozokalken i H. I-II og Coccolitkalken i H. III-IV lader sigikke afgøre.

I det store og hele maa man altsaa forestille sig, at Daniet i Hanstholm er sænket i Forhold til Omgivelserne. I ringest Grad er dette Tilfældet ved Rær, men herfra tiltager Indsænkningen til begge Sider; mod Vest, hvor Y.(?) Danium gaar ud under Havet, mod Øst, hvor AE. Danium er sænket dybere end Skrivekridtet ved Bjerge.

I Hjardemaal Bakkeøen er der kun konstateret Danium, alt hørende til Y. Danium, som gaar i Dagen paa Koter fra 7 til $25 \mathrm{~m}$; faa $\mathrm{km} \bmod$ S. ved Kjølby Gaard ligger Skrivekridtets Overgrænse paa $12 \mathrm{~m}$, herfra faldende mod Syd eller Sydøst; Partiet ved Kjølby Gaard maa altsaa være skilt fra Hjardemaal Bakkeø ved en Forkastning, idet sidstnævntes Danium ligger paa betydeligt lavere Niveau end Skrivekridtet ved Kjølby Gaard.

Under alle Omstændigheder maa Fladerne i denne Egn være fremkommet ved Erosion; var Øerne hævet i hele deres Udstrækning ved Jordskorpebevægelser, vilde man ikke finde dem omgivet af ældre Dannelser, Kridt. Men selv om de kun i nogen Grad havde Horstnatur, vilde det være ejendommeligt, om Erosionen netop havde skaanet de Arealer, hvor de blødere Bjergarter, Kridtet, var bragt op paa deres højeste Beliggenhed, mens de omgivende haardere Daniumbjergarter var blevet fjernet. Ifald Jordskorpebevægelser har spillet nogen Rolle her, maa man snarest antage det omvendte, at Bakkexerne repræsenterer Elementer, der er sænket, klemt ned mellem de omgivende Bjergarter, hvorved deres Basis er blevet beskyttet; i denne Retning tyder ogsaa de ovennævnte Forhold ved Bjerge, det lavtliggende Danium ved Hansted, hvor det $\mathrm{Y}$. Danium gaar ned til mindst $\div 10 \mathrm{~m}$, og endelig det $\mathrm{Y}$. Daniums lave Niveau i Hjardemaal Øen.

Selv om Brudlinier kan være medbestemmende ved disse Holmes Konfiguration, hvilket meget vel er tænkeligt, maa man dog væsentligt rette sin Opmærksomhed mod Erosionen som den Faktor, der har udført Arbejdet. Og her kan Havets Abrasion ikke i nogen større Udstrækning have gjort sig gældende; Havet kan næppe paa lavt Vand fjerne saa mægtige Kalkmasser, efterladende en Mængde Øer; heller ikke Iserosionen kan tænkes at frembringe dette Landskab. Ser vi paa de af Kalkbjergarter bestaaende Bakkeøer i denne Egn af Landet og dette 
Terræns Fortsættelse i Vendsyssel, maa man langt snarere give A. JESSEN Ret, naar han (41 S. 23-29) henleder Opmærksomheden paa den prækvartære Floderosion som Hovedfaktoren. Østpaa tilsløres de prækvartære Terrænformer af Istidsaflejringerne, men her, hvor Havet har fjernet disse, maa man i Bakkeøerne og de mellemliggende Flader hovedsagelig se Tertiærtidens Landskab, et af Floderosion præget Land med tilbagestaaende Erosionsrester.

Omkring Lønnerup Fjord ligger Skrivekridtets Overgrænse ved Kjølby Gaard som nævnt i 12 m Højde, ved Nye Kløv paa ca. 5 m, A. Danium ved Lønnerup I paa $4-8 \mathrm{~m}$ og Y. Danium ved Hovsør paa ca. $0 \mathrm{~m}$. Langs denne Strækning falder Lagene altsaa jævnt i sydlig Retning, uden dog at Retningen er nøjere fastslaaet; ifald Bryozokalken ved Dalgaard, som maa ligge omtrent i Havets Niveau, tilhører ÆE. Danium, maa Strygningen trækkes herfra omtrent i Retning af Lønnerup I, d. v. s. NØ.-SV., og Faldet bliver da i sydøstlig Retning. Ifald Kalken ved Dalgaard er Y. Danium, maa Faldretningen være endnu mere østlig, men paa den anden Side kan den ikke overskride Retningen SØ. i nogen nævneværdig Grad, thi i saa Tilfælde vilde Strygningsretningen komme til at nærme sig stærkt til Linien Kjølby Gaard- Lønnerup I, og dette er udelukket. Vi maa saaledes regne med en sydlig Faldretning som den sandsynligste.

Paa Vestsiden af Lønnerup Fjord maa Skrivekridtets Overgrænse ved Hov I, $1400 \mathrm{~m}$ V. f. Hovsør, ligge mellem $20 \mathrm{og} 30 \mathrm{~m}$ over Havet. Daniet udgør under Kvartæret den øverste Del af Hov og Sennels Aas, men paa Vestsiden heraf, $1200 \mathrm{~m} \mathrm{SV}$. f. Hov I, gaar Skrivekridtet dog op til mindst $28 \mathrm{~m}$. Ogsaa her synes Dislokationer under en eller anden Form at spille en Rolle, og sandsynligvis skilles Fjordens Øst- og Vestside fra hinanden ved en eller flere Forkastninger.

Det samme er i udpræget Grad Tilfældet med Strækningen herfra over Thisted til Vestkysten. Forkastninger, Foldninger eller skraatstillede Lag findes ved Thisted I, IV og VI og ved Dollerup I og II, ofte med Fald mod S.; den ringe Afstand mellem Daniet i denne Egn og Tertiæret ved Speringsø og Tilsted (104 A. 4. 3 og B. 4. 15) antyder, at Dislokationer maa udgøre Grænsen mellem de to Formationer. Hvorledes Nordgrænsen for Thisted-Egnens Danium er beskaffen, er uvist. De observerede Daniumlokaliteter (alle Y. D.) ligger ret højt (Thisted VI $36 \mathrm{~m}$, Thisted VII $15 \mathrm{~m}$, Thorsted IV $44 \mathrm{~m}$, Skaarup I ca. $35 \mathrm{~m}$ ), mens Skrivekridtet N. herfor ligger paa lavere Niveau (Skinnerup og Ø. Vandet $15 \mathrm{~m}$ ), saa maaske Undergrunden her er ret uforstyrret. AE. Danium er dog kun truffet lidt længere vestpaa ved Nystrup I (hvor Grænsen mellem Skrivekridt og Danium ligger paa $22 \mathrm{~m}$ ) og V. herfor, skydende sig ind mellem de ældre og de yngre Dannelser. At Brudlinier dog ogsaa kan gribe ind i denne Egn, fremgaar af A. Jessen's Paavisning af en 
Bruddal i Skrivekridtet ved Blegsø (45 S. 47); følgende Kotehøjder tyder i samme Retning: Skrivekridt ved Nystrup 22 m, A. Danium(?) ved Klokrøgel I $15 \mathrm{~m}$ og ved Vegebjerg II $19 \mathrm{~m}$, Y. Danium ved Vegebjerg I $15 \mathrm{~m}$.

Ved Legind hælder Lagene svagt mod SØ.

Paa Mors er Forholdene ret godt oplyst. Grænsen mellem Skrivekridt og A. Danium ligger ved Eerslev I paa 19 m, og ved Øxendal maa den ligge paa en lignende Højde; Y. Danium findes ved Eerslev IV paa $15 \mathrm{~m}$, Eerslev II $19 \mathrm{~m}$, Eerslev III $22 \mathrm{~m}$; endvidere Y. Danium Zone D ved Frøslevvang I-II paa ca. $31 \mathrm{~m}$. Paa alle Lokaliteter (baade de her nævnte og Lødderup og Tødse) har Lagene Fald bort fra det centrale Skrivekridtfelt.

I Salling er Forholdet mellem det noget tvivlsomme Danium ved Navtrup og Skrivekridtet omkring Batum-Torum-Elkjær Gaarde ukendt. Derimod kan man næppe betvivle, at Forkastninger maa danne Grænsen mellem det her horisontalt liggende Kridt og Tertiæret ved Branden Teglværk og Junget (104 B. 4.45 og C. 4. 21).

Paa Thyholm gaar Y. Danium i forstyrret Tilstand, hældende mod Øst, op til en Højde af $38 \mathrm{~m}$.

Stærkt begrænset er ligeledes Daniumomraadet ved Hjerm. Forkastninger ses i Hjerm I; Lagene her hælder stærkt mod SSØ., mens Lagene i Graven ved Vejrum hælder $\bmod \mathrm{N}$.

Ved Sevel hælder Lagene mod N.

Indenfor Mønsted-Omraadet findes stærke og uregelmæssige Forstyrrelser i Mønsted I, og hældende Lagstilling ved Mønsted III.

Den isolerede Forekomst ved Nøvling er i tektonisk Henseende ukendt, men Bjergarterne bærer Præg af stærke Forstyrrelser.

Paa en Række Punkter er det altsaa lykkedes at finde Rede i Forholdet mellem de forskellige Aflejringer, hvor disse grænser op til hinanden. I adskillige Tilfælde viser det sig herved, at Grænsen mellem forskellige Formationer dannes af Spring, eller det er i en hel Del Tilfælde lykkedes at paavise Forkastninger eller Forstyrrelser af anden Art i Profiler. De i Omtalen af de enkelte Daniumomraader nævnte Tilfælde kan suppleres med følgende: Strækningen Hjarbæk Fjord — Øst om Salling - op til Hovsør, hvor Tertiæret ligger dybt i Forhold til det omgivende Kridt og Danium, er sikkert begrænset mod disse Dannelser af Forkastninger; de sænkede Tertiær- og Daniumomraader Ø. f. Lønnerup Fjord - mens Kridtet og Daniet V. f. denne Fjord er hævet - danner den direkte Fortsættelse af denne Zone. Opmærksomheden maa endvidere rettes mod Forstyrrelserne i Lønstrup Klint (Jessen 42) og Mruthers' Spaltedale V. f. Aarhus (\%0). Moleret om- 
kring den vestlige Limfjord fremtræder stærkt forstyrret, men det er her vanskeligt at afgøre, i hvor høj Grad dette skyldes Istryk alene.

Der er dog givetvis meget langt igen, før man kan naa til et nogenlunde detailleret Kendskab til disse Fænomener. For en stor Del af de paaviste Forkastningers Vedkommende er det kun muligt at fastslaa deres Tilstedeværelse (med større eller mindre Sikkerhed), mens deres Forløb ikke kendes endnu. Desuden er tektoniske Forstyrrelser sikkert langt mere udbredte, end det fremgaar af det ovenfor fremsatte; over store Strækninger savner vi ganske Kendskab til Undergrunden, og indenfor mange Omraader kan Forkastninger overhovedet kun indirekte paavises som Formationsgrænser og da kun, hvis Springhøjden er betydelig; men det behøver den jo ingenlunde at være.

Alligevel har Forf. søgt — ved Hjælp af Kortet T. V — at skaffe en Oversigt over Forholdene og derved se, om det ikke skulde være muligt at udlede mere almindelige Synspunkter for Undergrundsforstyrrelserne i Jylland.

Det viser sig nu, at visse Omraader lader sig karakterisere som Hævningsfelter, adskilt ved mere eller mindre skarpt markerede Sænkningsfelter; atter andre Omraader maa nærmest karakteriseres som mere passive "Resistensfelter", men disse staar i principiel Henseende nær de første og maa forenes med dem. Udtrykkene Hævning og Sænkning maa naturligvis forstaas relativt.

Som udprægede Hævningsfelter maa nævnes: Klavsholm-Omraadet, Spentrup-Omraadet, Nordsalling og Mors, alle omgivne af yngre Dannelser, delvis med fremtrædende Fald i alle Retninger ud fra Hævningscentret. Mindre — og i deres Bygning mindre kendte - Omraader er Egnen V.f. Lønnerup Fjord, Thyholm, Hjerm, Sevel, Mønsted og Nøvling, samt Skinderup Gaarde og Ranum- og Vegger(Skrivekridt-)Omraadet. Som mere passive Omraader maa endvidere Djursland, Østhimmerland, Østerhanherrederne og Egnen N. f. Thisted og omkring Legind regnes herhen.

Som Sænkningsfelter maa regnes: Randers-Dalen, Egnen om Hobro, Partiet V. f. Vegger III, Strækningen Hovsør-Hjarbæk Fjord, Hanstholm og Hjardemaal Bakkeøer, Terrænet mellem Thisted og Mors, mellem Mors og Thyholm og S. f. Mors, mellem Mors og Salling (64 S. 426), samt det sydlige Salling; desuden maa det vestlige Djursland ( $\varnothing$. f. Klavsholm-Omraadet) være indsunket, og det samme gælder Daniet mellem Løgstør-Ranum og Ranum-Skinderup Gaarde. Ogsaa Omraaderne Thyholm, Hjerm, Sevel, Mønsted og Nøvling omsluttes formodentlig af Sænkningsfelter; om Forløbet af Forkastningerne i disse kan man drage Slutninger fra iagttagne Spring og Hældninger i de tilgængelige Profiler, og desuden kan man sandsynligvis regne med vigtige Sænkninger vinkelret paa de iagttagne Strygningsretninger. 
For at faa et lettere Overblik over Forholdene er Hævnings- og Sænkningsfelterne og de fastslaaede eller formodede Forkastningers Forløb indlagt paa T. VI.

I den øvrige Del af det sydskandinaviske Geosynklinalomraade forløber Hovedforkastningerne nogenlunde systematisk. I den skaanske Randzone er Retningen NV.-SØ., en lignende Retning har de paa Bornholm og i Nordtyskland indtil Pommern; i det store og hele er de parallele med Geosynklinalens Begrænsning mod Nordvest. Dette Forløb spores ogsaa i Nord- og Østsjælland, men her synes desuden en mere nord-sydlig Tendens at træde frem (Rosenkrantz 111), og denne Retning vinder stærkere Overhaand i det sydlige Jylland og Holsten, hvor Kridt- og Gipshorstene har Forløbet N.--S.

Vender man sig nu til det her behandlede Omraade, Nordjylland, er Regelmæssigheden ved første Øjekast fuldstændig forsvundet; flere forskellige Retninger skærer hinanden tilsyneladende ganske vilkaarligt. Men ved nærmere Eftertanke er Regelløsheden næppe ganske planløs. Den nord-sydlige Retning findes i de Spaltedale, MiLthers tolker som Udtryk for dybere tektoniske Forstyrrelser, den viser sig i Vesthimmerland, i det vestlige Limfjordsomraade, og den spiller vel ogsaa en Rolle S.f. den vestlige Limfjord. Dog gør paa mange Punkter en øst-vestlig Tendens sig gældende, og det karakteristiske for Nordjylland er, at de lange Horste mangler, mens Terræenet tvært imod er brudt op i mange smaa Hævningsomraader, begrænset paa alle Sider af hinanden skærende Sænkningsfelter.

Forklaringen herpaa ligger lige for. De tektoniske Forstyrrelser maa være betinget af hele Omraadets Geosynklinalnatur, og Hovedlinierne i den danske Undergrunds Tektonik er da ogsaa ofte blevet stillet i Forhold til Omgivelserne, specielt den iøjnefaldende Brudzone i Skaane (Forchhammer 16 og 21, Ussing 122, Milthers 70, Madsen 64 og $65 a$, Rosenkrantz 111). I det sydøstlige Danmark er Forholdene da ogsaa ret simple, idet Geosynklinalens Begrænsning mod NØ. forløber regelmæssigt, men i Nordjylland er de virkende Kræfter mere komplicerede. Begrænsningen er paa den ene Side Sverige, hvor Kysten og Sænkningerne i Kattegat forløber fra SSØ. mod NNV. med Fortsættelse i Kristiania-Fjord; men paa den anden Side er man her rykket tæt ind paa Norges Massiv, der skyder sig frem og danner en Afbrydelse paa Geosynklinalens ensrettede Forløb (om den med Afbøjning fortsættes ud mod Vest faar staa hen). Norges Indflydelse paa Forkastningernes Forløb træder med Tydelighed frem i »Den norske Rende«. Nordjylland ligger nu saa at sige klemt inde mellem de to Massiver, og naar der ved Jordskorpebevægelser opstaar tangentiale Tryk eller Spændinger, maa Forløbet af de opstaaede Brud indiceres af disse to. Med andre Ord, vi maa i den nordjyske Undergrunds Mosaik se Resultatet af en Interferens 
mellem et nord-sydligt (eller nordnordvest-sydsydøstligt) og et omtrent øst-vestligt Brudsystem ${ }^{1}$ ).

Tidspunktet for Forstyrrelserne i Nordjylland kan ikke fastslaas med Sikkerhed. At der har fundet i hvert Fald mindre Forskydninger Sted til forskellige Tider, kan dog betragtes som givet. Rosenkrantz har vist (111), at Forstyrrelserne i Nordøstsjælland indlededes i Slutningen af Daniumtiden, og ogsaa i Skaane eksisterede Grevie- $\AA$ sen allerede i Danium (Troedsson 121 b); i Holsten fandt store Forskydninger Sted flere Gange i Tertiærtidens senere Del (Gagel 25) og Madsen's Dislokationer ved Mariager Fjord maa formodentlig henføres til Tertiærtidens Slutning (65 a S. 20); Forstyrrelserne i Lønstrup Klint (saavel som paa mange andre Steder) stammer fra Istiden, og endelig er MrLTHERS' Spaltedale dannet i postglacial Tid.

Paleocænet findes ved Hvalløse og Svejstrup liggende paa Plateauet paa begge Sider af Randers-Dalen, hvilket kunde tyde paa, at dette har deltaget i Bevægelserne; men i de øvrige Egne af Jylland haves desværre saa faa Iagttagelser over Forholdet mellem tertiære og daniske Aflejringer, at det ikke giver Holdepunkter for Betragtninger af denne Art. Det tertiære Flintkonglomerat, hvis Hjemsted skal søges omkring Fur (JESSEN 46 S. 28), er sikkert dannet ved stærk Nedbrydning af en Stejlkyst, og en saadan kan i disse Egne vist kun tænkes opstaaet ved Jordskorpebevægelser. Endnu har man i Jylland ikke truffet Spor af Forstyrrelser i Daniumtid, saa Hovedmængden af de fremtrædende Brud maa anses for at være opstaaet i Løbet af Tertiærtiden.

1) Det maatte ventes, at de to Brudtendenser traadte tydeligere frem, naar man kom længere nord paa i Vendsyssel. I Dagen har vi her kun Lejlighed til at iagttage et enkelt forstyrret Omraade, nemlig i Profilet i Lønstrup Klint (42). Den lange Serie af Overskydninger her har fundet Sted med en Strygning paa ca. N. $67^{\circ}$ V.; derimod har Foldninger og Spring ved Stortorn fundet Sted med Retningen N. $80^{\circ} \varnothing$. Det forekommer Forf. sandsynligt, at man i disse to hinanden skærende Retninger maa se Udtryk for de samme to uensrettede Modstande. De har i Lønstrupegnen fremkaldt to hinanden uvedkommende Forstyrrelser; disse skærer saa tilfældigt hinanden i Stortornpartiet, hvor de — da de formodentlig er samtidige - har foraarsaget yderlig Komplikation. 


\title{
Litteraturfortegnelse.
}

\author{
Forkortelser:
}

K. D. V. S.: Det Kongelige Danske Videnskabernes Selskabs Skrifter.

D. G. U. : Danmarks Geologiske Undersøgelses Skrifter.

M. D. G. F.: Meddelelser fra Dansk Geologisk Forening.

S. G. U. : Sveriges Geologiska Undersöknings Skrifter.

G. F. F. : Geologiska Föreningens i Stockholm Förhandlingar.

1. 1835. Beck, H. H.: Bemærkninger om Danmarks Geologi. - Oplæste i det geologiske Selskab i London 16. December 1835. - København (udgivet af A. Clément 1917).

2. 1913. Bonnesen, E. P., Bøggild, O. B. og Ravn, J. P. J.: Carlsbergfondets Dybdeboring i Grøndals Eng ved København 18941907 og dens videnskabelige Resultater. - København.

3. 1824. BredsdorfF, J. H.: Geognostiske og mineralogiske Iagttagelser paa en Rejse i Nørre-Jylland i Juli og August 1823. — Tidsskrift for Naturvidenskaberne. 3 Bind. - København.

4. 1918. BøgGILd, O. B.: Den vulkanske Aske i Moleret samt en Oversigt over Danmarks ældre Tertiærbjergarter. - D. G. U. II Rk. Nr. 33. - København.

5. 1919. BøgGild, O. B.: Geologiske Forhold i Thisted Amt. - Daniel Bruun: Danmark, Land og Folk. Bd. II, S. 190. - København.

6. 1920. BøgGild, O. B.: Geologiske Forhold i Aalborg Amt. - Sammesteds. Bd. III, S. 10.

\%. 1920. Bøggild, O. B.: Geologiske Forhold i Viborg Amt. - Sammesteds. Bd. III, S. 182.

8. 1920. BøgGiLD, O. B.: Geologiske Forhold i Ringkøbing Amt. — Sammesteds. Bd. III, S. 380 .

9. 1920. Bøggrld, O. B.: Geologiske Forhold i Randers Amt. - Sammesteds. Bd. III, S. 541.

10. 1922. BøgGild, O. B.: Geologiske Forhold paa Fyn. - Sammesteds. Bd. IV, S. 8.

11. 1922. BøgGild, O. B.: Geologiske Forhold i Vejle Amt. — Sammesteds. Bd. IV, S. 132.

12. 1890. Davis, J. W.: The Fossil Fish of the Cretaceous Formations of Scandinavia. - The Scientifical Transactions of The Royal Dublin Society. Vol. IV (Ser. II), VI. - Dublin og London.

13. 1921. (Ekskursionsberetning): Ekskursionen til Randers-Egnen. 12.-14. Juli 1921. - M. D. G. F. Bd. 4, Oversigt over Møder og Ekskursioner, S. 4. - København. 
14. 1866. Fischer-Benzon: Ueber das relative Alter des Faxekalkes und ueber die in demselben vorkommenden Anomuren und Brachyuren. - Kiel.

15. 1825. Forchinamer, G.: Om de geognostiske Forhold i en Deel af Sjelland og Naboeøerne. - K. D. V. S. II. - København.

16. 1835. Forсhнамmer, G.: Danmarks geognostiske Forhold. - Universitetsprogram. - København.

1\%. 1840. Forсhнамmer, G.: Resultaterne af hans i 1840 fortsatte geognostiske Undersøgelser af Danmark. - K. D. V. S. Oversigt. København.

18. 1843. Forсhнамmer, G.: Über Geschiebebildungen in Dänemark und einem Theile von Schweden. - Poggendorfs Annalen. Bd. 58, S. 609.

19. 1847. Forсhнамmer, G.: Det nyere Kridt i Danmark. - Beretning om det 5te skandinaviske Naturforskermøde i Kjøbenhavn. S. 528 , - København.

20. 1858. Forchinmmer, G.: Den vestlige Deel af Liimfjordens Omgivelser. - Danmarks illustrerede Almanak. S. 84. - København.

21. 1858. Forchinmmer, G.: Bidrag til Skildringen af Danmarks geographiske Forhold i deres Afhængighed af Landets indre geognostiske Bygning. - Indbydelsesskrift til Kjøbenhavns Universitets Fest i Anledning af H. M. Kongens Fødselsdag. København.

22. 1860. Forchinmmer, G.: Om Lejringsforholdene og Sammensætningen af det nyere Kridt i Danmark. - Beretning om det 8. skandinaviske Naturforskermøde 1860. - København.

23. 1863. Forсhнамmer, G.: Danmarks geognostiske Forhold. - Naturforskerforsamlingen i Stockholm 1863. - Stockholm.

24. 1869. Forchinamer, G.: Jordskjælvet den 3die April 1841. - Samlinger til jydsk Historie og Topografi. II, S. 210.

25. 1906. GAgEL, C.: Ueber das Vorkommen von Schichten mit Inoceramus labiatus und Belemnites ultimus sowie des ältesten Tertiärs in Dithmarschen und über die tektonischen Verhältnisse dieses Gebietes. - Centralblatt für Mineralogie, Geologie und $\mathrm{Pa}-$ läontologie, S. 275. -.. Stuttgart.

26. 1898. Grönwall, K. A.: Danmarks yngsta krit- och äldsta tertiäraflagringar. - Förhandlingar vid 15de Skandinaviska Naturforskaremötet i Stockholm 1898. S. 223. - Stockholm.

27. 1899. Grönwall, K. A.: Några anmärkningar om lagerserien i Stevns Klint. - G. F. F. Bd. 21, S. 365. - Stockholm.

28. 1899. Grönwall, K. A.: Smånotiser om Jyllands krita. - M. D. G. F. Bd. 1, Nr. 5, S. 65 . - København.

29. 1900. Grönwall, K. A.: Borrade ekinidtagger från Danmarks krita. M. D. G. F., Bd. 1, Nr. 6, S. 33. - København.

30. 1900. Grönwall, K. A.: Släktet Dimyodon i Danmarks krita. - M. D. G. F. Bd. 1, Nr. 6, S. 73. - København.

31. 1907. Grönwall, K. A. og Harder, P.: Paleocæn ved Rugaard i Jydland. D. G. U. II. Rk. Nr. 18. - København.

32. 1919. Hadding, A.: Kritische Studien über die Terebratula-Arten der schwedischen Kreideformation. - Palaeontographica. Bd. 63. - Stuttgart.

33. 1923. Hadding, A.: Om uppfattningen av Terebratula lens Nilsson och 
nagra andra terebratulor i Danmarks danien. - M. D. G. F. Bd. 6, Nr. 13. - København.

34. 1922. Harder, P.: Om Grænsen mellem Saltholmskalk og Lellinge Grønsand og nogle Bemærkninger om Inddelingen af Danmarks ældre Tertiær. - D. G. U. II. Rk. Nr. 38. - København.

35. 1897. Hennig, A.: Revision af Lamellibranchiaterne i Nilssons "Petrificata Suecana formationis cretaceae«. - Kungl. Fysiogr. Sällskapets i Lund Handlingar. Ny Följd. Bd. VIII. - Lund.

36. 1898. Hennig, A.: Faunan i Skånes yngre krita. I. Echiniderna. Bihang till Kungl. Svenska Vet.-Akad. Handlingar. Bd. 24, Afd. IV, Nr. 2. - Stockholm.

3\%. 1899. Hennig, A.: Faunan i Skånes yngre krita. II. Lamellibranchiaterna. - Sammesteds, Nr. 7.

38. 1899. Hennig, A.: Faunan i Skånes yngre krita. III. Korallerna. Sammesteds, Nr. 8.

39. 1899. Hennig, A.: Studier öfver den baltiska Yngre kritans bildningshistoria. - G. F. F. Bd. 21, S. 1. - Stockholm.

40. 1899. Hennig, A.: Svar til D:r Grönwall med anledning af hans anmärkningar mot mina "Studier öfver den baltiska Yngre kritans bildningshistoriak. - G. F. F. Bd. 21, S. 379. — Stockholm.

41. 1905. Jessen, A.: Kortbladene Aalborg og Nibe (nordlige Del). - D. G. U. I. Rk. Nr. 10. - København.

42. 1916. Jessen, A.: Om Dislokationerne i Lønstrup Klint. - D. G. U. IV. Rk. Bd. 1, Nr. 4. - M. D. G. F. Bd. 5, Nr. 4. - København.

43. 1918. Jessen, A.: Udstrækningen af Randers Fjord i Litorinatiden. A. C. Johansen: Randers Fjords Naturhistorie. S. 14. København.

44. 1919. Jessen, A.: Geologiske Forhold i Hjørring Amt. - Daniel Bruun : Danmark, Land og Folk. Bd. II, Bog V, S. 17. - København.

45. 1920. Jessen, A.: Stenaldershavets Udbredelse i det nordlige Jylland. - D. G. U. II. Rk. Nr. 35. - København.

46. 1922. Jessen, A.: Kortbladet Varde. - D. G. U. I. Rk. Nr. 14. København.

47. 1923. Jessen, A. og Ødum, H.: Senon og Danien ved Voxlev. - D. G. U. II. Rk. Nr. 39. - København.

48. 1875. Johnstrup, F.: De geognostiske Forhold i Jylland. - Tidsskrift for Landøkonomi. 4. Rk., Bd. IX, S. 457. - København. (Den samme Afhandling er trykt under Titlen »Jyllands geognostiske Forhold.« Foredrag ved 13de danske Landmandsforsamling i Viborg. - København 1877).

49. 1876. Johnstrup, F.: Om Grønsandet i Sjælland. Vidensk. Meddelelser fra den naturhist. Forening i Kjøbenhavn. - København.

50. 1882. Johnstrup, F.: Oversigt over de geognostiske Forhold i Danmark. - Falbe-Hansen og Scharling: Danmarks Statistik.-København.

51. 1885. Koenen, A. v.: Ueber eine Paleocäne Fauna von Kopenhagen. Abhandlungen der Königl. Gesellschaft der Wiss. zu Göttingen, Bd. 32. - Göttingen.

52. 1925. Kramp, P.: Biologiske Dykkerundersøgelser ved Hanstholm. Ingeniøren. S. 194. - København.

53. 1925. Kramp, P.: Biologiske Dykkerundersøgelser for Vestkysthavneanlæggene. - Naturens Verden. S. 62. - København.

54. 1903. Lambert, J.: Description des Échinides Crétacés de la Belgique. 
I. Étude monographique sur le Genre Echinocorys. - Extr. des Mémoires du Musée Royal d’Histoire Natur. de Belgique. II. -

55. 1923. Lambert, J.: Referat af A. Jessen og H. Ødum: Senon og Danien ved Voxlev. - Revue de Geologie et des sciences connexes. S. 858, 1964. - Liéges.

56. 1867. Lundgren, B.: Palaeontologiska Iagttagelser öfver Faxekalken på Limhamn. - Lunds Univ. Årsskrift. T. III. - Lund.

5\%. 1885. LundGREN, B.: Undersökningar öfver Brachiopoderna i Sveriges Kritsystem. - Lunds Univ. Årsskrift. Bd. 20. - Lund.

58. 1885. Lundgren, B.: Anmärkningar om Spondylusarterna i Sveriges kritsystem. - S. G. U. Ser. C., Nr. 69. - Stockholm.

59. 1886. Lundgren, B.: Nagra anmärkningar om Ananchytes sulcata Goldf. - G. F. F. Bd. 8, S. 282. — Stockholm.

60. 1835. Lyell, C.: On the Cretaceous and Tertiary Strata of the Danish Islands of Seeland and Møen. - Transactions of the Geol. Society of London. II. Ser., Vol. V. - London.

61. 1902. Madsen, V.: Kortbladet Nyborg. - D. G. U. I. Rk. Nr. 9. København.

62. 1903. Madsen, V.: Om Kalken ved Rejstrup paa Fyn. - M. D. G. F. Bd. 2, Nr. 9, S. 33. - København.

63. 1903. Madsen, V., Nordmann, V. og Hartz, N.: Eem-Zonerne. - D. G. U. II. Rk. Nr. 17. - København.

64. 1916. Madsen, V.: Kvartære Dislokationer. - Forh. ved 16. skandin. Naturforskermøde. - Kristiania.

65 a. 1918. Madsen, V.: Om Tertiæret ved Mariager Fjord. - D. G. U. IV. Rk., Bd. I, Nr. 8. - København.

65 b. 1919. Madsen, V.: Landets Tilblivelse. - Daniel Bruun: Danmark, Land og Folk. Bd. I, S. 37. - København.

66. 1847. (Michaelis und Scherck): Amtlicher Bericht über die 24 Versammlung Deutscher Naturforscher und Aertzte in Kiel im September 1846. - Kiel.

6\%. 1908. Milthers, V.: Kortbladene Faxe og Stevns Klint. - D. G. U. I. Rk. Nr. 11. - København.

68. 1914. Milthers, V.: Mergel og Kalk i det nordvestlige Jylland. D. G. U. III. Rk. Nr. 11. - København.

69. 1916. Milthers, V.: Mergelaflejringerne i Hammerum Herred. - D. G. U. III. Rk. Nr. 13. - København.

70. 1916. Mrlthers, V.: Spaltedale i Jylland. - D. G. U. IV. Rk. Bd. 1, Nr. 3. - M. D. G. F. Bd. 5, Nr. 3. - København.

71. 1917. Mrhthers, V.: Mergelen i Holstebro Egnen. - D. G. U. III. Rk. Nr. 15. - København.

72. 1919. Mrlthers, V.: Mergelen i Djursland. - D. G. U. III. Rk. Nr. 18. - København.

73. 1913. Milthers, V. og Westh, T. Claudi: Viborg Egnens Mergellag. -D. G. U. III. Rk. Nr. 9. - København.

74. 1924. Mortensen, T.: Pighude (Echinodermer). — Danmarks Fauna. 27. - København.

75. 1894. Nathorst, A. G.: Sveriges Geologi. — Stockholm.

76. 1909. Nielsen, K. Brünnich: Brachiopoderne i Danmarks Kridtaflejringer. - K. D. V. S. 7. Rk., nat.-math. Afd., Bd. VI, Nr. 4. - København.

7\%. 1910. Nielsen, K. Brünnich: Om det i Københavns Havn ved Knip- 
pelsbro fundne Yngste Danien. - M. D. G. F. Bd. 3, S. 463. København.

78. 1911. Nielsen, K. Brünnich: Brachiopoderne i Faxe. - M. D. G. F. Bd. 3, S. 599. - København.

79 . 1912. Nielsen, K. Brünnigh: Cirripedierne i Danmarks Danien-Aflejringer. - M. D. G. F. Bd. 4, S. 19. - København.

80. 1913. Nielsen, K. Brünnich: Crinoiderne i Danmarks Kridtaflejringer. - D. G. U. II. Rk. Nr. 26. - København.

81. 1913. Nielsen, K. Brünnich: Moltkia Isis, Steenstrup og andre Octocorallia fra Danmarks Kridttidsaflejringer. - Mindeskrift for Japetus Steenstrup. XVIII. - København.

82. 1914. Nielsen, K. Brünnich: Some Remarks on the Brachiopods in the Chalk of Denmark. - M. D. G. F. Bd. 4, S. 287. - København.

83. 1915. Nielsen, K. Brünnich: Rhizocrinus maximus n. sp. og nogle Bemærkninger om Bourgueticrinus maximus Br. N. - M. D. G. F. Bd. 4, S. 391. - København.

84. 1917. Nielsen, K. Brünnich: Cerithiumkalken i Stevns Klint. - D. G. U. IV. Rk. Bd. 1, Nr. 7. - M. D. G. F. Bd. 5, Nr. 7. København.

85. 1917. Nielsen, K. Brünnich: Heliopora incrustans nov. sp. With a Survey of the Octocorallia in the Deposits of the Danian in Denmark. - M. D. G. F. Bd. 5, Nr. 8. - København.

86. 1918. Nielsen, K. Brünnich: Slægten Moltkia og andre Octocoraller i Sveriges Kridttidsaflejringer. - G. F. F. Bd. 40, S. 461. Medd. från Lunds Geol.-Mineral. Institution. Nr. 25. - Stockholm.

8\%. 1919. Nielsen, K. Brünnich: En Hydrocoralfauna fra Faxe og Bemærkninger om Danien'ets geologiske Stilling. - D. G. U. IV. Rk. Bd. 1, Nr. 10. - M. D. G. F. Bd. 5, Nr. 16. - København.

88. 1920. Nielsen, K. Brünnich: Inddelingen af Danien'et i Danmark og Skaane. - M. D. G. F. Bd. 5, Nr. 17. - København.

89. 1921. Nielsen, K. Brünnich: Nogle Bemærkninger om de store Terebratler i Danmarks Kridt- og Danienaflejringer. - M. D. G. F. Bd. 6, Nr. 3. - København.

90. 1922. Nielsen, K. Brünnich: Zoantharia from Senone and Paleocene Deposits in Denmark and Skaane. - K. D. V. S. nat.-math. Afd., 8. Rk., V, 3. - København.

91. 1894. Posselt, H.: Brachiopoderne i den danske Kridtformation. D. G. U. II. Rk. Nr. 4. - København.

92. 1851. Puggaard, C.: Møens Geologie. - København.

93. 1899. Ravn, J. P. J.: Et Par Bemærkninger i Anledning af A. Hennig: Studier öfver den baltiska Yngre kritans bildningshistoria. G. F. F. Bd. 21, S. 265. - Stockholm.

94. 1899: Ravn, J. P. J.: Et Par danske Kridtspongier. - M. D. G. F. Nr. 5, S. 23. - København.

95. 1902-03. Ravn, J. P. J.: Molluskerne i Danmarks Kridtaflejringer. K. D. V. S. 6. Rk. nat.-math. Afd., XI, 2, 4 og 6. - København.

96. 1908. Ravn, J. P. J.: Fortegnelse over Kridtforsteningerne fra Stevns Klint, Faxe, Herfølge, Aashøj og Solhøjsgaard (Svansbjerg). - 
V. Milthers: Kortbladene Faxe og Stevns Klint. D. G. U. I. Rk. Nr. 11. - København.

97. 1912. Ravn, J. P. J.: Om de saakaldte Bløddyræg fra vore Kridtaflejringer. - M. D. G. F. Bd. 4, S. 55. - Københarn.

98. 1914. Ravn, J. P. J.: Om Mellemoligocænets Udbredelse i Jylland. M. D. G. F. Bd. 4, S. 259. - København.

99. 1915. Ravn, J. P. J.: Om fossile Terebelliderør fra Danmark. - M. D. G. F. Bd. 4, S. 383. - København.

100. 1916. Ravn, J. P. J.: Kridtaflejringerne paa Bornholms Sydvestkyst og deres Fauna. I. Cenomanet. - D. G. U. II. Rk. Nr. 30. København.

101. 1917. Ravn, J. P. J.: Nye danske Forsteninger. - M. D. G. F. Bd. 5, Oversigt over Møder og Ekskursioner, S. 19. - København.

102. 1918. Ravn, J. P. J.: Kridtaflejringerne paa Bornholms Sydvestkyst og deres Fauna. II. Turonet. - D. G. U. II. Rk. Nr. 31. København.

103. 1921. Ravn, J. P. J.: Kridtaflejringerne paa Bornholms Sydvestkyst og deres Fauna. III. Senonet. IV. Kridtaflejringerne ved Stampe Aa. - D. G. U. II. Rk. Nr. 32. - København.

104. 1922. Ravn, J. P. J.: Geologisk Kort over Danmark. Dybere liggende Dannelser. - D. G. U. III. Rk. Nr. 22. - København.

105. 1925. Ravn, J. P. J.: Sur le Placement géologique du Danien. D. G. U. II. Rk. Nr. 43. - København.

106. 1920. Rosenkrantz, A.: Craniakalk fra Københavns Sydhavn. - D. G. U. II. Rk. Nr. 36. - København.

10\%. 1920. Rosenkrantz, A.: En ny københavnsk Lokalitet for forsteningsførende Paleocæn. - M. D. G. F. Bd. 5, Nr. 20. - København.

108. 1923. Rosenkrantz, A.: En Trionyx fra Craniakalk-Blokke i København. - M. D. G. F. Bd. 6, Nr. 19. - København.

109. 1924. Rosenkrantz, A.: De københavnske Grønsandslag og deres Placering i den danske Lagrække. - M. D. G. F. Bd. 6, Nr. 23. - København.

110. 1924. Rosenkrantz, A.: Nye Iagttagelser over Cerithiumkalken i Stevns Klint. - M. D. G. F. Bd. 6, Oversigt over Møder og Ekskursioner, S. 28. - København.

111. 1925. Rosenkrantz, A.: Undergrundens tektoniske Forhold i København og nærmeste Omegn. - M. D. G. F. Bd. 6, Nr. 26. København.

112. 1897. RørdaM, K.: Kridtformationen i Sjælland i Terrænet mellem København og Køge og paa Saltholm. - D. G. U. II. Rk. Nr. 6. - København.

113. 1909. Rørdam, K.: Geologi og Jordbundslære. Bd. II: Danmarks Geologi. - København.

114. 1820. Schlotheim, v.: Die Petrefactenkunde auf ihrem jetzigen Standpunkte. - Gotha.

115. 1892. Schlüter, C.: Die Regulären Echiniden der norddeutschen Kreide. II. Cidaridae, Salenidae. - Abhandl. der Königl. Preussische geol. Landesanstalt. Neue Folge, Heft. 5. - Berlin.

116. 1900. Segerberg, K. O.: De anomura och brachyura dekapoderna inom Skandinaviens Yngre krita. - G. F. F. Bd. XXII, S. 347. - Stockholm.

11\%. 1913. Spencer, W. K.: The Evolution of the Cretaceous Asteroidea. - 
Phil. Transactions of the Royal Society of London. Ser. B, Vol. 204, S. 99. - London.

118. 1837. Steenstrup, J.: Om Forverdenens Dyrearter af de tvende Familier Anatiferidæ (Gray) og Pollicipedidæ (Gray). — Naturhistorisk Tidsskrift, Bd. I, S. 358. - København.

119. 1839. Steenstrup, J.: Bidrag til Cirripedernes Historie. I. Anatiferidæ og Pollicipedidæ fra Kridtperioden. - Naturhistorisk Tidsskrift, Bd. II, S. 396. - København.

120. 1847. Steenstrup, J.: Moltkia og Cyathidium. Amtlicher Bericht ueber die 24 Versammlung Deutscher Naturforscher und Aerzte in Kiel 1846. - Kiel.

121 a. 1925. TArr, W. A.: Is the Chalk a Chemical Deposit? - The Geological Magazine. Vol. LXII of Whole Series, S. 252. - London.

121 b. 1923. Troedsson, G. T.: Om krokodilfynden i Skånes yngsta krita. - G. F. F. Bd. 45. S. 546. - Stockholm.

122. 1899. Ussing, N. V.: Danmarks Geologi. - D. G. U. III. Rk. Nr. 2. - København.

123. 1902. Ussing, N. V.: Mineralproduktionen i Danmark ved Aaret 1900 - D. G. U. II. Rk. Nr. 12. - København.

123 a. 1903. Ussing, N. V.: Om Jyllands Hedesletter og Teorier for deres Dannelse. - K. D. V. S. Oversigt, Nr. 2, S. 99. - København.

124. 1904. Ussing, N. V.: Danmarks Geologi. 2. Udgave.

125. 1907. Ussing, N. V.: Om Floddale og Randmoræner i Jylland. - K. D. V. S. Oversigt. S. 161. - København.

126. 1910. Ussing, N. V.: Dänemark. - Handbuch der Regionalen Geologie. - Heidelberg.

12\%. 1913. Ussing, N. V.: Danmarks Geologi. 3. Udgave ved P. Harder.

128. 1914. Withers, T. H.: Some Cretaceous and Tertiary Cirripedes Referred to Pollicipes. - Annals and Magazine of Nat. History. Ser. 8, Vol. XIV, S. 167. - London.

129. 1901. Woodward, H.: Crustacea from the Upper Cretaceous of Faxe, Denmark. - Geological Magazine, N. S., Dec. IV, Vol. VIII, S. 486. - London.

130. 1922. Øрuм, H.: Inoceramus tegulatus v. Hag. i det danske Skrivekridt. - M. D. G. F. Bd. 6, Nr. 10. - København. 


\section{Stedregister.}

\section{Jylland.}

$\mathrm{D}$ a $\mathrm{n} \mathrm{i} \mathrm{u} \mathrm{m}$.

Aalsø.................. 31

Aarslev................. 38

Aastrup................ 33

Abildgaarde............... 71

Aggersborg.............. 81

Aggersborg Gaard.......... 79

Albæk (v. Randers).......... 51

" (v. Skørping)......... 70

Allingaabro.............. 36

Arden.................. 60

Asfærg................ 51

Assens.................. . . 55

Avsum Gaard............................. 140

Baadsgaard.............. 88

Barmer.................. 74

Bislev................. 73

Bjerge................ 90

Bjerregrav............. 47

Bjørnsholm............. 73

Bolsande............... 118

Borup............... 46

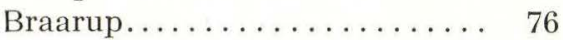

Bragerne. . . . . . . . . . . 86

Bredstrup Klint............ 32

Brøndum............... 76

Bulbjerg.............. 86

Bøgelund........................... 200

Dalbynedre............... 52

Dalbyovre............... 52

Dalgaard................. 98

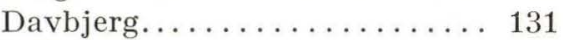

Dollerup............................... 110

Eerslev................ 120, 195

Ejstrup............... 50

Enslev.................. 31

Ersted.............. 69
Side

Faartoft. . . . . . . . . . . . 100

Faldgaarde.............. 74

Farstrup............... 75

Farsø................. 73

Febbersted............... 89

Fløjstrup.............. 36

Fredericia...........29, 204

Frederikseje............. 57

Frøslev Gaard.............. 125

Frøslevvang............... . 125

Gravlev.............. .63, 198

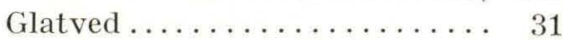

Grenaa................ 32

Grydsted............... 73

Gøttrup Strand............ 83

Hald. . . . . . . . . . . . . . . 51

Hammelev Gaard.......... 34

Hansted.................. 87

Havdal. . . . . . . . . . . . . 36

Helligkilde. . . . . . . . . . . 126

Helshage ................. 88

Hemdrup............................... 76

Hjardemaal. . . . . . . . . . . . 92

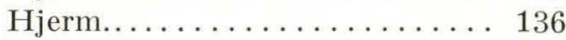

Hov ................. 99, 197

Hovsør. . . . . . . . . . . . . . 98

Hvalløse............. . 40, 204

Hvanstrup Gaard . . . . . . . . . 72

Hørning. . . . . . . . . . . . . 36

Jernit... . . . . . . . . . . . .44, 204

Jomfrubakken.............. 56

Kaase................. 91

Karlby Klint. . . . . . . . . . 34

Kastbjerg.............. 52

Kirial. . . . . . . . . . . . . . . 32

Kjølby................. 75 
Kjølby Gaard..........95, 196

Klavsholm... . . . . . . . . . . . . 40

Klim.................... 84

Klim Bjerg.............. 83

Klokrøgel................ 118

Kovsted.................. 48

Laaenhus. . . . . . . . . . . . . . . 59

Laen... . . . . . . . . . . . . 35

Langaa . . . . . . . . . . . . . . 44

Legind. . . . . . . . . . . . . . . . . 119

Lendrup Strand............ 78

Lime... . . . . . . . . . . . . . . 38

Lundgaard... . . . . . . . . . . . . . 73

Lødderup . . . . . . . . . . . . . . 126

Løgsted. . . . . . . . . . . . . . . 76

Løgstør... . . . . . . . . . . . . . . 77

Lønnerup . . . . . . . . . . . . . . 97, 197

Løvdal. . . . . . . . . . . . . . . . 59

Løvenholm . . . . . . . . . . . . . 36

Mariager.................. 56

Mejlby............... 51

Munksjørup............... 74

Mygind................ 38

Møllerup................. 30

Mønsted... . . . . . . . . . . . . . . . 132

Navtrup. . . . . . . . . . . . . . . . 126

Nybro... . . . . . . . . . . . . . . 32

Nye Kløv . . . . . . . . . . . . . .96, 197

Nystrup. . . . . . . . . . . .114, 199

N. Bjergegaard............ 83

Nøvling. . . . . . . . . . . . . . . . . 140

Oplev................. 66

Ove.................. 57

Over Hornbæk. . . . . . . . . . . . 45

Ove

Ovst Mølle.............. 46

Pindsminde............. 37

Purhus................. 49

Raasted............... 47

Randers................ 45

Revn................... 31

Rigtrup................ 39

Robstrup............... 33

Roldtved.... . . . . . . . . . . . . . 60

Roshage ............. 87

Rugaard............... 31

Ræbild................ 60

Rær.................... 88

Sandnæshage.............. 86

Sangstrup Klint............. 35

Sennels... . . . . . . . . . . . . . . 99
Side

Sevel................. 135

Skaarup... . . . . . . . . . . . . 109

Skader................... 39

Skillingbro............65, 203

Skive. . . . . . . . . . . . . . . . 128

Stavnsbjerg.. . . . . . . . . . . . 132

Stenalt............... 36

Stenbjerg (v. Torup)......... 85

" (v. Vorupør)........ 119

Stensmark............... 33

Stinesminde............... 59

Store Ajstrup............ 75

Storodde............ . . . . 102

Strøje...... . . . . . . . . . . 102

Stubbergaard Sø............ 135

Svejstrup. ... . . . . . . . . 46, 204

Svendstrup.............. 51

Sørup................. 70

Thisted................ 100

Thorsted................ 108

Tilsted................. 105

Timbæk Mølle.............. 66

Torup.................. 113

Torup Kløv............... 84

Torup Strand............. 85

Tustrup............... 37

Tved................... 92

Tødse... . . . . . . . . . . . . 122

Tørring................. 51

Valbjerg Huse............ 86

Valsted.................... 74

Vang. . . . . . . . . . . . . . . . 113

Vedø.................... 36

Vegebjerg................. 118

Veggerbro............... 70

Veggerslev.............. 36

Vejrum................. 135

V. Bjergegaard .......... 83

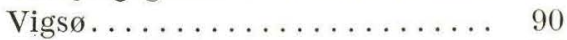

Vindblæs................ 76

Voldstedlund............... 57

Voldum.................. 39

Vorupør................... 119

Voxlev... . . . . . . . . . . . 72, 194

Ebeltoft . . . . . . . . . . . 30, 204

Orsted................. 36

Ø. Hornum............. 71

Ø. Jølby . . . . . . . . . . . . . . 119

Østerodde................. 102

Ø. Tørslev............... 51

Øxendal. . . . . . . . . . 126, 196 
Senoni um.

\begin{tabular}{|c|c|c|}
\hline & & Side \\
\hline Itu..... & 145 & Nystrup. . . . . . . . . . 114, 1 \\
\hline$\ldots \ldots \ldots$ & 91 & Rostrup............... 144 \\
\hline$\ldots \ldots \ldots \ldots \ldots$ & 144 & $\operatorname{Rær}, \ldots \ldots \ldots \ldots \ldots \ldots, 8$, \\
\hline 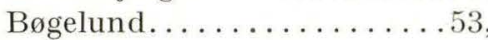 & 200 & Skovsted. \\
\hline Dalbynedre................ & 228 & Spentrup....... \\
\hline Eerslev. . . . . . . . . . . . . . & 195 & Tolstrup.............. \\
\hline Elkjær Gaarde... . . . . . . . . . & 144 & Torum................. \\
\hline Gravlev . . . . . . . . . . . . 63, & 198 & Tostrup........ \\
\hline Hov. . . . . . . . & 147 & Veggerbro.... \\
\hline Hjardemaal. . . . . . . . . & 95 & Vive.$\ldots \ldots \ldots \ldots \ldots \ldots$ \\
\hline Kornum................ & 142 & Volsted $\ldots \ldots \ldots \ldots \ldots \ldots$ \\
\hline Kjølby Gaard...........95, & 196 & Voxlev............... \\
\hline rkenfeld. . & 144 & Ørhage............... 141 \\
\hline & 143 & Ø. Vandet................. \\
\hline Jye Kløv . . . . . . . & 197 & Øxendal............... 196 \\
\hline
\end{tabular}

\section{Fyn.}

D a n i u m.

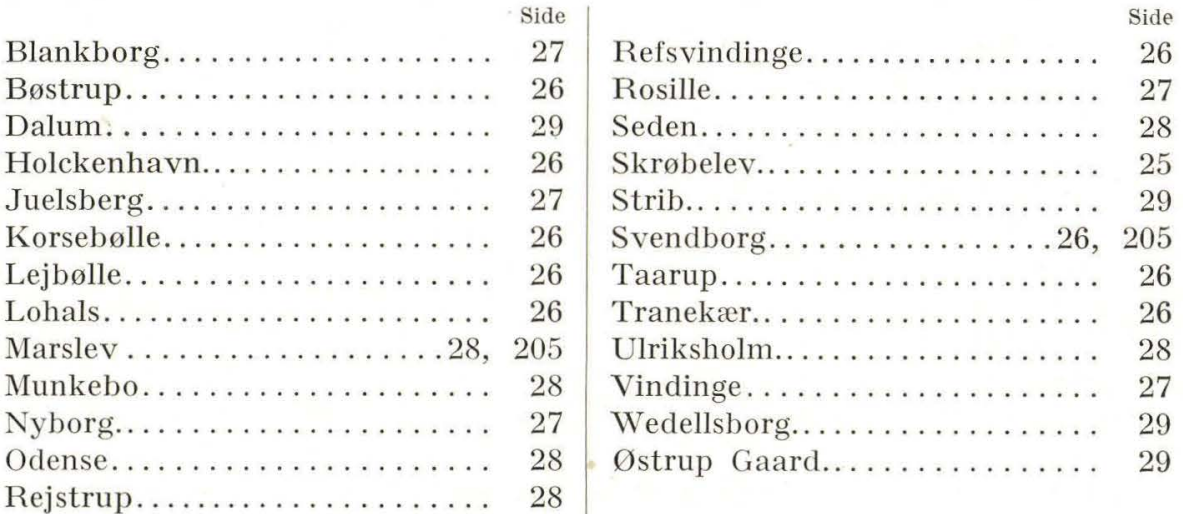




\section{Sum mary.}

\section{Chapters I-II. Historical Exposition.}

We shall here only give a short summary of the historical exposition contained in chapters I-II.

The knowledge of the Danian deposits in Denmark dates far back and has more especially been developed during the 19th century through the work of Forchinamer, Beck and Johnstrup. The researches of these men had for their object to demonstrate the correlation of the Danian deposits and their demarcation as regards the formations above and below. This work was approximately concluded in 1882, when Johnstrup published an exposition (50), in which he drew up the following table:

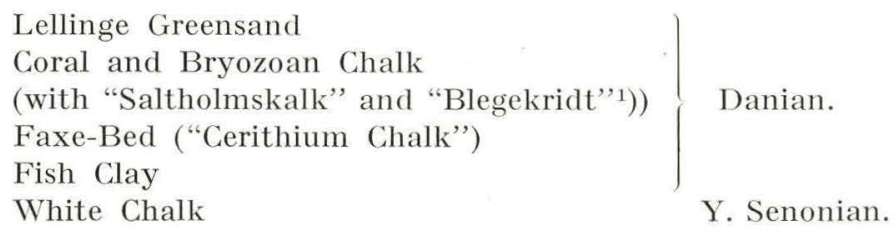

Danian.

Y. Senonian.

Acting on an earlier suggestion by v. Koenen, Grönwall subsequently excluded Lellinge greensand as belonging to the Eocene (Paleocene $\left.(26)^{2}\right)$ ).

This system was almost exclusively based on petrographical definitions and on stratigraphical observations, and during recent years further efforts have been made to enlarge our knowledge of the Danian on a more palæontological-stratigraphical basis.

Grönwall separated in 1898 (26) the youngest deposits of the Danian as a special formation, the Crania Limestone, and in a work from 1902-03 (95) Ravn adopts this appellation; Ravn transfers, however, the Fish clay and the Cerithium Chalk to the Senonian, so that his table looks as shown below:

1) Danish "Blegekridt" or "Coccolitkalk" = Coccolith Chalk is a predominating rock of the Danian; it is a white or slightly grey chalk, composed of calcareous ooze and containing a good deal of Coccoliths together with other microfossils. It is easily distinguished from the main constituent of the Upper Senonian, the White Chalk (Danish "Skrivekridt"), by its greater contents of somewhat coarser elements and beeing more rough to the touch; the White Chalk also contains a greater proportion of Coccoliths.

$\left.{ }^{2}\right)$ For the Paleocene clay and sand deposits, that follow above the Danian, RosenKRANTZ has in 1924 introduced the appellation Selandian, because their character, as_compared to foreign equivalents, has been a matter for controversy. 


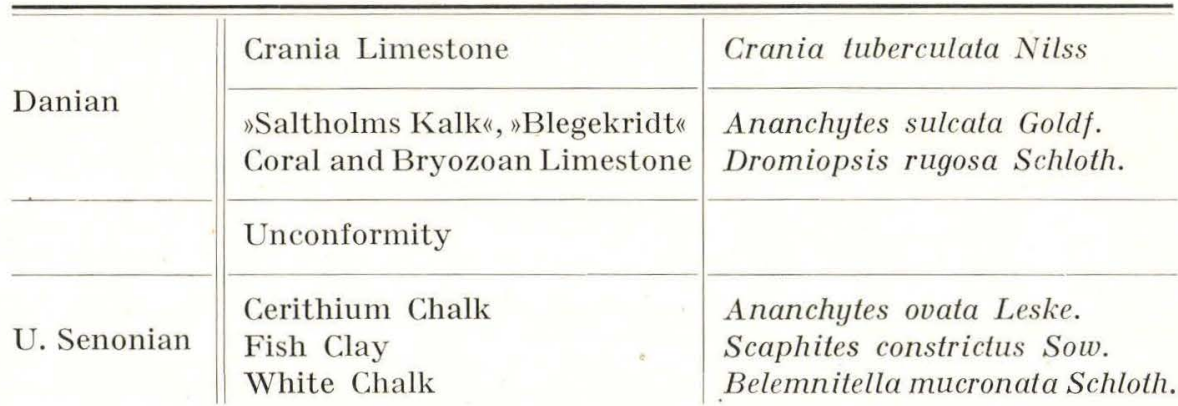

BrüNnich Nielsen accepts this classification in 1909 ( 76$)$, but makes a further division of the Danian in Older and Younger Danian, which makes his table look like this:

Danian $\left\{\begin{array}{l}\text { Y. Danian }\left\{\begin{array}{l}\text { Crania Limestone w. Terebratula lens and Crania tuber- } \\ \text { culata. } \\ \text { Y. Bryozoa Chalk w. T. lens. } \\ \text { "Saltholmskalk", Coccolith Chalk w. T. lens. } \\ \text { O. Danian }\end{array} \text {. Bryozoa Chalk w. Terebratula fallax var. faxensis. }\right.\end{array}\right.$

In 1924, Rosenkrantz (110) once more includes the Fish Clay and the Cerithium Chalk, which is definitely limited from the underlying White Chalk, in the Danian, comparing the Cerithium Chalk ("Brissopneustes-Bed") of Stevns Cliff to a similar deposit of Coccolith chalk, known from Voxlev in Jutland (47).

These works have, however, almost exclusively been founded on researches made in Sealand. Conditions in Jutland were less well known and have but rarely been included in stratigraphical studies. The object of the present work has, therefore, been partly to furnish additional information in regard to the extension of the Danian in Jutland and Funen, partly, on basis of this information, to throw further light on the geology of the Danian.

\section{Chapters III-IV. Description of Localities.}

Only the descriptions of the more important sections shall be given in translation.

Hvalløse I. Fig. 1 (Page 41) and T. III.

$500 \mathrm{~m} \mathrm{NE}$ of Hvalløse. Kote $27 \mathrm{~m}$.

On basis of researches made in collaboration with the State Geologist

Mr. V. Milthers, the following description of the section can be given.

Counted from the bottom:

D) $3 \mathrm{~m}$ Coccolith chalk, grayish-white in colour, not consolidated, smudging, rather soft, faintly gritty to the touch. - Under the microscope the chalk appears to consist of larger and smaller (until quite minute) particles, partly distinctly clastic in nature, partly — as regards some of the bigger ones - obviously cemented grains; small Foraminifera are present, and Coccoliths are very common; glauconite is not present.

The chalk contains a good deal of firestone.

C) $0.75 \mathrm{~m}$ Glauconitic clay. The chief constituent of this rock is fat clay, 
gray with a faintly yellow tint. Grains of quartz are only present in very small numbers. The green colour is caused by a very strong intermixture of glauconite in the form of round grains. The clay is not particularly laminated and only splitting in larger pieces.

In its lower part, $10-20 \mathrm{~cm}$, the glauconitic clay shows a conglomerate formation, containing an exceedingly large number of strongly rolled and ground pebbles and fossil fragments. The pebbles consist of a greenish or grayish-brown, strongly glauconitised limestone, partly formed like simple pebbles up to the size of a hen's egg, partly like casts of Echinocorys, Terebratula and others. All are strongly attacked by boring organisms.

The limit towards the underlying Coccolith chalk is definite, developed as a surface of denudation; the nearest part of the bed of Coccolith chalk is a solid band of flint, which apparently has stopped the abrasion. The surface of the limestone is much corroded and full of boreholes, which are filled with loose glauconitic material. The holes are generally sharply defined, cylindric, distinct boreholes, $0.5-0.75$ $\mathrm{cm}$ in diameter, but in addition may be found more irregular "ophiomorphic" inlets, probably due to Sponges. The holes have obviously been made after the formation of the flint band.

B) $0.25 \mathrm{~m}$ fat brownish clay; seems most likely to be an upper, decayed portion of C.

A) $2 \mathrm{~m}$ fat, gray clay, very light when in a dry condition and with a conchoidal fracture.

The Coccolith chalk is not particularly fossiliferous. The glauconitic clay is rich in fossils, containing, besides the fauna lying in secondary place, a rich, primarily imbedded fauna; see "Bilag $\mathrm{H}^{\prime}$. The upper, lightgray clay (A) also contains fossils.

The upper limit of the Danian must be placed over D, and the overlying series must be classed with the Selandian. The limestone belongs to Younger Danian (Zone D).

\section{Sveistrup.}

$2,4 \mathrm{~km}$ SE of Bjerregrav Station. The following description is based on observations made by the State Geologist Mr. V. Milthers, cand. polyt. Mr. A. Rosenkrantz and the author.

The conditions are very similar to those found at Hvalløse. Deepest down in a corner of the pit the Coccolith chalk was visible; the latter was of usual appearance, white, with a grayish tint, rather soft, slightly gritty to the touch.

The upper limit of the chalk is a distinct surface of denudation, full of boreholes. On the chalk rests a fat, gray marl, strongly reminding of layer $\mathrm{C}$ in Hvalløse, but fatter and lighter, the glauconitic contents being much poorer; it is also far more apt to split. At the base, this bed of clay contains a conglomerate of much worn pebbles, similar to those from Hvalløse and also much corroded by boring. In addition to the pebbles may be found the minutest bits of glauconite and greencoloured fragments of fossils. This basal conglomerate is, however, both poorer in pebbles and thinner than the corresponding layer at Hvalløse, although isolated pebbles may be found as much as $25 \mathrm{~cm}$ above the base.

Upwards this gray marl passes into lighter, Selandian species of marl, partly with brown transformatory products. 
The position of the beds is horizontal.

From the Coccolith chalk only few fossils exist. The overlying bed contains — besides the secondarily imbedded fossils - a fairly rich fauna, especially in the lower part of the bed; see "Bilag H". The Coccolith chalk must be classed as Y. Danian (Zone D), the overlying marl as Selandian.

Bøgelund. At the Fiord of Mariager. Fig. 2 (Page 41) and T. III. From the bottom:

F) $5 \mathrm{~m}$ White Chalk, pure white with small flashes of a grayish colour; these are partly irregularly shaped flares, partly shaped as ophiomorphæ. Otherwise, the chalk is ordinary typical White Chalk, not particularly fossiliferous.

E) $0.30 \mathrm{~m}$. Bed of clay, developed as a conglomerate. The clay is, when in a damp condition, soft, plastic, not laminated, very fine; when dry, it is hard, of a pale gray colour with a very faint yellowish tint.

The layer is af a pronouncedly transgressive character; it is true that there is a definite limit between it and the underlying chalk, but the surface of the latter is very rough, crumbling and full of fissures, into which the clay has penetrated. The clay is, moreover, filled with pebbles of White Chalk, most often only slightly rolled, subangular; the largest of the pebbles that were dug out measures $17 \mathrm{~cm}$ in length. Among them are both pebbles of typical White Chalk, undoubtedly originating from the underlying chalk, and also pebbles of gray chalk with somewhat lighter spots, of the same consistency as the rest of the local chalk; these latter cannot have been carried any distance and must, therefore, presumably have come from abraded portions of chalk of a more clayey consistency or more streaked with clay than the rest.

Towards the top, the pebbles decrease in number, the clay becomes lighter and harder and passes evenly into

D) $0.65 \mathrm{~m}$ Coccolith chalk. The layer is bordered at the top by a fairly solid band of firestone, $0.10 \mathrm{~m}$ thick.

C) $0.25 \mathrm{~m}$ Coccolith chalk. This chalk is far less consolidated than is usually the case with Coccolith chalk, forming an incoherent, sandy rock.

The layer passes without any line of demarkation into

B) $0.60 \mathrm{~m}$ consolidated Coccolith chalk. The chalk is very hard and does not split in any definite direction when submitted to a blow, but falls into greater and smaller lumps, separated by curving fissures with loose chalk powder. The chalk is a very fine-grained Coccolith chalk, containing no Bryozoa, but a good many Foraminifera; it contains, moreover, spots of a spongious structure and hollow spaces left by Sponge spicules; larger fossils have also left moulds in the hard chalk.

The upper $30 \mathrm{~cm}$ of this bed are honeycombed by a ramified and elaborate system of irregularly tubeshaped hollows, filled with material which has sunk down from the Bryozoan chalk lying above, more or less loosely layered; these portions of Bryozoan chalk may also often be slightly consolidated, so that it may be difficult to fix the limit between the two sorts of chalk. The hollows are in some cases found to be of distinctly spongious origin; in other cases they are boreholes.

The upper, horizontal surface of the Coccolith chalk is, where it is hard, roughly smoothed through an abrasion of, probably, no long duration. This surface, as well as the surface of the upper part of many 
of the hollow spaces filled with Bryozoan chalk, is covered by a thin coating of yellowish and greenish clay, that sometimes can form a thin layer; the same clayey greencoloured surface is seen on the sparsely present, small pebbles of Coccolith chalk that may be found in the lower part of the Bryozoan chalk.

A) $1.40 \mathrm{~m}$ Bryozoan chalk, pure, splitting, easily crumbling. The Bryozoa are very fine, numerous, imbedded in a fine matrix.

The fossils are indicated in "Bilag F." The beds A-E must be classed as Danian, the White Chalk F as Senonian.

Gravlev I. Fig. 4 (P. 61) and T. III.

Small, square pit, only $4,5 \times 2,5 \mathrm{~m}$. The walls were steep and offered good sections. The sequence of beds, from the bottom, was as follows:

G) White Chalk. It is white, in its upper part containing small, gray, definitely limited flares of clayey chalk; these have, at any rate partly, originated as fissures in the surface of the chalk, filled with clayey material from above.

F) $0.10 \mathrm{~m}$ Clay, developed as conglomerate. The clay itself is, when in a damp state, soft, very fat, not laminated, without intermixture of grains of sand or coarser material. The colour is gray, with a yellowish or faintly brownish tint.

The clay contains a very large number of chalk pebbles, varying in size from the tiniest grain to the size of a hen's egg. They are but slightly worn, more or less angular, and have undoubtedly broken loose from the underlying chalk without having been exposed to any considerable transport. The clay contains but few fossils, unmistakably White Chalk fossils on secondary place.

A piece of the clay, taken out as cleanly as possible, showed on analysis contents of $71.5 \% \mathrm{CaCO}_{3}$.

At the top this clay passes evenly into

E) $0.30 \mathrm{~m}$ white Coccolith chalk, exactly like bed D.

D) $0.80 \mathrm{~m}$ Coccolith chalk, soft, not consolidated, very poor in fossils.

Under the microscope the chalk is proved to consist of a fine powder of crystalline constituents which, in spite of the fact that the Coccolith chalk here gives a very White-Chalky impression, is less fine-grained than is the case with real White Chalk. Coccoliths are far rarer than in White Chalk.

C) $0.85 \mathrm{~m}$ Coccolith chalk. The chalk is rather well consolidated, but cracked and lumpy, so that it falls out in greater or smaller pieces and knots, either with an irregular, pitted surface or limited by joints; they are very hard, without any regular splitting when submitted to blows. Between the lumps, the chalk is quite loose and unconsolidated.

It is especially the middle zone of bed $\mathrm{C}$ that is thus consolidated; upwards and downwards the lumps become rarer and the chalk more homogeneous, but not as loose as the powder between the strongly consolidated parts. The bed may in its upper part contain a few Bryozoa.

Under the microscope, the least cemented portions of this bed prove almost identical with the underlying Coccolith chalk D. Here and there in the layer is seen isolated, whitish-gray flint concretions.

B) $0.20 \mathrm{~m}$ Coccolith chalk, very similar to the less consolidated and lumpy part of bed $\mathrm{C}$; contains more Bryozoa, but they are not predominating. A) $0.80 \mathrm{~m}$ Bryozoan chalk, well splitting, breaking out in square lumps. The 
Bryozoa predominate, imbedded in well preserved condition in a finegrained matrix.

Several bands of firestone are present.

The consolidated part of bed C contains among other things many moulds of aragonitic fossils, whereas the underlying Coccolith chalk $\mathrm{D}$ and $\mathrm{E}$ is very poor in fossils. A complete list of the determinated species will be found in "Bilag D". The beds A-F belong to the Danian, the underlying White Chalk $\mathrm{G}$ to the Senonian.

Skillingbro. Fig. 5 (P. 67) and T. III.

G-F) About $9 \mathrm{~m}$ pure Bryozoan chalk. The chalk has a matrix of fine-grained Coccolith chalk, in which are imbedded a great many finer and coarser Bryozoa; all interstices are quite filled with the groundmass.

E) $0.20 \mathrm{~m}$. The limestone consists of the same matrix as G-F, in which is imbedded a number of Bryozoa (and Foraminifera), but in considerably smaller quantities, so that the rock may be described as a transition between Bryozoan chalk and Coccolith chalk, rough to the touch, smudging; in addition a few grains of glauconite are seen.

D) $0.70 \mathrm{~m}$ Coccolith chalk; slightly rough, containing a number of Foraminifera, but hardly any Bryozoa.

C-A) About $2 \mathrm{~m}$ pure Coccolith chalk. There are also many bands of flint. The complete list of the fossils identified in these beds is to be found in "Bilag G". The beds A-D must be referred to the Y. Danian (Zone C), the beds E-G to O. Danian (Zone B).

Voxlev. (East of Nibe). T. III.

From the description given by A. JESSEN (47) we quote as follows:

From the bed of the river up to a height of about $6 \mathrm{~m}$ above the latter is White Chalk ("Skr."). This is of the usual type, contains rather little flint and is absolutely uniform all through. Only in the very topmost part it contains irregular streaks of grayish chalk, probably mixed with clay.

Above this bed of White Chalk is a layer of clay, the thickness of which varies from 2 to $8 \mathrm{~cm}$, and which, in spite of its great proportion of carbonate of lime $\left(73 \% \mathrm{CaCO}_{3}\right)$ has a gray, faintly brownish colour. Towards the top the layer of clay passes evenly into a $2 \mathrm{~m}$ thick bed of Coccolith chalk (D-A). The colour is not as pure white as that of the White Chalk; nevertheless, the supposition that it contained more clay was only partly confirmed through the analyses. It is more rough to the touch than White Chalk, but far more "dead" when beaten with a hammer. In its upper part it contains a good many fragments of Bryozoa, but otherwise the traces of animal life are extremely rare compared to what is to be found in the beds below and above.

The limit between "the Dead Bed" and the succeeding Bryozoan chalk (L) is formed by a layer of firestone, but is, nevertheless, far from definite; the lower part of the Bryozoan chalk is still a soft, compact limestone, containing few Bryozoa, and not until $30-40 \mathrm{~cm}$ above the layer of firestone, typical Bryozoan chalk may be seen.

The White Chalk belongs to the Senonian, the above-lying beds to the Danian. The more important fossils are indicated p. 194.

Aggersborg Gaard.

This locality, a fairly small lime pit, has given rise to controversy in regard to its stratigraphical position. Grönwall (28) was most inclined to refer the limestone, which contains a large quantity of Corals, to the basal 
beds of the Danian, while Ravn and Brünnich Nielsen compare it to the Coral limestone at Faxe.

The result of our examination confirms the opinion that the limestone at Aggersborg Gaard must be referred to Y. Danian (Zone C), and it must surely be taken to be a special Coral- and Bryozoa-bearing, local development of the normal Coccolith chalk of the Y. Danian.

Kjølby Gaard. Fig. 10-11 (P. 93) and T. III.

E. of Hunstrup Station. The series of beds from the bottom is as follows:

C) About $9 \mathrm{~m}$ White Chalk, typical, generally not particularly fossiliferous; nevertheless, a number of loose pieces of a more fossiliferous rock were found, but the place in the series of these latter has not been defined. The upper part of the White Chalk is not obviously different from the lower part. The chalk contains extremely little firestone.

B) $9 \mathrm{~cm}$ Clay. The limit against the underlying White Chalk is definite, but not smooth, partly wavy and pitted, partly a little cracked and split, so that the clay that fills up all the cavities sends small ramifications into the chalk.

The clay is very rich in lime; when dry it is of a light gray colour, at intervals containing fine, small spots of ochre. It is very fine, extremely fat and does not seem to contain quartz sand. On the other hand, it is full of pebbles of White Chalk. These vary very much in size, from the minutest to those as large as a hen's egg; the largest of the pebbles found was about $7 \mathrm{~cm}$ in length. The surface of the pebbles is more or less rough, they are often sharply angular and do not appear to have been rolled to any great extent. Besides pebbles of White Chalk this layer contains a number of White Chalk fossils, resting on secondary place.

A) $1.25 \mathrm{~m}$ Coccolith chalk. The quantity of clay in bed $\mathrm{B}$ decreases upwards and the White Chalk pebbles disappear. The rock becomes a homogeneous Coccolith chalk and turns more firm and hard; it is slightly smudging, very finegrained, white (sometimes faintly grayish) of colour. The chalk splits extremely badly when hit. It is exceedingly poor in fossils. As regards hollows, a few ochre-coloured, narrow holes are seen, evidently due to Sponges; fine holes due to Sponge spicules are common; furthermore there are 3 bands of firestone.

The White Chalk belongs to the Senonian, while the beds A-B must be referred to the Danian. The fossils are enumerated in "Bilag B".

Nye Kløv. S. of Kjølby Gaard.

In pits and small holes in the old cliff, a variety of limestone deposits are visible. For the purpose of getting a general view of the formations, a sketch of the cliff is annexed, seen from the flat tract of land in front of it (Fig 12, P. 97).

The limits between the different deposits are not directly visible, but counted from the bottom, the layers follow one another in this sequence: White Chalk (Fig. 12, ${ }_{1}$ ). Typical, fossiliferous.

Coccolith chalk (Fig. 12, ${ }_{2}$ ). At least reaching $6 \mathrm{~m}$ in thickness. The chalk is firm, rather fine, grayish white.

Bryozoan chalk (Fig. 12, ${ }_{3}$ ).

In these sections we find represented, therefore, the upper layer of the White Chalk and the lower layers of the Danian, since the Coccolith chalk 
must be referred to the Danian (Zone A) and the superposed Bryozoan chalk as well (Zone B). The fossils from the various formations are enumerated in "Bilag C".

Nystrup I. $10 \mathrm{~km}$ WNW of Thisted. Fig. 17-19 (P. 111 and 115) and T. III.

G) Digging at the bottom of the pit, showing a section of White Chalk; this was of the ordinary type, pure white, without any considerable contents of fossils.

F) Excavated vertically to the extent of $1,2 \mathrm{~m}$. White Chalk, the chief part of which is fine, rather soft, white, but full of gray Ophiomorphalike formations. These are horizontally placed; they are generally just as soft as the surrounding chalk, but are sometimes silicified in the centre and in that case they often show distinct remnants of the Sponge structure. Otherwise the chalk is very poor in fossils and does not show that increase in Bryozoa and other fossils which in many localities has been observed immediately beneath the upper limit of the Senonian. In its lower part, this bed changes character, the gray Ophiomorphæ disappearing and the chalk appearing as typical White Chalk, evidently in direct continuation of the White Chalk in the digging G.

E) $0.65-0.75 \mathrm{~m}$ Coccolith chalk. The bed contains small, isolated nodules of white-gray firestone, especially at the upper and lower limits of the bed. The chalk is solidified and very lumpy, finegrained, but yet somewhat coarser than that of the beds F and G; it is everywhere perforated with pores and hollows, partly due to imperfect cementation, partly to the dissolution of various organic contents, especially Sponge spicules, that have filled the whole of the chalk. A few $\mathrm{cm}$ of the bed, measured from the top, are not lumpy, but more homogeneous and softer. The transition between the hard, lumpy layer and this upper zone is, however, still quite even.

D) $6-8 \mathrm{~cm}$. A layer of chalk containing much clay $\left(87 \% \mathrm{CaCO}_{3}\right)$, laminated and much inclined to split. The chalk is very fine-grained, often a bit gritty, and the separate grains are not firmly cemented; similarly the rock is very soft. The layer may contain a good many Bryozoa, but these latter are very badly preserved. The transition from $\mathrm{E}$ up to this bed of clay is abrupt, but the limit is not absolutely definite; it is more definite in one excavation than in the other. Towards the top, the bed of clay is not sharply limited, but passes evenly into the succeeding bed.

C) $10-16 \mathrm{~cm}$ Coccolith chalk, containing a fairly large number of Bryozoa.

B) $20 \mathrm{~cm}$. Compact band of firestone.

A) Until $1.2 \mathrm{~m}$ Bryozoan chalk, partly harder and firmer, partly more laminated and splitting, generally splitting easily when submitted to a blow. It consists of a fine-grained, white groundmass containing a large quantity of not particularly well preserved, small and fine Bryozoa. The contents of Bryozoa are equal in the upper and the lower parts of the bed. Layers of firestone are present.

The fossils from the different beds are tabelled in "Bilag E". The White Chalk is Senonian, while the beds $\mathrm{A}-\mathrm{E}$ must be referred to the Danian.

Eerslev I. Fig. 20 (P. 123) and T. III.

This locality has formerly been examined by Forchinammer (16), K. J. V. Steenstrup and Ravn (95).

Counted from the bottom, the section shows the following: 
C) $6 \mathrm{~m}$ White Chalk. Of the usual type, rather soft and fine. The contents of fossils are not particularly great.

B) $0.25 \mathrm{~m}$ Hard limestone, white, but streaked with ochre-coloured fissures and cracks, partly straight, distinct joints, partly quite irregular fissures, appearing as hollows between the hard lumps of limestone. This layer contains a large number of tube-shaped, ramified hollow spaces, sometimes partly filled with a porous mass of chalk; they have arisen through the dissolution of siliceous Sponges, whose spicules have, moreover, left fine pores everywhere in the limestone. The rock is very fine-grained, completely corresponding in this respect to the underlying White Chalk; it is very homogeneous, since - besides the above mentioned Sponge pores - only now and then Foraminifera are seen imbedded in the chalk.

The layer B represents, undoubtedly, a solidified zone of the underlying White Chalk, with which it is united by means of an even transition.

A) $0.20 \mathrm{~m}$ Coccolith chalk. It is not as fine and homogeneous as the case is with layers B and C, but contains several coarser ingredients. The chalk is rather hard, very slightly smudgy; in the fine matrix a quantity of fine pores, left by Sponge spicules, are seen. The contents of Bryozoa (the Bryozoa being fine and thin) are very slight. Apart from this, the Coccolith chalk is very poor in fossils. It contains nodules of firestone, of a yellowish gray colour.

The stratigraphical position of this series of beds must be understood to be as follows: The White Chalk and its upper, consolidated layer (B) belong to the Senonian, while the superposed Coccolith chalk is Danian.

The Cliff of Stevns.

As a supplement, we shall here add a short description of the series of beds in the classical, often described locality known as the Cliff of Stevns, in the island of Sealand. The description is chiefly based on the investigations of Rosenkrantz (110).

Where the series of beds is completely developed, it looks as follows:

At the base White Chalk. When the deposition of White Chalk ceased, a regression and subsequent transgression have taken place, so that the White Chalk, with a sharply defined limit, is followed by a

Bed of clay, "Fiskeler" ("Fish Clay"), that only attains a thickness of a few $\mathrm{cm}$, lying in flat pits in the surface of the White Chalk. The clay is considerably laminated, sometimes developed as a conglomerate with White Chalk pebbles and cretaceous fossils on secondary place. Towards the top, this clay passes evenly into

Coccolith chalk of a thickness of up to $0.7 \mathrm{~m}$. Forchinamer named this bed of chalk "Cerithiumkalk", but Rosenkrantz (110) uses the name "Brissopneustes-bed" (RAvN (95) on the other hand makes use of the word "Cerithiumkalk" in a more comprehensive sense, including both Danian and Senonian rocks). The chalk is strongly consolidated and contains among other things many moulds of aragonitic shells. Above this follows with a definite limit

Bryozoan chalk. Before the formation of the Bryozoan chalk, another regression has taken place, so that this chalk rests on a surface of denudation.

Through this last denudation, the former bed of Coccolith chalk has 
been partly removed, so that the Bryozoan chalk in some places rests directly on the White Chalk; the Coccolith chalk (and the "Fish Clay") lies, as already mentioned, in flat pits between the White Chalk and the Bryozoan chalk. This regression caused not only the remaining remnants of the Coccolith chalk, but also the upper layers of the White Chalk to be consolidated in those places, where it lies directly under the Bryozoan chalk. In addition, the Bryozoan chalk has penetrated into cavities in the Coccolith chalk and the White Chalk.

\section{Chapter V. Palæontology.}

Chapter V deals with all the fossils found in the Danian and Senonian deposits in the localities that have been examined. The author has endeavoured to refer to all the places in litterature, where the Danian species in question are described or mentioned as existing in some localised deposit; as regards the Senonian species, however, reference is only made to litterature containing further information.

After each species follows a short statement concerning its occurrence. The system adopted is as follows:

In the case of the species found in Funen and Jutland, some further definition, for instance "Alm." (common), "Hyppig" (frequent) or the name of some locality is added to the indication of horizon; if no such remark is added, so that, for instance, only the indication "Y. Danian" appears, it will mean that the species in question may exist in the formation concerned, but has not been found therein in Funen or Jutland. The Senonian species are, however, only followed by an indication of locality, if the latter refers to one of the transition localities, or if the locality has not formerly been mentioned in litterature.

The varieties that are most frequently met with are not, in the text, supplied with any indication of locality, but are drawn up synoptically in "Bilag A". The "Bilag B-J" are of a more special sort.

Detailed descriptions of the fossils are only given in a limited number of cases, where the forms in question have not formerly been described, or where, for some reason, it was considered desirable to furnish a more detailed statement.

\section{Gorgonella torta Br. N.}

The characters indicated for the two species of Gorgonella described by BrÜNnich Nielsen, G. torta and G. tenuis, appear in such arbitrary combinations that the two forms cannot be kept apart.

Teichaster favosus Spencer.

Spencer founded var. retiformis, differing from the principal species by greater height, a partly different form of supero-marginalia and a finer reticulate sculpture; it was supposed to be peculiar for Y. Danian.

The specimens examined vary partly in accordance with the forms described by Spencer, but no correlation to their stratigraphical occurrence can be traced; the marginalia that must be referred to var. retiformis derive from the Bryozoan chalk of O. Danian. 
Tylocidaris vexillifera Schlüter.

(T. I).

This species appears in the Danian principally in two forms, between which, however, there is a perfectly even transition.

T. vexillifera f. a (Brünnich Nielsen's "older type", T. I, fig. 1) has in its typical development spines of almost spheric form, with a surface bearing an irregularly placed granulation; towards the distal end this is, however, sometimes arranged in rows.

T. vexillifera $f$. $a$ is found in O. Danian.

T. vexillifera f. $\beta$ (BRÜNNICH NiELsEn's "younger type", T. I fig. 2) has typically larger spines, the shape of which is less regularly spheric; the shaft widens itself more abruptly and is more pointed towards the distal end and provided with wing-shaped crests. The granulation is most frequently placed in rows and the grains are more pointed, especially towards the top.

T. vexillifera $f . \beta$ is found in Y. Danian, partly in its typical form, partly as a series of variants on both sides thereof; on one hand, spines without any tendency to wings, only with pointed grains placed in rows (the spine itself being pointed), on the other hand spines that are extended into flat, fan-shaped shafts (T. I fig. $2 \mathrm{~h}-\mathrm{i}$ ).

In addition to these two forms, a third type of $T$. vexillifera spines occurs in O. Danian. This type seems to differ from the series of development represented by the forms $\alpha-\beta$ and yet to be closely related to $f_{0} \alpha$, perhaps as a special variety (T. I, fig. 3 ). It is in this paper mentioned as $f . \gamma$. The spines are considerably larger than in $f$. $\alpha$, distinctly clubshaped, the heavy shaft becoming gradually expanded towards the distal end; the top of the spine is either evenly rounded or slightly flattened ( $47 \mathrm{~T}$. II fig. 3). The spines may either be evenly granulated all over or quite smooth with the exception of the upper part; in either case, this upper part has closely placed, more or less definitely marked rows of grains.

\section{Micraster (?) Desori n. sp.}

(T. II, fig. 1).

The test is rounded heart-shaped, narrower at the posterior end, attaining its greatest width a little in front of the apical disc, which seems to lie a trifle behind the middle of the test. The superior surface is evenly convex, slightly flattened around the anterior lateral ambulacra, highest at the apical disc, wherefrom a slight keel goes backwards.

The anterior unpaired ambulacrum is a deep groove, deepest where, as a semi-cylindrical excision, it goes down over the front edge; this groove is continued as far as to the peristome. The latter is placed well to the front, in the posterior part of the ambulacral groove, and this in conjunction with the prominent lip, which is more or less on a level with the almost flat plastron, makes the peristome turn towards the front. The peristome is semicircular.

The anterior lateral ambulacra are only faintly depressed, almost equally broad in the whole of their length, only very slightly constricted towards the front; they contain 25-30 pairs of ambulacral plates. The posterior lateral ambulacra are hardly depressed at all, they are of oval shape and very short, containing only $6-8$ pairs of ambulacral plates. 
The periproct is situated on the upper part of the steeply ascending posterior end. Dimensions of a couple of specimens (approximate):

$\begin{array}{rlll}\text { Length } & 37 \mathrm{~mm} . & \text { Breadth } & 34 \mathrm{~mm} . \\ \text { about } & 34,, & & 31 \%\end{array}$

Y. Danian.

$$
\begin{gathered}
\text { Serpula (Spirorbis) consolida n. sp. } \\
\text { (T. II, fig. 3) }
\end{gathered}
$$

The tube is regularly rolled up, conically, with an apical angle of about $90^{\circ}$; the cone with open umbilicus. The cross-section of the tube is more or less circular, somewhat flattened on the upper surface; this part is ornamented with fine spiral striæ; the edge towards the umbilicus is rounded, the outer edge sharply carinated. Outside the last mentioned edge another flattened part is to be seen, in its turn bordered by a less marked keel. The part between the latter and the irregularly outflowing suture is faintly striated. Lines of growth all over the shell, varices at intervals.

Height: $6 \mathrm{~mm}$. Greatest diameter: $9 \mathrm{~mm}$.

Y. and O. Danian.

$$
\begin{aligned}
& \text { Serpula proboscis n. sp. } \\
& \text { (T. II, fig. 2). }
\end{aligned}
$$

The specimen in question is a fragment of the tube, measuring $30 \mathrm{~mm}$ in length, $4 \mathrm{~mm}$ in outer diameter; the opening of the tube is $2 \mathrm{~mm}$; the two latter measurements apply to the younger part of the piece of tube, but the older part is only a little thinner.

The tube has almost certainly not been adherent in the whole of its length. The cross-section is square with rounded corners. The edges are formed by rounded longitudinal folds, the two upper ones being rounded in a broader and flatter way, the two lower ones narrower and sharper. Each of the three sides, which are unattached, has a longitudinal groove, not very deep. The fourth side, which is underneath, is flat or concave, provided with a fairly sharp keel in its median line.

The whole surface of the tube has fine, closely placed, irregular transversal wrinkles.

Y. Danian.

$$
\text { Crania pallida n. sp. }
$$$$
\text { (T. II, fig. 4). }
$$

Only one dorsal valve is known.

The valve is rounded trapezoidal, slightly convex, narrower posteriorly than in front. The posterior margin is slightly depressed.

The exterior surface is smooth; only faint lines of growth are discernible. The rather prominent umbo divides the longitudinal axis in about $1: 3$.

The interior shows a narrow, smooth limbus, interrupted by a slight depression at the middle of the posterior border; here, however, very faint traces of granulation are to be seen on the limbus.

The impressions of muscles are faint, scarcely visible. The impressions of divaricators are shortly ovate, the border line being more flattened towards the outer edge than inwards; they are situated at a fairly considerable distance from one another. The impressions of occlusors are a little closer together, almost at the middle of the valve; they are ovate, slightly diverging posterior- 
ly; between them, more anteriorly, a slightly elevated, heartshaped part is found; low ridges issue from this part and form a line of demarcation round the occlusor impressions. At the outer margins of the occlusors a faint depression is to be seen, extending in an arch inside the limbus towards the front, where it passes into the slanting outer edges of the heartshaped elevation.

Length about $=$ the greatest breadth, a little over $2 \mathrm{~mm}$.

O. Danian.

Terebratula lens Nilss.

The conception of this and of related forms has of late years been the subject of much discussion. BRÜNNich Nielsen regards all the species of Terebratula with a small foramen occurring in our Y. Danian as one species: $T$. lens, while HADDing wants to divide the forms referred to this species into 4 groups: T. lens Nilss, T. carnea Sow., T. carnea var. incisa Buch and T. subrotunda Sow.

By examining the existing material one can easily select types corresponding to the forms mentioned by HADDING (except the typical T. carnea Sow.), but between these types there are so many even transitions and a so apparently casual combination of the prominent characteristics, that very often it is impossible to decide, to which of the types in question a certain individual should be referred, a fact duly pointed out by BrüNNICH NiELSEN.

In this connection I have, therefore, preferred to consider this group under one head, but it should be clearly understood that this is done for practical reasons; it is, perhaps, all the more justifiable, because the group in question is found only in Y. Danian, not in O. Danian, and thus it does not, in this country, appear in direct continuity of the Senonian forms.

As regards the description of the various forms, I may refer to BRÜNNICH Nielsen and Hadding. I should only add the remark, that all the specimens belonging to this group, which have been found in Jutland, distinguish themselves by having a large cardinal process in the dorsal valve.

(Selandian.)

Y. Danian.

Pecten (Camptonectes) monotiformis Hennig.

(T. II, fig. 6).

Hennig's principal characteristics for this species are here rendered after Ravn:

Circular, unsymmetrical valves, $5-7 \mathrm{~mm}$ high and almost flat. The posterior ear is in both valves triangular and not definitely separated from the valve itself. - The surface of the right valve is smooth, with faintly indicated, concentric grooves. The anterior ear is rectangular and has a deep byssal sinus and a triangular incision in the part nearest the margin of the valve itself. The anterior ear is ornamented by finely granulated radial ribs. - On the surface of the left valve sharp, concentric lines of growth and fine radial ribs are seen; these latter are, however, only plainly visible in the neighbourhood of the umbo. Furthermore, a very fine transverse striation is observed, more or less like that of $P$. pulchellus Nilss.; the outer corner of the anterior ear is almost rectangular; it is larger than the posterior ear, which is obtuse-angular. The ornament of the valve is continued on the ears.

O. and Y. Danian. 
Pecten (Camptonectes?) cimbricus n. sp.

(T. II, fig. 7).

The right valve subcircular, slightly produced at the front, rather strongly convex; the edge of the hinge line inflexed. The ornament of the valve consists of very faint, radial ribs; where these cross the still fainter concentric lines of growth, small scale-formed nodules appear; this ornament is faintest (in one specimen almost invisible) at the centre of the valve. In addition, the whole surface of the valve (the ears included) is covered with a fine transversal striation.

The anterior ear is obtuse-angular at the upper, smoothly rounded at the lower angle and has a deep byssal sinus, which is continued in a narrow groove between the ear and the valve itself. It is ornamented with $4-5$ strong radial ribs, crossed by a distinct concentric striation which is strongest at the upper border. The posterior ear is only a trifle shorter than the anterior ear (counted from the umbo); it is obtuse-angular, (about $100^{\circ}$ ) without any definite limit between the ear and the valve; it is ornamented with the same kind of sculpture as the valve, but the ornament is much more faint.

The ornament reminds to some extent of that of the left valve in $P$. monotiformis, but that species has a smooth right valve; furthermore the two species are easily distinguished by means of the convex anterior border of $P$. cimbricus.

In addition to two entire right valves, fragment of the ventral part of a valve was found which, to judge from the shape, may possibly have belonged to a left valve. It is ornamented with a sculpture similar to that of the right valves, but closer and more distinct.

Dimensions: Height: $4.0 \mathrm{~mm}$. Length: $4.3 \mathrm{~mm}$.

Y. Danian.

$$
\text { , } 3.6 \quad, \quad 3.6,
$$

\section{Pecten (Chlamys) tesselatus Hennig.}

(T. II, fig. 5).

The right valve is furnished with the same tesselated ornament as the left valve; the number of costæ is increased by insertion. The posterior ear is almost rectangular, rather large, ornamented with radiating lines of small scales. The upper corner of the anterior ear is slightly obtuse-angular (only a little more than $90^{\circ}$ ), the lower corner is rounded rectangular. The front margin is slightly produced; the byssal sinus is placed in a depressed groove on the border line between the ear and the valve itself. The ornament consists of fine concentric ridges and radial grooves. The edge of the valve is a little inflexed along the hinge line.

O. and Y. Danian.

Anomia(?) asperella n. sp.

(T. II, fig. 8).

The outline rounded ovate, inequilateral, somewhat obliquely produced at the back. The hinge line very short. The right valve almost flat. The left valve more convex. The shell thin, lamellated. No foramen has been observed.

Both valves are ornamented with irregular lines and lamels of growth; these latter are crossed by fine radial ridges, resulting in the formation, on 
the lamels of growth, of radiating lines of closely arranged, tube-shaped scales of almost the same width as the flat interstices.

The largest of the two right valves measures $4 \times 4 \mathrm{~mm}$.

Y. Danian.

\section{Cerithium horningense n. sp.}

(T. II, fig. 9).

Fragments have been found of two specimens of a Cerithium, one with an apparently well preserved shell, the other as a mould on a Gryphea.

The valve is high, turreted. The whorls are almost flat, and the lower part of the whorl only projects a little over the slightly depressed suture. The ornament consists of fine, sharp, spiral furrows, leaving interstices in the shape of flat or slightly arched spiral ridges. The number of the furrows seems to increase by intercalation. The distance between the furrows varies somewhat irregularly; on the whole, the furrows lie most close together on the upper and central part of the whorl (18 furrows were counted on a whorl which is $4.3 \mathrm{~mm}$ high); near the lower suture the distance is greater, forming a couple of broader, flat ridges on the edge towards the base of the whorl, or this edge itself makes an arched, smooth keel; the angle of the edge is a little more than $100^{\circ}$, and the base of the whorl is very faintly convex, covered by the same spiral ornamentation which becomes gradually closer towards the canal. On some of the spiral ridges of the younger whorls of the shell, transverse or oblique imprints can be seen, so that the rib gets the appearance of a twisted cord, Beyond this, no other transverse ornamentation has been observed, except the extremely fine lines of growth, which in backward directed arches cover the whorls, with no influence on the above mentioned ornamentation.

Y. Danian.

$$
\text { Trophon sp. }
$$

Parts of the shell, including 3 whorls with a total height of $23 \mathrm{~mm}$, are preserved; the lowest of the 3 whorls is $9 \mathrm{~mm}$ high. The shell is covered with sharp, thin varices, slightly curved in a báckward direction; at the middle of the lower whorl their distance averages $1 \mathrm{~mm}$. Furthermore the shell is covered with a spiral ornamentation of low, rounded ridges with flat interstices; younger spiral ridges are seen between the older ones, all mounting the varices, numbering about 25 on the lower whorl. In addition, an extremely fine pattern of striae is observed crossing the whorls.

Y. Danian.

\section{Chapter VI. Stratigraphy.}

Zone A.

As will be seen from the sections through the limit between the White Chalk of the Senonian and the Danian, described in chapter III, the basal deposits of the Danian consist in all cases of a bed of Coccolith chalk. It is, as a rule, not very thick, but can attain a thickness of over $6 \mathrm{~m}$. In the different sections this Coccolith chalk may vary in appearance, and its limits upwards and downwards may show a different development. In several cases there is a strongly consolidated horizon in the Coccolith chalk, most often containing moulds and casts of the otherwise tracelessly vanished aragonitic fossils (Bøge- 
lund, Nystrup, Gravlev, Stevns); the consolidation has presumably occurred in conjunction with an elevation which has raised the beds in question to the surface or over the surface of the sea.

The limit downwards, to the White Chalk, is always definite; in many cases the Coccolith chalk begins at the base with a bed of clay, most often developed as a conglomerate with pebbles of the underlying White Chalk. In one locality, Eerslev, the uppermost zone of the White Chalk has been consolidated as a consequence of the regression that must have taken place previous to the deposition of the Coccolith chalk.

Also at the surface of Zone A, where it joins the Bryozoan chalk, similar phenomena due to regression occur. At Nystrup, the Coccolith chalk is definitely limited, towards the top, by a bed of clay, as a preliminary to the formation of Bryozoan chalk; a great part of the rich fauna of Echinodermata of this bed of clay probably rests on secondary place, so that a certain amount of denudation of the Coccolith chalk must have taken place. At Bøgelund, similar conditions are observed, although the bed of clay is wanting or is merely represented by a coating of clay on the surface of the Coccolith chalk; moreover, the upper part of the Coccolith chalk is much perforated with holes filled with Bryozoan chalk that has sunk down from above. On the Cliff of Stevns this later regression has caused denudation, so that the Coccolith chalk has partly disappeared, and the Bryozoan chalk in some places rests directly on the White Chalk, and at the same time, the chalk lying beneath the unconformity has become consolidated, both as regards the White Chalk and the remaining remnants of Coccolith chalk ("Cerithium Chalk").

These beds of Coccolith chalk, found in all the above named localities, may be said to represent the oldest deposit of the Danian, Zone A. The fauna in this zone (and in the adjoining beds in the sections) has been scheduled on the complete lists of fauna, "Bilag" B-F (p. 264-268; in abbreviated form in the tables p. 194-201). From the point of view of the fauna, this bed is characterized by the occurrence of a few Senonian forms, that must be regarded as relicts, existing side by side with the purely Danian forms that classify the bed as belonging to the Danian.

Most of the Senonian forms of relicts have only been found in isolated specimens; only Echinocorys ovatus seems to occur with such frequency as to attract more attention, having been found at Voxlev, Nye Kløv and in the Cliff of Stevns (also, though less surely identified, at Bøgelund and Kjølby Gaard). Among the Danian forms that are especially noteworthy must be mentioned Cyclaster Brünnichi and Tylocidaris vexillifer $f$. $\alpha$ and $\gamma$.

\section{Zone B.}

In all the places where it is possible to examine the top of Zone $\mathrm{A}$, the Coccolith chalk is followed by Bryozoan chalk; this is the case at Voxlev, Nye Kløv, (Hov I), Gravlev, Nystrup, Bøgelund and the Cliff of Stevns. The same Bryozoan chalk, easily recognizable and well characterized as far as the fauna is concerned, is, furthermore, found in a great number of localities, where it is not seen in contact with the underlying formations, for instance in the wellknown cliffs of Bulbjerg (and Skarreklit), Karlby and Sangstrup; Munksjørup (fig. 8, p. 81), Klim Bjerg (fig. 9, p. 81) and many others.

The Senonian relicts from Zone A have quite disappeared in the Bryozoan chalk. But Cyclaster Brünnichi and (especially) Tylocidaris vexillifera $\alpha$ and $\gamma$ may still be found, and in addition, several Danian forms have made their 
appearance, among which particularly Terebratula fallax $f$. tenuis is worthy of note. See for the rest the list p. 202.

The zones A and B represent, jointly, the older Danian with the following fossils of correlation:

\author{
Epitrochus vermiformis. \\ Tylocidaris vexillifera $a$. \\ " $", \quad \gamma$ \\ Cyclaster Brünnichi.
}

Zone C.

The upper limit of the Bryozoan chalk in. Zone B is only open for inspection in one locality, Skillingbro, where the Bryozoan chalk is covered by Coccolith chalk; the transition between the two rocks is quite even (the flintbands excepted). The fossils from the different beds of this interesting locality are enumerated in "Bilag G" (p. 269). Particular attention must be drawn to the fact that the Bryozoan chalk in the lower part of the section contains Terebratula fallax tenuis, whereas the Coccolith chalk at the top contains T. lens; the two forms appear side by side in one single bed in this section.

At Skillingbro Zone B is, then, followed by Coccolith chalk, but in other places the deposition of Bryozoan chalk must have been continued into the Y. Danian; we can, on basis of the available fauna, correlate a number of localities, containing sometimes Coccolith chalk and sometimes Bryozoan chalk, which form the lower part of the Y. Danian, Zone C. They are characterized by the following fossils, that occur throughout the Y. Danian (Zones C-D):

\author{
Ceratotrochus saltholmensis \\ Isis vertebralis \\ Tylocidaris vexillifera $\beta$ \\ Brissopneustes suecicus \\ Serpula dentata \\ ,, undulifera \\ Ditrupa Schlotheimi \\ Rhynchonella incurva typ. \\ Terebratula lens \\ Scalpellum Steenstrupi
}

and beside these, the following species, continuing from O. Danian Zone B:
Metopaster mammilatus typ.
Brissopneustes danicus
Serpula distincta
, erecta
Rhynchonella incurva fax.
Terebratula fallax tenuis

Among others, the following localities in Jutland must be referred to Zone C (Bc: Bryozoan chalk, Cc: Coccolith chalk):

Hammelev Gaard (Bc), Bjerregrav II-III (Cc), Aggersborg Gaard (Bc with Corals), Lendrup Strand (Bc \& Cc), Thisted I-III (Bc \& Cc), Dollerup I-II (Bc), Legind (Cc), Eerslev II-III (Cc).

If one accepts the above relationship as basis, one will also have to refer the Coral limestone and most of the Bryozoan chalk of the famous locality 
of Faxe in the Isle of Sealand to Zone C (as well as the Coral limestone at Annetorp in Scania).

\section{Zone D.}

In a great number of places, the youngest layer of the Danian has been found to be covered by the glauconitic clay or sand deposits of the Selandian.

In Jutland: Fredericia (Cc), Ebeltoft II (Cc), Hvalløse I-II (Cc), Sveistrup (Cc), Langaa (Cc), Jernit (Cc), Skive (B).

In Funen: Skrøbelev (Bc), Marslev (Bc), Svendborg (Bc), Odense (Cc), Dalum (Bc), Wedellsborg (Bc), Strib (Cc).

In Sealand: among others Lellinge $(\mathrm{Bc})$, Copenhagen ( $\mathrm{Cc}$ and coarser sediments).

In Scania: Klagshamn (Cc).

To these may be added a very long series of occurrences of Coccolith chalk in Jutland: the Cliff of Bredstrup, the country SE of Randers, Bjerregrav I, localities in the inner part of Mariager Fiord, Roldtved, Thisted IV-V, Frøslevvang, Sevel, Mønsted I, Vejrum, Hjerm and many more. Together with the above named places, where the stratigraphical conditions directly show that we have to deal with the very youngest deposits of the Danian, these localities form a group characterised by containing - - besides the above named fossils of correlation for the whole of the Y. Danian - the following superiding species:

\section{Graphularia Grönwalli Serpula Hisingeri

This group of localities, to which may be added still more occurrences in Sealand and Scania (Herfølge, certain parts of Bryozoan chalk at Faxe, Limhamn and others), partly of deviating petrographic nature (Bryozoan chalk, coarser limestone) may approximately be compared to "Craniakalken". Grönwall (26) established the "Zone with Crania tuberculata", to which he referred some of the above named localities in Sealand. Later on, these deposits have been dealt with in works by Ravn, BrünNich Nielsen and RosenKRANTz. The limit of the zone downwards has, up to the present, been somewhat uncertain, a circumstance which it is the object of the present work to endeavour to remedy, and at the same time it has been necessary slightly to modify the list of the characteristic species.

In conclusion, we would refer to the following table of the distribution of all the fossils of correlation in the various zones and to "Bilag I", where a large number of localities in Jutland and Funen are scheduled in the same table; the localities of Sealand have been classified in a similar table "Bilag J' (on basis of the present litterature). 


\begin{tabular}{|c|c|c|c|c|}
\hline & \multicolumn{2}{|c|}{ Older Danian } & \multicolumn{2}{|c|}{ Younger Danian } \\
\hline & A & B & $\mathrm{C}$ & $\mathrm{D}$ \\
\hline 1. Graphularia Grönwalli........... & & & . & $x$ \\
\hline 2. Serpula Hisingeri.............. & & & & $x$ \\
\hline 3. Crania tuberculata typ............ & & $\therefore$ & & $x$ \\
\hline 4. Argiope scabricula............. & & & & $x$ \\
\hline 5. $\quad, \quad$ Johnstrupi........... & & & & $x$ \\
\hline 6. $\quad, \quad$ Cimbrorum............ & & & & $x$ \\
\hline 7. Terebratula fallax typ........... & & & & $x$ \\
\hline 8. Lima testis.................. & & & & $x$ \\
\hline $9 . \quad, \quad$ bisulcata................ & & & & $x$ \\
\hline 10. Plicatula Ravni.............. & & & & $x$ \\
\hline 11. Ceratotrochus saltholmensis....... & & & $x$ & $\cdot \times$ \\
\hline 12. Isis vertebralis............... & & & $x$ & $x$ \\
\hline 13. Tylocidaris vexillifera $\beta \ldots \ldots \ldots$ & & & $\times$ & $x$ \\
\hline 14. Brissopneustes suecicus.......... & & & $x$ & $x$ \\
\hline 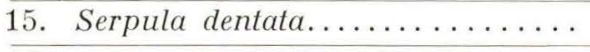 & & & $x$ & $x$ \\
\hline 16. $\quad, \quad$ undulifera............ & & & $x$ & $x$ \\
\hline 17. Ditrupa Schlotheimi............ & & & $x$ & $x$ \\
\hline 18. Rhynchonella incurva typ....... & & & $x$ & $x$ \\
\hline 19. Terebratula lens.............. & & & $x$ & $x$ \\
\hline 20. Scalpellum Steenstrupi......... & & & $x$ & $x$ \\
\hline 21. Metopaster mammilatus typ..... & & $x$ & $x$ & \\
\hline 22. Brissopneustes danicus......... & & $x$ & $x$ & \\
\hline 23. Serpula distincta.............. & & $x$ & $x$ & \\
\hline $24 . \quad, \quad$ erecta............... & & $x$ & $x$ & \\
\hline 25. Rhynchonella incurva fax....... & & $\times$ & $x$ & \\
\hline 26. Terebratula fallax tenuis......... & & $x$ & $x$ & \\
\hline 27. Epitrochus vermiformis......... & $(\times)$ & $x$ & & \\
\hline 28. Tylocidaris vexillifera $a \ldots \ldots \ldots$ & $\times$ & $x$ & & \\
\hline $29 . \quad, \quad, \quad \gamma \ldots \ldots \ldots$ & $\times$ & $x$ & & \\
\hline 30. Cyclaster Brünnichi............. & $\times$ & $x$ & & \\
\hline 31. Echinocorys ovatus............ & $\times$ & $x$ & & \\
\hline
\end{tabular}




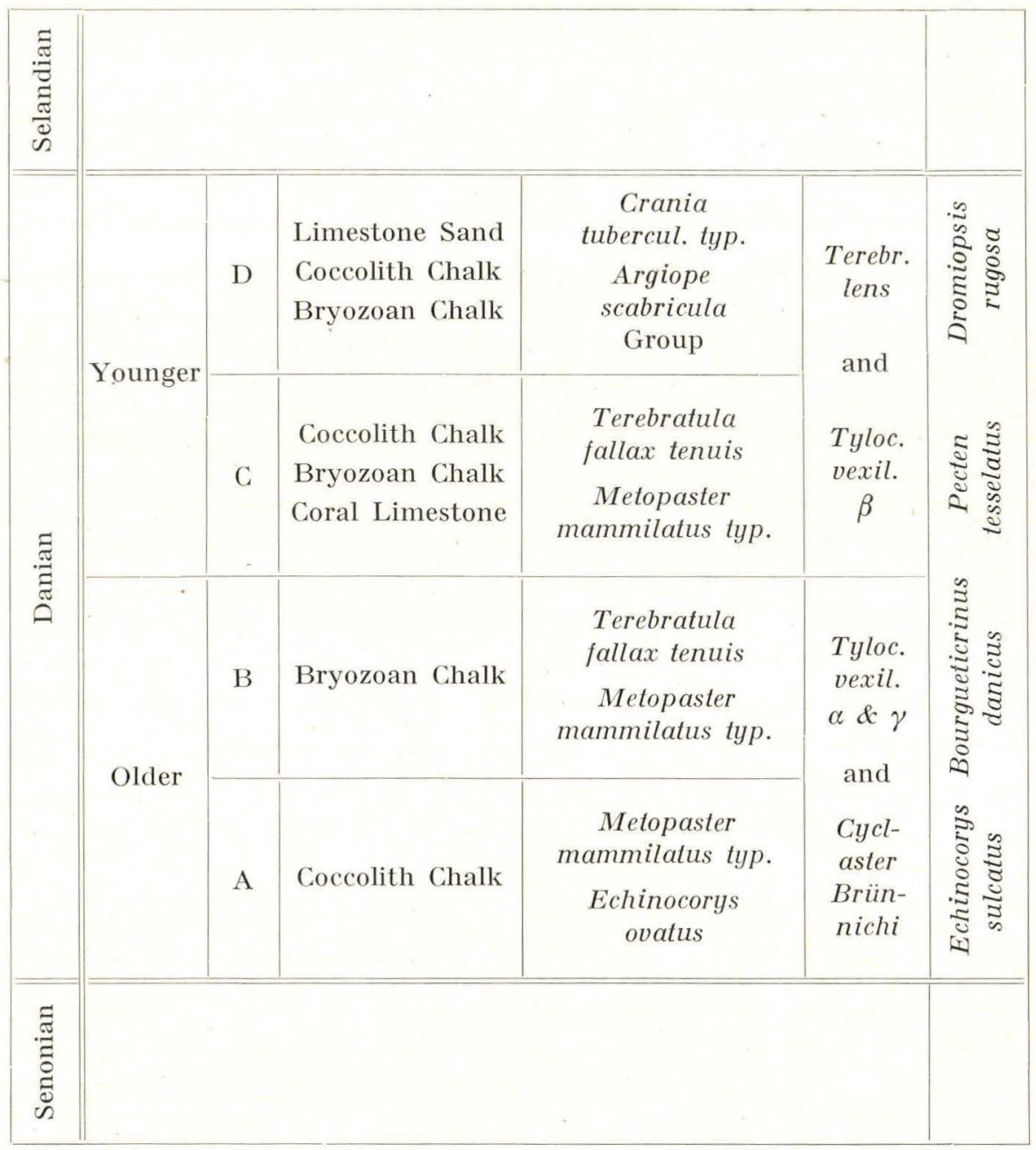

The division in O. and Y. Danian which has here been used, corresponds exactly to that employed by BrünNich Nielsen in his works ${ }^{1}$ ). The upper boundary of the Danian has by Grönwall been placed at the limit between the limestones and the clay and sand deposits of the Paleocene (Selandian), a limit that has subsequently been elaborated by RosEnkrantz (106) and is universally recognised. In exceptional cases, BRÜNNICH NiELsEn (88) and HARDER (34) have, however, suggested the inclusion of the clay and sand deposits of the Selandian in the Danian, in which case Harder wished to call these latter deposits Upper Danian and our Y. Danian: ,Middle Danian”, while the Lower Danian remained unaltered. Brünnich Nielsen and Harder conceive certain of the glauconitic clay formations of the Selandian as being contemporate with the lime deposits of the Y. Danian, only formed under different conditions of facies. This idea has, however, been strongly opposed and has been rejected by Rosenkrantz (109) and Ravn (105).

1) A reservation must, however, here be made in regard to the division in three, to which he subjected the Danian in his treatise of $1913(81)$. 
The transition from the deposit of almost pure calcareous sediment to sand and clay sediment is so comprehensive, that great importance must be ascribed to this limit.

As a final result of this examination of the Danian in Jutland and Funen - considered in conjunction with the corresponding deposits in Sealand and Scania - the table p. 266 may be drawn up:

\section{Chapter VII. Palæogeography.}

In regard to the distribution of sea and land, it must surely be considered an established fact, that the Danian sea did not cover the whole of Denmark, but was more limited in its extension than the White Chalk sea of the Senonian period, a subject which has been rather extensively dealt with by RAvN (95 p. 404 and foll. pp.). The rising must have commenced already towards the end of the Senonian period, seeing that the upper layer of the White Chalk in several places shows a deviating development and, particularly through its rich Bryozoa fauna, shows evidence of having been deposited on rather shalllow water; the many large Membranipora give proof of a vigorous vegetation of Alges.

It is not easy to determine the extent of this rising, but at the transition between the Senonian and the Danian, there is no doubt that great stretches of the territories, that are now covered with the Danian, have been either raised above the surface of the sea or have been raised to the littoral-zone or its immediate neighbourhood. Proof hereof may be found in the traces of abrasion and unconformity, and the solidified horizons that also exist in several places point in the same direction. These matters have been dealt with more in detail in the preceding chapters, and it has been shown, in agreement with RosenkRantz (110), that regression with subsequent transgression has taken place, both at the transition from the Senonian to Zone $\mathrm{A}$ and from Zone A to Zone B.

The deposition of the Bryozoan chalk of Zone B is, then, brought about by a transgression, whereby the Danian sea spreads over the White Chalk territory in the North of Jutland. We do not know the northern limit of the then existing expanse of the Danian sea, since a portion of the deposits must later have been removed by erosion. There is, however, hardly reason to believe that the sea, during the period of the Older Danian, should have had a much wider extension than the O. Danian has now; the territory north thereof must surely, as RAvN points out (95), have been land.

All the authors who have occupied themselves with kindred questions agree, that the Danian period was terminated by a new rising, during which the different rocks in Zone $\mathrm{D}$ were deposited on shallow water. In regard to the principal rock in the Danian, the Coccolith chalk, on the other hand, the conception seems to be, that it was deposited on deep water, representing the maximum of the Danian depression. This has been most emphatically maintained by Rørdam (112 p. 85), who considers the Coccolith chalk to have been formed at very great depths. RAvn (95 p. 418) refers the Coccolith chalk to a deeper facies than the Bryozoan chalk, while Hennig takes both rocks to have been formed on rather deep water; but in considering the reasonings of both the lastnamed authors it must be remembered, that at that time one did not yet distinguish between Bryozoan chalk from $O$. and Y. Danian. 
It seems doubtful, however, if this conception of the relationship between the Bryozoan chalk (especially that of O. Danian) and the Coccolith chalk is correct; the author would be more inclined to consider the Coccolith chalk of the Danian to have been deposited on a less considerable depth than the Bryozoan chalk. The Danian depression has surely reached its greatest depth during the deposition of the Bryozoan chalk of Zone B, and the rising which culminates at the termination of the Danian, had its first beginning already at the transition between $\mathrm{O}$. and Y. Danian.

The geographical distribution of the deposits already proves this. If one traces the N-NE limit bordering the extent of the different zones in Jutland, it will be seen, that the Older Danian everywhere goes a little further north than the Younger Danian. It is possible that, in view of later erosion, not too much importance must bee attached to this circumstance, but it is corroborated by the fact that we have not yet, in any locality, observed Y. Danian resting transgressively upon the White Chalk.

As regards the sediments, there does not appear to be any very noticeable difference between the greater part of the Coccolith chalk of the Y. Danian and the calcareous ooze that forms the groundmass of the Bryozoan chalk of the $\mathrm{O}$. and Y. Danian in Jutland. The deposition of this calcareous ooze has taken place all through the Danian period, the intermixture of autochthonous, benthogenous material of Bryozoa, Corals etc. varying according to time and place. The difference between the rocks in O. and Y. Danian may presumably primarily be ascribed to a variation in the speed of the sedimentation, which again must be referred to the commencing rising and the phenomena related thereto. The origin of the calcareous ooze is directly connected herewith, as it must be presumed that only a smaller (but certainly existing) part hereof is primary planktogenous material (Ussing, 124 p. 108); the greater part is doubtlessly of detrital, terrigenous origin, whether it derives from Senonian (or older Cretaceous) or - as regards the younger parts of the Danian — Danian deposits ${ }^{1}$.

The scantity of Bryozoa in Y. Danian is, probably, primarily due to the fact that the much increased supply of ooze has made it difficult for them to exist at the bottom of the sea.

The fauna of the Y. Danian is considerably richer in species than the fauna of the O. Danian; a closer consideration of the species and a number of petrographical circumstances seem to prove that the Y. Danian Coccolith chalk has been deposited on shallower water than the Bryozoan chalk of Zone B.

1) In very recent times it has been maintained by American students that the fine calcareous ooze that forms the White Chalk should have arisen through a simple, chemical, inorganic precipitation in the surface layer of the sea,, partly, perhaps, with the co-operation of Bacteria (see for instance TARR, $121 \mathrm{a}$ ). There is a good deal that favours this notion, and the considerations on which it is based may surely be applied to the deposits of the Danian. There are especially two factors that will favour a precipitation of microscopically fine crystals of $\mathrm{CaCO}_{3}$ of a saturated solution, that is: simple evaporation and a loss of $\mathrm{CO}_{2}$, and both these processes are accelerated by a rise of temperature.

The precipitation of the $\mathrm{CaCO}_{3}$ takes place, therefore, in the surface layers of the sea, while the water on deeper, colder levels are able to dissolve greater quantities of lime. In the Danian sea, which was a tropical or sub-tropical inland sea, with an abundant supply of dissolved salts from the surrounding lands, this precipitation and deposition of lime must, therefore, principally have happened in places, where the sea was least deep. A negative oscillation of level will at the same time cause a greater terrigenous supply at a given spot and an increased chemical precipitation of lime, so whether an augmented sedimentation of calcareous ooze principally is due to one or the other of the two processes, it may be taken as the result of an elevation. 
In Zone C Bryozoan chalk occurs in several places, presumably deposited in continuation of the deposition of the Bryozoan chalk of Zone B, and these localities represent places which, at the commencement of the rising, have been protected against increased invasion of calcareous ooze through their greater distance from the shore, greater depth or in some other way. In Jutland Bryozoan chalk is rarely found in Zone D, and in Sealand the youngest deposits of Zone D are developed as pronounced shallow-water or littoral deposits (lime sands and gravel).

We must, then, suppose that the maximum of the Danian depression in Denmark occurred in O. Danian (Zone B); at the transition to Y. Danian (Zone $\mathrm{C}$ ) rising and regression commence, which are continued till the end of the Danian period (Zone D); the Selandian commenced with a new, significant transgression.

The oscillation of level is represented by the curve on fig. 29 (p. 223).

\section{Chapter VIII. Tectonics.}

On the map T. V. is indicated the extent of the various pre-quarternary formations.

These pre-quaternary formations do not, however, everywhere lie undisturbed in a horizontal position; in many places there are inclining beds, folds and faults, and in other places such disturbances may be traced indirectly with more or less certainty. On T. V. are presented the observations of tectonic phenomena in Jutland which must be mentioned in this investigation.

In Funen, no disturbances of any kind have been discovered, and the impression of the sub-ground corresponds on the whole to the map drawn by RAVN (104).

On basis of these investigations it is possible to compile a schedule of the relative movements that have taken place in the sub-ground in the North of Jutland. A series of territories may be characterised as pronounced fields of elevation (fully traced in red or marked with red lines on T. VI), separated by more or less definitely marked fields of depression or riftvalleys (drawn with black lines, fully traced or stippled on T. VI); other territories must be characterised as being more passive, resisting territories (these are on $\mathrm{T}$. VI marked in red punctuation).

As pronounced fields of elevation may be mentioned: the territory near Klavsholm (SE. of Randers), Spentrup (N. of Randers), Nord-Salling (S. of Selde), the Isle of Mors (W. of Nykøbing), Thyholm; the territories around Hjerm (between Struer and Holstebro), Sevel (E. thereof), Mønsted (W. of Viborg) and Nøvling (SE. of Holstebro); further, the country W. of Lønnerup Fiord (S. of Østerild), the White Chalk fields W. of Vegger (S. of Nibe) and Skinderup Gaarde (W. of Aalestrup). As more risisting territories must be noted: Djursland (around Grenaa), Eastern Himmerland (AalborgNibe-Hadsund), Eastern Hanherreder (around Torup-Fjerritslev) and the country NW. of Thisted.

As fields of depression may be mentioned: the Valley of Randers, the country around Hobro, the district W. of the White Chalk near Vegger, the tract from Lønnerup Fiord (S. of Østerild) to Hjarbæk Fiord (near Viborg) 
the Danian in Hanstholm and around Hjardemaal (NW. of Østerild), S. of Thisted, the districts surrounding the field of elevation in the Isle of Mors, the southern part of Salling; further, the western part of Djursland (E. of the Klavsholm district) must have been depressed and the same is the case with the Danian N. and S. of the White Chalk near Ranum. It is probable that also the districts Thyholm, Hjerm, Sevel, Mønsted and Nøvling are surrounded by depressed fields; it is possible to form an idea of the procedure of the displacements in these localities by observing faults and dips in the sections.

In the remaining part of the South Scandinavian Geosynclinal the cource of the principal faults is comparatively systematic. In Scania the direction is NW.-SE., a similar direction is found in the Isle of Bornholm and in North Germany until Pommerania; on the whole, they may be said to be parallel with the demarcation of the geosynclinal towards the Northeast. This course is also traced in the North and East of Sealand, but here it seems that, in addition, a more north-southerly tendency becomes apparent (RosENKRANTZ 111), and this direction becomes more prominent in the southern part of Jutland and Holstein, where the chalk and gypsum horsts take the course $\mathrm{N}-\mathrm{S}$.

If one turns to the territory considered in this treatise, the North of Jutland, it seems at first sight that the regularity has completely disappeared; several different directions cross one another apparently quite casually. But on closer consideration one finds that the want of regularity is hardly entirely without plan. The north-southerly direction is found in the clefts that MiLTHERS ( 70 ) interprets as expressions for deeper tectonical disturbances; it shows itself in Western Himmerland, in the western territories near the Limfiord, and it probably also exists south of the Western Limfiord. Nevertheless, there are places, where an east-westerly tendency is prevalent, and the characteristic feature of North-Jutland is, that the long horsts, which are conspicuous in the above named countries, are absent, while the ground on the contrary is broken into many small plots of elevation, bordered on all sides by intercrossing fields of depression.

The explanation is quite simple. The tectonical dislocations must depend on the geosynclinal nature of the whole district, and the chief lines of the tectonics of the Danish underground have often been correlated to the surroundings, especially the prominent zone of faults in Scania (Forchнамmer 16 and 21 , Ussing 122, Milthers 70 , Madsen 64 and $65 a$, Rosenkrantz 111). In the Southeastern Denmark, the conditions are fairly simple, because the borderline of the geosynclinal towards NE. takes a regular course, but in North Jutland the forces at work are more complicated. The demarcation is on one side Sweden, where the coast and the depressions in the Kattegat go from SSE. towards NNW., with a continuation in the Fiord of Oslo; but on the other hand one has now arrived close to the massive of Norway, that pushes forward S. to SW. and interrupts the straight course of the geosynclinal (it must remain a question whether it is continued with a deviation in a westerly direction). The influence of Norway on the course of the dislocations becomes distinctly apparent in the "Norwegian channel". North Jutland is now, so to say, squeezed in between the two massives, and when movements in the crust of the earth give rise to tangential pressure or tension, the course of the fractures which have thus been caused, must depend on these two massives. In other words, we must in the mosaic of the underground in the North of Jutland see the result of an interaction between a north-southerly (or 
northnorthwest-southsoutheasterly) and an almost east-westerly fracture system $\left.{ }^{1}\right)$.

The time at which the disturbances in North Jutland took place cannot with certainty be determined. It may, however, be taken for granted that at any rate smaller displacements have occurred at different times. RosenKRANTZ has shown (111) that the dislocations in the northeastern part of Sealand commenced at the end of the Danian period, and also in Scania the "Grevie-Åsen" existed already in the Danian period (Troedsson $121 \mathrm{~b}$ ); in Holstein great displacements occurred several times during the later part of the Tertiary period (GAGEL 25), and MADSEn's dislocations near the Fiord of Mariager must presumably be referred to the end of the Tertiary period (65 a p. 20); the disturbances in the Cliff of Lønstrup (JEssen, 42) (as well as in many other places) are from of the glacial period, and finally, the clefts of Milthers were formed in post-glacial times.

The Paleocene is found at Hvalløse and Svejstrup, resting on the plateau on both sides of the Randers Valley, which might indicate that it has been included in the movements; but unfortunately so few observations exist from other parts of Jutland in regard to the relationship between Tertiary and Danian deposits, that there is hardly basis for speculations of that sort. The Tertiary firestone conglomerate, whose place of origin must be looked for around Fur (Jessen 46, p. 28), has surely arisen through the wave erosion of some steep coast, and such a coast can in these countries only be assumed to have arisen through movements in the crust of the earth. Up to the present, no trace has been found in Jutland of disturbances during Danian times, so that the main portion of the prominent fractures must have occurred in the course of the Tertiary period.

1) It was to be expected that the two fracture tendencies would become more distinct as one advanced further northwards in Vendsyssel. We have here only the chance of examining one disturbed locality, that is the section in the quaternary deposits in the Cliff of Lonstrup (42). The long series of reversed faults have here taken place with a strike of about N. $67^{\circ} \mathrm{W}$.; whereas foldings and faults at Stortorn have occurred in the direction N. $80^{\circ}$ E. The author would consider it probable that an expression for the same two differently directed resistances must be seen in these two opposite directions. In the tract of Lonstrup they have produced two mutually independent disturbances; these happen to cross one another in the Stortorn section, where - being presumably contemporary - they have caused further complications. 


\section{Bilag.}

I Bilag A er kun de mere almindeligt forekommende Arter opført; Udbredelsen af sjældnere optrædende Arter maa søges under Omtalen af de enkelte Arter i Kap. V.

I Bilagene $\mathrm{B}-\mathrm{H}$ er derimod medtaget alle bestemte Former fra de paagældende Lokaliteter. 
Spongiae.

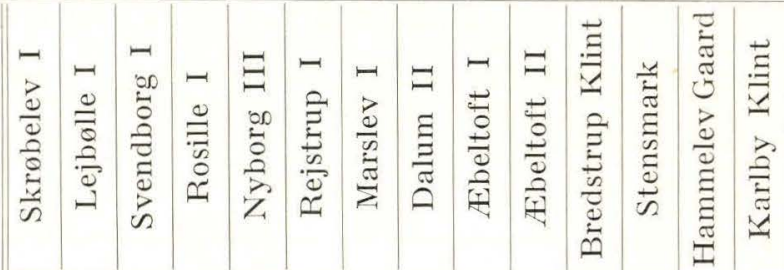

1. Plinthosella squamosa

2. Aphrocallistes sp.

3. Porosphaera universa.

$4 . \quad$ "

adhaerens.

Anthozoa.

5. Graphularia Grönwalli.

6. Gorgonella torta.

7. Isis Steenstrupi.

8. Moltkia Isis.

\section{Crinoidea}

9. Pentacrinus paucicirrhus.....

$10 . \quad$ "

-Type

11. " longus-Type.

12. Bourgueticrinus danicus

Asteroidea.

13. Metopaster mammilatus typ...

14.

15.

radiat.

16. Mitraster Hunteri.

(ubest.)

17. Teichaster favosus

18. Pycinaster crassus.

19. Chomataster acules.

20. Tholaster argus.

21.

ocellatus.

22. Lophidiaster pygmaeus.

Echinoidea.

23. Tylocidaris vexillifera

24.

25 .

$\beta \ldots \ldots$ ? ?

")

$\gamma \ldots \ldots$

26. Echinocorys sulcatus

27. Brissopneustes danicus.

$28 . \quad$ "

29.

suecicus.

$s p$ 
Spongiae.

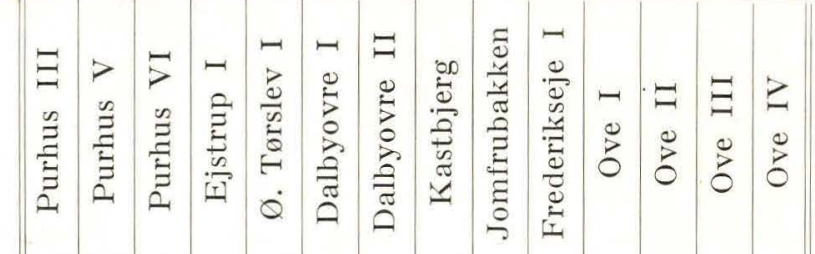

1. Plinthosella squamosa

2. Aphrocallistes sp.

3. Porosphaera universa.

$4 . \quad "$

adhaerens.

Anthozoa.

5. Graphularia Grönwalli.

6. Gorgonella torta.

7. Isis Steenstrupi.

8. Moltkia Isis.

Crinoidea.

9. Pentacrinus paucicirrhus..... 10.

11. " longus-Туре.

12. Bourgueticrinus danicus

-Туре

Asteroidea.

13. Metopaster mammilatus typ..

14.

»

1 radiat. .

15.

(ubest.)

16. Mitraster Hunteri.

17. Teichaster favosus.

18. Pycinaster crassus.

19. Chomataster acules

20. Tholaster argus

21.

ocellatus.

22. Lophidiaster pygmaeus.

Echinoidea.

23. Tylocidaris vexillifera

25.

》)

$\beta \ldots \ldots$

26. Echinocorys sulcatus.

$\gamma \ldots \ldots$

27. Brissopneustes danicus....... 28.

suecicus.

29.

sp 


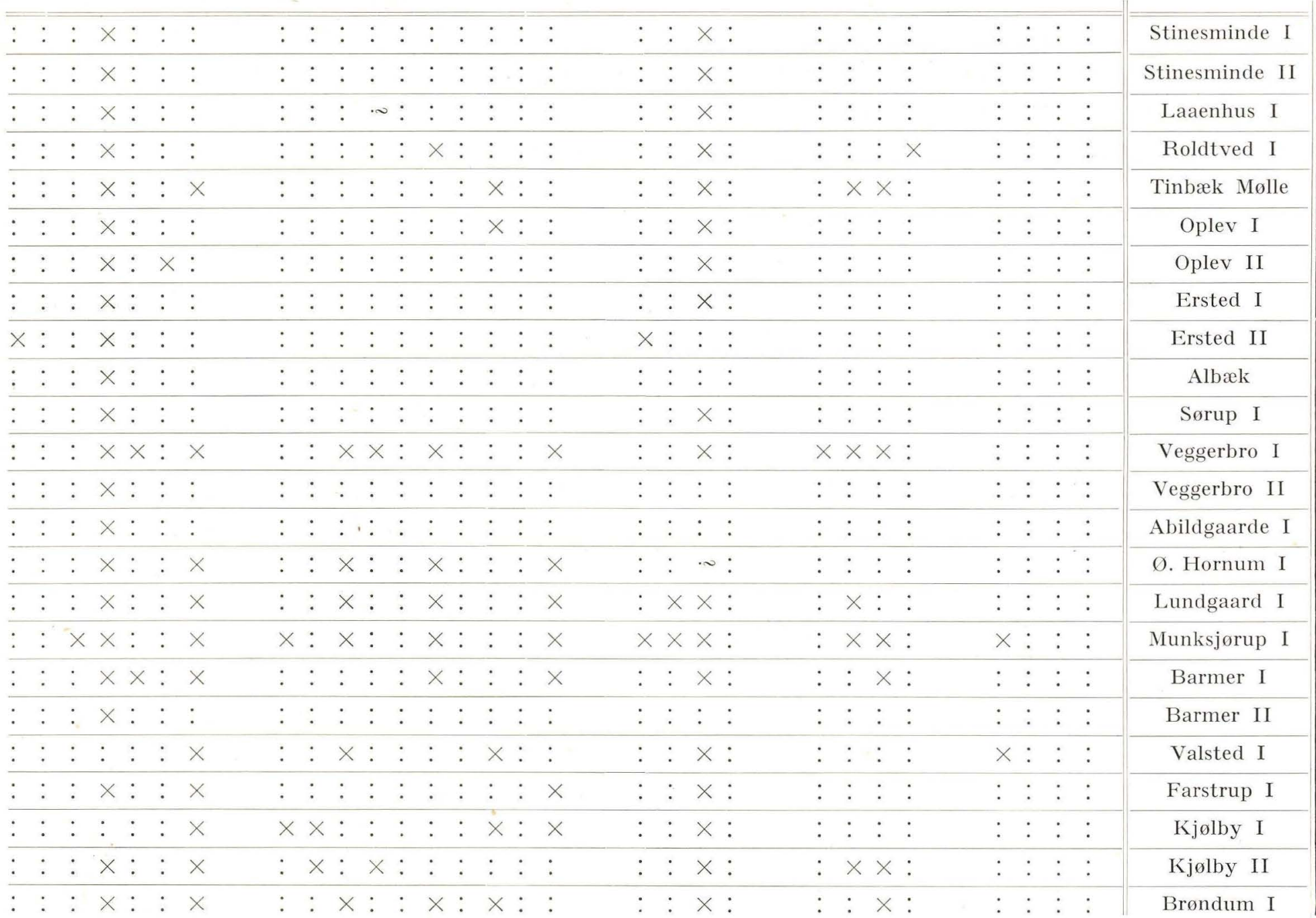


Spongiae:

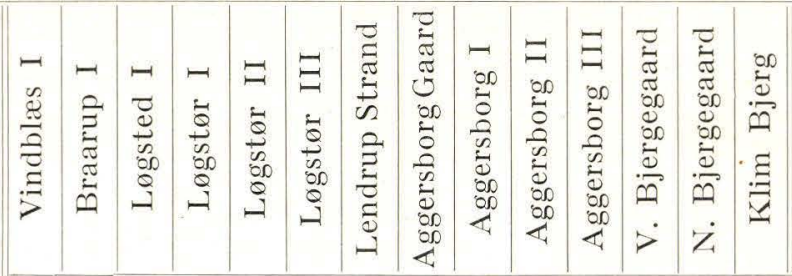

1. Plinthosella squamosa

2. Aphrocallistes sp.

3. Porosphaera universa.

$4 . \quad "$

adhaerens.

\section{Anthozoa.}

5. Graphularia Grönwalli.

6. Gorgonella torta.

7. Isis Steenstrupi.

8. Moltkia Isis.

Crinoidea.

9. Pentacrinus paucicirrhus....

$10 . \quad 》$

-Type

11. " longus-Туре.....

12. Bourgueticrinus danicus

Asteroidea.

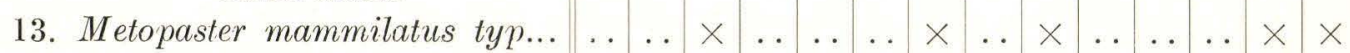

14. 》 $\gg$ radiat. .

15. "

16. Mitraster Hunteri...........

17. Teichaster favosus.

18. Pycinaster crassus.

19. Chomataster acules.

20. Tholaster argus.

21. " ocellatus...

22. Lophidiaster pygmaeus.

Echinoidea.

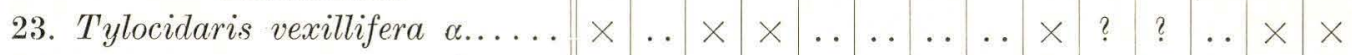

24. $\gg \quad " \quad \beta \ldots \ldots . . . .$.

25. $\gg \quad \gamma \ldots \ldots$

26. Echinocorys sulcatus.

27. Brissopneustes danicus.

$28 . \quad 》$

29. suecicus.

sp. 


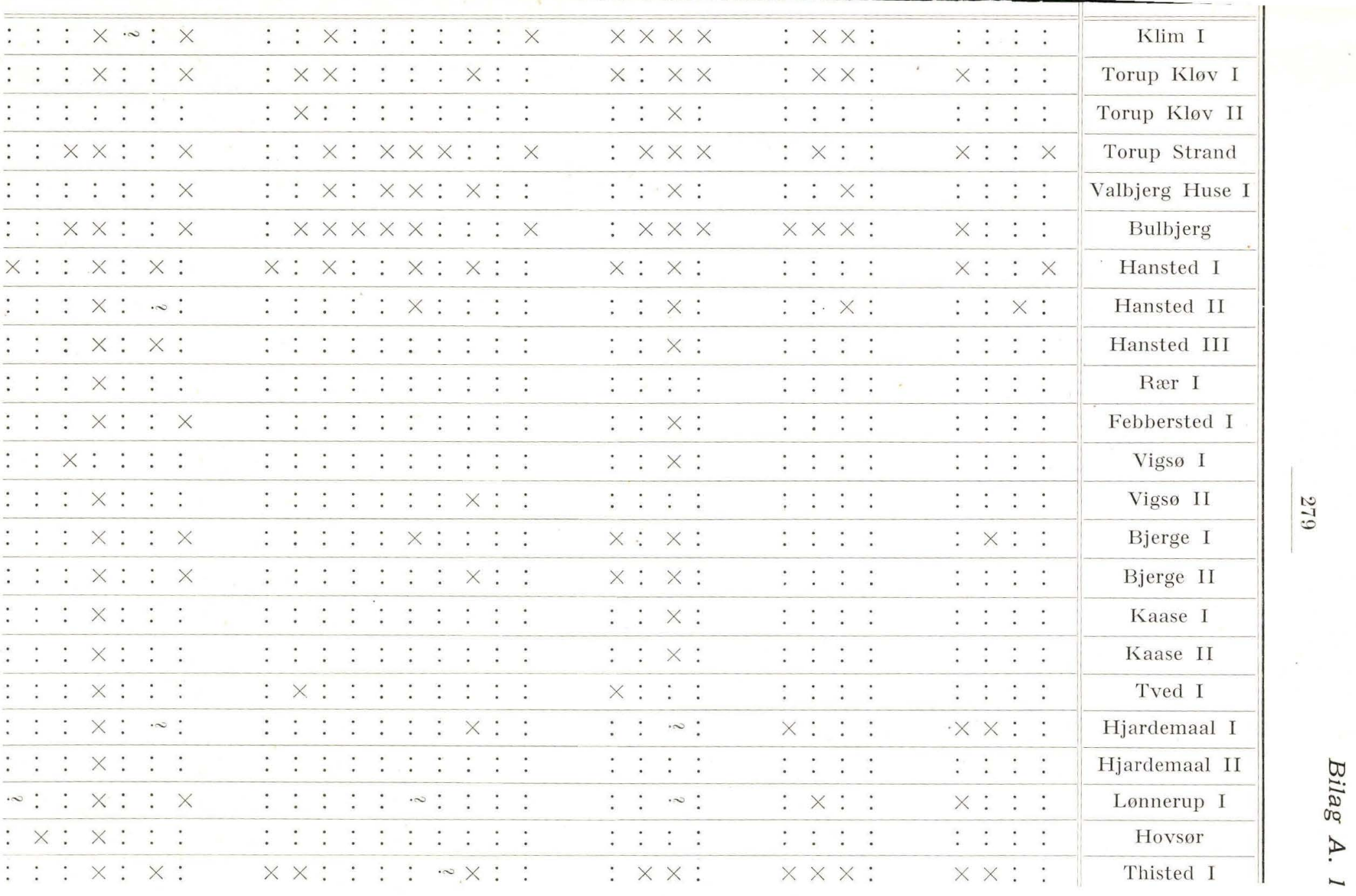




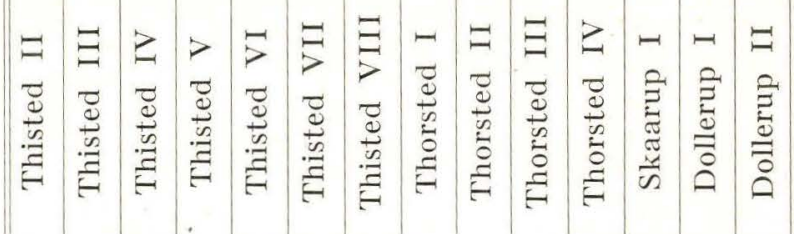

Spongiae.

1. Plinthosella squamosa

2. Aphrocallistes sp.

3. Porosphaera universa.

4.

adhaeren.

Anthozoa.

5. Graphularia Grönwalli.

6. Gorgonella torta.

7. Isis Steenstrupi...

8. Moltkia Isis.

Crinoidea.

9. Pentacrinus paucicirrhus.... 10.

11. \ longus-Туре.

12. Bourgueticrinus danicus

Asteroidea.

13. Metopaster mammilatus typ...

$14 . "$ " radiat.

15. " " (ubest.)

16. Mitraster Hunteri.

17. Teichaster favosus...

18. Pycinaster crassus.

19. Chomataster acules

20. Tholaster argus.

21.

ocellatus...

22. Lophidiaster pygmaeus.

Echinoidea.

23. Tylocidaris vexillifera

24.

25 .

" "

-Туре

$\times \times \times \times \times$ 


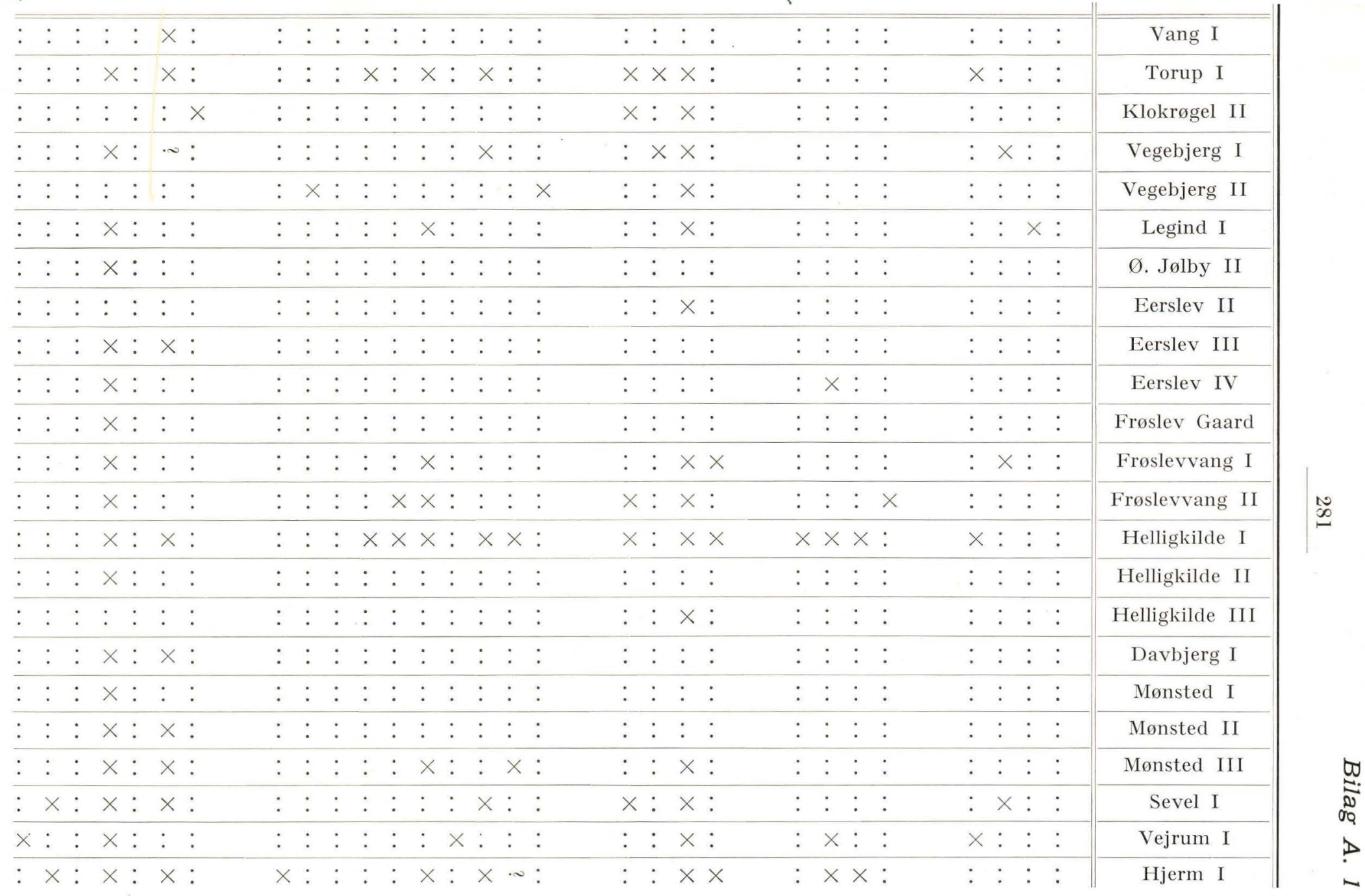


Vermes.

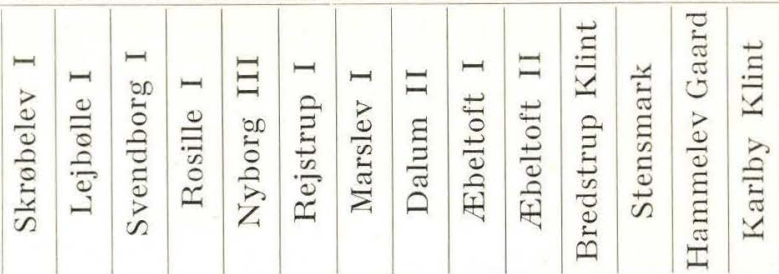

1. Serpula gordiatis.

2. \ laevicollis.

3. " contorta.

4. " aplanata.

5. " ascendens.

6. " multilineata.

7. " distincta.

8. " quinquedentata.

$9 . \quad$ "

dentata.

$10 . \quad$ 》

11. Ditrupa Schlotheimi.

12. Terebella sp...

Brachiopoda.

13. Crania ignabergensis.

14. \ tuberculata transv.

15. Rhynchonella incurva typ.

16. 》 》 $f a x$.

17. Argiope Koeneni.

18. \) Posselti.

19. » dorsata.

20. \faxensis...

21. Terebratula cfr. lens.

22. \ fallax typ...

$23 . "$ " tenuis.

24. Terebratulina striata.

Lamellibranchiata.

25. Pinna sp

26. Pecten monotiformis

27. 》 tesselatus.

28. Drmyodon Nilssoni.

29. $\gg$ costatus.

30. Spondylus faxensis.

31. \ danicus.

32. 》 sp.

33. Gryphaea vesicularis

34. Exogyra canaliculata 


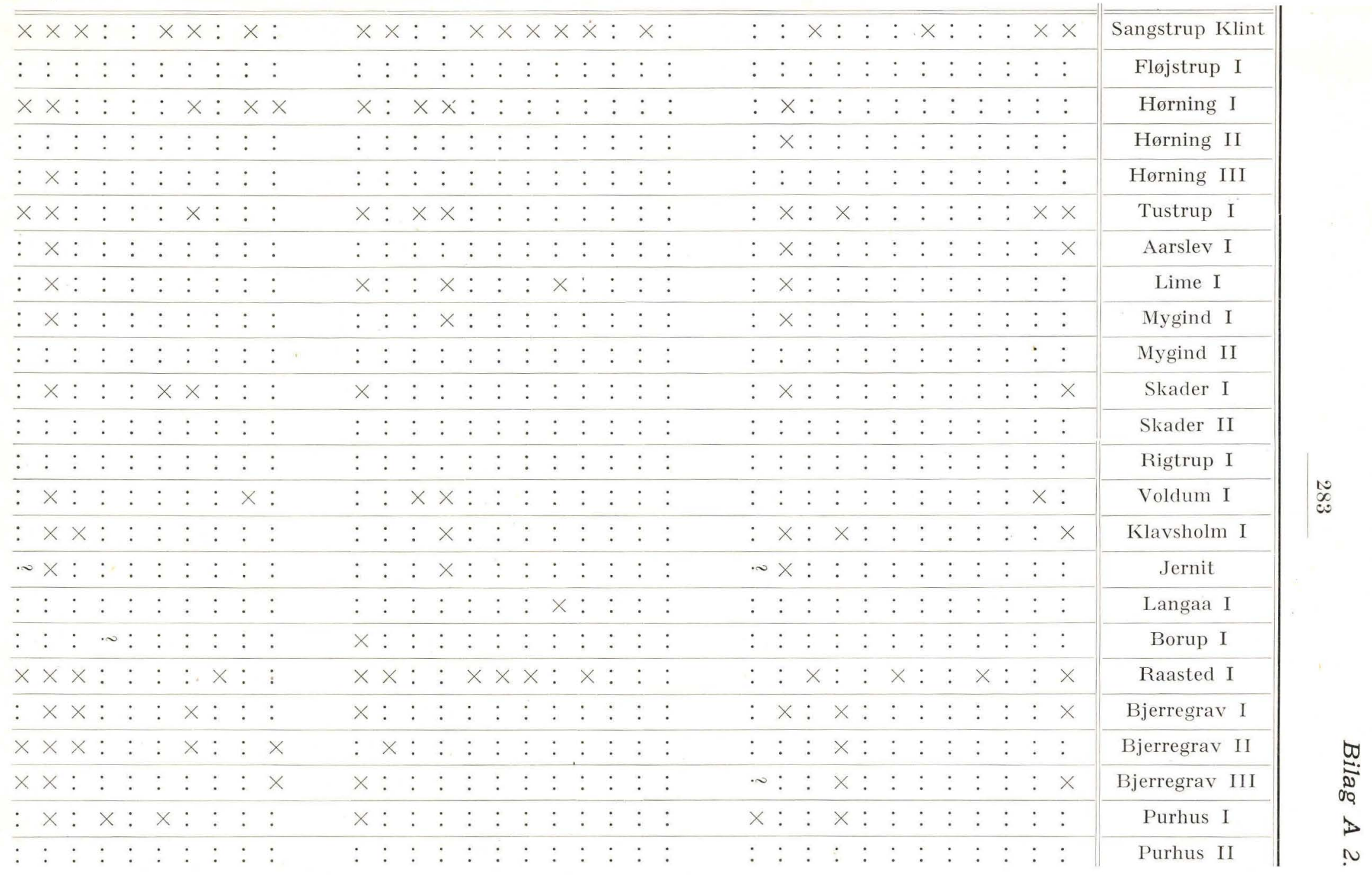


Vermes.

1. Serpula gordialis.

2. " laevicollis.

3. " contorta.

4. " aplanata.

5. " ascendens.

6. " multilineata

7. " distincta.

8. " quinquedentata.

9. " dentata

10. " erecta

11. Ditrupa Schlotheimi.

12. Terebella sp.

Brachiopoda.

13. Crania ignabergensis .

14. " tuberculata transv

15. Rhynchonella incurva typ.

16. " " fax.

17. Argiope Koeneni.

19. \dorsata.

20. \faxensis.

21. Terebratula cfr. lens.

22. " fallax typ.

$23 . \|$ " tenuis.

24. Terebratulina striata.

Lamellibranchiata.

25. Pinna sp

26. Pecten monotiformis

27. " tesselatus.

28. Dimyodon Nilssoni.

29. 》 costatus.

30. Spondylus faxensis.

31. " danicus.

32. " sp.

33. Gryphaea vesicularis

34. Exogyra canaliculata. 


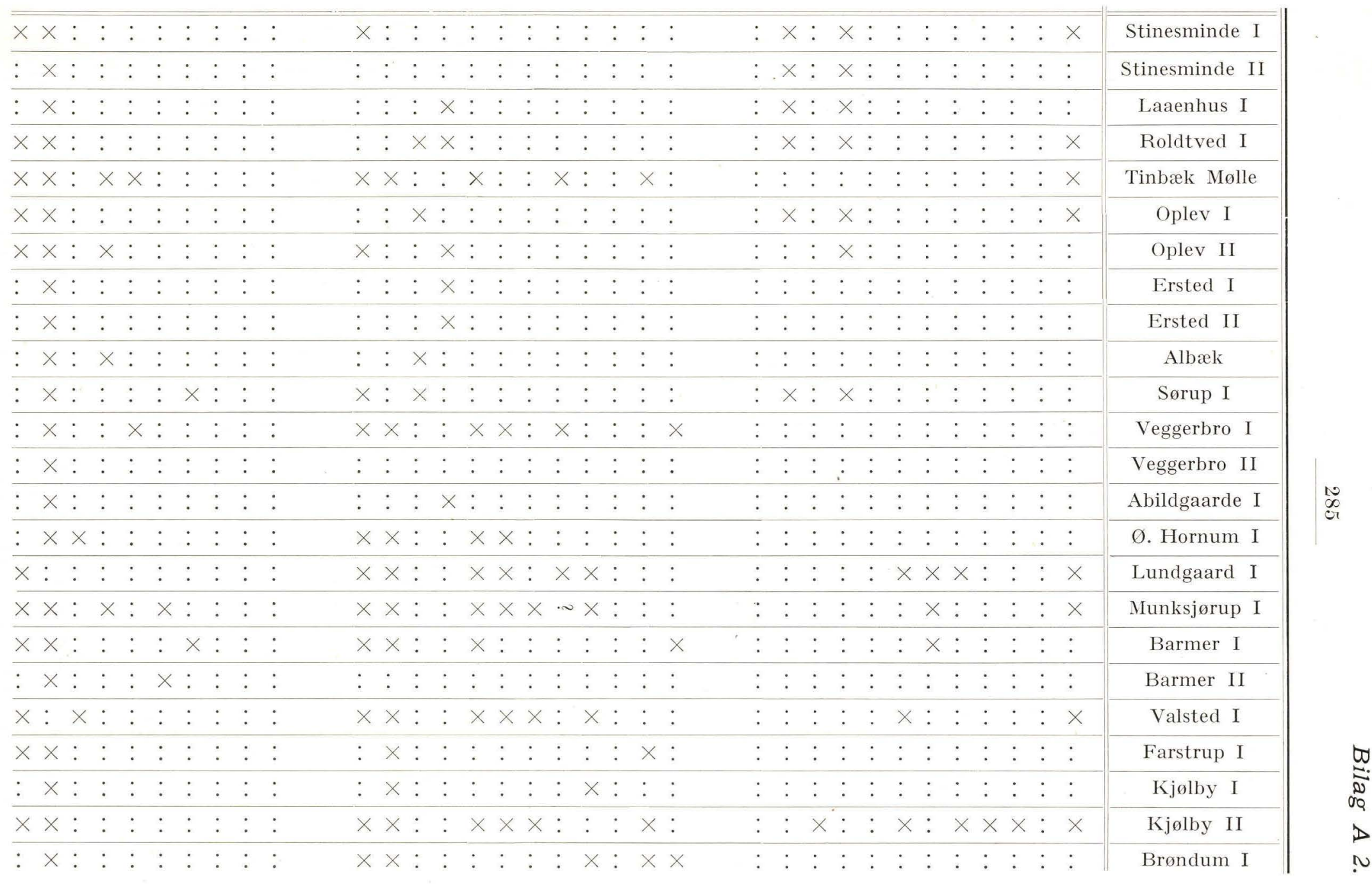




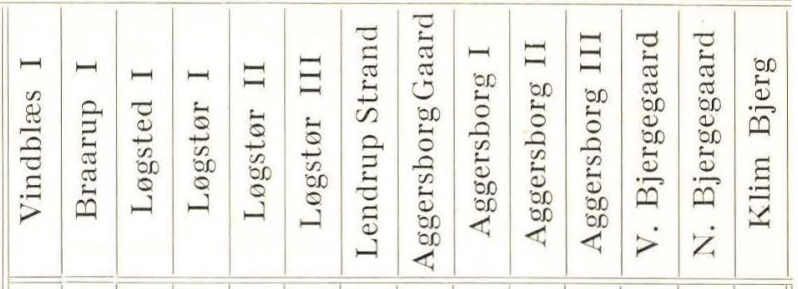

1. Serpula gordialis.

2. " laevicollis.

3. \ contorta.

4. " aplanata.

5. \ ascendens.

6. \ multilineata.

7. " distincta.

8. ") quinquedentata

$9 . \quad \gg$

10.

11. Ditrupa Schlotheimi.

12. Terebella sp...

Brachiopoda.

13. Crania ignabergensis.

14. " tuberculata transv.

15. Rhynchonella incurva typ.

$16 . " 》 f a x$.

17. Argiope Koeneni.

18. " Posselti.

19. 》 dorsata.

20. "faxensis.

21. Terebratula cfr. lens.

22. " fallax typ.

$23 . "$ " tenuis.

24. Terebratulina striata.

Lamellibranchiata.

25. Pinna sp.

26. Pecten monotiformis

27. » tesselatus.

28. Dimyodon Nitssoni.

29. \ costatus. .

30. Spondylus faxensis.

31. \ danicus.

32. " sp.

33. Gryphaea vesicularis

34. Exogyra canaliculata 


\begin{tabular}{|c|c|c|c|c|c|c|c|c|c|c|c|c|c|c|c|c|c|c|c|c|c|c|c|c|c|c|c|c|c|c|}
\hline$x$ & x : & $::$ & $:$ : & : $\quad x$ & : & $:$ & $:$ & $x$ & $x:$ & & : & $x \times$ & $x \times$ & $x:$ & x & & $x$ & : & : & : & $x$ & & . & : & $x>$ & $x \times$ & $<x$ & $:>$ & $x$ & Klim I \\
\hline$x$ & $\times \times$ & $x:$ & : : & : $\quad x$ & $x$ & & : & $x$ & $\times:$ & & $: \quad$ & $x \times$ & $x \times$ & $x:$ & $x$ & : & $x$ & : & : & : & $x$ & : & $x$ & $x$ & $x>$ & $x \times$ & : & $x>$ & $x$ & Torup Kløv I \\
\hline : & $::$ & $:$ : & : : & : : & $:$ & $:$ & : & $:$ & $::$ & & : : & : : & : : & : : & : & : & : & : & : & : & : & : & : & $:$ & : > & $x:$ & : & $:$ : & : & Torup Kløv II \\
\hline$\times$ & $\times:$ & $:$ & $x:$ & : : & $x$ & : & : & $x$ & $x:$ & & : & $\times$. &.$\infty x$ & $x:$ & $x$ & : & : & : & : & : & : & : & : & $x$ & $x>$ & $x \times$ & $x$ & $: \quad>$ & $x$ & Torup Strand I \\
\hline : & $\times:$ & $::$ & : & : : & $:$ & : & : & $x$ & $x:$ & & : & $x \times$ & $x \times$ & $x:$ & $x$ & : & $x$ & : & : & : & $:$ & : & : & $x$ & : : & : $x$ & $x$ & $:>$ & $x$ & Valbjerg Huse I \\
\hline$x$ & $x:$ & $x$ & $:$ : & : : & : & $x$ & : & $x$ & $x:$ & & $:$ & $x>$ & $x \times$ & $x>$ & $x \times$ & : & x & $x$ & : & : & $x$ & : & : & $x$ & $x>$ & $x \times$ & $x$ & $x>$ & $x$ & Bulbjerg \\
\hline$x$ & $\times:$ & $:$ & $x>$ & $x:$ & : & $x$ & : & $x$ & $x:$ & & : & $x>$ & $x \times$ & $x:$ & : & : & : & $x$ & : & : & $x$ & $\times$ & : & $:$ & $x>$ & $x \times$ & : & $:>$ & $x$ & Hansted I \\
\hline$x$ & $: \quad:$ & $x$ & : : & : : & : & $:$ & : & $x$ & $\times:$ & & : : & : > & $x:$ & : : & : : & : & : & $x$ & : & : & : & : & : & : & $:$ : & : : & : & $\times>$ & $x$ & Hansted II \\
\hline : & $\times:$ & $:$ & : & : & : & 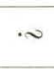 & : & $x$ & $::$ & : & $:$ & : : & : : & : : & : : & : & : & : & : & : & : & : & : & : & : & : : & $:$ & $::$ & : & Hansted III \\
\hline$x$ & $::$ & $:$ & : : & : : & : & $:$ & : & $x$ & : & : & : : & : : & : : & : : & : : & : & : & : & $:$ & : & : & : & : & : & $\times:$ & : : & $:$ & $::$ & : & Rær I \\
\hline : & $: \times$ & $:$ & $:$ & : & : & : & : & $:$ & : & : & : & : : & : : & : : & : : & : & : & : & $:$ & : & : & : & : & : & $:>$ & $x:$ & $:$ & $: \quad:$ & : & Febbersted I \\
\hline : & $x:$ & $x$ & $::$ & $::$ & : & $:$ & $:$ & $x$ & $x:$ & : & $:$ & $:>$ & $x:$ & : : & : : & : & $x$ & $x$ & $:$ & $:$ & : & : & $:$ & : & $:>$ & $x:$ & $:$ & $:>$ & $x$ & Vigsø I \\
\hline$x$ & $::$ & $:$ & : & : & : & $:$ & $:$ & $:$ & $\sim$ : & & $:$ & : : & : : & : : & : : & : & : & : & $:$ & : & $:$ & : & : & : & $:$ : & : : & $:$ & $:>$ & $x$ & Vigso II \\
\hline$x$ & $\times x$ & : & : & : $\times$ & $x$ & $:$ & : & $x$ & $x:$ & & : & : : & : : & : : & : : & : & x & : & $:$ & : & : & : & : & : & $:$ : & $::$ & : & $:$ : & $\cdot$ & Bjerge I \\
\hline : & $\infty:$ & $x$ & $: \quad:$ & : : & : & $x$ & : & : & $x:$ & & : & : : & : : & : : & : : & : & x & : : & : & : & $:$ & $:$ & x & : & $:$ : & $: \quad:$ & $:$ & $::$ & : & Bjerge II \\
\hline : & $: \quad \times$ & $x$ & : & : & : & : & $:$ & $x$ & $:$ : & : & $:$ & : & : : & : : & : : & : & : & : & $:$ & : & : & : & : & : & $:$ : & : : & : & $::$ & $:$ & Kaase I \\
\hline : & $\times:$ & : & : & : & : & : & : & $x$ & $: \quad:$ & & $\infty$ & : : & : & : & : : & : & : & : & $:$ & : & $:$ & : & : & : & : : & : : & $:$ & $::$ & : & Kaase II \\
\hline : & $::$ & $:$ & $::$ & : & : & : & $:$ & $x$ & $::$ & & $:$ & : & : : & : & $x:$ & : & : & : & $:$ & : & $x$ & : & $:$ & : & $:>$ & $\times:$ & $:$ & $:>$ & $x$ & Tved I \\
\hline$x$ & $x:$ & : & $\infty$ : & : & : & $:$ & : & $x$ & $\infty:$ & : & $:$ & : & $\times:$ & : & : : & : & : & : & : & $:$ & $:$ & : & $:$ & : & $:>$ & $x:$ & : & $:$ & $x$ & Hjardemaal I \\
\hline$:$ & $: \quad x$ & $:$ & $:$ : & : & : & $x$ & $x$ & $:$ & $:$ : & : & $:$ & : : & : : & : & : : & : & : & : & : & $:$ & : & : & : & : & $::$ & $::$ & $:$ & $:$ & : & Hjardemaal II \\
\hline$:$ & $::$ & $:$ & $:$ : & : & $x$ & : & : & $:$ & $x:$ & : & $:$ & : & $x:$ & : & : : & : & $:$ & $:$ & : & $:$ & $:$ & : & $:$ & : & : & $::$ & : & $:$ & $x$ & Lonnerup I \\
\hline : & $x \times$ & $:$ & $\sim$ : & : : & : & $:$ & : & $x$ & $::$ & : & : & $:$ : & : : & : : & : : & : & : & : & $:$ & $:$ & $:$ & : & : & $:$ & $: \quad:$ & $::$ & : & $:$ : & $:$ & Hovsør \\
\hline : & $\times:$ & $x$ & & $::$ & : & & : & & $::$ & & & & & & & & & & v & & & & & $:$ & & : : & : & $x$ & & Thisted I \\
\hline
\end{tabular}


Vermes.

1. Serpula gordialis.

2. \laevicollis.

3. 》 contorta.

4. $\gg$ aplanata.

5. 》 ascendens.

6. 》 multilineata.

7. \ distincta.

8. 1$)$ quinquedentata.

$9 . \quad$ "

dentata.

10. \ erecta.

11. Ditrupa Schlotheimi.

12. Terebella sp.

Brachiopoda.

13. Crania ignabergensis

14. " tuberculata transv.

15. Rhynchonella incurva typ

16. 》 $"$ fax.

17. Argiope Koeneni.

18. \ Posselti.

19. \ dorsata.

20. \faxensis.

21. Terebratula cfr. lens.

22. " fallax typ.

23. " $"$ tenuis

24. Terebratulina striata... 


\begin{tabular}{|c|c|c|c|c|c|c|c|c|c|c|c|c|c|c|c|c|c|c|c|c|c|c|c|c|c|c|c|c|c|c|c|c|c|}
\hline : & 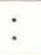 & $:$ & $:$ & $\vdots$ & : & : & : & : & : & : & $:$ & : & : & : & $:$ & & : & : & $x$ & : & : & : & & & & & & : & : & & & : & Vang I \\
\hline$>$ & $x$ & $x$ & : & : & : & : & $x$ & : & : & $:$ & $\sim$ & : & : & : & : & : & : & : & : & $:>$ & x & : & : & : & : & : & : & : & : & : & : & $\times x$ & Torup I \\
\hline : & : & : & : & : & : & : & : & : & : & $x$ & $x$ & : & : & : & : & : & : & : & : & : & : & : & $:$ & : & : & : & : & : & : & : & $:$ & : : & Klokrøgel II \\
\hline : & : & : & : & : & : & : & : & : & : & $x$ & $:$ & : & : & : & : & : & : & : & : & : & : & : & $:$ & : & : & : & $:$ & : & : & : & : & $\times \times$ & Vegebjerg I \\
\hline : & : & $:$ & : & : & : & : & : & $\times:$ & : & $x$ & $:$ & : & : & : & $:$ & : & : & : & : & $:$ : & : & : & $:$ & : & : & : & : & : & : & : & : & : : & Vegebjerg II \\
\hline : & $x$ & $x$ & : & $:$ & $x$ & : & : & $x$ & $x$ & $x$ & $x$ & $:$ & : & : & $:$ & : & : & $:$ & : & $:$ & : & : & $:$ & : & : & : & : & : & : & : & : & : : & Legind I \\
\hline : & $x$ & : & : & : & : & : & $:$ & : & : & $:$ & $:$ & : & : & : & : & : & : & : & $:$ & : : & : & $:$ & $:$ & : & : & : & $:$ & : & $:$ & $:$ & $:$ & : : & Ø.,Jølby II \\
\hline : & : & : & : & : & : & : & : & : & : & $:$ & : & : & : & : & : & : & : & : & : & : & : & : & : & $x$ & : & : & : & $:$ & $:$ & : & : & $:$ : & Eerslev II \\
\hline : & : & : & : & : & : & : & : & : & : & $x$ & $x$ & : & : & : & : & : & : & : & : & : & : & : & $:$ & : & : & : & : & : & : & : & : & : : & Eerslev III \\
\hline : & $:$ & : & : & $:$ & $:$ & : & : & : & : & $:$ & : & : & : & : & $:$ & : & : & : & : & $:$ : & : & : & $:$ & : & : & : & $:$ & : & : & : & : & : : & Eerslev IV \\
\hline : & : & $:$ & : & $:$ & : & : & : & : & : & $:$ & $:$ & : & : & : & : & : & : & : & $:$ & $:$ : & : & : & $:$ & : & : & : & $:$ & : & $:$ & : & : & : : & Frøslev Gaard \\
\hline : & $x$ & $x$ & : & $:$ & : & : & : & : & : & : & : & : & : & : & $:$ & : & : & : & : & : : & : & : & $x$ & : & : & $\cdot$ & : & $:$ & : & : & : & : : & Frøslevvang I \\
\hline : & $x$ & : & : & : & : & : & $:$ & : & : & $:$ & $:$ & $x$ & $\sim$ & : & : & : & : & : & : & $:$ & : & : & $x$ & & : & : & $:$ & : & $:$ & $:$ & : & $: \quad x$ & Frøslevvang II \\
\hline : & $x$ & $x$ & $x$ & : & $x$ & $x$ & $x$ & $:$ : & : & $x$ & $:$ & : & : & : & $:$ & : & $x$ & : & $x$ & $:$ : & : & $:$ & $:$ & : & : & : & $:$ & : & $x$ & : & : & $\times \times$ & Helligkilde I \\
\hline > & $x$ & : & : & : & : & : & : & : & : & $:$ & $:$ & : & : & : & : & : & : & : & $:$ & $:$ : & : & : & $:$ & : & : & : & : & : & $:$ & : & : & : : & Helligkilde II \\
\hline : & : & : & : & : & : & : & : & : & : & $:$ & : & : & : & : & : & : & : & : & : & : : & : & : & $:$ & : & : & : & : & : & $:$ & : & : & : : & Helligkilde III \\
\hline : & $:$ & : & : & : & : & : & : & : & : & : & $:$ & : & $x$ & : & : & : & : & : & $:$ & $:$ : & : & : & $:$ & : & : & : & $:$ & : & : & : & : & : : & Davbjerg I \\
\hline : & $x$ & $:$ & : & : & : & : & $:$ & $x$ & $x$ & : & $:$ & : & : & : & $:$ & : & $:$ & : & : & $:$ & : & $:$ & $x$ & : & $x$ & : & $:$ & $:$ & $:$ & : & $:$ & $: \quad x$ & Monsted I \\
\hline : & $x$ & $:$ & : & : & : & : & $:$ & : & : & : & $:$ & : & $x$ & : & : & : & $:$ & : & : & $:$ & : & : & $:$ & : & : & : & : & : & : & : & : & : : & Mønsted II \\
\hline : & $:$ & $:$ & $:$ & $:$ & : & : & $:$ & : & : & $:$ & $\sim$ & $:$ & $x$ & : & $:$ & : & : & : & $\therefore$ & $:$ & : & : & $:$ & : & : & : & : & : & : & $:$ & $:$ & : : & Mønsted III \\
\hline & $x$ & $:$ & : & : & : & : & $x$ & : & : & $:$ & : & $x$ & & : & : & : & : & : & $x$ & : : & : & : & : & : & : & : & : & : & : & : & : & $: \quad x$ & Sevel I \\
\hline : & $x$ & : & $x$ & : & x & $x$ & & & : & $x$ & $:$ & $:$ & $x$ & & $:$ & : & : & : & $:$ & $:$ : & : & : & & & : & : & : & : & : & : & : & : : & Vejrum I \\
\hline & $x$ & $\times$ & & : & $x$ & & $x$ & & x & & : & : & & : & $x$ & & & & & & & : & & & : & . & & & $x$ & & & $:>$ & Hjerm I \\
\hline
\end{tabular}




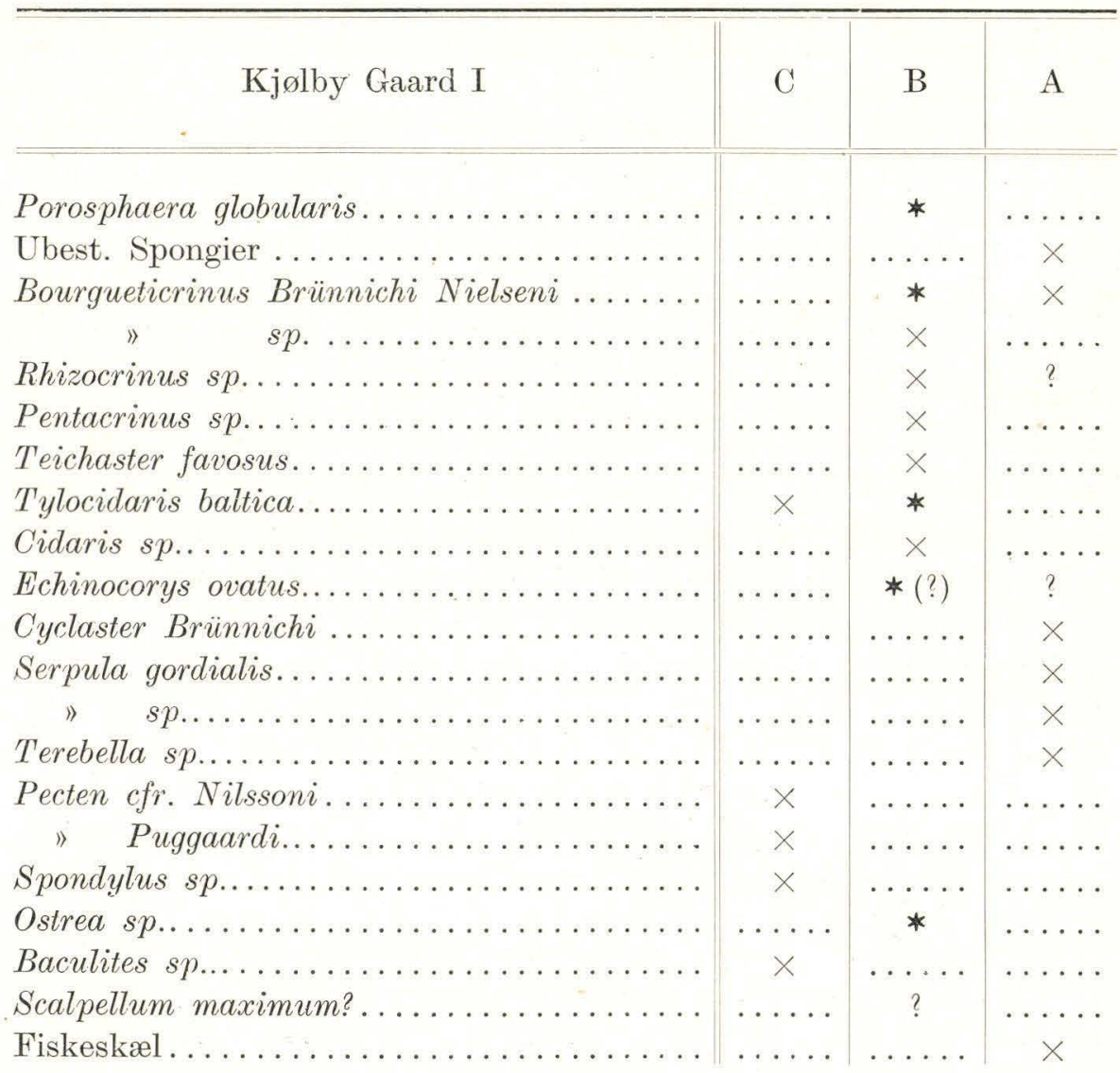

En * betegner, at vedkommende Fossil ligger paa sekundært Leje i Lerlaget; dog maa bemærkes, at dette muligvis gælder endnu flere end de med * betegnede. 


\begin{tabular}{|c|c|c|c|c|}
\hline Nye Kløv & $\begin{array}{l}\overrightarrow{\vec{E}} \\
\frac{\vec{G}}{0} \\
\vec{E} \\
\frac{\vec{G}}{n}\end{array}$ & 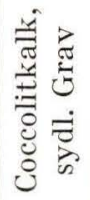 & 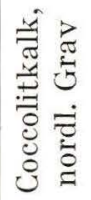 & 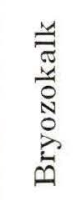 \\
\hline Aphrocallistes sp................... & $\ldots$ & $x$ & $\ldots$ & $\ldots$ \\
\hline Porosphaera umbonata..................... & $\ldots$ & $x$ & $\ldots$ & $\ldots$ \\
\hline 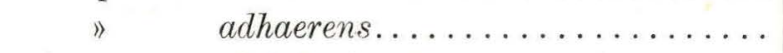 & $\ldots$ & $\ldots$ & $\ldots$ & $x$ \\
\hline 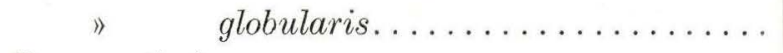 & $\times$ & $\ldots$ & $\ldots$ & $\ldots$ \\
\hline 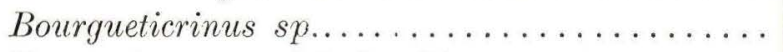 & $\ldots$ & $\times$ & $\ldots$ & $x$ \\
\hline Pentacrinus paucicirrhus-'Typen............. & $\ldots$ & $x$ & $\ldots$ & $\ldots$ \\
\hline 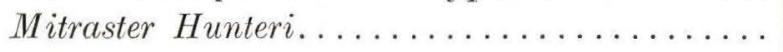 & $\ldots$ & $x$ & $\ldots$ & $\ldots$ \\
\hline Teichaster favosus................... & $\ldots$ & $x$ & $\ldots$ & $x$ \\
\hline Tylocidaris vexillifera $\alpha \ldots \ldots \ldots \ldots \ldots \ldots$ & $\ldots$ & $\ldots$ & $\ldots$ & $x$ \\
\hline 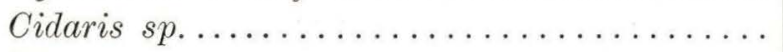 & $\times$ & $\times$ & $\ldots$ & $x$ \\
\hline Phymosoma sp..................... & $\ldots$ & $x$ & $\ldots$ & $x$ \\
\hline Echinocorys sulcatus................... & $\ldots$ & $x$ & $\times$ & $\ldots \ldots$ \\
\hline 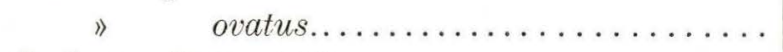 & $\times$ & $x$ & $\ldots$ & $\ldots$ \\
\hline Cyclaster Brünnichi .................. & $\ldots$ & $x$ & $\ldots$ & $x$ \\
\hline 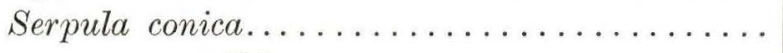 & $x$ & $\ldots$ & $\ldots$ & $\ldots$ \\
\hline 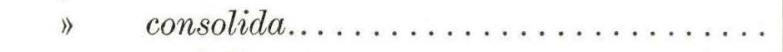 & $\ldots$ & $\cdots$ & $\ldots$ & $\times$ \\
\hline 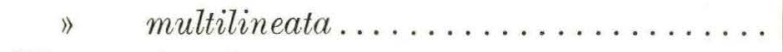 & $\ldots$ & x & $\ldots$ & $\ldots$ \\
\hline 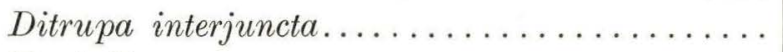 & $\ldots$ & $\ldots$ & $\times$ & $\ldots \ldots$ \\
\hline Terebella $s p . \ldots \ldots \ldots \ldots \ldots \ldots \ldots \ldots \ldots$ & $\ldots$ & $\times$ & $\ldots$ & $\ldots \ldots$ \\
\hline 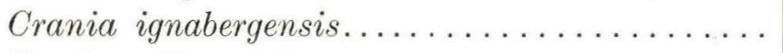 & $\ldots$ & $\ldots$ & $\ldots$ & $x$ \\
\hline 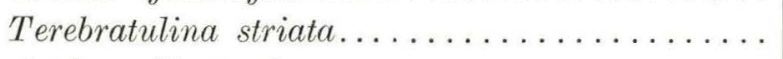 & $\times$ & $\ldots$ & $\ldots$ & $\ldots$ \\
\hline 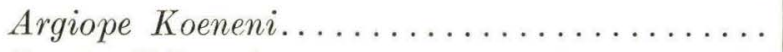 & $\ldots$ & $\times$ & $\ldots$ & $\ldots$ \\
\hline Pecten Nitssoni................ & $\times$ & $\ldots$ & $\ldots$ & $\ldots$ \\
\hline 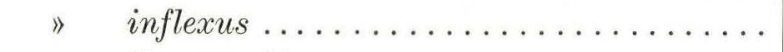 & $x$ & $\ldots$ & $\ldots$ & $\ldots$ \\
\hline 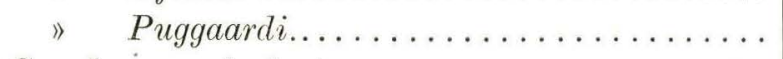 & $x$ & $\ldots$ & $\ldots$ & $\ldots \ldots$ \\
\hline Gryphaea vesicularis .............. & $x$ & $x$ & $\times$ & $\cdots$ \\
\hline 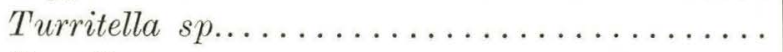 & $\ldots$ & $\ldots$ & $x$ & $\ldots$ \\
\hline 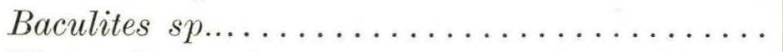 & $\times$ & $\ldots$ & $\ldots$ & $\cdots$ \\
\hline Ubest. Crustacé............ & & & & \\
\hline
\end{tabular}




\begin{tabular}{|c|c|c|c|c|c|c|c|}
\hline Gravlev I & G & $\mathrm{F}$ & $\mathrm{E}$ & $\mathrm{D}$ & C & B & A \\
\hline Porosphaera universa........... & & & & & $x$ & $\ldots$ & $\cdots$ \\
\hline " umbonata........... & & & & & $x$ & ... & $x$ \\
\hline " adhaerens.......... & & & & & $x$ & $\ldots$ & $\times$ \\
\hline Aphrocallistes sp............. & & & & & $x$ & $\ldots$ & $\ldots$ \\
\hline Parasmilia biseriata ............. & & & & & $x$ & $\ldots$ & $\ldots$ \\
\hline$" \quad$ cincta $\ldots \ldots \ldots \ldots \ldots$ & & & & & $x$ & $\ldots$ & $\ldots$ \\
\hline 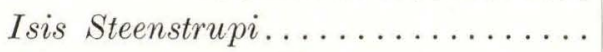 & & & & & $x$ & $\ldots$ & $\ldots$ \\
\hline Bourgueticrinus Hagenowi......... & & * & & & $\ldots$ & & $\ldots$ \\
\hline$» \quad$ danicus.......... & & & & & & $\ldots$ & $x$ \\
\hline Pentacrinus paucicirrhus......... & & & & & $\ldots$ & $\ldots$ & $x$ \\
\hline$\| \quad$ » $\quad$-Typen.... & & & & & $x$ & $\ldots$ & $x$ \\
\hline$" \quad$ longus-Typen........ & & & & & $\ldots$ & $\ldots$ & $x$ \\
\hline$" \quad$ miliaris........... & & & & & $\ldots$ & $\ldots$ & $x$ \\
\hline Metopaster mammilatus typ....... & & & & & $\ldots$ & $\ldots$ & $x$ \\
\hline 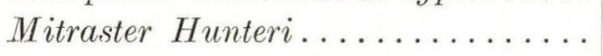 & & & & $\cdots$ & $\ldots$ & $\ldots$ & $x$ \\
\hline Teichaster favosus............... & & & & & x & $\ldots$ & $x$ \\
\hline Chomataster acules .............. & & & & & $\ldots$ & & $x$ \\
\hline Lophidiaster pygmacus........... & & & & & $x$ & $\ldots$ & $\ldots \ldots$ \\
\hline Cidaris subvesiculosa ........... & & & & & $x$ & $\ldots$ & $\ldots$ \\
\hline Tylocidaris vexillifera $\gamma \ldots \ldots \ldots$ & & & & & $x$ & $x$ & $x$ \\
\hline Phymosoma sp............... & & & & & $x$ & $\ldots$ & $x$ \\
\hline Echinocorys sulcatus . ......... & & & & $\ldots$ & $x$ & $\ldots$ & $x$ \\
\hline Cyclaster Brünnichi............ & & & & $x$ & $x$ & & $x$ \\
\hline Serpula gordialis.............. & & & & $\ldots$ & $x$ & $\ldots$ & $x$ \\
\hline Ditrupa interjuncta............. & & & & $\ldots$ & $x$ & $\ldots$ & $x$ \\
\hline 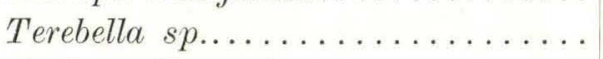 & & & & $x$ & $\ldots$ & $\ldots$ & $\ldots$ \\
\hline Argiope Koeneni............... & & & & $\ldots$ & $x$ & $\ldots$ & $x$ \\
\hline 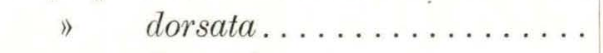 & & & & $\ldots$ & $x$ & $\ldots$ & $x$ \\
\hline 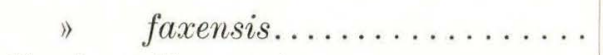 & & & & & $x$ & & $\times$ \\
\hline Terebratulina striata............. & & & & $\ldots$ & $x$ & & $x$ \\
\hline Pecten monotiformis.............. & & & & 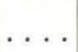 & $\ldots$ & $\ldots$ & $x$ \\
\hline Dimyodon Nilssoni.............. & & & & & $x$ & & $\ldots$ \\
\hline Gryphaea vesicularis............. & & & & $x$ & $x$ & $\ldots$ & $x$ \\
\hline Exogyra canaliculata............ & & & & $\ldots$ & $x$ & & $\ldots$ \\
\hline Arca Forchhammeri............. & & & & & $x$ & $\ldots$ & $\ldots$ \\
\hline Limopsis Höninghausi........... & & & & & $x$ & & $\ldots$ \\
\hline Pholadidea sp................ & & & & & $x$ & & $\ldots$ \\
\hline Cerithium balticum ............ & & & & & $x$ & & $\cdots$ \\
\hline$» \quad s p \ldots \ldots \ldots \ldots \ldots \ldots$ & & & & & $x$ & & . . \\
\hline Pleurotoma cfr. Sleenstrupi........ & & & & & $x$ & & $\cdots$ \\
\hline Cinutia danica............... & & & & & $x$ & & $\cdots$ \\
\hline Tornatina sp............... & & & & $\ldots$ & $x$ & $\ldots$ & $\ldots$ \\
\hline Baculites sp............... & $x$ & & & & & & \\
\hline
\end{tabular}

* sekundært Leje. 


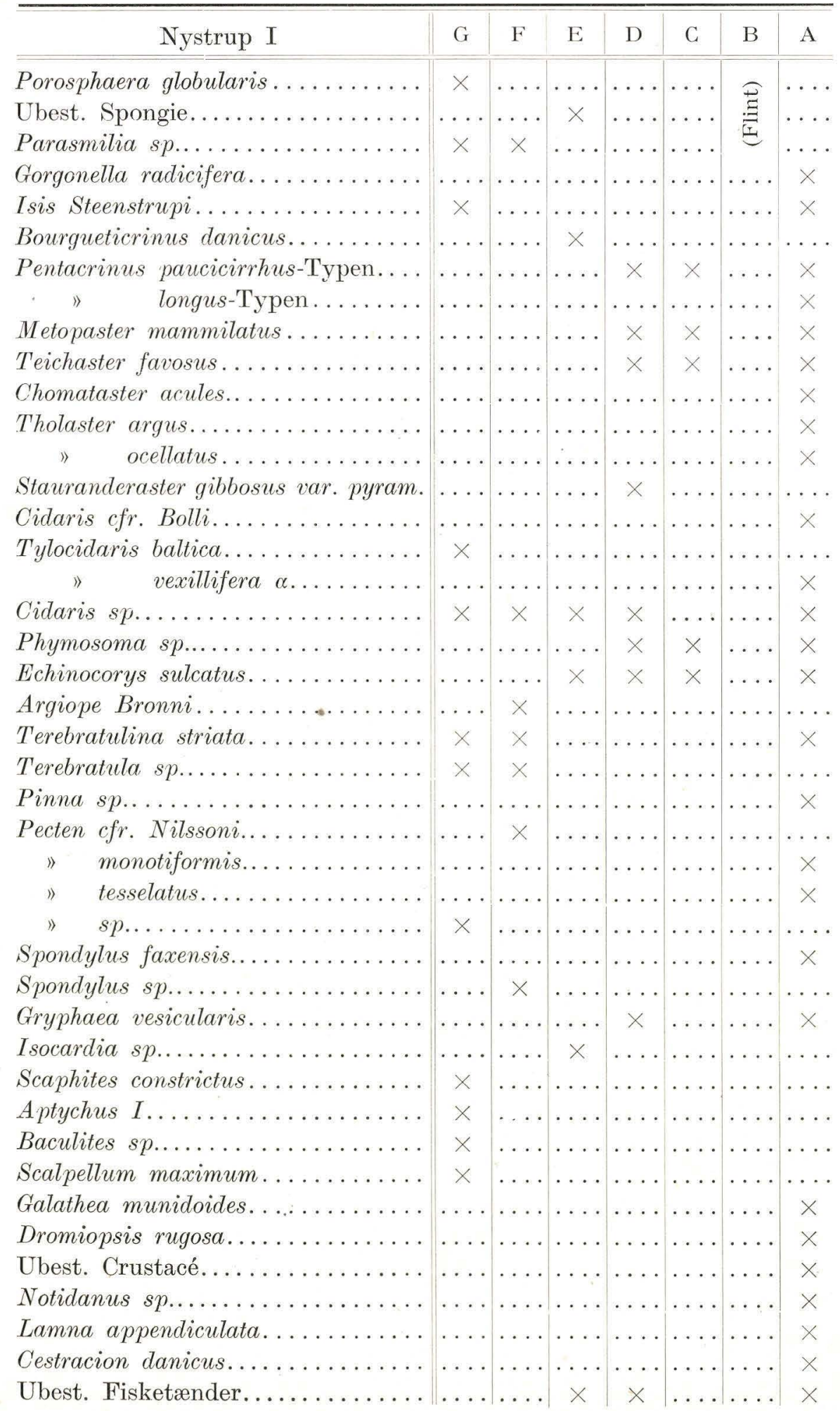




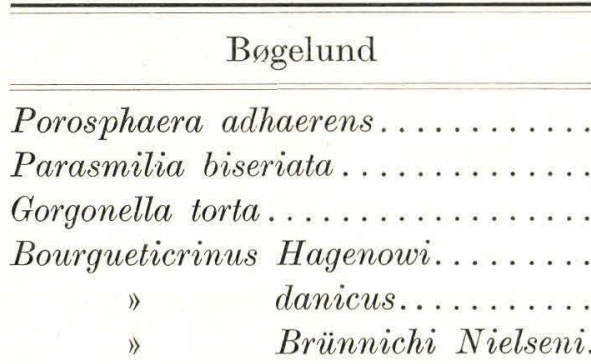

Pentacrinus paucicirrhus-Typen.

Tylocidaris baltica.

$$
\text { 》vexillifera } \left.\alpha^{1}\right) \text {. }
$$

Cidaris sp..

Phymosoma sp...

Echinocorys sulcatus.

"sp. (ovatus?)

Cyclaster Brünnichi.

Serpula gordialis.

» multilineata

Ditrupa interjuncta.

Crania ignabergensis.

Rhynchonella retracta

Terebratula fallax tenuis.

Terebratulina striata.

$$
\text { » semiglobularis }{ }^{2} \text { ). }
$$

Argiope Koeneni.

$$
\begin{aligned}
& \text { » } \\
& \text { Posselti. } \\
& \text { dorsata. } \\
& \text { faxensis }
\end{aligned}
$$

Avicula danica.

Pecten monotiformis...

"Nilssoni.

"spathulatus.

" pulchellus.

\Puggaardi.

Dimyodon Nilssoni.

Spondylus sp.

Ostrea semiplana.

Gryphaea vesicularis.

Exogyra canaticulata.

Gyropleura Münsteri.

Isocardia sp.

Fusus sp.

Scaphites constrictus.

Scyllium sp...

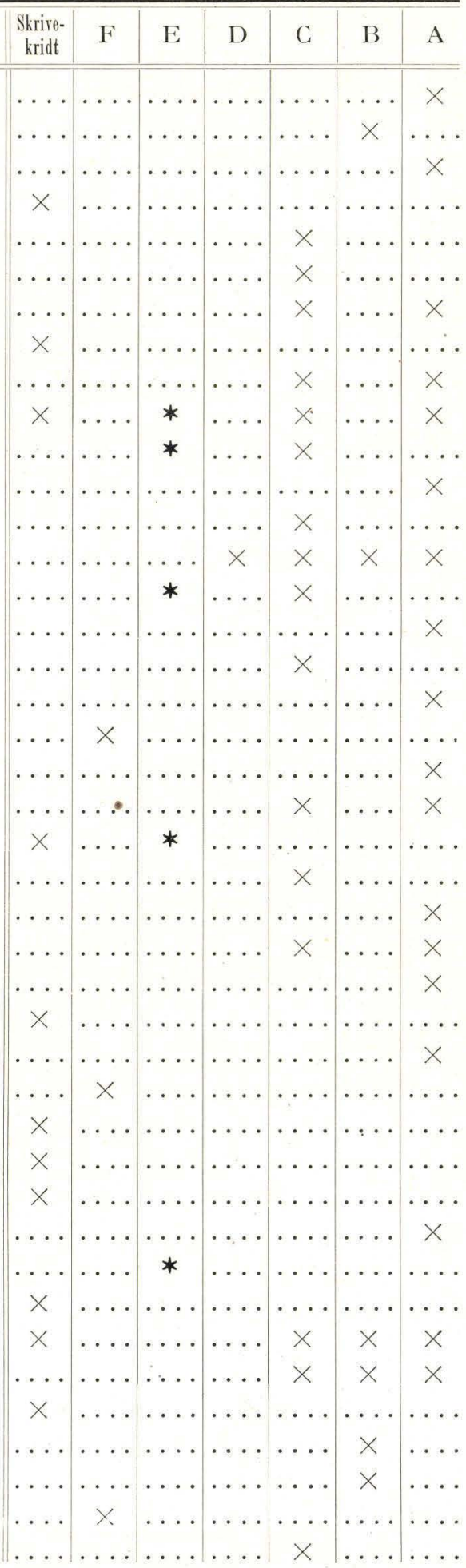

* sekundært Leje. - ${ }^{1}$ ) Ekspl. fra Lag C tilhører muligvis t. $\gamma$. 2) Ekspl. fra Lag E ligger muligvis paa primært Leje. 


\begin{tabular}{|c|c|c|c|c|c|c|c|c|}
\hline Skillingbro & G & $\begin{array}{c}0 \\
0 \\
0 \\
0 \\
1 \\
\Xi \\
0 \\
0 \\
\Xi \\
\Xi \\
\Xi\end{array}$ & $\mathrm{F}$ & E & D & C. & B & A \\
\hline Porosphaera adhaerens............. & $\cdots$ & $x$ & $\cdots$ & $\cdots$ & $\cdots$ & $\cdots$ & $\cdots$ & $\cdots$ \\
\hline Pentacrinus paucicirrhus-Typen $\left.{ }^{1}\right) \ldots .$. & $x$ & $x$ & . & $\cdots$ & . & $x$ & $x$ & $x$ \\
\hline$s p \ldots \ldots \ldots \ldots \ldots$ & . & $x$ & . & . & . & . & . & . \\
\hline Bourgueticrinus sp.? (Stilkled)........ & . & $x$ & . & $\ldots$ & . & $\cdots$ & . & $\cdots$ \\
\hline Metopaster mammilatus............ & $\cdots$ & $x$ & $\cdots$ & $x$ & $\cdots$ & $\cdots$ & $\cdots$ & . \\
\hline Teichaster favosus $\left.{ }^{2}\right) \ldots \ldots \ldots \ldots \ldots$ & $\cdots$ & $\cdots$ & $\cdots$ & . & $\cdots$ & . & $\cdots$ & . \\
\hline Tylocidaris vexillifera $\alpha \ldots \ldots \ldots \ldots$ & $x$ & $\cdots$ & $\cdots$ & $\cdots$ & $\cdots$ & . & . & . \\
\hline 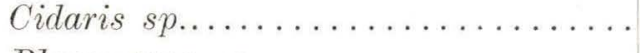 & $\cdots$ & $x$ & $\cdots$ & $\cdots$ & $x$ & $\cdots$ & $\cdots$ & . \\
\hline Phymosoma sp................... & $\cdots$ & $x$ & $\cdots$ & . & $\cdots$ & . & $\cdots$ & . \\
\hline Echinocorys sulcatus.............. & $x$ & . & $x$ & x & $x$ & . & $\cdots$ & . \\
\hline Brissopneustes danicus $\left.{ }^{3}\right) \ldots \ldots \ldots \ldots$ & . & $\cdots$ & $\cdots$ & . & . & $\cdots$ & . & . \\
\hline Serpula gordialis $\left.{ }^{4}\right) \ldots \ldots \ldots \ldots$ & $\cdots$ & $\cdots$ & $\cdots$ & . & $\cdots$ & $\cdots$ & $\cdots$ & . \\
\hline$" \quad$ laevicollis................ & $\cdots$ & $\cdots$ & $\cdots$ & . & $x$ & $\cdots$ & . & . \\
\hline$" \quad$ quinquedentata............ & . & $x$ & . & . & . & . & . & . \\
\hline$" \quad$ distincta $\ldots \ldots \ldots \ldots \ldots$ & $\cdots$ & $x$ & $\cdots$ & . & $\cdots$ & $\cdots$ & . & . \\
\hline${ } \operatorname{erecta}_{\ldots} \ldots \ldots \ldots \ldots \ldots \ldots$ & $\cdots$ & $x$ & $\cdots$ & . & $\cdots$ & . & $\cdots$ & . \\
\hline 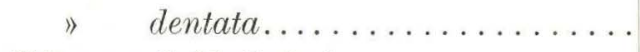 & . & . & . & . . & . & X & . & . \\
\hline Ditrupa Schlotheimi.............. & $\cdots$ & $\cdots$ & $\cdots$ & . & . & $x$ & . & . \\
\hline Terebella sp......... & $\cdots$ & $\cdots$ & $x$ & . & . & . & $\cdots$ & . \\
\hline Argiope Koeneni $\left.{ }^{5}\right) \ldots \ldots \ldots \ldots$ & . & . & . & . & . & . & $\cdots$ & . \\
\hline Terebratulina striata............... & x & $x$ & . & . & $x$ & . & x & x \\
\hline Terebratula lens................... & $\cdots$ & $\cdots$ & $\cdots$ & . & $x$ & $x$ & $x$ & $x$ \\
\hline fallax tenuis............. & $x$ & $x$ & $x$ & $x$ & $\times$ & . & . & . \\
\hline » $\left.\quad s p \cdot{ }^{6}\right) \ldots \ldots \ldots \ldots \ldots$ & $\cdots$ & $\cdots$ & . & . & . & . & . & . \\
\hline Pecten tesselatus $\left.{ }^{7}\right) \ldots \ldots \ldots \ldots \ldots$ & . & . & . & $\cdots$ & . & . & . & . \\
\hline Spondylus danicus................ & $x$ & $\cdots$ & . & . & . & $\cdots$ & $\cdots$ & . \\
\hline$\left.» \quad s p .^{8}\right) \ldots \ldots \ldots \ldots \ldots \ldots$ & $x$ & . & . & . & $\cdots$ & . & . & . \\
\hline Dimyodon Nilssoni............... & . & . & . & . & $x$ & . & . & . \\
\hline Gryphaea vesicularis............... & $x$ & $x$ & $x$ & $x$ & $x$ & $x$ & $x$ & $x$ \\
\hline Exogyra canaticulata.............. & . & $\cdots$ & $x$ & x & $x$ & $\cdots$ & . & . \\
\hline Pleurotoma niloticiformis? $\left.{ }^{9}\right) \ldots \ldots \ldots \ldots$ & $\cdots$ & $\cdots$ & $\cdots$ & $\cdots$ & $\cdots$ & $\cdots$ & - & $\cdots$ \\
\hline Lamna appendiculata $\left.{ }^{10}\right) \ldots \ldots \ldots \ldots$ & $\cdots$ & $\cdots$ & $\cdots$ & $\cdots$ & $\cdots$ & $\cdots$ & $\cdots$ & $\cdots$ \\
\hline Fiskeskæel. . . . . . . . . . . . . . . . . & . & $\ldots$ & $x$ & $x$ & . . & . & . & . \\
\hline
\end{tabular}

$\left.{ }^{1}\right)$ desuden fra D, E eller F. — ${ }^{2}$ ) fra ubestemt Lag. — ${ }^{3}$ ) fra E eller F-G. ${ }^{4}$ ) fra A, B eller C. - ${ }^{5}$ ) fra A, B, C eller D, samt fra D, E eller F. — ${ }^{6}$ ) fra E eller F-G. - ${ }^{7}$ ) fra $E$ eller $F-G .-{ }^{8}$ ) samt D, E eller F. - ${ }^{9}$ ) fra A, B, C eller D. - ${ }^{10}$ ) fra A, B. C eller D. 


\begin{tabular}{|c|c|c|c|c|c|c|c|c|c|c|c|c|c|}
\hline \multirow[b]{2}{*}{ - } & & \multicolumn{5}{|c|}{ Hvalløse I } & \multicolumn{4}{|c|}{ Svejstrup I } & \multicolumn{3}{|c|}{$\begin{array}{l}\text { Ebel- } \\
\text { toft II }\end{array}$} \\
\hline & & 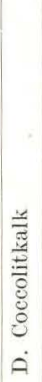 & 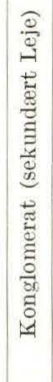 & 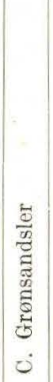 & 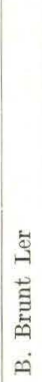 & 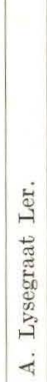 & (1) & 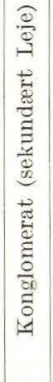 & 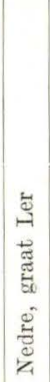 & 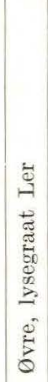 & 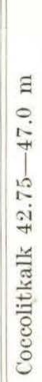 & 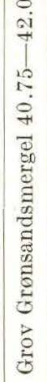 & 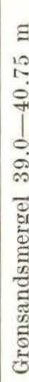 \\
\hline
\end{tabular}

Trochocyathus calcitrapa Koen

Ceratotrochus Milthersi.

Graphularia Grönwalli.

Bourgueticrinus danicus............

Rhizocrinus maximus.

Teichaster favosus.

Lophidiaster pygmaeus.

Tylocidaris vexillifera $\beta$

Cidaris sp.

Phymosoma sp.

Echinocorys sulcatus.

Brissopneustes sp...

Serpula gordialis.

"dentata.

Ditrupa Schlotheimi.

Terebratula lens.

Lima testis.

Pecten Prestwichi Koen.

" bisculptus Koen...

Gryphaea vesicularis.

Exogyra canaliculata.

Crenella sphaericula.

Nucula densistria Koen.

Leda crassistria Koen.

" ovoides Koen.

Arca limopsis Koen.

" praescabra Koen...

Cucullaea Dewalquei Koen.

Astarte trigonula Koen.

Dentatium undiferum Koen...

" rugiferum Koen 


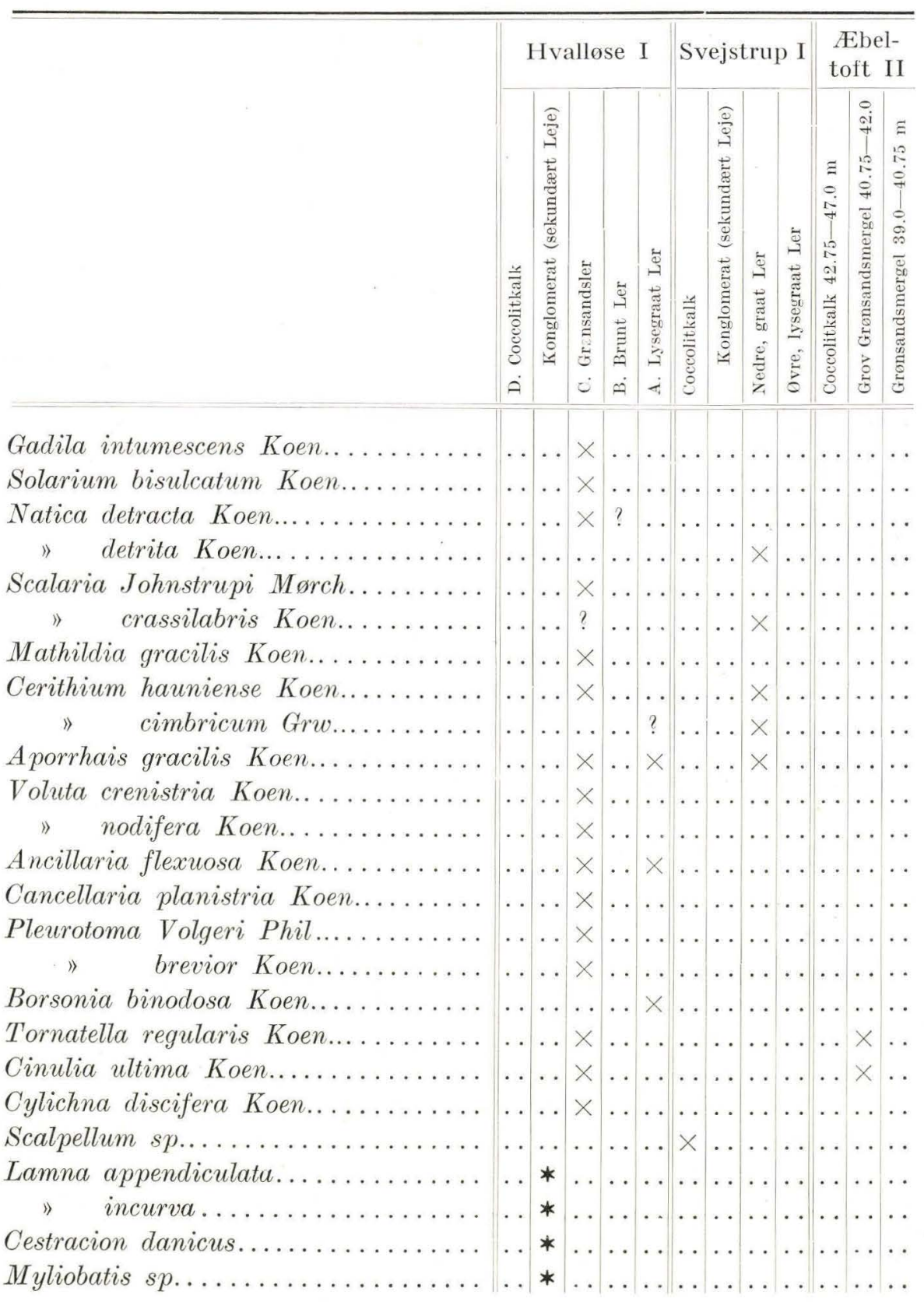

Myliobatis sp.

* Paa sekundært Leje. 
1. Graphularia Grönwalli.

2. Serpula Hisingeri.

3. Crania tuberculata typ.

4. Argiope scabricula.

5. " Johnstrupi.

6. " Cimbrorum.

7. Terebratula fallax typ.

8. Lima testis.

9. " bisulcata.

10. Plicatula Ravni.

11. Ceratotrochus saltholmensis

12. Isis vertebralis.

13. Tylocidaris vexillifera $\beta$...

14. Brissopneustes suecicus.

15. Serpula dentata.

16. " undulifera.

17. Ditrupa Schlotheimi.

18. Rhynchonella incurva typ...

19. Terebratula lens.

20. Scalpellum Steenstrupi.........

21. Metopaster mammilatus typ

22. Brissopneustes danicus...

23. Serpula distincta.

24. " erecta.

25. Rhynchonella incurva fax.

26. Terebratula fallax tenuis.

27. Epitrochus vermiformis.

28. Tylocidaris vexillifera

$29 . \quad 》$

30. Cyclaster Brünnichi

31. Echinocorys ovatus. 


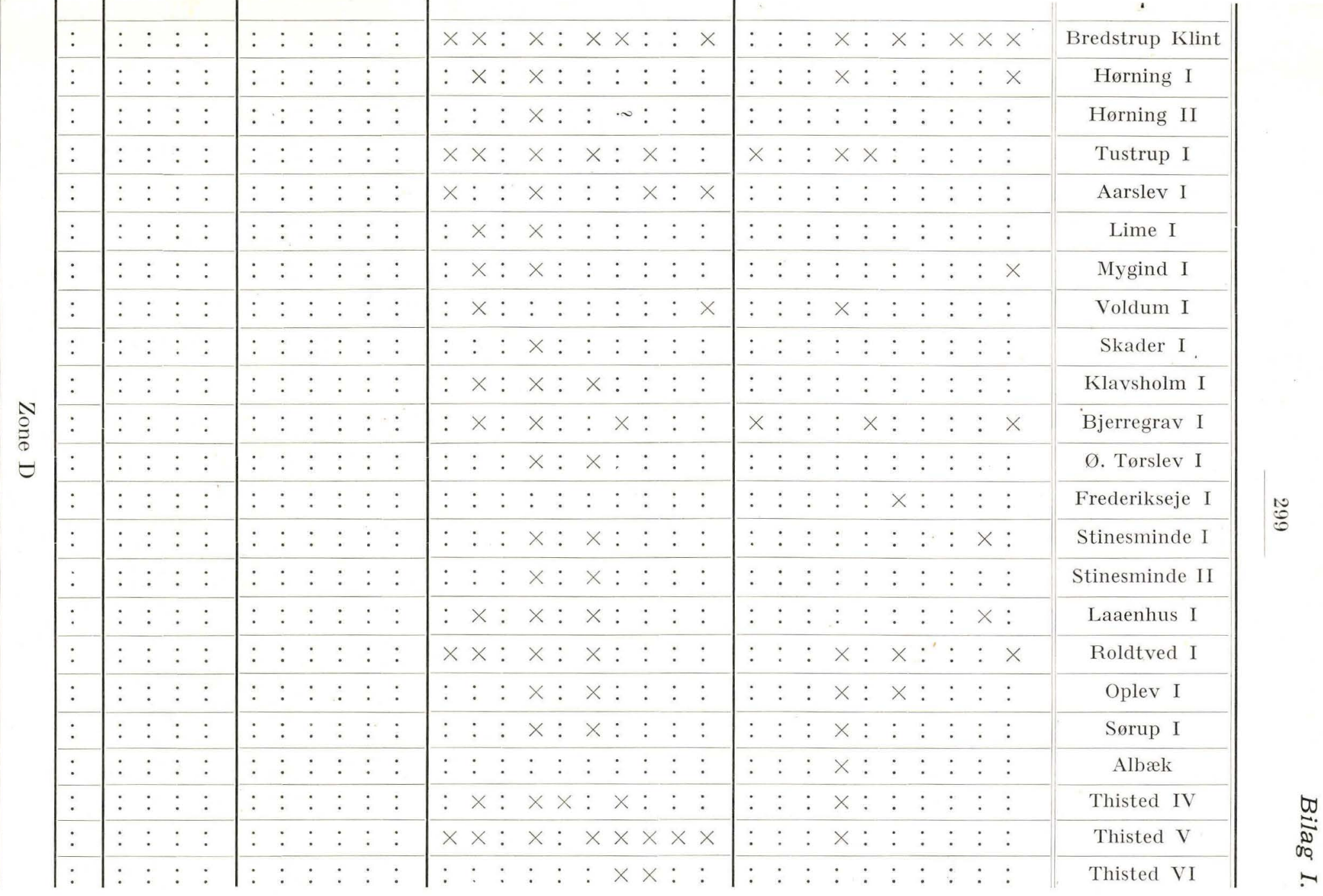


1. Graphularia Grönwalli.

2. Serpula Hisingeri. .

3. Crania tuberculata typ...

4. Argiope scabricula..

$5 . \quad 》$

Johnstrupi.

6. "

Cimbrorum.

7. Terebratula fallax typ.

8. Lima testis. .

9. \ bisulcata.

10. Plicatula Ravni.

11. Ceratotrochus saltholmensis.

12. Isis vertebralis.

13. Tylocidaris vexillifera $\beta$

14. Brissopneustes suecicus.

15. Serpula dentata

16. " undulifera...

17. Ditrupa Schlotheimi.

18. Rhynchonella incurva typ

19. Terebratula lens.

20. Scalpellum Steenstrupi.

21. Metopaster mammilatus typ.

22. Brissopneustes danicus.

23. Serpula distincta.

24. " erecta.

25. Rhynchonella incurva fax.

26. Terebratula fallax tenuis.

27. Epitrochus vermiformis

28. Tylocidaris vexillifera

29.

30. Cyclaster Brünnichi.

31. Echinocorys ovatus. 


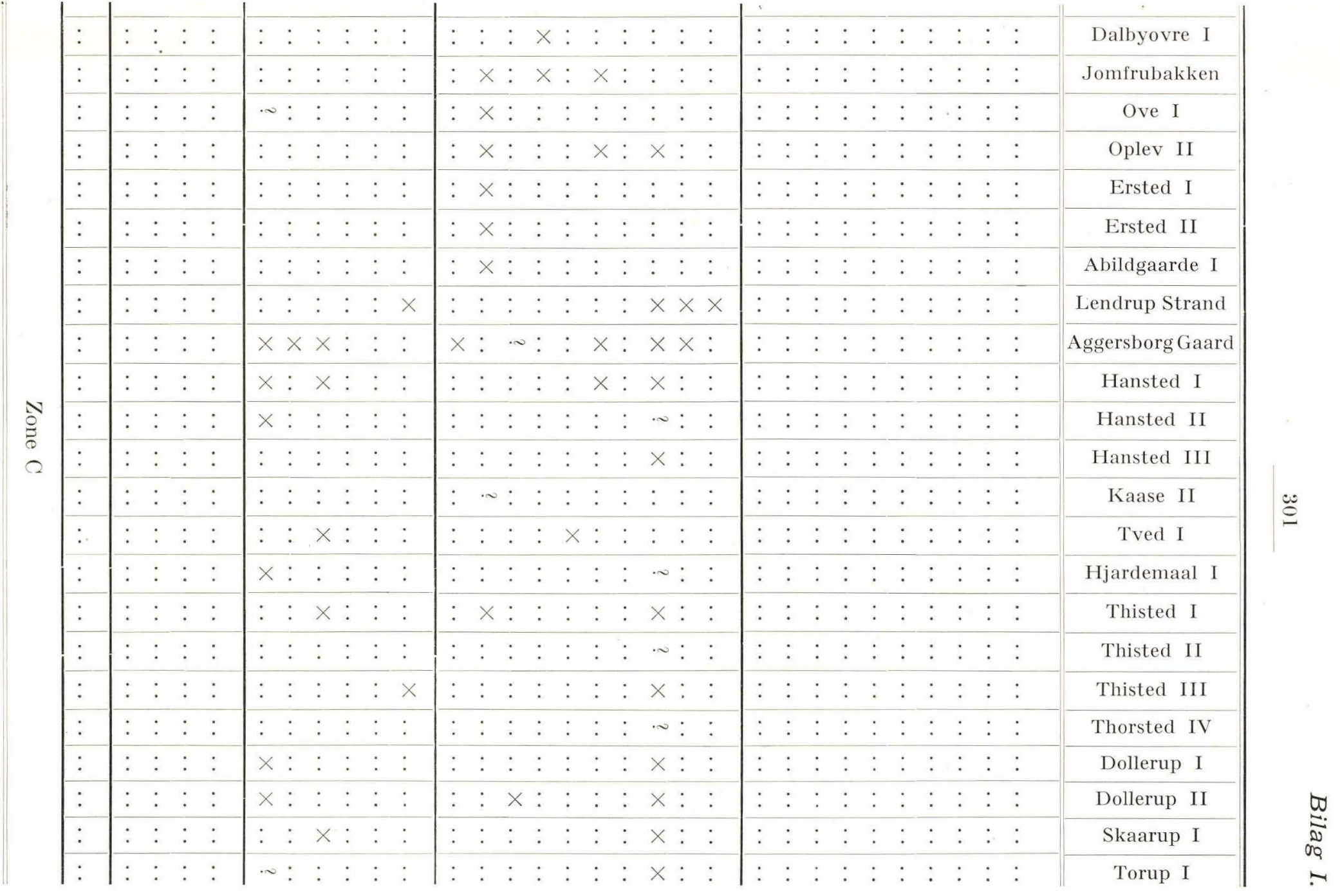




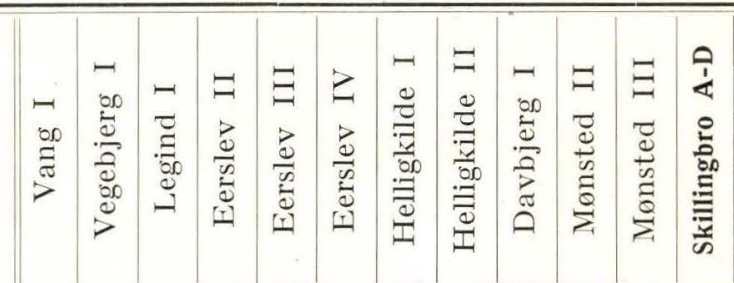

1. Graphularia Grönwalli.

2. Serpula Hisingeri.

3. Crania tuberculata typ...

4. Argiope scabricula.

5. \ Johnstrupi.

6. " Cimbrorum.

7. Terebratula fallax typ

8. Lima testis.

9. " bisulcata.

10. Plicatula Ravni.

11. Ceratotrochus saltholmensis

12. Isis vertebratis

13. Tylocidaris vexillifera $\beta$

14. Brissopneustes suecicus...

15. Serpula dentata.

16. \ undulifera

17. Ditrupa Schlotheimi

18. Rhynchonella incurva typ.

19. Terebratula lens.

20. Scalpellum Steenstrupi.

21. Metopaster mammilatus typ.

22. Brissopneustes danicus

23. Serpula distincta.

24.

erecta.

25. Rhynchonella incurva fax.

26. Terebratula fallax tenuis.

27. Epitrochus vermiformis

28. Tylocidaris vexillifera

29.

30. Cyclaster Brünnichi.

31. Echinocorys ovatus

Zone C 


\begin{tabular}{|c|c|c|c|c|c|c|c|c|c|c|c|c|c|c|c|c|c|c|c|c|c|c|c|c|c|c|c|c|c|c|c|}
\hline \multirow{23}{*}{ 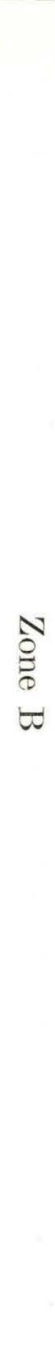 } & : & : & : & $x$ & & $\times:$ & $x$ & $x$ & $x$ & & : & : & : & : & : & : & $\therefore$ & : & : & : & : & $:$ & : & : & $:$ & : & : & : & : & : & Skillingbro E-G \\
\hline & : & : & : & $x:$ & & $x \times$ & $x$ & : & $x$ & & $:$ & $:$ & : & : & : & : & : & : & : & : & : & : & : & : & $:$ & : & : & $:$ & : & : & Sangstrup Klint \\
\hline & : & : & $x$ & $x:$ & & $\times \times$ & : & : & $x$ & & : & $:$ & $:$ & $:$ & : & : & : & : & : & $:$ & : & : & : & : & : & : & : & : & : : & : & Karlby Klint \\
\hline & : & : & : & $x:$ & & $\times:$ & : & : & : & & : & : & : & : & : & $:$ & : & : & : & : & : & : & : & : & : & : & : & : & : & : & Stensmark \\
\hline & : & : & : & $x:$ & & $\times \times$ & x & $x$ & $x$ & & : & : & : & : & : & : & : & : & : & : & : & : & : & : & : & : & : & : & : & : & Raasted I \\
\hline & : & : & : & $x:$ & & $x \times$ & : & : & $:$ & & : & $:$ & : & : & : & $:$ & : & : & : & : & : & : & : & : & : & : & : & : & : & : & Purhus III \\
\hline & : & $:$ & : & $::$ & & $\times:$ & $x$ & : & $x$ & & : & $:$ & $:$ & : & : & $:$ & : & $:$ & $:$ & : & : & : & : & : & : & : & : & : & $:$ : & : & Kastbjerg I \\
\hline & : & : & : & $x:$ & & $\times:$ & : & : & : & & : & $:$ & $:$ & : & : & : & : & : & : & : & : & $:$ & : & : & : & : & : & : & $:$ : & : & Ove II \\
\hline & : & : & : & $x:$ & & $\times:$ & : & : & $x$ & & : & $\vdots$ & : & : & : & : & : & : & : & $:$ & : & : & : & : & : & : & : & : & $:$ : & : & Ove III \\
\hline & : & : & : & $::$ & & $\times:$ & : & : & : & & : & : & $:$ & : & : & $:$ & : & : & : & : & : & : & : & : & : & : & : & : & : & : & Ove IV \\
\hline & : & $:$ & : & $x:$ & & $\times \times$ & : & : & : & & : & : & : & : & : & : & : & : & $:$ & : & : & : & : & : & : & : & : & : & $:$ : & : & Tinbæk Mølle \\
\hline & $:$ & : & : & $x:$ & & $\times:$ & : & : & $:$ & $\times$ & : & : & $:$ & : & : & $:$ & : & : & : & : & : & : & : & : & : & : & : & : & : & : & Ø. Hornum I \\
\hline & : & : & : & $x:$ & & $\times \times$ & : & : & $:$ & $x$ & : & $:$ & $:$ & : & : & : & : & $:$ & : & : & : & : & : & : & : & : & : & : & : : & : & Veggerbro I \\
\hline & : & : & : & $x:$ & & $\times \times$ & : & x & $:$ & & $:$ & : & : & : & : & : & : & : & : & : & : & : & : & : & : & : & : & : & : & : & Valsted I \\
\hline & : & : & $x$ & $x:$ & & $\times:$ & : & : & $:$ & & : & : & : & : & : & : & : & : & : & : & : & : & : & : & : & : & : & : & $:$ : & : & Barmer I \\
\hline & : & : & : & $x:$ & & $x:$ & : & $\sim$ & $:$ & $x$ & : & : & : & : & : & $:$ & : & : & : & : & : & : & : & : & : & : & : & : & $:$ : & : & Farstrup I \\
\hline & : & : & : & $\times:$ & & $\times \times$ & : & : & $:$ & $x$ & : & : & : & : & : & $:$ & $:$ & : & $:$ & : & : & : & : & $:$ & : & : & : & : & $::$ & : & Kjølby I \\
\hline & : & : & : & $x$ & & x: & $x$ & $x$ & $:$ & & : & : & : & : & : & : & : & : & $:$ & : & : & : & : & : & : & : & : & : & $:$ : & : & Kjølby II \\
\hline & : & : & : & $\times:$ & & $\times \times$ & : & : & : & & : & : & : & : & : & : & : & : & : & : & : & : & : & : & : & : & : & : & : & : & Brøndum I \\
\hline & : & : & : & $:$ : & & $: \times$ & : & $x$ & $:$ & $x$ & $:$ & : & $:$ & : & : & : & : & : & $:$ & $:$ & : & $:$ & : & : & : & : & : & : & : & : & Lundgaard I \\
\hline & : & : & : & $x:$ & & $\times \times$ & : & : & $x$ & $x$ & : & : & : & : & : & : & : & : & : & : & $:$ & : & : & $:$ & : & : & : & : & : & : & Munksjørup I \\
\hline & : & : & : & $x:$ & & $::$ & : & : & : & : & : & : & $:$ & : & : & $:$ & : & : & : & : & : & : & : & : & : & : & : & : & : & : & Vindblæs I \\
\hline & : & & : & $x:$ & & $\times \times$ & : & $x$ & $:$ & $x$ & : & & : & : & : & : & : & : & : & . & . & & : & & : & & & & & & Logsted I \\
\hline
\end{tabular}




WIn

1. Graphularia Grönwalli.

2. Serpula Hisingeri.

3. Crania tuberculata typ.

4. Argiope scabricula.

5. " Johnstrupi. ...

6. " Cimbrorum.

7. Terebratula fallax typ.

8. Lima testis.

9. " bisulcata.

10. Plicatula Ravni...

11. Ceratotrochus saltholmensis

12. Isis vertebralis.

13. Tylocidaris vexillifera $\beta$.

14. Brissopneustes suecicus

15. Serpula dentata.

16. \ undulifera

17. Ditrupa Schlotheimi.

18. Rhynchonella incurva typ...

19. Terebratula lens.

20. Scalpellum Steenstrupi.

21. Metopaster mammilatus typ.

22. Brissopneustes danicus...

23. Serpula distincta

24. 》 erecta

25. Rhynchonella incurva fax...

26. Terebratula fallax tenuis.

27. Epitrochus vermiformis

28. Tylocidaris vexillifera $\alpha$

29.

》)

30. Cyclaster Brünnichi.

31. Echinocorys ovatus.

Zone B 


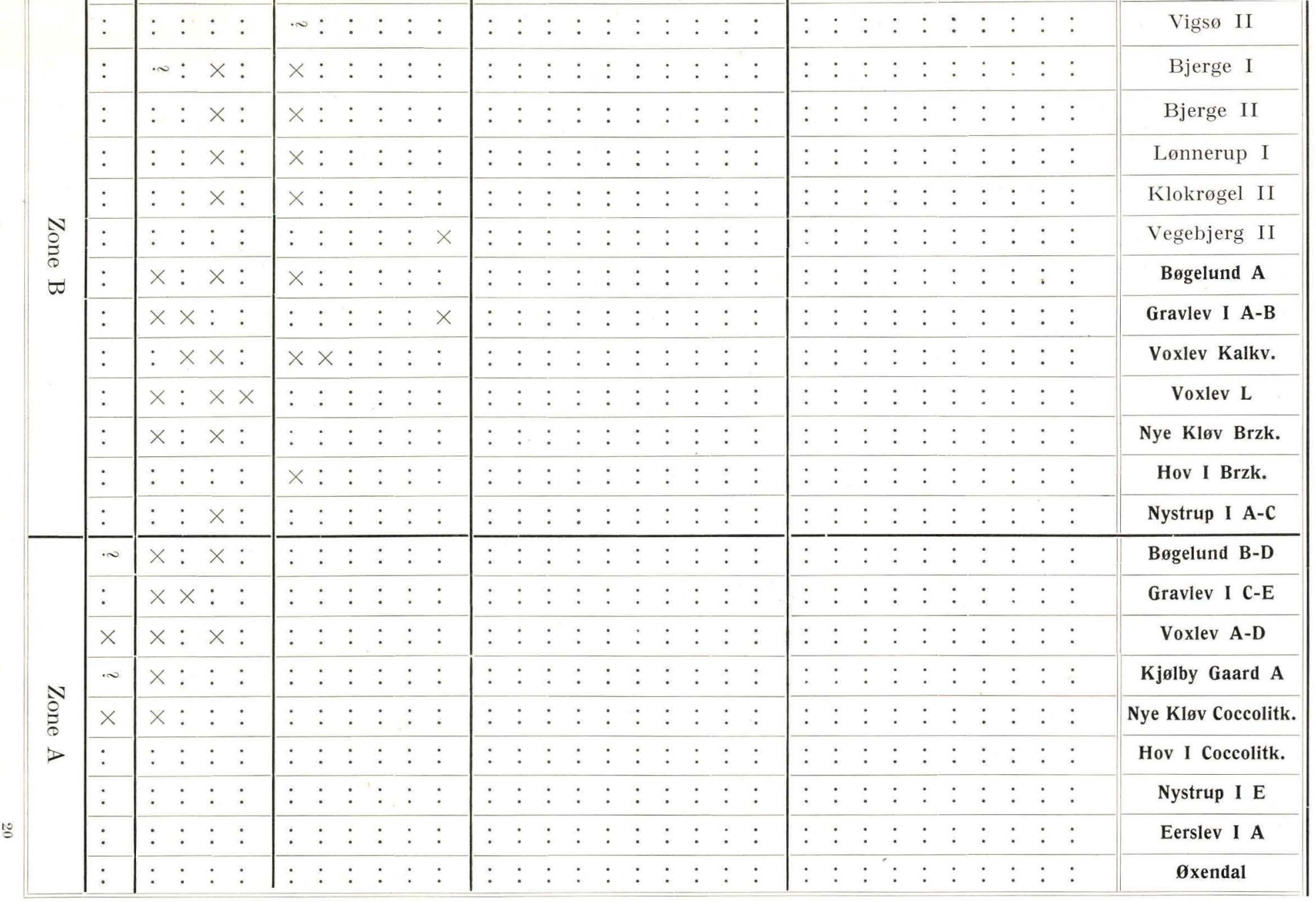




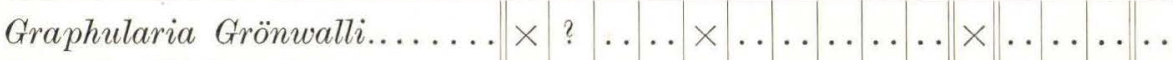

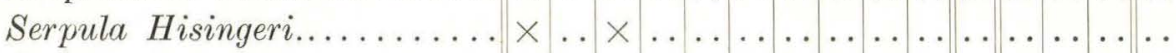
Crania tuberculata typ...... $\times \ldots \times$ ? $\times \times \times \times \times \times \ldots \ldots \ldots \ldots$

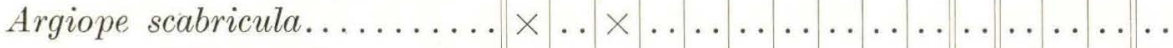
${ }^{\prime}$ Johnstrupi........... $\ldots \ldots \ldots \ldots \ldots \ldots \ldots \ldots \ldots \ldots$ " Cimbrorum.................................

T'erebratula fallax typ......... $\ldots \ldots \times \times \times \ldots \times \ldots \ldots \ldots \ldots$ Lima testis............. . . $\times \ldots \ldots \ldots \ldots \ldots \ldots \ldots \ldots$ " bisulcata......... . . . . . . . . . . . . . .

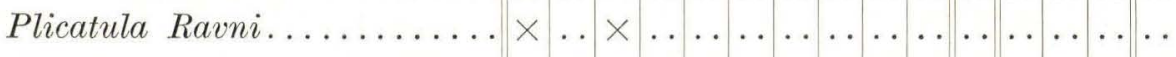

Ceratotrochus saltholmensis... $. \times \ldots \times \ldots \times \times \ldots \ldots \ldots \ldots \ldots \ldots \ldots$ Isis vertebratis............ $\ldots \times \ldots \ldots \ldots \ldots \times \ldots \ldots \ldots$ Tylocidaris vexillifera $\beta \ldots \ldots \times \ldots \times \times \ldots \ldots \ldots \ldots \ldots \ldots \ldots$ Brissopneustes suecicus..... $\times \ldots \times \times \ldots \ldots \ldots \ldots \ldots \ldots \ldots$ Serpula dentata.......... $\ldots \ldots \ldots \ldots \ldots \ldots \ldots \ldots \ldots$

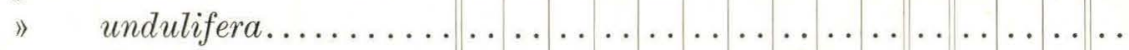
Ditrupa Schlotheimi........ $. \ldots \times \ldots \times \ldots \ldots \ldots \ldots \ldots \ldots$ Rhynchonella incurva typ....... $\ldots \ldots \times$ ? . . . . . $\ldots \ldots \ldots \ldots \ldots$ Terebratula lens.......... $\times \times \times \ldots \times \times \times \ldots \times \ldots \ldots \ldots \ldots$

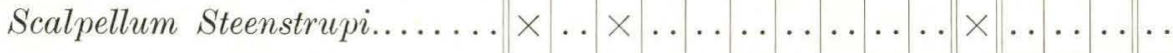

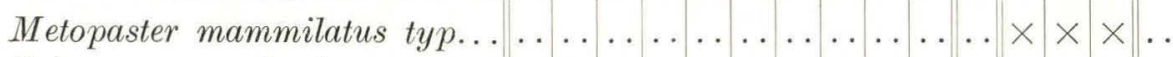
Brissopneustes danicus........................... . . . .

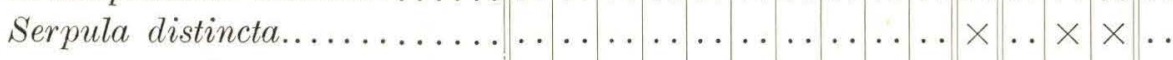

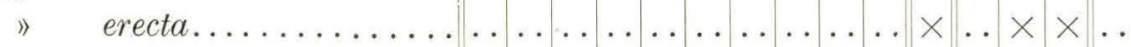

Rhynchonella incurva faxensis

Terebratula fallax tenuis.........................$\times \times \times \times$. .

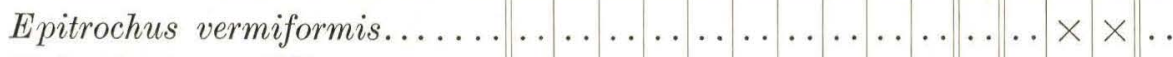
Tylocidaris vexillifera $\alpha \ldots \ldots \ldots \ldots \ldots \ldots \ldots \ldots \ldots \ldots \ldots \times \times \times \ldots$

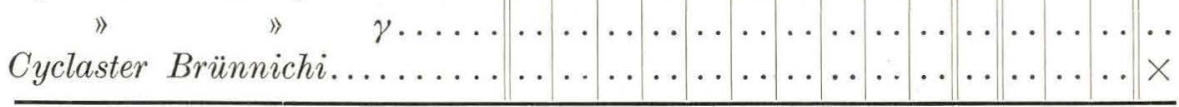

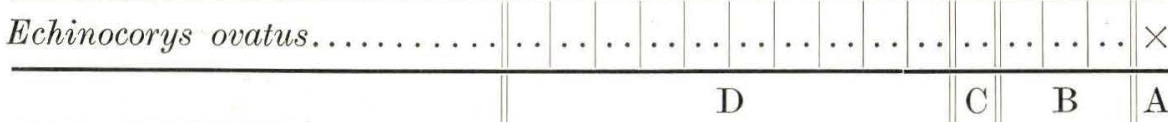

1) Alle københavnske "Nedre Craniakalk«-Lokaliteter under eet.

Oplysningerne om Serpula distincta og S. erecta skyldes Hr. Dr. BRÜNNICH Nielsen; om Cylaster Brünnichi og om Brissopneustes suecicus fra Aashøj (tidligere bestemt som B. danicus (96)) Hr. Museumsinspektør Ravn. 


\section{Tavle I.}

Fig. 1. Tylocidaris vexillifera Schlüter forma a n. f.......... 159 a-e: Bulbjerg.

f-h: Kjølby II.

$-2$.

- 3 . Schliuter forma $\beta$ n. $f$

a: Thisted VI.

b: Tustrup I.

c-f: Dollerup I.

g: Mønsted III.

h: Sevel I.

i: Sevel I; fra Fladen og fra Kanten.

Schlüter forma $\gamma n . f . \ldots \ldots \ldots . \ldots . . \ldots 159$ a: Gravlev I C.

b-d: Barmer I.

Alle i naturlig Størrelse.

Originalerne tilhører DanMarks GEOLOGISKE UNDERSøgELSE. 
Tavle I.

D. G. U. II R. Nr. 45.
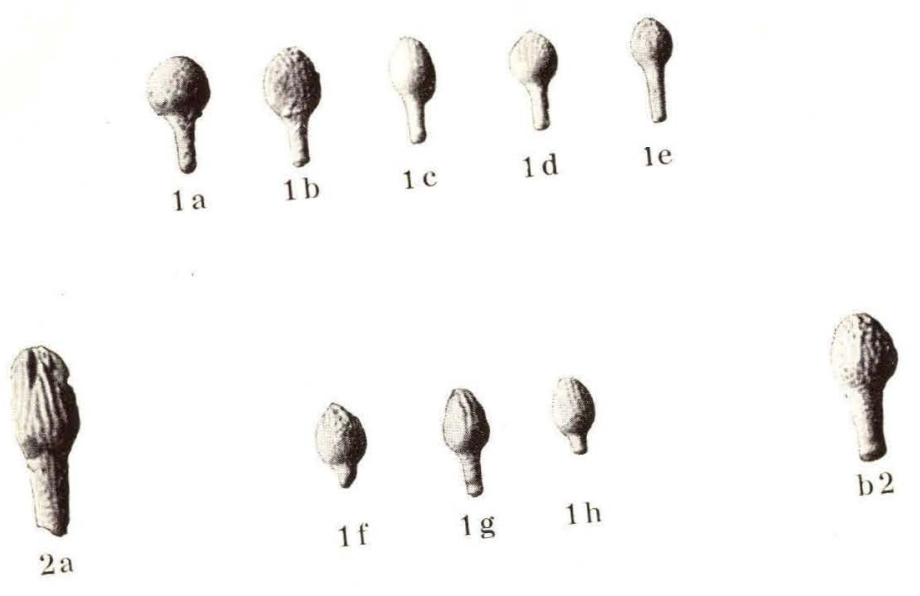

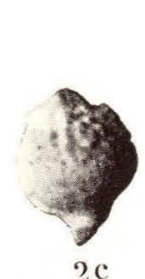

gc
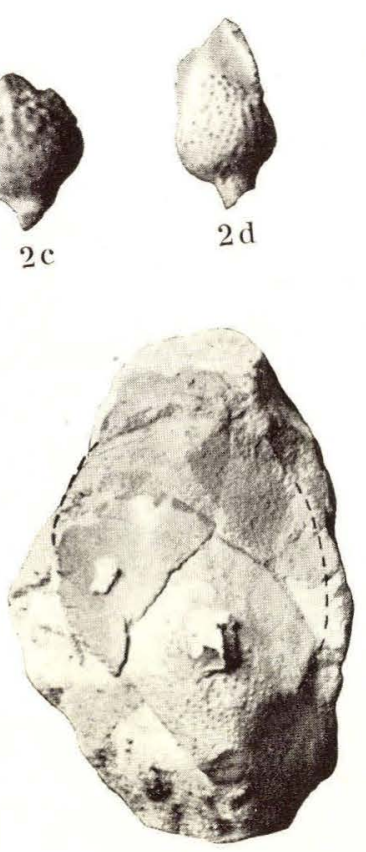

$2 \mathrm{~h}$

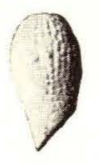

3 a

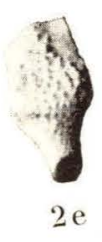

e
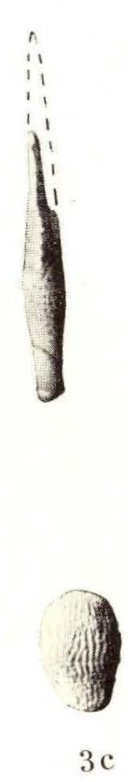
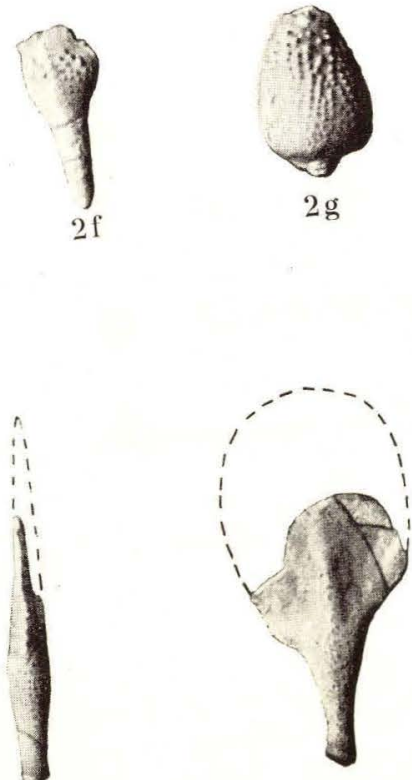

$2 \mathrm{i}$
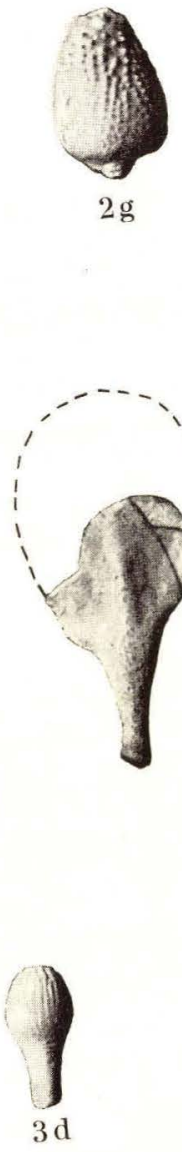


\section{Tavle II.}

Fig. 1 a. Micraster Desori n. sp. København (Knippelsbro); ovenfra. 1:1. 162 - b. " " . Purhus I; nedenfra. $1: 1$.

- c. " " " " ; forfra. $1: 1$.

- 2. Serpula proboscis n. sp. Dollerup I. $2: 1 \ldots \ldots \ldots \ldots \ldots 6$

- 3 a. Serpula consolida n. sp. Kaase II; fra Siden. $2: 1 \ldots \ldots \ldots 165$

- b. " " . " ; ovenfra. $2: 1$.

- 4. Crania pallida n. sp. Overskal. Løgsted I. $3: 1 \ldots \ldots \ldots \ldots 169$

- 5 a. Pecten tesselatus Hennig. Højreskal. Sevel I. 2:1 . . . . . . 180

- b. " " . Venstreskal. Nystrup I A. $2: 1$.

- 6. Pecten monotiformis Hennig. Venstreskal. Nystrup I A. $3: 1$. 178

- 7. Pecten cimbricus n. sp. Højreskal. Thisted V. $3: 1 \ldots \ldots . .179$

- 8 a. Anomia (?) asperella n. sp. Højreskal. Torup I. $3: 1 \ldots \ldots 182$

- b. " " . Venstreskal. Tustrup I. $3: 1$.

- 9. Cerithium horningense n. sp. Hjerm I. $2: 1 \ldots \ldots \ldots \ldots$

Originalerne til Fig. 1 a og Fig. 9 tilhører Universitetets Mineralogiske og Geologiske Museum. De øvrige tilhører Danmarks geologiske UnderSøGELSE. 
D. G. U. II R. Nr. 45.

Tavle II.

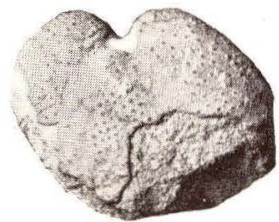

1b

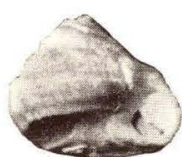

3 a

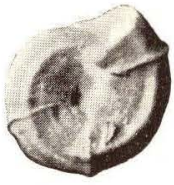

$3 \mathrm{~b}$

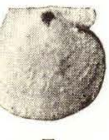

7

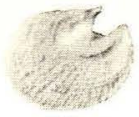

8 a

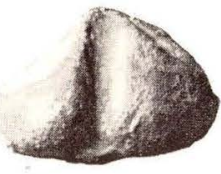

$1 \mathrm{c}$

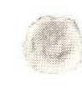

4

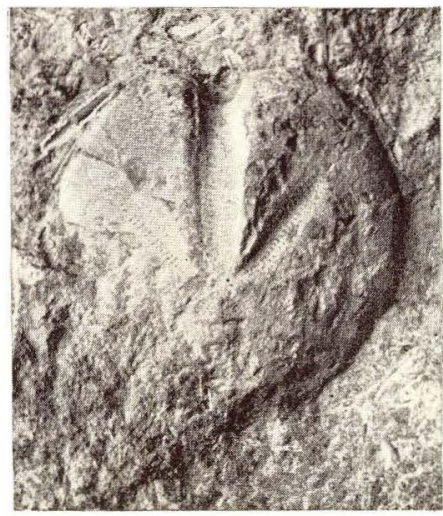

$1 \mathrm{a}$

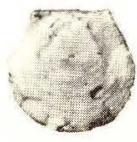

6

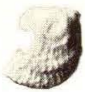

$8 \mathrm{~b}$

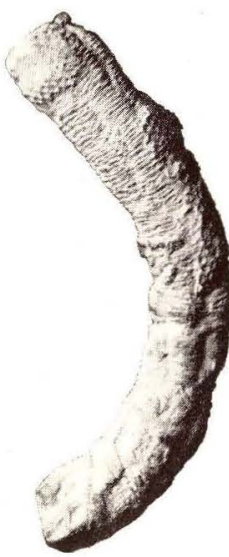

2

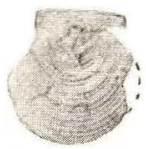

5 a

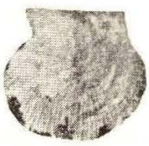

$5 \mathrm{~b}$

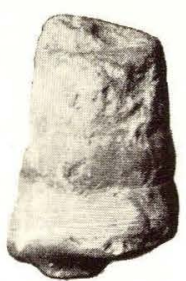

9 


\section{Tavle III.}

Jyske Overgangsprofiler.

Selandium — Yngre Danium: Hvalløse I . . . . . . . . . 40

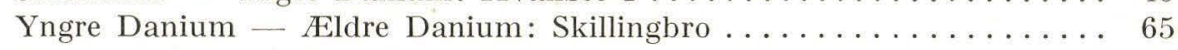

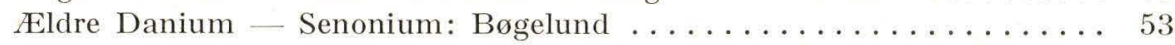

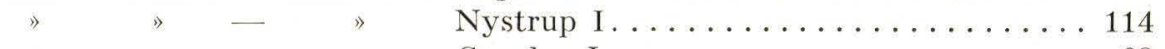

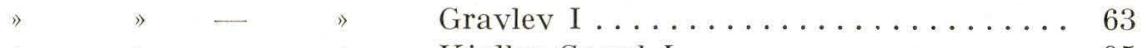

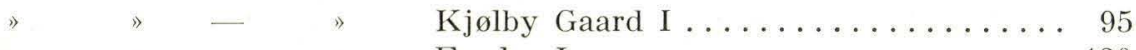

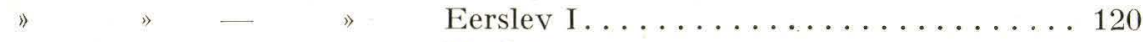

$" \quad$ " $"$ Voxlev ............... 72

Skr. $=$ Skrivekridt. $\quad$ Cck. $=$ Coccolitkalk.

Brzk. = Bryozokalk. Grsl. = Grønsandsler.

Skravering angiver Hærdning af det paagældende Lag. 


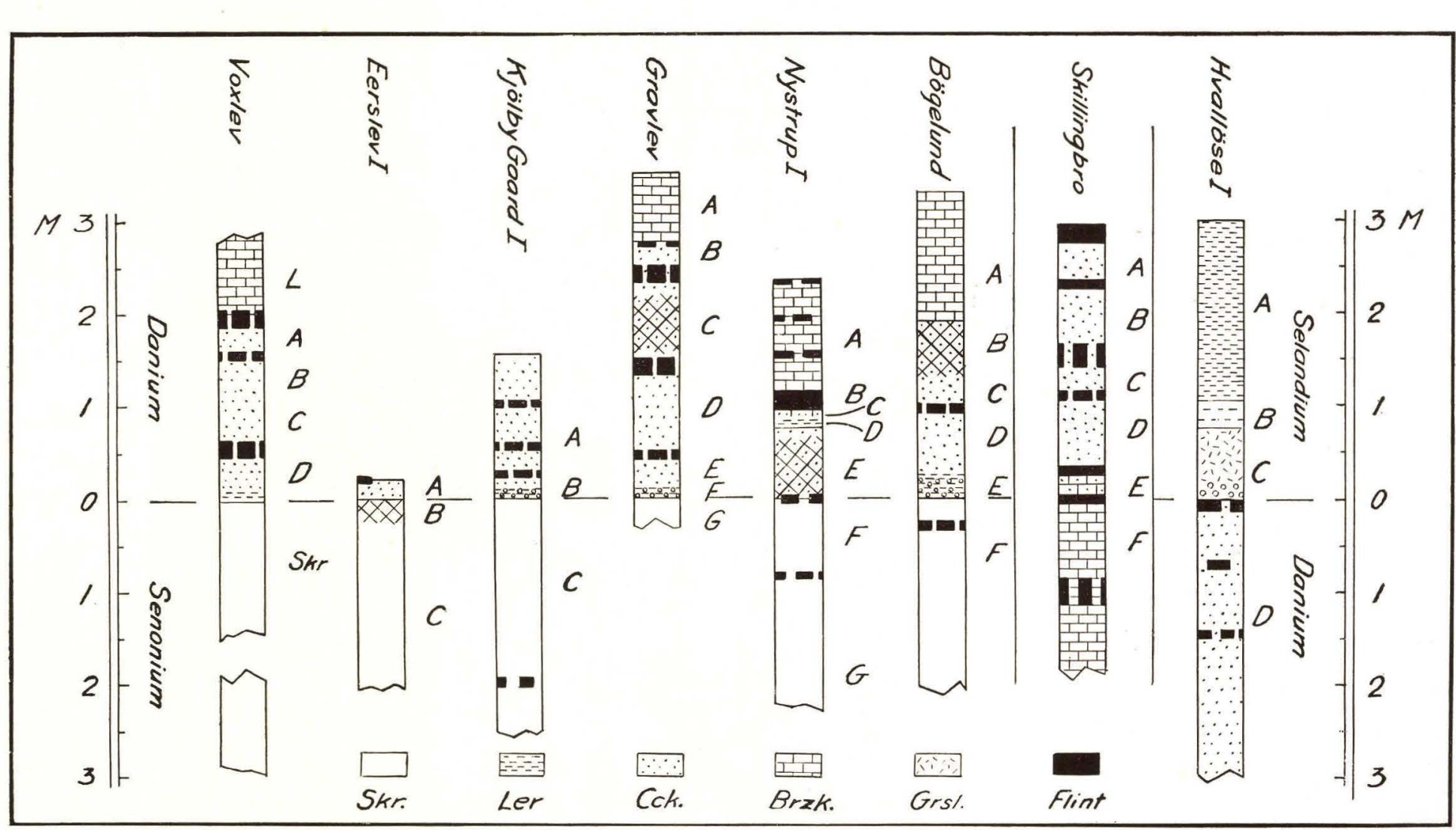




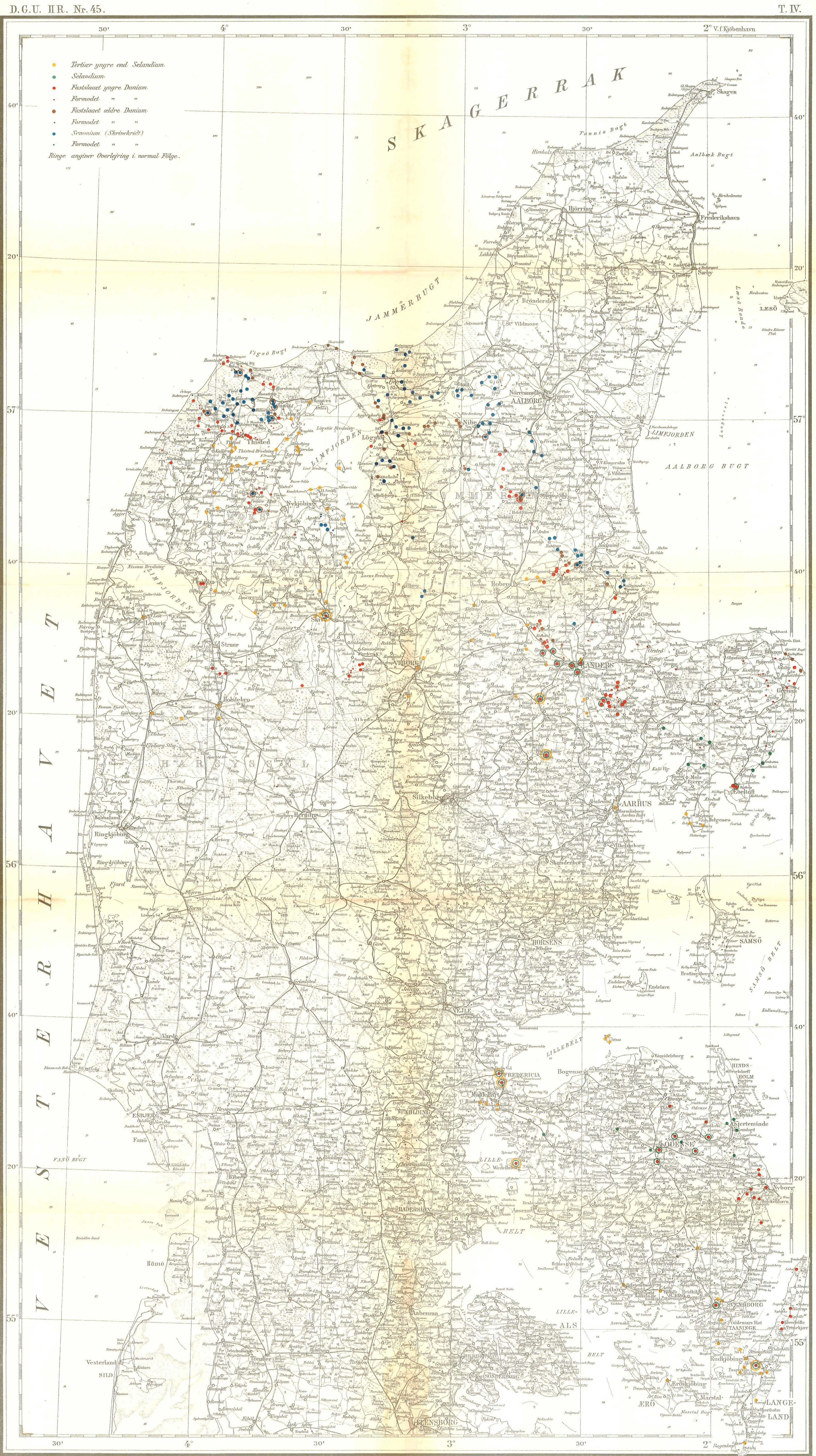


Tavle V.

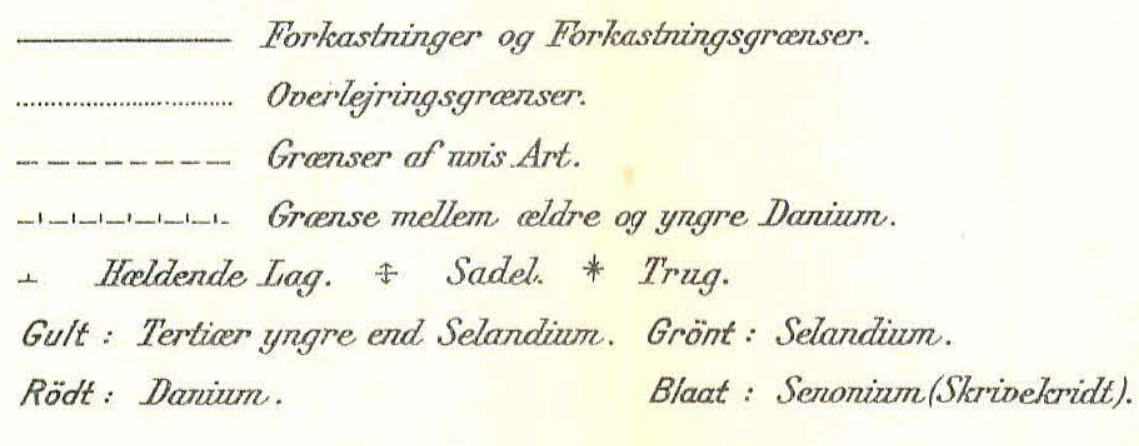

Gult : Terticer yngre end Selandium. Grönt: Selandium.

Rö́dt: Danum

Blaat : Senonium(Skrivekridt).
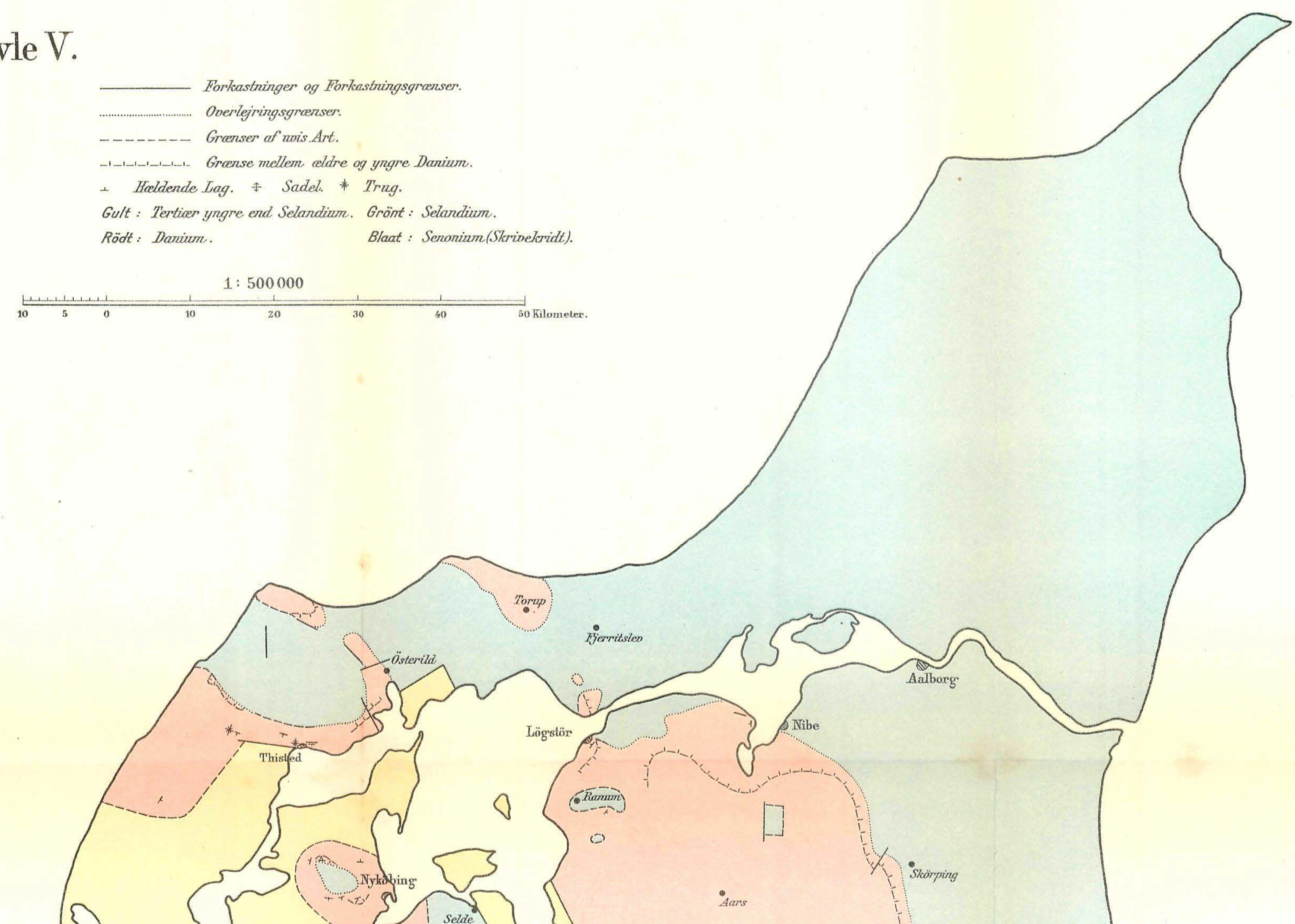

0
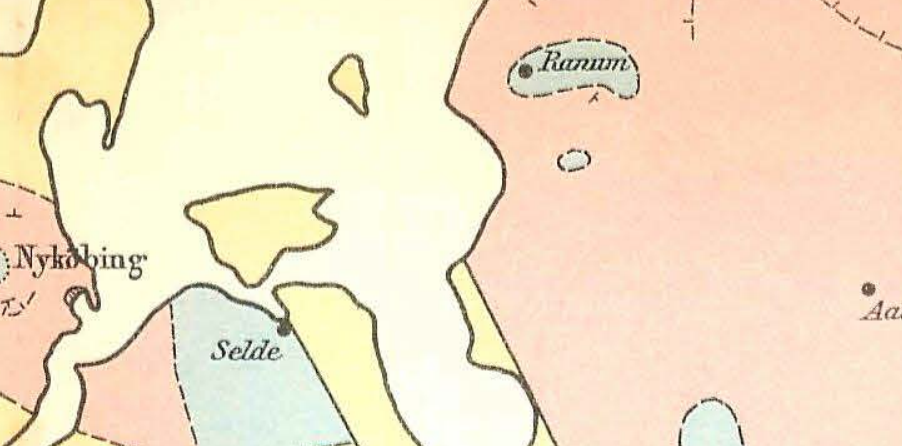

5 (5)
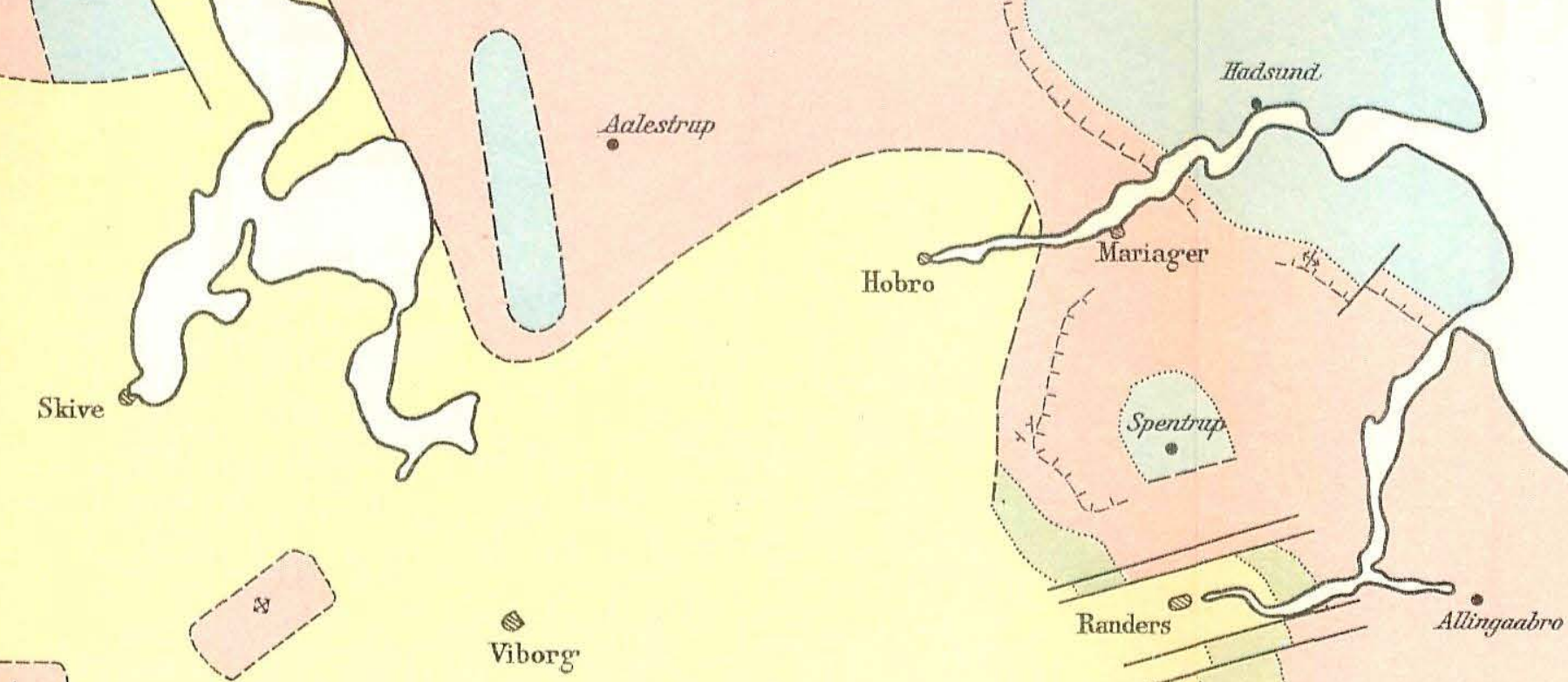

[]

Holsteroro

$\left(\begin{array}{c}0 \\ -1\end{array}\right.$

viorerg

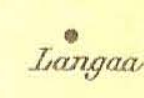

Hirmmel

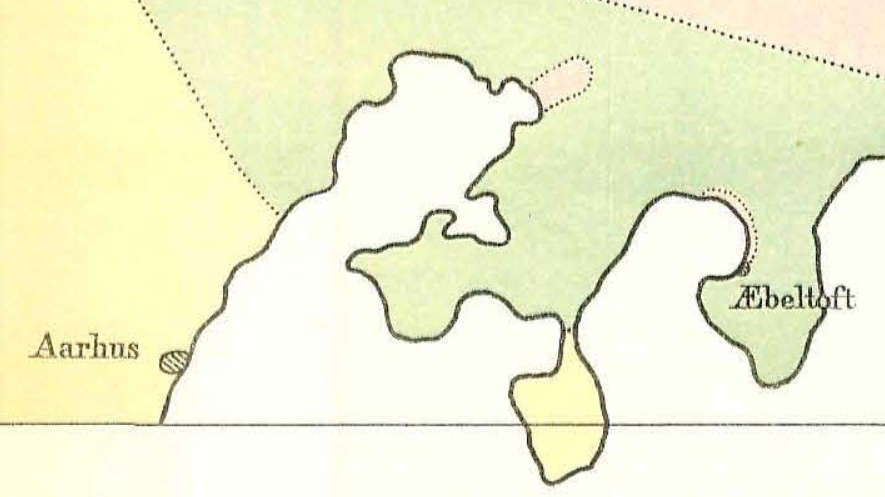


D.G.U. IIR. Nr. 45.

Skematisk Orersigt over Nordjyllands Tektonik.

Rödt: Hoeoningsfelter:

Sort: Saenkningsfelter:

Linierne angiver med större eller mindre

Sikkerhed Dislokationernes Retning.
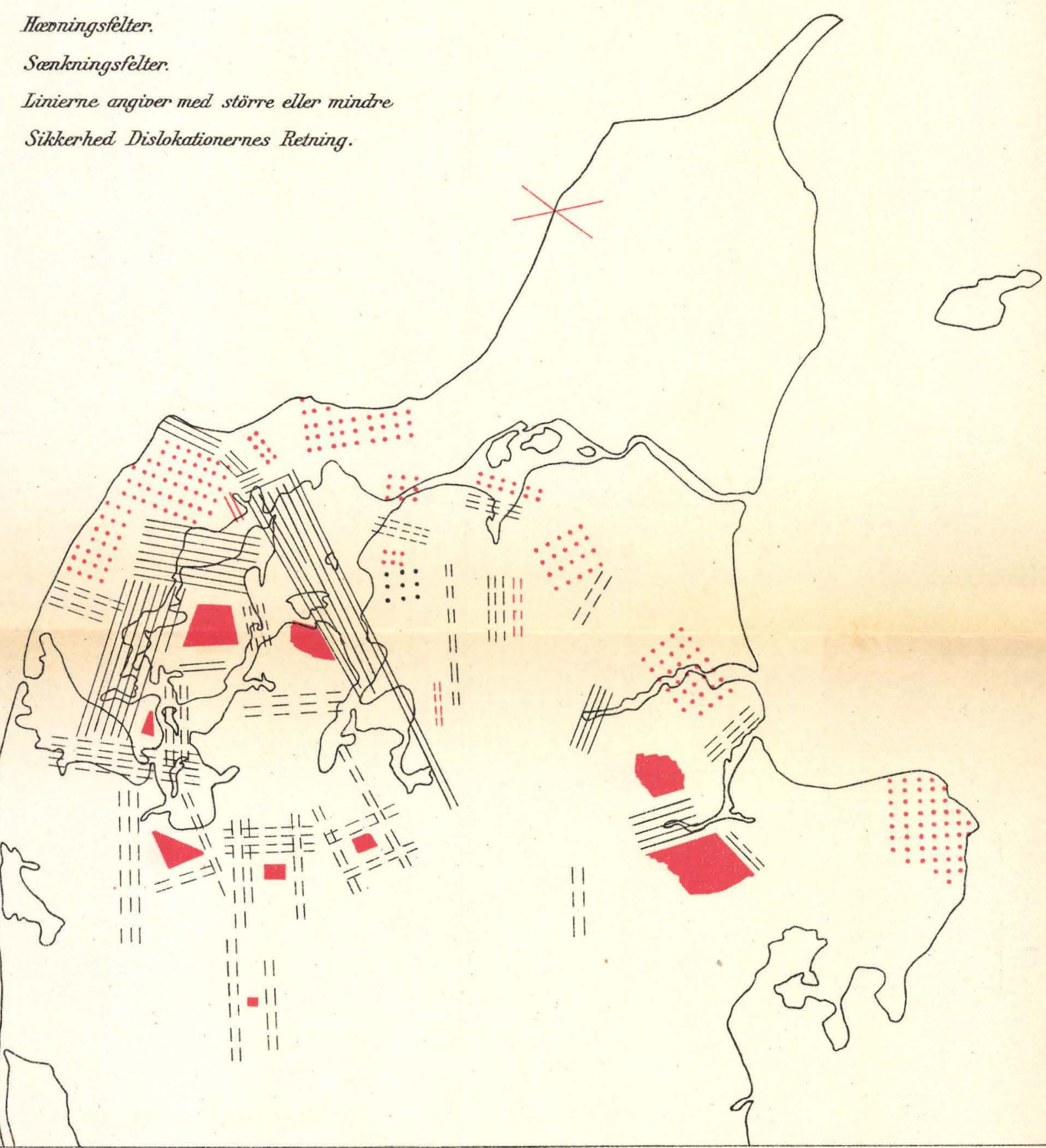

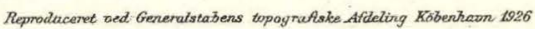

